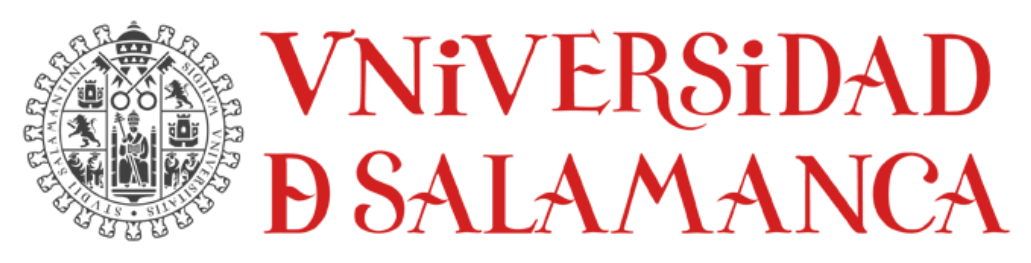

FACULTAD DE GEOGRAFÍA E HiSTORIA DEPARTAMENTO DE HISTORIA DEL ARTE - BELlAS ARTES

Tesis doctoral

La memorización monástica y las imágenes de la Psychomachia: el uso de la figuración miniada y monumental de las virtudes y los vicios como mnemotecnias

Jennifer Solivan Robles

Directora: Dra. Lucía Lahoz

Salamanca, 2017 


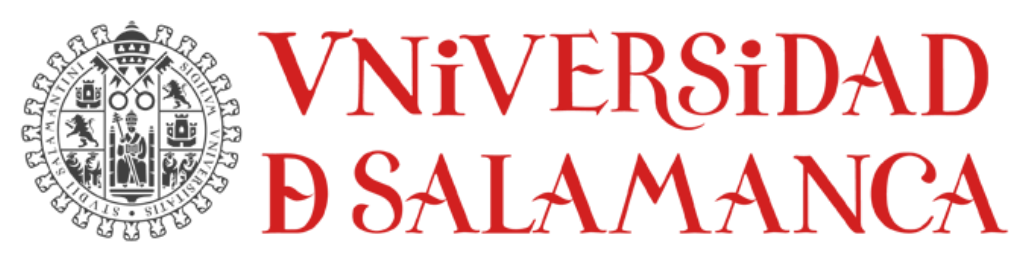

FACULTAD DE GEOGRAFÍA E HiSTORIA DePartamento de Historia del ARTE - Bellas ARTES

\author{
Tesis doctoral
}

\title{
La memorización monástica y las imágenes de la Psychomachia: el uso de la figuración miniada y monumental de las virtudes y los vicios como mnemotecnias
}

Jennifer Solivan Robles

$\mathrm{V}^{\circ} \mathrm{B}^{\circ}$ Directora de la tesis doctoral:

Fdo. Dra. Lucía Lahoz 
"A mi abuelo Braulio,

de quien me viene la pasión por

la historia y el conocimiento, y no vio terminado este proyecto". 


\section{ÍNDICE}

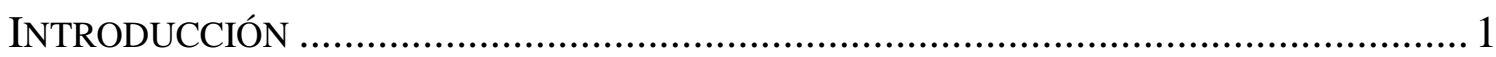

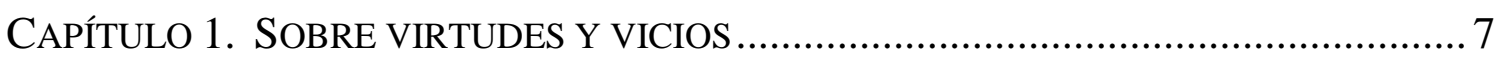

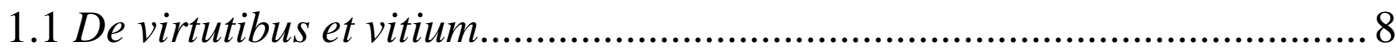

1.2 Virtudes vs. Vicios: yuxtaposición de las fuerzas ..................................... 13

1.3 Vicios y virtudes en el arte medieval..................................................... 16

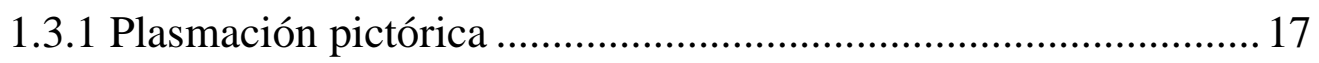

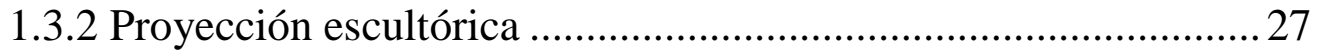

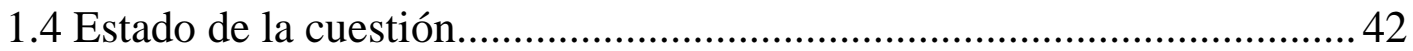

1.4.1 El método formalista ............................................................ 43

1.4.2 El método iconográfico e iconológico ………………………....... 47

1.4.3 Otros trabajos de casos particulares .............................................. 70

CAPÍTULO 2. VICIOS, VIRTUDES Y MEMORIA: RELACIÓN DE CONCEPTOS .................77

2.1 ¿Qué es la memoria y cómo funciona? ...................................................... 78

2.1.1 Mundo grecolatino: retórica........................................................ 78

2.1.2 Edad Media: moral y meditación ................................................ 80

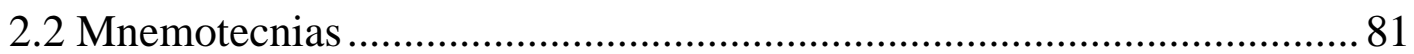

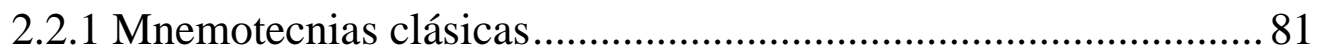

2.2.2 Mnemotecnias medievales ....................................................... 85

2.3 Reconstruyendo las mnemotecnias medievales: estado de la cuestión en torno a los estudios de la memoria artificial ........................................... 91

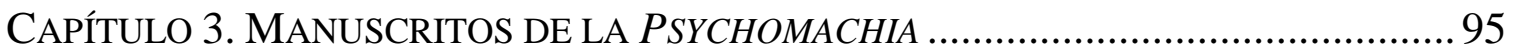

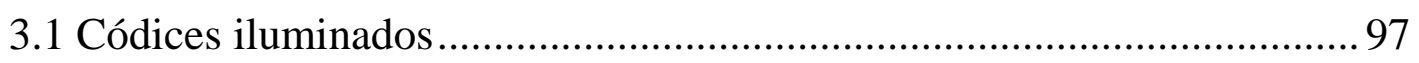

3.1.1 Manuscrito Burm.Q.3 ………………........................................ 103

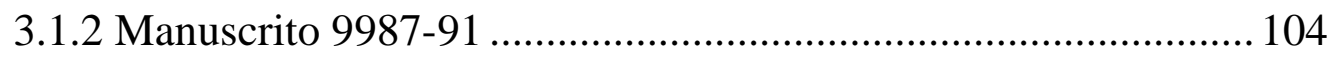

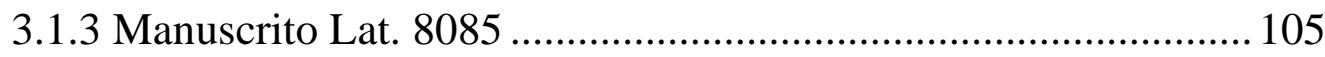

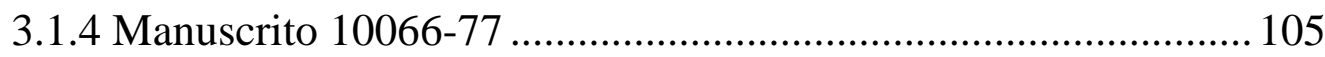


3.2 Monasterio, locus litterarum: contexto de los cinco códices miniados

3.2.1 Escuelas monásticas: la enseñanza de la gramática y la retórica

3.2.2 El acto de leer en el contexto monacal .................................................. 114

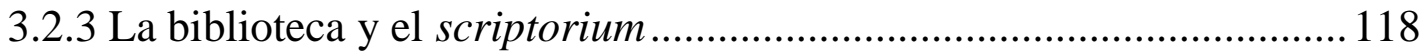

3.2.4 La memoria y las técnicas de memorización......................................... 121

\section{CAPÍTULO 4. MiNIATURAS DE LA PSYCHOMACHIA COMO MECANISMOS}

MNEMÓNICOS

4.1 A de Abraham, el Prefacio de la Psychomachia ........................................ 140

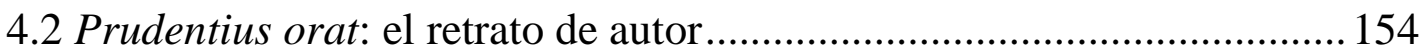

4.3 Batalla del alma o Psychomachia: los combates ..................................... 162

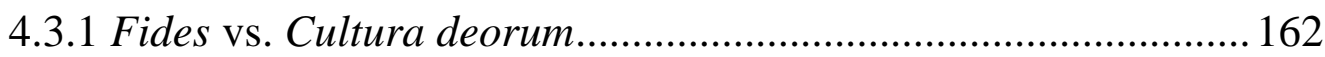

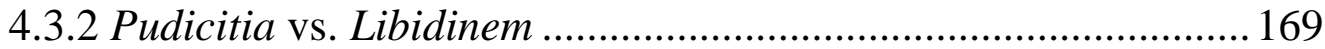

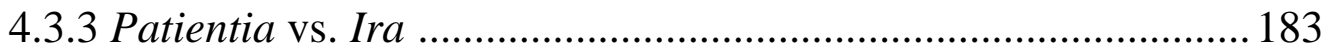

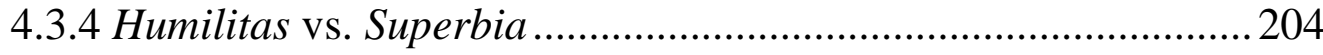

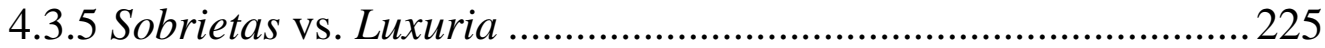

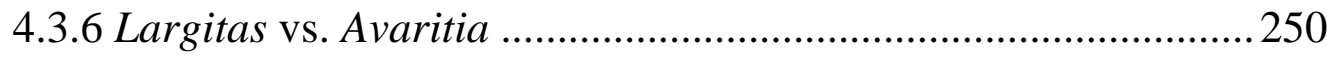

4.3.7 Concordia vs. Discordia .............................................................283

4.3.8 Construcción del templo de Sapientia .........................................310

4.4 Ascenso a la sabiduría: consideraciones finales sobre los combates.......317

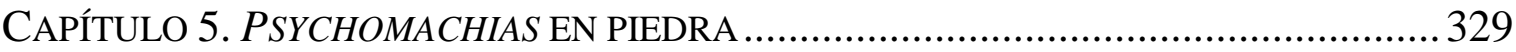

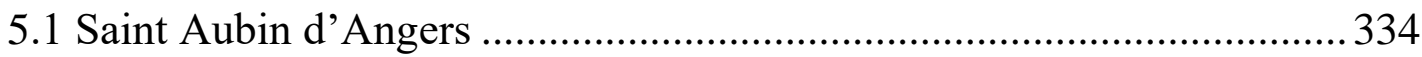

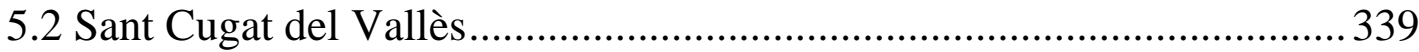

5.2.1 De san Cucufato a Saint-Denis: fundación y vinculación del cenobio con el mundo carolingio

5.2.2 Schola, magistri et alumni: enseñanza y aprendizaje en el cenobio. 
Capítulo 6. DuCtus en El Claustro: El uso DE las MNEMOTECNIAS EN EL PROCESO DE EDUCACIÓN Y MEDITACIÓN .................................................. 351

6.1 Los capiteles de Sant Cugat del Valles............................................... 356

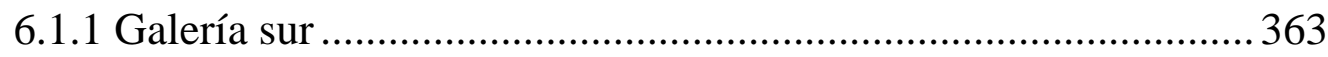

6.1.1.1 Historias del Antiguo Testamento ................................. 364

6.1.1.2 Historias del Nuevo Testamento ................................... 373

6.1.1.3 La Psychomachia de Sant Cugat del Vallès.................... 384

6.1.2 Galerías este, norte y oeste................................................ 394

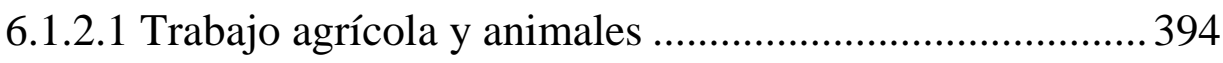

6.1.2.2 Vida en el claustro.................................................... 402

6.1.2.3 Obediencia y humildad............................................ 405

6.2 El claustro como meditationis machina ............................................. 418

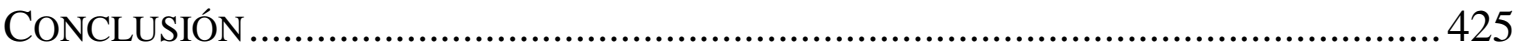

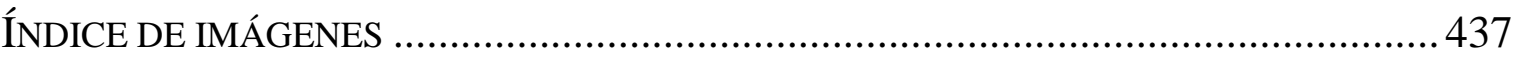

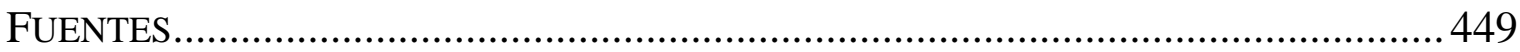

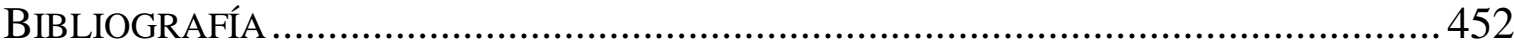




\section{AgRADECIMIENTOS}

Estos cuatro años de proyecto de tesis han sido arduos, si no hubiese sido por el apoyo, ayuda y motivación de muchas personas, el mismo no se habría podido realizar. En una tesis en la que se trata el tema de las virtudes y los vicios, resulta que la fe y la esperanza en términos personales fueron claves para el desarrollo de la misma. Gracias a Dios por darme la fe y la esperanza de que podría realizar este proyecto.

Mi más sincero agradecimiento a mi directora de tesis, la Dra. Lucía Lahoz. En primer lugar, por haberme permitido realizar este trabajo con ella. En segundo por las tantas conversaciones que me enriquecieron y me ofrecieron puntos de vistas alternos no sólo para mejorar la investigación, sino para formarme y crecer como historiadora del arte. Por último, he de agradecer el apoyo incondicional que me brindó durante todo este tiempo. Igualmente quiero mostrar mi gratitud a mi compañero de doctorado, Jorge Jiménez López, por todos los ratos que quedamos para dialogar sobre el proyecto, pero sobre todo por haberme acogido e integrado no sólo en el entorno académico, sino también en otras actividades de la Facultad. Gracias por ser un verdadero compañero.

El desarrollo de este proyecto no hubiera sido posible sin el aval económico brindado por el Programa de Becas para la Especialización en Catalogación y Preservación del Patrimonio Histórico, Cultural y Artístico, adscrito a la Universidad de Puerto Rico. Mi más eterna gratitud al programa y la comisión, espero volver a mi isla y retribuir lo que se me ha dado.

Agradezco la atención del personal de la Biblioteca Real de Bélgica por haberme permitido la oportunidad de consultar sus manuscritos e igualmente por toda la ayuda brindada a distancia por correspondencia electrónica. Igualmente, mi gratitud al personal del museo de Sant Cugat del Vallès, por haberme acogido y permitido documental los capiteles y brindado bibliografía para el desarrollo del proyecto. 
Un espacio clave para cualquier proyecto de tesis es la biblioteca. Todo el personal de las distintas bibliotecas de la universidad fue de mucha ayuda, pero deseo agradecer de forma particular al de la Facultad de Geografía e Historia, sobre todo a Juan Carlos, Miguel Ángel, Noelia y Alberto. Muchas gracias por siempre auxiliarme con los recursos bibliográficos y más importante por todo el aliento que me daban cada vez que pasaba por allí.

En términos personales, agradezco a mi esposo Juan Carlos, no solamente por el apoyo que me ha brindado en estos años, sino también por soportarme y tenerme paciencia durante la realización de la tesis. También a mis padres y mis suegros especialmente por haber creído en mí y haberme motivado tanto sobre todo en los momentos más oscuros. Y a mi abuela Victoria por ser una inspiración y por su apoyo y disposición para que yo lograra esto. Un agradecimiento especial a Teresa, quien siendo mi profesora fue quien me introdujo al tema de los vicios y las virtudes en el arte medieval, y ahora como amiga me ha aconsejado y apoyado para lograr esto.

Por último y no menos importante, mi más sincero agradecimiento a todas esas personas en Puerto Rico y España que me han acompañado en este largo caminar, pero sobre todo a mis amigos salmantinos del Barrio de San Bernardo. Eran esos viernes de coro y encuentro los que volvían más liviana la carga. ¡Muchas gracias, Ceci, Julia, Dalila y Paco, Inma y Bene, Mariángeles y Tony, María José y Tomas, Josefina y Pepe, Manu, Sole y Rosa y Paco! 


\section{INTRODUCCIÓN}

Ya en el mundo antiguo encontramos representaciones de los conceptos de algunas virtudes como son la Fortaleza o la Justicia. Durante la Edad Media estas imágenes ganaron gran popularidad y se insertaron en un sin número de medios, desde trabajos de orfebrería hasta en la escultura monumental de las fachadas de las catedrales góticas. Las imágenes de los vicios y virtudes en mayor o menor grado en épocas posteriores se siguieron utilizando. La época contemporánea no ha sido la excepción y en pleno siglo XXI se pueden señalar ejemplos, como son la personificación de la Justicia la cual continúa portando sus atributos por excelencia: la espada y la balanza. Actualmente la plasmación de dichos conceptos morales, con mayor interés en los vicios, se continúan utilizando en la cultura popular y se han extendido a los medios del mundo contemporáneo: el cine, la televisión y la animación ${ }^{1}$. La pervivencia de las representaciones de estos conceptos morales denota un afecto, tendencia, inclinación o disposición por parte del hombre a los mismos.

\footnotetext{
${ }^{1}$ A pesar de la popularidad del tema, sobre todo de los vicos, en la cultura contemporánea apenas hemos podido identificar estudios que aborden la pervivencia de estas personificaciones en la actualidad. En el 2013 en la ciudad de Israel se realizó el congreso Beauty, Bravery, Blood and Glory: Ancient Virtues and Vices in Modern Popular Culture, en el que se exploraron la pervivencia de los conceptos y las representaciones clásicas en el siglo XX y XXI. Para agosto de 2017 la editorial Brill publicará el libro The Reception of Ancient Virtues and Vices in Modern Popular Culture: Beauty, Bravery, Blood and Glory en el que las autoras: "offer a comprehensive collection of chapters dealing with the reception of antiquity in popular media of the modern era (19th-21st centuries). These media include theatrical plays, cinematic representations, Television drama, popular newspapers or journals, poems and outdoor festivals. For the first time in Classical Reception Studies, ancient Jewish literature and imagery are included in the discussion. The focus of the volume is both the continuity and variance between ancient and modern sets of values, which appear in the new interpretations of the ancient stories, figures and protagonists". "The Reception of Ancient Virtues and Vices in Modern Popular Culture", Brill Publishers. Disponible en: http://www.brill.com/products/book/reception-ancient-virtues-and-vices-modern-popular-culture
} [Consulta: 3/abril/2017] 
Particularmente, mi primer encuentro con el tema de las imágenes de los vicios y virtudes fue durante mis años de carrera en Puerto Rico, como parte de un trabajo de un curso de Historia del Arte Medieval. El mismo me llevó a cuestionarme la importancia y la popularidad que gozó el tema durante el período medieval. Cuando inicié el proyecto de tesis le propuse a mi tutora estudiar los vicios y las virtudes en la Edad Media, proyecto ambicioso cuya envergadura no conocía. Pues resulta, como se expone en el primer capítulo de nuestro trabajo, que imágenes de estos conceptos abstractos se elaboraron a lo largo de todo el medioevo y en todos los medios y contextos posibles del período.

La revisión bibliográfica aportó importantes pistas para el desarrollo de la tesis, especialmente el trabajo de la historiadora de la memoria Kimberly Rivers, pues ésta en su libro Preaching the Memory of Virtue and Vice. Memory, Images, and Preaching in the Late Middle Ages estudia el uso de las imágenes mentales de los vicios y las virtudes por partes de frailes y predicadores para organizar sus sermones. Inspirada en el trabajo de Rivers, y siguiendo el orden cronológico de las obras hasta hoy en día identificadas en las que se plasman estos conceptos abstractos, nos percatamos de la presencia de dichas nociones morales y su vínculo con las mnemotecnias en el contexto monacal. Esto nos llevó a cuestionarnos si la plasmación de conceptos abstractos, específicamente de las virtudes y los vicios pudieron haber sido utilizadas como técnicas de memorización.

Partimos de este cuestionamiento para establecer el objetivo principal de nuestra investigación: estudiar cómo las representaciones de la Psychomachia pudieron haber sido utilizadas por los miembros de las comunidades de religiosos como mecanismos mnemónicos para la memorización de información. En el contexto monacal son principalmente dos motivos principales por los que un individuo debía aprender de memoria algo: para instruirse en las materias propias de las artes liberales -el trivium y el quadrivium- y para obtener los conocimientos necesarios que le permitirían y facilitarían el manejo de las Sagradas Escrituras y la meditación. Esto da pie para establecer los objetivos secundarios de nuestro trabajo. En primer lugar: analizar el vínculo que pudo haber existido entre las miniaturas y 
esculturas de la Psychomachia en el contexto monacal como técnicas de memorización que auxiliaban las mentes de los jóvenes pupilos, permitiendo a estos aprender los conocimientos del trivium, particularmente de la gramática e igualmente de conceptos morales abstractos como son los vicios y las virtudes. El segundo punto, tratar de abordar cómo la memorización de las imágenes de estos conceptos abstractos pudo ser utilizadas por los monjes en el proceso de meditación.

El objeto de estudio de nuestra investigación son las miniaturas de cinco códices miniados de la Psychomachia y un capitel la galería sur del claustro de Sant Cugat del Vallès en el que se esculpieron ocho figuras femeninas, siete de éstas virtudes coronadas pisoteando vicios vencidos. El principal criterio de selección de estas obras particulares es el estado de conservación en el que nos han llegado, en el caso de los códices se preservan todos los folios y por ende todas las ilustraciones de los mismos. Respecto al capitel de Sant Cugat, por una parte, cabe destacar el buen estado de conservación en el que se encuentra el mismo y por otro el hecho de que a pesar de los estragos del tiempo, el programa iconográfico del claustro de este cenobio se conserva tal cual fue realizado en época medieval.

El análisis formal e iconográfico de las representaciones de la Psychomachia permite identificar el uso de distintos elementos propios de las técnicas mnemónicas de la antigüedad y la Edad Media. En el caso particular de los manuscritos, la disposición de las miniaturas con relación al soporte, los elementos formales y compositivos se tienen en cuenta para identificar dichos elementos. La presencia de temas iconográficos bien establecidos en torno al período en el que se ilustraron estos códices igualmente confirma el interés por la familiaridad y la intención de que la información expresada visualmente aquí por medio del texto y la imagen se inscriba en la mente del usuario. Con relación al capitel, es de suma importancia la disposición del mismo respecto al resto de los chapiteles labrados del claustro de Sant Cugat y las distintas escenas de las Sagradas Escrituras plasmadas en los mismos. Los temas iconográficos tratados en el claustro catalán se abordan desde los diversos sentidos de las Escrituras, siguiendo la noción mnemónica de lugar de recopilación. 
Los distintos capítulos de nuestra disertación son producto del proceso de investigación, en donde ha sido necesario la definición de conceptos y nociones abstracta, la reconstrucción de espacios, entornos y contextos y el análisis propio de las representaciones pictóricas y escultóricas. El primer capítulo de nuestro trabajo tiene sobre todo un carácter monográfico en el que se brinda el trasfondo conceptual, histórico, bibliográfico y metodológico que será utilizado en el desarrollo de la tesis. Puesto que los conceptos de los vicios y las virtudes en la Edad Media y las representaciones de éstos son productos, además de la teología, igualmente de la filosofía clásica, la primera sección del primer capítulo se centra en definir y clarificar las distintas nociones de vicios y virtudes. En este apartado se trata, aparte de la explicación de los conceptos desde la concepción moral cristiana, el desarrollo histórico de los mismos por los filósofos griegos y retóricos romanos hasta ser adoptados por los teólogos medievales. También se aborda cómo y cuándo la idea de vicio/vicios y virtud/virtudes se yuxtapuso como fuerzas contrarias.

Tratadas las nociones conceptuales, proseguimos con la identificación de varias obras en distintos medios y contextos en los que se plasman los vicios y las virtudes. Aquí no nos limitamos únicamente al registro de obras, también se ha tratado de establecer los espectadores y posibles usos y funciones de estos objetos. Nos centramos principalmente en manuscritos y escultura, en primer lugar, por ser estos los dos medios en los que más se difundieron los vicios y las virtudes. En segundo, porque se vinculan directamente con las obras objetos de estudio de nuestra investigación.

Nuestro trabajo no se da un vacío, pues ya tan temprano como en el 1895 encontramos estudios que abordan las imágenes de los vicios y virtudes. Hemos dedicado el último apartado del capítulo uno a la elaboración del estado de la cuestión de los distintos estudios que se dedican parcial o totalmente al análisis de las representaciones de las personificaciones de los conceptos morales en el arte medieval. Si bien los trabajos de Richard Stettiner, Helen Woodruff, Adolf Katzenellenbogen, Joanne S. Norman y los artículos de Rosemond Tuve se consagran exclusivamente al análisis de las distintas plasmaciones de los conceptos morales, 
dos de los trabajos de Émile Mâle en torno al Arte Medieval han sido fundamentales para el desarrollo del estado de la cuestión por su gran aporte para con la iconografía de los vicios y las virtudes y llegando a ser considerado por muchos historiadores del arte autoridad en el tema. La elaboración del estado de la cuestión se estableció en base al tratamiento metodológico de la Historia del Arte desde el cual los vicios y las virtudes se han estudiado, principalmente el formalismo y la iconografía e iconología.

Para estudiar la relación entre las imágenes de los vicios y las virtudes y las técnicas mnemónicas en el contexto monacal es necesario entender el funcionamiento de la memoria y las distintas técnicas de memorización en el período histórico al que nos circunscribimos. Hemos dedicado el capítulo 2 "Vicios, virtudes y memoria: relación de conceptos", a definir y establecer qué era y cómo funcionaba la memoria en la Edad Media. Puesto que las definiciones y mnemotecnias del medioevo se nutrieron de las fuentes clásicas, tratamos brevemente también los conceptos según el mundo grecolatino. El segundo capítulo finaliza con un breve estado de la cuestión sobre los distintos estudios que analizan y reconstruyen las técnicas mnemónicas clásicas, pero sobre todo medievales.

Los capítulos 3 y 4 de nuestro trabajo se centra en el poema de la Psychomachia y los manuscritos miniados de ésta. El tercero versa sobre el contexto histórico en el que se escribió la obra literaria e igualmente en el que se elaboraron los distintos manuscritos iluminados objeto de estudio de esta investigación. Con relación a los cinco códices que estudiamos, se identificaron los distintos monasterios en los que se elaboraron o a los que pertenecieron estos en los siglos IX y X. Puesto que la cultura libraría dentro del contexto monacal se encuentra estrechamente vinculada no sólo con la meditación, sino también con la educación, en este capítulo hemos tratado de reconstruir cómo funcionaban las escuelas monásticas, las distintas actividades en torno a los libros y el proceso de enseñanza dentro de estos cenobios.

En el capítulo 4 analizamos la función mnemónica de las miniaturas de las cinco copias miniadas de la Psychomachia. Esto se logra siguiendo la estructura del poema, la cual como explicaremos con más detenimiento en el capítulo, tiene un fin mnemónico. A través del análisis formal e iconográfico hemos identificado una serie 
de elementos que en conjunto con el texto y la ubicación de las distintas miniaturas dentro del poema aluden claramente a los distintos consejos y reglas de las mnemotecnias antiguas y medievales. Queremos aclarar que para nuestro análisis tomamos en consideración la distribución de las imágenes con relación al folio, sin embargo, solamente incluimos las miniaturas para conveniencia del lector. En la bibliografía se adjuntan los respectivos enlaces electrónicos para consultar los manuscritos en su totalidad.

Los últimos dos capítulos de la disertación se dedicaron al estudio de figuraciones escultóricas de la Psychomachia dentro del contexto monacal. Por los motivos antes expresado, el principal objeto de estudio de estos capítulos es el monasterio de Sant Cugat del Vallès, específicamente su claustro. Puesto que para entender el uso de las mnemotecnias es necesario comprender el entorno en el que se crean o utilizan las distintas imágenes de la Psychomachia, el capítulo 5 lo hemos dedicado a los aspectos históricos y a la reconstrucción del currículo de enseñanza y el proceso de educación de este cenobio.

En el último capítulo se explica el discurso iconográfico del claustro catalán y el recorrido visual, meditativo y simbólico del mismo. La importancia de la Psychomachia en el claustro de Sant Cugat estriba en que es la llave de acceso a entender el programa iconográfico de la clausura, pues el mismo conecta los distintos niveles cognitivos de los temas representados en los distintos capiteles. 


\section{CAPítulo 1}

\section{SOBRE VIRTUDES Y VICIOS}

Virtud y vicio son conceptos abstractos que durante muchos siglos se han utilizado para designar ciertas cualidades atribuidas sobre todo a los hombres. En breves palabras y resumiendo los distintos significados que tienen estos dos conceptos podemos decir que el término virtud se utiliza para designar un comportamiento positivo mientras que el sustantivo vicio designa una conducta o proceder negativo. Desde la perspectiva cristiana la virtud se define como la frecuente buena disposición de los poderes del hombre a algún acto de bien, es:

“...un hábito, modo o manera de ser de una cosa, en cuanto se hace posible por haber en ésta una potencialidad, virtualidad o capacidad de ser especialmente determinada. [...] La noción de virtud, así entendido, como hábito o modo de ser específico, que reitera los actos -en cuanto buenos- y perfecciona por ello al ser que la posee, se aplica justamente al hombre"”.

El vicio se define como la contraposición a la virtud, como la frecuente degradación y la disposición a conductas malas o nocivas, "moralmente hablando, la palabra vicio equivale a hábito, inclinación, propensión o inclinación mala²".

El uso de estos sustantivos en plural designa un conjunto de cualidades propias de un individuo, siendo variadas las aptitudes, fortalezas o defectos que designan comportamientos virtuosos o viciosos. Pese a los muchos vicios y virtudes que existen, la moral cristiana enfatiza un grupo específico, dentro de las virtudes: fe,

\footnotetext{
1 "Virtud", en Enciclopedia de la religión católica. Tomo VII. Barcelona: Dalmau y Jover, S. A., 1956. pp. 682-683. Ver también: "Virtue", en The New Catholic Encyclopedia. Tomo 14. 2da edición. Washington: Thomson \& Gale, 2003. P. 548.

2 "Vicio", en Enciclopedia de la religión católica. Tomo VII. Barcelona: Dalmau y Jover, S. A., 1956. p. 630. Ver también: "Vice" en The New Catholic Encyclopedia. Tomo 14. 2da edición. Washington: Thomson \& Gale, 2003. p. 474.
} 
esperanza, caridad, justicia, prudencia, templanza y fortaleza; y en los vicios: lujuria, pereza, gula, ira, envidia, avaricia y soberbia. A pesar de que existe tal recopilación, existen muchos otros conceptos que se entienden por virtudes y vicios, como la humildad, la castidad, la generosidad, la tristeza, la injusticia o la codicia.

Parecería que estos términos siempre se han yuxtapuesto, donde uno es el contrario del otro, sin embargo, no es así. El desarrollo de estas nociones y su introducción al mundo cristiano proviene de fuentes de distintas épocas e incluso de distintas zonas geográficas.

\subsection{De virtutibus et vitium}

El sustantivo virtud, del latín virtus, se relaciona con la virilidad e igualmente se vincula a la bondad moral. El origen del esquema que hasta hoy nos llega de siete virtudes es distinto. Éste es producto de las dos divisiones que encasillan las mismas: virtudes teologales y virtudes cardinales, la cual principalmente se basa en las fuentes escritas o textuales de las que provienen. El grupo de tradición más antigua es el de las virtudes cardinales compuesto por prudencia, justicia, templanza y fortaleza, siendo su origen y sus fuentes anteriores al cristianismo. En el Antiguo Testamento en el libro de la Sabiduría estas cuatro cualidades morales se mencionan, y se describen como frutos de la sabiduría cuya posesión es de sumo provecho para el hombre ${ }^{3}$.

A pesar de ser mencionadas en las Sagradas Escrituras el desarrollo de las virtudes cardinales dentro de la moral cristiana medieval se nutrió mayoritariamente del pensamiento de varios filósofos clásicos, específicamente de tres: Platón, Aristóteles y Cicerón. Estos autores en distintas obras mencionan la prudencia, la justicia, la templanza y la fortaleza como cualidades morales que conducen a la

\footnotetext{
${ }^{3}$ Sabiduría 8:7.
} 
perfección humana natural ${ }^{4}$. Platón discute las cuatro en el IV libro de La República. En el mismo menciona la relación de cada una de estas virtudes con los distintos oficios y estamentos sociales y cómo la práctica de las mismas conduce a que un estado sea completamente bueno ${ }^{5}$.

Para Aristóteles, la virtud es bella y buena, definiéndola como la facultad de producir y conservar los bienes, y también, la facultad de procurar muchos y grandes servicios de todas clases y en todos $\operatorname{casos}^{6 \%}$. Por lo tanto, si el hombre que la práctica, procura grandes servicios éste no sólo trabaja por conseguir grandes cosas, sino que también proporciona de grandes cosas y servicios a otros hombres ${ }^{7}$.

Si bien Platón y Aristóteles definieron estos conceptos abstractos, fue la definición formulada por Cicerón en De Inventione la que más hondo caló en el mundo cristiano. Este filósofo romano entendía la virtud como un hábito de la mente, consistente con la moderación y la razón que se divide en cuatro partes: prudencia, justicia, fortaleza y templanza ${ }^{8}$.

Los primeros cristianos utilizaron las virtudes morales dadas por los filósofos del mundo antiguo pues entendía que los hombres en gracia de Dios necesitaban moderarse a sí mismos y era a través del ejercicio de éstas cuatro cualidades que esto era posible 9 . San Ambrosio fue quién llamó al grupo conformado por la prudencia, la justicia, la fortaleza y la templanza cardinales ${ }^{10}$. El obispo milanés no sólo se limitó

\footnotetext{
4 "Virtudes", en Enciclopedia de la religión católica. Tomo VII..., pp. 684-685. Ver también: "Vices and Virtues", en VAucheZ, André (ed.). Encyclopedia of the Middle Ages. Vol. II, K-Z. Cambrige: James \& Clarke Co., 2000. p. 1512.

${ }^{5}$ Platón. La República, Libro IV, 427e. Edición consultada: Dialogos IV. República. trad. de Conrado Eggers Lan. Biblioteca Clásica Gredos, 94. Madrid: Gredos, 1988.

${ }^{6}$ ARISTÓteles. Retórica, I, 9, 1366a, 37-38. Edición consultada: Retórica. Trad. de Quintín Racionero. Biblioteca Clásica Gredos, 142. Madrid: Editorial Gredos, S.A., 1999.

${ }^{7}$ ARISTÓTELES. Retórica, I, 9, $1366 \mathrm{~b}$.

${ }^{8}$ CiCERÓN. De Inventione, II, 53, 159. Edición consultada: La invención retórica, trad. de S. Núñez. Biblioteca Clásica Gredos, 245. Madrid: Gredos, D.L.1997.

9 “Virtudes cardinales", en Enciclopedia de la religión católica. Tomo VII..., pp. 687-688.

10 "Et quidem scimus virtutes esse quattuor cardinals, temperantiam iustitiam prudentiam fortitudinem". SAn Ambrosio. Comentario a San Lucas, V, 62. Edición consultada: Obras de San Ambrosio, I. Tratado sobre el Evangelio de San Lucas. Edición de Manuel Garrido Bonaño. Biblioteca de Autores Cristianos. Madrid: La Editorial Católica, 1966. p. 260.
} 
a nombrarlas, sino que también profundizó en la relación de éstas con la vida del propio cristiano. En sus comentarios al Paraíso, Ambrosio compara el alma humana con la tierra fértil del Jardín del Edén, la fuente de la que brotan los cuatro ríos es Jesús, que a la misma vez encarna la sabiduría y los riachuelos u arroyos que emanan del mismo corresponden a cada una de las virtudes cardinales. De la misma manera que estos riegan la tierra fértil del paraíso, la prudencia, la justicia, la fortaleza y la templanza deben irrigar el alma del hombre con la sabiduría como fuente principal de éstas ${ }^{11}$.

San Agustín retoma la definición y las partes de las virtudes establecidas por Cicerón, "La virtud es una disposición del alma conforme al modo de ser de la naturaleza y a la razón ${ }^{12}$ ", y más adelante afirma que "todas estas cosas han de ser buscadas sin interés alguno ${ }^{13}$ ". Para este Doctor de la Iglesia las cuatro virtudes cardinales poseen un valor equiparable, siendo el ejercicio de las misma en el alma humana de igual peso, "y aquellos que en una virtud cualquiera fueren iguales, por ejemplo, en fortaleza, han de ser también iguales en prudencia, justicia y templanza ${ }^{14}$ ". La práctica de las virtudes cardinales para el hombre cristiano es posible sólo a través de la religión y de la fe ${ }^{15}$ pues las virtudes son grandes bienes

\footnotetext{
${ }^{11}$ San Ambrosio. De Paradiso, Libro I, Cap. 3. Edición consultada: Hexameron, Paradise, Cain and Abel, trad. de John J. Savage. Nueva York: Fathers of the Church, 1961. pp. 294-296.

12 "Virtus est animi habitus naturae modo atque rationi consentaneus. Quare ómnibus partibus eius cognitis, tota vis erit simplicis honestatis considerata SAN AGUSTín. De diversis quaestionibus octoginta tribus, XXXI, 1. Edición consultada: "Ochenta y tres cuestiones diversas", en Obras completas de San Agustín, XL. Escritos varios, 2do. Versión de Teodoro C. Madrid. Biblioteca de Autores Cristianos. Madrid: La Biblioteca Católica, 1995. pp. 95-96.

13 "Atque haec omnia propter se solum, ut nihil adiungatur emolumenti, petenda sunt". SAN AGUSTín. De diversis quaestionibus octoginta tribus, XXXI, 2. Edición consultada: "Ochenta y tres cuestiones diversas", en Obras completas de San Agustín, XL..., p. 98.

14 "ut quicumque fuerint aequales, verbi gratia, in fortitudine, aequales sint et prudentia, et Temperantia, et iustitia”. SAN Agustín. De Trinitate, Libro VI, 6. Edición consultada: Obras de San Agustín, V. Tratado de la Santísima Trinidad. Versión y traducción de Fr. Luis Arias. Biblioteca de Autores Cristianos. Madrid: La Editorial Católica, S.A., 1956. p. 444.

${ }^{15}$ San Agustín. Civitate Dei, Libro IV, 20. Libro X, 25. Edición consultada: Obras de San Agustín, XVI. La Ciudad de Dios. Edición de José Moran. Madrid: Editorial Católica, S.A., 1958. pp. 299, 679-682.
} 
dados por Dios que permiten al hombre vivir rectamente a través del ejercicio de ellas ${ }^{16}$.

El segundo grupo de virtudes, las teologales, lo comprenden: la fe, la esperanza y la caridad. Su concepción es cristiana y se encuentran directamente relacionada con el pensamiento paulino. San Pablo en su epístola a los Corintios es el primero en mencionarlas: "Ahora subsisten la fe, la esperanza y la caridad, estas tres. Pero la mayor de todas ellas en la caridad ${ }^{17}$ ". Desde su concepción las virtudes teologales, como indica su nombre, se encuentra directamente ligadas a Dios ${ }^{18}$. Lo que quiere decir que éstas son infundidas en el hombre directamente por Dios, a diferencia de las virtudes cardinales las cuales el individuo puede obtener a través de su esfuerzo.

El sustantivo en latín de vicio, es vitium y significa defecto, imperfecto o impedimento. Dentro del mundo cristiano se utiliza de manera genérica para designar ciertos comportamientos y actos como son la soberbia o la ira. A pesar de que algunos de los conceptos que hoy entendemos como vicios o comportamientos viciosos ya se conocían en el mundo antiguo $^{19}$, la noción de los mismos que predominó durante toda la Edad Media es producto del ascetismo monástico oriental. El listado de virtudes, a pesar de que en muchas ocasiones se incluyen más de las siete -como se ha establecido en la sección anterior-, en mayor o menor grado siempre responde a las

\footnotetext{
16 "Virtutes igitur quibus recte vivitur, magna bona sunt: species autem quorumlibet corporum, sine quibus recte vivi potest, mínima bona sunt: potentiae vero animi sine quibus recte vivi non potest, media bona sunt. Virtutibus nemo male utitur: caeteris autem bonis, id est, mediis et minimis. non solum bene, sed etiam male quisque uti potest. Et ideo virtute nemo male utitur, quia opus virtutis est bonus usus istorum, quibus etiam non bene uti possumus. Nemo autem bene utendo male utitur. Quare abundantia et magnitudo bonitatis Dei non solum magna, sed etiam media et mínima bona esse praestitit. Magis laudanda est bonitas eius in magnis quam in mediis, et magis in mediis quam in minimis bonis: sed magis in ómnibus quam si non omnia tribuisset". SAN AGUSTín. De libero arbitrio, Libro II, 19. Edición consultada: "Del libre albedrío", en: Obras de San Agustín. III. Obras filosóficas. Versión de Evaristo Seijas. Biblioteca de Autores Cristianos. Madrid: La Editorial Católica, S.A., 1963. pp. 313-314

${ }^{17} 1$ Corintios 13:13.

18 "Virtudes teologales", en Enciclopedia de la religión católica. Tomo VII..., p. 688.

${ }^{19}$ Para una profundización en el tema ver: HaworTh, Kenneth R. Deified Virtues, Demonic Vices, and Descriptive Allegory in Prudentius' Psychomachia. Amsterdam: A.M. Hakkert, 1980.
} 
cardinales y teologales. Sin embargo, el desarrollo de una lista de vicios dentro de la moral cristiana ha cambiado con más frecuencia hasta convertirse en la lista actual mejor conocida como los pecados capitales, frutos de los teólogos del siglo XIII ${ }^{20}$.

La primera lista de vicios la propuso el monje asceta Evagrio Póntico. Éste nació alrededor del año 345 en Ibora, en la provincia romana de Ponto. Fue ordenado lecto por Basilio el Grande y diácono por Gregorio de Nisa, sin embargo, dio fin a su carrera en Constantinopla al aceptar el monacato. Pasó una temporada en un monasterio en Egipto, luego durante dos años vivió en la comunidad de monjes de Nitria y los últimos años de su vida se retiró a Kellia (las celdas) en dónde dedicó su vida al ascetismo y la escritura ${ }^{21}$. Es uno de los pensadores griegos más importantes para las teorías del monacato ${ }^{22}$.

La meta de retirarse al desierto era adquirir el conocimiento real de la divinidad, conectar con Dios, y esto sólo podía alcanzarse una vez las pasiones del alma se encontrarán bajo un firme control $^{23}$. Para poder dominar estos afectos perniciosos, Evagrio redactó en el Praktikos, una guía práctica para la vida asceta la cual consistía en una lista de ocho tentaciones o males que afectaban a los monjes en su proceso de meditación: gula, lujuria, avaricia, ira, tristeza, pereza, vanagloria y orgullo.

Esta lista de ocho males, o vicios, que aquejan el alma humana fue introducida al occidente latino aproximadamente a finales del siglo IV por Juan Casiano ${ }^{24}$. Este monje asceta fue quién introdujo las reglas del monacato oriental en Europa, especialmente las ideas de Evagrio, revisando y adaptando las mismas a las necesidades del monacato occidental. Casiano conservó la lista de ocho vicios de

\footnotetext{
${ }^{20}$ NEWHAUSER, Richard. The Treatise on Vices and Virtues in Latin and the Vernacular. Turnhout, Belgique: Brepols, 1993. p. 99.

${ }^{21}$ NEWHAUSER. The Treatise on Vices and Virtues..., p. 99.

${ }^{22}$ NEWHAUSER. The Treatise on Vices and Virtues..., p. 100.

${ }^{23}$ NEWHAUSER. The Treatise on Vices and Virtues..., p. 100.

${ }^{24}$ Newhauser. The Treatise on Vices and Virtues..., p. 108.
} 
Evagrio $^{25}$. El listado de siete, mejor conocido hoy en día, es producto de la revisión que Gregorio Magno realizó.

San Gregorio reexamino y modificó el octal de Evagrio, reduciendo la lista de ocho a siete pecados principales en los que puede caer el hombre cuya raíz es la soberbia u orgullo ${ }^{26}$. La lista de este papa con ciertas modificaciones, básicamente se compone de los siguientes vicios: la lujuria, la pereza, la gula, la ira, la envidia, la avaricia y la soberbia. La misma también se conoce como los pecados capitales por el hecho de que estos vicios pueden conducir a la práctica de otros vicios y actos $\operatorname{pecaminosos}^{27}$.

\subsection{Virtudes vs. Vicios: yuxtaposición de las fuerzas}

Los vicios y virtudes como conceptos abstractos son producto del pensamiento de distintos filósofos y teólogos. En los casos antes expuestos se aprecia el desarrollo de dichos conceptos de manera individual. San Agustín en su discusión sobre la definición ciceroniana de las virtudes afirma que, que en la práctica de la virtud se deben evitar aquellas cosas opuestas o las que parecen próximas y semejantes a la virtud y no lo son:

\footnotetext{
"Se deben evitar por sí mismas no sólo las cosas que les son opuestas, como la cobardía a la fortaleza, y la injusticia a la justicia, sino también aquellas cosas que parecen próximas y semejantes, pero que son muy diferentes. Así, la desconfianza es algo contrario a la confianza y por eso mismo es un vicio; la audacia no es algo contrario, sino cercano y próximo a la confianza, y con todo es un vicio. De este modo, a cada virtud se le puede encontrar un vicio
}

\footnotetext{
${ }^{25}$ NEWHAUSER. The Treatise on Vices and Virtues..., pp. 108-109.

26 "Deadly Sins", en The New Catholic Encyclopedia. Tomo. 4. 2da edición. Washington: Thomson \& Gale, 2003. p. 565.

27 "Deadly Sins", en The New Catholic Encyclopedia. Tomo. 4. 2da edición. Washington: Thomson $\&$ Gale, 2003. p. 565.
} 
contiguo, sea designado con un nombre concreto, como la audacia que está muy cerca de la confianza, la terquedad de la perseverancia, la superstición que está muy próxima a la religión, sea designado sin nombre alguno preciso ${ }^{28}$ ".

Ya Tertuliano en el siglo II había hecho una corta alusión a estas fuerzas opuestas. En su tratado moral De Spectaculis, en el cual aconseja a los cristianos a no asistir a los espectáculos romanos, afirma que la lucha que ellos han de contemplar es la de la impureza derrocada por la castidad, la perfidia muerta por la fe, la crueldad aplastada por la compasión y la insolencia echada a la sombra por la modestia, por la cual serán coronados ${ }^{29}$. A pesar de las referencias en los trabajos de Agustín y Tertuliano a estos comportamientos como actitudes opuestas, la yuxtaposición o el tratamiento de los vicios y virtudes como fuerzas antagónicas es producto de la literatura tardo antigua y medieval.

La primera referencia literaria dedicada exclusivamente al tema de los vicios y las virtudes y en la que dichos conceptos morales aparecen como antagónicos es el poema de la Psychomachia, cuyo título se traduce por Batalla del alma o Combate de vicios y virtudes ${ }^{30}$. Este poema alegórico fue escrito a finales del siglo $\mathrm{V}$ por el poeta hispano latino Aurelio Clemente Prudencio. En su obra, Prudencio convirtió los conceptos abstractos de vicios y virtudes en figuras alegóricas. A través del poema se presentan siete batallas entre diversos vicios y virtudes: Fe e Idolatría, Castidad y Lujuria, Paciencia e Ira, Humildad y Soberbia, Sobriedad y Molicie, Caridad y Avaricia, Concordia y Discordia. Básicamente en cada escena se narra la lucha entre las fuerzas opuesta y como las virtudes vencen a sus enemigas los vicios. A pesar de que no se conoce con exactitud para quién o con qué propósito Prudencio

\footnotetext{
${ }^{28}$ SAN AGUSTín. De diversis quaestionibus octoginta tribus, XXXI, 2. Edición consultada: "Ochenta y tres cuestiones diversas", en Obras completas de San Agustín, XL..., p. 98.

${ }^{29}$ Tertuliano. De Spectaculis, 29. Edición consultada: Tertullian, Apology, De Spectaculis. Traducción de: T.R. Glover. Cambridge: Harvard University Press, 1977.

${ }^{30}$ Helen Woodruff traduce Psychomachia por: "The War of the Soul", La batalla del alma. Richard Newhauser se refiere a ella como "Battle of Vices and Virtues", Batalla de vicios y virtudes. Newhauser. The Treatise on Vices and Virtues..., p. 161. WOODRUFF, Helen. "The Illustrated Manuscripts of Prudentius", Art Studies (1929), p. 34.
} 
escribió la Psychomachia, el poeta establece que la finalidad de su obra es proveer al lector de las distintas herramientas que le ayudarán a combatir los vicios y/o pasiones que le acechan que el lector aprenda a reconocer estos monstruos y pueda discernir cual el modo de vencerlos: "El modo de vencer está al alcance nuestro, si podemos describir de cerca las figuras mismas de las virtudes y los monstruos que contra ellas luchan con fuerzas perniciosas ${ }^{31}$ ". A pesar de que no todas las batallas corresponden a los vicios y virtudes establecidos en las distintas listas de los primeros siglos de la cristiandad, la noción de la lucha entre fuerzas antagónicas establecida en la Psychomachia influenciaría el pensamiento, la literatura y el arte de los siglos venideros.

El poema de Prudencio, la Psychomachia, es una de las primeras alegorías medievales ${ }^{32}$, sirviendo durante toda la época medieval de fuente de inspiración para un sin número de obras literarias y representaciones alegóricas del tema. Según Richard Newhauser la Psychomachia fue una de las principales fuentes de inspiración para los posteriores autores de tractatus de vitiis et virtutibus (tratados de vicios y virtudes $)^{33}$, tratados que fueron sumamente populares durante toda la Edad Media y alrededor de todo el continente europeo. Fueron escritos en distintas regiones geográficas en latín y lengua vernácula ${ }^{34}$. Entre estos se encuentran el trabajo de William Perault, Summa de virtutibus et vitiis (1236) y el Somme le roi (1279) de Laurent d'Orléans. Este tipo de texto se estructuran a través del uso de los vicios y las virtudes como personas dramáticas en el caso de las moralidades y en trabajos

\footnotetext{
${ }^{31}$ Prudencio, Aurelio. Psychomachia, vv. 18-20. Edición consultada: Obras Completas de Aurelio Prudencio, traducción de: A. Ortega, introducción general de: I. Rodríguez. Ed. bilingüe. Biblioteca de Autores Cristianos 427. Madrid: Editorial Católica, 1981.

32 "Allegory", en VAuCHEZ, André (ed.). Encyclopedia of the Middle Ages. Vol. II, A-J. Cambrige: James \& Clarke Co., 2000. p. 44. NoRmAN, Joanne S. Metamorphoses of an Allegory: The Iconography of the Psychomachia in Medieval Art. New York: P. Lang, 1988. p. 1.

33 "It is obvious that Prudentius's Psychomachia was a major source of inspiration for authors of treatises on the vices and virtues". NEWHAUSER. The Treatise on Vices and Virtues..., p. 161.

${ }^{34}$ Para una lista complete de los tratados de vicios y virtudes en latín y vérnaculo ver: NEWHAUSER, Richard. A Supplement to Morton W. Bloomfield et al.: "Incipits of Latin Works on the Virtues and Vices, 1100-1500 A.D.”. Turnhout: Brepols, 2008. NEWHAUSER, Richard. The Treatise on Vices and Virtues in Latin and the Vernacular. Turnhout, Belgique: Brepols, 1993. BLOOMFIELD, Morton W. Incipits of Latin Works on the Virtues and Vices, 1100-1500 A.D.: Including a Section of Incipits of Works on the Pater Noster. Cambridge: The Medieval Academy of America, 1979.
} 
narrativos como alegorías de estas personificaciones. En muchos casos los tractatus de vitiis et virtutibus utilizaron la metáfora de la lucha o una personificación para educar en moral a los iletrados ${ }^{35}$.

La Psychomachia no sólo incidió en la producción de otras obras literarias, sino que también es el texto que más representaciones alegóricas inspiró en toda la Edad Media. Los ejemplos más antiguos que sobreviven hoy en día son del siglo IX y corresponden a las miniaturas de manuscritos iluminados de la Batalla del alma. Sin embargo, hay historiadores del arte que afirma que ya tan temprano como en el siglo $\mathrm{V}$ debieron existir códices miniados del poema y por lo tanto representaciones de dichas alegorías ${ }^{36}$. La Psychomachia no sólo inspiraría representaciones alegóricas basadas en el texto de Prudencio, sino que también fue la fuente de inspiración para nuevas obras literarias que a su vez producirían nuevas representaciones alegóricas de los vicios y las virtudes.

\subsection{Vicios y virtudes en el arte medieval}

El tema de los vicios y las virtudes es uno que a lo largo de la historia ha intrigado a los hombres. Fue sumamente representado en el arte medieval e incluso se continuó utilizando, en otras épocas, el mismo hoy en día pervive por ejemplos en representaciones de la Justicia. Las personificaciones de estos conceptos morales durante la Edad Media gozaron de un significado profundo y a la misma vez eran la

\footnotetext{
${ }^{35}$ NEWHAUSER. The Treatise on Vices and Virtues..., p. 90.

${ }^{36}$ SteTtineR, Richard. Die Illustrierten Prudentiushandschriften. Berlin: Druck von J.S. Preuss, 1895. p. 151. MÂLE, Émile. El arte religioso del siglo XIII en Francia: el Gótico. Madrid: Encuentro, [1898] 2001. p. 134. WoODRUFF, Helen. "The Illustrated Manuscripts of Prudentius". Art Studies (1929), pp. 34. KATZENELlEnBogen, Adolf. Allegories of the Virtues and Vices in Mediaeval Art, from Early Christian Times to the Thirteenth Century. New York: W.N. Norton \& Company, Inc., 1964. p. 1.
} 
vinculación directa el mundo antiguo con la cultura cristiana ${ }^{37}$. La riqueza icónica y semántica del tema hizo que durante toda la época medieval el mismo gozara de gran popularidad: convirtiéndose en el asunto central de muchas obras literarias de índole moral, filosófico, poético, etc. y plasmándose en un sin número de medios y contextos. En este período el tema se insertó en prácticamente todos los medios conocidos por los hombres que vivieron durante esta época, motivo por el cual se puede encontrar imágenes de los vicios y/o las virtudes en: manuscritos, objetos de orfebrería de toda clase y sobre todo de uso litúrgico, en las portadas de iglesias, en sepulcros, en tallas de madera, frescos, retablos, tapíces, etc. A priori, la presencia de los vicios y las virtudes en estos distintos medios se vincula directamente con la significación tropológica que estas personificaciones aportan al objeto en cuestión ${ }^{38}$. La representación de estos conceptos responde, a parte del medio en el que se plasman, al contexto y al público al que se encontraban destinadas.

\subsubsection{Plasmación pictórica}

Las representaciones más antiguas medievales de los vicios y las virtudes se encuentran en manuscritos, siendo éste uno de los medios en el que más plasmaciones se identifican. La primera obra escrita en la que se incluyen imágenes de estos conceptos morales es la Psychomachia de Prudencio. Hoy en día se conservan códices iluminados que van desde el siglo IX hasta el XIII. En los ejemplares más antiguos, llegamos a encontrar hasta noventa miniaturas que ilustran y acompañan los distintos versos del poema, con particular énfasis pictórico en las escenas en las que ambas fuerzas se enfrentan, y la victoria de la virtud (Miniaturas 1-90).

\footnotetext{
${ }^{37}$ ELSNER, Jas. Art and the Roman Viewer: The Transformation of Art from the Pagan World to Christianity. Cambridge: University Press, 1995. p. 7. PANOFSKY, Erwin. El significado en las artes visuales. Madrid: Alianza, 1985. pp. 59, 69.

38 "in order that they may convey a special meaning beyond that of their actual practical purpose, many things are finally imbued with moral significance". KATZENELLENBOGEN. Allegories of the Virtues and Vices in Mediaeval Art..., p. 50-51.
} 


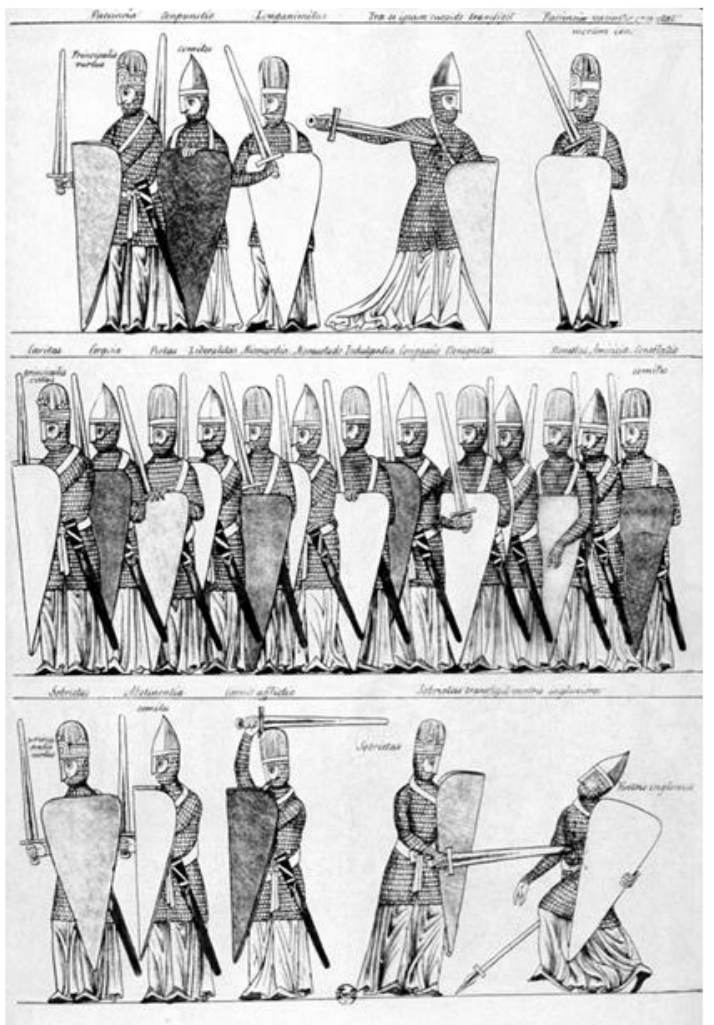

Figura 1. Psychomachia (c. 1170). Fol. 201r, Hortus Deliciarum.

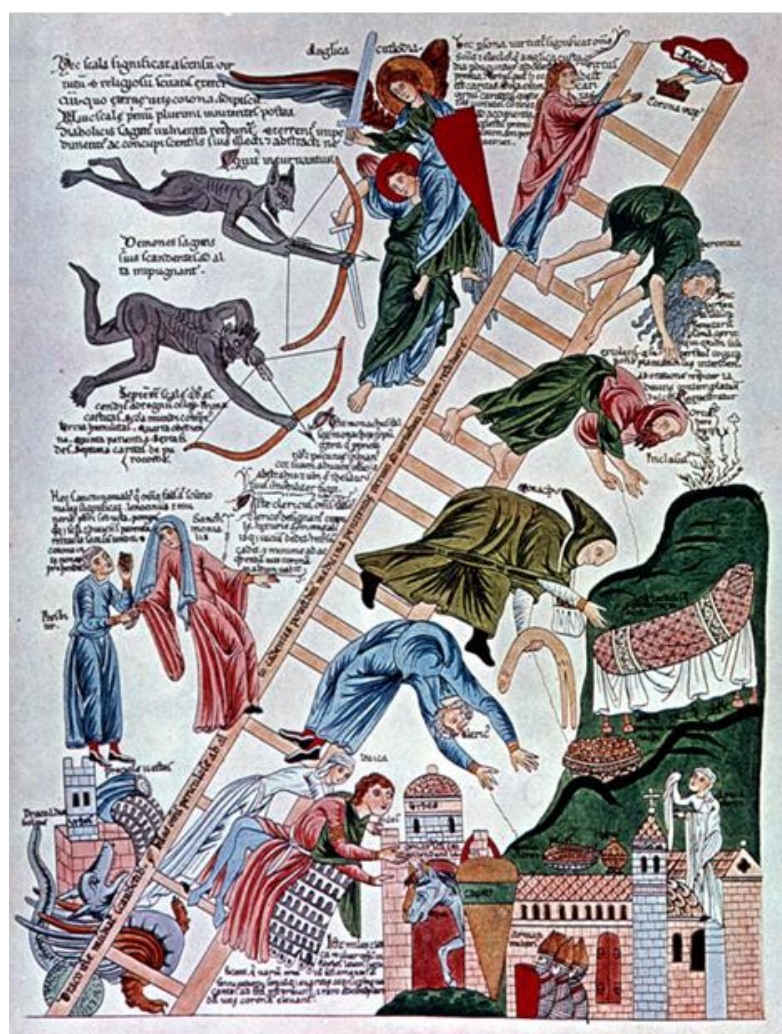

Figura 3. Escala de virtudes (c. 1170). Fol. 216r, Hortus Deliciarum.

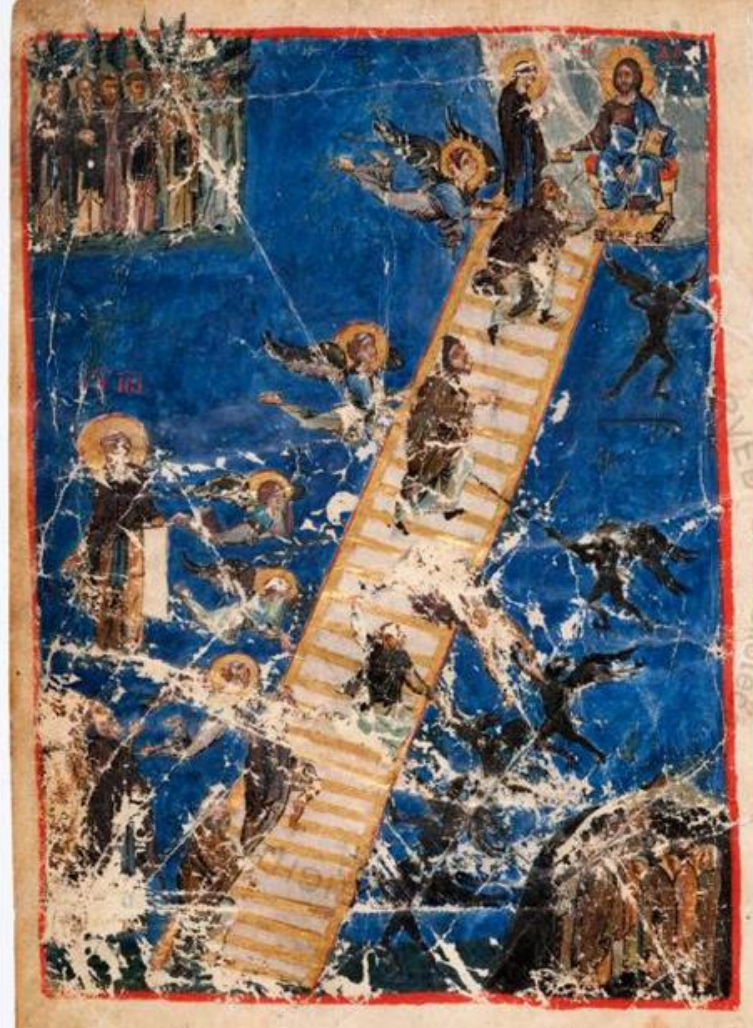

Figura 2. Scala Paradisi (Siglo XI). Vat. Gr. 394. Biblioteca Vaticana, Roma.

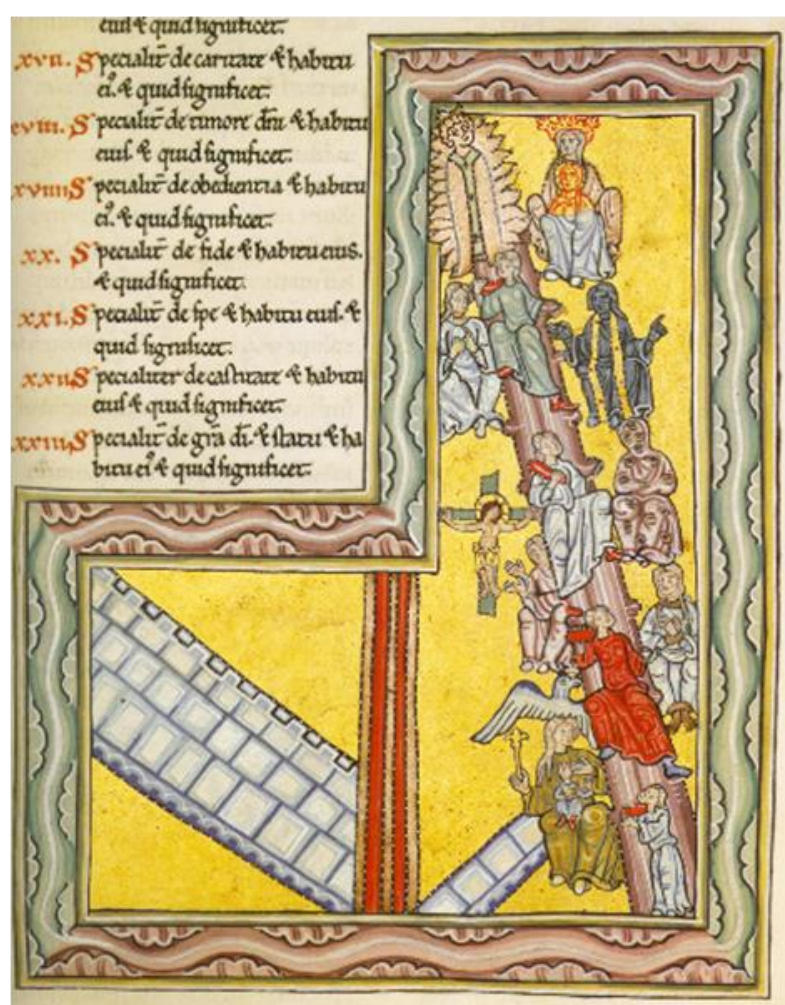

Figura 4. Escala de las virtudes (Siglo XII). Liber Scivias [Fáscimil]. Abadía de St. Hidelgarda, Eibingen. 
La importancia de las imágenes de los vicios y las virtudes en el poema de la Psychomachia, no sólo reside en el hecho de que son las imágenes más antiguas identificadas del tema, sino también que las mismas contribuyeron al desarrollo iconográfico, especialmente las miniaturas en las que se proyectan a las virtudes como guerreras o victoriosas sobre los vicios vencidos, sirviendo de modelo para la plasmación del tema en otros códices y eventualmente en la escultura monumental ${ }^{39}$. Además de los códices de la Psychomachia durante la Edad Media encontramos diversas obras literarias en las que se insertaron imágenes del tema. Algunas de éstas obras continuaron plasmando el momento de la batalla, uno de los ejemplos más famosos es el Hortus Deliciarum ${ }^{40}$ (siglo XII) de Herrada de Landsberg (Fig. 1). En el mismo se aprecia la lucha entre los ejércitos de los vicios y las virtudes.

La plasmación de los vicios y las virtudes en manuscritos no se limitó al combate de estas personificaciones. Igualmente surgieron nuevas iconografías del tema las cuales se vinculan directamente con la alegoría o con la narrativa que el autor construyó en el texto. Una de las primeras es la plasmación visual de la Scala Paradisi de Juan Climáco (siglo VI) en un manuscrito del siglo XI. En el texto se recoge cómo el hombre asciende a Dios por medio de una escalera, en el trayecto éste es ayudado por las distintas virtudes las cuales le auxilian en su acometido mientras que por otra parte los diferentes vicios tratan de hacerle caer de la escalera para que no llegue al cielo. La miniatura más antigua del tema sobrevive en un manuscrito del siglo XI (Fig. 2) ${ }^{41}$. El texto de Climáco se inspira en la visión de Jacob en Génesis 28: 1242. Junto a la Psychomachia, la Scala Paradisi, también llamada la Escalera de las virtudes o Escala de las virtudes sirvió como inspiración para los escritos y

\footnotetext{
${ }^{39}$ Ver: NORMAN, Joanne S. Metamorphoses of an Allegory: The Iconography of the Psychomachia in Medieval Art. New York: P. Lang, 1988. KAtZENELLENBOGen. Allegories of the Virtues and Vices in Mediaeval Art..., pp. 1-13.

${ }^{40}$ El manuscrito original del siglo XII fue destruido en un incendio a finales del siglo XIX, hoy en día sólo se conservan algunas fotos del mismo y folios fáscimiles realizados a principios del siglo XIX.

${ }^{41}$ Cod. Gr. 394, Bibliotieca Vaticana, Roma. KatZenellenbogen. Allegories of the Virtues and Vices in Mediaeval Art..., p. 22.

42 "Y tuvo un sueño; soñó con una escalera apoyada en tierra, y cuya cima tocaba los cielos, y he aquí que los ángeles de Dios subían y bajaban por ella".
} 
visiones de otros autores. En el compendio enciclopédico del Hortus Deliciarum además de la lucha entre vicios y virtudes se incluyó este motivo iconográfico (Fig. $3)$.

Otro ejemplo en el que se inserta la escala es en el Liber Scivias (1175) de la monja Hildegarda de Bingen ${ }^{43}$, en el que se recogen las visiones de ésta. Al texto le acompañan distintas miniaturas que visualmente plasman lo expresado por medio de la palabra escrita, siendo uno de los motivos el de la escala (Fig. 3). En el Liber Scivias también encontramos otras iconografías de las virtudes directamente inspiradas en las visiones de Hildegarda descritas en el texto como lo es la torre de las virtudes (Fig. 5) ${ }^{44}$.

A partir de finales del siglo XIII se comienzan a utilizar imágenes de los vicios y las virtudes en textos en lengua vernácula, cuya plasmación se ha desvinculado de los textos anteriores. Uno de estos primeros es el tratado Somme le roi (1279) escrito por el fraile dominico Laurent para el rey de Francia Felipe III. En el mismo se compilan los elementos de la fe que todo cristiano debe conocer como: los Diez Mandamientos, el Credo, y los vicios y las virtudes. La copia miniada más antigua que hoy en día se conserva es de 1294. De la serie de quince miniaturas, en siete se recogen representaciones de las virtudes como damas coronadas, acompañadas por el vicio contrario y escenas que representan la práctica de ambos conceptos (Fig. 6). Gracias a su gran popularidad durante la Edad Media fue traducido al provenzal, italiano, inglés y al neerlandés, además de sobrevivir un considerable número de copias iluminadas del texto ${ }^{45}$.

\footnotetext{
${ }^{43}$ El manuscrito original, iluminado bajo la supervisión de Hidelgarda durante la Segunda Guerra Mundial se perdió. De este códice miniado hoy en día se conserva un facímil elaborado antes de su desaparición por las monjas de la abadía de San Hidelgarda en Eibingen.

${ }^{44}$ KAtZenellenbogen. Allegories of the Virtues and Vices in Mediaeval Art..., pp. 42-44.

${ }^{45}$ TUVE, Rosemond. "Notes on the Virtues and Vices, Part II." Journal of the Warburg and Courtauld Institutes Vol. 27 (1964), pp. 42-43.
} 


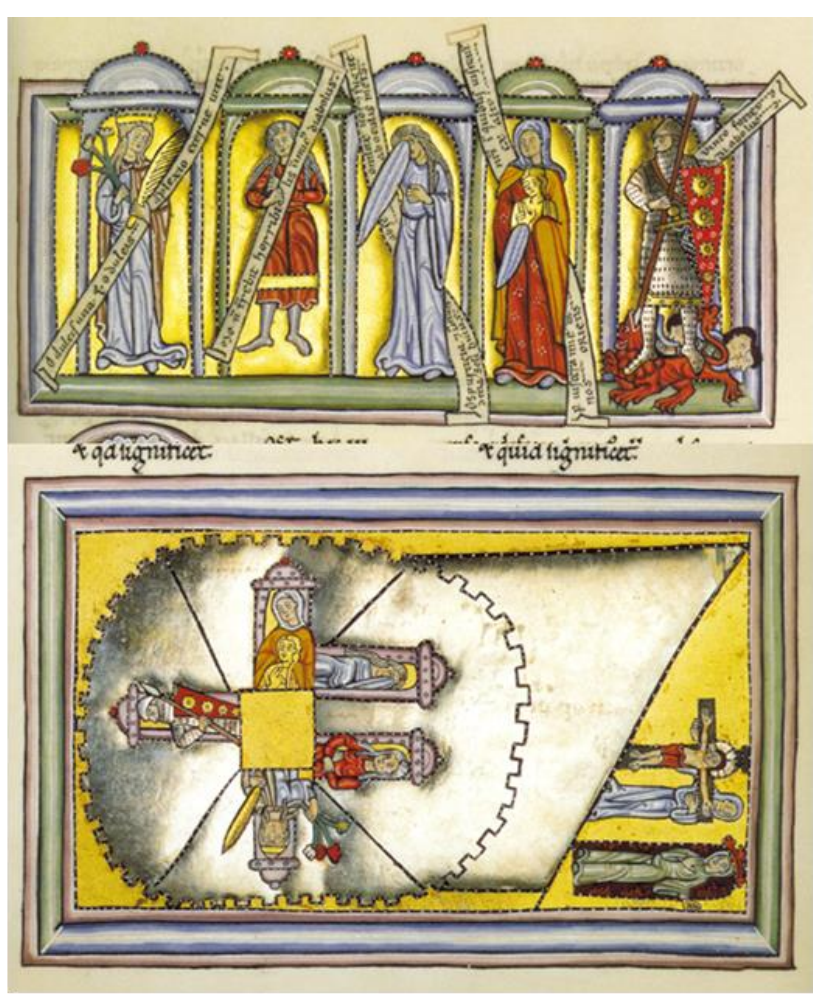

Figura 5. Torre de las virtudes (Siglo XII). Dos miniaturas del Liber Scivias [Fáscimil]. Abadía de St. Hidelgarda, Eibingen.

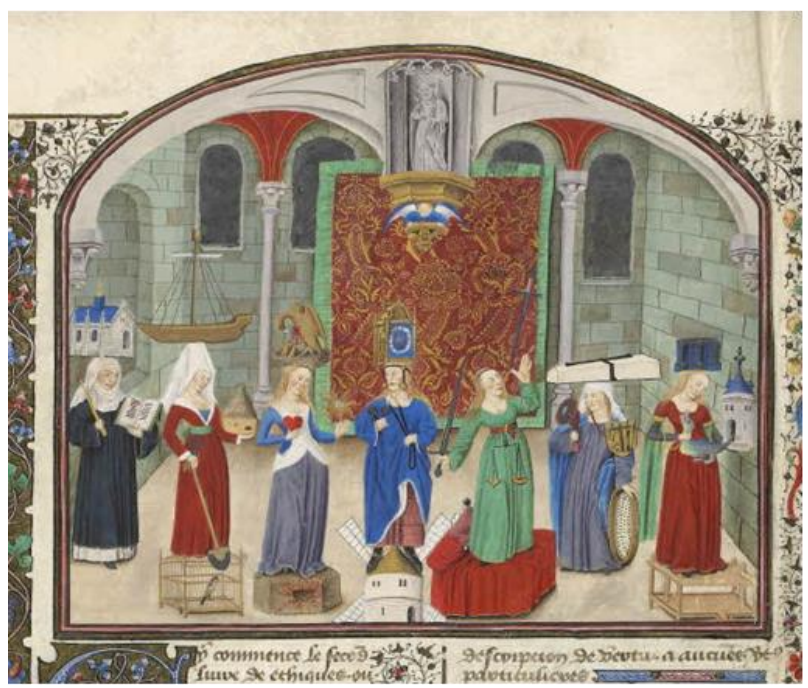

Figura 7. Virtudes cardinales y teologales (Siglo XV). Ética de Aristóteles. Fol. 17v, Ms. I.2. Bibliothèque Municipale, Rouen.

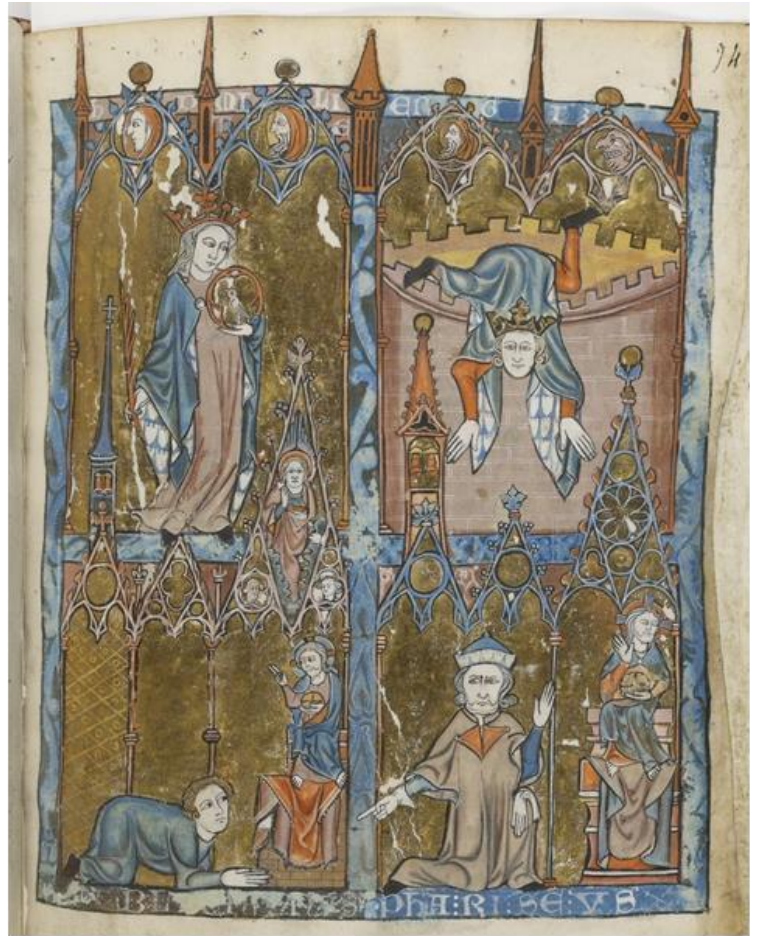

Figura 6. Humildad y Orgullo (1294). Somme le roi. Fol. 74r, Ms. Fr. 938. Biblioteca Nacional de Francia, París.

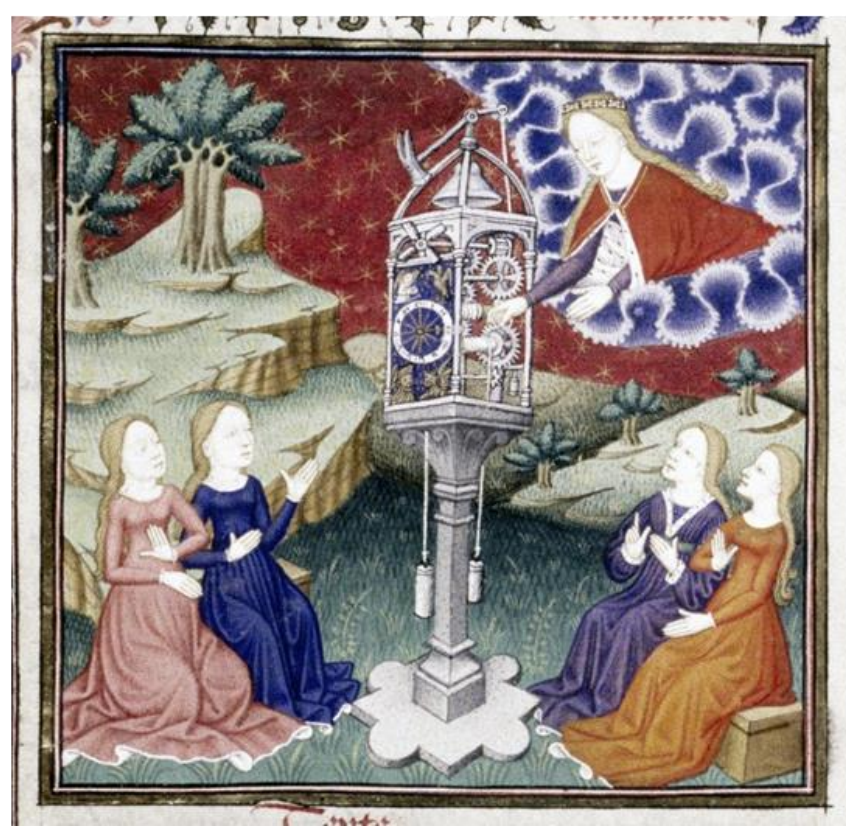

Figura 8. Templanza (c. 1450). Epitre d'Othéa. Fol. 28v, Ms. Laud. Misc. 570. Bodleian Library, Oxford. 
Algunos ejemplos más tardíos sobre representaciones de las virtudes en manuscritos pertenecen al siglo XV. En estos encontramos un cambio iconográfico radical, donde ahora sólo aparecen las virtudes sujetando una serie de atributos. Miniaturas de estas nuevas virtudes decoran el inicio de los libros de la Ética de Aristóteles de una traducción al francés realizada por Nicolas Oresme (Fig. 7) ${ }^{46}$, las iluminaciones del Laud misc. 570 que incluye el trabajo de Christine de Pizan Epitre d'Othéa (1400) y un tratado en francés de virtudes identificado como Livre des quatre Vertus Cardinaulx (Figs. 8 y 9) ${ }^{47}$ o varios manuscritos con la traducción al francés de Jean Courtecuisse de De Quatuor virtutibus de Sénèque (1470) y la recopilación histórica de Jean Mansel La Fleur des Histoires de 1467 (Fig. 10) ${ }^{48}$.

El contexto en el que se utilizan las distintas representaciones de los vicios y las virtudes en manuscritos es variado. Cada manuscrito, tiene un contexto y un público específico. Estas imágenes alegóricas responden y se asocian al público al que apelan e igualmente se vinculan directamente con el texto al que acompañan y con elementos más intrínsecos como la distribución de las mismas en el códice. Los manuscritos de la Psychomachia, el Hortus Deliciarum y el Liber Scivias (Figs. 3, 4 y 5) fueron creados en importantes abadías de distintas partes del continente europeo y sus usuarios debieron ser los miembros de estas comunidades de religiosos. Herrada de Landsberg compuso el Hortus Deliciarum para que las monjas, especialmente las novicias, de la abadía de Hohenburg, aprendieran conocimientos bíblicos, morales y teológicos. Algo similar ocurrió con el Liber Scivia de Hidelgarda.

En cuanto a las miniaturas de vicios y virtudes en códices en lengua vernácula el público o los comitentes de estas obras ha cambiado, en lugar de vincularse al contexto monacal ahora vemos que se encuentran dirigidas a un público noble cortesano. El Somme le roi (Fig. 6) fue escrito para el rey Felipe III y a pesar de que

\footnotetext{
${ }^{46}$ Ms. I 2, signatura antigua Ms. 927 (Bibliothèque Municipale, Rouen).

${ }^{47}$ Ms. Laud. Misc. 570 - Bodleian Library, Oxford. Harley Ms. 4431 - British Museum, Londres.

${ }^{48}$ Ms. Fran. 9186 (Bibliothèque Nationale de France, París). Ms. 282 (Bibliothèque du château de Chantilly). De quatuour virtutibus cardinalibus durante la Edad Media fue erroneamente atribuido a Séneca. Éste tratado realmente recoge el trabajo de Martín de Braga, Formula vitae honestae.
} 
no se conserva esa primera copia, si se sabe que la misma se encontraba ilustrada ${ }^{49}$. La carrera literaria de Chrsitine de Pizan se desarrolló entre las cortes de Luis de Orleans, Felipe II de Borgoña, Juan I de Borgoña y el rey Carlos VI de Francia. Jean Courtecuisse dedicó su traducción al francés de De Quatuor virtutibus de Sénèque (Fig. 10) al duque de Berry. Jean Mansel trabajó cerca del entorno de Felipe III, duque de Borgoña y su trabajo La Fleur des Histoires es una compilación histórica que va desde la Creación hasta el reinado de Carlos VI de Francia (Fig. 10). Las imágenes de las virtudes en estos textos se insertan en distintos tratados y textos de contenido alegórico y moral, en los cuales se resaltan las cualidades morales de un buen gobernante claramente apelando a la idea de espejo de príncipes tan popular durante esta época.

Aunque con menos ejemplos, bien sea por desconocimiento o porque los mismos no han llegado hasta nosotros, la plasmación pictórica de los vicios y las virtudes se extendió a la pintura al fresco y de tabla. Una de las representaciones más tempranas son los frescos de Giotto di Bondone en la Capilla Scrovegni en Padua (1305) (Fig. 11). En éste se representan las siete virtudes y siete vicios en grisalla, simulando esculturas de tamaño natural. Estas catorce imágenes forman parte de un ciclo de frescos dedicado a la vida de la Virgen y Cristo que decoran la capilla. A pesar de ser un ejemplo en pintura, el contexto en el que se plasmaron estos conceptos morales es de uso funerario, después de todo Enrico Scrovegni la construyó como lugar de descanso eterno para él y su descendencia, uso funerario ${ }^{50}$, y la manera de representarse los vicios y las virtudes emula la escultura. Por lo tanto, al igual que las esculturas en sepulcros ${ }^{51}$, el significado de los vicios y virtudes de Giotto por su ubicación sirven de soporte al resto del programa iconográfico, pero igualmente se vinculan directamente con el mecenas, cuyo sepulcro se encuentra en el altar.

\footnotetext{
${ }^{49}$ TUVE. "Notes on the Virtues and Vices, Part II..., p. 42.

${ }^{50}$ HARrison, Charles. "The Arena Chapel: Patronage and Authorship", en: Siena, Florence and Padua, art, society and religion 1280-1400. Vol. II, Case studies, ed. D. Norman. New Haven: Yale University Press, 1995. pp. 88-90. JACOBUS, Laura. "The Tomb of Enrico Scrovegni in the Arena Chapel, Padua". The Burlington Magazine, Vol. 154, No. 1311 (2012). p. 403.

${ }^{51}$ El tema de los vicios y las virtudes se discutirá con más detenimietno en el apartado 1.3.2.
} 


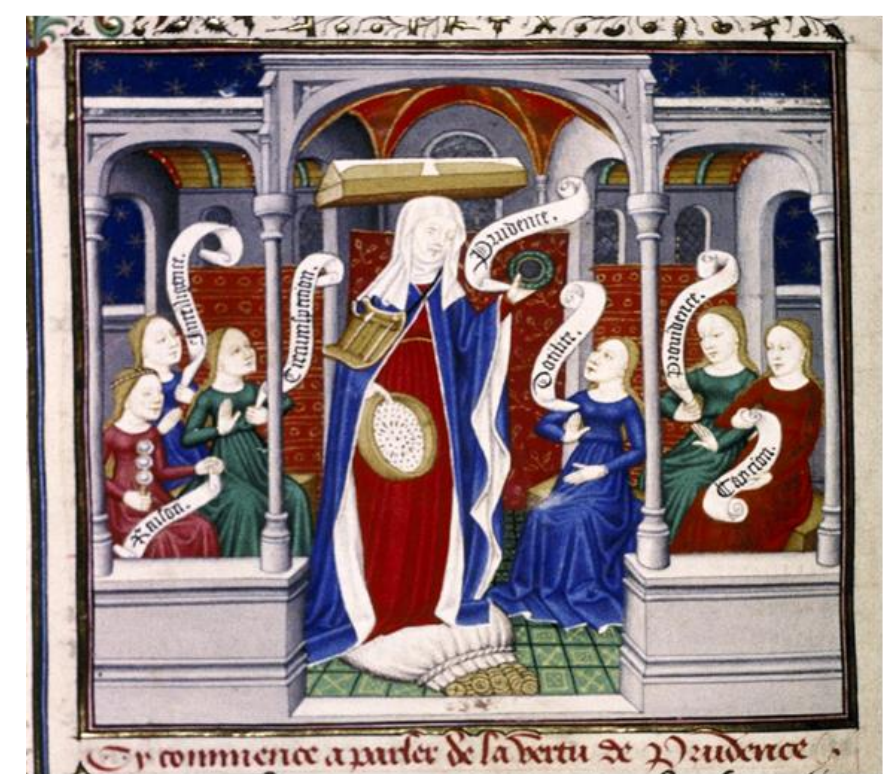

Figura 9. Prudencia (c. 1450). Livre de quatre vertu Cardinaulx. Fol. 9v, Ms. Laud. Misc. 570. Bodleian Library, Oxford.

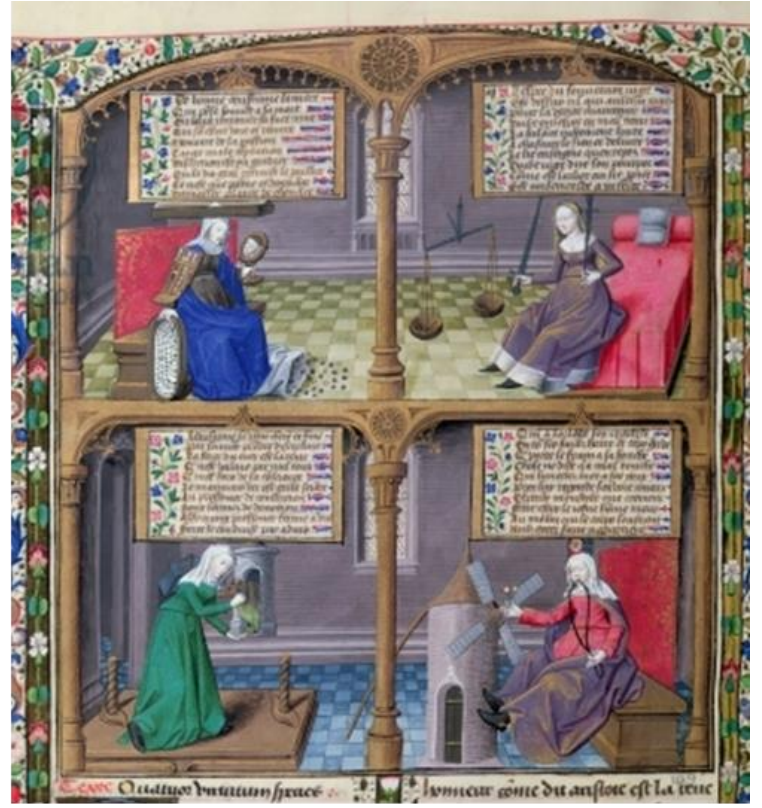

Figura 10. Virtudes cardinales (1470). De Quatuor virtutibus de Sénèque y La Fleur des Histoires. Fol. 240v Ms. 282.

Bibliothèque du château de Chantilly.

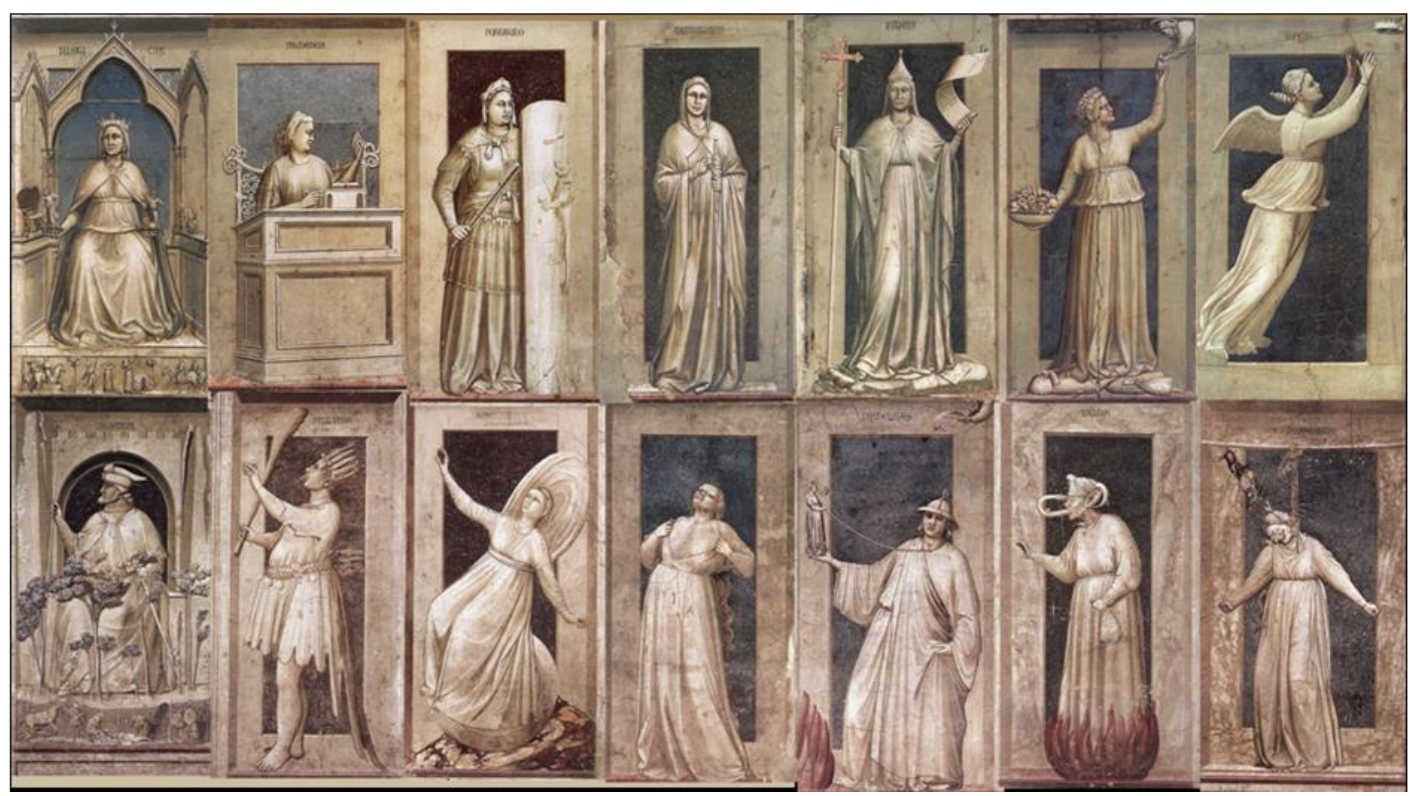

Figura 11. De izquierda a derecha, de arriba abajo: Justicia, Prudencia, Fortaleza, Templanza, Fe, Caridad, Esperanza, Injusticia, Locura, Inconstancia, Ira, Idolatría, Envidia y Desesperación. (1305). Giotto di Bondone. Fresco. Capilla Scrovegni, Padua. 


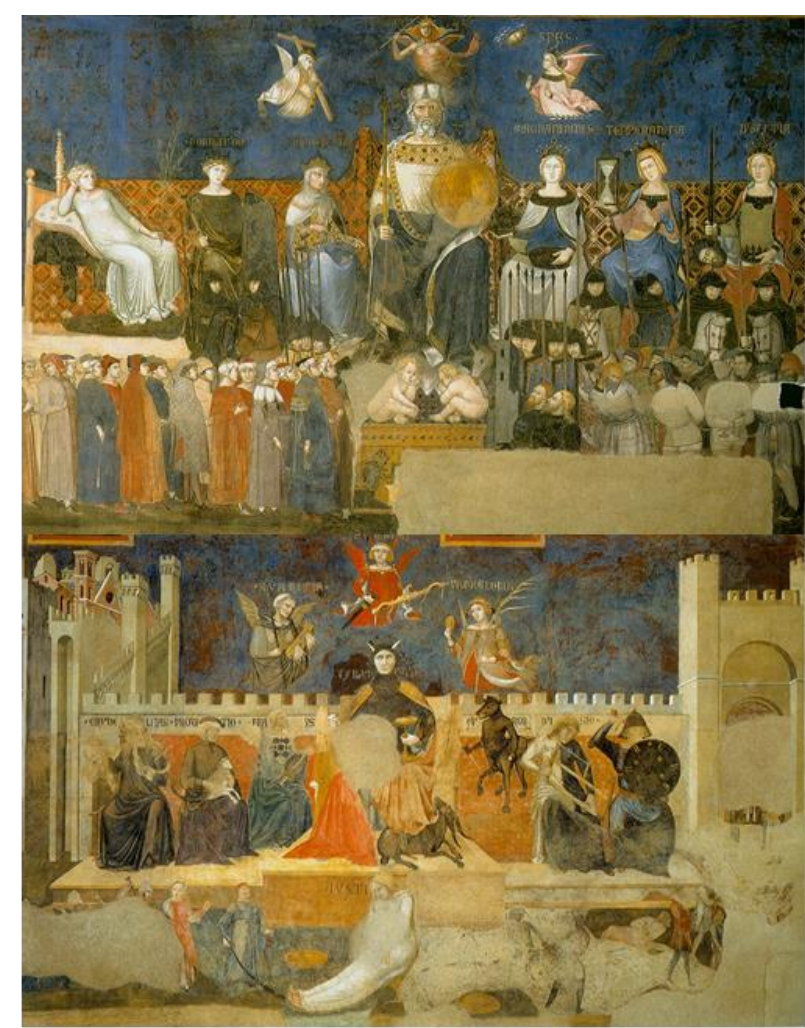

Figura 12. Virtudes en la Alegoría del buen Gobierno y Vicios en la Alegoría del mal gobierno (1139). Ambrogio Lorenzetti. Fresco. Palacio Público de Siena.

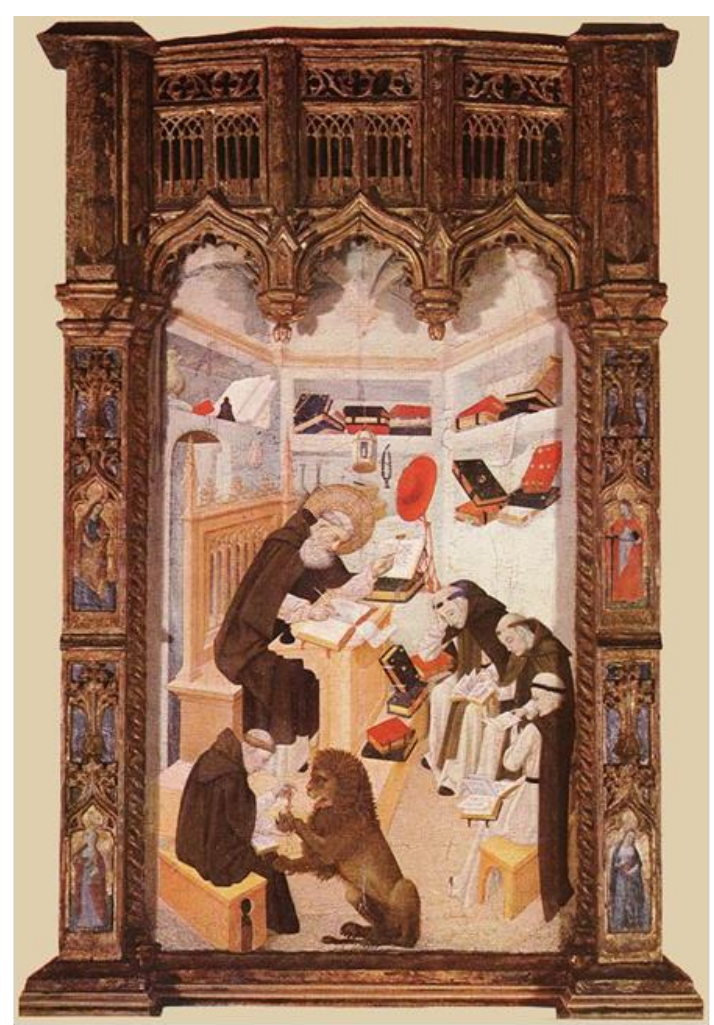

Figura 13. San Jerónimo en su celda (1450). Nicolas Francés. Pintura sobre tabla. National Gallery of Ireland, Dublín.

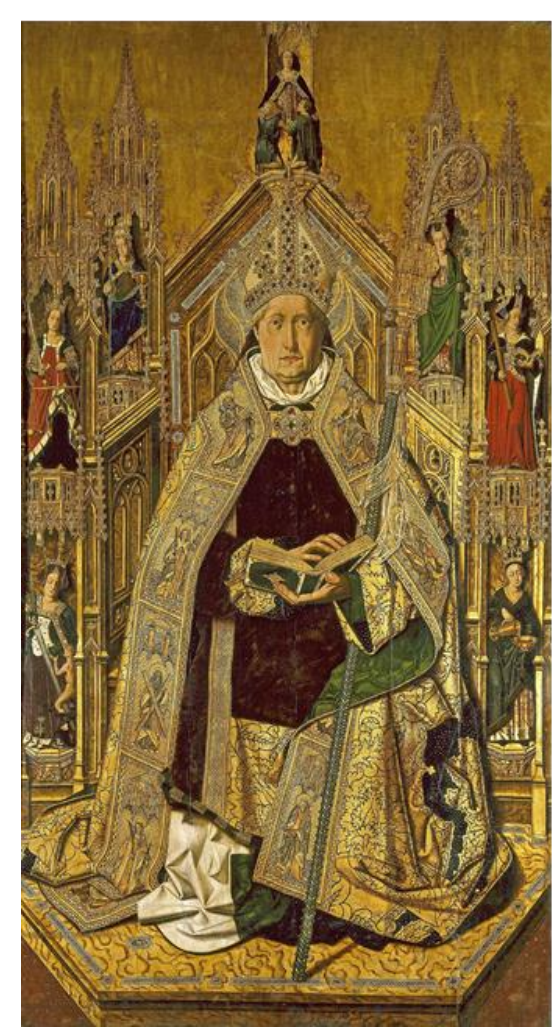

Figura 14. Santo Domingo de Silos entronizado como obispo (1474-1477). Bartolomé Bermejo . Pintura sobre table. Museo del Prado, Madrid.

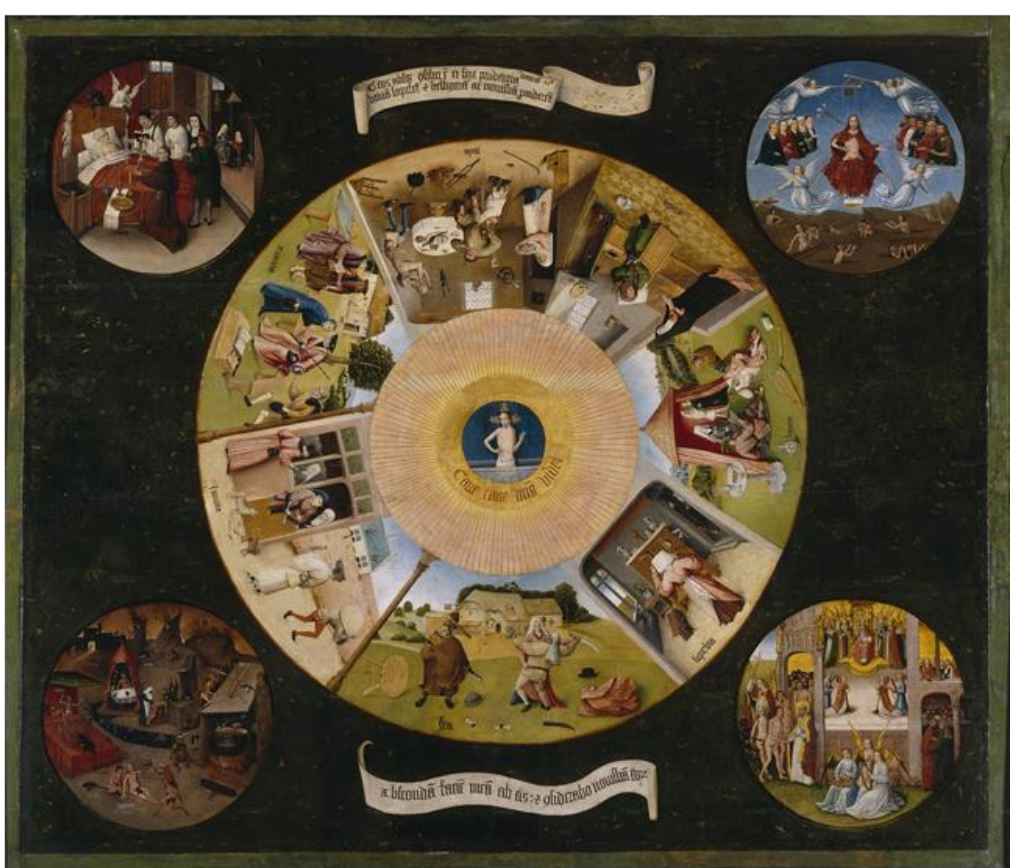

Figura 15. Mesa de los pecados capitales (1505-1510). Jheronimus Bosch. Museo del Prado, Madrid. 
La obra de Giotto influiría en el trabajo de otros artistas, no sólo estilísticamente sino también por la elección de temas. De 1339 la Alegoría del buen y el mal gobierno de Ambrogio Lorenzetti (Fig. 12). Por una parte, en las escenas del buen gobierno se encuentran las virtudes como guías del buen gobernante y en su contraposición se encuentran el orgullo, la soberbia y la vana gloria sobre la cabeza del tirano del mal gobierno.

La plasmación de estas personificaciones en los distintos frescos responde directamente al espacio y el discurso icónico en el que se insertan. En el caso de la obra de Lorenzetti, se incluyen en un contexto civil, como exemplum de cuales son las cualidades morales que se deben tener para el buen devenir del gobierno, o sea la práctica de las virtudes por parte de los gobernantes tienen como resultado estabilidad y buen porvenir mientras que la gobernanza motivada por los actos viciosos tiene como resultado todo lo contrario.

Algunos ejemplos en pintura sobre tabla que hemos podido identificar en los cuales bien se plasman las virtudes o bien los vicios son: San Jerónimo en su celda (1450), atribuido a Nicolás Francés (Fig. 13) ${ }^{52}$, Santo Domingo de Silos entronizado como obispo (1474-1477) de Bartolomé Bermejo (Fig. 14) y la Mesa de los pecados capitales (1505-1510) del Bosco (Fig. 15). En los primeros dos ejemplos la figura central a la que las virtudes acompañan son santos. La composición de la obra y el número de virtudes representadas podrían transmitir distintas ideas. A priori, en ambos casos, como en los sepulcros de santos anteriormente mencionados, es una exaltación a la figura del protagonista como un hombre virtuoso.

Las virtudes teologales y cardinales junto a la figura entronizada de santo Domingo de Silos (Fig. 14), al igual que en los sepulcros, visualmente exaltan cómo fueron el soporte moral de la vida del santo por el cual el individuo ganó dicho apelativo $^{53}$. En el caso de San Jerónimo en su celda (Fig. 13), se insertaron las virtudes cardinales heredadas del pensamiento de los filósofos de la antigüedad y el

\footnotetext{
${ }^{52}$ Esta obra de Nicolás Francés actualmente se encuentra en el National Gallery of Ireland, en Dublín.

${ }^{53}$ Moskowitz. “A Tale of Two Cities..., p. 4. Franco Mata. "Arte y literatura..., p. 25.
} 
protagonista de la obra se encuentra en plena faena literaria. Estas cuatro cualidades morales se relacionan directamente con la inteligencia, la prudencia era considerada una virtud intelectual que conduce a la práctica del resto de las virtudes esenciales para la vida cristiana ${ }^{54}$. Por lo tanto, la plasmación de las personificaciones heredadas del mundo clásico, en conjunto con las acciones de las figuras en la obra, exaltan los procesos cognitivos que conducen a la sabiduría.

La Mesa de los pecados capitales (Fig. 15) se representan siete escenas que muestran los distintos actos viciosos que conducen a cometer los pecados capitales. La misma se inserta en la tradición de los espejos morales, siendo un espejo de pecadores en el que el espectador podía contemplar la conducta de actos viciosos que le podrían ganar la condenación eterna ${ }^{55}$.

\subsubsection{Proyección escultórica}

La plasmación de las virtudes y los vicios de los manuscritos iluminados a principios del siglo XII se trasladó la escultura monumental, específicamente en las fachadas de templos. El cambio de medio requirió igualmente un cambio del lenguaje icónico, y para que esto fuera posible los escultores románicos simplificaron y sintetizaron el poema en un momento específico de la narrativa: el final del combate y el triunfo de las virtudes sobre los vicios ${ }^{56}$. En las arquivoltas de las portadas de iglesias románicas, usualmente en números pares que responden al resto del programa

${ }^{54}$ CICERÓN. De Inventione, II, 53, 160. Edición consultada: La invención retórica, trad. de S. Núñez...

${ }^{55}$ GIBSON, Walter S. "La "Mesa de los pecados capitales": muerte, juicio y eternidad", en: El Bosco y la tradición pictórica de lo fantástico. Barcelona: Galaxia Gutenberg, 2006. pp. 168-169.

${ }^{56}$ En su revisión al trabajo de Paul Deschamps, Pierre Bouffard coincide con éste y admite que dada las limitaciones del medio los escultores tuvieron que simplificar el tema. BOUFFARD, Pierre. "La Psychomachie sur les portails romans de la Saintonge" Zeitschrift Für Schweizerische Archäologie Und Kunstgeschichte = Revue Suisse D'art et D'archéologie = Rivista Svizzera D'arte E D'archeologia = Journal of Swiss Archeology and Art History, Vol. 22 №. 1-3 (1962), p. 19. DESCHAMPS, Paul. Le combat des vertus et des vices sur les portails romans de la Saintonge et du Poitou. Caen: Henri Delesques, Imprimeur-Éditeur, 1914. p. 4. 
iconográfico, se aprecian las virtudes vestidas como guerreras: con cota de malla, espada, escudo o lanza, aplastando a los vicios vencidos (Figs. 16, 17, 18 y 19).

Estas representaciones escultóricas de los vicios y las virtudes gozaron de gran popularidad en el sur-oeste de Francia, zona en la que se encuentran los primeros ejemplos en las primeras décadas del siglo XII ${ }^{57}$. Según Katzenellenbogen el ejemplo más temprano, con fecha de 1130, se encuentra en las arquivoltas del arco de una ventana del transepto sur de la iglesia de St. Pierre d'Aulnay (Fig. 16) ${ }^{58}$. En éste y otros ejemplos en los arcos de las ventanas de algunos templos como en la iglesia de Gripperie-Saint-Symphorien o Saint-Nazaire de Corme-Royal (Figs. 17 y 18), junto a las arquivoltas en las que se insertaron las virtudes triunfantes se incluyen elementos decorativos $^{59}$. Eventualmente pasó a representarse en la fachada principal de estos templos en conjunto con otros motivos iconográficos, cómo los Ancianos del Apocalipsis, el Cordero con ángeles, las vírgenes sabias y necias, el zodiaco o temas apocalípticos (Fig. 19) ${ }^{60}$.

\footnotetext{
${ }^{57}$ Bouffard, Pierre. "La Psychomachie sur les portails romans..., p. 19. KATZENELLENBOGEN. Allegories of the Virtues and Vices in Mediaeval Art..., p. 58. DESCHAMPS. Le combat des vertus et des vices sur les portails romans..., p. 3.

${ }^{58}$ KATZENELlenbogen. Allegories of the Virtues and Vices in Mediaeval Art..., p. 17. DesChAMPS. Le combat des vertus et des vices sur les portails romans..., pp. 5-6.

${ }^{59}$ Bouffard apunta al carácter sumamente "decorativo" (décoratif) del tema en la iglesia de St. Pierre d'Aulnay. Según él: "Le parti décoratif est ici très clair et l'itégration dans l'architecture est telle que ces figures ont perdu toute grâce, toute élégance et toutes les subtilités plastiques...". BOUFFARD, Pierre. "La Psychomachie sur les portails romans..., p. 20.

${ }^{60}$ Ver: Hourihane, Colum (ed.). Virtue \& Vice: The Personifications in the Index of Christian Art. Princeton: Department of Art and Archaeology of Princeton University in association with Princeton University Press, 2000. NORMAN, Joanne S. Metamorphoses of an Allegory: The Iconography of the Psychomachia in Medieval Art. New York: P. Lang, 1988. pp. 27-47. BOUFFARD. "La Psychomachie sur les portails romans... KATZENELLENBOGEN. Allegories of the Virtues and Vices in Mediaeval Art..., pp. 17-19. DESCHAMPS. Le combat des vertus et des vices sur les portails romans....
} 

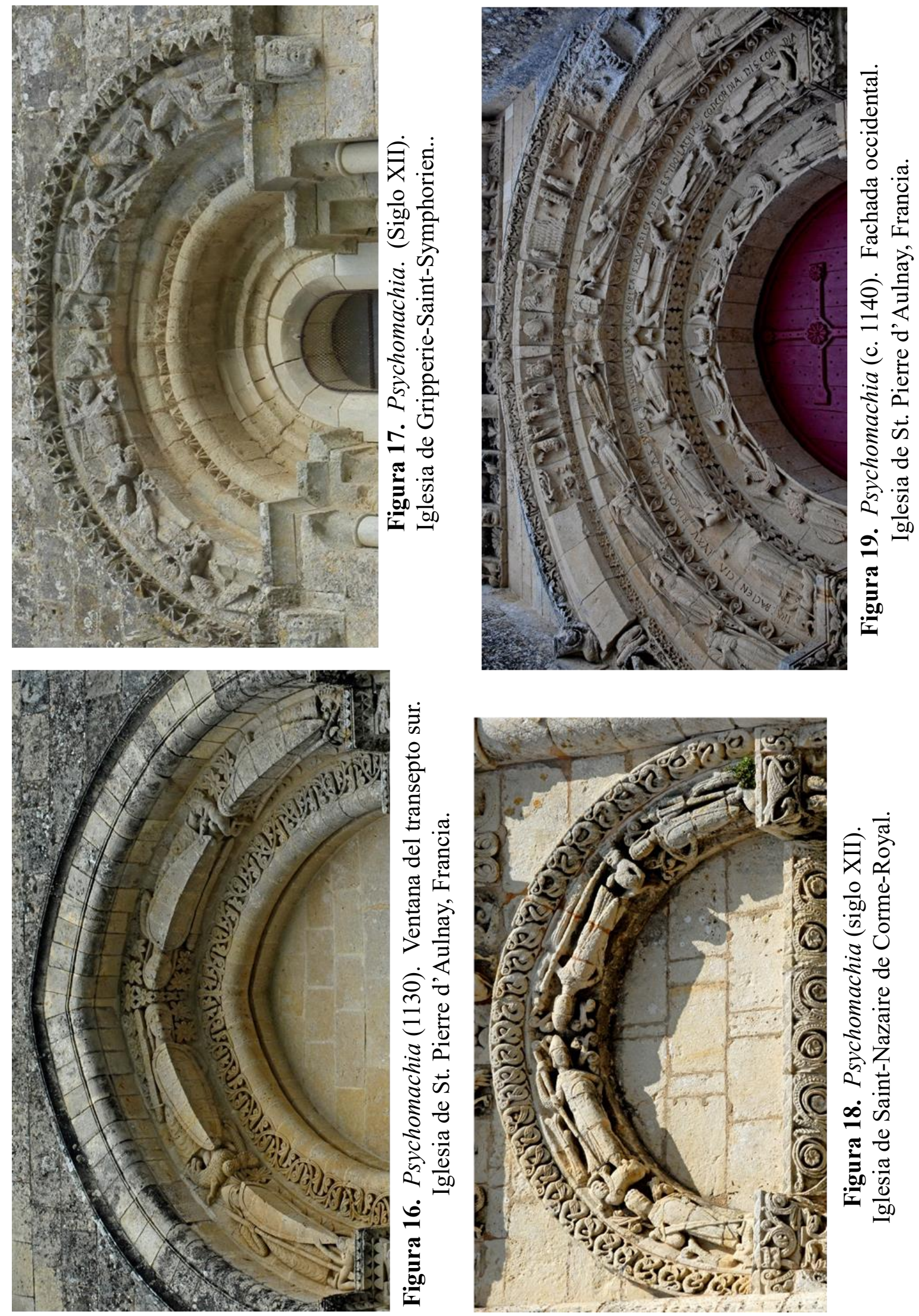


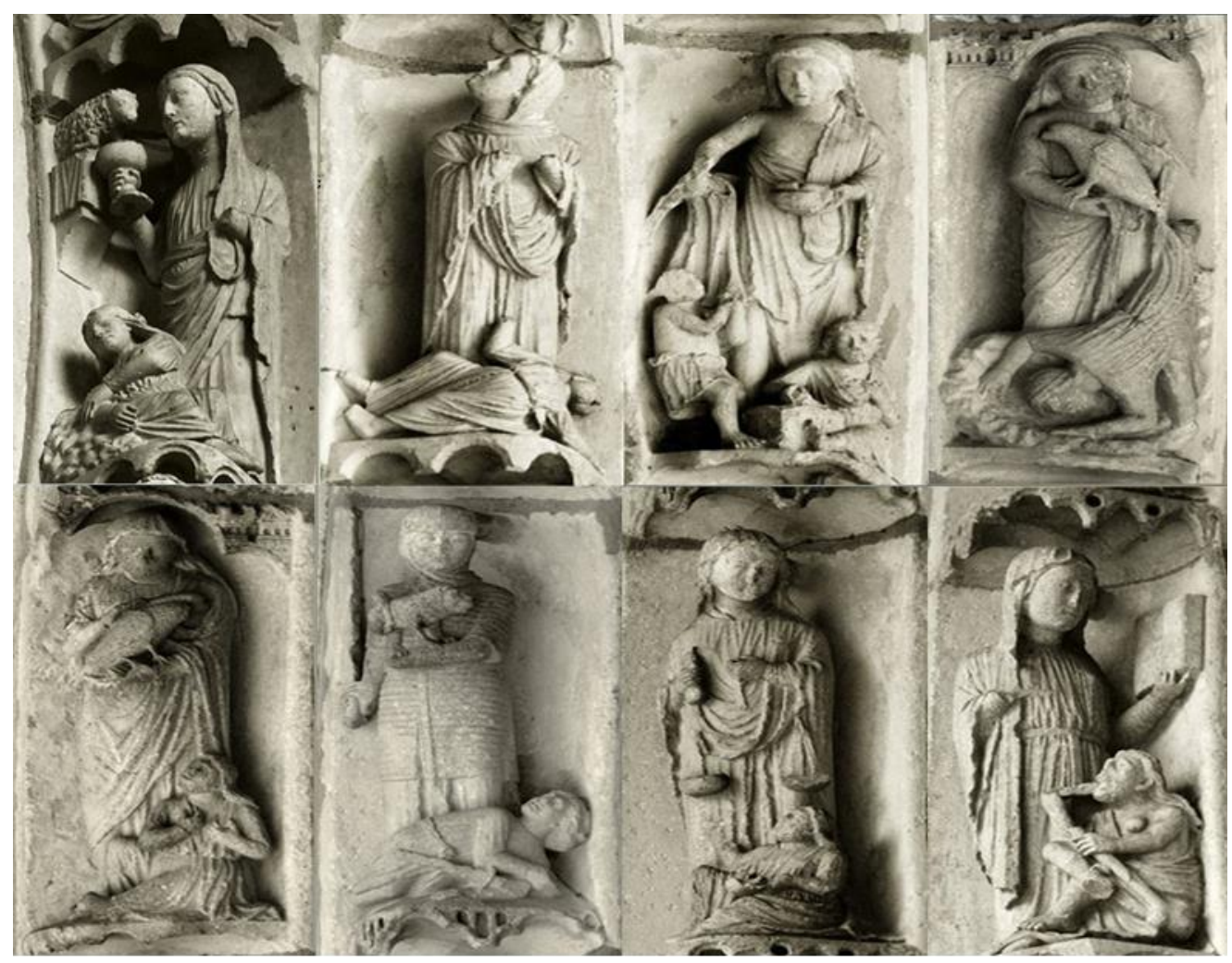

Figura 20. De izquierda a derecha, de arriba abajo: Fe e Idolatría, Castidad y Lujuria, Esperanza y Desesperanza, Caridad y Avaricia, Humildad y Soberbia, Castidad y Lujuria, Fortaleza y Cobardía, Justicia e Injusticia, Prudencia y Locura. Arquivoltas del arco izquierdo de la fachada norte. (1198) Catedral de Notre Dame de Chartres, Francia.

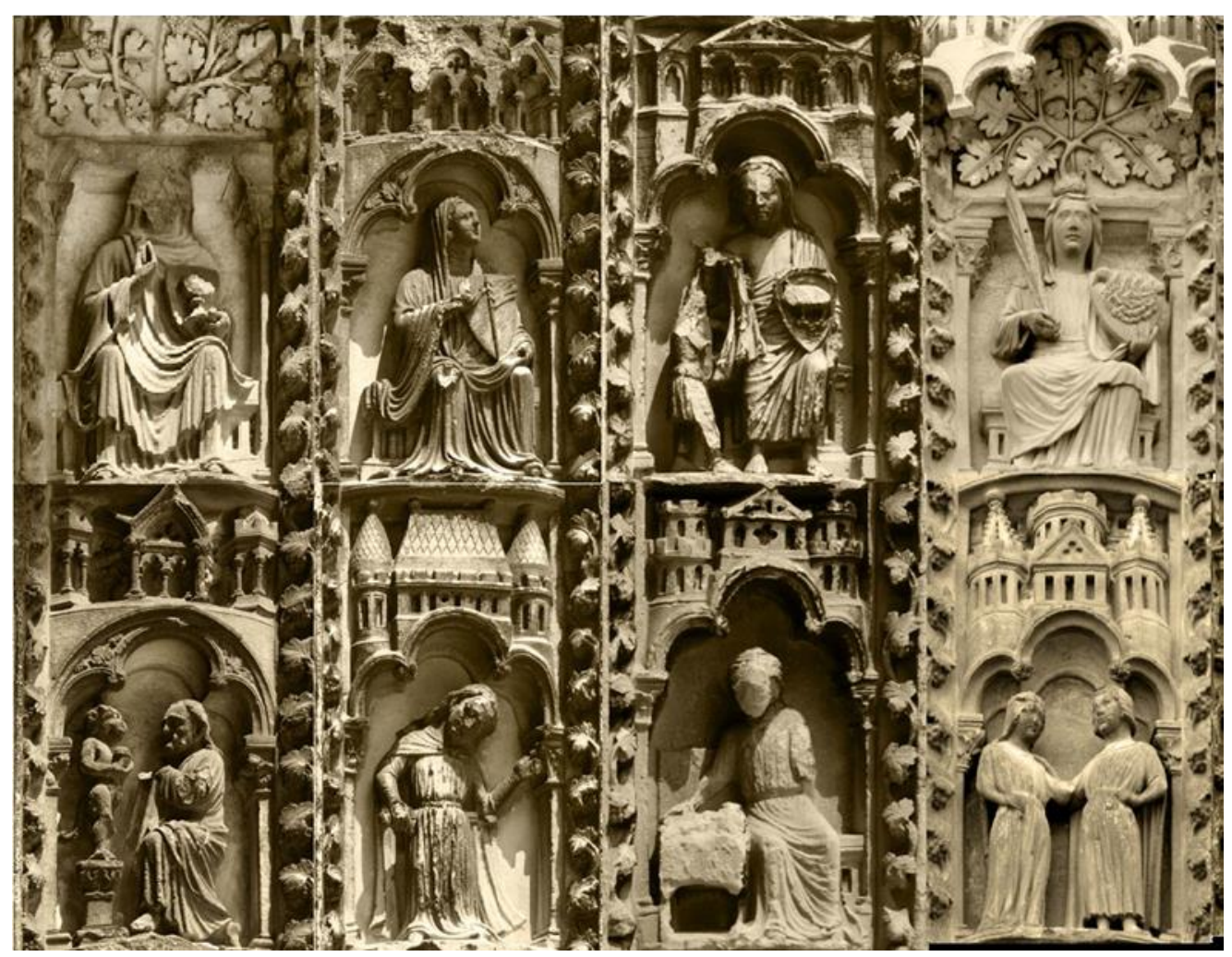

Figura 21. De izquierda a derecha, de arriba abajo: Fe, Esperanza, Caridad, Castidad, Idolatría, Desesperanza, Avaricia, Lujuria.

Columnas del pórtico sur. (1225) Catedral de Notre Dame de Chartres, Francia. 
El triunfo de las virtudes como se representan en la escultura románica gradualmente se extendió más allá de los límites de su provincia de origen ${ }^{61}$, y como sucedió con las imágenes en códices, la iconografía del tema entre los siglos XII y XIII comienza a mostrar variaciones que las distancian de esas primeras esculturas románicas de las virtudes pisoteando a los vicios vencidos, y al igual que en los manuscritos, el mismo comienza a mostrar variaciones. Este nuevo trato iconográfico de los vicios y las virtudes surge en Francia y uno de los ejemplos más temprano es la fachada de la catedral de Notre Dame de París, sin embargo, es en el pórtico norte y sur de la catedral de Chartres donde se puede percibir la evolución de la iconografía de los vicios y virtudes (Figs. 20 y 21). En la portada sur de finales del siglo XII las virtudes son figuras femeninas que ya no visten armaduras ni armas que las vinculen con el combate (salvo el caso de Fortaleza, pues la armadura y las armas son sus atributos por excelencia), todas se encuentran ataviadas con túnica larga y algunas cubren sus cabellos con un manto. Junto a los pies de éstas se plasmó con menores dimensiones las figuras de los vicios (Fig. 20). Con las esculturas de la portada sur de Chartres, se introduce el uso de atributos por parte de estas personificaciones para la identificación de las mismas.

En el pórtico norte del mismo templo, de aproximadamente 1225, encontramos la segunda plasmación escultórica de los vicios y las virtudes (Fig. 21). Las personificaciones se han separado, se dedica un espacio para cada una de las repersentaciones escultórica de estos conceptos morales, como sucede en las miniaturas de Somme le roi. Las virtudes se plasman en un trono, símbolo de la victoria y sujetan un escudo con su correspondiente atributo. En el espacio inferior contiguo se insertaron las figuras de los vicios. Estos se plasmaron por medio de sus actos. "La virtud está representada en su esencia y el vicio en sus efectos ${ }^{62 "}$. A lo largo de todo el siglo XIII este modelo se extendió por toda Francia y se insertó en

\footnotetext{
61 "The theme of the triumph of the virtues as expressed in architecture gradually extended itself far beyond the limits of its original province and thus, like the later Psychomachia manuscripts, it sometimes loses its original features, which are characterized by fierce unrestraint". KATZENELlenbogen. Allegories of the Virtues and Vices in Mediaeval Art..., p. 19.

${ }^{62}$ MÂLE, Émile. El arte religioso del siglo XIII en Francia...., p. 140.
} 
las grandes catedrales góticas como París, Amiens, Laon, Sens, Reims y Estrasburgo ${ }^{63}$.

A partir del siglo XIV el tema comienza a aparecer en el exterior de templos en Italia, uno de los mejores ejemplos identificados y conservados se encuentra en el campanario de la catedral de Santa María del Fiore en Florencia, en el que el segundo nivel de la edificación encerrado en diamantes se incluyeron las virtudes teologales y cardinales entronizadas y con sus respectivos atributos, acompañadas de las artes liberales, los planetas y los sacramentos (Fig. 22). Un ejemplo medieval tardío, aproximadamente de 1500 (Fig. 23), de las virtudes en la fachada de un templo lo encontramos en la iglesia de San Pablo de Valladolid (España). Aquí se incluyeron siete virtudes, las tres teologales y las cuatro cardinales, muy similar el modelo iconográfico de los manuscritos del siglo XV.

A partir del siglo XIV surgen representaciones de las virtudes en la escultura funeraria en Italia. El primero testimonio dentro del contexto fúnebre es el arca de santo Domingo de Guzmán, obra de Nicolas Pisano realizada a mediados del siglo XIII. Hoy en día sólo sobrevive el sarcófago con los relieves, sin embargo, esta obra sería inspiración para las tumbas de otros santos como la de san Agustín o san Pedro Mártir (Fig. 24) ${ }^{64}$. Estos sepulcros, sobre todo el del fundador de los dominicos también sirvió de modelo para los conjuntos funerarios de nobles, papas, reyes, etc. Los primeros casos del tema en los monumentos fúnebres de laicos se documentan

${ }^{63}$ Ver: Hourihane. Virtue \& Vice: The Personifications...

KATZENELLENBogen. Allegories of the Virtues and Vices in Mediaeval Art..., pp. 19, 75-84. MÂLE. El arte religioso del siglo XIII en Francia...., pp. 141-156.

${ }^{64}$ Arca de san Pedro Mártir (1338), Giovanni di Balduccio. Basílica de San Eustorgio, Milán. Arca de san Agustín de Hipona (1362). Basílica de San Pietro in Ciel d'Oro, Pavía. Bibliografía consultada sobre el tema: MosKOwITZ, Anita. "Giovanni di Balduccio's Arca di San Pietro Martire: Form and Function". Arte Lombarda, Vol. 96/97 (1991), pp. 7-18. "A Tale of Two Cities: Pavia, Milan, and the Arca di Sant'Agostino". Notes in the History of Art, Vol. 11, No. 2 (1992), pp. 1-9. Nicola Pisano's Arca Di San Domenico and Its Legacy. Pennsylvania: Pennsylvania State University, 1994. "Tomb of St Peter Martyr", The Cast Court Collection of the Victoria and Albert Museum. Disponible en: http://collections.vam.ac.uk/item/O40973/tomb-of-st-peter-martyr-plastercast-di-balduccio-giovanni/. [Consulta: 11 de noviembre de 2015]. 
en una serie de sepulturas de la Casa de Anjou en Nápoles ${ }^{65}$. En el mundo italiano las virtudes en el contexto funerario consisten de figuras femeninas de pies, portan atributos que permiten su fácil identificación y se insertan en las columnas que sostienen la yacija del fenecido (Fig. 25).

El tema cruzó rápidamente el Mediterráneo y tan temprano como en el siglo XIV se encuentran ejemplos en la península ibérica en sepulcros de nobles y monarcas (Figs. 26 y 27) ${ }^{66}$. Las imágenes de las virtudes en el arte funerario hispano

${ }^{65}$ Entre estos ejemplos destacan varios pertenecientes a la casa de Anjou cómo los de: sepulcro de María de Hungría reina de Nápoles (1362) en Santa María Donnaregina, Nápoles; sepulcro de Catalina de Habsburgo duquesa de Calabria (1325), San Lorenzo Maggiore, Nápoles; sepulcro María princesa de Calabria (1328) en Santa Clara, Nápoles; sepulcro de María de Valois (1330) en Santa Clara, Nápoles y el sepulcro de Roberto I en Santa Clara, Nápoles. Bibliografía consultada sobre el tema: FRANCO MATA, Ángela. "Arte y literatura. El monumento sepulcral de Margarita de Brabante. Iconografía y significación de yacentes femeninos reales en la Baja Edad Media.”, en: Lecturas de Historia del Arte, №. 2 (1990), pp. 24-44. PAOLETTI, John T. y Gary M. RADKE. La Italia del Renacimiento. Madrid: Ediciones Akal, S.A., 2002. Kelly, Samantha. The New Solomon. Robert of Naples (1390-1343) and Fourteenth-Century Kingship. Leiden; Boston: Brill, 2003. MICHALSKY, Tanja. "The local eye: Formal and social distinctions in late quattrocento Neapolitan tombs", en: Art and Architecture in Naples, 1266-1713: New Approaches. Ed. Cordelia Warr et. Janis Elliot. West Sussex: Wiley-Blackwell, copl, 2010. D'OviDIO, Stefano. “Cernite Robertum Regem virtute refertum. La 'fortuna' del monumento sepolcrale di Roberto D'Angiò in S. Chiara”, en: La chiesa e il convento di Santa Chiara: committenza artistica, vita religiosa e progettualità politica nella Napoli di Roberto d'Angiò e Sancia di Maiorca. Battipaglia: Laveglia \& Carlone, 2014.

${ }^{66}$ En orden cronológico, presentamos una lista de los sepulcros identificados en el contexto hispano en los que se incluyeron representaciones de las virtudes: Sepulcro del Canciller López de Ayala y Leonor de Guzmán (1399) en el Convento de San Juan de Quejana, Álava. Sepulcro de María de Ulloa y Juan Rodríguez de Fonseca (finales siglo XV) en la Colegiata de Toro, Zamora. Sepulcro de Constanza de Castilla (c. 1475/1500) en el Museo Arqueológico Nacional, Madrid. Sepulcro del Arzobispo Alonso Carillo de Acuña (1482-1489) en el Museo Catedralicio de Álcala. Sepulcro de Álvaro de Luna y Juna Pimentel (1489), Sebastián de Toledo en la Catedral de Toledo. Sepulcro de Juan II e Isabel de Portugal (1493), Gil de Siloe en la Cartuja de Miraflores, Burgos. Sepulcro de don Pedro de Castilla y su mujer doña Beatriz Fonseca (finales del siglo XV), iglesia de San Lorenzo el Real en Toro. Sepulcro de don Alonso de Cárdenas y doña Leonor de Luna (finales del siglo XV), iglesia de Santiago de Llenura, Badajoz. Bibliografía consultada sobre el tema: CRUZADA VILlAAMIL, Gregorio. "Retablo y sepulcros de la capilla de D. Álvaro de Luna en la Catedral de Toledo", en: El Arte en España, Tomo VI (1867), pp. 73-82. WeTHEY, Harold E. Gil de Siloe and His School. A Study of Late Gothic Sculpture in Burgos. Cambridge; Massachusetts: Harvard University Press, 1936. PROSKE, Beatrice Gilman. Castilian sculpture, Gothic to Renaissance. New York: Hispanaics society of America, 1951. ARCO Y GARAY, Ricardo del. Sepulcros de la Casa Real de Castilla. Madrid: Consejo Superior de Investigaciones Científicas, Instituto Jerónimo Zurita, 1954. CARRETE y PARRONDO, Juan. "Sebastián de Toledo y el sepulcro de Don Álvaro de Luna.” Revista de Ideas Estéticas. Vol. 33, № 131 (1975), pp. 37-43. YARZA LUACES, Joaquín. 
adquieren un carácter propio, pues mientras que en todas las tumbas italianas en las que se incluyen imágenes de las virtudes, éstas se colocan debajo de la yacija a modo de sosten, en los sepulcros hispanos se insertan directamente en el cuerpo de ésta, en contraste las mismas se plasmaron en posición sedente y si bien en muchos de los ejemplos las virtudes portan atributos ya conocidos, en algunos casos encontramos que se adopta un nuevo modelo iconográfico como es el caso del sepulcro de Juan II e Isabel de Portugal (Fig. 22) cuyas representaciones de las virtudes son más cercanas a las utilizadas en la iglesia de San Pablo de Valladolid y de las miniaturas del siglo XV. También se ha de resaltar que en los ejemplos de finales del siglo XIV y los del siglo XV la mayoría de los sepulcros son dobles, son un conjunto funerario destinado a un matrimonio.

Las representaciones escultóricas de los vicios y las virtudes varían de acuerdo al templo y la ubicación con respecto a éste en la que se inserta el tema. Las primeras plasmaciones se incluyeron en las fachadas de iglesias románicas, las cuales en su mayoría se encuentran en la ruta de peregrinación a Santiago de Compostela (Figs.

Los Reyes Católicos: paisaje artístico de una monarquía. Madrid: Nerea, D.L. 1993. LAHOZ, Lucía. Escultura funeraria gótica en Álava. Vitoria-Gasteiz: Diputación Foral de Álava, D.L. 1996. FERNÁNDEZ GONZÁLEZ, Etelvina. "Don Álvaro de Luna, condestable de Castilla y maestre de Santiago: hombre de su tiempo y promotor de las artes", en: La nobleza peninsular en la Edad Media. VI Congreso de Estudios Medievales. Ávila: Fundación Sánchez Albornoz, D.L. 1999. PEREDA ESPESO, Felipe, "El cuerpo muerto del rey Juan II, Gil de Siloé y la imaginación escatológica." (Observaciones sobre el lenguaje de la escultura en la alta Edad Moderna)", Anuario del Departamento de Historia y Teoría del Arte, Vol. XIII (2001), pp. 53-85. RODRÍGUEZ PORTO, Rosa M. "Fartan sus iras en forma semblante: La tumba de Álvaro de Luna y el status de la imagen en la Castilla tardomedieval”. Espacio, Tiempo y Forma, Serie VII, Historia del Arte No. 16 (2003), pp. 11-28. YARZA LUACES, Joaquín. Isabel la Católica: promotora artística. León: Edilesa, D.L., 2005. YARZA LuACES, Joaquín. La Cartuja de Miraflores. I. Los sepulcros. Cuadernos de Restauración de Iberdrola Vol. XIII. Bilbao: Fundacion Iberdrola, 2007. CARO DOBÓN, Luis y María Edén FERNÁNDEZ SUÁREZ. "Los enterramientos reales de la Cartuja de Miraflores". Ambio Ciencias: revista de divulgación 2 (2008), pp. 23-37. RuIZ MALDONADO, Margarita. "Los CastillaFonseca en la iglesia de San Lorenzo de Toro (Zamora), en Estudios de Historia del Arte en memoria de la profesora Micaela Portilla. Vitoria-Gasteiz: Arabako Foru Aldundia. Euskara, Kultura eta Kirol Saila. Diputación Foral de Álava, 2008. PÉreZ MARTín, Sergio et. Luis Vasallo Toranzo. "El patronazgo de los Fonseca en la Colegiata de Toro", en: Anuario del Instituto de Estudios Zamoranos Florián de Ocampo, $\mathrm{N}^{\mathrm{O}} 28$ (2011), pp. 231-254. SEDANO MARTín, Teresa. La idea y el sentimiento de la muerte en la Edad Media en Toro (Zamora). Zamora: Instituto de Estudios Zamoranos "Florián de Ocampo", 2013. 
16, 17, 18 y 19). El público de estas imágenes debieron ser sobre todo los peregrinos que se dirigían a visitar la tumba del santo Jacobeo, por ende, las personificaciones en estas iglesias se vinculan directamente con la acción de peregrinar, no sólo en términos terrenales, sino también espirituales. Después de todo la batalla interior experimentada por los peregrinos en dirección a Santiago, remite al espectador a la batalla del alma en la que las virtudes se enfrentan a los vicios ${ }^{67}$. La relación con el viaje o el caminar se corrobora también en los temas que acompañan a las virtudes triunfantes en las arquivoltas de las portadas de estas iglesias, los cuales suelen ser de índole apocalíptico, en el que se incluyen representaciones de los Ancianos del Apocalipsis, el Agnus Dei, y las vírgenes sabias y las vírgenes necias (Fig. 19). El triunfo de las virtudes junto a los distintos temas apocalípticos en un llamado a los fieles en la entrada del templo a emular el camino de la virtud y así estar preparados para el Juicio Final ${ }^{68}$.

La presencia de los vicios y las virtudes en las catedrales góticas igualmente debió vincularse con su entorno, los espectadores y el programa iconográfico al que acompañaban (Figs. 20 y 21). Estas edificaciones conforman el núcleo de las ciudades emergentes, gozando de un público más variado ${ }^{69}$. Igualmente, los temas iconográficos que se insertan en las distintas portadas de los templos son diversos y más complejos. En la mayoría de los casos los vicios y las virtudes se incorporan en las arquivoltas de una portada cuyo tema principal en el tímpano de ésta es de índole mariano, pero igualmente encontramos casos en el que pueden acompañar otra temática $^{70}$. Por ejemplo, la fachada occidental de la seo de Sens en donde las esculturas de las virtudes se insertaron junto al martirio de san Esteban, santo patrón del templo.

\footnotetext{
${ }^{67}$ NORMAn. Metamorphoses of an Allegory: The Iconography of the Psychomachia..., pp. 5 y 29.

${ }^{68}$ KAtZENELlenbogen. Allegories of the Virtues and Vices in Mediaeval Art..., p. 10.

${ }^{69}$ Ver: DuBY, Georges. La época de las catedrales: arte y sociedad 980-1420. Madrid: Cátedra, D.L. 1993.

${ }^{70}$ Con relación a los programas iconográficos de las catedrales francesas ver: SAUERLÄNDER, Willibald. La sculpture gothique en France: 1140-1270. París: Flammarion, cop. 1972. Con relación al programa de Notre Dame de París ver: KatZenellenbogen. Allegories of the Virtues and Vices in Mediaeval Art... MÂLE. El arte religioso del siglo XIII en Francia....
} 


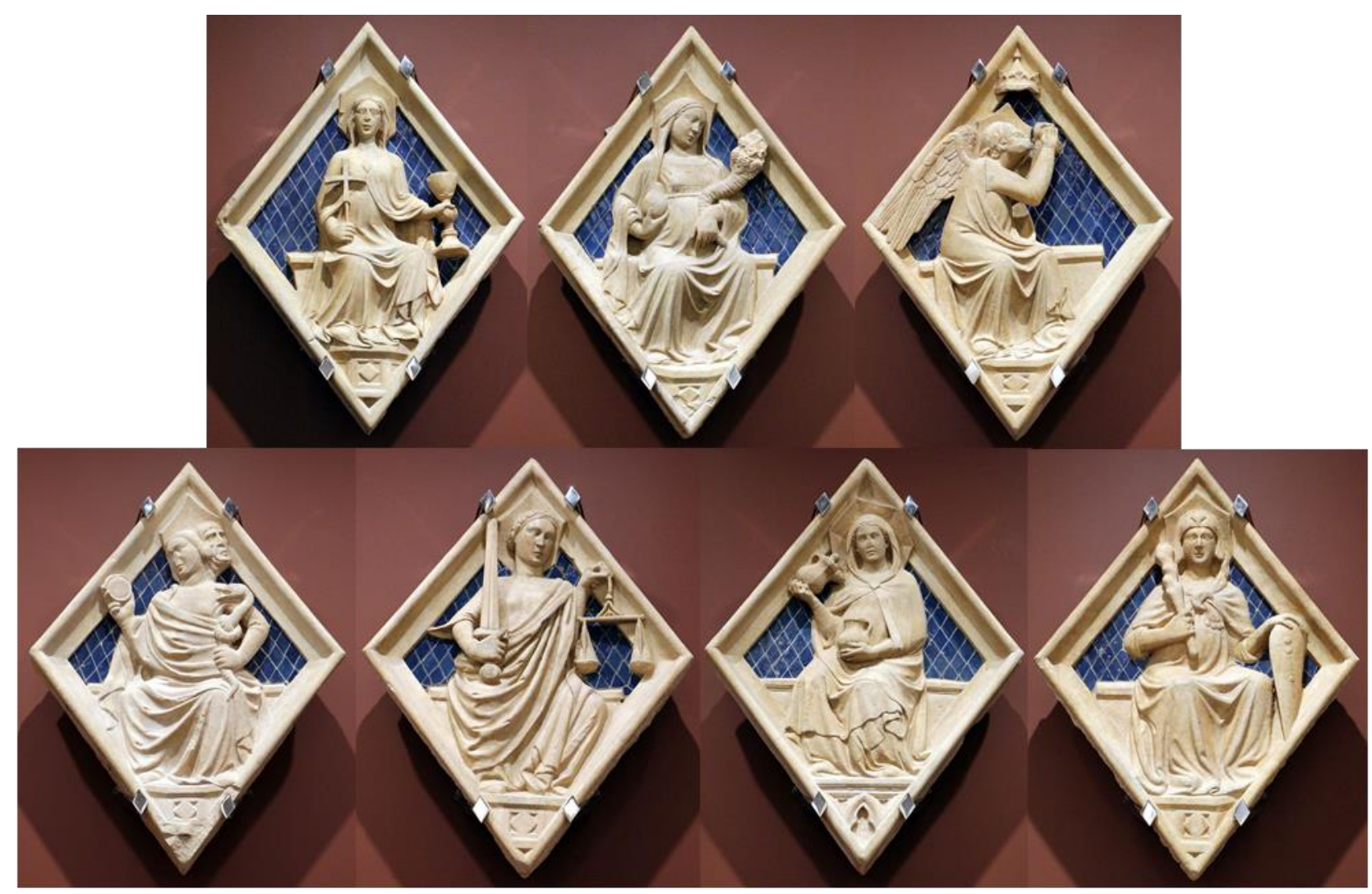

Figura 22. Virtudes teologales y cardinales (Siglo XIV). Taller de Andrea Pisano. Lado sur, campanario. Catedra de Santa María del Fiore, Florencia.
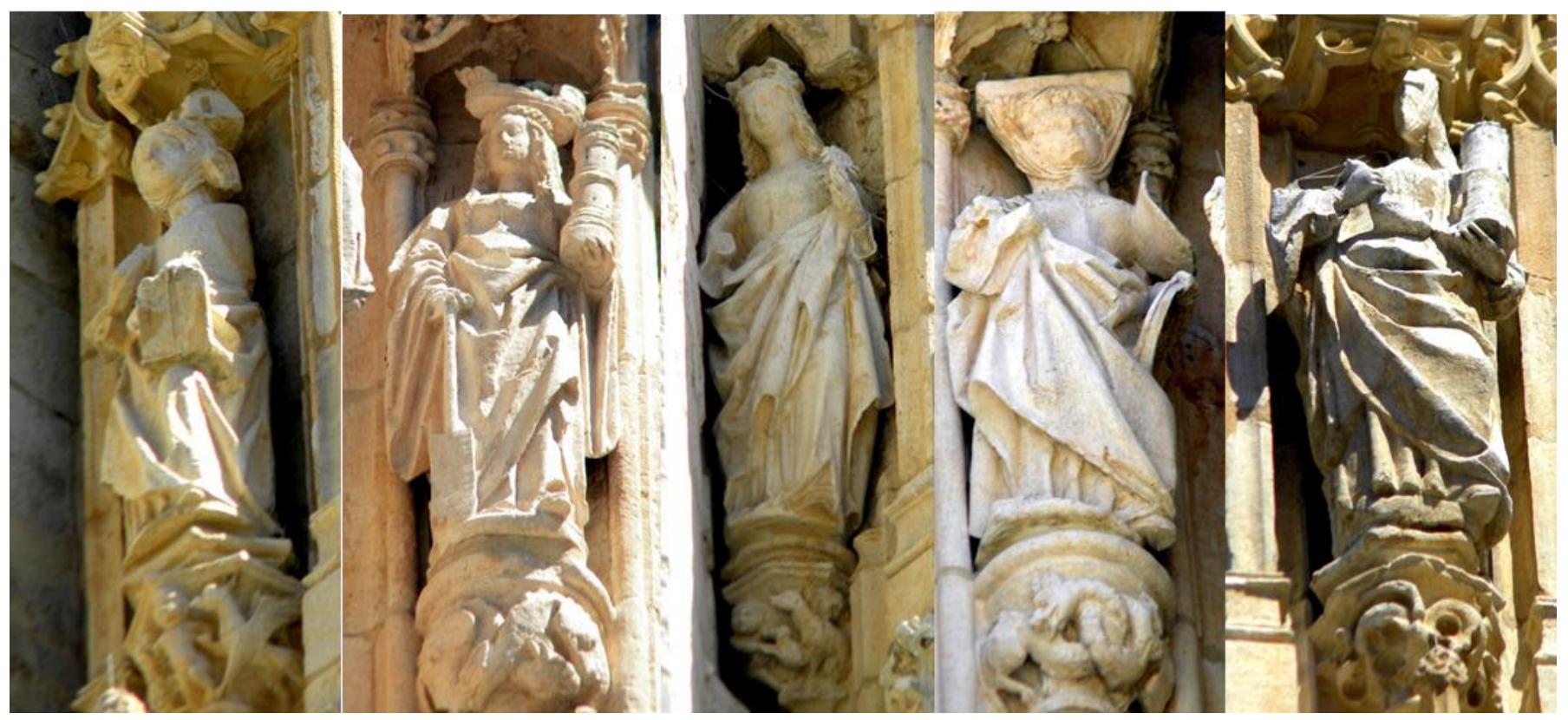

Figura 23. Fe, Esperanza, Caridad, Prudencia y Fortaleza (c. 1500). Simon de Colonia. Fachada. Iglesia de San Pablo, Valladolid. 
En cuanto a la recensión y el público de las portadas góticas francesas, y de las representaciones de los vicios y las virtudes en las mismas, Katzenellenbogen había relacionado la plasmación de estos conceptos morales en las catedrales galas, específicamente la de Chartres, con la escuela catedralicia y los pensadores y estudiantes de ésta (Fig. 20) ${ }^{71}$. En este caso particular la presencia de imágenes alegóricas de las artes liberales, las cuales se enseñaban en la scuola, y de esculturas de distintos filósofos y pensadores cuyos escritos eran utilizados en la enseñanza del trivium y el quadrivium, contribuyen a vincular el programa iconográfico de la portada sur de esta seo con la escuela ${ }^{72}$.

Otro factor que no se ha de perder de perspectiva en cuanto a las imágenes de los vicios y las virtudes en el contexto de las catedrales góticas en la práctica de la prédica sobre todo por parte de los miembros de las órdenes mendicantes. Es sabido que los frailes utilizaban esquemas mentales de los vicios y virtudes para construir, organizar y exponer sus sermones, lo que nos lleva a conjeturar que igualmente la presencia de éstas imágenes fueran refuerzos mnemónicos para el predicador, pero igualmente para el público receptor del sermón ${ }^{73}$.

\footnotetext{
${ }^{71}$ KAtZenellenbogen. Allegories of the Virtues and Vices in Mediaeval Art..., p. 75.

${ }^{72}$ Bibliografía consultada sobre el tema: Clerval, A. Les écoles de Chartres au Moyen-Age : (du Ve au XVIe siècle). Frankfurt : Unveränderter Nachdruck, 1965. MALE, Émile. Notre-Dame de Chartres. París: Flammarion, 1963. HeImanN, Adelheid. "The Capital Frieze and Pilasters of the Portail Royal, Chartres", Journal of the Warburg and Courtauld Institutes. Vol. 31 (1968), pp. 73 102. KatZenellenbogen, Adolf. The Sculptural Programs of Chartres Cathedral: Christ, Mary, Ecclesia. Baltimore: The John Hopkins Press, 1968. BALDWIN, John W. The Scholastic Culture of the Middle Ages 1000-1300. Lexington: D.C. Heath and Company, 1971. JEAUNEAU, Édouard. L'âge d'or des écoles de Chartres. Chartres: Editions Houvet, 1995. KIDSON, Peter. Sculpture at Chartres. London: Academy Editions, 1974.

${ }^{73}$ Kimberly A. Rivers sugiere que los predicadores del siglo XIII y XIV utilizaban imágenes mentales de los vicios y las virtudes para esquematizar y ordenar sus sermones. RIVERS, Kimberly A. Preaching the Memory of Virtue and Vice. Memory, Images, and Preaching in the Late Middle Ages. Turnhout: Brepols, 2010. En relación con la prédica ver: ChARLAND, T.M. Artes praedicandi: contribution à l'histoire de la rhétorique au Moyen Age. París: J. Vrin, 1936. Ross, Woodburn O. "A Brief Forma Predicandi", Modern Philology: Critical and Historical Studies in Literature, Medieval Through Contemporary. Vol. 34, №. 4 (1937), pp. 337-344. ABOU-EL-HAJ, Barbara. "The Urban Setting for Late Medieval Church Building: Reims and its Cathedral Between 210 and 1240", Art History. Vol. 11, No. 1 (1988), pp. 17-41. BRISCOE, Marianne G. et Barbara H. Jaye.
} 
En el caso de la escultura funeraria se vincula directamente con la memoria y el recuerdo del fenecido y por lo tanto el discurso icónico responde a perpetuar dichos conceptos. La presencia de las virtudes en las tumbas de santos ciertamente es certera y no del todo rara (Fig. 24). Katzenellenbogen afirma que no es extraño encontrar el mismo en los santuarios o sepulcros pues éste responde a las descripciones de las vidas de santos en las que tanto se alaban las cualidades virtuosas y los arduos sufrimientos que los mismos tuvieron que enfrentar por la fe y que tan estimables volvieron a estos modelos ${ }^{74}$. La tipología de los sepulcros y el lugar en el que se insertan las personificaciones de las virtudes también juegan un papel importante con el recuerdo a transmitir. La tipología de los sepulcros de santos, en los que los sarcófagos que custodian las reliquias se encuentran elevados, resalta la función del monumento como punto focal de veneración del santo ${ }^{75}$. Los temas iconográficos de estos sepulcros se leen en clave ascensional y las distintas virtudes en los basamentos de los mismos son el soporte físico y metafórico de la vida del santo ${ }^{76}$. Soporte físico que sostiene la yacija en la que reposan los restos mortales (las reliquias) y a la misma vez el cuerpo simbólico del santo (el yacente) ${ }^{77}$. Y metafórico pues las virtudes son el apoyo y soporte de la vida terrenal del santo, las cuales después de la muerte (representada en la yacija) le ganarían la recompensa celestial a éste (representado en el último registro del monumento $)^{78}$. Las virtudes en este sentido se relacionan directamente con la santidad del finado ${ }^{79}$.

Artes praedicandi. Turnhout: Brepols, 1992. AlBERTE González, Antonio. Retórica medieval: historia de las artes predicatorias. Madrid: Centro de Lingüística Aplicada Atenea, 2003.

74 "It is not surprising to find representations of virtues on shrines, for in all descriptions of the lives of the saints the manifold virtuous qualities of these model fighters and sufferers for the faith are highly praised". KATZENELlENBOGEN, Adolf. Allegories of the Virtues and Vices in Mediaeval Art, from Early Christian Times to the Thirteenth Century. New York: W.N. Norton \& Company, Inc., 1964. p. 46.

${ }^{75}$ Moskowitz. "Giovanni di Balduccio's Arca di San Pietro Martire..., p. 8.

${ }^{76}$ Moskowitz. "A Tale of Two Cities..., p. 6.

${ }^{77}$ BeLting. Antropología de la imagen..., p. 179.

${ }^{78}$ Moskowitz. "A Tale of Two Cities..., p. 4.

${ }^{79}$ FrANCO MATA, Ángela. "Arte y literatura. El monumento sepulcral de Margarita de Brabante. Iconografía y significación de yacentes femeninos reales en la Baja Edad Media.”, en: Lecturas de Historia del Arte, No. 2 (1990), p. 25. 

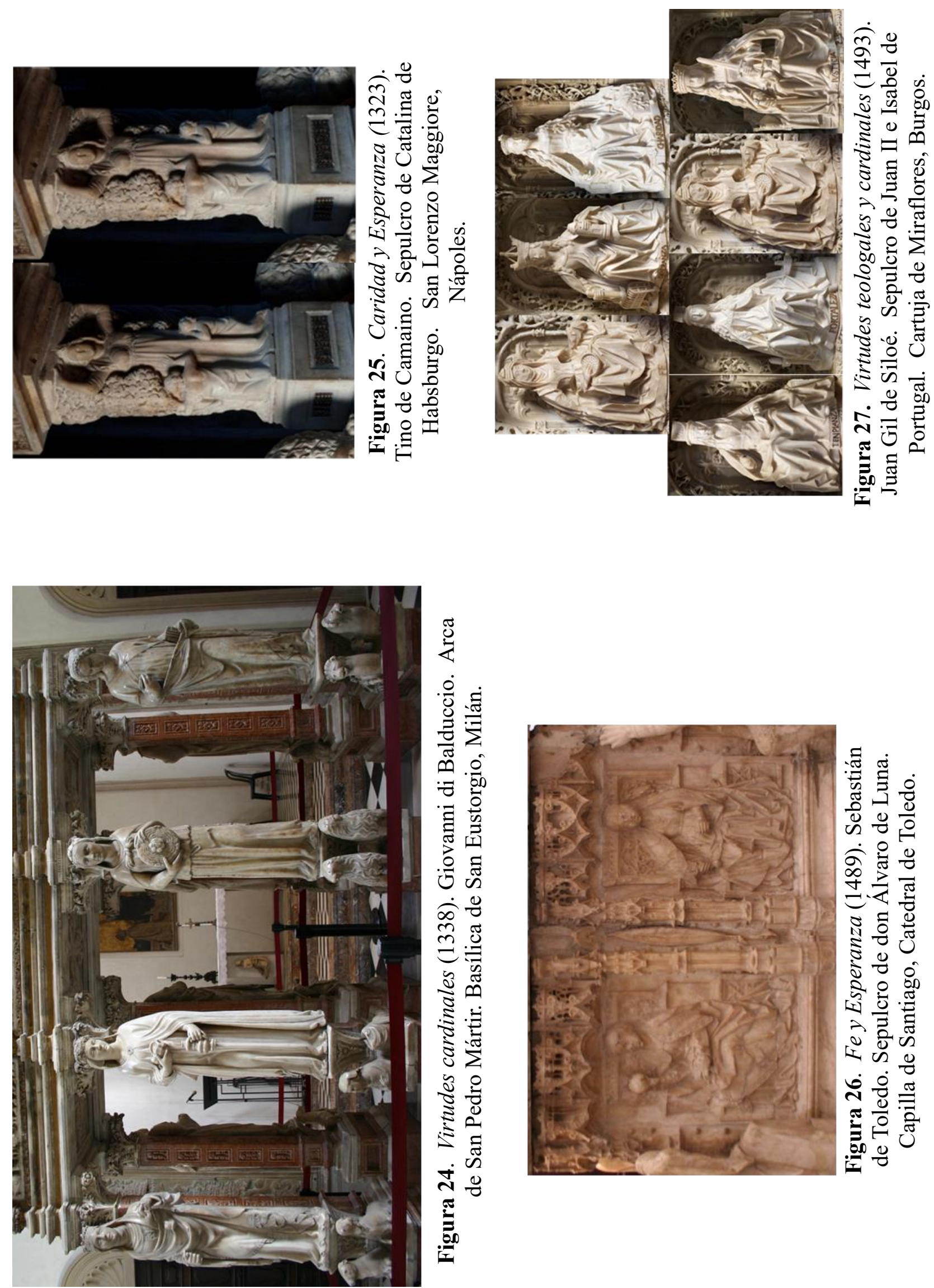
Los significados de las plasmaciones de estos conceptos en los monumentos funerarios de laicos son diversos, respondiendo a los deseos del finado o de sus descendientes (Figs. 25, 26 y 27). Los sepulcros y las inscripciones en las tumbas fueron utilizadas para exaltar el linaje, la genealogía del difunto y sus virtudes y hazañas heroicas, asegurándose de que fueran estos los recuerdos del fenecido legados a la posteridad ${ }^{80}$. Por lo tanto, las representaciones de las virtudes en las sepulturas de monarcas y nobles, permitiría que a los mismos se les recordara por la práctica de tal o cual virtud. La representación de la caridad, en muchos sepulcros a través de una escena, recordaba la práctica en vida por parte del difunto de esta virtud $^{81}$.

Anteriomrnete se estableció que uno de los primeros ejemplos en los que se identifican las virtudes en las tumbas de laicos fueron en una serie de monumentos fúnebres de la casa de Anjou (Fig. 25). La presencia de estas personificaciones en los sepulcros angevinso honran al fenecido como representante de su familia ${ }^{82}$. También se ha de resaltar que la casa de Anjou poseía una serie de miembros canonizados, como san Luis IX, santa Isabel de Hungría y de más reciente canonización y directamente vinculado al rey Roberto I, su hermano san Luis de Toulouse $^{83}$. Por tanto, el uso de la tipología de sepulcro adoptada en las tumbas de santos en los monumentos funerarios angevinos en conjunto con las virtudes monumentaliza el carácter dinástico del programa y transciende la dimensión familiar del mismo ${ }^{84}$.

\footnotetext{
${ }^{80}$ ARIÈs. El hombre ante la muerte..., pp. 188-195.

${ }^{81}$ Gómez BÁrCENA, María Jesús. "La liturgia de los funerales y su repercusión en la escultura gótica funeraria en Castilla", La idea y el sentimiento de la muerte en la historia y en el arte de la Edad Media (I). Ciclo de conferencias celebrado del 1 al 5 de diciembre de 1986, coord. por M. Núñez Rodríguez y E. Portela Silva. Santiago de Compostela: Universidad de Santiago de Compostela, 1988. p. 50.

82 "Unprecedented for the tomb of a woman- recognized neither for her outstanding religious or political deeds - were the caryatids of the Virtues, derived from contemporary tombs of saints, whose function was to honour the deceased as the representative of her family". MICHALSKY, Tanja. "The local eye: Formal and social distinctions..., p. 63.

${ }^{83}$ PAOLETTI. La Italia del Renacimiento..., p. 124.

${ }^{84}$ MiCHALSKY, Tanja. "The local eye: Formal and social distinctions..., p. 65.
} 
Si bien en los sepulcros de nobles y monarcas la plasmación de las virtudes se utiliza para exaltar y celebrar la virtud del finado, se han identificado casos en los que estas representaciones alegorícas se asocian a la obra literaria del fenecido. Uno de los primeros casos identificados es el del Canciller Pedro López de Ayala, cuya presencia de estos conceptos morales en su monumento funerario igualmente se vincula con su Rimado de Palacio ${ }^{85}$. Algo parecido ocurre con el sepulcro de Don Álvaro de Luna (Fig. 26) ${ }^{86}$.

A parte de todos estos significados con los que la presencia de las virtudes imbuye los monumentos funerarios, no se ha de olvidar que las mismas en el contexto fuenrario igualmente "se fijan con un sentido escatológico, en tanto en cuanto que su práctica es el pasaje al más allá y conlleva la Gloria Eterna ${ }^{87}$ ",

A parte de estas obras identificadas, y los medios de las mismas, encontramos imágenes de los vicios, las virtudes o ambos temas en muchos otros medios. Fueron sumamente popular en objetos de orfebrería de toda clase, pero con mayor ímpetu en los de usos litúrgico ${ }^{88}$. La gran cantidad de representaciones de estos conceptos abstractos han sido objeto de estudios de muchos historiadores del arte y filólogos. Desde el campo de la Historia del Arte algunas de las obras ya abordasdas y temas

\footnotetext{
${ }^{85}$ Fue la profesora Lucía Lahoz quien se percató de la presencia del tema en este conjunto. Al igual que en los monumentos angevinos, la presencia de las virtudes en este sepulcro exalta y celebra la virtud del finado. Por otra parte, la profesora Lahoz establece una conexión entre la presencia de las virtudes en la sepultura del Don Pedro López de Ayala con su obra literaria, especialmente con su Rimado de Palacio. En éste en Canciller trata el tema de las virtudes y los vicios. De las ocho virtudes y dos vicios representados, se pueden encontrar alusiones en el Rimado a ambos vicios identificados y a seis virtudes. Éste es un poema didáctico-moral en el que Don Pedro en cierta manera describe a la sociedad de su época, dedicando así distintos apartados a los distintos personajes de su época. LAHOZ. Escultura funeraria gótica en Álava ..., pp. 179-181.

${ }^{86}$ En el caso de Don Álvaro de Luna, en su sepulcro se plasmaron las cuatro virtudes cardinales y éste en su Libro de las virtuosas e claras mugeres exalta la vida de diastitnas mujeres de la historia cuyas vidas fueron bienaventuradas gracias a la posesión de las cuatro virtudes cardinales. VÉLEZSAINZ, Julio. "Mecenazgo y representación: imágenes de Álvaro de Luna en el Libro de las virtuosas e claras mugeres, el castillo de Escalona y la Catedral de Toledo", en: Hispanic Review, Vol. 80, №. 2 (2012), pp. 175-198.

${ }^{87}$ LAHOZ, Lucía. "La escultura en la corona de Castilla: una polifonía de ecos", Artigrama. Vol. 26 (2011), p. 263.

${ }^{88}$ KatZenellenbogen. Allegories of the Virtues and Vices in Mediaeval Art..., pp. 50-51.
} 
iconográficos han sido estudiados desde el formalismo, la iconografía y la iconología. En el siguiente apartado se expone el estado de la cuestión de los distintos estudios que tratan las plasmaciones de los vicios y las virtudes durante la época medieval.

\subsection{Estado de la cuestión: estudios en torno a las representaciones de los vicios y las virtudes}

Desde muy temprano en la historia el tema de los vicios y las virtudes ha estado estrechamente ligado a la literatura y al arte. Esta relación ha incidido en un sin número de estudios y trabajos en torno al tema en la Edad Media, los cuales provienen principalmente del campo de la Literatura y la Historia del Arte, siendo más fructíferos los del primero pues muchos de estos se encuentran única y exclusivamente dedicados al trabajo de Prudencio ${ }^{89}$.

Dentro de la Historia del Arte encontramos estudios fundamentales como los de Richard Stettiner, Émile Mâle, Helen Woodruff, Rosemond Tuve, Adolf Katzenellenbogen y más reciente el tomo dedicado por el Index of Christian Art al tema ${ }^{90}$. Las principales metodologías utilizadas por estos historiadores del arte para abordar el tema son el formalismo y la iconografía e iconología.

\footnotetext{
${ }^{89}$ En el campo de la Literatura destacan los trabajos de Macklin Smith, Kenneth R. Haworth, Richard Newhauser y más recientes los trabajos de Sinéad O’Sullivan y Kimberly Rivers. Estos han sido de especial relevancia para nuestra investigación, especialmenta para la segunda parte de la tesis en la que estudiamos varios manuscritos miniados de la Psychomachia. SMITH, Macklin. Prudentius' "Psychomachia": A Reexamination. Princeton: Princeton University Press, 1976. HAWORTH, Kenneth R. Deified Virtues, Demonic Vices, and Descriptive Allegory in Prudentius' Psychomachia. Amsterdam: A.M. Hakkert, 1980. NEWHAUSER, Richard. The Treatise on Vices and Virtues in Latin and the Vernacular. Turnhout, Belgique: Brepols, 1993. O’Sullivan, Sinéad. Early Medieval Glosses on Prudentius'Psychomachia: The Weitz Tradition. Leiden; Boston: Brill, 2004. O'Sullivan, Sinéad. Early Medieval Glosses on Prudentius' Psychomachia: The Weitz Tradition. Leiden; Boston: Brill, 2004. RIVERS, Kimberly A. Preaching the Memory of Virtue and Vice. Memory, Images, and Preaching in the Late Middle Ages. Turnhout: Brepols, 2010.

${ }^{90}$ STETTINER, Richard. Die Illustrierten Prudentiushandschriften. Berlín: Druck von J.S. Preuss, 1895. MALE, Emile. L'art religieux de la fin du Moyen Âge en France. Étude sur l'iconographie
} 


\subsubsection{El método formalista}

\section{Richard Stettiner}

El historiador del arte alemán Richard Stettiner ${ }^{91}$ fue el primero que estudio las representaciones de los vicios y virtudes. En Die illustrierten Prudentiushandschriften (Los manuscritos ilustrados de Prudencio) de 1895, producto de su disertación doctoral, éste prestó atención a las imágenes de los vicios y las virtudes. El objeto de estudio de Stettiner son las distintas miniaturas de diecinueve manuscritos iluminados con obras de Prudencio, específicamente las que ilustran la Psychomachia (Miniaturas 1-90). La primera parte de su investigación consiste en una descripción detallada de cada uno de estos diecinueve códices, que incluye información técnica de los mismos, la procedencia u origen de estos, su ubicación y bibliografía sobre cada ejemplar.

La segunda parte del trabajo de Stettiner es un estudio comparativo de los manuscritos en el que analiza la disposición de las figuras, la relación entre lo narrado en el texto y la imagen que lo ilustra y por último las armas que llevan los vicios y las virtudes. A partir de la comparación de estos elementos, Stettiner dividió los diecinueve códices en dos grandes grupos que descienden de un ancestro en común ${ }^{92}$.

du Moyen Âge et sur ses sources d'inspiration. París: Librairie Armand Colin, [1908] 1922. WoOdRUFF, Helen. "The Illustrated Manuscripts of Prudentius". Art Studies (1929), pp. 31-79. MÂLE, Emile. El arte religioso del siglo XIII en Francia: el Gótico. Madrid: Encuentro, [1898] 2001. KatZenellenbogen, Adolf. Allegories of the Virtues and Vices in Mediaeval Art, from Early Christian Times to the Thirteenth Century. New York: W.N. Norton \& Company, Inc., [1939] 1964. TUVE, Rosemond. "Notes on the Virtues and Vices, Part I: Two Fifteenth-Century Lines of Dependence on the 12th and 13th Centuries." Journal of the Warburg and Courtauld Institutes Vol. 26 No. 3/4 (1963), pp. 264-303. TUVE, Rosemond. "Notes on the Virtues and Vices, Part II." Journal of the Warburg and Courtauld Institutes Vol. 27 (1964), pp. 42-72. TUVE, Rosemond. Allegorical Imagery. Some Medieval Books and Their Posterity. Princeton; New Jersey: Princeton University Press, [1966] 1977. NORMAN, Joanne S. Metamorphoses of an Allegory: The Iconography of the Psychomachia in Medieval Art. New York: P. Lang, 1988. HouRIHANE, Colum (ed.). Virtue \& Vice: The Personifications in the Index of Christian Art. Princeton: Department of Art and Archaeology of Princeton University in association with Princeton University Press, 2000.

91 KoPITZSCH, Franklin et. Dirk BRIETZKE. Hamburgische Biografie: Personenlexikon. 2, Christians. Vol. 2. Hamburg: Christians Verlag, 2003. p.408.

${ }^{92}$ STETTINER. Die Illustrierten Prudentiushandschriften..., p. 151. 
Este historiador del arte se percató de que las figuras, la vestimenta, los elementos arquitectónicos y la distribución de las figuras en los manuscritos más antiguos son muy similares a motivos artísticos propios del arte tardo antiguo. Estas semejanzas le llevaron a determinar qué tan temprano como en el siglo V existieron códices ilustrados de la Psychomachia ${ }^{93}$. Además de dividir los manuscritos en dos grupos, Stettiner desarrolló un estema en el que se aprecia el desarrollo de las distintas copias. El hipotético manuscrito del siglo $\mathrm{V}$ se encuentra a la cabeza de este estema. Alrededor de los siglos VII y VIII surgieron los arquetipos de este primer códice los cuales incidieron en la creación de nuevas copias. Las mismas eventualmente se dividirían creando dos vertientes de las que provienen los manuscritos que hoy sobreviven: un manuscrito de origen carolingio del siglo IX y una copia anglosajona de entre los siglos IX y $\mathrm{X}^{94}$.

La procedencia de los distintos códices, según el estema de Stettiner (Fig. 28) se resume de la siguiente manera: los manuscritos del Grupo I descienden de la copia anglosajona y en su mayoría son franceses y anglosajones mientras los manuscritos del Grupo II descienden del carolingio del año 800 y provienen de la zona del Rin y del valle de Mosa ${ }^{95}$. En la tercera parte de su estudio, Stettiner describe las distintas miniaturas, los manuscritos en las que éstas se encuentran y las distintas variaciones que muestran por códice.

Puesto que el objeto de investigación de Stettiner eran los manuscritos iluminados de Prudencio él no se circunscribió a una región geográfica particular, sino que a la hora de seleccionar las obras simplemente escogió estudiar todos los ejempleares hasta su época conocidos que poseyeran ilustraciones. Es por esto que en su estudio encontramos códices procedentes de Francia, Inglaterra, Bélgica y Alemania. El trabajo de Stettiner no es sólo el primer trabajo en el que se catalogaron los diversos manuscritos iluminado de la Psychomachia, igualmente es pionero en el analáisis filiar de estas copias.

\footnotetext{
${ }^{93}$ STETTINER. Die Illustrierten Prudentiushandschriften..., p. 201.

${ }^{94}$ STETTINER. Die Illustrierten Prudentiushandschriften..., p. 201.

${ }^{95}$ STETTINER. Die Illustrierten Prudentiushandschriften..., p. 184.
} 


\section{Helen Woodruff}

El 1929 se publicó en la revista Art Studies el artículo de Helen Woodruff "The Illustrated Manuscripts of Prudentius ${ }^{96 "}$. El trabajo de ésta es una revisión de Die Illustrierten Prudentiushandschriften y lo más cercano a una traducción que existe del mismo. Woodruff dedica las primeras páginas de su publicación a explicar y resumir el trabajo y las conclusiones de Stettiner. Su objeto de estudio son veinte manuscritos iluminados de la Psychomachia, los diecinueve ya estudiados por Stettiner, más el manuscrito $\mathrm{H}$ el cual se deduce Stettiner no estudió pues consiste de un solo folio con dos dibujos de Superbia ${ }^{97}$. La autora introduce al lector a los hallazgos más importantes del trabajo de Die Illustrierten Prudentiushandschriften y describe los veinte manuscritos que estudiará en la segunda parte de su trabajo. Helen Woodruff no descarta la idea establecida por Stettiner sobre el primer manuscrito iluminado del siglo $\mathrm{V}$, realmente la fundamenta comparando los motivos ya resaltados por el historiador del arte aleman con monumentos y manuscritos paleocristianos cuya datación no era conocida en la época de éste ${ }^{98}$.

Dado que el trabajo de esta historiadora del arte es una revisión de la obra de Stettiner, ella igualmente analiza la relación texto e imagen de cada manuscrito para establecer similitudes y diferencias entre ambos registros. No obstante, Woodruff no sólo se limita a las miniaturas de la batalla entre los vicios y virtudes, igualmente atiende las escenas del prefacio en el que se representan escenas de la vida de Abraham y el rescate de Lot y algunas de las efigies de Prudencio. Gracias a estas imágenes deduce que el arquetipo que sirvió de modelo al resto de los manuscritos debió iluminarse entre los siglos VI y VII ${ }^{99}$, un siglo antes de la fecha propuesta por Stettiner. Además de retrasar la cronología Woodruff propone que dos fueron los arquetipos que sirvieron de modelos a los dos grupos de manuscritos ${ }^{100}$. La

\footnotetext{
${ }^{96}$ WOODRUFF. "The Illustrated Manuscripts..., pp. 31-79.

${ }^{97}$ Según Woodruff, este manuscrito se encuentra en el Museum für Kunst und Gewerbe de Hamburgo.

${ }^{98}$ WOODRUFF. "The Illustrated Manuscripts..., p. 67.

${ }^{99}$ WoODRUFF. "The Illustrated Manuscripts..., p. 71.

${ }^{100}$ WoODRUFF. "The Illustrated Manuscripts..., p. 74.
} 
cronología y el estema propuesto por esta historiadora se resume de la siguiente manera: de manuscrito del siglo $\mathrm{V}$ surgieron dos arquetipos los cuales serían la fuente de influencia directa de los dos grupos. El lugar de origen del arquetipo del Grupo I debió encontrarse en el sur de la Galia, norte de Italia o alguna región cercana a éstas donde la presencia de los estilos asiáticos era mayor. Por otra parte, el manuscrito prototipo del Grupo II probablemente fue hecho en Italia ${ }^{101}$.

Helen Woodruff en "The Illustrated Manuscripts of of Prudentius” desarrolló un nuevo estema en el que gráficamente se aprecia la cronología y el desarrollo de los distintos arquetipos propuestos por ella (Fig. 29). El mismo parte del desarrollado por Stettiner en 1895, con el hipotético manuscrito del siglo V. La mayor diferencia del estema de Woodruff con el de su predecesor se encuentran en el desarrollo de los grupos. En el nuevo estema las divisiones de los grupos se perciben con más claridad, los códices del Grupo I descienden directamente de los arquetipos del siglo VI y los manuscritos del segundo provienen de un prototipo anterior a este siglo. La autora incluye varios arquetipos intermedios de manuscritos creados en el siglo IX para explicar las similitudes existentes entre manuscritos del Grupo I y II ${ }^{102}$.

El trabajo de Helen Woodruff aporta nueva evidencia que ayuda a corroborar la datación del primer manuscrito iluminado de la Psychomachia. Mientras que Stettiner propone la evolución de los códices desde el norte de Europa, influencia carolingia, anglosajona y franca, Woodruff plantea una evolución que proviene directamente del Mediterráneo. Sin embargo, al igual que Stettiner, esta autora no brinda información sobre la procedencia del posible primer manuscrito iluminado el cual han datado ambos del siglo $\mathrm{V}$.

\footnotetext{
${ }^{101}$ WOODRUFF. "The Illustrated Manuscripts..., pp. 74-75.

${ }^{102}$ WOODRUFF. "The Illustrated Manuscripts..., p. 50.
} 


\subsubsection{El método iconográfico e iconológico}

\section{Émile Mâle}

Si bien el estudio de Richard Stettiner es el primer trabajo que trata el tema de los vicios y las virtudes de forma indirecta a través del estudio de las miniaturas de los manuscritos de la Psychomachia, el historiador francés Émile Mâle fue el primero en ocuparse del tema desde la iconografía. A pesar de no dedicarse única y exclusivamente al estudio de los vicios y las virtudes, en dos de sus trabajos prestó especial atención al tema de los vicios y las virtudes. El primer estudio en el que éste abordó el tema fue en su tesis doctoral L'art religieux du XIII ${ }^{e}$ siècle en France $(1899)^{103}$. Para este historiador las grandes catedrales francesas eran enciclopedias gráficas del pensamiento medieval ${ }^{104}$ y basándose en esta idea en su estudio trató de relacionar las fachadas de dichos templos con el conocimiento enciclopédico recogido por Vicent de Beauvais en el Speculum Majus ${ }^{105}$. El desarrollo de L'art religieux du XIII ${ }^{e}$ siècle en France sigue el esquema de Vicent de Beauvais, razón por la cual los distintos capítulos del estudio se dividen según los distintos espejos descritos por el fraile dominico en su obra. Es en el capítulo dedicado al Speculum Morale el que el historiador del arte aborda las representaciones de los vicios y las virtudes en las catedrales francesas. En el mismo afirma que la fuente literaria que inspiró las representaciones en el arte románico es la obra de Prudencio, la Psychomachia, y que a su vez las esculturas en las fachadas de las iglesias del XI y el XII influenciarían en las plasmaciones góticas del tema. Puesto que su interés en los vicios y las virtudes se encuentra estrechamente relacionado con el Speculum Morale, presta atención al mensaje moral que transmiten las imágenes de éstas.

Mâle describe brevemente los distintos versos de la Psychomachia, sobre todo los de las batallas entre los vicios y virtudes, centrándose principalmente en las descripciones de la apariencia física y las armas de cada una de éstas. Al igual que

${ }^{103}$ MÂLE, Émile. L'art religieux du XIII siècle en France (1899), edición consultada El arte religioso del siglo XIII en Francia: el Gótico. Madrid: Encuentro, 2001.

${ }^{104}$ MÂLE. El arte religioso del siglo XIII en Francia..., pp. 11, 47.

${ }^{105}$ MÂLE. El arte religioso del siglo XIII en Francia..., p. 50. 
Sttetiner, afirma que el primer manuscrito iluminado del poema pudo ser del siglo $\mathrm{V}$, sin embargo, su conclusión proviene del análisis de un manuscrito específico y no de la obra de Stettiner ${ }^{106}$. Tras describir el poema de Prudencio, se centra en el Hortus Deliciarum por las representaciones de los vicios y las virtudes como guerreras. La descripción de estos códices miniados le sirve de hilo conductor para explicar el desarrollo del tema en la escultura medieval y explicar porque en las primeras alegorías de los vicios y las virtudes en el arte románico las virtudes son figuras femeninas vestidas como guerreras y armadas con lanzas las cuales pisan al vicio derrotado que a veces es presentado como un monstruo ${ }^{107}$. Resalta el carácter de lucha que aún poseen estas representaciones pues el vicio y la virtud se encuentran juntos afirmando que las mismas pueden considerarse psychomachias (batallas del alma). Según Mâle es en la catedral de Chartres donde se representa por última vez la lucha de los vicios y las virtudes (Fig. 20) ${ }^{108}$.

La aserción hecha por este historiador del arte de que la última representación de la lucha de los vicios y las virtudes se representa en Chartres es para afirmar que a partir del siglo XII y XIII surge una nueva manera de plasmar el tema en la escultura y suele ser propia del arte de estos siglos. Ya no se representa la lucha, la Psychomachia, sino que se inserta a la virtud sola, de manera estática, majestuosa y entronizada, portando algún atributo que permite su identificación; por otra parte, el vicio se encuentra en acción y por debajo de la virtud ${ }^{109}$. Es realmente esta nueva forma de representar los conceptos morales las que le interesa estudiar a Mâle puesto que la misma se desarrolló en Notre-Dame de París y a partir de aquí se copiaría en otras importantes catedrales francesas (Fig. 21).

Dentro del interés de Mâle en el conocimiento enciclopédico provisto por el Speculum, éste identifica otras variantes iconográficas del tema cuyo criterio

\footnotetext{
${ }^{106}$ El primer manuscrito ilustrado de Prudencio se remonta quizá al mismo siglo en que vivió el poeta, porque el manuscrito del siglo X que posee la Biblioteca Nacional de París está adornado con miniaturas de aspecto bastante arcaico y visiblemente copiadas de un original muy antiguo. MÂLE. El arte religioso del siglo XIII en Francia..., pp. 134-135.

${ }^{107}$ MÂLE. El arte religioso del siglo XIII en Francia..., p. 135.

${ }^{108}$ MÂLE. El arte religioso del siglo XIII en Francia..., p. 137.

${ }^{109}$ MÂLE. El arte religioso del siglo XIII en Francia..., p. 140.
} 
principal de selección se basa en que las mismas posean una fuente literaria de inspiración como por ejemplo la Escalera de los vicios y las virtudes y el Árbol de las virtudes (Figs. 3 y 4) y el Árbol de los vicios, el primero influenciado por la obra de Honorio de Autumn y el segundo por el trabajo de Hugo de San Víctor ${ }^{110}$.

El trabajo de Mâle se centra principalmente en el estudio de las catedrales góticas francesas y éste concluye que en las fachadas de estos templos se representa el conocimiento enciclopédico de la época, por lo tanto, la función principal de las mismas es la enseñanza de dichos saberes ${ }^{111}$ llevándolo a afirmar que "en todas las obras estudiadas hemos descubierto espíritus familiarizados con el conjunto de las ciencias eclesiásticas ${ }^{112}$ ". Por consiguiente, las esculturas de los vicios y las virtudes en las catedrales góticas responden al conjunto de los comportamientos morales asignados por la Iglesia y que todo fiel debe seguir, motivo principal por el cual las personificaciones de conceptos morales se insertan en las catedrales. Esta conclusión es sólo aplicable al caso francés específicamente a las catedrales que Mâle estudió: Paris, Amiens y Reims, dejando incluso en un segundo plano la catedral de Chartres. Otra crítica que podemos hacer al trabajo de Mâle con respecto al estudio de los vicios y las virtudes es que estudia únicamente imágenes que se inspiran directamente en textos, o sea, representaciones que tienen referentes literarios. Esto deja un gran paréntesis abierto en su trabajo pues el mismo llega a afirmar que ha buscado un referente literario para el ciclo de las doce virtudes y los doce vicios de Notre-Dame de París y sin embargo no encontró ningún texto que le ayudará a descifrar esta nueva manera de representar los vicios y las virtudes en el arte medieval francés ${ }^{113}$.

Este no es el único trabajo en el que Émile Mâle profundizó sobre el tema. En 1908 este autor publicó L'art religieux de la fin du Moyen Âge en France. Étude sur l'iconographie du Moyen Âge et sur ses sources d'inspiration ${ }^{114}$. Cómo indica el

\footnotetext{
${ }^{110}$ MÂLE. El arte religioso del siglo XIII en Francia..., pp. 137-138.

${ }^{111}$ MÂLE. El arte religioso del siglo XIII en Francia..., p. 426.

${ }^{112}$ MÂLE. El arte religioso del siglo XIII en Francia..., p. 428.

${ }^{113}$ MÂLE. El arte religioso del siglo XIII en Francia..., p. 143.

${ }^{114}$ MALE, Émile. L'art religieux de la fin du Moyen Âge en France. Étude sur l'iconographie du Moyen Age et sur ses sources d'inspiration. (1908) 2da edición. Paris : Librairie Armand Colin, 1922.
} 
título del mismo, en este estudio el historiador trata diversas manifestaciones artísticas realizadas entre los siglos XIV, XV y principios del XVI. Los distintos capítulos y apartados de esta obra se centran en las diferentes manifestaciones religiosas y las nuevas prácticas piadosas de las postrimerías de la Edad Media. En la segunda parte del mismo dedica un capítulo enteró a la nueva iconografía de los vicios y virtudes. Mâle concluye que a partir del siglo XIV las representaciones escultóricas sobre todo en las portadas de las iglesias disminuyen mientras que las de los manuscritos y libros florecen, desligándose vicios y virtudes como temas independientes y no en contraposición como en los siglos anteriores.

Son dos manuscritos de la segunda mitad del siglo XV los que le sirvieron a Mâle como referente del origen de la nueva iconografía de las virtudes ${ }^{115}$. Ahora pasan a plasmarse únicamente las tres virtudes teologales y las cuatro cardinales convirtiéndose en la manera más común de representarlas en Flandes y Francia en el siglo XVI. Es una iconografía de mucha complejidad pues las virtudes llevan una serie de objetos/atributos en las manos y en la cabeza. Según Mâle, y a modo de resumen pues el mismo reconoce que no existen más de una serie en la que se representen las siete virtudes de la misma forma, esta nueva iconografía de las virtudes se plasma de la siguiente manera en la Francia y Flandes del siglo XVI: la Justicia lleva la balanza y la espada, la Fortaleza arranca al dragón una torre, la Templanza sujeta con una mano un reloj y con la otra una brinda o un par de gafas, la Prudencia sostiene un espejo, la Fe sujeta una vela, y en la otra mano las tablas de la ley o una pequeña iglesia, la Esperanza puede llevar un barco o el ancla del mismo y la Caridad sujeta con una mano un corazón y en la otra el anagrama de Cristo (Figs. 7 y 10$)^{116}$.

Mâle al estudiar las imágenes de las virtudes en el siglo XV y XVI establece que en dichas fechas existían dos iconografías estos conceptos morales, la francesa y la italiana. La francesa responde a la anteriormente mencionada, la cual surge de

115 Ms. I 2, signatura antigua Ms. 927 (Bibliothèque Municipale, Rouen) y el Ms. Fran. 9186 (Bibliothèque Nationale de France, París). MALE. L'art religieux de la fin du Moyen Âge en France..., pp. 311-312.

${ }^{116}$ MALE. L'art religieux de la fin du Moyen Âge en France..., pp. 319-320. 
manuscritos iluminados, mientras que la iconografía italiana se desarrollón en los monumentos funerarios, con un carácter más sobrio que la francesa, pues las mismas sólo sujetan un objeto/atributo que permite su identificación. Básicamente las virtudes italianas que Mâle describe se resumen de la siguiente manera: la Fe lleva un cáliz o la cruz, la Esperanza es una mujer que extiende sus manos al cielo o para sujetar una corona y lleva una cornucopia o una rama florecida. La Caridad se reconoce por los niños que le rodean y amamanta, algunas ocasiones puede sujetar en una mano un corazón que eleva hacia Dios. La Templanza sujeta en cada mano una vasija y vierte agua de una a la otra. La Prudencia se representa con tres caras. La Fortaleza lleva un mazo o una espada y la piel de un león. La Justicia no ha sufrido cambios y lleva sus atributos tradicionales, espada y balanza ${ }^{117}$. Las virtudes italianas por medio de distintos artistas franceses, especialmente de Jean Perréal (en España encontramos manuscritos de éste bajo el nombre Guillermo de Perault), se introdujeron en el arte francés fusionándose con las francesas e incluso llegando a sobreponerse sobre las mismas ${ }^{118}$.

Mâle igualmente trata la nueva iconografía de los vicios, la cual ahora se encuentra independiente de las virtudes. En este período se opta por representar siete, aquellos conocidos también como los pecados capitales -lujuria, gula, avaricia, pereza, ira, envidia y soberbia- y continúan plasmandose como en las catedrales góticas, en acción ${ }^{119}$. Según el autor, en un manuscrito de finales del siglo XIV surge una nueva iconografía de los vicios que sigue directamente la lista de los pecados capitales y consiste en personificaciones de los vicios montando distintos animales simbólicos ${ }^{120}$. Esta nueva manera de plasmar a los vicios se sirve de los distintos estratos de la sociedad para personficar el concepto moral: el Orgullo es un rey, monta un león y en la mano lleva un águila; la Envidia es un monje que monta un perro y sostiene un gavilán; la Ira es una mujer sobre un jabalí con un gallo; la Pereza es un campesino sobre un asno y en su mano izquierda lleva un búho; la Avaricia la

\footnotetext{
${ }^{117}$ MALE. L'art religieux de la fin du Moyen Âge en France..., pp. 321-322.

${ }^{118}$ MALE. L'art religieux de la fin du Moyen Âge en France..., pp. 324-327.

${ }^{119}$ MALE. L'art religieux de la fin du Moyen Âge en France..., pp. 328-329.

${ }^{120}$ Ms. Fra. 400 (Bibliothèque Nationale de France, París). MALE. L'art religieux de la fin du Moyen Âge en France..., pp. 330-331.
} 
personifica un mercader que monta un topo y lleva una lechuza; la Gula es un jovenzuelo montando un lobo con un milano y la Lujuria es una dama que monta una cabra y lleva una paloma ${ }^{121}$. Eventualmente sólo se ilustraban la personificación sobre el animal.

Al inicio del capítulo dedicado a los vicios y las virtudes Mâle afirma que en los siglos que estudia estas fuerzas opuestas se representan de manera independiente siendo mayor en número de obras en las que se identifican los vicios. Sin embargo, éste tras adentrar a lector a las personificaciones de los pecados capitales concluye el apartado de estos identificando otra iconografía de origen italiano, los vicios como personajes famosos de la historia. Pese a resaltar el carácter individual del vicio, este motivo no es posible sin la presencia de las virtudes pues para representar al mismo, siempre encontramos a tal o cual virtud pisando victoriosa a un personaje de la historia cuyo vicio o actos viciosos le llevaron a su perdición. La identificación de los vicios en esa iconografía es posible por medio de la virtud que le vence: la Justicia vence a Nerón, la Fortaleza a Holofernes, la Templanza a Epicuro, la Prudencia a Asurbanipal, la Caridad a Herodes, la Esperanza a judas y la Fe a Arrio ${ }^{122}$.

L'art religieux de la fin du Moyen Âge en France. Étude sur l'iconographie du Moyen Âge et sur ses sources d'inspiration es un trabajo ambicioso que abarca un gran número de obras cuya procedencia es diversa. Ha llamado nuestra atención el tema de la cronología con respecto a la nueva iconografía de las virtudes. Mâle establece que es en dos manuscritos de la segunda mitad del siglo XV donde se encuentran las primeras representaciones de esta plasmación, sin embargo, es por medio de las vidrieras de la catedral de Rouen de 1521 que el nuevo motivo iconográfico de las virtudes se difunde por toda Francia, e incluso a otras partes de Europa. El ejemplo que brinda para corroborar la influencia gala en la periferia es el sepulcro de Juan II e Isabel de Portugal en la cartuja de Miraflores en Burgos, no

\footnotetext{
${ }^{121}$ MALE. L'art religieux de la fin du Moyen Âge en France..., p. 331.

${ }^{122}$ MALE. L'art religieux de la fin du Moyen Âge en France..., pp. 334-336.
} 
obstante, este conjunto funerario se finalizó en 1493, mucho antes que las vidrieras de Rouen ${ }^{123}$.

\section{Adolf Katzenellenbogen}

Uno de los trabajos más conocidos y citados en torno al tema de las imágenes de los vicios y las virtudes es Allegories of the Virtues and Vices in Mediaeval Art, from Early Christian Times to the Thirteenth Century (1939) del historiador del arte alemán Adolf Katzenellenbogen ${ }^{124}$. Es el primer estudio dedicado exclusivamente a las alegorías de los vicios y las virtudes en distintos medios como lo son: manuscritos, escultura, vidrieras y las artes menores. Katzenellenbogen además de adentrarse en los aspectos iconográficos también utiliza la metodología de la iconología a la hora de abordar el tema. Conjuga los conceptos teológicos con las plasmaciones del tema, teniendo en cuenta los antecedentes visuales del tema, la ubicación y las funciones que las mismas tenían o para la que fueron creada pues estas sutilezas influyen directamente en el significado de la imagen final.

Este trabajo se divide en dos grandes partes las cuales se enfocan en las representaciones dinámicas y las representaciones estáticas del tema ${ }^{125}$. El primer grupo responde a imágenes en las que se muestra la lucha de los vicios y las virtudes o la victoria de la virtud sobre el vicio. Las estáticas encasillan todas las figuras antropomorfas de estas fuerzas opuestas, las virtudes majestuosas y estáticas ya mencionadas por Mâlé ${ }^{126}$.

En el grupo de las representaciones dinámicas, Katzenellenbogen identifica tres principios artísticos que son constantes y dominantes: 1) las mismas están

\footnotetext{
${ }^{123}$ MALE. L'art religieux de la fin du Moyen Âge en France..., pp. 318-319.

${ }^{124}$ KATZENELLENBOGEN, Adolf. Allegories of the Virtues and Vices in Mediaeval Art, from Early Christian Times to the Thirteenth Century (1939), edición consultada: New York: W.N. Norton \& Company, Inc., 1964.

125 "Dynamic representations of the conflict between Virtues and Vices" y "Static representations of systems of Virtues and Vices". KATZENELLENBOGEN. Allegories of the Virtues and Vices in Mediaeval Art..., pp. 1 y 27.

${ }^{126}$ MÂLE. El arte religioso del siglo XIII en Francia..., p. 140.
} 
inspiradas en un tenso dramatismo producto de conflicto dual de las fuerzas opuestas; 2) los vicios y las virtudes se presentan juntos como una imagen unificada y, 3) las armas que portan las personificaciones son armas reales que no responden a atributos particulares que indican la supremacía del vencedor ${ }^{127}$. Además de estas constantes en los vicios y virtudes dinámicas, este autor también señala tres motivos o temas iconográficos dentro de este grupo: la Psychomachia entiéndase la lucha entre los vicios y las virtudes, las Virtudes triunfantes (Figs. 16, 17, 18 y 19) y la Escala de las virtudes (Figs. 3 y 4).

Este historiador del arte también estudia los manuscritos iluminados de la Psychomachia y utiliza la catalogación hecha por Stettiner. A partir del estudio de dos códices en particular, Katzenellenbogen reitera que la primera obra ilustrada es del siglo V, coincidiendo así con las afirmaciones de sus predecesores ${ }^{128}$. Entiende que estos dos manuscritos se encuentran estrechamente relacionados con ese primero y que los mismos reflejan una influencia directa del arte romano. Para éste, distintas escenas como las batallas, los vicios atacando a las virtudes, la distribución del botín, el regreso al campamento y el discurso final de las virtudes victoriosas corresponden a escenas seculares que se encuentran en los ciclos narrativos de las columnas conmemorativas romana ${ }^{129}$.

Este autors además de relacionar las escenas representadas en los manuscritos de la Psychomachia con el arte romano también encuentra influencias del arte antiguo en el motivo iconográfico que llama las Virtudes triunfantes (The Virtues triumphant). Las Virtudes triunfantes que describe Katzenellenbogen responden a las imágenes en las que se encuentra las virtudes de manera victoriosa. Éstas visten

\footnotetext{
${ }^{127}$ KATZENellenbogen. Allegories of the Virtues and Vices in Mediaeval Art..., p. 26.

128 "The archetype of all these manuscripts no longer exists. But the manuscripts $P^{l}$ and Le $e^{l}$, which, in spite of much modification and weakening, have preserved the essential features most faithfully, allow one to conclude that it was produced as early as the 5th century". KATZENELLENBOGEN. Allegories of the Virtues and Vices in Mediaeval Art..., p. 4.

129 "What he wished to illustrate -episodes such as battle scenes, the advance of the adversaries to the attack, the flight of the conquered, the rule of terror of victorious vices, the distribution of booty, the return to the campo and the solemn final address to the virtues- this all corresponded to secular scenes in Roman relief sculpture, especially the great cycles on the triumphal columns. KatZenellenbogen. Allegories of the Virtues and Vices in Mediaeval Art..., p. 5.
} 
como guerreras, llevan lanza y escudo y pisotean al vicio vencido (Figs. 16, 17, 18 y 19). Este motivo fue la forma más común de representar el tema en la escultura románica, sobre todo en las fachadas de iglesias como en la de Saint-Pierre de la Tour en Aulnay, sin embargo, el mismo no surgió en el arte románico, sino en las artes menores. Para Katzenellenbogen esta manera de mostrar la victoria, aplastando al vencido, proviene del arte del antiguo oriente -arte bizantino-, y el mismo había sido utilizado por el arte paleocristiano para representar el triunfo del cristianismo sobre todos sus adversarios. En términos tropológicos es el triunfo de la virtud o de la persona virtuosa sobre las fuerzas destructivas ${ }^{130}$. De las artes menores, las Virtudes triunfantes pasaron a representarse en la escultura monumental románica, sobre todo en las arquivoltas y capiteles de los templos, y esto a su vez incidió en la creación de otras obras a menor escala, un intercambio constante entre las artes menores y mayores $^{131}$. Katzenellenbogen resume que el desarrollo de esta forma particular de los vicios y las virtudes se encuentra determinado no sólo por los cambios en las concepciones o programas teológicos, sino que también por leyes intrínsecas de los medios utilizados por los escultores, orfebres, miniaturistas o esmaltadores ${ }^{132}$.

El último motivo que el autor incluye en el estudio de las representaciones dinámicas de los vicios y las virtudes es la Escalera de las virtudes o Escala de las virtudes (Figs. 3 y 4). Émile Mâle menciona esta forma de tratar el tema y lo relaciona con la obra de Honorio de Autun. Para Katzenellenbogen es la obra de Juan Clímaco, La escalera del divino ascenso (Scala Paradisi), la fuente de inspiración de este motivo el cual fue muy representado por los artistas griegos y en el siglo XII se extendió a occidente siendo su mayor difusora la monja Herrada de Landsberg ${ }^{133}$. La Escala de las virtudes se representó principalmente en manuscritos.

La segunda parte del trabajo de Katzenellenbogen se centra en las representaciones estáticas del tema y es a ésta la que más atención presta el autor. El estudio de este motivo iconográfico es un tanto más complicado pues el mismo no se

\footnotetext{
${ }^{130}$ KatZenellenbogen. Allegories of the Virtues and Vices in Mediaeval Art..., p. 14.

${ }^{131}$ Katzenellenbogen. Allegories of the Virtues and Vices in Mediaeval Art..., p. 20.

${ }^{132}$ KAtZEnEllenbogen. Allegories of the Virtues and Vices in Mediaeval Art..., p. 21.

${ }^{133}$ KAtZenellenbogen. Allegories of the Virtues and Vices in Mediaeval Art..., p. 24.
} 
desarrolló como una unidad y distintos motivos y temas se entrelazan para presentar la lucha interna del alma humana resultando en complicadas composiciones las cuales son entendidas por el espectador por medio de pequeñas sutilezas ${ }^{134}$. En las representaciones estáticas de los vicios y las virtudes Katzenellenbogen discute varios motivos iconográficos que carecen de la tensión dramática del grupo anterior y para analizar los mismos de forma genérica divide estos en tres grupos: Las virtudes en forma humana, Alegorías particulares de los vicios y las virtudes y el Ciclo de NotreDame de París.

De estas tres divisiones de las representaciones estáticas, el grupo de Las virtudes en forma humana es el más concreto de todo, pues básicamente consiste en imágenes de distintos personajes bíblicos e históricos acompañados por ciertas virtudes las cuales exaltan el valor moral de la persona. Se pueden plasmar de dos maneras: varias virtudes personificadas junto al personaje que exaltan o distintas virtudes se colocan separadas del personaje central y la composición se arregla de tal manera que las mismas indican que responden al personaje central de la imagen ${ }^{135}$. En la mayoría de los casos se representan un grupo de virtudes concretas, usualmente las cuatro virtudes cardinales, y es por medio de algún atributo o inscripción se identifican las mismas ${ }^{136}$. Esta forma de plasmar dichos conceptos morales se utiliza desde la época de los primeros cristianos, y su fuente de inspiración fueron mosaicos romanos en los que se encuentra Virgilio rodeado por las musas o Baco acompañado por las cuatro estaciones. Las imágenes más antiguas que hoy en día se conservan de Las virtudes en forma humana provienen de monasterios egipcios de Alejandría sin embargo este motivo proliferó con más vivacidad en el occidente latino ${ }^{137}$.

Las virtudes en forma humana no se relacionan con un aspecto concreto de la realidad, sino que su significado depende del lugar en el que se insertan y su relación con el tema central de la composición. Puesto que estas imágenes obedecen a un tema mayor encontramos esta iconografía de las virtudes en manuscritos, textos

\footnotetext{
${ }^{134}$ KatZenellenbogen. Allegories of the Virtues and Vices in Mediaeval Art..., p. 27.

${ }^{135}$ KATZENELLENBogen. Allegories of the Virtues and Vices in Mediaeval Art..., p. 28.

${ }^{136}$ KATZENELLENBogen. Allegories of the Virtues and Vices in Mediaeval Art..., pp. 55-56.

${ }^{137}$ KATZEnELLEnBogen. Allegories of the Virtues and Vices in Mediaeval Art..., pp. 27-30.
} 
litúrgicos, altares, relicarios, sagrarios, cálices, patenas, aguamaniles, coronas, puertas, candelarios y tumbas. Las imágenes de las virtudes en todos estos objetos pueden transmitir un significado especial que sobrepasa el carácter práctico de los mismos, imbuyendo a todos estos objetos de significado tropológico ${ }^{138}$.

Antes de adentrarse en las virtudes representadas en las portadas de las catedrales góticas francesas Katzenellenbogen discute otras alegorías particulares en las que se representan los vicios y las virtudes ya sea en contraposición o independientes. Estas alegorías particulares incluyen un sin número de referentes tomados del mundo como: figuras humanas, animales, árboles u otros objetos ${ }^{139}$. En las alegorías en las que ciertas figuras antropomorfas responden a ciertas virtudes destacan notables personajes del Antiguo Testamento como referencia al vicio o la virtud, por ejemplo: Abrahán representa la Obediencia, Moisés la Mundicia, Job la Paciencia o Judit y Jael la Humildad ${ }^{140}$. En el caso de los vicios sobresalen las imágenes de dos figuras humanas, el mísero y el lascivo, que han sucumbido a los vicios de la lujuria y la avaricia. Estas dos figuras viciosas pasan entonces a representar el vicio en sí y se convierten en la Lujuria y la Avaricia personificadas. Las mismas son reconocible por medio de los castigos pertinentes a sus vicios. El tema se originó en el suroeste de Francia, en la escultura románica de la catedral de Toulouse y de ahí se extendió a otras zonas representándose en las jambas, pórticos, fachadas y capiteles de distintas iglesias ${ }^{141}$.

Otros motivos iconográficos que Katzenellenbogen analiza son: el Árbol de las virtudes y el árbol de los vicios, El paraíso místico y La rueda de la falsa religión y la rueda de la verdadera religión. En su mayoría estos motivos iconográficos se encuentran inspirados en distintos textos medievales. Mâle relaciona las representaciones del Árbol de las virtudes y el árbol de los vicios con el pensamiento de Hugo de San Víctor y textos como Somme le Roi ${ }^{142}$, en cambio Katzenellenbogen

\footnotetext{
${ }^{138}$ KAtZenellenbogen. Allegories of the Virtues and Vices in Mediaeval Art..., p. 51.

${ }^{139}$ Katzenellenbogen. Allegories of the Virtues and Vices in Mediaeval Art..., p. 74.

${ }^{140}$ Katzenellenbogen. Allegories of the Virtues and Vices in Mediaeval Art..., p. 57.

${ }^{141}$ KAtZEnellenbogen. Allegories of the Virtues and Vices in Mediaeval Art..., pp. 58-59.

142 MÂlE. El arte religioso del siglo XIII en Francia..., pp. 137-138
} 
entiende que este motivo iconográfico deriva de parábolas tomadas del Nuevo Testamento y fue utilizado para iluminar ciertos tratados y textos como el Liber floridus de Lambert y De fructibus carnis et spiritus del Pseudo Hugo ${ }^{143}$.

Katzenellenbogen es el primero en identificar El paraíso místico y La rueda de la falsa religión y la rueda de la verdadera religión como motivos iconográficos de los vicios o las virtudes. El primero, El paraíso místico, se inspira y suele representarse en manuscritos del Speculum Virginum y en éste se encuentran las cuatro virtudes cardinales acompañadas de los cuatro evangelistas, los doctores de la iglesia y las beatitudes. Por otra parte, La rueda de la falsa religión y la rueda de la verdadera religión nacen del trabajo de Hugo de Folieto, De rota verae et falsae religionis. Puesto que el trabajo de Hugo de Folieto se encuentra dirigido a la vida monástica en las representaciones de este motivo iconográfico se plasman las figuras de unos monjes y como una rueda, parecida a la rueda de la fortuna, se mueve. En el caso de la falsa religión, los intervalos de la rueda designan vicios particulares propios de la vida monástica y como en muchas ocasiones el mal proceder de un monje para obtener algo le lleva a otro mal. El movimiento de esta rueda es el resultado de los pecados cometidos por los monjes ${ }^{144}$. La rueda de la verdadera religión es la antítesis de la anterior, pues en ésta el movimiento de la rueda se rige por ciertas virtudes y realmente ilustra dentro del plano tropológico como la consecución de una virtud lleva a otra ${ }^{145}$.

La discusión de todos estos motivos iconográficos de los vicios y virtudes es importante porque el ciclo de Notre-Dame de París es la conjunción de todos estos en un solo sistema, ya que en el mismo encontramos reminiscencias de las distintas variantes de la Psychomachia, de las virtudes encerradas en medallones,

\footnotetext{
143 "Thus the difference between good and evil has, for ages past, been illustrated by the parable of two contrasted trees. The fruits of the spirit are already enumerated in the New Testament (Galat. $V, 22$ sq.) and the good three with its fruits contrasted with the bad (Matth. VII, 17 sq.). This striking conception was extended more and more later on. Two trees are usually employed; their roots are Humilitas and Superbia, their branches virtues and vices respectively, for they are always productive either of good or of evil". KATZENELLENBOGEN. Allegories of the Virtues and Vices in Mediaeval Art..., p. 63.

${ }^{144}$ KATZENELLENBogen. Allegories of the Virtues and Vices in Mediaeval Art..., p. 71

${ }^{145}$ KatZENellenbogen. Allegories of the Virtues and Vices in Mediaeval Art..., p. 72.
} 
representaciones alegóricas con ejemplos humanos o simbolismos animales, etc ${ }^{146}$. La importancia del ciclo de Notre-Dame de París no estriba únicamente en que es la conjunción de todos los motivos antes discutido, sino que también es el nacimiento de una nueva forma de plasmar los vicios y las virtudes que será utilizada posteriormente en el resto de las catedrales francesas como también afirma Mâle. Pese a que Émile Mâle estudia estas representaciones, el mismo admite no haber obtenido resultado alguno pues no logra descifrar el por qué, a parte de las tres virtudes teologales y las cuatro cardinales, se han escogido tales o cuales virtudes en el ciclo de Notre-Dame de París ${ }^{147}$.

Katzenellenbogen analiza el ciclo de París en función al resto del programa iconográfico principal y del entorno en donde se encuentra el mismo. A diferencia de Mâle, si encuentra un referente textual para explicar el ciclo de París. Según él, el núcleo para este ciclo de vicios y virtudes es la idea de Hugo de San Víctor que conjuga la Humildad (la raíz de todo bien), las virtudes teologales y las virtudes cardinales a las cuales se han incluido otra serie de virtudes que complementan las anteriores. Se representan doce virtudes en relación a los doces apóstoles que se encuentran sobre éstas, pero a la vez la distribución de las virtudes responde a dos aspectos del hombre: el individuo y la sociedad ${ }^{148}$. De igual forma los vicios responden a la antítesis de cada virtud, pero también se encuentran relacionados entre sí simétricamente. Mientras que las virtudes en el ciclo de Notre-Dame de París pueden entenderse como el resumen de todos los motivos iconográficos analizados por Katzenellenbogen, el vicio se plasma a través de ejemplos que ilustran los mismos en forma de pecados del diario vivir, tanto así que el autor relaciona los mismos con los castigos de los Penitenciales ${ }^{149}$.

\footnotetext{
${ }^{146}$ KatZenellenbogen. Allegories of the Virtues and Vices in Mediaeval Art..., p. 81.

${ }^{147}$ Émile Mâle aclara que: "Claramente se ve por qué, en Notre-Dame de París, no hay más que doce virtudes: es que sólo había doce lugares que llenar debajo de los doce apóstoles. El número doce fue conservado en Chartres, aunque la disposición arquitectónica fuese diferente, porque trabajaban según un modelo aceptado. Pero esto no explica por qué tal virtud ha sido escogida en lugar de otra". MÂLE. El arte religioso del siglo XIII en Francia..., p. 161.

${ }^{148}$ KAtZenellenbogen. Allegories of the Virtues and Vices in Mediaeval Art..., pp. 80-81.

${ }^{149}$ KAtZenEllenbogen. Allegories of the Virtues and Vices in Mediaeval Art..., p. 78.
} 
Si bien Katzenellenbogen estudia muchos de los motivos iconográficos estudiados por Émile Mâle en L'art religieux du XIII ${ }^{e}$ siècle en France, el gran aporte del historiador alemán en contraposición con el francés estriba en que desde la perespectiva iconológica no se limita única y exclusivamente al análisis iconográfico y a la busquedad de posibles fuentes literarias, sino que igualmente toma en consideración el lugar o contexto en el que se insertan los vicios y las virtudes y cómo los mismos contribuyen a la riqueza de significados de estas alegorías.

\section{Louis Réau}

Entre 1955 y 1959 el historiador del arte francés Louis Réau publicó Iconographie de l'art chrétien ${ }^{150}$, un compendio de tres volúmenes dedicados a estudiar diversos motivos iconográficos propios del arte cristiano. La introducción general de su trabajo consiste en un apartado completo del tema de los vicios y las virtudes. Esta sección básicamente es un resumen de los motivos y temas iconográficos ya antes discutidos por Stettiner, Mâle, Woodruff y Katzenellenbogen. Réau agrupa los distintos motivos y de modo sintético explica cómo se conocen los mismos en otros idiomas, en qué consisten estos, brinda ejemplos muy concretos por siglos, menciona las obras literarias que inspiran las iconografías más conocidas y provee una breve bibliografía en relación con el motivo iconográfico que explica.

Réau utiliza en su trabajo los motivos identificados por sus antecesores e intenta precisar más las distintas iconografías razón por la cual en su apartado sobre vicios y virtudes hay más divisiones del tema. No obstante, la mayoría de las divisiones de los motivos iconográficos establecidas por Réau bien pueden ser estudiadas desde las divisiones establecidas por Katzenellenbogen pues las mismas se ajustan perfectamente a las representaciones de Las virtudes en forma humana ${ }^{151}$.

\footnotetext{
${ }^{150}$ RÉAU, Louis. Iconographie de l'art chrétien, edición consultada Iconografía del arte cristiano. Introducción general. Barcelona: Ediciones del Serbal, [1955-59] 2008.

${ }^{151}$ Las divisiones hechas por Réau que representan a Las virtudes en forma humana incluyen: La justicia de Cambises, La justicia de Trajano, La justicia de Otón, La justicia de Arquimbaldo, personificaciones de la Avaricia y la Lujuria, La ascensión de Alejandro, La inmersión de Alejandro
} 
Mientras Mâle y Katzenellenbogen concluyen sus trabajos con los vicios y virtudes de la catedral de Notre-Dame de París, motivo que Réau llama Las virtudes heráldicas, éste dedica un apartado a las representaciones de los vicios y las virtudes posteriores al siglo XIII ${ }^{152}$, el cual ya había sido tocado por Mâle en L'art religieux de la fin du Moyen Âge en France. Étude sur l'iconographie du Moyen Âge et sur ses sources d'inspiration. La iconografía ya estudiada por Mâle, Réau la denomina la tercera iconografía francesa de las virtudes y los vicios, e igualmente utiliza la misma como hilo conductor para analizar las formas en que se representó el tema en Italia $^{153}$. Réau culmina su discusión sobre los vicios y las virtudes con la Iconología de Cesare Ripa y resume los atributos más usuales utilizados por Ripa para las siete principales virtudes y los siete pecados capitales.

\section{Rosemond Tuve}

Si bien el área de trabajo de Rosemond Tuve es la literatura inglesa los estudios de ésta en torno a distintos textos bajo medievales son de suma importancia para el estudio de la iconografía de las virtudes, sobre todo de la nueva iconografía de las virtudes identificada a principio del siglo XX por Émile Mâle. Sus hallazgos se recogen en dos artículos publicados por en el Journal of the Warburg and Courtauld Institutes, la primera parte de su investigación "Notes on the Virtues and Vices, Part I: Two Fifteenth-Century Lines of Dependence on the 12th and 13th Centuries" de 1963 y al año siguiente la segunda parte "Notes on the Virtues and Vices, Part II"154. Muchos de los planteamientos expuestos por Tuve en estos dos artículos fueron

en batiscafo al fondo del mar, El lay de Aristóteles, El lay de Virgilio. RÉAU, Louis. Iconografía del arte cristiano. Introducción general. Barcelona: Ediciones del Serbal, 2008. pp. 197-210.

${ }^{152}$ RÉAU. Iconografía del arte cristiano. Introducción general..., p. 219.

${ }^{153}$ RÉAU. Iconografía del arte cristiano. Introducción general ..., pp. 221-227.

154 TUVE, Rosemond. "Notes on the Virtues and Vices, Part II." Journal of the Warburg and Courtauld Institutes Vol. 27 (1964), pp. 42-72. "Notes on the Virtues and Vices, Part I: Two Fifteenth-Century Lines of Dependence on the 12th and 13th Centuries." Journal of the Warburg and Courtauld Institutes Vol. 26 N ${ }^{\circ} .3 / 4$ (1963), pp. 264-303. 
retomados en el libro que publicó el 1966, Allegorical Imagery. Some Medieval Books and Their Posterity ${ }^{155}$.

El tema principal de estudio de Tuve es el poema The Faerie Queen del inglés Edmund Spenser. En su afán por entender el uso de las virtudes en la obra del poeta, ésta analiza todas las obras literarias en las que se incluyeron alegorías textuales y gráficas de las virtudes y fueron posibles fuentes de influencias en el trabajo de Spenser. En la primera parte de "Notes on the Virtues and Vices" abordas los textos y miniaturas de un manuscrito de mediados del siglo XV, el Laud misc. 570 de la Biblioteca Bodleian: la Epitre d'Othéa de Christine de pisan y un tratado en francés titulado Livre des quatre Vertus Cardinaulx (Figs. 8 y 9). En ambos textos además de tratar el tema de las virtudes también éstas se ilustran. Tuve afirma que el tratado sobre las cuatro virtudes cardinales es una traducción fragmentaria del trabajo de Juan de Gales, Breviloquium de virtutibus. El aproximamiento del Breviloquium a las virtudes muestra un vínculo muy estrecho con textos clásicos del tema, sobre todo con las partes de cada una de las cuatro virtudes cardinales establecidas por Cicerón y Macrobio ${ }^{156}$.

El principal aporte de su trabajo para con la Historia del Arte es una nueva cronología y nueva forma de entender la iconografía de las virtudes de finales del siglo XV, también llamada nueva iconografía de las virtudes, lo cual logra a través del estudio de las miniaturas del Ms. Laud misc. 570. Ésta se plasma en el trabajo de Christine de Pizan y en el tratado de virtudes de dicho manuscrito, sin embargo, estos ejemplos son anteriores a los identificados por Mâle, con fecha de 1450. Las miniaturas de los manuscritos tratados por Mâle se insertó en una traducción de la Ética de Aristóteles hoy en día conservado en la Biblioteca Municipal de Rouen y dos códices con la traducción al francés de De Quatuor virtutibus de Sénèque de Jean Courtecuisse en la Biblioteca Nacional en París y el otro en la Biblioteca de Chantilly

155 TuVE, Rosemond. Allegorical Imagery. Some Medieval Books and Their Posterity. Princeton; New Jersey: Princeton University Press, [1966] 1977.

${ }^{156}$ TUVE. "Notes on the Virtues and Vices, Part I..., pp. 266-272. 
(Figs. 7 y 10) ${ }^{157}$. Fechados aproximadamente en 1470 estos manuscritos son veinte años más tardíos que el de la Bodleian. El análisis filológico de Tuve revela que la nueva iconografía aquí representada no responde ni a los textos ni a las glosas de estos manuscritos.

En el tratado de vicios y virtudes de mediados de siglo XV de Laud misc. 570 se insertaron las virtudes, según la nueva iconografía: con distintos objetos en sus manos y cabeza, acompañadas por unas damas (Figs. 8 y 9). Todas estas figuras femeninas se encuentran identificadas por una cartela. Cada una de estas damas corresponden a las distintas partes de las virtudes según Macrobio y Cicerón ${ }^{158}$. En el texto de Christine de Pizan, en la miniatura de Templanza, las cartelas han desaparecido pero cuatro damas continúan acompañando a la virtud. Tuve identifica otros manuscritos anteriores a los ejemplos tratados por Mâle en los que se representan las virtudes con estos objetos, entre estos la recopilación histórica de Jean Mansel La Fleur des Histoires de $1467^{159}$ y una copia de Epitre d'Othéa de $1400^{160}$. Los objetos junto y las cartelas en las miniaturas no son meros atributos o descripciones, sino que los mismos responden a los oficios de las distintas facetas o aspectos de las virtudes correspondiente, los cuales definen la complicada naturaleza de cada una de las virtudes ${ }^{161}$. A partir de la segunda mitad del siglo XV, ya no se representan las cartelas o las doncellas, pero los extraños objetos que éstas portan continúan resaltando la tradición ciceroniana y macrobiana de las partes de las virtudes $^{162}$. Todo esto le lleva a concluir que este nuevo motivo iconográfico debió surgir antes de $1410^{163}$.

En la segunda parte de "Notes on the Virtues and Vices" Tuve estudia la iconografía de los vicios y las virtudes en varias copias de finales del siglo XIII y

157 Ms. I 2, signatura antigua Ms. 927 (Bibliothèque Municipale, Rouen). Ms. Fran. 9186 (Bibliothèque Nationale de France, París). Ms. 282 (Bibliothèque du château de Chantilly).

${ }^{158}$ TUVE. "Notes on the Virtues and Vices, Part I..., p. 282.

${ }^{159}$ Ms. 6797 (British Library, Londres). TUVE. "Notes on the Virtues and Vices, Part I..., p. 280.

${ }^{160}$ Según la información del British Museum, éste es de 1410-1414. Ms. Harley 4431 (British Museum, Londres). TUVE. "Notes on the Virtues and Vices, Part I..., p. 282.

161 TUVE. "Notes on the Virtues and Vices, Part I..., pp. 283, 287.

${ }^{162}$ TUVE. "Notes on the Virtues and Vices, Part I..., p. 287.

${ }^{163}$ TUVE. "Notes on the Virtues and Vices, Part I..., p. 283. 
principios del XIV de Somme le Roi (Fig. 6). Según ésta el grupo de siete virtudes que aparecen en estos manuscritos no responde a las cuatro cardinales y tres teologales. A partir de su análisis del texto y la estructura de la obra del hermano Laurent, el cual es un tratado sobre los siete dones del Espíritu Santo, Tuve establece que las virtudes en Somme le Roi surgen de las siete Beatitudes que a su vez son el resultado de la práctica de los siete dones del Espíritu Santo, las virtudes se nutren del Espíritu Santo ${ }^{164}$. Cada división del texto el mismo comienza con una breve descripción del don, seguido por la virtud, el vicio y la Beatitud correspondiente. Dada su relación con los dones del Paráclito, Tuve les llama dones-virtudes ${ }^{165}$.

Tuve presta especial atención a ciertos elementos de miniaturas específicas. Por ejemplo, los animales que se encuentran a los pies de las virtudes. De modo general establece que los mismos no son atributos, sino que estos son animales conquistados los cuales muestran en sentido figurado la naturaleza de la oposición moral. Se centra principalmente en la figura del unicornio que aparece bajo los pies de Humildad, cambio iconográfico que surge en las copias del siglo XIV ${ }^{166}$.

En cuanto a los vicios, la elección de estos se basa en mostrar la acción contraria a la virtud a la que acompañan. Con particular interés en Envidia, vicio el cual se representa a través de la figura de Elí y en algunos manuscritos en lugar de ser identificado como envidia se etiqueta como hely ${ }^{167}$.

La miniatura se divide en cuatro escenas, las dos superiores corresponden a la virtud y al vicio. En las dos inferiores se representan acciones y escenas en las que se práctica la virtud correspondiente o el vicio correspondiente. La inspiración de muchas de estas son historias bíblicas, sobre todo veterotestamentarias, y $\operatorname{cotidianas}^{168}$.

\footnotetext{
164 TUVE, Rosemond. "Notes on the Virtues and Vices, Part II..., pp. 45-46, 49-50.

${ }^{165}$ Gift-virtues. TUVE. "Notes on the Virtues and Vices, Part II..., p. 45.

166 TUVE. "Notes on the Virtues and Vices, Part II..., pp. 60-61.

${ }^{167}$ TUVE. "Notes on the Virtues and Vices, Part II..., p. 46.

168 TUVE. "Notes on the Virtues and Vices, Part II..., pp. 56-58.
} 
Para la autora esta iconografía de las siete virtudes como frutos de las Beatitudes se utilizó en algunos breviarios, salterios y libros de horas por su relación con los siete salmos penitenciales, los sacramentos, día de la semanas y peticiones del Padre Nuestro ${ }^{169}$. Incluso la exegesis del hermano Laurent en Somme le Roi incidió en la creación de otros esquemas basados en el número doce, y junto a éstos los doce Apóstoles, los artículos del credo y los meses del año. Más allá de estos textos, los dones-virtudes fueron utilizados en otros medios y contextos. Tuve vincula los bajos relieves de las catedrales de París, Chartres y Amiens, una vidriera en la catedral de Estrasburgo con este esquema de siete. Igualmente surgieron ilustraciones en manuscritos de árboles, ruedas, diagramas con royos o cajas en los que se insertaron las peticiones del Padre Nuestro, los dones del Espíritu Santo y vicios y virtudes. Para la autora, estos grupos paralelos de siete son mnemotecnias que permiten al espectador abordar un concepto y a la misma vez evocar otro ${ }^{170}$.

\section{Ellen Kosmer}

Otro motivo iconográfico en torno a las virtudes es El jardín de las virtudes. El mismo fue identificado por Ellen Kosmer durante los años setenta en un artículo publicado en la Revista del Instituto Warburg titulado "Gardens of Virtue in the Middle Ages" (1978) ${ }^{171}$. En este corto artículo Kosmer básicamente discute las representaciones alegóricas de las virtudes en un jardín en donde éstas como jardineros cuidan de distintos árboles. Según Kosmer, es el tratado del siglo XIII, Somme le roi, el texto que introduce esta nueva iconografía de las virtudes ${ }^{172}$. Pese a que es el trabajo del hermano Laurent para la obra que sienta las bases para este motivo iconográfico, ya encontramos representaciones de este jardín pero de manera esquemática en el Liber Floridus y en el Speculum Virginum ${ }^{173}$. Sin embargo, éstas

\footnotetext{
169 TUVE. "Notes on the Virtues and Vices, Part II..., pp. 65-66.

170 TUVE. "Notes on the Virtues and Vices, Part II..., p. 65.

${ }^{171}$ Kosmer, Ellen. "Gardens of Virtue in the Middle Ages." Journal of the Warburg and Courtauld Institutes, Vol. 41 (1978), pp. 302-307.

${ }^{172}$ KOSMER. "Gardens of Virtue in the Middle Ages..., p. 302.

${ }^{173}$ Kosmer. "Gardens of Virtue in the Middle Ages..., p. 303.
} 
más que ser un jardín de las virtudes se relación más cercanamente al tema iconográfico de El paraíso místico discutido por Adolf Katezenellenbogen pues se encuentran en relación con los padres de la iglesia, los evangelistas y las beatitudes ${ }^{174}$.

Kosmer no sólo identifica el sentido anagógico y tropológico de este motivo, ella va más allá y afirma que además de ser una metáfora con carácter didáctico también estas imágenes se pueden entender como simples representaciones de un jardín propio del siglo XIII ${ }^{175}$. Este motivo iconográfico es un tanto escaso puesto que sólo se limitó algunas copias manuscritas de Somme le roi, y es muy difícil encontrar influencias del mismo en otros manuscritos o representaciones que no respondan a la obra del hermano Laurent ${ }^{176}$.

\section{Joanne S. Norman}

A finales de la década de los ochenta se publicó el estudio de Joanne S. Norman Metamorphoses of an Allegory: The Iconography of the Psychomachia in Medieval Art fruto de su tesis doctoral ${ }^{177}$. El campo de estudio de Norman es la literatura, por ende, su trabajo parte del estudio de la obra de Prudencio, la Psychomachia, las representaciones de los códices e igualmente otros ejemplos en los que se plasman el concepto de psychomachia. Retoma la idea de Mâle, entendiendo la Batalla del alma como la lucha entre nociones abstractas, particularmente entre los vicios y virtudes. Norman examina el motivo de la psychomachia en la literatura y el arte, le interesa estudiar las influencias del poema de Prudencio y las plasmaciones plásticas del mismo en otras obras literarias y

\footnotetext{
${ }^{174}$ KAtZenellenbogen. Allegories of the Virtues and Vices in Mediaeval Art..., pp. 69-70.

${ }^{175}$ KOSMER. "Gardens of Virtue in the Middle Ages..., p. 305.

176 KOSMER. "Gardens of Virtue in the Middle Ages..., p. 306.

177 Tesis presentada en 1979 al Departamento de Inglés de la Universidad de Ottawa bajo el título de The Psychomachia in Medieval Art: Metamorphoses of an Allegory. En 1988 la misma se publicó bajo el título de Metamorphoses of an Allegory: The Iconography of the Psychomachia in Medieval Art. NORMAN, Joanne S. Metamorphoses of an Allegory: The Iconography of the Psychomachia in Medieval Art. New York: P. Lang, 1988.
} 
artísticas y cómo la interacción entre imagen y texto influye y transforma el significado del primer motivo, creando igualmente nuevos motivos ${ }^{178}$.

Esta autora utiliza el método propuesto por Erwin Panofsky en Iconografía e Iconología para identificar varias obras de arte, en su mayoría manuscritos iluminados y esculturas, en las que se incluye el motivo de la psychomachia y el tema principal al que responde La Batalla del Alma ${ }^{179}$. Esto le lleva a examinar las imágenes y las distintas variantes de éste para concluir con la interpretación del contexto intelectual y social de las obras o motivos estudiados ${ }^{180}$. Norman analiza muchas de las obras ya tratadas por los autores antes mencionados como son: los manuscritos iluminados de la Psycomachia, las esculturas románicas del sur oeste de Francia y las representaciones de las portadas de algunas catedrales góticas coincidiendo con estos autores en muchos aspectos.

Puesto que Norman proviene del campo de la literatura, presta especial atención al hecho de que los vicios y las virtudes se plasman como figuras femeninas. Establece que la representación de los conceptos como mujeres se vincula directamente con el texto de Prudencio, se mantiene la concordancia entre el género de todos los sustantivos en latín y las imágenes de los conceptos abstractos ${ }^{181}$. El cuidado extraordinario que presta Norman al texto de la Psychomachia la conduce a encontrar reminiscencias directas del texto de Prudencio en representaciones posteriores al siglo XII.

En cuanto a las esculturas románicas de la psychomachia, sobre todo las del sur oeste de Francia, la autora entiende que el forcejeo moral de los vicios y las virtudes en estas representaciones se vinculan directamente con la guerra santa y se resalta el mismo a través de las predicas de las cruzadas, las enseñanzas de Cluny y la liturgia que se enfoca en la lucha contra el diablo. Igualmente relaciona las representaciones de las esculturas de esta zona con el culto a Santiago y la

\footnotetext{
${ }^{178}$ NoRman. Metamorphoses of an Allegory: The Iconography of the Psychomachia..., p. 3.

${ }^{179}$ NORMAN. Metamorphoses of an Allegory: The Iconography of the Psychomachia..., pp. 3-4

${ }^{180}$ NORMAN. Metamorphoses of an Allegory: The Iconography of the Psychomachia..., pp. 5-6.

${ }^{181}$ NORMAN. Metamorphoses of an Allegory: The Iconography of the Psychomachia..., p. 13.
} 
peregrinación a su santuario en Santiago de Compostela pues la lucha entre los vicios y las virtudes, entre el bien y el mal, es comparable a un largo peregrinar del alma humana. Norman entiende que no se puede separar el culto a Santiago con la Reconquista de España y que por lo tanto la cruzada se encuentra estrechamente ligada a la peregrinación ${ }^{182}$. La autora afirma igualmente que un gran número de las iglesias donde se insertan psychomachias además de encontrarse cerca de las rutas de peregrinación, fueron construidas a mediados del siglo XII y eran en su mayoría fundaciones monásticas que tenían conexiones con la reforma de Cluny, la regla benedictina o los cánones agustinianos (siempre partiendo de ejemplos franceses). Dicho contexto le sirve para explicar el por qué la elección de esta alegoría tan sofisticada, afirmando que el significado tropológico de la batalla espiritual y el triunfo en el alma humana de la virtud sobre el vicio era cónsono con los principios acéticos de la vida monástica ${ }^{183}$.

Para el caso de las esculturas posteriores al siglo XII, especialmente aquellas en las que se encuentran a las virtudes victoriosas o entronizadas en las catedrales góticas, Joanne S. Norman entiende que los símbolos que portan las virtudes se vinculan a ciertos sistemas abstractos de moral y no a textos particulares ${ }^{184}$. Según la autora en esta nueva iconografía hay una gran variedad de atributos tomados de fuentes dispersa las cuales representan de manera gráfica el afán de muchos teólogos medievales por analizar y categorizar el mal y el pecado ${ }^{185}$. Es una nueva iconografía creada en respuesta a la penitencia espiritual laica propia de los centros urbanos de los siglos XIII y producto de muchas de las disposiciones del IV Concilio de Letrán $^{186}$.

El interés de Norman por estudiar las imágenes de la batalla, le llevan a interpretar la figura de David como otra manera de plasmar una psychomachia.

\footnotetext{
${ }^{182}$ NORMAN. Metamorphoses of an Allegory: The Iconography of the Psychomachia..., pp. 28-29. ${ }^{183}$ NORMAN. Metamorphoses of an Allegory: The Iconography of the Psychomachia..., pp. 33-34. ${ }^{184}$ NORMAN. Metamorphoses of an Allegory: The Iconography of the Psychomachia..., pp. 68-69. ${ }^{185}$ NORMAN. Metamorphoses of an Allegory: The Iconography of the Psychomachia..., pp. 93, 113. ${ }^{186}$ NORMAN. Metamorphoses of an Allegory: The Iconography of the Psychomachia..., pp. 5, 101 102.
} 
Muchas escenas de la vida del rey David incluso aparecen como representaciones de la victoria de las virtudes humanas sobre el vicio ${ }^{187}$. Entre los ejemplos que brinda de este combate de vicios y virtudes se encuentran David versus Goliat, equiparable a la Humidad versus la Soberbia y David contra Saúl como la Paciencia contra la $\operatorname{Ira}^{188}$.

Puesto que la literatura es su principal campo de estudio esta autora concluye su trabajo identificando una serie de obras literarias de finales del siglo XIV las cuales retoman la idea de Prudencio del conflicto moral. Estas obras son el trabajo de Guillaume de Deguileville, Pèlerinage de la vie humaine y la Etymachia. En ambas se se insertaron nuevas imágenes delas virtudes luchando contra los vicios. Norman intepretas estas como nuevas alegorías de la batalla del alma (Psychomachia) ${ }^{189}$. Estas ilustraciones de batalla inspiradas en su mayoría en los manuscritos de la Etymachia tuvieron gran auge en la confección de tapetes en el siglo XVI.

\section{Index of Christian Art}

En el 2000 en Index of Christian Art (Índice de Arte Cristiano) publicó el catálogo Virtue \& Vice: The Personifications in the Index of Christian Art. Éste es una recopilación de las obras de artes registradas por el Índice en las que se representan los vicios y las virtudes ${ }^{190}$. En el catálogo se han identificado más de mil obras en distintas partes de Europa y los Estados Unidos en las que se representan los vicios y/o las virtudes ${ }^{191}$. Además de ubicar todas estas representaciones de una misma temática en un solo corpus, se han identificado imágenes de un sin número de

\footnotetext{
${ }^{187}$ NORMAN. Metamorphoses of an Allegory: The Iconography of the Psychomachia..., p. 143.

${ }^{188}$ NORMAN. Metamorphoses of an Allegory: The Iconography of the Psychomachia..., pp. $146 \mathrm{y}$ 152.

${ }^{189}$ NORMAN. Metamorphoses of an Allegory: The Iconography of the Psychomachia..., p. 181.

${ }^{190}$ Hourinane, Colum, ed. Virtue \& Vice: The Personifications in the Index of Christian Art. Princeton: Department of Art and Archaeology of Princeton University in association with Princeton University Press, 2000.

${ }^{191}$ Hourihane. Virtue \& Vice: The Personifications..., p. 4.
} 
vicios y virtudes además de las siete tradicionales ${ }^{192}$. El volumen incluye también una recopilación de ensayos en torno a distintos motivos iconográficos de los vicios y las virtudes, o vicios y virtudes particulares.

\subsubsection{Otros trabajos de casos particulares}

Como hemos visto, la mayoría de los trabajos que tratan el tema de las representaciones de los vicios y las virtudes en el arte medieval parten o se centran en ejemplos franceses o ingleses por mencionar algunos. Sin embargo, estos no son las únicas investigaciones que tratan las representaciones de estas zonas, pues a lo largo de nuestra investigación hemos identificado una serie de trabajos que abordan ejemplos particulares en las mismas. Para el caso francés, estos artículos se centran en obras que se encuentran en el suroeste de este país. Los estudios de Paul Deschampsy Pierre Bouffard se centran en iglesias de las regiones de Saintonge y Poitou y el artículo de Fraïsse Chantal en la zona de Moissac.

Deschamps y Bouffar estudian específicamente las esculturas románicas de la Psychomachia en los templos de esta región de Francia (Figs. 16, 17, 18 y 19). En Le combat des vertus et des vices sur les portails romans de la Saintonge et du Poitou $^{193}$, a principios del siglo XX, Deschamps identificó una serie de iglesias románicas, del siglo XII, en las zonas de Poitou y Saintonge (suroeste de Francia) en las que se representan más que la lucha entre los vicios y las virtudes, la victoria de las virtudes sobre los vicios. Parte principalmente del análisis estilístico y afirma que en estas imágenes se han unificado ciertos símbolos para mantener la armonía en la plasmación escultórica puesto que las descripciones de Prudencio y las miniaturas de la Psychomachia prácticamente son imposible recrear en la arquitectura ${ }^{194}$. Para Deschamps las esculturas de las arquivoltas de las iglesias de estas zonas más que

\footnotetext{
${ }^{192}$ En el catálogo se han identificado 227 personificaciones, 109 responden a las virtudes y 118 a los vicios. Hourihane. Virtue \& Vice: The Personifications..., p. 151.

${ }^{193}$ DesChamPS, Paul. Le combat des vertus et des vices sur les portails romans de la Saintonge et du Poitou. Caen: Henri Delesques, Imprimeur-Éditeur, 1914.

${ }^{194}$ DesChAMPS. Le combat des vertus et des vices..., p. 4.
} 
estar inspiradas en el texto de Prudencio su fuente escrita es un texto de Tertuliano ${ }^{195}$. Dadas las similitudes estilísticas entre las esculturas de Poitou y Saintonge, Deschamps establece que en la región del suroeste de Francia debió existir una escuela, y que de ésta zona luego se extenderían los modelos a la periferia ${ }^{196}$.

Unos años más tardes Pierre Bouffard se centra en las esculturas de la psychomachia en iglesias románicas de la zona de Saintonge. En "La Psychomachie sur les portails romans de la Saintonge ${ }^{197 "}$ el autor coincide con algunas de las afirmaciones de Émile Mâle y Paul Deschamps sobre estos ejemplos. La principal aportación de Bouffard para con las esculturas románicas de la Psychomachia en Saintonge es la idea de que a través del carácter ornamental de la escultura se muestra a los espectadores cristianos, a modo de advertencia, un tema directamente relacionado con la lucha del bien y el mal y se deja muy claro que camino debe escoger aquel que desee ganar la vida eterna ${ }^{198}$.

Fraise Chantal en "Un traité des vertus et des vices illustré à Moissac dans la première moitié du XIe siècle ${ }^{199}$ " estudia las miniaturas del manuscrito Lat. 2077 de la Biblioteca Nacional de París. Este códice se elaboró en la abadía de Moissac alrededor del siglo XI y el mismo posee distntas obras de escritores y teólogos medievales. Puesto que la autora analiza las imágenes del mismo, presta especial atención al tratado de vicios y virtudes que se incluyó al final del manuscrito y al que pertenecen las diez iluminaciones. Chantal fue la primera en identificar que el tratado moral se elaboró alternando los textos de otros dos textos de vicios y virtudes: el $D e$ conflictu vitiourum et virtutum de Ambrosio de Autpert y el De vitiis et virtutibus de Halitgaire de Cambrai ${ }^{200}$. El uso de los textos de estos autores no es aleatorio, sino

\footnotetext{
${ }^{195}$ DESCHAMPS. Le combat des vertus et des vices..., p. 10.

${ }^{196}$ DESCHAMPS. Le combat des vertus et des vices..., p. 17.

${ }^{197}$ BOUFFARD, Pierre. "La Psychomachie sur les portails romans de la Saintonge" Zeitschrift Für Schweizerische Archäologie Und Kunstgeschichte = Revue Suisse D'art et D'archéologie = Rivista Svizzera D'arte E D'archeologia = Journal of Swiss Archeology and Art History, Vol. 22 N $.1-3$ (1962), pp. 19-21.

${ }^{198}$ BOUFFARD. "La Psychomachie sur les portails romans..., p. 21.

${ }^{199}$ FRAÏSSE, Chantal. "Un traité des vertus et des vices illustré à Moissac dans la première moitié du XI ${ }^{\mathrm{e}}$ siècle." Cahiers de Civilisation Médiévale 42 No. 167 (1999), pp. 221-242.

${ }^{200}$ FRASSE. "Un traité des vertus et des vices illustré à Moissac..., p. 222.
} 
que sigue un esquema y entre los folios 162 al 174 primero aparece un capítulo del tratado de Autpert, seguido inmediatamente por el capítulo homólogo de Halitgaire y culmina con una mininatura la cuyo arregló composicionla conjuga las descripciones de ambos textos ${ }^{201}$. A través del análisis del texto y las imágenes Fraisse Chantal trata de demostrar que las miniaturas se encuentran íntimamente unidas a las palabras y las mismas son un comentario visual del texto que revela el conocimiento que el escritor poseía de los tratados de Autpert y de Halitgaire ${ }^{202}$. En la última parte del artículo la autora analiza las influencias directas que las representaciones de las virtudes, pero sobre todo los vicios, muestran con los manuscritos miniados de la Psychomoachia y como las mismas se insertan en la tradición de estos ${ }^{203}$.

Para el caso de Inglaterra podemos mencionar el artículo de Rosalie B. Green $^{204}$ que se concentra en catorce grupos escultóricos de los vicios y las virtudes en el vestíbulo de la sala capitular de la catedral de Salisbury. Lo limitado de los estudios sobre representaciones de los vicios y las virtudes en Inglaterra, se debe en gran medida como indica Green, la escase de ejemplos sistemáticos de ciclos sobre los vicios y las virtudes, en gran medida por los extragos del pasado del territorio ${ }^{205}$. En "Virtues and Vices in the Chapter House Vestibule in Salisbury", la autora analiza iconográficamente las distintas imágenes y las compara con modelos similares, princpalmente los de la catedral de Laón. Para Green las esculturas del lado derecho del arco representan las virtudes teologales y cardinales y las fuerzas contrarias a las mismas. Las personficaciones del lado izquierdos son de los pecados capitales y sus remedios. Su hipótesis se ve avalada a través del orden en el que se plasmaron estos

\footnotetext{
${ }^{201}$ FRAÏSSE. "Un traité des vertus et des vices illustré à Moissac..., p. 223.

${ }^{202}$ FRAÏSSE. "Un traité des vertus et des vices illustré à Moissac..., p. 225.

${ }^{203}$ FRAÏSSE. "Un traité des vertus et des vices illustré à Moissac..., pp. 236-239.

${ }^{204}$ GREEN, Rosalie B. "Virtues and Vices in the Chapter House Vestibule in Salisbury." Journal of the Warburg and Courtauld Institutes Vol. 31 (1968), pp. 148-158.

205 "Even allowing for hyperbole it would seem that the figures ought not be ignored in the history of English Gothic art, already made difficult enough by the depredations of the past; and in any case too few systematic cycles of Virtues and Vices exist to warrant the omission of an eloquent and vivacious example". GREEN. "Virtues and Vices in the Chapter House..., pp. 153-154.
} 
conceptos morales, pues el mismo se ajusta al tradicional acrónimo SALIGIA utilizado en la Baja Edad Media como mecanismo mnemónico ${ }^{206}$.

En el caso español hasta el momento sólo hemos logrado indentificar tres estudios dedicados exclusivamente al tema de los vicios y/o las virtudes en la plástica, los estudios de Juan José Calzaa Toledano y Salvador Andrés Ordax analizan ejemplos escultóricos. El trabajo más reciente identificado es el de el de María Dolores Teijeira Pablos que se concentra en las representaciones de ciertos vicios en las sillerías de los coros hispanos.

Juan José Calzada Toledano identifica la presencia de las virtudes cardinales y los pecados capitales en los capiteles de la iglesia de Santa María del Campo ${ }^{207}$. Su trabajo tiene principalmente un carácter iconográfico. En el mismo, el autor identifica las distintas influencias pictóricas y literaris de los distintos conceptos morales plasmados en este templo. El trabajo de Salvador Andrés Ordax también tiene un carácter iconográfico. El artículo de este autor se centra en las siete esculturas de las virtudes cardinales y teologales en la fachada de la iglesia de San Pablo de Valladolid $\left(\right.$ Fig. 23) ${ }^{208}$. En el mismo describe las representaciones escultóricas de las alegorías morales y su vinculación directa con las esculturas de las virtudes en el sepulcro de Juan II e Isabel de Portugal en la Cartuja de Miraflores, resaltando la influencia francesa ya identificada por Émile Mâle de ambos ejemplos. En las últimas quince páginas del artículo se incluyeron fotografías de los ejemplos tratados.

María Dolores Teijeira Pablo estudia las represntaciones de vicios y actos pecaminosos en las sillerías de los coros tardogóticos de las catedrales de León, Zamora, Oviedo y Ciudad Rodrigo ${ }^{209}$. Ésta tiene en cuenta la estrecha relación que

\footnotetext{
${ }^{206}$ GREEN. "Virtues and Vices in the Chapter House..., pp. 153-154.

${ }^{207}$ CALZADA ToledAno, Juan José. "Las virtudes y los vicios en Santa María del Campo", en Boletín de la institución Fernán González 80 №. 222/1 (2001), pp. 123-145.

${ }^{208}$ ANDRÉS ORDAX, Salvador. "Iconografía de las virtudes a fines de la Edad Media: la facahda de San Pablo de Valladolid", BSAA Arte. N No. 72-73 (2006-2007), pp. 9-34.

${ }^{209}$ TeIJeIRA PABLOS, María Dolores. "Vicio y ¿castigo? en las sillerías del coro: una visión crítica del pecado en el tardogótico hispano", Clío \& Crímen: Revista del Centro de Historia del Crimen de Durango. $\mathrm{N}^{\circ} .7$ (2010), pp. 159-176.
} 
guardan los distintos conceptos representados y como su trato artístico y ubicación juegan un papel fundamental para el mensaje que transmiten en contraposición a los conceptos morales del bien insertados en la parte superior y más visible del coro. Teijeira tiene en cuenta el público para el que se encuentran destinadas estas imágenes. Los vicios y pecados, plasmados por medio de las acciones del acto vicioso, del combate entre bestias o bestias y hombres o seres monstruosos en las misericordias, pomos, apoyamanos y otros soportes secundarios del coro servían para recordar gráficamente a la persona que los utilizaba la debilidad de éste además de la inferioridad del tema ${ }^{210}$.

Como se aprecia en el estado de la cuestión, gran parte de los estudios dedicados a los vicios y las virtudes en la plástica medieval tratan el tema principalmente desde la iconografía y el formalismo. En términos iconológicos cabe destacar sobre todo el trabajo de Katzenellenbogen, quien tan temprano como en los años 30, se percató de la necesidad de analizar no sólo los aspectos formales e iconográficos de estas representaciones alegóricas, sino también, el contexto en el que se insertaban. El trabajo de Joanne Norman, sigue por esta línea, sin embargo, tenemos que destacar el artículo de María Dolores Teijeira Pablo. A pesar de la brevedad del trabajo de Teijeira, ésta resalta y presta especial atención a un elemento importanticimo para el estudio de las imágenes de los vicios y las virtudes: la audiencia. Y es que según el contexto y el medio en el que se insertan estos conceptos morales, la audiencia y la función del objeto en el que se plasman cambian, incidiendo así en su significión. En este sentido nos perctamos de que ciertos casos, como son los manuscritos iluminados de la Psychomachia o el capitel de Sant Cugat del Vallés se elaboraron dentro del contexto medieval, por lo tanto, al igual que las sillerías de los coros, el público y los usuarios de estos ejemplos debieron ser los miembros de los distintos cenónbios.

A través de la revisión bibliográfica para la elaboración del estado de la cuestión, nos hemos percatado de que existe una estrecha relación entre las

${ }^{210}$ TeIJEIRA PABlos. "Vicio y ¿castigo? en las sillerías del coro..., pp. 170-171. 
representaciones de los vicios y las virtudes, la memoria y las técnicas mnemónicas. Desde el campo de la literatura se ha explorado la función mnemónica de las imágenes mentales de dichos conceptos morales. Para nuestra investigación nos proponemos estudiar la función mnemónica de las imágenes de los vicios y las virtudes que fueron utilizadas o se insertaron en el contexto monacal, partiendo principalmente de obras que gracias al buen estado en el que se encuentrna es posible reconstruir completamente el programa iconográfico en el que se insertaron. Son de especial interés las miniaturas de cinco manuscritos iluminados de las Psychomachia de Prudencio y los capiteles del claustro del monasterio de Sant Cugat del Vallès, particularmente uno que se encuentra en la galería sur en el que se esculpio el momento del triunfo de las virtudes.

Para estudiar la función mnemónica de las imágenes de los vicios y las virtudes en los manuscritos de la Psychomachia y en el capitel de Sant Cugat del Vallès partimos del análisis formal e iconográfico. Identificado los elementos físicos intrínsecos de las imágenes y el uso de temas y motivos iconográficos conocidos por la audiencia a la que se dirige la obra, aplicaremos las distintas teorías y nociones de la construcción de mnemotécnias para entender como las imágenes de los vicios y las virtudes sirvieron al espectador para la memorización de información necesaria en el proceso de aprendizaje y de meditación. Antes de adentrarnos al estudio de los manuscritos y el capitel, es necesario establecer la relación intrínseca que desde la antigüedad ha existido entre estos conceptos morales y la capacidad cognitiva. Igualmente es un imperativo definir y establecer como funcionaban las distintas técnias mnemónicas en el período en el que fueron creadas las obras estudiar. 


\section{CAPÍtulo 2}

\section{VICIOS, VIRTUDES Y MEMORIA: RELACIÓN DE CONCEPTOS}

La revisión historiográfica de los estudios de los vicios y las virtudes sobre todo en el campo del arte y la literatura revelan una relación directa entre el tema y la memoria. Desde la antigüedad además de vincularse con la moral, los vicios y las virtudes se relacionan estrechamente con la memoria. En el mundo antiguo, específicamente el tema de las virtudes que hoy conocemos como cardinales, no sólo se abordó en los tratadistica sobre moral, sino que también las mismas son mencionadas en tratados de retórica en referencia con la capacidad de memorización del orador. Las definición aristotélica y ciceroniana de las virtudes se recogen en los trabajos de retórica de estos autores como son la Rétorica de Aristóteles y De Inventione de Cicerón. Es Cicerón quien profundiza más en la relación de las virtudes con la memoria. Para este orador la memoria forma parte de la virtud de la prudencia ${ }^{1}$.

A través de san Agustín, el vínculo de la memoria con las virtudes, específicamente con la prudencia, pasó al mundo medieval. Las definiciones que éste hace de las virtudes se nutrió de la definición ciceroniana sobre la memoria². Alberto Magno, santo Tomas de Aquino continuarían avalando la relación entre la virtud de la prudencia y la memoria y sobre todo la necesidad de ambas para el ejercicio del

\footnotetext{
1 "La prudencia es el conocimiento de lo que está bien y lo que está mal y lo que no es ni una cosa ni otra. Sus partes son la memoria, la inteligencia y la previsión. La memoria es la facultad que permite al espíritu recordar los acontecimientos pasados; la inteligencia, lo que hace comprender los acontecimientos presentes; y la previsión, lo que permite adivinar las cosas antes de que sucedan." CiCERÓn. De Inventione, II, 53, 160. Edición consultada: La invención retórica, trad. de S. Núñez. Biblioteca Clásica Gredos, 245. Madrid: Gredos, D.L.1997. YATES, Frances Amelia. El arte de la memoria. Madrid: Taurus, [1966] 1974. p. 74. CARRUTHERS, Mary. The Book of Memory: A Study of Memory in Medieval Culture. Cambridge: Cambridge University Press, 1992. p. 65.

2 O'BRIEN. "Virtue", The New Catholic Encyclopedia. Tomo 14. 2da edición. Washington: Thomson \& Gale, 2003. p. 548.
} 
resto de las virtudes ${ }^{3}$. La prudencia era considerada una virtud intelectual que conduce a la práctica del resto de las virtudes esenciales para la vida cristiana. Para la moral cristiana, el papel de la memoria es importante pues ésta es la facultad que presenta o representa las experiencias y las bases por las cuales se deben emitir los juicios morales, los cuales se encuentran estrechamente ligados a la práctica de las virtudes ${ }^{4}$. El tema de la memoria, asimismo como el de las virtudes, fue tratado por los filósofos grecolatinos y los conceptos de éstos fueron retomados por los teólogos tardo antiguos y medievales.

\section{1 ¿Qué es la memoria y cómo funciona?}

\subsubsection{Mundo grecolatino: retórica}

Desde la antigüedad los hombres han tratado de entender cómo funciona el proceso de memorización, cómo los individuos son capaces de inscribir en su mente las vivencias experimentadas y luego poder reutilizar los conocimientos adquiridos una y otra vez. Mnemosyne en la Antigua Grecia era la diosa titánide de la memoria, la rememoración, en lenguaje y las palabras. Representaba la facultad de memorización que se necesitaba para preservar los distintos relatos históricos y míticos antes de la invención de la escritura. Igualmente era la madre de las nueve musas $^{5}$.

Según Platón, para poder recordar todo aquello experimentado por los sentidos imprimimos en nuestra alma las percepciones y pensamientos producto de éstas experiencias de la misma manera que se imprime en la cera el sello de un anillo. Se

\footnotetext{
${ }^{3}$ CARRUTHERS, Mary. The Craft of Thought. Meditation, Rhetoric, and the Making of Images, 4001200. Cambridge: Cambridge University Press, 1998. p. 13, 99.

${ }^{4}$ CARruthers. The Book of Memory..., p. 68.

${ }^{5}$ Platón en el Teeteto llega a considerar que la memoria es un don de Mnemósine, la madre de las Musas. Platón. Teeteto, 191d. Edición consultada: Diálogos V. Parménides, Teeteto, Sofista, Político. Biblioteca Clásica Gredos, 117. Madrid: Editorial Gredos, S.A., 1988.
} 
recordará aquello cuya imagen haya quedado bien impregnada en la cera de nuestra alma, y aquello que no se haya grabado o cuya imagen sea borrosa se olvida o simplemente se desconoce ${ }^{6}$. La concepción platónica de la memoria, pervivirá en el mundo clásico y épocas posteriores.

Además de Platón, Aristóteles trató la memoria, e incluso dedicó un breve tratado a ésta De memoria et reminiscentia. En éste Aristóteles coinciden con algunos de los planteamientos de Platón, la idea de que la memoria se encuentra en el alma, y el hecho de que se han de grabar en esta como un dibujo las experiencias de aquello que se ha percibido a través de alguno de los sentidos ${ }^{7}$. Sin embargo, éste hace hincapié en el factor tiempo el cual juega un papel importante en las memorias pues se recuerdan aquellas experiencias pasadas, ya vividas y experimentadas:

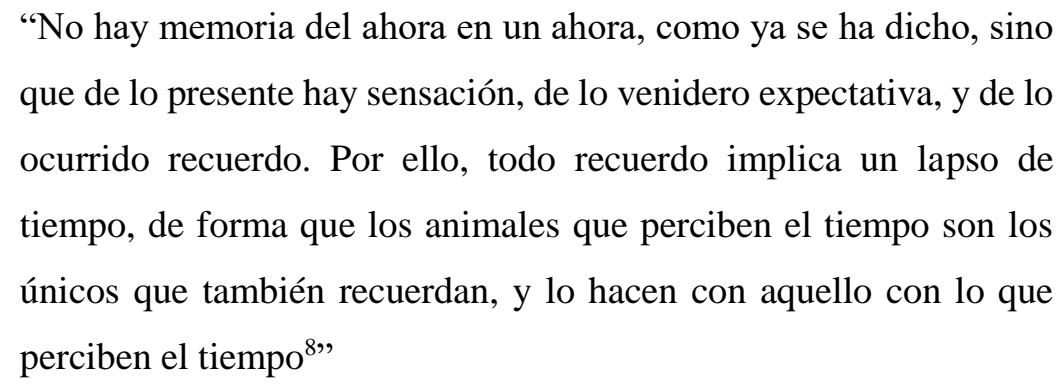

Para Cicerón la memoria es una de las tres partes de la prudencia, junto a la inteligencia y la previsión. Es a través de la memoria que se pueden recuperar las cosas que han sido, "La memoria es la facultad que permite al espíritu recordar los acontecimientos pasados $9 "$.

\footnotetext{
6 "si queremos recordar algo que hayamos visto u oído o que hayamos pensado nosotros mismos, aplicando a esta cera las percepciones y pensamientos, los grabamos en ella, como si imprimiéramos el sello de un anillo. Lo que haya quedado grabado lo recordamos y lo sabemos en tanto que permanezca su imagen. Pero lo que se borre o no haya llegado a grabarse lo olvidamos y no lo sabemos". Platón. Teeteto, 191d.

${ }^{7}$ ARISTÓTELES. De memoria et reminiscentia, 449b 9-19, 450a 25-35. Edición consultada: Acerca de la generación y la corrupción. Tratados breves de historia natural, traducción de: E. La Croce y A. Bernabé Pajares. Madrid: Editorial Gredos, S.A., 1987. pp. 234-235.

${ }^{8}$ ARISTÓTELES. De memoria et reminiscentia, 449b 27-30.

9 "La prudencia es el conocimiento de lo que está bien y lo que está mal y lo que no es ni una cosa ni otra. Sus partes son la memoria, la inteligencia y la previsión. La memoria es la facultad que permite al espíritu recordar los acontecimientos pasados; la inteligencia, lo que hace comprender los
} 
La importancia de la memoria y sobre todo de poder recordar efectivamente lo aprendido era una facultad indispensable para los poetas y especialmente para los oradores ${ }^{10}$. Estos, como se explicará más adelante, utilizaban imágenes mentales que permitían estructurar ordenadamente el discurso a exponer.

\subsubsection{Edad Media: moral y meditación}

La concepción medieval de la memoria surge de las obras de san Agustín. Para éste la naturaleza del alma humana se divide en tres: memoria, en dónde radica la ciencia, inteligencia en dónde radica el ingenio y voluntad en donde radica la acción $^{11}$. Puesto que en la memoria reside la ciencia, el conocimiento, es en ésta donde el hombre almacena las imágenes de todas las impresiones captadas a través de cualquiera de los sentidos ${ }^{12}$. Además de guardar en el tesoro de la memoria todo aquello percibido por los sentidos en esta parte del alma, que es una virtud, también se inscriben los distintos conocimientos, "todas aquellas nociones aprendidas de las artes liberales ${ }^{13}$ ". La noción agustiniana de la memoria perviviría en gran medida hasta la aparición de Alberto Magno y Tomás de Aquino.

En el siglo XIII Alberto Magno logra conciliar la definición aristotélica sobre el tiempo y la ciceroniana sobre los $l o c i^{14}$. Desde el planteamiento ontológico entonces la memoria recuerda aquellas cosas pasadas por una predisposición natural, sin embargo, desde la perspectiva cognitiva la mente entrenada a través del hábito puede recordar aquellas cosas almacenadas en ésta y por medio de la virtud de la

\footnotetext{
acontecimientos presentes; y la previsión, lo que permite adivinar las cosas antes de que sucedan." CICERÓn. De Inventione, II, 53, 160. Edición consultada: La invención retórica, trad. de S. Núñez... ${ }^{10}$ FEnTRES, James et. Chris WiCKHAM. Memoria social. Madrid: Cátedra, 2003. p. 67.

${ }^{11}$ San Agustín. De Trinitate X, xi, 17-18. Edición consultada: Obras de San Agustín, Tratado de la Santísima Trinidad. Edición bilingüe, Tomo V. Edición de: Luis Arias. Madrid: Biblioteca de Autores Cristianos, 1956. pp. 605-607.

12 San Agustín. Confesiones, X.viii.12. Edición consultada: Obras de San Agustín, Las confesiones. Texto Bilingüe, Tomo II. Edición de: Ángel Custodio Vega. Madrid: Biblioteca de Autores Cristianos, 1973.

${ }^{13}$ San Agustín. Confesiones, X.ix.16. Obras de San Agustín, Las confesiones...

${ }^{14}$ CARruthers. The Craft of Thought ..., p. 13.
} 
prudencia utilizar estos recuerdos para discernir entre lo que está bien o mal. Todo existe en un tiempo y espacio determinado, los recuerdos a pesar de ser experiencias pasados permanecen en el presente en el lugar que el alma crea para almacenar las imágenes de estos. Los mismos a pesar de ser experiencias pasadas se mantienen siempre presentes en el alma ${ }^{15}$.

La importancia de la memoria para el hombre medieval se vinculaba directamente con la moral y la meditación. Era necesario que el cristiano guardara en lo más profundo de su ser los distintos conceptos, los cuales junto a la virtud de la prudencia harían posible emitir los juicios morales que le ganarían el Cielo o el Infierno $^{16}$.

\subsection{Mnemotecnias}

Para un individuo es posible mejorar su memoria natural por medio de la memoria artificial ${ }^{17}$. Este concepto apela a la retentiva la cual puede reforzarse a través de distintas técnicas de memorización, mnemotecnias. Desde la antigüedad los hombres han buscado mejorar la memoria artificial y para lograrlo han desarrollado distintos mecanismos mnemónicos que refuerzan la misma.

\subsubsection{Mnemotecnias clásicas}

En el mundo antiguo, la importancia de aumentar la capacidad de memorización de un individuo era necesaria específicamente dentro del ámbito del aprendizaje. Esta facultad se vinculaba directamente con el estudio del trivium y el

\footnotetext{
${ }^{15}$ Alberto Magno. De bono, Tractatus IV, Quaestio II "De Patribus Prudentia", transcripción de Mary Carruthers. CARRUTHERS. The Book of Memory..., pp. 268-269.

${ }^{16}$ CARRUTHERS. The Book of Memory..., p. 43.

${ }^{17}$ RIVERS. Preaching the Memory..., p. 86.
} 
quadrivium, pues la memoria jugaba un papel clave principalmente con relación al estudio de la retórica. Fueron los trabajos de distintos pensadores del mundo clásico los que sentaron las bases para estas prácticas. En distintos tratados sobre retórica se exalta la importancia de esta capacidad a la hora de estudiar esta materia y como si de manuales prácticos se tratasen, en los mismos se explica la forma más eficaz de memorizar. Serán el De Oratores de Cicerón, el Instituto oratoria de Quintiliano y el tratado anónimo (pero durante mucho tiempo atribuido a Cicerón) la Rhetorica Ad Herennium las obras que en gran parte sentaron las bases del funcionamiento de la memoria artificial y los que más influencia tuvieron en el desarrollo de la memoria artificial, las técnicas de memorización ${ }^{18}$.

La invención del arte de la memoria, que no es otra cosa que las mnemotécnicas, fue inventada por el poeta Simónides. Así lo indica Cicerón en su De Oratore, obra en la que recoge el relato en el que el poeta explica cómo se ha de memorizar $^{19}$.
“[...] se dice que Simónides había identificado a cada uno de los que había que enterrar por acordarse en qué lugar estaba recostado cada cual. Y que entonces, advertido de esta circunstancia, había iluminado su recuerdo. $\mathrm{Y}$ en consecuencia, que quienes quisieran cultivar esta parcela del espíritu, deberían tomar esos lugares y, aquello que quisieran retener en la memoria, habían de modelarlo con la mente y colocarlo en dichos lugares; que así ocurriría que la secuencia de las posiciones recordaría la secuencia de las cosas y que utilizaríamos esos lugares como la cera, y las figurillas como las letras $^{20,}$

A partir de este relato es posible explicar cómo funcionaba en el mundo antiguo la memoria artificial. "La memoria artificial es la memoria que ha sido

\footnotetext{
${ }^{18}$ YATES. El arte de la memoria..., p. 14.

${ }^{19}$ YATES. El arte de la memoria..., p. 14.

${ }^{20}$ CiCERÓn, De oratores. II, 86, 353-354. Edición consultada: Sobre el orador. trad. de José Javier Iso. Biblioteca Clásica Gredos, 300. Madrid: Gredos, 2002.
} 
reforzada por cierto aprendizaje y una serie de reglas teóricas ${ }^{21}$ ", o sea las técnicas de memorización. La técnica mnemónica del Ad Herennium parte de los loci e imagines, lugares e imágenes ${ }^{22}$. Las imágenes serían las cosas que se desean memorizar y los lugares la forma de organizarlas en la mente.

Como indica el relato, primero se escogerán las cosas a memorizar. La memoria tiene la capacidad de recordar palabras, ad verba, y cosas, ad res. Según los tratados clásicos y en términos generales estas mnemotécnicas del mundo antiguo consistían en la creación de imágenes mentales. Se exhortaba a los jóvenes pupilos de retórica la memorización ad res por ser más efectiva ${ }^{23}$. Para que esto fuera posible el primer paso es crear imágenes mentales también llamadas phantasmatas de las ideas o conceptos a memorizar. Esto amparado en la idea aristotélica de que se piensa en imágenes ${ }^{24}$ y de que las palabras también son imágenes, en su forma concreta o su forma gráfica, entiéndase escrita ${ }^{25}$. Debían crearse imágenes mentales de cosas a memorizar, y si éstas eran palabras era necesario convertirlas en imágenes ${ }^{26}$, pero estas imágenes mentales no eran cualquier imagen, sino imagines agentes ${ }^{27}$, imágenes activas cercanas a la realidad pero que a la misma vez que exalten los sentidos por ser extraordinarias, memorables y encontrarse fuera de lo común ${ }^{28}$. "La función de ad res es: impresionar emocionalmente la memoria a causa de su rareza o particular idiosincrasia ${ }^{29}$ ".

Una vez creadas estas imágenes el estudiante procedería a organizarlas de tal forma que pudiera memorizar el texto o discurso a exponer. Estos tratados no

\footnotetext{
${ }^{21}$ Rhetorica ad Herennium. III, 16, 28. Edición consultada: Retórica a Herenio. trad. de S. Núñez. Biblioteca Clásica Gredos, 244. Madrid: Gredos, 1997.

${ }^{22}$ Rhetorica ad Herennium. III, 16, 29. YATES. El arte de la memoria..., p. 15.

${ }^{23}$ Rhetorica ad Herennium. III, 24.

${ }^{24}$ Según Aristóteles: "De ahí también que cuando se contempla intelectualmente, se contempla a la vez y necesariamente alguna imagen: es que las imágenes son como sensaciones sólo que sin materia”. Aristóteles. De Anima. 432a 9-10. Y YATES. El arte de la memoria..., pp. 48-49.

${ }^{25}$ CARRUTHERS. The Book of Memory..., p. 18.

${ }^{26}$ Rhetorica ad Herennium. III, 20, 33-34.

${ }^{27}$ Rhetorica ad Herennium. III, 21, 35. YATES. El arte de la memoria..., p. 46.

${ }^{28}$ Rhetorica ad Herennium. III, 22, 37. YATES. El arte de la memoria..., p. 23.

${ }^{29}$ YATES. El arte de la memoria..., p. 30.
} 
alentaban la memorización de los textos palabra por palabra, memoria verborum, sino que, a través de la creación de los phantasmatas, se recordaban cosas y por ende la palabra principal o la noción general del $a d \operatorname{res}^{30}$. Estas imágenes funcionaban como tropos y en muchos casos, sobre todo a la hora de crear representaciones mentales de conceptos abstractos como los vicios y las virtudes, el resultado fueron complejas alegorías con forma de hombres o mujeres ${ }^{31}$. La Rhetorica ad Herennium brinda un ejemplo de cómo deben crearse estas imágenes:

\begin{abstract}
"A menudo recordamos todo un conjunto de objetos con un solo signo y una sola imagen. Por ejemplo el acusador dice que un hombre fue envenenado por el acusado, asegura que cometió el crimen para apoderarse de la herencia y sostiene que hay numerosos testigos y cómplices del hecho. Si para facilitar nuestra defensa queremos recordar este primer punto, nos formaremos un primer entorno con la imagen de todos los hechos. Si lo conocemos personalmente, nos imaginaremos a la víctima de la que se trata enferma y acosta en su lecho. Si no lo conocemos, para poder recordar rápidamente nos imaginaremos algún otro enfermo, siempre que no sea de una clase inferior. Situaremos al acusado junto al lecho del enfermo, con una copa en la mano derecha, en la izquierda las tablillas y en el dedo anular unos testículos de carnero. De este modo podremos recordar los testigos, la herencia y el muerto envenenado ${ }^{32}$."
\end{abstract}

Una vez creada la representación mental del ad res ésta debía inscribirse en la memoria como si de un sello de cera se tratara, para que así la impronta de la misma quedara estampada en la tabilla de la memoria ${ }^{33}$.

Dada la cualidad activa del proceso de memorización, entiéndase el poder almacenar, recuperar y utilizar lo memorizado, las imágenes mentales debían ubicarse de tal forma que se pudieran llevar a cabo estos procesos. Después de todo

\footnotetext{
${ }^{30}$ CARRUTHERS. The Book of Memory..., p. 73.

31 "A menudo recordamos todo un conjunto de objetos con un solo signo y una sola imagen". Rhetorica ad Herennium. III, 20, 33. YATES. El arte de la memoria ..., p. 46.

${ }^{32}$ Rhetorica ad Herennium. III, 20, 33.

${ }^{33}$ YATES. El arte de la memoria..., p. 50. CARRUTHERS. The Book of Memory..., pp. 38-39.
} 
a la hora de exponer un discurso se necesitaba hacerlo de forma coherente. Esto era posible gracias a la creación de loci, espacios mentales en los que se guardaban los phantasmatas. Estos espacios consistían en la creación mental de la representación de un lugar en el que se pudiera guardar lo deseado. En el mundo antiguo la arquitectura fue el modelo por excelencia para crear estos lugares abstractos ${ }^{34}$. Se debía imaginar un edificio con todos los detalles posibles del mismo: las diversas habitaciones, espacios y todos los objetos que decoran las mismas ${ }^{35}$. Los phantasmatas serían almacenados en las distintas estancias del edificio en cuestión siguiendo un orden que permitiera como si de un paseo se tratara recuperar las representaciones mentales archivadas en los diferentes lugares y poder reproducir el discurso o texto memorizado ${ }^{36}$. Este sistema permite no solamente exponer lo memorizado en el orden exacto, sino que también permite la exposición de extractos del mismo o en un orden distinto al memorizado ${ }^{37}$.

\subsubsection{Mnemotecnias medievales}

Los conceptos de memoria del mundo clásico, sobre todo de imágenes mentales para recordar algo pasarían al mundo cristiano a través de san Agustín $^{38}$. Dentro del contexto cristiano los primeros en tener contacto con las mnemotécnicas fueron los monjes. El currículo de los religiosos además de constar de las obras de los padres de la Iglesia también incluía los textos de autores clásicos, entre estos los

\footnotetext{
34 Los ejemplos inmediatos expuestos en la Rhetorica ad Herennium son edificaciones arquitectónicas: "una casa, un intercolumnio, una habitación, una bóveda o cualquier cosa parecida". Rhetorica ad Herennium. III, 16, 29.

${ }^{35}$ YATES. El arte de la memoria..., p. 15.

36 "Creo también que es necesario ordenar esos entornos para que su confusión no nos impida seguir las imágenes y podamos partir del entorno que queramos, sea cual sea su posición en la serie, al comienzo o al final, y localizar y expresar así lo que hemos situado en esos entornos”. Rhetorica ad Herennium. III, 17.

${ }^{37}$ CARRUTHERS. The Book of Memory..., pp. 18-19.

${ }^{38}$ YATES. El arte de la memoria..., p. 66. CARRUTHERS. The Craft of Thought ..., p. 11.
} 
tratados de retórica de Cicerón ${ }^{39}$. A pesar de que en el contexto monástico la retórica no se practicaba, la misma si se estudiaba pues era parte del estudio del trivium y el quadrivium. El monacato encontró en el estudio de la retórica clásica importantes herramientas para con la moral. Las técnicas de ésta materia se aplicaron a los conceptos morales de la cristiandad y gracias a las mismas los religiosos podían memorizar los conceptos por los cuales sus vidas debían regirse para ganar el Cielo ${ }^{40}$. La memoria se tornó en la facultad que presenta o representa las bases por las cuales se deben ejercer los juicios morales ${ }^{41}$. Esto era necesario para el ejercicio de la oración y la meditación.

Las prácticas mnemónicas clásicas de imagines y loci se adaptaron a las necesidades de los monjes. Fueron diversos modelos cercanos al entorno de los libros y bibliotecas los lugares mentales que el monacato utilizó para ubicar los phantasmatas. Destacan los modelos de celdas o estanterías y por excelencia el manuscrito, específicamente los folios de éstos ${ }^{42}$.

Para los pensadores medievales la mente era una especie de estantería de libros custodia de la percepción ${ }^{43}$. El modelo de celdas partía de los espacios de una cuadricula mental semejante a uno o más estantes de libros. Las distintas celdas de este librero pasaron a ser los loci de este sistema mientras que la construcción de las imágenes agentes permaneció igual. Para memorizar de forma ordenada dentro del sistema de cellae era necesario asociar cada uno de los espacios o cuadriculas mentales con un signo gráfico, letras, cifras, etc. y así poder recuperar con mucha más eficiencia la información ${ }^{44}$. Este sistema se asemeja mucho a los diagramas y planos que encontramos hoy en día en las bibliotecas para conducir a los usuarios hasta los recursos deseados. Estos planos por lo general muestran la disposición gráfica de las

\footnotetext{
${ }^{39}$ Hasta el siglo XII la Rethorica ad Herenniun se atribuyó a Cicerón. REYNOLDS, Suzanne. Medieval Reading: Grammar, Rhetoric and the Classical Text. Cambridge: Cambridge University Press, 1996. p. 23.

${ }^{40}$ YATES. El arte de la memoria..., p. 108. CARRUTHERS. The Craft of Thought..., p. 11.

${ }^{41}$ CARRUTHERS. The Book of Memory..., p. 28.

${ }^{42}$ GEARY. "Memoria"..., p.533.

${ }^{43}$ CARRUTHERS. The Book of Memory..., p. 43.

${ }^{44}$ CARruthers. The Craft of Thought ..., p. 108. GeARY. "Memoria"..., p.533.
} 
distintas estanterías y estos, dependiendo la materia o tema de interés, se enumeran de acuerdo a los estándares de la Clasificación Decimal Universal (CDU). Gracias al mismo de antemano se saben datos tales como que los libros que comienzan con el dígito 7 suelen ser de arte o los que comienzan con 8 de literatura o filología.

Otras mnemotecnias identificadas por Carruthers se encuentra estrechamente ligada a los manuscritos. De forma genérica, consistía en utilizar las distintas partes que constituyen el folio - columnas, párrafos- como los loci y los elementos gráficos -iniciales, subtítulos- o pictóricos -miniaturas, colores, etc.- como las imagines del mundo clásico ${ }^{45}$. Para la autora estos no son meros elementos estéticos, o en el caso de las miniaturas ilustrativos, sino que son ejercicios y ejemplos que han de ser estudiados y recordados con igual esfuerzo que las palabras escritas ${ }^{46}$. Los mismos auxiliarían a retener de forma más eficiente el texto sobre el que versan. Era por este motivo que se exhortaba a memorizar siempre de la misma fuente escrita, pues así la mente retendría la disposición del folio en cuestión ${ }^{47}$.

El mundo medieval igualmente utilizó la arquitectura como lugares de la memoria. Sin embargo, el uso de estas estructuras se basó principalmente en la idea paulina del buen arquitecto:

"Conforme a la gracia de Dios que me fue dada, yo, como buen
arquitecto, puse el cimiento, y otro construye encima. iMira cada
cual cómo construye! Pues nadie puede poner otro cimiento que el
ya puesto, Jesucristo. Y si uno construye sobre este cimiento con
oro, plata, piedras preciosas, madera, heno, paja, la obra de cada cual
quedará al descubierto; la manifestará el Día, que ha de revelarse por
el fuego. Y la calidad de la obra de cada cual, la probará el fuego.

\footnotetext{
${ }^{45}$ CARruthers. The Book of Memory..., p. 9. RIVERS. Preaching the Memory..., p. 47.

46 "I would modify the common understanding of the various diagrams and drawings even, in some cases, the full illustrations that we find in monastic manuscripts. They are not just "aids" to understanding, as we would say, implying their subservient role to language and that they are in some basic way unnecessary to knowing. They are exercises and examples to be studied and remembered as much as are the words". CARRUTHERS. The Craft of Thought..., p. 142. MCKITTERICK, Rosammond. "Script and Book Production", Carolingian Culture: Emulation and Innovation. Cambridge: Cambridge University Press, 1997. p. 225.

${ }^{47}$ CARRUTHERS. The Book of Memory..., p. 93.
} 
Aquél, cuya obra, construida sobre el cimiento, resista, recibirá la recompensa. Más aquél, cuyá obra quede abrasada, sufrirá el daño. Él, no obstante, quedará a salvo, pero como quien pasa a través del fuego. ¿No sabéis que sois santuario de Dios y que el Espíritu de Dios habita en vosotros? Si alguno destruye el santuario de Dios, Dios le destruirá a él; porque el santuario de Dios es sagrado, y vosotros sois ese santuario ${ }^{48}$."

A partir de este texto se desarrolló una técnica mnemónica que utiliza el plano y el alzado de los edificios para crear estructuras mentales, las cuales Carruthers llama superestructuras ${ }^{49}$. En la antigüedad los espacios arquitectónicos servían como los lugares en los que se almacenaría la información. En la Edad Media la arquitectura presta los cimientos sobre los cuales se organizará, como si de capaz se tratara, todo el conocimiento que desea memorizarse fundamental primordialmente para la meditación. Ejemplo de esto es los cuatro sentidos de las Sagradas Escrituras en donde los distintos significados, alegóricos, histórico, anagógico y tropológico, de un texto se superponen y concatenan ${ }^{50}$.

Además de su importancia para el aprendizaje de la moral, las mnemotécnicas eran utilizadas como parte del proceso de meditación. A la hora de meditar, los monjes debían concentrarse en pensamientos virtuosos. Los mismos eran productos de las distintas oraciones, textos, salmos. Estos gracias a los phantasmatas quedaban inscritos en su memoria, de la misma forma que se inscribía en una tablilla de cera ${ }^{51}$, organizándose por medio de la estructura del folio o de las superestructuras. Para las mnemotecnias medievales, sobre todo dentro del contexto monacal la idea de peregrinaje, de viaje fue sumamente importante. El acto de meditar era un peregrinar a través de todos esos recuerdos almacenados auxiliados por la estructura del folio del manuscrito o a la superestructura en base a un texto bíblico cuya meta es Dios ${ }^{52}$.

\footnotetext{
${ }^{48} 1$ Corintios 3: 10-17.

${ }^{49}$ CARRUTHERS. The Craft of Thought..., p. 17.

${ }^{50}$ CARRUTHERS. The Craft of Thought..., p. 18

${ }^{51}$ CARRUTHERS. The Book of Memory..., p. 38.

${ }^{52}$ CARRUTHERS. The Craft of Thought..., pp. 40-44.
} 
Durante la meditación, el individuo tenía que evitar divagar, y centrarse en las representaciones mentales que le ayudarían a avanzar hacia Dios ${ }^{53}$.

En el siglo XII los métodos pedagógicos cambiaron y algunos hombres de este período para estudiar para sus exámenes, preparar sus lecciones o debates y componer sus sermones se sirvieron de las antiguas técnicas mnemónicas ${ }^{54}$. No sería hasta el siglo XIII, con el surgimiento de los frailes dominicos y franciscanos que se reevaluarían las prácticas mnemónicas y se reviviría el arte de la retórica ${ }^{55}$. Los frailes no sólo se servirían de las prácticas de memorización para beneficio propio, cómo los monjes, sino que también estas les servirían para recordar y exponer coherentemente un discurso en forma de sermón. Los frailes se vieron en la necesidad de recordar y exponer coherentemente un discurso en la forma de un sermón. No sólo debían recordar el mismo, sino que también era importante que su audiencia retuviera éste ${ }^{56}$. Estos sermones instruían a los laicos en el conocimiento de los preceptos morales y les proveían una manera de recordarlos ${ }^{57}$.

Durante los siglos que comprenden la Baja Edad Media los ars predicandi se volvieron una herramienta esencial a la hora de comenzar a elaborar un nuevo sermón $^{58}$. A pesar de que la mayoría de estos no tratan técnicas o ayudas para la memoria, los mismos se encuentran sumamente influenciados por las técnicas del mundo clásico ${ }^{59}$. Una de las características más importantes de la prédica era la brevitas, que en este sentido se refiere a la exposición sucinta del mensaje moral que se quiere transmitir a los laicos ${ }^{60}$. Para que el sermón fuera breve el mismo tiene que construirse ordenadamente y exponerse en dicha forma. El sermón se dividía en secciones y dentro de cada una se organizaba material que se relacionara. Los siete

\footnotetext{
${ }^{53}$ RIVERS. Preaching the Memory..., p. 131.

54 "The twelfth century was a time of transition in pedagogical methods. Scholars made use of ancient memory methods as they studied for their exams, prepared their lectures and disputation, and composed their sermons". RIVERS. Preaching the Memory..., p. 71.

${ }^{55}$ RIVERS. Preaching the Memory..., p. 71.

${ }^{56}$ Rivers. Preaching the Memory..., p. 153.

${ }^{57}$ RIVERS. Preaching the Memory..., p. 145.

${ }^{58}$ RIVERS. Preaching the Memory..., p. 151.

${ }^{59}$ Rivers. Preaching the Memory..., pp. 150-152, p. 161.

${ }^{60}$ Rivers. Preaching the Memory..., p. 157, p. 166.
} 
dones del Espíritu Santo, las siete virtudes y vicios, son algunos de los ejemplos de formas de dividir y organizar mentalmente el material a predicar ${ }^{61}$. Los predicadores debían recordar cosas (res) ya conocidas a ellos para poder componer, recordar y organizar sus sermones ${ }^{62}$. Estos nuevos oradores, los predicadores, no sólo utilizarían las imágenes mentales para guardar y exponer sus sermones, sino que mientras predicaban introducían éstas en sus discursos, además de para su beneficio, para que quedaran inscritas en las mentes de su audiencia ${ }^{63}$. Al compartir las imágenes mentales con estos, los frailes trataban de que las enseñanzas morales, sobre todos los conceptos de vicio y virtud, quedaran impresos en las mentes de sus receptores quienes no poseían ni los conocimientos ni el tiempo para practicar le lectura meditativa $^{64}$.

La relación entre vicios, virtudes y memoria pervivirá durante toda la Edad Media. A partir del siglo XIV el tema de las virtudes sobre todo tendrá una importante relevancia en el contexto funerario, haciendo hincapié en la noción de rememoración y conmemoración ${ }^{65}$. Es así como en testamentos, oraciones, inscripciones e incluso en monumentos funerarios el tema se menciona para exaltar tal o cual virtud como cualidad particular del fenecido y como llave de acceso a la salvación de éste.

Dada esta innegable relación a nivel literario y epistemológico, para este estudio se propone analizar la relación entre las representaciones plásticas de los vicios y las virtudes y la memoria. Es de particular interés tratar los distintos usos y funciones de las imágenes de estos conceptos morales para con la memoria. Para lograr esto, es necesario considerar los distintos campos y estancias de estudio de la

\footnotetext{
${ }^{61}$ RIVERS. Preaching the Memory..., pp. 162-163.

${ }^{62}$ RIVERS. Preaching the Memory..., p. 167.

${ }^{63}$ RIVERS. Preaching the Memory..., p. 4.

${ }^{64}$ RIVERS. Preaching the Memory..., p. 145.

${ }^{65}$ Los trabajos de Philippe Ariès son de los primeros estudios en torno a la muerte en apuntar la relación directa de los monumentos funerarios en relación con la memoria. ARIES, Philippe. Essais sur l'histoire de la mort en Occident: du Moyen Âge à nos jours (1975) y L'homme devant la mort (1999), ediciones consultadas : Historia de la muerte en Occidente: desde la Edad Media hasta nuestros días. Barcelona: El Acantilado, 2000. y El hombre ante la muerte. Madrid: Taurus, 1999.
} 
memoria y a partir de las mismas proponer el acercamiento metodológico para el estudio de las imágenes.

\subsection{Reconstruyendo las mnemotecnias medievales: estado de la cuestión en torno a los estudios de la memoria artificial}

Hoy en día, el estudio de la memoria se puede abordar desde un sin número de campos del conocimiento: la psicología, la filosofía, la neurología, la historia moderna, etc ${ }^{66}$. Desde la filosofía o la historia estudiar e identificar la memoria resulta una labor complicada pues cuando los académicos afrontan la misma no trabajan con un objeto, sino con un proceso ${ }^{67}$. Los medios tecnológicos actuales, sobre todo los ordenadores, permiten un mayor entendimiento de este proceso y a la misma vez proveen del vocabulario necesario para explicar el mismo ${ }^{68}$. En términos genéricos, con ayuda de la jerga propia de la informática, y partiendo de la premisa de que la memoria es un proceso, se puede establecer que la memoria es el procedimiento o el mecanismo por el cual el hombre almacena, organiza, recupera y utiliza activamente conceptos e ideas. Estos conceptos pueden abarcar conocimientos morales, religiosos, sociales, gramáticos, literarios, etc., en fin las diversas ramas del conocimiento humano. Este proceso "no es un receptáculo pasivo, sino un proceso de reestructuración activa, en la que los elementos pueden retenerse, reordenarse o

\footnotetext{
${ }^{66}$ FENTRES. Memoria social..., p. 19.

${ }^{67}$ Según Mary Carruthers: "Memoria refers not to how something is communicated, but to what happens once one has received it, to the interactive process of familiarizing-or textualizing-which occurs between oneself and others' words in memory." y para Howard Williams "[...] the phenomenon of memory in modern academic research is elusive and difficult to define. Memory is difficult to recognize, since it is a process rather than a fixed entity." CARRUTHERS, Mary. The Book of Memory: A Study of Memory in Medieval Culture. Cambridge: Cambridge University Press, 1992. p. 13. Williams, Howard. Death and Memory in Early Medieval Britain. Cambridge: Cambridge University Press, 2005. p. 2.

${ }^{68}$ Carruthers compara el funcionamiento de la memoria humana con el de la memoria de un ordenador o el de un registro postal. CARRUTHERS. The Book of Memory..., p. 29.
} 
suprimirse ${ }^{69 "}$ algo así como cuando se busca un documento en el disco duro del ordenador o cierta información en internet.

Patrick Geary en el Diccionario razonado del occidente medieval ${ }^{70}$ afirma que el tema de la memoria desde el campo de las humanidades y las ciencias sociales se puede abordar desde tres perspectivas: la memoria intelectual o culta, la memoria social y la memoria trascendente. La memoria culta es aquella utilizada por los intelectuales para el almacenamiento y utilización de información, directamente relacionada con las técnicas mnemónicas ${ }^{71}$. La memoria social compete a las distintas prácticas sociales cuya pervivencia es posible gracias a la continuación de las mismas por parte de la posteridad, destacando los actos de rememoración y conmemoración. En tercer lugar, la memoria trascendente, es aquella que trata con conceptos abstractos, ideas e imaginación de cosas no tangibles en el mundo abstracto $^{72}$.

El tema de la memoria culta desde siempre ha fascinado al hombre, razón por la cual desde la antigüedad se han escritos textos y tratados que explican el funcionamiento y la utilidad de ésta para el proceso de aprendizaje. Hoy en día distintos autores, sobre todo del campo de la literatura y la filología, se han dedicado a tratar de reconstruir y explicar cómo funcionaba la memoria intelectual en épocas pasadas. Una de las pioneras en este campo fue la inglesa Frances Yates, con su estudio El arte de la memoria publicado en $1966^{73}$. Éste es el resultado de las investigaciones realizadas por la autora al amparo del Instituto Warburg ${ }^{74}$. En el

\footnotetext{
${ }^{69}$ Fentres. Memoria social...,p. 62. . Madrid: Cátedra, 2003. p. 19. GEARY, Patrick. "Memoria", en: en J. Le Goff y J.C. Schmitt (eds.), Diccionario razonado del Occidente medieval, trad. de A. I. Carrasco Manchado. Madrid, Ediciones Akal S.A., 2003. p. 527.

${ }^{70}$ GEARY. "Memoria"..., pp. 527-536.

${ }^{71}$ GEARY. "Memoria"..., pp. 532-533.

${ }^{72}$ CARRUTHERS. The Book of Memory..., p. 51.

${ }^{73}$ YATES, Frances. The Art of Memory (1966), edición consultada: El arte de la memoria. Madrid: Taurus, 1974.

${ }^{74}$ Ver el prefacio de El arte de la memoria. YATES. El arte de la memoria... QUIVIGER, François. "Frances Yates and the Mnemonic Works of Giordano Bruno", The Warburg Institute, University of London. Disponible en: http://warburg.sas.ac.uk/library/digital-collections/giordano-bruno/yatesbrunos-mnemonics/ [Consulta: 2 de febrero de 2016].
} 
mismo Yates explica el funcionamiento de las distintas mnemotécnicas desde la antigüedad greco-latina hasta el siglo XIX. Su reconstrucción de dichas técnicas se fundamenta principalmente en el análisis de textos de las distintas épocas que estudia. Son de especial relevancia los capítulos que la autora dedica a las técnicas mnemónicas del mundo clásico y medieval.

A pesar de la inquietud de Yates con las técnicas de memorización, su incursión en la memoria medieval fue un tanto limitada pues "La palabra "mnemotecnia" parecía inadecuada para abarcar la recomendación escolástica del arte de la memoria ${ }^{75}$ ". Muchas de las cuestiones no tratadas por Yates en torno a la memoria medieval veinticinco años más tardes serían contestadas por Mary Carruthers. Ésta es especialista en literatura y retórica medieval y técnicas mnemónicas y memoria. Sus trabajos sobre memoria son esenciales para entender las técnicas de memorización del medioevo. The Book of Memory: A Study of Memory in Medieval Culture ${ }^{76}$ es el primer trabajo publicado de Carruthers en el que trata el tema de la memoria en la Edad Media. Éste se centra en el análisis de las influencias de los tratados de retórica clásica en el mundo medieval y como las prácticas mnemónicas expuestas en estos se adaptaron a las necesidades de la cultura y el contexto medieval gracias a los distintos teólogos y pensadores de la época. Carruthers conduce un análisis más exhaustivo del funcionamiento de las mnemotecnias medievales en The Craft of Thought. Meditation, Rhetoric, and the Making of Images, 400-120077.

Este segundo trabajo Carruthers puede considerarse una extensión más rigurosa de lo expuesto en The Book of Memory. En el mismo analiza con más detenimiento los trabajos de distintos teólogos y pensadores medievales para tratar de reconstruir las mnemotecnias utilizadas en el contexto monacal entre el siglo $\mathrm{V}$ y el XIII. Si bien en su primer trabajo se centraba en el uso de los manuscritos y el

\footnotetext{
${ }^{75}$ YATES. El arte de la memoria..., p. 6.

${ }^{76}$ CARRUTHERS, Mary. The Book of Memory: A Study of Memory in Medieval Culture. Cambridge: Cambridge University Press, [1990] 1992.

${ }^{77}$ CARRUTHERS. The Craft of Thought...
} 
texto de estos para memorizar, aquí expone que otros medios como la escultura, la pintura fueron utilizados con este propósito.

Un estudio más reciente que aborda el tema de las prácticas de memorización en la Edad Media es Preaching the Memory of Virtue and Vice. Memory, Images, and Preaching in the Late Middle Ages $^{78}$ de la profesora Kimberly Rivers, especialista en historia medieval, memoria y mnemotécnicas. Como indica el título del libro, el mismo versa sobre las técnicas utilizadas para la memorización de sermones. Las mismas según la autora no sólo eran mecanismo para que los predicadores pudieran memorizar los sermones a exponer, sino también para que su público retuviera los mismos de forma más eficaz. Dado el interés de Rivers en la prédica, su trabajo trata principalmente los siglos de la Baja Edad Media, con énfasis particular en la prédica de las órdenes mendicantes. Ésta además de utilizar muchas de las fuentes de época ya tratadas por Yates y Carruthers, incluye en su repertorio bibliográfico sermones y ars praedicandi bajo medievales los cuales le permiten reconstruir cómo funcionaban las prácticas mnemónicas de los predicadores.

${ }^{78}$ RIVERS. Preaching the Memory... 


\section{Capítulo 3}

\section{ManUSCRitos de LA PSYCHOMACHIA}

En distintos textos medievales se incluyeron representaciones de los vicios y las virtudes, sin embargo, la obra cuyas copias más abundan con miniaturas del tema es la Psychomachia. Este poema alegórico fue escrito por Aurelio Clemente Prudencio, poeta y retórico, nacido en el norte de España a mediados del siglo IV ${ }^{1}$. Cristiano conocedor de la cultura clásica entre los años 392 al 405 compuso varias obras las cuales incluyen la Psychomachia ${ }^{2}$. El título de la misma puede traducirse por la Batalla del alma o el Combate de vicios y virtudes ${ }^{3}$. Prudencio en su obra utiliza elaboradas alegorías para describir cómo en el interior del hombre, en lo más profundo de su alma, se desata una constante batalla entre distintos vicios y virtudes. El poeta desarrolla el pensamiento paulino de que el cristiano para encarar exitosamente las fuerzas del mal debe armarse con armas espirituales, afirmando que éstas son las distintas virtudes con las que el lector se topará a lo largo del poema ${ }^{4}$.

La Psychomachia alcanzó gran popularidad muy pronto. Tan temprano como en el siglo V circulaban copias de este poema en distintas partes de Europa. La fama

\footnotetext{
${ }^{1}$ Se debate su lugar de nacimiento, entre Calahorra, Tarragona y Zaragoza. RoDRíGUEZ, Isidoro. "Introducción general", en: Obras Completas de Aurelio Prudencio. Ed. bilingüe. Biblioteca de Autores Cristianos 427. Madrid: Editorial Católica, 1981. pp. 3-4.

${ }^{2}$ RodRíGueZ. "Introducción general”, Obras Completas de Aurelio Prudencio..., p. 29.

${ }^{3}$ Helen Woodruff traduce Psychomachia por: "The War of the Soul", La batalla del alma. WOODRUFF, Helen. "The Illustrated Manuscripts of Prudentius", Art Studies (1929), p. 34. Richard Newhauser se refiere a ella como "Battle of Vices and Virtues", Batalla de vicios y virtudes. NEWHAUSER, Richard. The Treatise on Vices and Virtues in Latin and the Vernacular. Turnhout, Belgique: Brepols, 1993. p. 161.

4 Psychomachia vv. 1-20. Obras Completas de Aurelio Prudencio..., pp. 312-313. KAtZenellenbogen, Adolf. Allegories of the Virtues and Vices in Mediaeval Art, from Early Christian Times to the Thirteenth Century. New York: W.N. Norton \& Company, Inc., 1964. p. 1.
} 
de las obras de Prudencio, especialmente la Batalla del alma, se extendió hasta el siglo $\mathrm{XVI}^{5}$. Isidoro Rodríguez afirma que a Prudencio:

"Le estudiaron con afán y le imitaron con celo todas las clases, edades y sexos; los monjes y los obispos, los seglares y las mujeres. Se le leía en las isla Británicas, en Alemania, Bélgica, Suiza, Francia, Italia, España...; por todas las latitudes hallamos sus manuscritos. Se le leía en casa, en las abadías y catedrales, centros oficiales de estudio del Medioevo, y los venerables jerarcas de la Iglesia prodigaban el códice prudenciano a los tiernos efebos..."

Gracias a la popularidad que gozaron las obras de Prudencio durante la Edad Media, hoy en día sobreviven en todo el continente europeo más de trecientos manuscritos con los trabajos del autor ${ }^{7}$, siendo las copias de la Psychomachia copias que más abundan. El códice más antiguo que actualmente se conserva con copia del Combate de vicios y virtudes es del siglo VI, el manuscrito Lat. 8084 de la Biblioteca Nacional de Francia ${ }^{8}$. A esto se ha de añadir que una veintena de ejemplos miniados de este poema perviven en estas distintas bibliotecas. Las copias iluminadas son producto de las ricas construcciones alegóricas de Prudencio. Según Sinéad O’Sullivan las alegorías de Prudencio son vívidas representaciones de los combates y Mary Carruthers afirma que las imágenes que construye el autor a través de la

\footnotetext{
${ }^{5}$ RoDRíGUEZ. “Introducción general”, Obras Completas de Aurelio Prudencio ..., p. 65.

${ }^{6}$ RODRÍGUEZ. "Introducción general”..., p. 65.

${ }^{7}$ Según Kenneth R. Haworth, hoy en día existen más de trecientos manuscritos de la Psychomachia. Sin embargo, Isidoro Rodríguez hace la salvedad que se han estudiado más de trescientos manuscritos de las distintas obras de Prudencio, siendo los ejemplares de la Psychomachia los que más abundan. HAWORTH, Kenneth R. Deified Virtues, Demonic Vices, and Descriptive Allegory in Prudentius' Psychomachia. Amsterdam: A.M. Hakkert, 1980, p. 66.
}

8"Latin 8084", Bibliothèque nationale de France. Disponible en: http://archivesetmanuscrits.bnf.fr/ead.html?id=FRBNFEAD000067345 [Consulta: 24 de enero de 2015] 
narrativa han sido pintadas para el ojo de la mente ${ }^{9}$. Ésta cualidad activa del texto llevó a que la obra fuera iluminada tan temprano como en el siglo $\mathrm{V}^{10}$.

\subsection{Códices iluminados}

Los veinte manuscritos iluminados de la Psychomachia han sido estudiados por filólogos e historiadores del arte. Son los estudios particularmente de Richard Stettiner y Helen Woodruff los que mayor cuidado prestan a los mismos, pues los resultados de sus trabajos llevaron al desarrollo del estema de filiación filológica y estilística de estos códices, los cuales han sido reproducidos y traducidos en las figuras 27 y 28. El primer estema fue realizado por Stettiner en su trabajo Die Illustrierten Prudentiushandschriften. Éste estudió diecinueve manuscritos y Helen Woodruff fue quien identificó el número veinte. Es muy probable que Stettiner no haya estudiado el número veinte por el hecho de que de este códice sólo sobrevive un folio en el que aparecen dos miniaturas ${ }^{11}$.

Estema, del latín stemma, no es otra cosa que el "árbol genealógico de los manuscritos e impresos que han transmitido un texto ${ }^{12}$ ". Stettiner y Woodruff utilizaron más que las cualidades filológicas, las características estilísticas para establecer los ejemplos más antiguos y cómo estos sirvieron de modelo a los posteriores. Stettiner en su catalogación utilizó letras mayúsculas para identificar los distintos manuscritos. Estas letras aluden a las distintas ciudades en las que se

\footnotetext{
${ }^{9}$ O'Sullivan, Sinéad. Early Medieval Glosses on Prudentius'Psychomachia: The Weitz Tradition. Leiden; Boston: Brill, 2004, p. 3. CARRUTHERS, Mary. The Craft of Thought. Meditation, Rhetoric, and the Making of Images, 400-1200. Cambridge: Cambridge University Press, 1998, p. 148.

${ }^{10}$ KatZenellenbogen. Allegories of the Virtues and Vices in Mediaeval Art..., p. 1. WoOdruff. "The Illustrated Manuscripts of Prudentius"...,p. 34. STETTINER, Richard. Die Illustrierten Prudentiushandschriften. Berlin: Druck von J.S. Preuss, 1895. p. 151. MÂLE, Émile. El arte religioso del siglo XIII en Francia: el Gótico. Madrid: Encuentro, [1898] 2001. p. 134.

${ }^{11}$ WoOdRUfF. "The Illustrated Manuscripts of Prudentius"...,p. 46.

${ }^{12}$ LÁZARo CARRETER, Fernando. Diccionario de términos filológicos. Madrid: Editorial Gredos, S.A., 1981. p. 380.
} 
encuentran las bibliotecas que custodian estos códices. Puesto que hay bibliotecas que poseen más de una copia miniada de la Psychomachia, se añadió un número. Los mejore ejemplos para entender el sistema de Stettiner son los cuatro códices conservados en la Biblioteca Nacional de Francia. Todos se identifican a través de la letra $\mathrm{P}$, la cual remite a la ciudad de ubicación París, y un número.

Otros estudiosos de estos manuscritos han revisado el trabajo de Stettiner y han mantenido la clasificación y la división hecha por éste, como se puede apreciar en el estema de Woodruff (Fig. 28) ${ }^{13}$. Ésta autora conserva las letras designadas por Stettiner para referirse a los mismos manuscritos. Como explicamos en el estado de la cuestión, la revisión de Woodruff a Die Illustrierten Prudentiushandschriften, resultó en nuevas dataciones y filiaciones entre manuscritos además de introducir La novedad en el estema de ésta es que introduce otras letras para establecer los modelos originales y arquetipos perdido de los cuales surgieron los códices conservados.

Como se aprecia en los estemas de Richard Stettiner y Helen Woodruff (Figs. 27 y 28), los códices se dividen en dos grupos que descienden el primer prototipo del siglo V. Gracias al catálogo y estema elaborado por Stettiner y al segundo estema realizado por Woodruff la procedencia y el origen de los distintos códices se encuentra sumamente acotado y puede ubicarse. Los manuscritos se dividen en dos grupos que se aprecian en ambos estemas. Los códices representados a la izquierda son los que pertenecen al Grupo I. En éste encontramos ocho códices de origen francés y anglosajón fechados entre los siglos X al XIII ${ }^{14}$. Según Stettiner, estos descienden de una copia anglosajona ejecutada entre los siglos IX y $\mathrm{X}^{15}$. Para Woodruff el arquetipo que sirvió de modelo para los códices franceses y anglosajones

\footnotetext{
${ }^{13}$ WoODRUFF. "The Illustrated Manuscripts of Prudentius"...

${ }^{14}$ Manuscritos del Grupo I: Ms. 23 (C), Corpus Christi College Library, Cambridge. Voss. Lat. Oct. $15\left(\mathrm{Le}^{1}\right)$, Bibliotheek der Universiteit, Leiden. Add. $24199\left(\mathrm{Lo}^{1}\right)$, Cott. Cleo.C. VII (Lo $\left.{ }^{2}\right)$, Cott.Titus D.XVI (Lo $\left.{ }^{3}\right)$, British Library, Londres. Clm. 29031 b. (M), Stadtbibliothek, Múnich. Ms. Lat. 8318 $\left(\mathrm{P}^{1}\right)$, Ms. Lat. $15158\left(\mathrm{P}^{4}\right)$, Bibliothèque Nationale de France, París.

${ }^{15}$ STETTINER. Die Illustrierten Prudentiushandschriften..., pp. 168-169.
} 
del Grupo I, identificado por medio de la letra B, fue un códice del siglo VI proveniente del sur de la Galia, el Norte de Italia y regiones adyacentes ${ }^{16}$.

El Grupo II, plasmado a la derecha de ambos estemas, posee un mayor número de manuscrito con un total de doce. En este grupo es que se identifican las copias miniadas más antiguas conservadas, $\mathrm{P}^{2}, \mathrm{Le}^{2}$ y Be, con fecha del siglo IX ${ }^{17}$. El origen o procedencia de los códices de este conjunto se encuentra cerca del río Rin y del valle de Mosa. Stettiner los vincula a una copia carolingia del $800^{18}$. Según Woodruff la copia carolingia -identificada en el stemma con la letra R- de la que surgen los manuscritos de este grupo es una copia de un ejemplar del siglo V ilustrado bajo la letra A- cuya procedencia se encuentra en Italia. Este manuscrito A igualmente fue el modelo del códice del siglo VI -el B-, el cual hizo de modelo para el Grupo I ${ }^{19}$.

De la veintena de copias miniadas de la Psychomachia son de especial interés cinco manuscritos que poseen copias iluminadas de la Psychomachia. Estos son: el Burm. Q.3 de la Biblioteca de la Universidad de Leiden, el manuscrito Lat. 8085 de la Biblioteca Nacional de Francia, los manuscritos 10066-77 y 9987-91 de la Biblioteca Real de Bélgica y el códice 264 de la Biblioteca Civil de Berna los cuales han sido identificados en los dos estemas por medio de un círculo rojo. Dicha elección se encuentra sustentada en las diversas características que los mismos comparten, no obstante, son cuatro los principales elementos que se han considerado para la elección de los mismos. En primer lugar, cabe destacar que tres de las cinco copias son de los ejemplos miniados más antiguos que sobreviven de la Psychomachia, con una cronología de la última década del siglo IX. En este sentido

\footnotetext{
${ }^{16}$ WoODRUFF. "The Illustrated Manuscripts of Prudentius"...,p. 75.

${ }^{17}$ Manuscritos del Grupo II: Ms. 9987-91 ( $\left.\mathrm{B}^{1}\right)$, Ms. 10066-77 (B²), Ms. 9968-72 (B33), Bibliothèque royale de Belqique, Bruselas. Cod. 264 (Be), Burgenbibliothek, Berna. Ms. 135 (G), Stiftsbibliothek, San Galo. Ms. No. 81 (K) Dombibbliothek, Colonia. Burm.Q.3 (Le²), Bibliotheek der Universiteit, Leiden. Ms. 22 (Ly), Bibliothèque Municipal de Lyon. Ms. Lat. $8085\left(\mathrm{P}^{2}\right)$, Ms. Lat. $18554\left(\mathrm{P}^{4}\right)$, Bibliothèque Nationale de France, París. Ms. 536 (V), Bibliothèque Municipale de Valenciennes. Manuscrito identificado por Woodruff como $\mathrm{H}$ pertenece al Museum für Kunst und Gewerbe, Hamburgo.

${ }^{18}$ STETTINER. Die Illustrierten Prudentiushandschriften..., p. 173.

${ }^{19}$ WOODRUFF. "The Illustrated Manuscripts of Prudentius"...,p. 75.
} 
entendemos que son las copias que mejor podrían revelar el propósito o la utilidad por la que los distintos folios de este poema fueron ilustrados. Segundo, son los códices en los que la Batalla del alma posee el mayor número de miniaturas, en tres de esto se identificaron noventa miniaturas, repartidas entre las distintas escenas del prefacio y el poema y hasta dos efigies del autor en cada códice. Como más adelante se demostrará, las distintas imágenes siguen muy de cerca la narración de Prudencio, por lo tanto, gracias a la cantidad de iluminaciones de estos ejemplos es posible reconstruir el discurso icónico de los mismos. Tercero, estas distintas ilustraciones del poema se encuentran acompañadas por un título que describe de forma resumida la misma. Gran parte de estos tituli fueron tomados del texto y en muchos casos utilizan términos muchos exequibles para una población en aprendizaje. En último lugar, y no menos importante, cabe destacar que estos ejemplos seleccionados pertenecen al Grupo II de los estemas, y además de compartir cualidades estilísticas la zona geográfica en las que se elaboraron o fueron utilizados se encuentra muy acotada. Estos cinco manuscritos fueron miniados en distintas abadías de las zonas cercanas al río Rin y el valle del Mosa. Como parte de nuestra investigación, identificamos la ubicación de los distintos cenobios que albergaron estos códices y constatamos este dato. En la figura 29, Ubicación de los monasterios en los que se crearon o pertenecieron los manuscritos Burm.Q.3, Ms.Lat. 8085, Ms.9987-91, Ms. 10066-77 y Cod. 264, se etiquetaron en rojo las abadías de San Denis, San Amand, San Laurent, San Remí, Reichenau y San Galo. A través de la figura 29 no sólo corroboramos visualmente esta delimitación geográfica, sino que también podemos resaltar el vínculo cercano de estas abadías con el mundo carolingio, pues como podemos ver la gran mayoría se encuentran muy cerca de Aquisgrán, capital del imperio carolingio. 


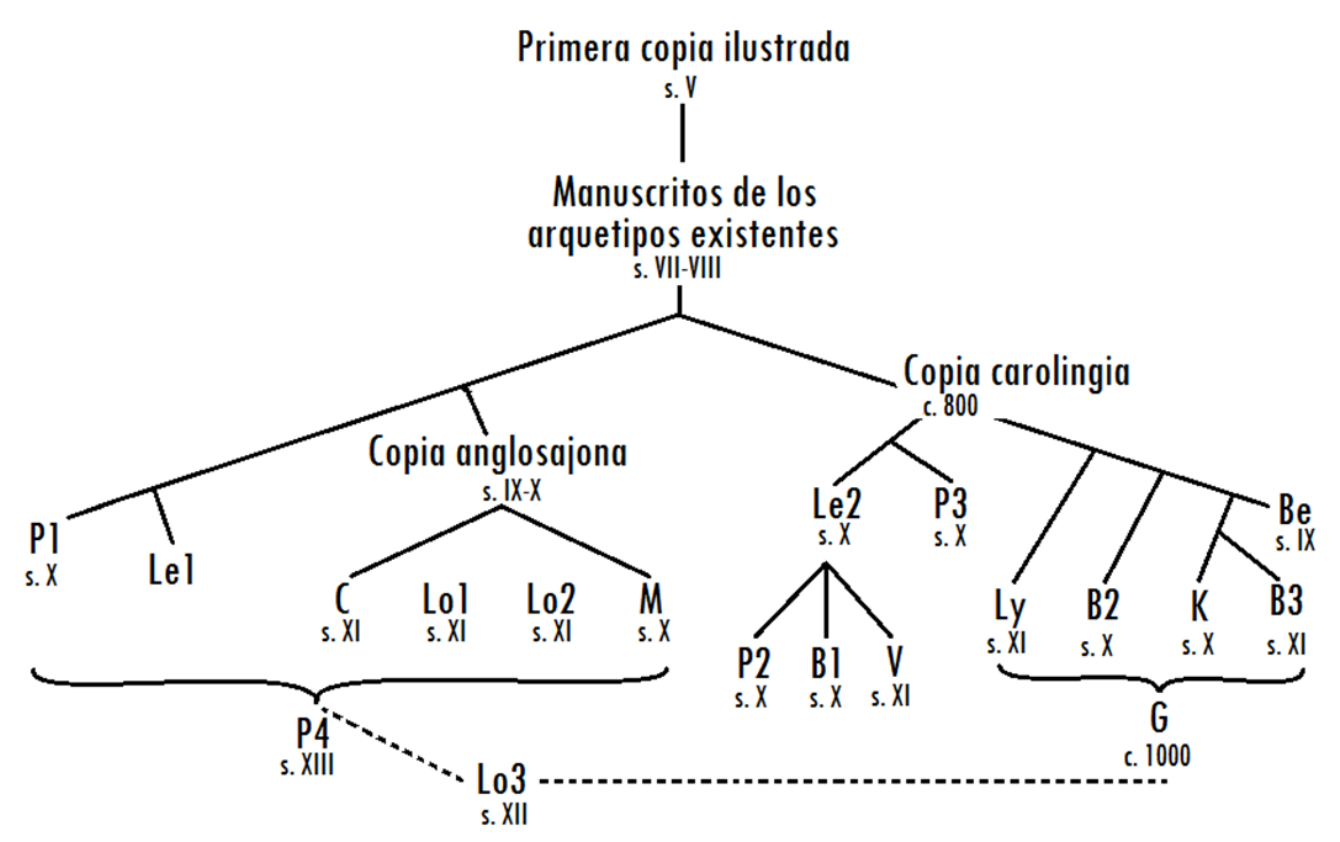

Figura 28. Estema elaborado por Richard Stettiner (1895).

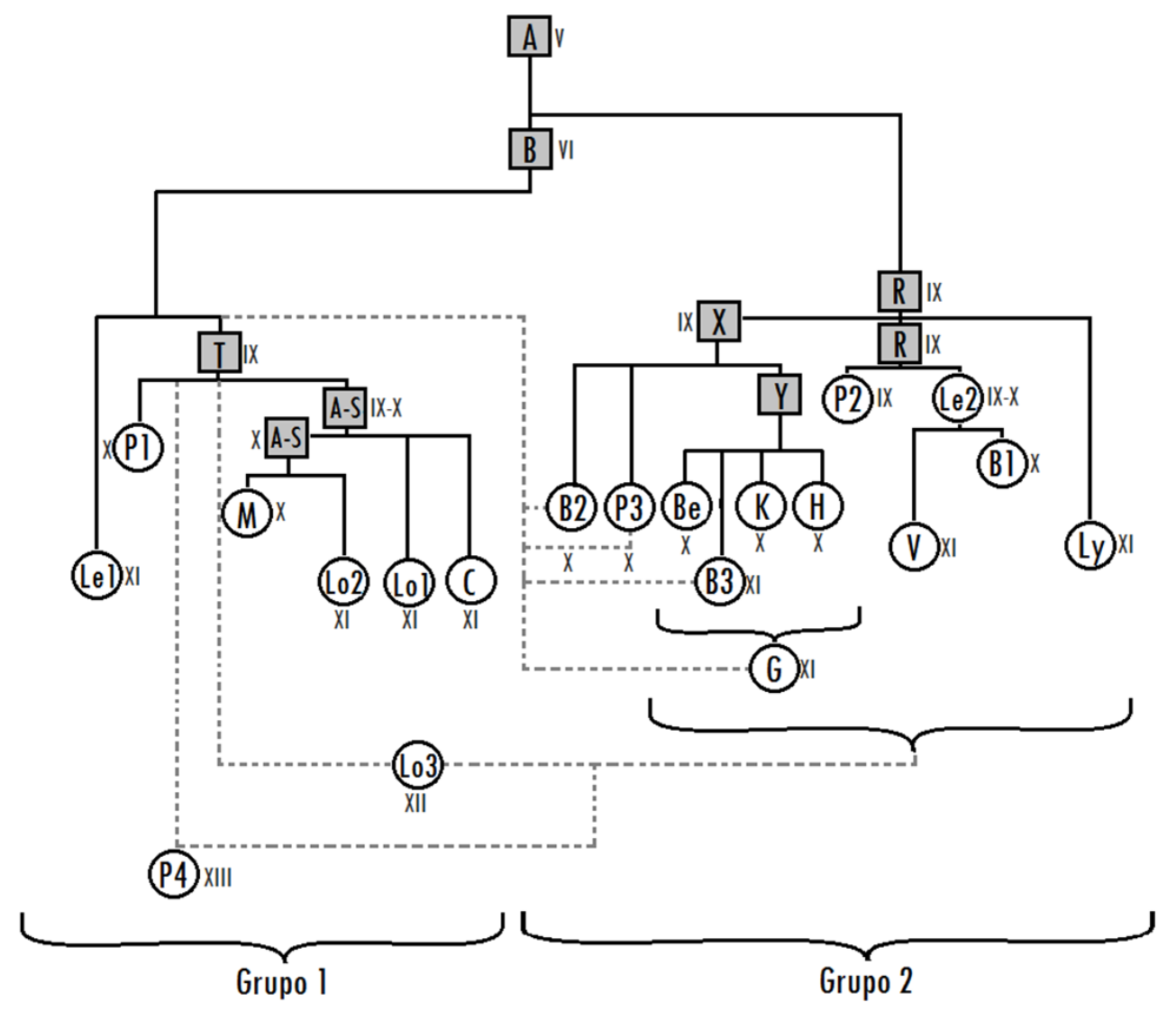

Figura 29. Estema elaborado por Helen Woodruff (1929). 


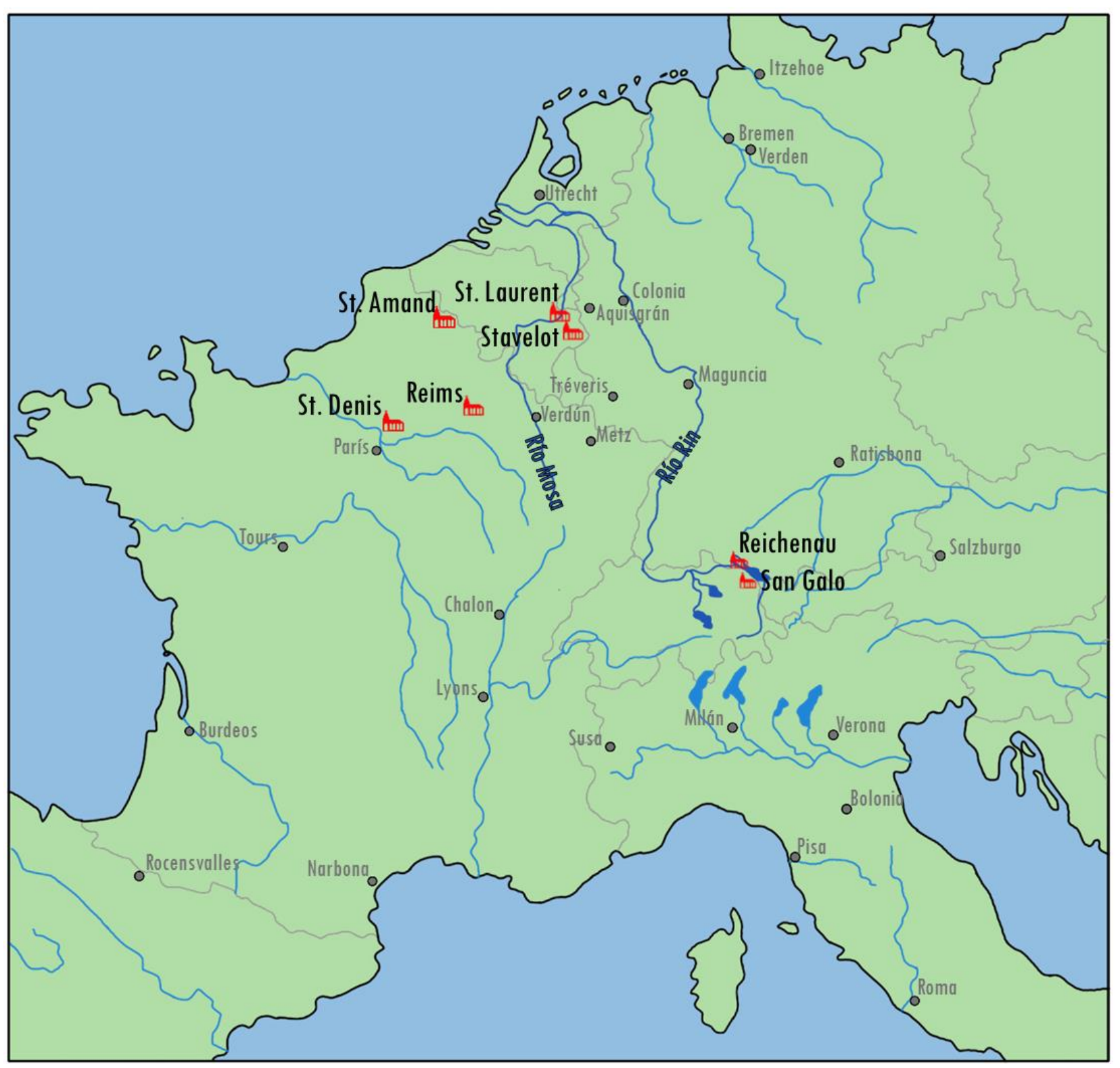

Figura 30. Ubicación de los monasterios en los que se crearon o pertenecieron los manuscritos Burm.Q.3, Ms.Lat. 8085, Ms.9987-91, Ms. 10066-77 y Cod. 264 


\subsubsection{Manuscrito Burm. Q.3}

Ubicación actual: Biblioteca de la Universidad de Leiden (Bibliotheek der

Universiteit de Leiden)

\section{Catalogación de Stettiner: $\mathrm{Le}^{2}$}

Burm. Q. 3. contiene 181 folios escritos en una columna. Mide 24,4 cm x 15 cm. Éste códice se compone de distintas obras fechadas entre los siglos IX y X. La primera es un tratado de gramática (Tractatus ad grammaticam) (Fols. 1v-8v), el cual según Stettiner se añadió luego al manuscrito ${ }^{20}$. El resto del códice consiste en una compilación del siglo IX de algunas de las obras de Prudencio: Praefatio (Fol. 9), Cathemerinon (Fols. 10r-29r, 83v- 88r), Peristephanon (Fols. 29v-83v), Apotheosis (Fols. 88v-105r), Hamartigenia (Fols. 105r-119v), Psychomachia (Fols. 120r-149v), Contra Symmachum (Fols. 150r-178r) y el Dittochaeum (Fols. 178v-181v). La Psychomachia posee 90 miniaturas, insertadas dentro del texto acompañadas por un título en letras rojas que describe la imagen. El mismo data de las últimas décadas del siglo IX, convirtiéndole en una de las copas miniadas más antiguas de la Psychomachia y el posible modelo para los otros dos manuscritos del siglo IX.

Según Stettiner, el mismo proviene de la abadía de Egmond (abadía de San Adalberto) en los Países Bajos. Helen Woodruff entiende que el mismo se vincula al círculo de la Escuela de Reims. Katzenellenbogen lo asocia al norte de Francia, a la abadía de Saint-Amand. La información más reciente sobre la procedencia de este manuscrito sugiere que el mismo se creó en Saint-Denis en el segundo cuarto del siglo IX y posteriormente fue llevado a la abadía de Egmond ${ }^{21}$. Si se tiene en cuenta el hecho de que no fue hasta el siglo X que la abadía de Egmond se fundó, es muy

\footnotetext{
${ }^{20}$ STETTINER. Die Illustrierten Prudentiushandschriften ..., p. 33.

${ }^{21}$ BERGMANN, Rolf. Katalog der althochdeutschen und altsächsischen Glossenhandschriften. Band I. Berlin: Walter de Gruyter, 2005. p. 363. BISCHOFF, Bernhard. Katalog der festländischen Handschriften des neunten Jahrhunderts: (mit Ausnahme der wisigotischen). T. 2, Laon Paderborn. Wiesbaden: Harrassowitz, 2004. p. 47.
} 
probable que el mismo sea de Saint-Denis. Estilísticamente recuerda al salterio de Utrecht $^{22}$.

\subsubsection{Manuscrito 9987-91}

Ubicación actual: Biblioteca Real de Bélgica, Bruselas (Bibliothèque Royale de Belgique)

\section{Catalogación de Stettiner: $B^{1}$}

El manuscrito 9987-91 tiene 157 folios los cuales miden aproximadamente 24 $\mathrm{cm}$ x $16 \mathrm{~cm}$. La mayor parte del texto se encuentra escrito a una columna. Éste códice es muy similar al Burm. Q.3. El mismo se compone de seis obras de Prudencio: Cathemerinon (Fols. 1r-17r, 64r-66v), Peristephanon (Fols. 17r-63v), Apotheosis (Fols. 66v-83v), Hamartigenia (Fols. 83v-99v), Psychomachia (Fols. 100r-129r), Contra Symmachum (Fols. 130r-157v). Al igual que los dos ejemplos anteriores, la Psychomachia posee 90 miniaturas que siguen el texto, las mismas se ubican entre los diferentes versos y poseen un título que las describe. Éstas son estilísticamente similares a las del manuscrito Burm. Q.3. Stettiner y Woodruff lo dataron como una obra del siglo X, no obstante, Katzenellenbogen y la información reciente de la Biblioteca Real de Bélgica establecen que el mismo es de la segunda mitad del siglo IX de la abadía de Saint-Amand ${ }^{23}$.

\footnotetext{
${ }^{22}$ WOODRUFF. "The Illustrated Manuscripts of Prudentius"..., p. 52.

${ }^{23}$ BERGMANN. Katalog der althochdeutschen und altsächsischen Glossenhandschriften. Band I..., p. 363. BISCHOFF. Katalog der festländischen Handschriften des neunten Jahrhunderts: (mit Ausnahme der wisigotischen). T. 2..., p. 47. "Prudentius, Carmina”, Bibliothèque numérique de la Bibliothèque royale de Belgique. Disponible en: http://belgica.kbr.be/fr/coll/ms/ms9987_91_fr.html [Consulta : 7 de noviembre de 2013]. KATZENELLENBogen. Allegories of the Virtues and Vices in Mediaeval Art..., p. 4.
} 


\subsubsection{Manuscrito Lat. 8085}

Ubicación actual: Biblioteca Nacional de Francia (Bibliothèque Nationale de France)

\section{Catalogación de Stettiner: $\mathrm{P}^{2}$}

El manuscrito lat. 8085 se compone de 82 folios escritos a dos columnas los cuales miden aproximadamente $21 \mathrm{~cm}$ x $17 \mathrm{~cm}$. Contiene seis obras de Prudencio: Cathemerinon (Fols. 3r-11r, 37v-40r), Peristephanon (Fols. 11r-37v), Apotheosis (Fols. 40r-48r), Hamartigenia (Fols. 48r-55r), Psychomachia (Fols. 55v-70r), Contra Symmachum (Fols. 70r-82v). Al igual que el Burm. Q. 3 el poema de la Psychomachia se encuentra completamente ilustrado con 90 miniaturas coloreadas, intercaladas con el texto y cada una con su título correspondiente escrito en letras rojas. El mismo es de finales del siglo IX, entre los años 877 y 899 . Su procedencia se encuentra ligada a la escuela de Reims y estilísticamente es muy cercano al salterio de Douce ${ }^{24}$.

\subsubsection{Manuscrito 10066-77}

Ubicación actual: Biblioteca Real de Bélgica, Bruselas (Bibliothèque Royale de Belgique)

\section{Catalogación de Stettiner: $\mathrm{B}^{2}$}

El manuscrito 10066-77 de la Biblioteca Real de Bélgica tiene 157 folios que miden $25,5 \mathrm{~cm}$ x $17,5 \mathrm{~cm}$. El mismo se compone de distintos textos fechados entre los siglos X y XIV. Los trabajos que corresponden al siglo X son: la Psychomachia de Prudencio (Fols. 112r-139r) y el Physiologus (Fols. 140r-156v), Comentarios a la Arithmetica de Boecio por Gerbertus Aureliacensis (Fol. 157r), Commentarius in

\footnotetext{
${ }^{24}$ PORCHER, Jean. Les manuscrits à peintures en France du VIIème au XIIème siècle. París: Bibliothèque nationale, 1954. p. 42. WoODRUFF. "The Illustrated Manuscripts of Prudentius" ..., p. 60. STETTINER. Die Illustrierten Prudentiushandschriften..., pp. 38-42.
} 
Ciceronis Topica (Fol. 161r) y varias notas sobre gramática (Fols. 139v, 161v-162r). Los textos del siglo XII son: el De mirabilibus mundi de Solino (llamado también Collectanea rerum memorabilium) (Fols. 4v-65r), glosas a la Psychomachia de Prudencio (Fols. 85v-86r), listas de palabras hebreo-latín y griego-latin (Fols. 80r85r) y un glosario bíblico (Fols. 89r-111v). Este códice posee diversas miniaturas que corresponden a los textos del Psysiologus y la Psychomachia. El segundo tiene 52 miniaturas y el ciclo de imágenes está incompleto. Entre los distintos versos del poema de Prudencio hay espacios en blancos, los cuales muy probablemente se encontraban destinados a una o varias iluminaciones. La Psychomachia es el texto más antiguo del códice, con fecha del siglo X. Por otra parte, la procedencia de éste manuscrito no se encuentra del todo clara. La Biblioteca Real de Bélgica lo vincula a la región del Mosa, a la antigua abadía de Stavelot. Gracias a la inscripción en uno de sus folios se sabe que el mismo posteriormente perteneció a la abadía de SaintLaurent de Lieja.

\subsubsection{Cod. 264}

Ubicación actual: Biblioteca Civil de Berna (Burgerbibliothek)

\section{Codificación de Stettiner: Be}

El códice 264 tiene 145 folios que miden 27,3 cm x $21 \mathrm{~cm}$. El mismo contiene todas las obras de Prudencio: Praefatio (Fols. 2r-2v), Cathemerinon (Fols. 3r-17v), Peristephanon (Fols. 20r-28v, 50r-74v), Psychomachia (Fols. 31r-48v), Dittochaeon (Fols. 76r-80r), Contra Symmachum (Fols. 118r-145r). Partes del Peristephanon, específicamente las dedicadas a las vidas de los santos Román y Casiano se encuentran iluminadas. Igualmente, la Psychomachia se encuentra iluminada. Está escrita a una columna y dentro de las mismas se intercalan 38 miniaturas con el texto. Éstas se encuentran completamente coloreadas. Algunas poseen un título en rojo que 
las describe. Data del c. 900 de la región del lago de Constanza, probablemente vinculado a los monasterios de San Galo o Reichenau ${ }^{25}$.

A través de la descripción física de los cinco códices que contienen copias miniadas de la Psychomachia podemos analizar otros aspectos de los mismos. En primer lugar, se encuentra la datación cronológica. A partir de la información más reciente provista por las distintas bibliotecas en las que se conservan estos cinco manuscritos y catálogos, algunas de las fechas de los manuscritos no coinciden con las propuestas por los historiadores de la primera mitad del siglo XX. Esto se aplica sobre todo al manuscrito 9987-91 $\left(\mathrm{B}^{1}\right)$. Stettiner y Woodruff dataron el mismo del siglo X, sin embargo, la Biblioteca Real de Bélgica ha atrasado la cronología a la última década del siglo IX, aproximadamente el 890. Es muy probable que esta copia miniada de la Psychomachia se haya elaborado en esta centuria, pues en términos estilístico el Ms. 9987-91 es muy similar a Burm.Q.3, similitud que llevó a Stettiner y Woodruff a indicar que el modelo del códice belga fue la copia de la Universidad de Leiden, como se aprecia en los estemas. Incluso nos atrevemos a pensar que más que uno de estos manuscritos ser el modelo del otro, realmente los dos surgen de el arquetipo R, realizado en la abadía de Reims, del siglo IX identificado por Woodruff (Fig. 28).

El tercer manuscrito del siglo IX, el Lat. 8085 también muestras ciertos problemas filiales. Según Stettiner y Woodruff el modelo de este códice fue el ejemplo de Leiden, el Burm.Q.3. A pesar de las sutiles diferencias estilísticas que

\footnotetext{
${ }^{25}$ UTZ, Sabine. "Bern, Burgerbibliothek, Cod. 264-Prudentius Carmina", e-codices - Virtual Manuscript Library of Switzerland. Disponible en: http://www.ecodices.unifr.ch/en/list/one/bbb/0264 [Consulta: 18 de noviembre de 2014]. UTZ, Sabine. "Reprise et réivention des manuscrits antiques à l'époque carolingienne: l'exemple du Prudence de la Burgerbibliothek de Berne (Codex 264)", Actualiser le passé: figures antiques du Moyen Âge à la Renaissance. Laussane: Université de Laussane, 2012. p. 34. BERGMANN. Katalog der althochdeutschen und altsächsischen Glossenhandschriften. Band I..., p. 260. BISCHOFF. Katalog der festländischen Handschriften des neunten Jahrhunderts: (mit Ausnahme der wisigotischen). T. 1..., p. 120. WoOdRUFF. "The Illustrated Manuscripts of Prudentius"..., p. 43. STETTINER. Die Illustrierten Prudentiushandschriften..., pp. 88-89.
} 
muestran estas dos Psychomachias: principalmente identificadas en la forma de representar la vestimenta de los vicios y virtudes, la policromía de las escenas o la distribución de las imágenes y el texto en dos columnas, es posible igualmente reconocer ciertas reminiscencias de los manuscritos Burm.Q.3 y 9987-91. Creemos que realmente el modelo del ejemplo parisino es el códice belga. Esto se deduce partiendo de la cronología propuesta por la Biblioteca Real de Bélgica y el hecho de que en Lat. 8085 y 9987-91 se repitió un error en el orden en el que se colocaron las miniaturas 66 a la 72 .

Si bien ya hemos indicado que las imágenes de estas cinco copias de la Psychomachia comparten similitudes estilísticas, especialmente las del siglo IX, se ha de resaltar igualmente que la composición y disposición de las mismas en el folio es muy parecida. Las distintas miniaturas se insertan en un orden específico: anteceden los versos correspondientes a las acciones que plasman. Esto incluso se repite en el manuscrito Lat. 8085 que fue copiado en dos columnas. Es muy probable que las dimensiones de los folios hayan permitido mantener la misma disposición de texto e imágenes. El tamaño de los distintos folios ronda entre los $24 \mathrm{~cm}$ de largo y los $17 \mathrm{~cm}$ de ancho, medida muy parecida a un folio A4 $(29.7 \mathrm{~cm} \mathrm{x} 21 \mathrm{~cm})$, lo que permite un fácil manejo del códice y completo acceso al campo visual del espectador.

Un último elemento en común entre estos cinco códices que queremos destacar son el resto de textos que acompañan a la Psychomachia. Las copias miniadas de la Batalla del alma no se encuentran aisladas, sino que los manuscritos a los que estas pertenecen incluyen otras obras literarias, como otros escritos de Prudencio (excepto Ms. 10066-77) pero también se han identificados textos y tratados relacionados con las disciplinas del quadrivium, pero sobre todo del trivium específicamente con el aprendizaje y el ejercicio de la gramática. La presencia de estos trabajos escritos junto a las obras de Prudencio no es extraña en el contexto en el que se elaboraron estos códices, pues los mismos formaban parta del currículo de enseñanza de las abadías y monasterios a los que pertenecieron estos cinco manuscritos. 


\subsection{Monasterio, locus litterarum: contexto de los cinco códices miniados}

Los cincos manuscritos antes identificados fueron ilustrados en importantes scriptorium y/o utilizados en importantes monasterios y abadías medievales, vinculadas al mundo carolingio cómo: San Amand, San Denis, San Laurent y San Galo. Incluso el manuscrito parisino, Ms. Lat. 8085, se puede relacionar al entorno monacal. A pesar de que este códice se vinculó a la Escuela de Reims, la cual operaba primordialmente en la Catedral de Reims, también se puede asociar a la abadía de San Remi en Reims gracias a la relación estrecha que este cenobio mantuvo con el obispado. Desde el siglo VIII hasta el X San Remi fue una abadía episcopal y su abad era el obispo de Reims, relación que le ganó el nombre de Monastère de Reims ${ }^{26}$. Todos estos monasterios antes mencionados en algún punto de su historia adoptaron la regla benedictina e igualmente promovieron el renacimiento carolingio. Entre los siglos VII y X éstas gozaron del favor de la monarquía e incluso en ciertos casos los abades tenían que ser aprobados por el rey ${ }^{27}$. Se convirtieron así en lugares privilegiados donde incluso los hijos de los monarcas eran enviados a estudiar. En la

\footnotetext{
${ }^{26}$ PRACHE, Anne. Saint-Remi de Reims: l'oeuvre de Pierre de Celle et sa place dans l'architecture gothique. Genève: Droz, 1978. p. 10. Poussin, Clovis (Abbé). Monographie de l'abbaye et de l'église de St-Remi de Reims, précédée d'une notice sur le saint apôtre des Francs d'après Flodoard. Reims: Lemoine-Canart, 1857. p. 52.

${ }^{27}$ El favor de la monarquía se manifestaba de distintas maneras. En muchas ocasiones los monarcas concedían el abaciazgo a algún individuo como acto de recompense a su lealtad o su buena labor. Ejemplo de esto es Fardulfo, a quien Carlomagno nombró abad de San Denis luego de que éste notificara al monarca los planes de conspiración de su hijo Pepino. También a éstas se les podía otorgar el título de monasterio regio, y con éste título se podían obtener inmunidad. Ejemplo de esto es la abadía de San Galo que bajo los reinados de Luis el Piadoso y Luis el Germánico se le otorgó este título. CLARK, J. M. The Abbey of St. Gall as a Centre of Literature and Art. Cambridge: Cambridge University Press, 1926. p. 5. FÉLIBIEN, Michel. Histoire de l'abbaye royale de SaintDenys en France: contenant la vie des abbez qui l'ont governée depuis onze cens ans, les hommes illustres qu'elle a donnez à l'Eglise \& à l'Etat, les privileges accordez par les souverains pontifes \& par les evêques, les dons des rois, des princes \& des autres bienfacteurs: avec la description de l'eglise \& de tout ce qu'elle contient de remarquable: le tout justifié par des titres authentiques \& enrichi de plans, de figures \& d'une carte topographique. París: Chez Frederic Leonard, 1706. p. 62.
} 
abadía de San Amand se educó uno de los hijos de Carlos Martel, Jérôme, y dos hijos de Carlos el Calvo, Pépin y Drogon ${ }^{28}$.

Estos cenobios no sólo tenían una estrecha relación con el mundo carolingio y los monarcas, sino que entre ellos también existían un vínculo cercano. Los miembros de una comunidad pasaban a otra, ya fuese para servir como maestros en las escuelas o incluso como abades. A finales del siglo VIII Waldo de Reichenau era “dean" en San Galo y estableció una confraternidad entre este cenobio y la abadía de Reichenau, en el 786 fue nombrado abad de Reichenau y en el 806 abad de San Denis $^{29}$. Hincmaro de Reims (806-882) quien fue arzobispo de Reims y consejero de Carlos el Calvo estudió bajo la tutela de Hilduino en la abadía de San Denis ${ }^{30}$. El abad de San Galo Gozbert (816-836) encomendó al abad de Reichenau Walafrido Strabo (808-849) la biografía de san Galo ${ }^{31}$. Goslin (834-886) entró a la abadía de San Remi para convertirse en monje, eventualmente llegó a ser abad de San Amand y San Denis ${ }^{32}$.

En el siglo VIII a través de la Admonitio Generalis, Carlomagno estipuló que en los monasterios de todo el imperio se debían establecer escuelas en las que se enseñaran los salmos, gramática, cálculo y música. Estas abadías no fueron la excepción, su relación con la monarquía y con los distintos cenobios supuso la rápida implementación de la ordenanza real ${ }^{33}$. Las escuelas en estos centros se crearon para educar a los niños oblatos y a los hijos de nobles ${ }^{34}$. San Galo incluso llegó a tener dos escuelas, una en el interior del monasterio destinada a la instrucción de los

\footnotetext{
${ }^{28}$ Platelle, Henri. Le temporel de l'abbaye de Saint-Amand des origines a 1340. París: Librairie d'Argences, 1962. p. 65.

${ }^{29}$ CLARK. The Abbey of St. Gall as a Centre..., pp. 58-59.

${ }^{30}$ FrIEND, A.M. "Carolingian Art in the Abbey of St. Denis", Art Studies; Medieval, Renaissance and Modern Vol. 1 (1923), p. 73.

${ }^{31}$ CLARK. The Abbey of St. Gall as a Centre..., p. 7.

${ }^{32}$ Platelle. Le temporel de l'abbaye de Saint-Amand..., p. 59.

${ }^{33}$ Platelle. Le temporel de l'abbaye de Saint-Amand..., p. 65. Clark. The Abbey of St. Gall as a Centre..., p. 93. D'AYZAC, Félicie-Marie-Emilie. Histoire de l'abbaye de Saint-Denis en France. Tome Premier. París: Imprimerie Impériale, 1860. p. 61.

${ }^{34}$ Platelle. Le temporel de l'abbaye de Saint-Amand..., pp. 65-66. CLARK. The Abbey of St. Gall as a Centre..., p. 8. D'AYZAC. Histoire de l'abbaye de Saint-Denis..., pp. 13-15. FÉLIBIEN. Histoire de l'abbaye royale de Saint-Denys en France..., p. 61.
} 
novicios y oblatos y otra a parte de la clausura, a las afueras, en la que laicos pudientes, sacerdotes seculares y los hijos de ricos nobles se educaban ${ }^{35}$. Una vez adquirido los conocimientos básicos los novicios continuaban estudiando bajo la tutela de sus maestros. Los maestros de estas abadías eran considerados "scholars" (erudito o sabio) ${ }^{36}$, los mismos mantenían vínculos cercanos con otras abadías, pues como parte de su proceso de formación visitaban otros monasterios para adquirir nuevos conocimientos y en muchas ocasiones se volvían los magistri de materias $\operatorname{avanzadas}^{37}$.

\subsubsection{Escuelas monástica: la enseñanza de la gramática y la retórica}

El currículo general de estas abadías consistía en la enseñanza de las disciplinas del trivium y el quadrivium y su relación con el estudio de las Sagradas Escrituras. No obstante, antes de aprender las siete materias de las artes liberales, los estudiantes tenían que aprender de memoria elementos básicos de la fe cómo: el credo, el Padre Nuestro y los salmos ${ }^{38}$. Los pupilos aprendían estas oraciones y otros conocimientos a través de la repetición: el magister repetía una y otra vez hasta que los alumnos memorizaban los ciento cincuenta salmos ${ }^{39}$. Una vez memorizadas estas oraciones necesarias para la práctica del oficio divino, los estudiantes comenzaban a aprender a leer y escribir en latín. La asistencia diaria al oficio permitía a los jóvenes oblatos familiarizarse y adquirir conocimientos pasivos de las formas del latín ${ }^{40}$. El

\footnotetext{
${ }^{35}$ Clark. The Abbey of St. Gall as a Centre..., p. 94.

${ }^{36}$ ClARK. The Abbey of St. Gall as a Centre..., p. 10.

37 "Des maître plus instruits, qui avaient eux-mêmes recueilli leur savoir dans différents centres, y enseignaient les sujets plus âgés et capables 'études plus relevées." Platelle. Le temporel de l'abbaye de Saint-Amand..., p. 65.

${ }^{38}$ CLARK. The Abbey of St. Gall as a Centre..., pp. 97-98.

39 "As the pupils could not read, the teacher had to repeat the Psalms again and again until the whole hundred and fifty were thoroughly remembered". CLARK. The Abbey of St. Gall as a Centre..., p. 98.

40 "Attendance at services provided the young oblate with a passive knowledge of the shapes of Latin words. Although the sense was no doubt quite unintelligible, the words of the liturgy, the Psalms, and to some extent the hymns and the rest of the Bible as well, would gradually have become familiar, furnishing the teacher with a great stock of examples upon which to draw [...]". LAW, Vivien. "The
} 
primer libro a leer era el salterio, el cual ya debían saber de memoria gracias a la repetición constante de su contenido en clases y el oficio. A esto le seguía la memorización de listas de palabras, y practicar las letras del alfabeto en tablillas de cera. Estos ejercicios se combinaban con el estudio de la gramática, la primera disciplina del trivium que estos aprendían.

La importancia de la gramática en el contexto monacal se basa en la noción de que a través de esta disciplina se puede tener un mejor entendimiento de la palabra de Dios manifestada en las Escrituras, es el primer paso para develar los secretos ocultos de la Biblia ${ }^{41}$. Las bases teóricas se aprendían a partir de textos clásicos, pero sobre todo de los trabajos de contemporáneos cómo Alcuino, Pablo el Diácono y Pedro de $\mathrm{Pisa}^{42}$. Si bien eran los textos de estos autores los que sentaron el conocimiento teórico de la gramática, el conocimiento práctico se obtenía por medio de la lectura del salterio ${ }^{43}$. A esto se incluía el estudio de poetas cristianos, siendo Prudencio uno de los autores más importantes que formaba parte del currículo y sus obras eran utilizadas como ejemplos de los principios gramaticales ${ }^{44}$. La elección de textos en verso para jóvenes aprendices resulta acertada, pues la misma auxilia a la memoria, los poemas y los textos en verso que se aprenden de memoria se fijan mejor en la mente que los textos en prosa ${ }^{45}$. Además de estas obras, otro recurso que mejoraba la memoria y el proceso de aprendizaje de los jóvenes pupilos eran las listas de palabras ${ }^{46}$.

Study of Grammar", Carolingian Culture: Emulation and Innovation. Rosamond McKitterick. Cambridge: Cambridge University Press, 1997. p. 88.

${ }^{41}$ O'Sullivan. Early Medieval Glosses on Prudentius' Psychomachia..., p. 91. LAw. "The Study of Grammar", Carolingian Culture: Emulation..., p. 99.

${ }^{42}$ LAW. "The Study of Grammar", Carolingian Culture: Emulation..., p. 92.

${ }^{43}$ GiBsON-WoOD, Carol. "The 'Utrecht Psalter' and the Art of Memory", RACAR: revue d'art canadienne / Canadian Art Review. Vol. 14, No. 1/2 (1987), p. 11. RICHE, Pierre. "Le rôle de la mémoire dans l'enseignement médiéval", Jeux de mémoire. Aspects de la mnémotechnie médiévale. dirección de: Bruno Roy y Paul Zumthor. Montréal: Presses de l'Université de Montréal, 1985. p. 137.

${ }^{44}$ O’Sullivan. Early Medieval Glosses on Prudentius' Psychomachia..., p. 11. Clark. The Abbey of St. Gall as a Centre..., pp. 101-102.

${ }^{45}$ RICHÉ. "Le rôle de la mémoire dans l'enseignement médiéval”, Jeux de mémoire..., p. 143.

${ }^{46}$ Riche. "Le rôle de la mémoire dans l'enseignement médiéval", Jeux de mémoire..., p. 141. ClARK. The Abbey of St. Gall as a Centre..., p. 99. 
Los estudiantes luego de estudiar gramática, eran introducidos a la retórica o la dialéctica. El orden en que éstas se enseñaban cambiaba dependiendo la escuela. La dialéctica se utilizaba para definir ideas y formular argumentos ${ }^{47}$. Los pupilos igualmente estudiaban retórica, sobre todo la teoría. Cicerón continuó siendo la autoridad su De Inventione junto a la Rhetorica ad Herennium, la cual en este período se le atribuyó su autoría, fueron los textos más utilizados para enseñar y aprender esta disciplina del trivium $^{48}$. Dentro del contexto del monasterio la exposición de discursos no tenía mucho uso, esto llevo a que la enseñanza de la retórica se redirigiera a la formación de los ciudadanos de la Ciudad de Dios, enfocándose primordialmente en la invención literaria y no en las tareas persuasivas del retórico ${ }^{49}$. El concepto de inventio, en esta época era utilizado para referirse al acto de pensar ${ }^{50}$. La invención era esencial sobre todo para el proceso de meditación, pues en el contexto monacal la meditación no es otra cosa que el arte de crear pensamientos sobre $\operatorname{Dios}^{51}$.

Si se considera el currículo de enseñanza de las escuelas de estos monasterios la presencia de las obras de Prudencio es perfectamente comprensible. Algunos de los manuscritos incluso son prueba de la relación intrínseca entre el trabajo de este poeta cristiano y la gramática. El códice Burm.Q.3 comienza con un tratado de gramática (Fols. 1v-8v) y Ms. 10066-77 en los folios 139v, 161v-162r tiene notas sobre gramática y en los folios $89 \mathrm{r}$ al $111 \mathrm{v}$ listas de palabras. Si bien estos folios fueron o no fueron integrados al códice en el mismo período en el que se incluyeron

\footnotetext{
${ }^{47}$ LAW. "The Study of Grammar", Carolingian Culture: Emulation..., p. 97. ClARK. The Abbey of St. Gall as a Centre..., p. 117.

${ }^{48}$ ButTERFIELD, David. "Classical Manuscripts at St Gall and Reichenau", Tours of the Libraries of Reichenau and St. Gall. California: UCLA Digital Library, 2012. Disponible en: http://www.stgallplan.org/en/tours_classical_mss.html [Consulta: 25 de abril de 2015] REYNOLDS, Suzanne. Medieval Reading: Grammar, Rhetoric and the Classical Text. Cambridge: Cambridge University Press, 1996. p. 28. CLARK. The Abbey of St. Gall as a Centre..., pp. 114-115.

${ }^{49}$ CARRUTHERS. The Craft of Thought ..., p. 11.

${ }^{50}$ CARRUTHERS. The Craft of Thought..., p. 61.

51 "Monastic meditation is the craft of making thoughts about God". CARRUTHERS. The Craft of Thought..., p. 2.
} 
o copiaron los trabajos de Prudencio, aun así, evidencian la importancia de la obra de este autor para el aprendizaje de la gramática.

Puesto que la procedencia de los cinco manuscritos que aquí estudiamos se vincula directamente con el contexto monacal, los espectadores o usuarios de estos códices debieron ser los monjes que conformaban la comunidad de religiosos. Las imágenes de estas cinco Psychomachias miniadas igualmente debieron servir a los lectores del poema, no sirviendo como meros elementos estéticos que se encuentran insertados entre los versos del poema de Prudencio. A priori, las distintas miniaturas del poema recuerdan ilustraciones textuales. La función de éstas se encuentra estrechamente ligada con el currículo de enseñanza de estos cenobios, y las mismas fueron utilizadas para auxiliar o entender el texto, como glosas ${ }^{52}$, pero igualmente como mecanismos mnemónicos que ayudaban a memorizar los distintos versos del poema. que auxilian o sirven para entender el texto, glosas, pero igualmente debieron tener una función cercana con el currículo de enseñanza de estos cenobios. En estas obras existe una estrecha relación entre palabra-imagen-memoria, que se puede confirmar por medio de la integración de las imágenes en el texto y los tituli que acompañan a éstas. Para entender dicha relación es necesario igualmente reconstruir cómo era el acto de leer entre los siglos IX y X.

\subsubsection{El acto de leer}

Las distintas miniaturas en los cinco códices de la Psychomachia que aquí se estudian se encuentran entrelazadas entre los versos del poema, lo que significa que el lector leía las imágenes y el texto. El individuo conecta las imágenes a las palabras que lee y viceversa. Para comprender esto es necesario reconstruir como era el acto de leer en el medioevo y en qué consistía ser un letrado en la época a la que nos hemos circunscrito a lo largo de nuestra investigación.

\footnotetext{
${ }^{52}$ CAMILLE, Michael. "Seeing and Reading: Some Visual Implications of Medieval Literacy and Illiteracy”. Art History Vol. 8, № 1 (marzo 1985), p. 38.
} 
El concepto actual sobre letras y letrado es un tanto distinto al de la época medieval, y el mismo varía según el período que se estudie, pues ser letrado dentro de la cultura monástica no era igual que ser un letrado en la Baja Edad Media en torno las emergentes ciudades ${ }^{53}$.

Dentro de la cultura monástica, principalmente en el contexto alto medieval las letras (litterae) más que estar relacionadas con el acto de escribir, se relacionaban con el acto de hablar y escuchar ${ }^{54}$. Isidoro utiliza la palabra littera indistintamente para designar el carácter gráfico y el sonido propio de éstas ${ }^{55}$. Las letras son formas que indican voces, pero a su vez son auxiliares de la memoria para hacer presente por medio de la vista las voces de personas que no están presentes ${ }^{56}$. Por ende, las litterae no sólo eran aquellos caracteres que se expresaban gráficamente, sino también aquello que se pronunciaba. Si se parte de que las palabras se componen de letras, se puede transponer dicha conclusión a las palabras también. La importancia de la unión de imagen y sonido reside en cómo era el acto de leer en los primeros siglos de la Edad Media. Éste consistía principalmente en la lectura en voz alta, Michael Camille le llama lectura oíble o audible (audible reading): las palabras se observan, se pronuncian y se escuchan ${ }^{57}$.

Desde la tardía antigüedad la forma más común de leer era en voz alta ${ }^{58}$. Leer sin pronunciar palabra era tan raro que el mismo Agustín cuenta en sus confesiones como quedó asombrado al ver al obispo Ambrosio leyendo sin pronunciar palabra

\footnotetext{
${ }^{53}$ Camille afirma que el significado de las palabras al igual que las imágenes cambian dependiendo la época. CAMILLE, Michael. "The Gregorian Definition Revisited: Writing and the Medieval Image", en: L'image. Fonctions et usages des images dans l'Occident médiéval. Actes du be "International Workshop on Medieval Societies", Centre Ettore Majorana (Erice, Sicile, 17-23 Octobre 1992), ed. de J. Baschet y J.C. Schmitt. Paris: Le Léopard d'or, 1996. p. 91.

${ }^{54}$ CAMILLE. "Seeing and Reading, ..., p. 28.

${ }^{55}$ Etimologías, Libro I, iii. 1. Edición consultada: Isidoro de Sevilla. Etimologías. Edición bilingüe, traducción y notas de: J. Oroz Reta y M.A. Marcos Casquero, introducción de: M.C. Díaz y Díaz. Madrid: Biblioteca de autores cristianos, 1982-1983. CARRUTHERS. The Book of Memory..., p. 111. CAMiLle. "The Gregorian Definition, ..., p. 92.

56 "Litterae autem sunt indices rerum, signa verborum, quibus tanta vis est, ut nobis dicta absentium sine voce loquantur". Etimologías, Libro I, 3, 1.

${ }^{57}$ RichE. "Le rôle de la mémoire..., p. 136. CAMILLE. "Seeing and Reading, ..., p. 28.

${ }^{58}$ CARRUTHERS. The Book of Memory, ..., p. 170.
} 
$\operatorname{alguna}^{59}$. Varios eran los motivos por los que se alentaba la lectura audible, como: el beneficio y aprovechamiento de aquellos que no eran letrados y también para memorizar de manera más efectiva los textos.

Dentro de la comunidad de religiosos el acto de leer más que ser un acto privado, era uno comunitario ${ }^{60}$, colectivo, del cual se beneficiaban todos los monjes especialmente aquellos que no sabían leer. En las diferentes actividades que tenían lugar dentro de una abadía se pueden identificar momentos en los que se utilizaba la lectura audible. Por ejemplo, durante el servicio se leían en voz alta las Sagradas Escrituras, los salmos e himnos. Durante el transcurso de la comida un lector leía en voz alta mientras el resto de la comunidad comía en silencio y le escuchaba y durante las lecciones el maestro leía en voz alta el contenido de su libro.

Pese a que en la alta y plena Edad Media las abadías y monasterios eran los centros custodios de la cultura y el conocimiento, no todos los miembros de estos eran completamente letrados. Contrario a la creencia popular de que todos los religiosos medievales leían y escribían en estos cenobios había frailes que si sabían leer y otros que no ${ }^{61}$. Realmente los monjes que sabían leer constituían la minoría de los religiosos y muchos pese a saber escribir o más bien copiar textos no necesariamente podían leer aquello que copiaban ${ }^{62}$. Los oblatos eran un grupo sustancial dentro de las abadías y a pesar de que muchos de estos una vez culminada su educación decidían tomar los votos religiosos y continuar como miembros de la comunidad $^{63}$, aun así, se encontraban en formación, siendo varios los años que le tomarían a estos el adquirir los distintos conocimientos necesarios para manejar por si solos textos complejos. Además de los alumnos en formación en la comunidad se podían encontrar otros miembros que no sabían leer: los hermanos legos, aquellos

\footnotetext{
${ }^{59}$ Confesiones, VI.iii.3. Edición consultada: Obras de San Agustín, Las confesiones. Texto Bilingüe, Tomo II. Edición de: Ángel Custodio Vega. Madrid: Biblioteca de Autores Cristianos, 1973.

${ }^{60}$ CAMILLE. "Seeing and Reading, ..., p. 33.

${ }^{61}$ CAMILLE. "Seeing and Reading, ..., p. 32.

${ }^{62}$ ReYnOLdS, Suzanne. Medieval Reading: Grammar, Rhetoric and the Classical Text. Cambridge: Cambridge University Press, 1996. p.3. CAMILLE. "Seeing and Reading..., p. 28.

${ }^{63}$ Poussin. Monographie de l'abbaye et de l'église de St-Remi de Reims..., p. 48.
} 
cuya labor principal eran los trabajos manuales. Estos hombres por lo general ingresaban al monasterio de adultos y en muchos de los casos no tenían educación. Existen casos de hermanos legos tan temprano como en el siglo $\mathrm{X}$, sin embargo, la presencia de estos se hizo más notoria a partir del siglo XI cuando el número de hermanos incrementó ${ }^{64}$. Si se consideran los distintos miembros que constituían la comunidad monacal y los tres grupos de religiosos que Camille identifica según su facultad para enfrentarse a un texto, se puede afirmar que en estas comunidades había individuos letrados (litteratus), individuos que dependían de estos primeros para acceder a la transmisión escrita a los cuales podríamos llamar semi-letrados y los iletrados 65 .

Para un escriba o un copista escribir básicamente consistía en hacer una buena copia de aquello dictado y no necesariamente le volvía un litteratus (letrado), ya que en el contexto del monasterio un letrado era aquel que además de poder leer y escribir latín comprendía lo escrito en esta lengua ${ }^{66}$. Lo primero que aprendían los jóvenes eran los dogmas y las diferentes enseñanzas de la Iglesia, pero esto no significaba que necesariamente comprendieran lo que estaban memorizando. De hecho, se puede establecer que estos eran semi-letrados y no completamente letrados porque no entendían todo. Puesto que muchos podían pronunciar aquello que leían en latín, para ser considerado un letrado era esencial que el individuo fuera capaz de entender lo que leía. En muchos casos los semi-letrados necesitaban del letrado para poder acceder por completo a la transmisión escrita, entiéndase entender los textos. Incluso el saber leer no implicaba el saber o poder escribir ${ }^{67}$. El latín era la lengua

\footnotetext{
${ }^{64}$ LAWRENCE, Clifford Hugh. Medieval Monasticism: Forms of Religious Life in Western Europe in the Middle Ages. London; New York: Longman, 1989. p. 178. KNOWLES, David. El monacato cristiano. Madrid: Ediciones Guadarrama, S.A., 1969. pp. 73-74. D'AYZAC. Histoire de l'abbaye de Saint-Denis en France..., p. 75.

${ }^{65}$ Los religiosos de una comunidad se pueden dividir según sus facultad para enfrentarse a un texto. Los completamente letrados, los individuos que dependían de las capacidades de los letrados para tener acceso a la transmisión escrita y los iletrados. CAMILLE. "Seeing and Reading..., p. 32. BÄUML, Franz H. "Varieties and Consequences of Medieval Literacy and Illiteracy", Speculum Vol. 55, No. 2 (Abril 1980), p. 242.

${ }^{66}$ CAMILLE. "Seeing and Reading..., p. 28.

${ }^{67}$ REYNOLDS. Medieval Reading..., p. 28
} 
institucional y en la que se desarrollaban los textos, sin embargo, en el diario vivir se utilizaban las lenguas vernáculas ${ }^{68}$. Por ende, aunque muchos de los monjes de una comunidad podían leer los distintos códices que poseía el monasterio, letrados y semiletrados; muy pocos eran capaces de comprender el contenido de los mismos.

A raíz del problema de los semi-letrados se desarrollaron distintas herramientas y recursos que volvieron más asequibles estos distintos códices a estos individuos. Una de las más conocidas cuyo uso se generalizó fue la glosa en lengua vernácula $^{69}$. A través de las glosas un religioso letrado explicaba el contenido, el logos, del texto en cuestión de manera escrita en la lengua vulgar y volvía el texto más asequible al semi-letrado. Además, en muchos casos la lectura era conducida por un lector profesional que hacía de maestro el grammaticus $^{70}$. La lectura en voz alta permitía cierta comprensión de lo leído, pero la misma no era producto de las reflexiones individuales, sino de los individuos letrados y cuestionamientos e introspecciones en torno a los ciclos de pintura monumental, esculturas y otras muchas representaciones plásticas ${ }^{71}$. Por ende, las imágenes contribuían como si de glosas se tratara para que aquellos que no eran letrados del todo pudieran comprender los manuscritos a los que se enfrentaban.

\subsubsection{La biblioteca y el scriptorium}

Las distintas abadías en las que se crearon o a las que pertenecieron los manuscritos Burm.Q.3, Ms. Lat. 8085, Ms. 9987-91, Ms. 10066-77 y Cod. 264 poseyeron importantes bibliotecas y scriptoriums. Hoy en día gracias a algunos inventarios que sobreviven y a los escritos de algunos de los magistri que enseñaron en estos cenobios es posible, hasta cierto punto, conocer las materias y autores cuyas obras se custodiaban en estas bibliotecas y eran utilizados para la enseñanza del

68 CAMILLE. "The Gregorian Definition..., p. 98. BÄUML. "Varieties and Consequences of Medieval..., p.239.

${ }^{69}$ O’Sullivan. Early Medieval Glosses on Prudentius' Psychomachia..., p. 82.

${ }^{70}$ REYNOLDS. Medieval Reading..., p. 29.

${ }^{71}$ CAMILlE. "Seeing and Reading..., p. 33. 
trivium y el quadrivium. La mayor parte de estos eran autores clásicos, los padres latinos y griegos, poetas cristianos de la tardía antigüedad y las Sagradas Escrituras ${ }^{72}$. Algunos de los autores cuya presencia es más notoria en los inventarios o en los trabajos de los monjes son: Ambrosio, Jerónimo, Agustín, Gregorio Magno, Prudencio, Marciano Capella, Boecio, Beda, Alcuino, Donato, Prisciano, Quintiliano, Virgilio, Horacio, Terencio, Cicerón y Ovidio.

Durante la época carolingia, y posteriormente, los libros fueron el principal recurso para la diseminación cultural $^{73}$. El scriptorium desempeño un papel importante en este proceso a través del intercambio, el préstamo, la copia y producción de libros. En algunos escritorios como los de San Galo y Reichenau la producción de códices se encontraba destinada a satisfacer las necesidades de la escuela y la biblioteca del propio monasterio ${ }^{74}$. Estos tomaban prestados a otras bibliotecas sus textos y los copiaban en sus scriptorium. También había abadías que eran famosas por la producción y exportación de ciertos libros, ejemplo de esto es el scriptorium de San Amand cuyos misales eran muy reconocidos ${ }^{75}$.

La historia de la producción de códices se remonta a los primeros siglos de la cristiandad. Los primeros manuscritos datan del siglo II d.C. sin embargo, no fue hasta el siglo IV y V que el uso de estos se tornó en la norma y dejó a un lado el papiro $^{76}$. Pese a que tan temprano en la historia los códices fueron utilizados como mecanismos para transmitir y circular textos, la transmisión de los trabajos de muchos autores clásicos, cristianos y judíos se debió en mayor parte a las copias del siglo IX

\footnotetext{
${ }^{72}$ CARruthers. The Craft of Thought..., p. 11. Platelle. Le temporel de l'abbaye de SaintAmand..., p. 68. Clark. The Abbey of St. Gall as a Centre..., pp. 91-124. POUSSIN. Monographie de l'abbaye et de l'église de St-Remi de Reims..., pp. 70-71. D' AYZAC. Histoire de l'abbaye de Saint-Denis..., p. 15.

${ }^{73}$ MCKITTERICK, Rosammond. "Script and Book Production", Carolingian Culture: Emulation and Innovation. Cambridge: Cambridge University Press, 1997. p. 221.

${ }^{74}$ MCKITTERICK. "Script and Book Production", Carolingian Culture: Emulation and..., p. 242.

${ }^{75}$ MCKITTERICK. "Script and Book Production", Carolingian Culture: Emulation and..., p. 243.

${ }^{76}$ WeITZMANN, Kurt. El rollo y el códice. Un estudio del origen y el método de la iluminación de textos. Madrid: Nerea, D.L. [1947] 1990. pp. 58, 60. WeITZMAnN, Kurt. Studies in Classical and Byzantine Manuscript Illumination. Ed. Herbert L. Kessler. Chicago \& London: The University of Chicago Press, 1971. p. 96.
} 
de estos. La estructura de los ejemplares del siglo IX proveyó así los modelos e influenció la comprensión visual y estética de estos textos en épocas posteriores ${ }^{77}$. Los hombres de esta centuria fueron los responsables del mise-en-page de muchos manuscritos que hoy en día se conservan. Dicha disposición no es arbitraria, sino que la misma se hace conscientemente y tiene un propósito. Los distintos elementos visuales en el folio, cómo el uso de diferentes formas, tamaños, tipos de letras, imágenes, la disposición del texto, las columnas y las miniaturas seducen y persuaden al lector ${ }^{78}$. Iniciales en distintos colores, diagramas, tablas, mapas del mundo, tablas de planetas y el zodiaco, tablas para el cálculo, miniaturas son elementos que ayudan al lector a una mayor comprensión del texto. Según Rosamond McKitterick la utilización de estos recursos visuales para explicar, visualizar e interpretar las ideas de un texto es una innovación carolingia ${ }^{79}$.

El manuscrito es por excelencia la superficie en la que imagen y texto se conjugan. Las miniaturas de estos cinco códices no son meros elementos estéticos que adornan las páginas del poema. Imagen y texto se complementan y ayudan al lector.

"The physical book's surfaces provide "support" for the laid-out page, including its decoration and punctuation, and these features in turn support the memory of a reader by providing forms for the "matters" (res) of a work, visual markers in the form of written letters, dots and curlicues, painted scenes, and so on, which make the matter readily memorable and thus make it into a subject for meditation $^{80}$ ".

Las miniaturas pueden transmitir de forma más eficiente el significado de las palabras e igualmente pueden ayudar a éste a memorizarlas, en el caso de las Psychomachias

77 GARRISON, Mary. "The Emergence of Carolingian Latin Literature and the Court of Charlemagne", Carolingian Culture: Emulation and..., p. 112. MCKITTERICK, Rosammond. "Script and Book Production", Carolingian Culture: Emulation and..., p. 231.

${ }^{78}$ MCKITTERICK. "Script and Book Production", Carolingian Culture: Emulation and..., p. 231.

${ }^{79}$ MCKITTERICK. "Script and Book Production", Carolingian Culture: Emulation and..., p. 225.

${ }^{80}$ CARRUTHERS. The Craft of Thought ..., p. 102. 
miniadas aprender de memoria los versos del poema ${ }^{81}$. En estas cinco copias miniadas de la obra de Prudencio, éste se representa una o dos veces. En todos los casos a la efigie de éste le acompaña un título el cual es posible comprehender a través de la miniatura. Las imágenes y los tituli de éstas se encuentran alternadas con el texto, creando una relación estrecha entre imagen-palabra-memoria.

\subsubsection{La memoria y las técnicas de memorización}

Para los eruditos medievales la memoria era una capacidad cognitiva indispensable para el aprendizaje de cualquier cosa, sobre todo a leer, escribir o ambas. El papel de la memoria durante toda la Edad Media fue significativo pues ésta era el arca que retenía todo el conocimiento que se aprendía de los libros, en ella se guardaban los distintos sermones a pronunciar a las masas y sobre todo se retenían los comportamientos morales que habrían de ganar la salvación eterna ${ }^{82}$. La memoria era una de las capacidades que más se alentaba a desarrollar, una de las principales razones era por el limitado acceso que había a los libros.

Cómo anteriormente se ha establecido, la memorización era una capacidad importante que debían desarrollar los monjes desde que entraban al monasterio. Los niños que se educaban dentro del cenobio tenían que aprender de memoria los principios de la fe, el credo, el Pater Noster y los salmos ${ }^{83}$. La principal mnemotecnia

\footnotetext{
${ }^{81}$ MCKITTERICK. "Script and Book Production", Carolingian Culture: Emulation and..., p. 231. CAMILLE. "Seeing and Reading..., p. 38.

${ }^{82}$ El trabajo de Kimberly A. Rivers explora el uso de imágenes mentales de los vicios y virtudes como mecanismos mnemónicos para la predicación sobre todo a partir del siglo XII y XIII. Rivers, Kimberly A. Preaching the Memory of Virtue and Vice. Memory, Images, and Preaching in the Late Middle Ages. Turnhout: Brepols, 2010. Para el tema de la memoria y la moral remitirse a los trabajos de Yates y Carruthers.

83 "As the pupils could not read, the teacher had to repeat the Psalms again and again until the whole hundred and fifty were thoroughly remembered". CLARK. The Abbey of St. Gall as a Centre..., p. 98.
} 
que estos utilizaban para aprender y retener estos conocimientos era la repetición constante, el mecanismo más básico y no necesariamente el más eficiente ${ }^{84}$.

Además de su relevancia con la educación y la enseñanza, la memoria asimismo jugaba un papel importante para con la moral y la meditación. Era necesario que el cristiano guardara en lo más profundo de su ser los distintos conceptos que junto a la virtud de la prudencia harían posible emitir los juicios morales que le ganarían el Cielo o el Infierno ${ }^{85}$. Dentro del contexto monacal en primera instancia la memoria permitía a los jóvenes adquirir las nociones básicas de la fe y conocer los salmos, elementos indispensables de su formación. Para el resto de los monjes esta capacidad era esencial para la práctica de la meditación. La meditación se nutría de pensamientos creativos, los cuales no surgen de la nada, sino que se construyen sobre estructuras recordadas, sobre recuerdos previos ${ }^{86}$.

La memoria natural, entiéndase la capacidad innata de memorizar, se reforzó por medio de distintas mnemotecnias. Las técnicas mnemónicas utilizadas en el contexto monacal se nutrieron de los textos antiguos de Cicerón, Quintiliano o Marciano Capella, formando así distintos métodos de memorización adaptados a las necesidades de los monjes. La memorización se encontraba sumamente ligada a la vista, incluso en relación con el aprender a leer, pues pese a la lectura realizarse en voz alta, aun así, era necesario ver las distintas letras y palabras y memorizar estas imágenes ${ }^{87}$. Para lograr memorizar existían diversas mnemotécnicas que eran utilizadas en los diferentes centros de saber. Sin embargo, dos eran las principales técnicas de memorización: los religiosos podían memorizar cosas (res) o palabras $(\text { verba })^{88}$.

\footnotetext{
${ }^{84}$ CARruthers. The Craft of Thought..., p. 117. Burns, E. Jane. "La répétitions et la mémoire du texte", Jeux de mémoire. Aspects de la mnémotechnie médiévale. dirección de: Bruno Roy y Paul Zumthor. Montréal: Presses de l'Université de Montréal, 1985. p. 65.

${ }^{85}$ CARRUTHERS. The Book of Memory..., p. 43.

${ }^{86}$ CARRUTHERS. The Craft of Thought..., p. 23.

${ }^{87}$ CARRUTHERS. The Book of Memory..., p. 19.

${ }^{88}$ CARRUTHERS. The Book of Memory..., p. 73.
} 
Los mecanismos de memorización utilizados en la Edad Media provienen de textos clásicos, en los cuales se recomienda sobre todo la memorización ad res, la memorización de cosas, en lugar de la ad verba, palabra por palabra, siendo la primera más efectiva que la segunda ${ }^{89}$. A través de la memoria ad res se memorizan imágenes mentales (phantasmata), las cuales a su vez eran producto de imágenes materiales, imágenes de la memoria o imágenes lingüísticas ${ }^{90}$.

Según los distintos textos clásicos, la memorización ad res era posible a través de la creación de loci en los cuales se guardarían phantasmata de aquello que se quería memorizar. Los autores clásicos utilizan las distintas estancias de espacios arquitectónicos para establecer estos loci, espacios que debían poseer la mayor cantidad de información posible como las distintas ubicaciones de las diferentes estancias y los objetos que adornaban las mismas ${ }^{91}$. Patrick Geary hace una sutil diferenciación de cómo fueron utilizadas las técnicas mnemónicas durante los primeros siglos del medioevo. Según éste, el aprendizaje y la práctica de las mnemotecnias en la antigüedad establecía el uso de espacios tridimensionales, por excelencia espacios arquitectónicos, para designar los loci donde se almacenarían los phantasmata. En la Edad Media esto cambió y el plano bidimensional, mejor representado como la página o el folio de un libro, pasó a ser el lugar por excelencia para ubicar los $l o c i^{92}$.

Para el período histórico en el que se miniaron los manuscritos de la Psychomachia aquí tratados, la página del manuscrito se convirtió en un instrumento

\footnotetext{
${ }^{89}$ YATES, Frances Amelia. El arte de la memoria. Madrid: Taurus, 1974. Geary, Patrick. "Memoria", en: Diccionario razonado del Occidente medieval, trad. de A. I. Carrasco Manchado, en J. Le Goff y J.C. Schmitt (eds.). Madrid, Ediciones Akal S.A., 2003. p. 533.

${ }^{90}$ SCHMITT, Jean-Claude. "Imago: de l'image à l'imaginaire", en: L'image. Fonctions et usages des images dans l'Occident médiéval. Actes du 6e "International Workshop on Medieval Societies", Centre Ettore Majorana (Erice, Sicile, 17-23 Octobre 1992), ed. de J. Baschet y J.C. Schmitt. Paris: Le Léopard d'or, 1996. p. 29.

${ }^{91}$ Yates en su trabajo dedicado a la memoria describe algunos de los tratados clásicos sobre la memoria, como el Ad Herennium y De Inventione, el De oratore de Cicerón y el Instituto oratoria de Quintiliano. YATES. "Las tres fuentes latinas del arte clásica de la memoria”, en: El arte de la memoria..., pp. 13-41.

${ }^{92}$ GEARY. "Memoria..., p. 533. YATES. El arte de la memoria...
} 
importante para la memorización, tanto así que tradicionalmente se aconsejaba memorizar siempre de la misma fuente escrita ${ }^{93}$. Dada esta práctica eventualmente Hugo de San Víctor transfirió las practicas mnemónicas a la estructura de la página y a las decoraciones de ésta, siguiendo el consejo tradicional pues memorizar imágenes de fuentes con distintas estructuras se prestaba a la confusión ${ }^{94}$. Las columnas, párrafos e incluso las ilustraciones en los folios de los códices se convirtieron en los loci de la memoria ${ }^{95}$. El constante hincapié en memorizar imágenes se debe a que a través del uso de éstas es posible retener más información de forma más efectiva ${ }^{96}$.

Al entender la importancia de la memoria en los siglos IX y X, época en la que fueron miniadas las obras aquí tratadas se establece de manera más concreta la relación palabra-imagen-memoria. Esta correspondencia se da de la siguiente manera: el individuo lee un texto que necesita memorizar, la primera o primeras imágenes que percibe son las palabras del mismo. Para poder retenerlas es necesario que cree phantasmata de éstas, los cuales serán percibidos y analizados por la mente, reteniendo así el escrito que se desea recordar ${ }^{97}$. El estímulo visual es importante porque vuelve más fácil el recordar, sobre todo cosas ( $a d$ res), pues se piensa en imágenes ${ }^{98}$. Éstas se deben imprimir en la mente como un sello de cera y las mismas deben ser memorables. Por memorable se entiende que han de exaltar los sentidos y esto se logra a través de figuras llamativas, de aspecto humano que sean extraordinariamente bellas o feas, nobles o ridículas, sonrientes o llorosas; figuras sangrientas, o monstruosas, o excelentemente ejecutadas, pero mal coloreadas, y todas éstas deben encontrarse realizando gestos o acciones extremadamente vigorosos $^{99}$. Las imágenes mentales son signos (signa) que funcionan como pistas o

\footnotetext{
${ }^{93}$ CARruthers. The Book of Memory..., p. 9.

${ }^{94}$ Rivers. Preaching the Memory..., p. 47.

${ }^{95}$ Patrick Geary resalta el uso de imágenes en los manuscritos como procedimientos mnemotécnicos. GEARY. "Memoria..., p. 533.

${ }^{96}$ CARRUTHERS. The Book of Memory..., p. 73.

${ }^{97}$ CARRUTHERS. The Book of Memory..., p. 17.

${ }^{98}$ YATES. El arte de la memoria..., p. 49.

${ }^{99}$ YATES. El arte de la memoria..., p. 30. CARRUTHERS. The Book of Memory..., p. 133.
} 
señales que vuelven presente aquello (ad res) con lo que en nuestra mente asociamos dicha imagen ${ }^{100}$.

Los estudiosos contemporáneos que han tratado de reconstruir la memoria medieval, como Mary Carruthers o Frances Yates afirman, que los phantasmata en muchas ocasiones se convirtieron en representaciones concretas que dieron como resultado la plasmación de estos en distintos medios. La creación de imágenes mentales o reales- era un proceso reciproco pues igualmente representaciones conocidas podían ser utilizadas como imágenes mentales, esto incluso aceleraba el proceso de memorización pues el individuo no tenía que crear imágenes de la nada, sino que ya le eran dadas ${ }^{101}$.

Como se ha evidenciado a lo largo de este capítulo, las abadías de San Amand, San Denis, San Laurent, San Galo y San Remi, por su vínculo estrecho con el mundo y el renacimiento carolingio poseyeron escuelas monásticas en las que se estudiaban las disciplinas del trivium y el quadrivium, y el estudio de la primera proveyó a los miembros de la comunidad los rudimentos necesarios para en última instancia poder practicar de la Lectio Divina. La gramática adentraba a los monjes al ejercicio de la lectura y por medio de la retórica y la dialéctica se exhortaba a la invención, la creación de pensamientos que permitía adentrarse en el ejercicio de la meditación. Ya Mary Carruthers había señalado que las distintas miniaturas de los códices iluminados de la Psychomachia claramente fueron diseñadas con una función pedagógica elemental, pero igualmente fueron utilizadas como tropos de invención para adultos instruidos como diseños heurísticos útiles para la meditación ${ }^{102}$.

\footnotetext{
${ }^{100}$ CARRUTHERS. The Craft of Thought..., p. 14.

${ }^{101}$ YATES. El arte de la memoria..., p. 103.

102 "This figures is of particular interest because, while clearly designed for elementary pedagogy, it was also used as a trope of invention by learned adults, a heuristic design useful for meditation and sermon-making". CARRUTHERS. The Craft of Thought..., p. 140.
} 


\section{CAPítulo 4}

\section{Miniaturas de la PSYCHOMACHIA COMO MECANISMOS}

MNEMÓNICOS

La Psychomachia durante las alta y plena Edad Media fue un recurso indispensable dentro de las comunidades de religiosos, primeramente, como parte del currículo de estudio sobre todo para la enseñanza de la gramática ${ }^{1}$, por su peso tropológico y su estructura de pequeña Biblia, pues comienza con una historia veterotestamentaria tomada del Génesis y concluye con alusiones al Apocalipsis ${ }^{2}$. La gran cantidad de glosas que poseen muchos manuscritos de este poema, incluyendo los cinco aquí tratados, y el uso de la obra de Prudencio como autoridad confirman la gran popularidad de este texto durante la Edad Media ${ }^{3}$. A esto se ha de sumar que la lucha contra los vicios surge dentro del movimiento monástico, por lo tanto, era imperante que los miembros de estas comunidades conocieran las fuerzas perniciosas a las que se enfrentaban y siguiendo el consejo paulino se armaran de las armas para vencer ${ }^{4}$.

\footnotetext{
${ }^{1}$ O'Sullivan, Sinéad. Early Medieval Glosses on Prudentius' Psychomachia: The Weitz Tradition. Leiden; Boston: Brill, 2004. p. 11.

${ }^{2}$ Sinéad O'Sullivan entiende que la estructura de la Psychomachia recuerda a la Biblia, sin embargo, para Gernot Wieland la inclusión de episodios de la vida de Abraham y alusiones al Apocalipsis no son pruebas suficientes para afirmar que la estructura del poema es bíblica. A pesar de la afirmación de Wieland, hemos de destacar la gran cantidad de alusiones a distintas historias del Antiguo y Nuevo Testamento sobre todo en los discursos pronunciados por las distintas virtudes. O'SulLIVAN. Early Medieval Glosses..., p. 128. WIELAND, Gernot. "Review Early Medieval Glosses on Prudentius' 'Psychomachia': The Weitz Tradition”, en: Speculum Vol. 80, No. 3 (Julio 2005), p. 945.

${ }^{3}$ Sinéad O'Sullivan estudia las glosas de algunos de los manuscritos de Prudencio, incluyendo cuatro de los aquí tratados. Dada la gran cantidad de glosas y el hecho de que muchas se encuentran en lengua vernácula la autora concluye en que la Psychomachia fue un texto sumamente importante y utilizado durante época carolingia y posteriormente. O'SulLIVAN. Early Medieval Glosses..., p. 20. Haworth, Kenneth R. Deified Virtues, Demonic Vices, and Descriptive Allegory in Prudentius' Psychomachia. Amsterdam: A.M. Hakkert, 1980. p. 1.

4 "Revestíos de las armas de Dios para poder resistir a las acechanzas del Diablo". Efesios 6:11.
} 
El concepto de los vicios se encuentra sumamente relacionado a la vida asceta y la memoria. Los mismos surgen por la necesidad de que los monjes memoricen e inscriban en sus mentes los males que les aquejan y así pueden reconocer, estar alertas y alejarse de los mismos. Evagrio Póntico desarrolló una lista de males, o pasiones (vicios), que afectan la concentración de los monjes en el ejercicio de la oración. Estos son pensamientos irracionales arraigados al alma, cuyo origen son las sensaciones y recuerdos producidos bajo las influencias de estas pasiones ${ }^{5}$. Por ende, era importante que el individuo se mantuviera lejos de los mismos para poder obtener el verdadero conocimiento de Dios.

Para que los religiosos memorizaran los vicios que asediaban su alma, ya tan temprano como en el siglo IV, partiendo de la primera letra de cada mal, se desarrollaron acrónimos como técnicas de memorización, mnemotecnias ${ }^{6}$. La lista de Evagrio, latinizada por Juan Casiano resultó en GLAITAVS (gula, luxuria, avaritia, ira, tristia, accidia, vana gloria, superbia). Gregorio Magno desarrolló la lista de siete bajo el siguiente orden: VIITAGL (vana gloria, invidia, ira, tristia, avaritia, gula, luxuria). En la Plena y Baja Edad Media el orden más común de la lista de vicios era SIIAAGL (superbia, invidia, ira, avaritia, accidia, gula, luxuria). Y en el siglo XII Enrique de Susa como mecanismo mnemónico popularizo la lista bajo el nombre SALIGIA (superbia, accidia, luxuria, ira, gula, invidia, avaritia) ${ }^{7}$. El orden de las listas corresponde a la importancia y la secuencia a seguir a la hora de conquistar los mismos.

Durante toda la Edad Media los tratados de vicios y virtudes se popularizaron con el fin de que los receptores de los mismos pudieran aprender de memoria dichos conceptos morales. Esto no sólo se limitó al ámbito literario, sino que también se

\footnotetext{
${ }^{5}$ NEWHAUSER, Richard. The Treatise on Vices and Virtues in Latin and the Vernacular. Turnhout, Belgique: Brepols, 1993. p. 100.

${ }^{6}$ NEWHAUSER. The Treatise on Vices and Virtues..., p. 181.

${ }^{7}$ Newhauser dedica todo un apartado a discutir estas distintas listas. NEWHAUSER. The Treatise on Vices and Virtues ..., pp. 180-192. NEwHAUSER, Richard G. "These Seven Devils': The Capital Vices on the Way to Modernity", Sin in Medieval and Early Modern Culture: The Tradition of the Seven Deadly Sins, eds. R.G. Newhauser et S.J. Ridyard. Woodbridge: York Medieval Press, 2012. p. 159.
} 
introdujeron en las prédicas para beneficios de los individuos que no tenían acceso a la transmisión escrita. La memoria ha de recordarnos de los beneficios, sobre todo de aquellos que provienen de $\operatorname{Dios}^{8}$, por ende, era importante que igualmente los laicos aprendieran de memoria cuales eran los pecados a evitar para no terminar en el Infierno y las virtudes a practicar para ganar el Cielo ${ }^{9}$.

Puesto que el poema de la Psychomachia era clave para el estudio de la gramática y brindaba la manera de vencer los vicios que invadían los pensamientos y actos de los religiosos, era esencial que los monjes aprendieran de memoria la obra de Prudencio ${ }^{10}$. La memoria juega un papel significativo para con la moral, pues ésta provee la facultad que presenta o representa las experiencias, las bases por las cuales se deben hacer los juicios morales ${ }^{11}$. Este valor moral de la memoria era importante para la oración y la meditación. Desde el punto de vista de la gramática, la memorización era indispensable, tanto así que leer y memorizar se enseñaban como la misma actividad $^{12}$.

Anteriormente se ha discutido cómo era el acto de leer dentro del cenobio. La lectura audible era utilizada como un mecanismo mnemónico pues por medio de la constante repetición de los textos estos quedaban grabados en la memoria ${ }^{13}$. Sin embargo, la audición no era el mejor sentido a utilizar para la memorización, sino la vista $^{14}$. Con relación a los cinco códices miniados de la Psychomachia objeto de nuestra investigación, podemos entonces establecer que los jóvenes pupilos, y los

\footnotetext{
${ }^{8}$ RIVERS, Kimberly A. Preaching the Memory of Virtue and Vice. Memory, Images, and Preaching in the Late Middle Ages. Turnhout: Brepols, 2010. p. 108.

${ }^{9}$ Rivers. Preaching the Memory..., p. 200.

${ }^{10}$ O'Sullivan. Early Medieval Glosses..., p. 131.

${ }^{11}$ CARRUTHERS, Mary. The Book of Memory: A Study of Memory in Medieval Culture. Cambridge Studies in Medieval Literature. Cambridge: Cambridge University Press, 1992. p. 68.

${ }^{12}$ CARruthers. The Book of Memory..., p. 101.

${ }^{13}$ CAMILLE, Michael. "Seeing and Reading: Some Visual Implications of Medieval Literacy and Illiteracy". Art History Vol. 8, No 1 (marzo 1985), p. 30.

${ }^{14}$ CARruthers. The Book of Memory..., p. 73. CAMILle, Michael. "The Gregorian Definition Revisited: Writing and the Medieval Image", en: L'image. Fonctions et usages des images dans l'Occident médiéval. Actes du 6e "International Workshop on Medieval Societies", Centre Ettore Majorana (Erice, Sicile, 17-23 Octobre 1992), ed. de J. Baschet y J.C. Schmitt. Paris : Le Léopard d'or, 1996, p. 99.
} 
monjes de la comunidad, además de por medio de la repetición verbal y la audición, gracias a las miniaturas que acompañan el texto podían inscribir en sus mentes de manera más efectiva el poema de Prudencio a través de la vista.

Ya en la década de 1990, Mary Carruthers había afirmado que Prudencio estructuró su poema con un carácter mnemónico, considerando el mismo una épica visible $^{15}$. Si bien la obra del poeta en el siglo XIX fue tildada de desagradable y mórbida, Carruthers resalta que son dichas cualidades partes de los recursos mnemónicos empleados por el autor ${ }^{16}$. Ésta entiende que Prudencio construyó escenas, imágenes memorables, a través del uso de lo mórbido, lo desagradable o lo repugnante para inscribir en la mente de los más jóvenes el ad res de su obra. Incluso el mismo poeta afirma que en el poema se han dibujado imágenes para reproducirlas en nuestra vida ${ }^{17}$. El uso de estos elementos corresponde con la definición de las imágenes agentes hecha en la Rhetorica ad Herennium. Prudencio como ciudadano romano que era, fue educado en el trivium y el quadrivium, el norte de la península Ibérica durante la época del autor fue un centro importante para el estudio de la retórica ${ }^{18}$, lo que hace muy probable que éste conociera y supiera utilizar los consejos mnemónicos provistos por los tratados de retórica del mundo antiguo. Además del uso de lo mórbido y desagradable, Carruthers identifica otras mnemotecnias utilizadas en el poema cómo: la división de la composición en trozos fáciles de recordar o el uso de textos bíblicos cómo lugares mnemónicos de recopilación ${ }^{19}$.

\footnotetext{
15 “Prudentius' Psychomachia, a visible epic”. CARRUTHERS. The Craft of Thought..., p. 143.

${ }^{16}$ CARRUTHERS. The Craft of Thought..., p. 143.

${ }^{17}$ CARruthers. The Craft of Thought..., p. 145. PRUdencio. Praefatio vv. 1-19. Edición consultada: Obras Completas de Aurelio Prudencio. Traducción de A. Ortega, introducción general de: I. Rodríguez. Ed. bilingüe. Biblioteca de Autores Cristianos 427. Madrid: Editorial Católica, 1981. p. 310.

${ }^{18}$ RODRÍGUEZ. "Introducción general..., p. 19, PRUDENCIO. Introducción al prefacio general vv. 7-21, Obras Completas de Aurelio Prudencio... "Northern Spain was a well-established center for rhetorical study in Prudentius' time". HaWORTH. Deified Virtues, Demonic Vices..., pp. 2, 70.

${ }^{19}$ CARruthers. The Craft of Thought..., pp. 143-150. Burns, E. Jane. "La répétitions et la mémoire du texte", Jeux de mémoire. Aspects de la mnémotechnie médiévale. dirección de: Bruno Roy y Paul Zumthor. Montréal: Presses de l'Université de Montréal, 1985. p. 66.
} 
Para O'Sullivan la estructura del poema recuerda a la de las Sagradas Escrituras, pues éste comienza con historias veterotestamentarias, específicamente recogidas en el Génesis, durante los distintos combates se hacen alusiones al Antiguo y el Nuevo Testamento y culmina con alusiones apocalípticas ${ }^{20}$. A pesar de que la estructura del poema podría recordar a la Biblia, la misma realmente es un recurso mnemónico para el lector medieval. Las distintas historias y alusiones bíblicas funcionan como los loci, los espacios en la memoria para el almacenamiento en el que distintas historias se acumulan ${ }^{21}$. En el entorno y contexto al que se circunscriben los distintos códices miniados ya mencionados, cada verso de la Biblia servía para los miembros de la comunidad como un lugar de recopilación para otros textos y diversos conocimientos. Cada verso de la Biblia podía volverse un lugar de recopilación para otros textos y la concatenación de otros conocimientos, por lo tanto, la vinculación directa del poema de Prudencio con la Biblia resalta asimismo el carácter mnemónico de la obra.

Las técnicas de memorización empleadas en los novecientos quince versos de la Psychomachia no sólo se circunscribieron al poema, sino que las mismas fueron adaptadas y utilizadas en las miniaturas de los manuscritos más antiguos. Si bien los estudiosos de estos códices, específicamente Katzenellenbogen y Woodruff, han identificado numerosas reminiscencias del arte romano en estos ejemplos ilustrados de la Psychomachia ${ }^{22}$, se desconoce si la disposición de las imágenes dentro del texto responde a la copia perdida del siglo $\mathrm{V}$ o son una invención del período en el que fueron creados, concretamente del siglo IX. Después de todo Otto Pächt afirma que "con frecuencia las ediciones de autores antiguos copiaron también la decoración pictórica, a menudo modificándola y parafraseándola a su arbitrio ${ }^{23}$ ". Cualquier de las dos ideas apuntan a un interés particular por la memorización del material escrito al que acompañan. El mundo carolingio utilizó diagramas, tablas y miniaturas cómo

\footnotetext{
${ }^{20}$ O'Sullivan. Early Medieval Glosses on Prudentius' Psychomachia..., p. 20.

${ }^{21}$ CARRUTHERS. The Craft of Thought..., p. 144.

${ }^{22}$ KatZenellenbogen, Adolf. Allegories of the Virtues and Vices in Mediaeval Art, from Early Christian Times to the Thirteenth Century. New York: W.N. Norton \& Company, Inc., 1964. p. 5. WoOdRUfF, Helen. "The Illustrated Manuscripts of Prudentius", Art Studies (1929), pp. 66-67.

${ }^{23}$ PÄCHT, Otto. La miniatura medieval: una introducción. Madrid: Alianza, 1987. p. 35.
} 
explicaciones visuales que permitían un mejor entendimiento del texto al que acompañaban, convirtiéndose en refuerzos $\operatorname{cognitivos}^{24}$.

El salterio de Utrecht, una de las obras más importantes de la época y que influenció considerablemente otros manuscritos ${ }^{25}$ emplea dichos recursos, pues el mismo posee ciento sesenta y seis miniaturas que ilustran los cientos cincuenta salmos y otras oraciones. Por mucho tiempo sólo se apeló al carácter literal de éstas imágenes, "ilustración literal", sin embargo, en las mismas se utilizaron recursos propios de la retórica para imbuir de mayor significación las representaciones visuales de los salmos ${ }^{26}$. Además del empleo visual de los tropos para desencadenar los distintos significados de las Escrituras, en el salterio de Utrecht igualmente se emplearon algunas de las técnicas mnemónicas utilizadas en la Alta Edad Media y heredadas del mundo antiguo. Para Carol Gibson-Wood las miniaturas que acompañan los distintos salmos son imágenes memorables de los distintos versos, facilitando así a los jóvenes aprendices el proceso de memorización del texto ${ }^{27}$.

Según los estudiosos del salterio, el mismo fue comisionado por el obispo de Reims para Carlos el Calvo. Sobre dicha comisión y las fechas de ejecución existen discrepancia. Algunos han considerado el salterio como una comisión del obispo Ebbo de Reims, como un regalo a Luis el Piadoso y su mujer por el nacimiento de su hijo Carlos el Calvo fechándolo entre el 820 y el 830 y para otros la obra es una comisión del obispo Hincmaro de Reims cómo regalo a Carlos el Calvo ${ }^{28}$. Si bien el

\footnotetext{
${ }^{24}$ MCKITTERICK, Rosammond. "Script and Book Production", Carolingian Culture: Emulation and Innovation. Cambridge: Cambridge University Press, 1997. p. 225.

${ }^{25}$ Sobre la influencia el salterio de Utrecht en el mundo carolingio ver: TSELOS, Dimitri. "The Influence of the Utrecht Psalter in Carolingian Art”, en: The Art Bulletin Vol. 39, No. 2 (junio 1957), pp. 87-96.

${ }^{26}$ SÁNCHEZ AMEIJEIRAS, Rocío. Los rostros de las palabas. Imágenes y teoría literaria en el Occidentel medieval. Madrid: Akal, 2014. pp. 181-194. GIBSON-WoOD, Carol. "The 'Utrecht Psalter' and the Art of Memory", RACAR: revue d'art canadienne / Canadian Art Review. Vol. 14, No. 1/2 (1987), p. 10. DUfRENnE, Suzy. Les illustrations du Psaltier d'Utrecht : sources et apport carolingien. París: Ophrys, D.L. 1978. p. 151

${ }^{27}$ GiBSON-WoOD. "The 'Utrecht Psalter' and the Art of Memory..., pp. 9-15, 33-35.

28 SÁNCHEZ AMEIJEIRAS. Los rostros de las palabas..., p. 186. "The Utrecht Psalter", Universiteitsbibliotheek Utrecht, Utrecht, 2013. Disponible en: http://bc.library.uu.nl/utrecht-
} 
salterio fue hecho para un miembro de la realeza, no se puede descartar que el mismo se realizó dentro del contexto monástico y que éste era uno de los textos básicos utilizados para educar a los jóvenes pupilos. Como se ha discutido anteriormente, el salterio era el primer libro que debían memorizar los jóvenes antes de instruirse en el resto de las materias de las artes liberales. Los hijos de la realeza no se encontraban exentos de dicho aprendizaje, después de todos recibían su educación en un monasterio, por ende, no se deben descartar las técnicas mnemónicos y otros recursos propios de la retórica en la elaboración de las imágenes de este salterio.

El poema de la Psychomachia inicia con el prefacio del mismo en el cual en sesenta y ocho versos se narran distintos episodios de la vida de Abraham. A estos versos le siguen los novecientos quince que comprenden el poema como tal. A pesar de la extensión del poema, el texto y las imágenes que acompañan al mismo se pueden dividir en base a los distintos eventos y batallas que se desarrollan a través de éste ${ }^{29}$. Los primeros veinte versos y últimos veintisiete se encuentran dedicados a una oración o plegaria la cual se encuentra acompañada por una efigie del poeta. El resto de las divisiones corresponderían a los siete combates descritos en la obra y el episodio final que resume la victoria de las virtudes y la construcción del templo de Sapientia.

Los tres manuscritos del siglo IX poseen noventa miniaturas que recogen visualmente las distintas partes del poema, siguiendo los versos de éste. Gracias a la disposición de las imágenes en las copias más antiguas es posible establecer el orden de las iluminaciones en los manuscritos del siglo X. La ubicación de éstas no es arbitraria, en los distintos códices la imagen precede el texto sobre el que versa y

psalter.html [Consulta: 17 de diciembre de 2016]. ChAZELLE, Celia. "Archbishops Ebo and Hincmar of Reims and the Utrecht Psalter", Speculum, Vol. 72, No 4 (Octubre 1997), pp. 1055-1077. ${ }^{29}$ Mary Carruthers afirma que el poema está dividido en capítulos. CARRUTHERS. The Craft of Thought..., p.146. En la edición bilingüe de la Psychomachia de Alfonso Ortega y Isidoro Rodríguez se hace hincapié en la división del poema. Como recurso para el lector en la parte superior de la versión en castellano se indican los distintos combates: La fe y la idolatría pp. 311-313; La castidad y la lujuria pp. 315-317; La paciencia y la ira p. 319; La soberbia y la humildad pp. 321-327; La molicie y la sobriedad pp. 329-335; La avaricia y la caridad pp. 337-347; La discordia y la concordia pp.349-359. Obras Completas de Aurelio Prudencio. Ed. bilingüe. Biblioteca de Autores Cristianos 427. Madrid: Editorial Católica, 1981. 
poseen una estructura. Las ilustraciones recogen visualmente en los distintos combates las siguientes acciones: el vicio entra al campo de batalla, el vicio ataca, la virtud contraataca, la virtud vence y la virtud increpa al vicio vencido.

El poema se estructura en distintas partes, siendo la primera el Praefatio, le sigue la oración o invocación del autor, los distintos combates entre las distintas virtudes y vicios, el final del poema que apela a la construcción del templo de la Sabiduría y la oración de gracias. Carruthers entiende que el poema se divide en capítulos $^{30}$. Dichas divisiones son un recurso mnemónico, pues para aprender sobre todo textos estos debían ser divididos en pedazos que hicieran más fácil su memorización, una vez memorizado el ad res de cada uno de estos pedazos estos se unen para conocer el todo ${ }^{31}$.

Los distintos elementos y consejos mnemónicos aplicados a la memorización de textos e incluso identificados por Mary Carruthers en el poema de la Psychomachia también se aplican a las miniaturas de los manuscritos Burm.Q.3, Ms. Lat. 8085, Ms. 9987-91, Ms. 10066-77 y Cod. 264. A priori, el uso de imagines y loci es el recurso mnemónico más fácil de identificar y el que más se utiliza a lo largo de todo el poema de la Psychomachia. Primeramente, se ha de destacar que las mayorías de las miniaturas que acompañan al poema se encuentran insertadas directamente en las columnas en las que se escribió el texto, sobre todo aquellas en las que se representan las distintas escenas de las virtudes y vicios, por lo tanto, a la hora de estudiar las imágenes igualmente se tienen que considerar el texto al que acompañan y su relación con el mismo como un todo ${ }^{32}$. Todos los manuscritos, excepto el parisino (Ms. Lat. 8085), han sido escritos a una columna en la que se encuentra el texto intercalado con las distintas escenas que ilustran el mismo. El Ms. Lat. 8085 es interesante porque el poema en este códice se escribió en dos columnas, no obstante, las imágenes mantienen la misma disposición dentro del texto que ene 1

\footnotetext{
30 "In fact the Psychomachia is divided into chapters". CARRUTHERS. The Craft of Thought..., p. 146.

${ }^{31}$ CARRUTHERS. The Craft of Thought..., p. 58.

${ }^{32}$ PÄCHT, Otto. La miniatura medieval: una introducción. Madrid: Alianza, 1987. p. 10.
} 
resto de los códices: las mismas se encuentran en ambas columnas siguiendo la estructura del texto y no ocupando grandes espacios del folio.

Los tituli se han escrito sobre la escena que se ilustra en un color distinto al del texto, rojo, permitiendo así su identificación cómo los títulos de las imágenes y evitan que el lector confunda los mismos con los versos del poema. El manuscrito Lat. 8085 los títulos y las miniaturas de la 66 a la 73 no coinciden. Este problema fue tratado por Woodruff, quien afirma que el mismo es producto de la utilización de varios manuscritos como modelos para la elaboración del Ms. Lat. 8085 33 . El orden de las imágenes de este códice es el mismo de Ms. 9987-91. Según Stettiner en algún momento los folios 120 al 121 de este códice se descompaginaron o desordenaron ${ }^{34}$. Si bien los folios del códice belga (9987-91) se encuentran fuera del orden que le corresponden, gracias a una nota aclaratoria al pie de página de los folios 119v, 120v, $121 \mathrm{v}$ se aclara al lector el orden que debe seguir ${ }^{35}$. A esto se ha de sumar que, pese a la desorganización de los folios, los versos del poema, los tituli y las miniaturas coinciden con el orden de Burm.Q.3, el ejemplar más antiguo. Algún usuario del códice parisino se tomó la molestia de corregir algunos de los títulos mal colocados del códice Ms. Lat. 8085 para clarificar el error en las miniaturas 67, 68, 71, 72 y 73.

A pesar del problema que presenta Ms. Lat. 8085, la forma en la que se maneja el texto, en la que éste se lee es la misma. El oblato o el monje que estuviera utilizando estos códices primero se topa con el título e inmediatamente con la miniatura y luego con los versos sobre los que versa la imagen. En estos cinco códices las mismas escenas anteceden los mismos versos. En mayor o menor grado todas se han representado de forma similar, con vestimenta, atributos y gestos parecidos. En todos llama la atención que los vicios se plasmaron de manera singular, también se ha de apuntar de que ciertas escenas del poema son de particular interés

\footnotetext{
${ }^{33}$ WoODRUFF. "The Illustrated Manuscript..., pp. 57-59.

${ }^{34}$ STETTINER, Richard. Die Illustrierten Prudentiushandschriften. Berlin: Druck von J.S. Preuss, 1895. p. 44.

${ }^{35}$ Nota folio 119v: Quaere hoc signu pagina tertia sequenti. Nota folio 120v: Quaere hoc signum pagina tertia sequenti. Nota folio 121v: Quaere hoc signum in praedenti pagina quarta.
} 
pues se han mantenido en todos estos manuscritos, ejemplo son aquellas en las que las virtudes amonestan a los vicios o las que éstas dan muerte a los vicios.

A primera instancia estas similitudes en composición y estilos se entiende por el hecho de que estos manuscritos pertenecen todos al mismo grupo de la catalogación y estema realizado por Stettiner y Woodruff (Figs. 27 y 28). Realmente son estas características las que ayudaron a estos investigadores a filiar los distintos manuscritos iluminados. Entre los mismos existen otras relaciones que no son tangibles visualmente, pero ya se han traído a colación, cómo: la zona en la que se elaboraron y su relación con importantes abadías las cuales en su mayoría eran benedictinas y estaban relacionadas con el mundo carolingio.

Las similitudes en la ubicación de las imágenes en ciertas partes del texto de estos manuscritos recuerdan que los monasterios se prestaban entre ellos códices para copiar los mismos y ampliar sus bibliotecas ${ }^{36}$, hecho que explica las semejanzas entre estos. En el caso particular de los cinco códices que estudiamos la probabilidad es muy alta, pues como se aprecia en la figura 3, las abadías a las que pertenecieron los mismos se encontraban en la misma zona geográfica. Sin embargo, la ubicación de las miniaturas no es arbitraria, pues éstas preceden los versos en los que se describe la escena representada. Se comienza por leer los versos en imagen y luego en palabras escritas. El uso de las columnas y la disposición de las miniaturas funcionan como los loci, se colocan estas imágenes en lugares específicos del texto para recordar el ad res del mismo. A través del ad res, se recuerdan cosas que remiten al tema o asunto, lo que permite retener la esencia de lo memorizado y a la hora de exponerlo se puede recurrir a parafrasear el texto, pero manteniendo la idea general del mismo ${ }^{37}$.

En relación con las mnemotecnias, las imágenes en estos códices de la Batalla del alma no sólo sirven de loci, asimismo en éstas se pueden identificar otra serie de particularidades que contribuyen a la memorización del poema. Los distintos gestos que realizan los vicios y virtudes las hacen memorables. A través la gestualidad de

\footnotetext{
${ }^{36}$ PÄCHT. La miniatura medieval..., p. 16.

${ }^{37}$ CARRUTHERS. The Book of Memory..., p. 87.
} 
las figuras protagónicas es posible recordar las acciones principales descritas en el poema. Uno de los gestos que más se repite es el de la mano levantada, ademan que se aprecia también en las efigies de Prudencio e igualmente en las escenas en las que se pronuncian palabras, sobre todo aquellas en las que las virtudes increpan a los vicios muertos. En escenas más engorrosas, la sutiliza de los gestos en conjunto con el verbo utilizado en el título brinda al espectador la clave para desentrañar por completo la acción memorable, el ad res, de la imagen.

Un elemento mnemónico heredado directamente de las técnicas del mundo antiguo y utilizado por el autor en los versos y traducido por el miniaturista a imagen es el uso de las imágenes memorables. En muchas de las representaciones se utiliza la plasmación de acciones extremadamente vigorosas ${ }^{38}$ para exaltar los sentidos y volver memorables las mismas. Esto se utiliza particularmente en dos momentos precisos de los distintos combates: la batalla entre las fuerzas opuestas en las que por lo general el vicio se lanza o precipita sobre la virtud para hacerle daño y el momento en el que el vicio es vencido, cuya derrota es fruto de su actitud viciosa. Las vencedoras traspasan las gargantas de sus oponentes (Miniatura 13), a algunas le cortan su cabeza (Miniatura 36) e incluso a una la desmiembran (Miniatura 81). A esta serie de representaciones vigorosas se pueden sumar aquellas en las que otros vicios, como la Ira, Superbia o Luxuria, por medios de sus propias acciones encuentran su derrota (Miniaturas 24, 33, 47 y 48). Los vicios vencidos, una vez muertos, sus cuerpos adquieren posiciones extrañas, no del todo humana.

En el momento en el que inicia el combate entre ambas fuerzas, la virtud se plasma estática y serena, mientras que el vicio que los vicios se plasmaron tal y cómo indican los versos: agitados y furiosos. La descripción física de los vicios, cómo las teas de Ira, el peinado pomposo de Superbia, la apariencia lángida de Luxuria o las bolsas de dinero de Avaritia, manifiestan de forma concreta la naturaleza abstracta de estos $^{39}$. Los distintos gestos de los personajes expresan de forma física el movimiento interior del alma, los sentimientos, la vida moral de un individuo. La

\footnotetext{
${ }^{38}$ CARRUTHERS. The Book of Memory..., p. 133.

${ }^{39}$ HaWORTH. Deified Virtues, Demonic Vices..., p. 109.
} 
serenidad o lo hierático recuerda lo eterno y a Dios, siendo propio de la virtud, mientras que la movilidad y los movimientos desenfrenados son propios de actitudes inconstantes y más terrenales, propias del vicio ${ }^{40}$.

La fealdad y lo mórbido se utilizan en las distintas miniaturas cómo características físicas de los vicios para exaltar las emociones del espectador, tornando las mismas en imágenes dignas de recordar, imágenes memorables. En el poema los vicios son descritos como monstruos salvajes, algunos echan espumarajos por la boca otros melenudos o con los ojos brotados. Estos atributos se plasmaron también visualmente en las distintas representaciones de estas fuerzas perniciosas. Los distintos vicios son figuras furiosas que llevan sus melenas sueltas, despeinadas, semejantes a llamas, características que se asocia con el mal y el vicio ${ }^{41}$. En el manuscrito 10066-77 además del cabello despeinado como lenguas de fuego, los rostros de éstas se colorearon de verde, resaltando así la monstruosidad y la fealdad del vicio ${ }^{42}$.

Ciertos detalles de las ilustraciones contribuyen a la exaltación de los sentidos, además de la vitalidad de la misma, como lo es la sangre. En los cinco códices, independientemente sean monocromos o policromos, los iluminadores pintaron la sangre en alguna variante de rojo que exalta la misma. El rojo es el color más memorable de todos ${ }^{43}$, el uso del mismo denota por parte del iluminador un interés particular porque estos detalles sean reconocidos por el espectador, detalles que se encuentran igualmente recogidos en los versos.

Algunas miniaturas en los distintos códices poseen atributos que no son mencionados en el poema, particularmente el uso del nimbo o de la rama de palma.

\footnotetext{
${ }^{40}$ Schmitt, Jean-Claude. La raison des gestes: dans l'occident Médiéval. París: Gallimard, 1992. pp. 26-29. CAMILLE, Michael. Image on the Edge: The Margins of Medieval Art. London: Reaktion books, 1992. p. 60.

${ }^{41}$ GARNIER, François. Le langage de l'image au Moyen Âge (II). Grammaire des gestes. París: Le Léopard d'Or, 2003. p. 78.

42 "Bloody figures, or monstrosities, or figures brilliantly but abnormally colored should be used [...]". CARRUTHERS. The Book of Memory..., p. 133.

${ }^{43}$ CARRUTHERS. The Craft of Thought..., p. 200.
} 
En el caso del nimbo, las virtudes en los manuscritos del siglo $\mathrm{X}$ y algunas de las efigies de Prudencio lo llevan. La rama de palma se circunscribe únicamente a la representación de los mártires en la miniatura 10. Estos símbolos poseen una significación bien establecida cultural y socialmente con respecto al entorno en el que se utilizan, la familiaridad del espectador con dichos atributos permite al usuario asimilar y recordar los mismos con mucha más facilidad ${ }^{44}$. Esto igualmente sucede con las miniaturas del Praefatio, en el que se recogen distintos sucesos de la vida de Abraham. En el mismo se utilizan temas iconográficos ya conocidos y utilizados en diversos medios y contextos, como el Sacrificio de Isaac o la visita de los tres ángeles, para plasmar los versos en los que se recogen los mismos.

La vigorosidad, los gestos y las distintas particularidades de todas estas miniaturas las vuelven imagines agentes, imágenes cercanas a la realidad que despiertan las emociones del espectador por medio de sus ornamentos, cualidades y acciones, grabando así impresiones más claras en la mente de los oblatos y monjes que se enfrentaban a estos códices ${ }^{45}$. El elemento afectivo es importante pues auxilia la memoria de cualquier individuo y en nuestro caso particular de los religiosos semiletrados ${ }^{46}$. Según Mary Carruthers las imágenes que Prudencio creó fueron pintadas para el ojo de la mente. En las mismas se aprecia un esfuerzo por no agobiar al estudiante con detalles: la narrativa utiliza pocos detalles, pero los mismos son particularmente vívidos y específicos. Esto concuerda con las técnicas básicas para la creación de imágenes mentales, según las cuales de debe ser cuidadoso y no abrumar el ojo de la mente con imágenes en exceso y aquellas que se utilicen deben ser llamativas e igualmente toda una experiencia sensorial "sinestética" 47 . Estas

\footnotetext{
${ }^{44}$ BeLting, Hans. Antropología de la imagen. Madrid: Katz, 2007. pp. 23-25. YATES. El arte de la memoria..., p. 147. WARBURG, Aby. Atlas Mnemosyne. Madrid: Akal, D.L. 2010. pp. 3-4.

${ }^{45}$ CARRUTHERS. The Craft of Thought..., p. 16. YATES. El arte de la memoria..., p. 23. Rhetorica ad Herennium, III, 37.

${ }^{46}$ YATES. El arte de la memoria..., p. 23. CAMILLE. "Seeing and Reading..., p. 37.

47 'Prudentius' images are painted for the mind's eye. Effort is made not to overwhelm the student with detail: the narrative details are few but they are particularly vivid and specific. This accords with a basic technique for making such images: one must be careful not to overwhelm the mental eye with an excess of images. And those one has must be extreme, "eye-catching" of course, but also fully synaesthetic, a fully realized sensory experience that includes recreated sound (the screams and
} 
características sirven para establecer que las miniaturas de estos cinco manuscritos iluminados de la Psychomachia fueron utilizadas como mecanismos mnemónicos para memorizar el poema.

\subsection{A de Abraham, el Prefacio de la Psychomachia}

El prefacio de la Psychomachia consta de sesenta y ocho versos y seis miniaturas que de manera pictórica plasman lo narrado en el texto. Las seis miniaturas recogen momentos de la vida de Abraham que prefiguran los combates, tal y cómo Prudencio afirman en los versos 51 y 52: "Este cuadro ha sido antes dibujado para ser el modelo que debe reproducir nuestra vida con medida fiel" 48 .

El prefacio comienza introduciendo al lector a la figura de Abraham y algunas de sus hazañas, entre éstas una breve alusión al sacrificio de Isaac, a pesar de que el nombre de su hijo no se menciona en el poema. En los manuscritos Burm.Q.3, Ms. Lat. 8085, Ms. 9987-91, Ms. 10066-77 una miniatura en la que se plasma el Sacrificio de Isaac (Miniatura 1) precede a estos versos.

La escena representa el momento en que Dios detiene a Abraham de sacrificar a su hijo. En los códices del siglo IX la composición es muy parecida, sobre todo la de Burm.Q.3 y 9987-91. Abraham se colocó, como protagonista de la escena, en el centro. A la derecha, sobre el altar, con un gesto de desesperación se plasmó a Isaac listo para ser sacrificado. Su padre lo sujeta por los cabellos. En el lado opuesto a la figura de Isaac se ve la mano de Dios deteniendo a Abraham y bajo ésta, enredado en un arbusto el carnero que pasará a ser el sacrificio en lugar de Isaac. El manuscrito Lat. 8085 se aprecia el uso de color como elemento innovador en comparación con

cries and battle trumpets) and taste (chiefly of blood and crushed bone) and odor (vomit and blood but also crushed violets) and touch (chiefly pain)". CARRUTHERS. The Craft of Thought..., p. 148. 48 "Haec ad figuram praenotata est línea / quam nostra recto vita resculpat pede". PRUDENCIO. Praefatio vv. 51-52. Obras Completas de Aurelio Prudencio..., p. 310. 
las otras dos imágenes del siglo IX. Por medio del color se realza la presencia de Dios, primeramente, su mano ya no brota de un lado del folio, sino que la misma surge de las nubes representadas por medio de las líneas onduladas, igualmente se utiliza un color distinto al resto de la composición para atraer la mirada del espectador.

La composición de la miniatura del Sacrificio de Isaac en el manuscrito 10066-77 es distinta al resto y su lenguaje visual es mucho más rico. Si bien la figura de Abraham continua en el centro, las figuras de Isaac, el cordero y la mano de Dios se han intercambiado. El iluminador de este ejemplo prestó más cuidado en los gestos faciales de Abraham e Isaac. Si en los códices anteriores la desesperación del joven se recoge por medio de los gestos de sus extremidades, aquí se recoge en su rostro pues sigue muy de cerca el relato del Génesis: "Luego ato a su hijo ${ }^{49 "}$. El manto de la mano de Dios se decoró con lo que parecen ser lenguas de fuego que de cierto modo evocan al sol. De la punta de los dedos de Dios emergen unas líneas onduladas amarillas, la expresión visual de la voz que ordena a Abraham a detenerse. En esta miniatura del siglo $\mathrm{X}$, al igual que en la del manuscrito parisino, se utiliza el color sin embargo gracias a los trazos y las líneas la miniatura resultante es una llena de movimiento que visualmente traduce la tensión del relato veterotestamentario y ayuda a que la imagen posea una cualidad memorable.

A pesar de las leves diferencias entre las miniaturas del siglo IX y las del X, encontramos en la composición de todos los cuatro ejemplos las mismas figuras y elementos. Esto en gran medida se debe a que el esquema composicional utilizado en la miniatura 1 no es del todo nuevo. Los iluminadores utilizaron un modelo tomado directamente de los primeros siglos de la cristiandad y que se copió en sarcófagos, frescos mosaicos ${ }^{50}$. Dada la antigüedad de este motivo iconográfico, la

\footnotetext{
${ }^{49}$ Génesis 22: 9.

${ }^{50}$ SMITH, Alison. "The Iconography of the Sacrifice of Isaac", American Journal of Archeology. Vol. 26 (1922), pp. 159-173.
} 


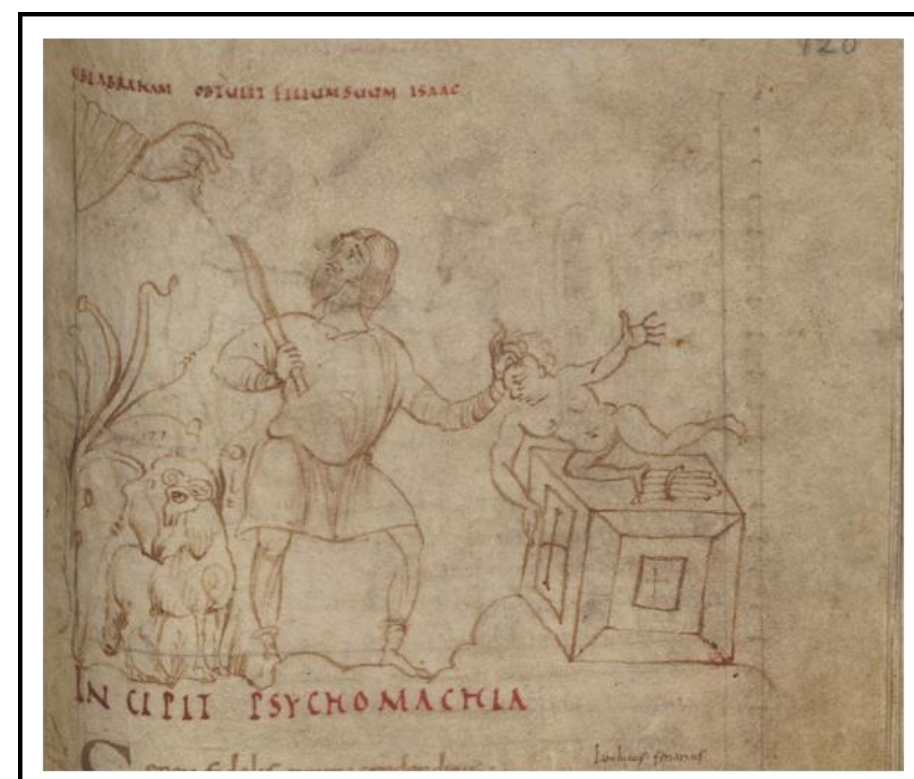

Burm.Q.3, fol. 120r. Siglo IX.

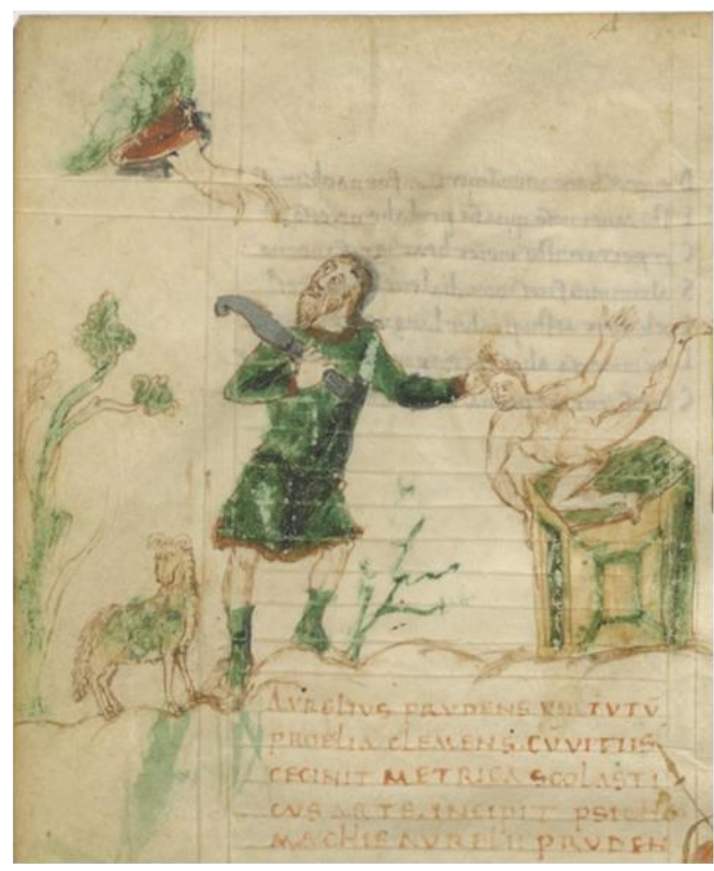

Ms. Lat. 8085, fol. 55v. Siglo IX.

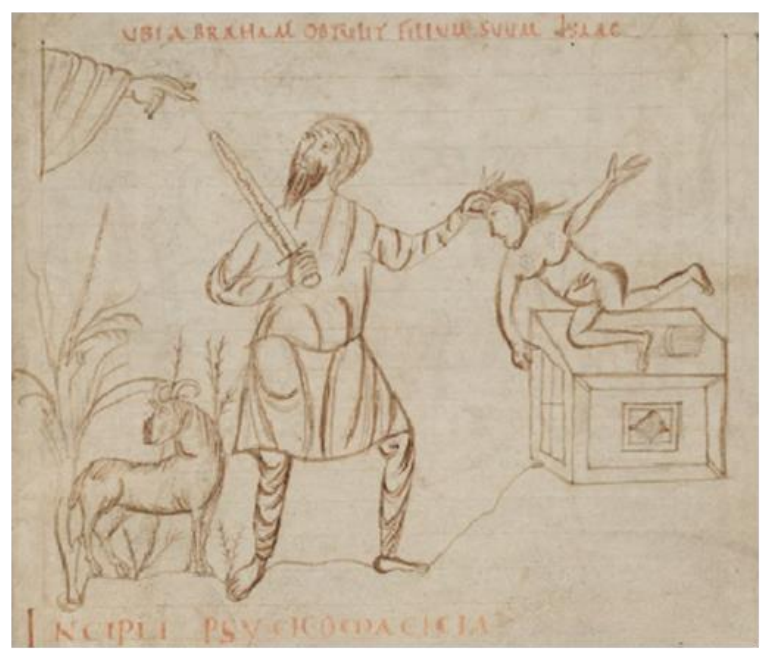

Ms. 9987-91, fol. 100r. Siglo IX.

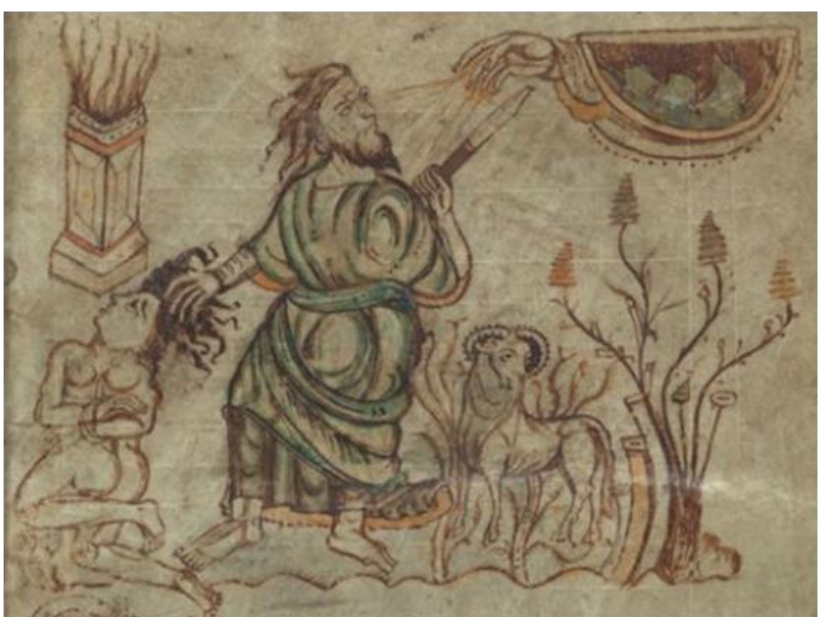

Ms. 10066-77, fol. 112r . Siglo X.

Miniatura 1. Sacrificio de Isaac 


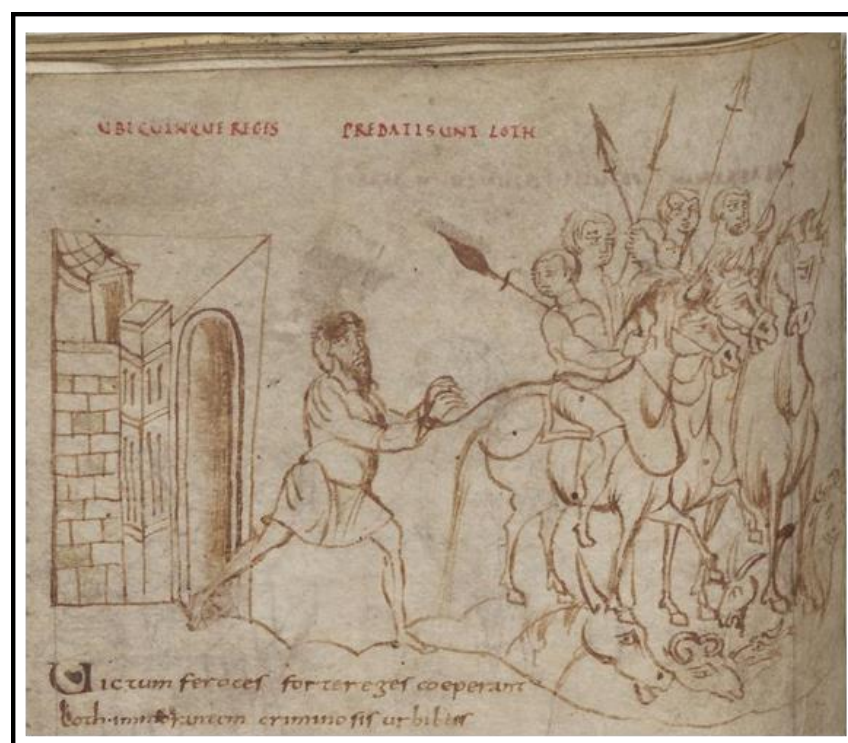

Burm.Q.3, fol. 120v. Siglo IX.

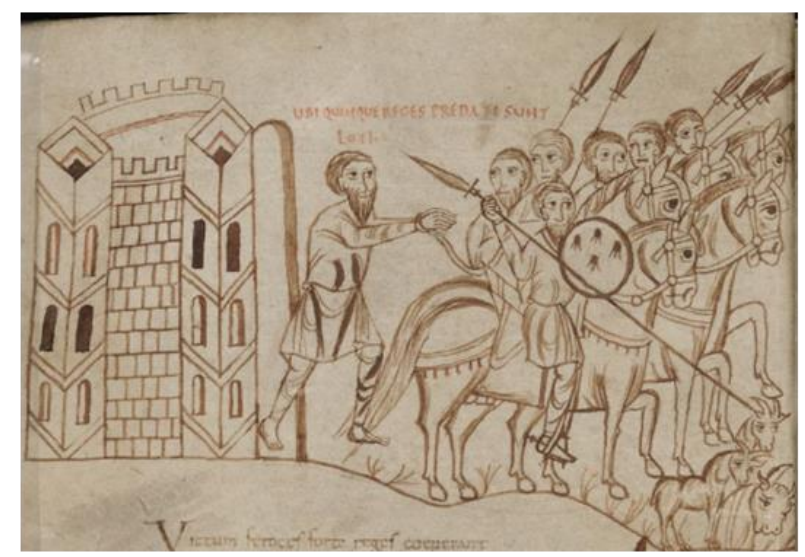

Ms. 9987-91, fol. 100v . Siglo IX.

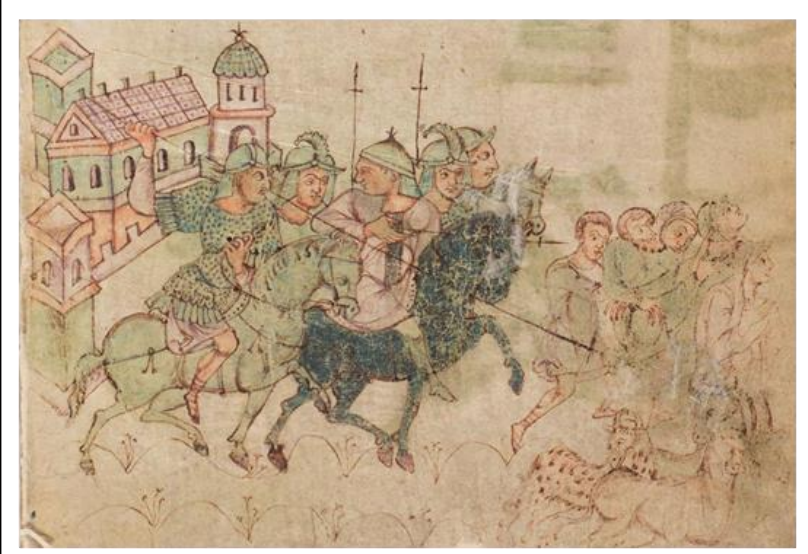

Cod. 264, pág. 61. Siglo X.

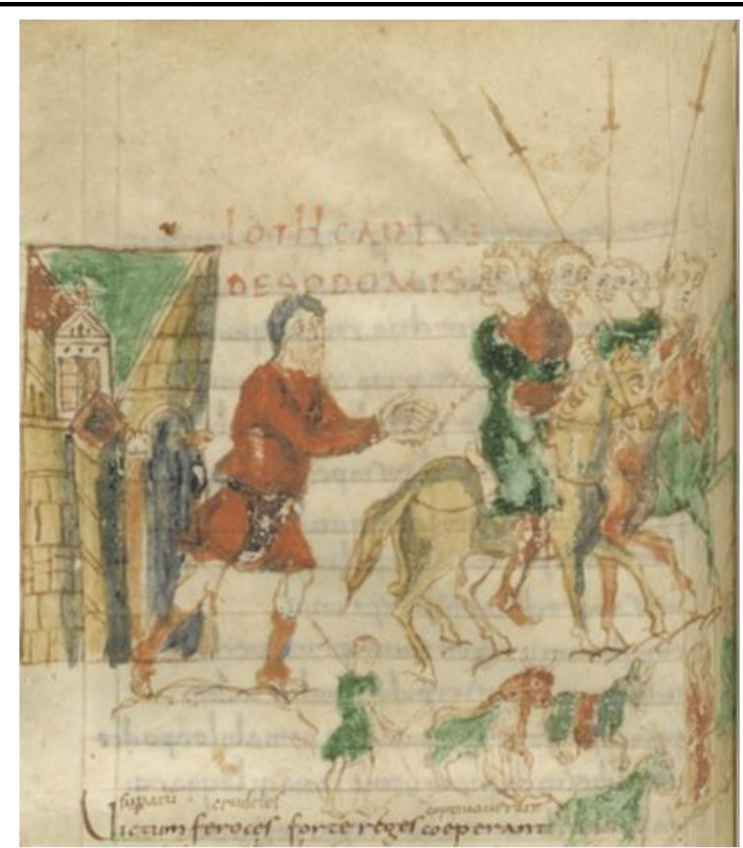

Ms. Lat. 8085, fol. 55v. Siglo IX.

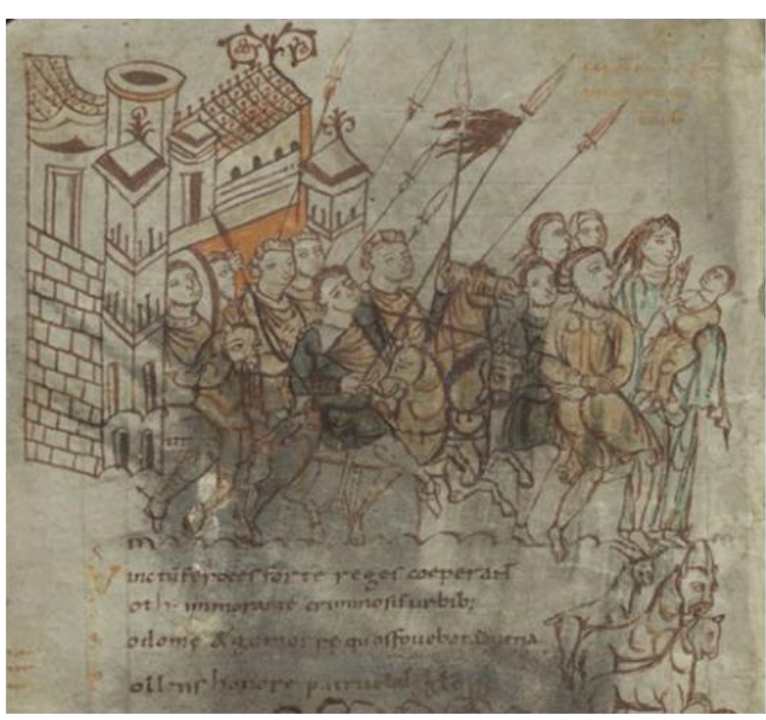

Ms. 10066-77, fol. 112v. Siglo X.

Miniatura 2. Captura de Lot 
presencia de una historia veterotestamentaria -el Sacrificio de Isaac- cuyas imágenes debían ser bien conocida por los usuarios de estos manuscritos, sirve de señal mnemónica, en primer lugar, por la familiaridad con la misma. En segundo, por sus cualidades memorables que se recogen representando un momento lleno de tensión y vigorosidad, Abram sujeta a su hijo desesperado por los cabellos y Dio le detiene. Las cualidades memorables de la imagen se realzan por medio de los elementos intrínsecos de la imagen: las líneas y el color. La representación del sacrificio hace hincapié entonces en las palabras del poeta: en Abraham como padre y sobre todo como fiel servidor de $\operatorname{Dios}^{51}$. En la Edad Media este tema iconográfico solía representarse en la escultura monumental, en capiteles o relieves a la entrada de los templos. En el caso de los manuscritos iluminados de la Psychomachia, el mismo se utiliza al comienzo del poema. Si bien los medios y contextos, e incluso las dimensiones, son distintas a las de la portada, vemos igualmente una intención de marcar o señalar el inició, la entrada o el comienzo del poema por medio de la miniatura del Sacrificio de Isaac.

El resto del prefacio se concentra en la historia de Lot y Abraham. Las miniaturas 2, 3, 4, y 5 plasman: la captura de Lot por los reyes de Sodoma y Gomorra, Abraham y su ejército salen al rescate de Lot, el triunfo de Abraham y la ofrenda de Abraham y Melquisedec. Los episodios más famosos de la vida de Lot en la plástica medieval son los de la destrucción de las ciudades de Sodoma y Gomorra y el momento en que éste es embriagado por sus hijas ${ }^{52}$. Las escenas de la vida de Lot plasmadas en las miniaturas 2, 3 y 4 no poseen paralelos en el repertorio icónico del arte paleocristiano ${ }^{53}$, por tanto, los iluminadores se sirvieron de escenas parecidas en otros textos para representar los mismos.

\footnotetext{
${ }^{51}$ Prudencio. Praefatio vv. 1-19. Obras Completas de Aurelio Prudencio..., p. 310.

${ }^{52}$ RÉAU, Louis. Iconografía del arte cristiano. Iconografía de la Biblia. Antiguo Testamento. Tomo 1, Vol. 1. Barcelona: Ediciones del Serbal, 1999. p. 142

53 "Scene (2), Lot captured from Sodom by the four kings, has no parallel in the repertory of Early Christian Art. The same is true of scenes (3) and (4)...". WoODRUFF. "The Illustrated Manuscript..., p. 71.
} 
La falta de precedente pudo incidir en las leves diferencias de la composición. Las miniaturas del siglo $\mathrm{X}$ son mucho más ricas en detalles que las del siglo IX. En la escena de la Captura de Lot, se representó el momento en que Lot es apresado por los reyes Quedorlaómer de Elam, Tidal de Goyim, Amrafel de Sumeria y Arioc de Elasar como narra Génesis 14: 10-11. En la miniatura se aprecia a Lot, atado por las manos, saliendo de Sodoma. Éste es arrastrado por sus captores que montan a caballo y sujetan sus armas. En los manuscritos del siglo X, Ms. 10066-77 y Cod. 264 en lugar de ser arrastrado, Lot es empujado y apurado con una lanza de uno de los reyes a caballo.

La figura de Lot se encuentra bien acompañada por animales u otras figuras humanas. Según el relato bíblico los cuatro reyes habían tomado otros cautivos y Abraham igualmente los libero (Génesis 14: 16). Más adelante en el Prefacio, en los versos 29-31 aparecen todos estos personajes y animales representados en esta miniatura liberados: "Fragit catenas et rapinam liberat: / aurum puellas parvulos monilia / greges equarum vasa uestem buculas".

Los rebaños en los cinco ejemplos de la miniatura 1 igualmente pueden ser una libertad del miniaturista, basada en el texto bíblico y no directamente en los versos del poema. Según el Génesis, los captores se llevaron a Lot y todas sus pertenencias, podríamos entender que los animales representados son los rebaños de Lot. En los códices de siglo X aparecen además otras figuras humanas: en 10066-77 una mujer con un niño en brazos justo al lado de Lot, en Cod. 264 varias figuras femeninas con velos. En este caso se incluyó a la familia de $\operatorname{Lot}^{54}$.

En torno a la figura de los reyes captores existe discrepancia en los cinco casos estudiado. Si bien el relato veterotestamentario específica que eran cuatro reyes, sólo Ms. Lat. 8085 muestra los mismo. En Burm.Q.3 y Cod. 264 se plasmaron cinco y en los dos códices belgas, 9987-91 y 10066-77, a pesar de que se plasmaron seis los tituli de esta indican que son cinco reyes.

\footnotetext{
${ }^{54}$ WOODRUFF. "The Illustrated Manuscript..., p. 60.
} 


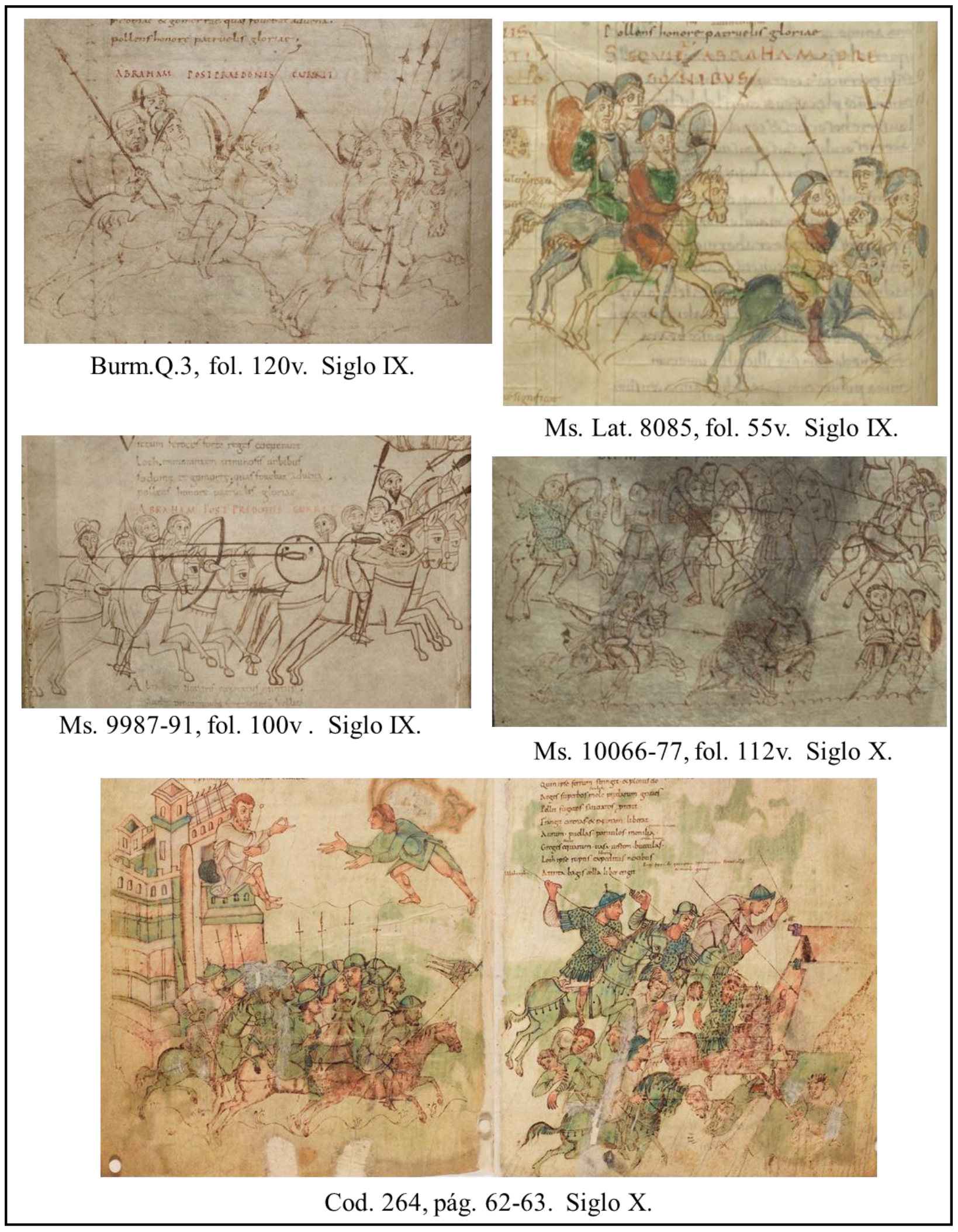

Miniatura 3. Rescate de Lot 


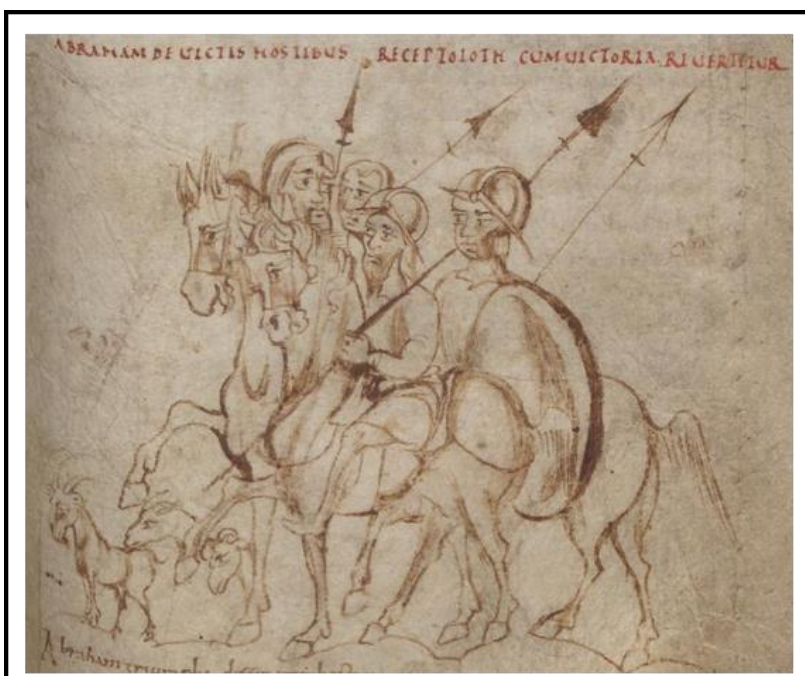

Burm.Q.3, fol. 121r. Siglo IX.

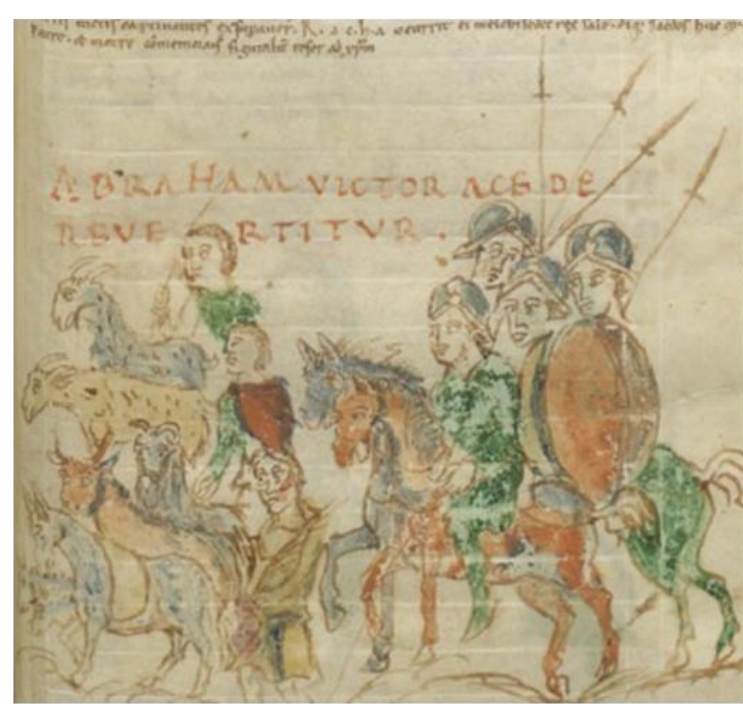

Ms. Lat. 8085, fol. 56r. Siglo IX.

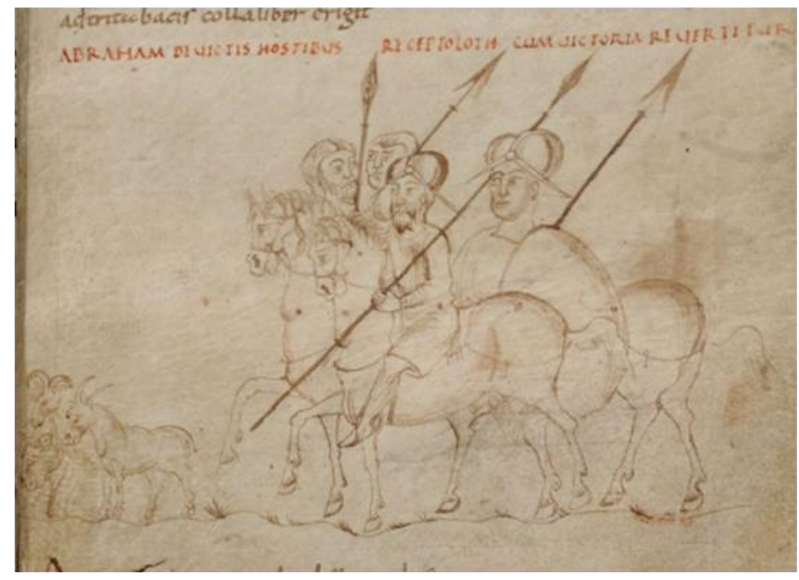

Ms. 9987-91, fol. 101r. Siglo IX.

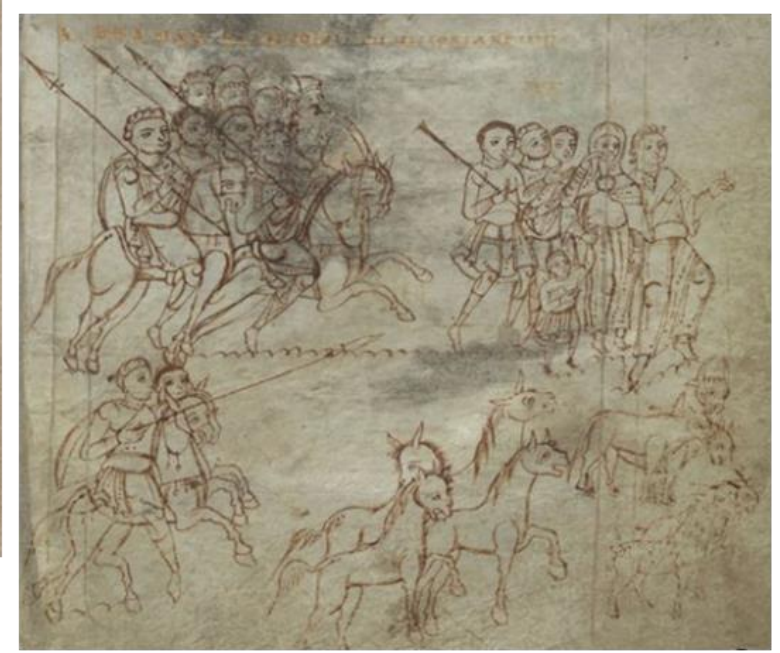

Ms. 10066-77, fol. 113r. Siglo X.

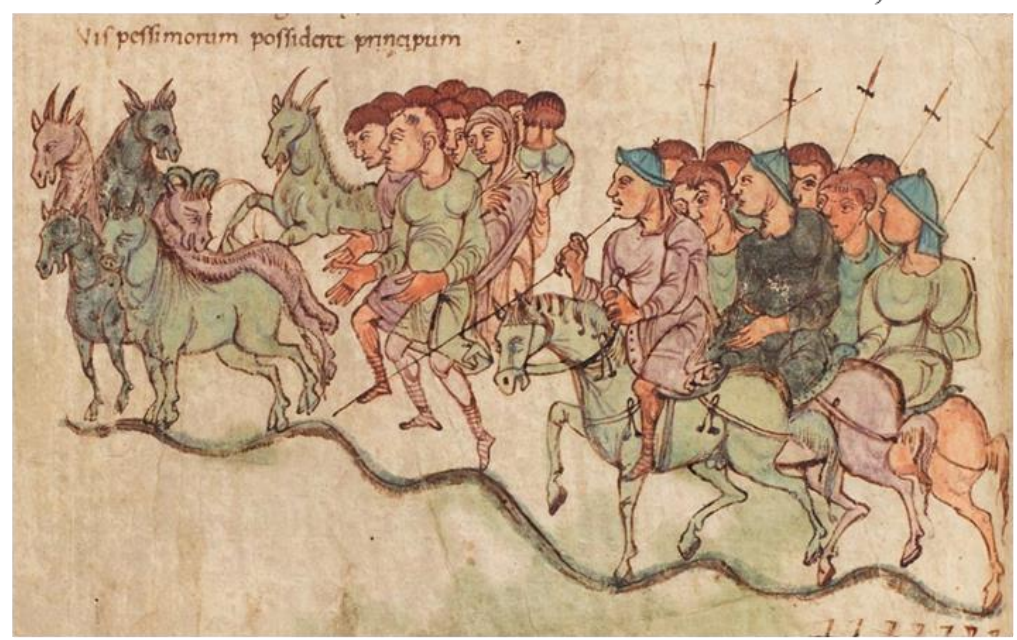

Cod. 264, pág. 64. Siglo X.

Miniatura 4. Triunfo de Abraham. 
La miniatura 3, el Rescate de Lot, que antecede los versos del prefacio 19-33 se relacionan directamente con lo narrado en Génesis 14: 14-15. En esta escena se representa el momento en el que Abraham sale con sus hombres a perseguir al enemigo para rescatar a su sobrino. En los manuscritos del siglo IX, Burm.Q.3, Ms. Lat. 8085 y Ms. 9987-91 se aprecia la persecución por parte de los hombres congregados por Abraham. En Ms. 10066-77 además se representó la batalla. Si bien en 9987-91 se recoge visualmente cómo el ejército de Abraham persigue a los enemigos, esta imagen se acerca más a las representaciones del siglo $\mathrm{X}$ donde uno de los miembros de la caballeriza hiere a uno de sus oponentes.

Como se estableció anteriormente, el lenguaje pictórico de los manuscritos del siglo X es mucho más rico y la escena del Rescate de Lot es uno de los mejores ejemplos. Las imágenes se representan con mucha más vivacidad y esto se logra por medio de la línea y el abigarramiento y la gestualidad exagerada de los hombres que luchan. El códice de la biblioteca de Berna, el 264, provee al espectador más detalles. En este manuscrito el Rescate de Lot se plasmó en dos folios. En el fol. 62v el ejército de Abraham sale detrás de los captores de su sobrino y en el folio contiguo, en el 63r se muestra la batalla de las huestes del patriarca contra las de los pérfidos reyes. En la parte superior de la imagen del fol. $62 \mathrm{v}$ se aprecian dos figuras, añadidos de este manuscrito $^{55}$ que proveen más información visual: uno de los hombres que escapa avisa a Abraham de lo sucedido ${ }^{56}$.

La miniatura 4, Triunfo de Abraham, cierra el ciclo de la captura y rescate de Lot. Nuevamente encontramos que el miniaturista más que inspirarse en los verso de Prudencio para la representación de la escena, en el verso 34 del prefacio el poeta sólo establece que Abram regreso con la gloria, se basa en el texto veteotestamentarios. Según el Génesis: "Abram recuperó todo lo que se habían llevado, liberó a Lot y lo que le habían quitado y liberó también a las mujeres y a los

\footnotetext{
${ }^{55}$ WOODRUFF. "The Illustrated Manuscript..., p. 64.

${ }^{56}$ Prudencio. Praefatio vv. 19-21. Obras Completas de Aurelio Prudencio..., pp. 308-309. Génesis 14: 13.
} 
demás cautivos ${ }^{57}$ ". En las miniaturas de Burm.Q.3, Ms. 9987-91 y Lat. 8085 todas las posesiones recuperadas se plasman a través del ganado. En los ejemplos del siglo $\mathrm{X}$ además del ganado también se incluyen las mujeres y demás cautivos narrados en el relato bíblico.

El interés principal de Prudencio, y por consiguiente del miniaturista, en los versos e imágenes que recogen la captura y rescate de Lot es destacar la figura de Abraham a través de la hazaña heroica de éste. El patriarca para lograr el rescate arma a su ejército y lucha contra los reyes de Sodoma y Gomorra, ciudades impías cuyos habitantes eran dados a todos los vicios. En relación con el mismo poema de la Batalla del alma, el rescate de Lot, prisionero de estos bárbaros viciosos anticipa al lector a los distintos combates de las virtudes y $\operatorname{los}_{\text {vicios }}{ }^{58}$.

La representación de la Ofrenda de Abraham y Melquisedec en la miniatura 5 más que estar tomada directamente de los versos del prefacio corresponde a al texto bíblico. En parte esto puede ser a que es un tema iconográfico ya utilizado en los primeros siglos de la cristiandad ${ }^{59}$. En los versos 38 al 44 del prefacio se establece que Melquisedec ofreció manjares celestiales. En la imagen que antecede al texto claramente se incluyen otros detallas que están tomados del relato del Génesis, según el cual el sacerdote de Dios trajo pan y vino y lo bendijo y luego Abraham entregó al Melquisedec una décima parte de lo conseguido al recuperar a su sobrino $\operatorname{Lot}^{60}$.

En las miniaturas aparece en el lado derecho la figura de Abraham ofreciéndole al sacerdote un cordero (en Ms. 10066-77 es una cabra). En los manuscritos del siglo IX de izquierda a derecha se ve la figura que representa a Abraham, junto a sus pies una pequeña cabra. En el centro un altar sobre el cual se representó un cáliz y un pedazo de pan y junto al mismo el sacerdote Melquisedec.

\footnotetext{
${ }^{57}$ Génesis 14: 16.

${ }^{58}$ CARRUTHERS. The Craft of Thought..., p. 145.

59 WOODRUFF. "The Illustrated Manuscript..., p. 67. RÉAU. Iconografía del arte cristiano. Iconografía de la Biblia. Antiguo Testamento. Tomo 1, Vol. ..., p. 159.

${ }^{60}$ Génesis 14: 18-20.
} 
Los gestos de las manos del sacerdote en estos tres manuscritos indican que éste ofrece los dones del altar a Melquisedec.

La composición de las miniaturas del siglo $\mathrm{X}$ muestras ciertos cambios. El pequeño animalito a los pies de Abraham se eliminó. Se continúa representando el altar, pero el mismo se encuentra dentro de un templo y se ha trasladado al lado derecho de la composición. El templo pues el altar es un elemento intrínseco de este espacio $^{61}$ : es el lugar dónde se encuentra éste. En los códices 10066-77 y 264 en las escenas que hay un altar el mismo se representa dentro del templo, como se puede apreciar en las miniaturas 7 y 16. En el centro de la composición ahora se encuentra el sacerdote Melquisedec, los gestos de éste han cambiado. Él recibe el sacrificio que se hará en el altar a la derecha. En el manuscrito 10066-77 se ha eliminado el cáliz, y parecería cómo si el pequeño animal que ofrece Abraham fuera a ocupar su lugar.

En términos mnemónico esta imagen sirve como lugar de recopilación en el que se concatenan otros conocimientos. "El sacrificio de Melquisedec consagrando el pan y el vino es una prefiguración de la Cena ${ }^{62}$, , por lo tanto, es un símbolo eucarístico. El miniaturista o algún usuario del códice 9987-91 se tomó la molestia hacer hincapié en el significado eucarístico de la escena, marcando un con una cruz la oblea del pan. Al igual que a escena del Sacrificio de Isaac, aquí también se utiliza una imagen bien familiar para resaltar la cualidad memorable y por consiguiente mnemónica de la representación.

La miniatura que cierra el prefacio de la Psychomachia es el momento en el que los tres ángeles visitan a Abraham (Miniatura 6). Los versos de Prudencio únicamente indican que tres ángeles visitan a Abraham y que Sara queda embarazada. La miniatura posee más información que está tomada del relato bíblico cómo son la

\footnotetext{
${ }^{61}$ WOODRUFF. "The Illustrated Manuscript..., p. 62.

${ }^{62}$ Iconografía del arte cristiano. Iconografía de la Biblia. Antiguo Testamento. Tomo 1, Vol. ..., p. 159.
} 


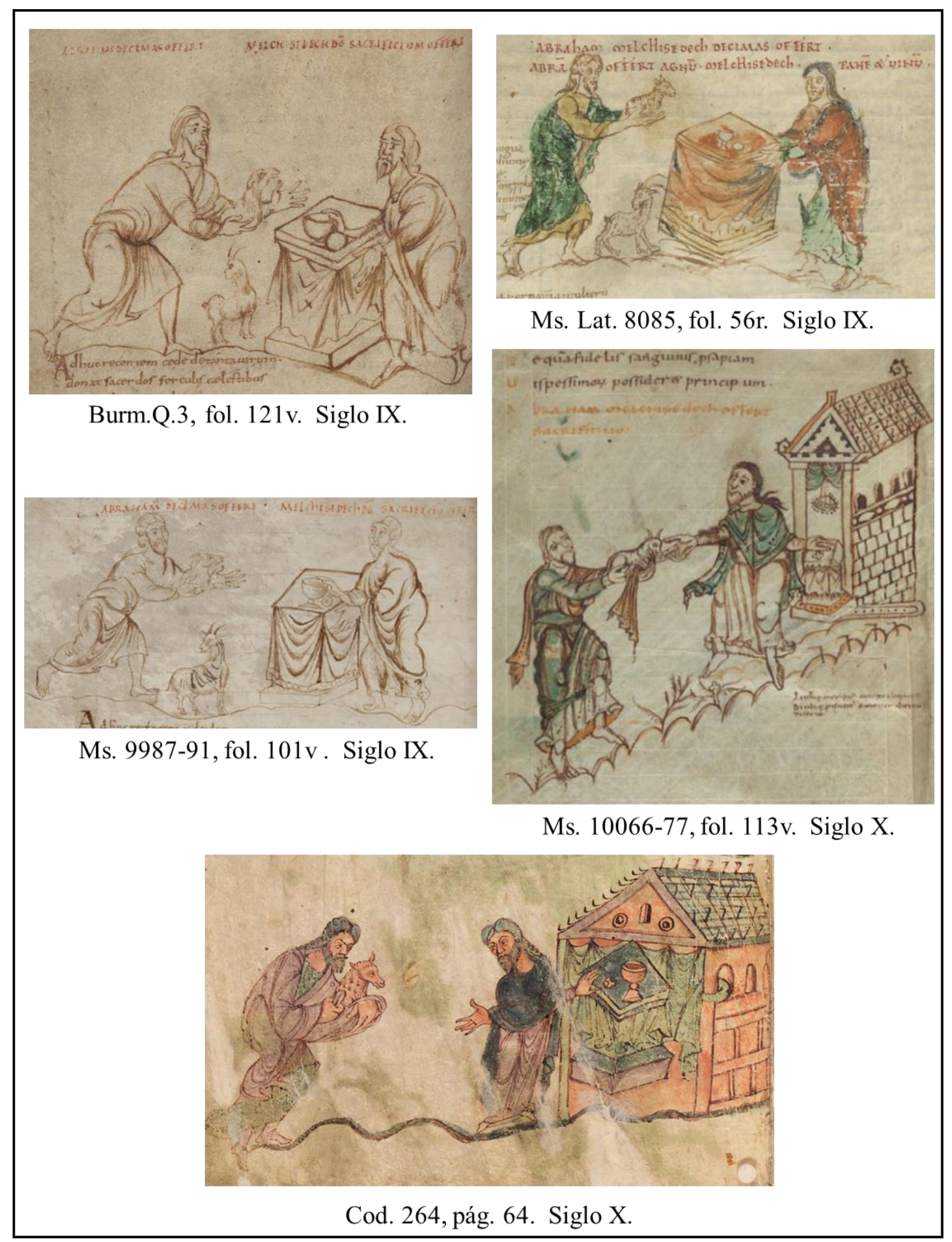

Miniatura 5. Ofrenda de Abraham y Melquisedec. 


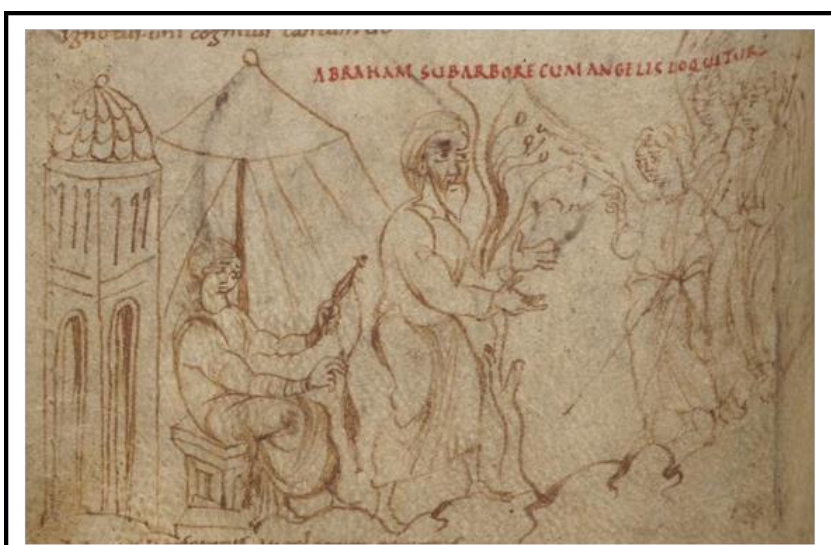

Burm.Q.3, fol. 121v. Siglo IX.

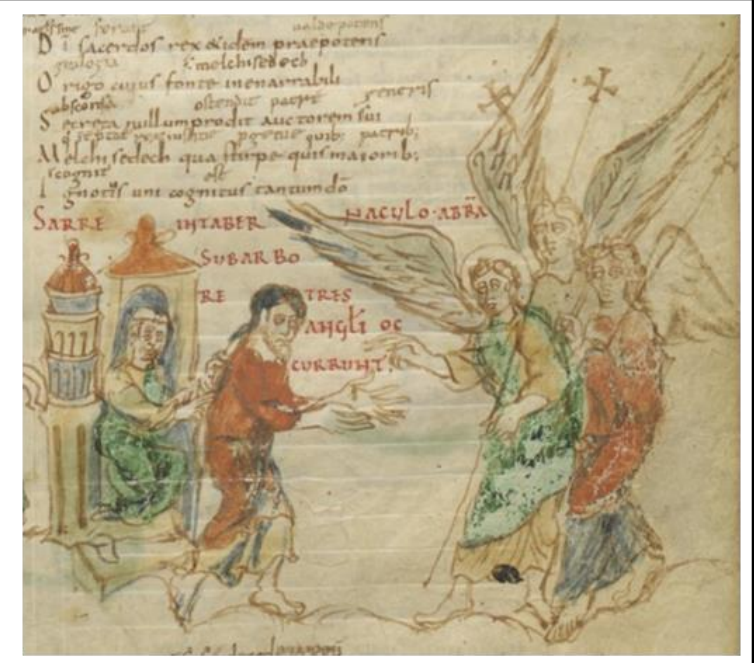

Ms. Lat. 8085, fol. 56r. Siglo IX.

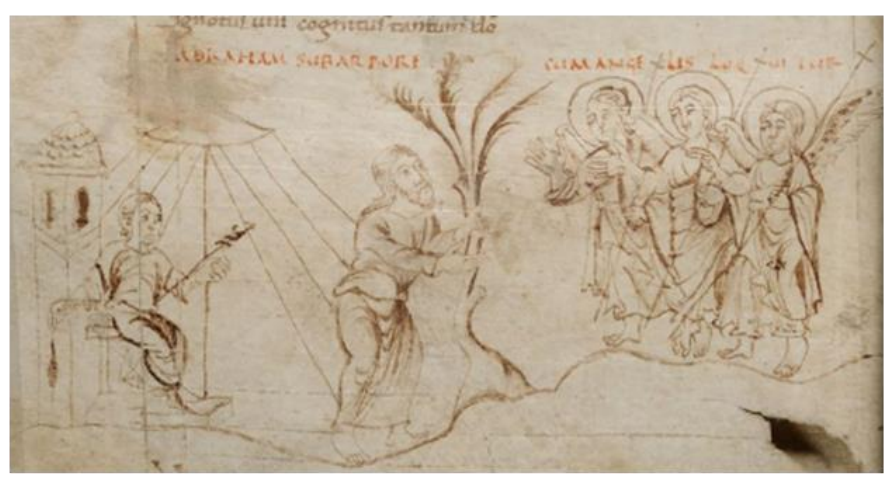

Ms. 9987-91, fol. 101v. Siglo IX.

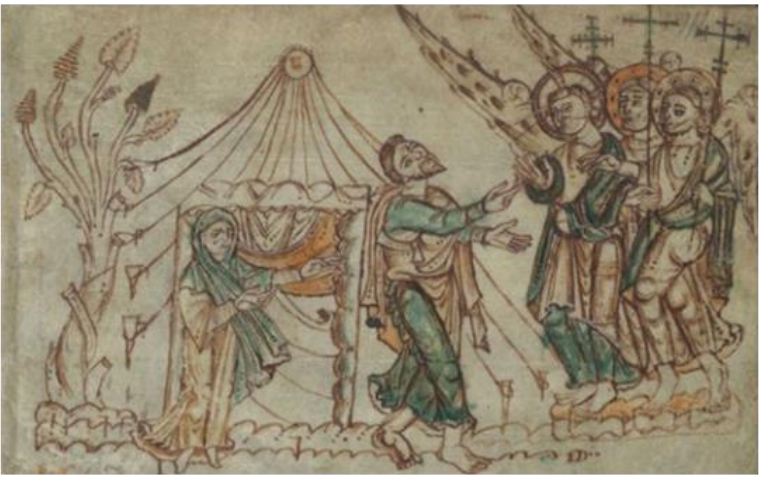

Ms. 10066-77, fol. 114r. Siglo X.

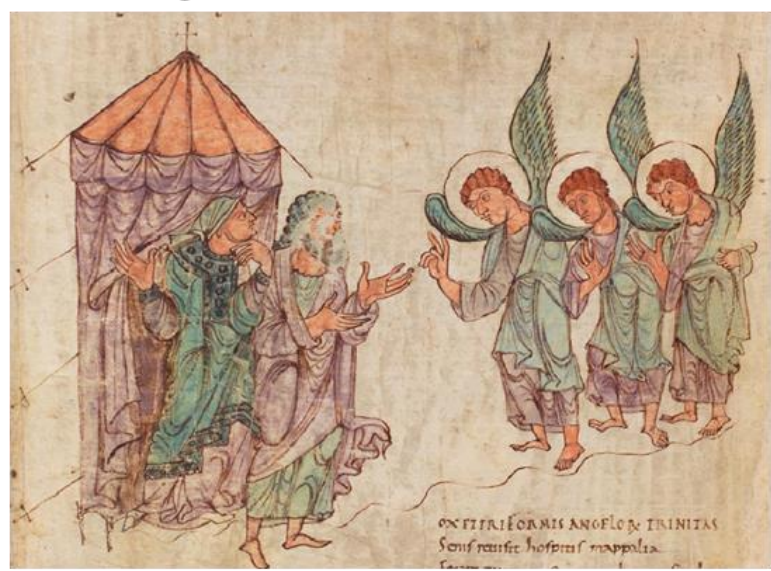

Cod. 264, pág. 65. Siglo X.

Miniatura 6. Abraham y los tres ángeles 
presencia del árbol, indicando el lugar dónde según el Antiguo Testamento se le aparecieron los ángeles a Abraham: la encina de Mambré63. Al igual que con la miniatura 1 y 5, la imagen de Abraham y los tres ángeles es un tema iconográfico del cual se encuentran ejemplos tan temprano como en el siglo $\mathrm{V}$ y se conocía bajo el nombre de la Hospitalidad de Abraham o la Filoxenia de Abraham. En las cinco imágenes de esta miniatura los ángeles se representan alados y con nimbos, clara alusión a su cualidad de ser divino. La mujer del patriarca, Sara, se plasmó sentada dentro de la tienda. En los códices del siglo IX ésta hace labores, específicamente hila y junto a la tienda un edificio. Estos elementos en los manuscritos posteriores fueron eliminados.

En cuanto a la encina de Mambré, el carácter de ésta como punto de encuentro sólo se resalta en Burm.Q.3 y Ms. 9987-91. En Ms. 10066-77 se mueve al lado izquierdo de la composición y en Ms. Lat. 8085 y Cod. 264 el árbol desapareció por completo. En las cinco miniaturas los gestos de Abraham y los ángeles son los mismos: dialogo y en ninguno falta la figura de Sara. Por lo tanto, el interés principal del miniaturista es resaltar, como indican los versos 45 al 49, el momento en el que los visitantes anuncian el nacimiento de Isaac a sus padres, una clara prefiguración de la Anunciación a la Virgen. Si se tiene en cuenta el orden cronológico según las Sagradas Escrituras, la miniatura del Sacrificio de Isaac, imagen con la que abre el prefacio, sería la siguiente a la de Abraham y los tres ángeles. Puesto que el prefacio imita la estructura del poema en pequeño, la miniatura 6 resalta cómo Abraham por su fe y en su proceder fue recompensado por Dios, recompensa que se ve cumplida en el momento en el que "Sara mira asombrada venir a su útero marchito el don de la fértil juventud, madre sin flujo menstrual, gozosa de tener un heredero ${ }^{64}$ ".

La historia de Abraham como prefacio del poema tiene un carácter mnemónico. El empleo de juego y asociaciones de palabras, del alfabeto y las etimologías eran utilizadas para ordenar información y permitir memorizar la misma más efectivamente. Se utiliza el nombre de Abraham como una nota o señal: su

\footnotetext{
${ }^{63}$ Genesis 18: 1.

${ }^{64}$ Prudencio. Praefatio vv. 46-49. Obras Completas de Aurelio Prudencio..., pp. 310-311.
} 
nombre comienza con la primera letra del alfabeto latino, él es el padre de la fe y uno de los primeros patriarcas. Su nombre igualmente sirve como lugar mnemónico de recopilación. El mismo se divide en tres sílabas las cuales se pueden conectar al resto de los personajes de la historia: Isaac, Lot, Sara e igualmente los tres ángeles ${ }^{65}$. El ciclo completo de Abraham funciona como un lugar mnemónico de recopilación en los que las distintas historias bíblicas a la misma vez se concatenan con los distintos significados de las escrituras, sobre todo en clave mariana y cristológica ${ }^{66}$.

\subsection{Prudentius orat: el retrato de autor}

En los cincos códices estudiados se incluyó una figura antropomorfa ante un altar, la cual es posible identificar como una efigie de Prudencio gracias a los tituli que acompañan a la misma (Miniatura 7). En cuatro de los cinco manuscritos incluso se representó al poeta dos veces (Miniaturas 7 y 90). La presencia de un retrato de autor es sumamente curiosa pues en ninguna parte del poema hay alusiones al autor. Woodruff prestó atención a estas miniaturas para tratar la filiación ${ }^{67}$, no obstante paso por alto el hecho de que éstas son una creación del iluminador o el individuo detrás de la elaboración de estos manuscritos. El retrato del autor sirve para corroborar por una parte como eran utilizados estos manuscritos en la época en la que fueron

\footnotetext{
65 "The starting-point, or principle, in the preamble chain is the name Abraham. This name is specially marked by an ornament, etymology, as it also is in Genesis, for it was lengthened by a syllable from the earlier name Abram. This is a meaningless detail to us, but Roman students, who learned to read by syllables, would have paid it full attention. The name "Abraham" is then treated as a gathering site for a network of stories linked to him, those of Isaac, Lot, Sarah, and the visit of the three angels". CARRUTHERS. The Craft of Thought..., p. 145.

${ }^{66}$ WOODRUFF. "The Illustrated Manuscript..., pp. 71-72.

${ }^{67}$ WoOdRUFF. "The Illustrated Manuscript..., p. 52.
} 
realizados, los mismos se leían en voz alta y por otra parte continúan el ductus ${ }^{68}$ o línea del poema.

En los códices del siglo IX (Miniatura 7) se representa al autor antecediendo los primeros veinte versos del poema los cuales son una invocación. En las miniaturas aparece Prudencio junto a un altar, de tradición pagana ${ }^{69}$, el cual ocupa gran parte de la composición, delegando la estructura arquitectónica a un segundo plano. En los tres folios apenas se puede apreciar la fachada del templo la cual se conforma de dos columnas, rematadas con capiteles más o menos elaborados y un frontón, recordando así las fachadas de los templos romanos. Ante el altar Prudencio se arrodilla y extiende sus manos con las palmas alzadas al cielo, gesto utilizado en la figuración para indicar el acto de $\operatorname{orar}^{70}$. El título que acompaña la miniatura de Prudencio en el Burm. Q.3 y Ms. 9987-91 es Prudentius orat, en el manuscrito de la biblioteca de París se lee Prudentii. Invocatio giusde (Miniatura 7).

La segunda efigie del autor en estos tres códices precede los últimos veinticinco versos del poema los cuales son una oración de gracias (Miniatura 90). En éstas el altar ha sido eliminado y sólo queda la fachada del templo, la cual se encuentra más elaborada. Frente a la misma aparece el poeta, esta vez de pie, pero un poco por debajo del templo, mirando hacia éste y con las manos extendidas. La inscripción que acompaña las tres miniaturas pone: Prudentius gratias agit do.

Las iluminaciones de los manuscritos del siglo $\mathrm{X}$ son un poco más elaboradas que las del IX (Miniatura 7). Todas conservan el altar y el templo, el primero en el interior del segundo y los mismos siguen los modelos propios del arte carolingio ${ }^{71}$. El edificio representado en los folios de la primera parte del poema es una estructura completamente cerrada, la única apertura que posee es por la que se ve el altar y sobre

\footnotetext{
${ }^{68}$ Ductus es la forma por la cual una obra a través de su composición conduce al espectador a sus distintos fines o metas. Este término es de partícula relevancia en el capítulo 5 de nuestro trabajo. Ver: Beyond Words. Cambridge University Press, 2010. pp. 190-213.

${ }^{69}$ WOODRUFF. "The Illustrated Manuscript..., p. 69.

${ }^{70}$ GARNIER, François. Le langage de l'image au Moyen Âge (I). Signification et symbolique. París: Le Léopard d'Or, 1982. p. 223.

${ }^{71}$ WOODRUFF. "The Illustrated Manuscript..., p. 67.
} 
él una lámpara que recuerda más a una corona votiva. En ambas miniaturas los laterales poseen vanos y en el caso del folio 114v del Ms. 10066-77, también una especie de arquería. En este folio particular la fachada del templo consiste en un arco y dos vanos. El poeta se encuentra sentado en lo que parece ser una mesa de un scriptorium, sobre la cual reposa un códice. Alrededor del autor se hayan distintos objetos relacionados con el acto de escribir como el tintero o la pluma y rollos de pergaminos los cuales permiten llegar a la conclusión que el espacio representado es uno dedicado a la escritura. La efigie de Prudencio que finaliza el poema en el manuscrito 10066-77 muestra una estructura arquitectónica distinta a las antes descrita. En éste, el templo más que recordar un templo, recuerda una torre, la misma remata el altar y se encuentra decorada con una lámpara y una cruz.

Los gestos de Prudencio en la invocación de las miniaturas del siglo X son un tanto más complicados que en las imágenes del siglo IX (Miniatura 7). En Ms. 10066-77 y el Cod. 264 el poeta con la mano derecha toca un códice mientras que la izquierda la alza con la palma abierta. En la miniatura de la Biblioteca de la Burguesía de Berna el autor específicamente sujeta con su siniestra un instrumento, un estilete, con el cual escribe en el folio. Por otra parte, en el códice del siglo X de la Biblioteca Real de Bélgica el autor simplemente agarra el códice y con su mano izquierda hace un gesto muy particular, pues mientras la eleva toca con su pulgar su barbilla. Los tituli de estos son distintos, en el Ms. 10066-77 sobre la figura antropomorfa escrito en amarillo pone Prudentius scolastic orat. En el Cod. 264 la identificación del mismo ha sido más difícil e inscritas en rojo en este fondo morado se ha podido leer Prudenti... oratio poetate, el resto de la inscripción es ilegible dado a lo gastado que se encuentran los pigmentos.

A priori la presencia del retrato de Prudencio, el autor de la obra, recuerda a los retratos de autor utilizados en manuscritos de obras clásicas e inclusive a los retratos de los evangelistas. Incluso en los manuscritos Ms. Lat. 8085, Ms. 10066-77 y Cod. 264 se le representó con nimbo, evocando así los retratos de Evangelistas ${ }^{72}$.

\footnotetext{
${ }^{72}$ STETTINER. Die Illustrierten Prudentiushandschriften..., p. 234.
} 
Los retratos de autor, se colocaban al inicio de la obra y servían de frontispicio de la misma $^{73}$. En el caso de la efigie de Prudencio, a pesar de ser una representación del poeta, de los nueve casos identificados en los cinco manuscritos solamente dos de siguen muy de cerca el modelo tradicional de retrato de autor en manuscritos, en el que a éste se le suele retratar con los objetos del oficio ${ }^{74}$. Los manuscritos 10066-77 y Cod. 264 son los que introducen al retrato de autor ${ }^{75}$. Es gracias a los tituli que la figura postrada puede identificarse con Prudencio. Con relación a los retratos de autores en manuscritos Weitzmann afirma que:

"La última forma de aprovechar las posibilidades artísticas de un códice fue la creación de una sola pintura que ocupaba toda la página. Esto ocurrió muy poco después de la invención del códice pero en un principio se limitó a un caso muy concreto, al frontispicio, que podía representar retratos de los autores, individualmente o en grupo [...]. Estas imágenes pueden inspirarse en pasajes concretos del texto, pero no son ilustraciones del texto en sentido estricto; no estuvieron nunca incorporadas a las columnas de texto ni tenían una conexión física con el texto como las escenas narrativas, sino que precedía, como unidad aislada, todo el códice... ${ }^{76}$ "

Si se considera la afirmación de Weitzmann se puede concluir que estos retratos no funcionan del todo como frontispicio de la obra pues los mismos (con excepción del Cod. 264) no ocupan una página completa. A pesar de anteceder los versos que dan inicio a la Batalla del alma, no se colocaron como tal en el inicio de la obra que responde al Praefatio, el cual en los manuscritos del siglo X es identificado como el incipit Psychomachia y se encuentra acompañado por la

\footnotetext{
${ }^{73}$ WeitZMAnN, Kurt. El rollo y el códice. Un estudio del origen y el método de la iluminación de textos. Madrid: Nerea, D.L. 1990. p. 81. WeItZmann, Kurt. Studies in Classical and Byzantine Manuscript Illumination. Ed. Herbert L. Kessler. (ed.) Herbert L. Kessler. Chicago \& London: The University of Chicago Press, 1971. p. 14.

74 "To fill the empty space the illustrator added a capsa for scrolls and a lectern but, significantly, no writing table, because the poet is depicted meditating, holding the finished product, a roll, in his hands, and is not occupied with writing". WeITZMAnN. Studies in Classical..., p. 115.

${ }^{75}$ WOODRUFF. "The Illustrated Manuscript..., p. 61.

${ }^{76}$ WeITZMAnN. El rollo y el códice..., p. 81.
} 
miniatura 1 que recoge el Sacrificio de Isaac. Por último, la presencia de la efigie de Prudencio se relaciona directamente con el texto y éstas se insertaron en las columnas del mismo, como el resto de las miniaturas. La efigie de Prudencio sólo se puede explicar a través del mismo poema.

Las miniaturas de estos códices siguen muy de cerca el texto de Prudencio. Una vez culminado el Praefatio inicia el poema con una plegaria a Dios en la que se pide que seamos capaces de derrotar las pasiones, los vicios, y poder proseguir por el camino de las virtudes y culminan indicándole al lector que a su alcance se encuentra el modo de vencer dichas pasiones ${ }^{77}$. El poema no solamente inicia con una plegaria, sino que también culmina de la misma forma, con la diferencia que la primera oración es una invocación mientras que la segunda es una oración de gracias ${ }^{78}$.

La presencia del retrato de Prudencio se vincula directamente con las plegarias al inicio y al final del poema. Al leer los versos de la invocación al principio del poema y los de gracias al culminar el mismo, dentro del monasterio podría haber parecido que más que leer las palabras expresadas por el autor, éstas eran producto del lector de turno. Identificar la voz de las mismas es un tanto complicado, pues se encuentran escritas en la tercera persona singular o en la primera persona plural. La efigie de Prudencio aclara esta complicación. El que pronuncia las palabras es el autor como nos indican las imágenes, y así es posible hacer presente por medio de la imagen e igualmente por la articulación de las palabras voces que no lo están.

Por una parte, los títulos que acompañan las miniaturas ayudan a identificar a la figura antropomorfa que aparece en éstas, pues en todas encontramos en nombre del poeta Prudencio, pero a la misma vez las figuras aclaran el sentido de los tituli. En cuatro de las inscripciones la palabra que describe la acción del autor es orat. A primera instancia ésta indica que Prudencio dice u ora, no obstante, no en todos los

\footnotetext{
${ }^{77}$ Prudencio. Psychomachia, vv. 1-20. Obras Completas de Aurelio Prudencio..., pp. 310-311.

${ }^{78}$ Prudencio. Psychomachia, vv. 888-915. Obras Completas de Aurelio Prudencio..., pp. 360361.
} 


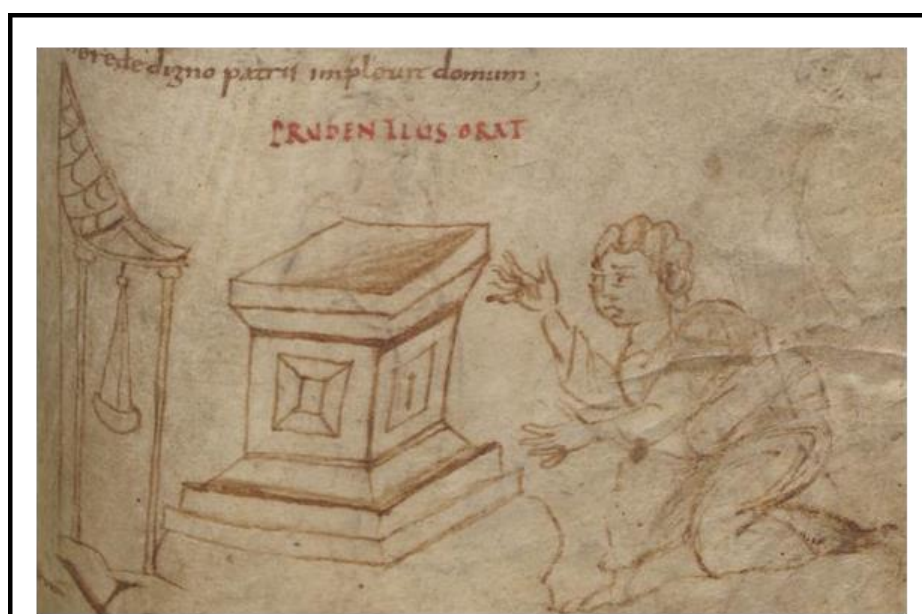

Burm.Q.3, fol. 122r. Siglo IX.

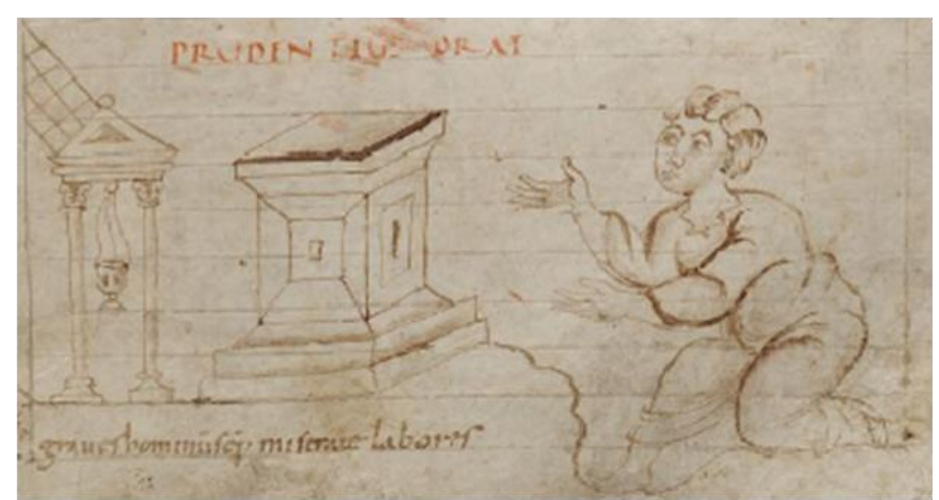

Ms. 9987-91, fol. 102r. Siglo IX.

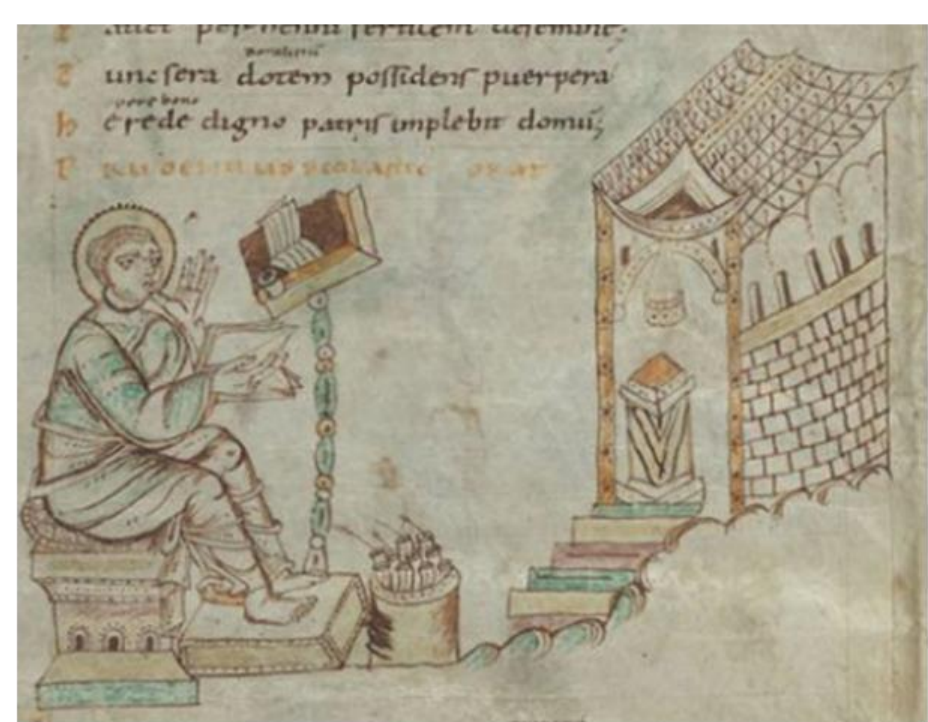

Ms. 10066-77, fol. 114v. Siglo X.

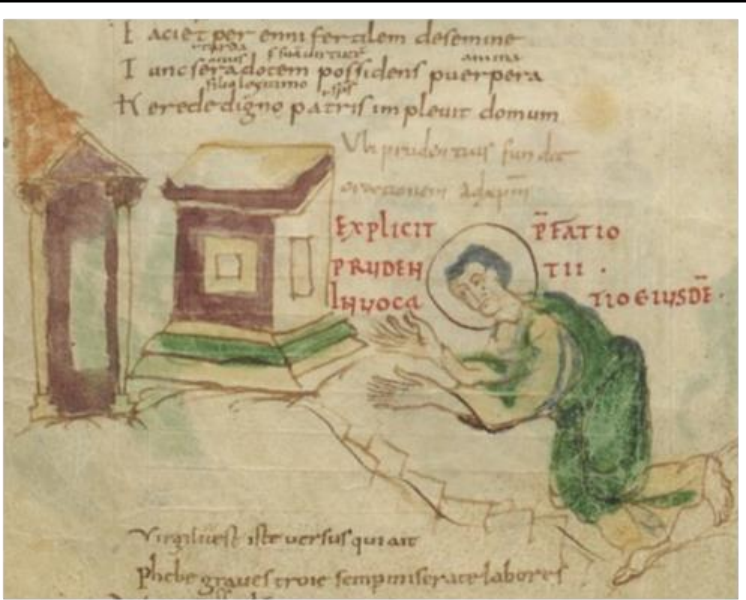

Ms. Lat. 8085, fol. 56v. Siglo IX.

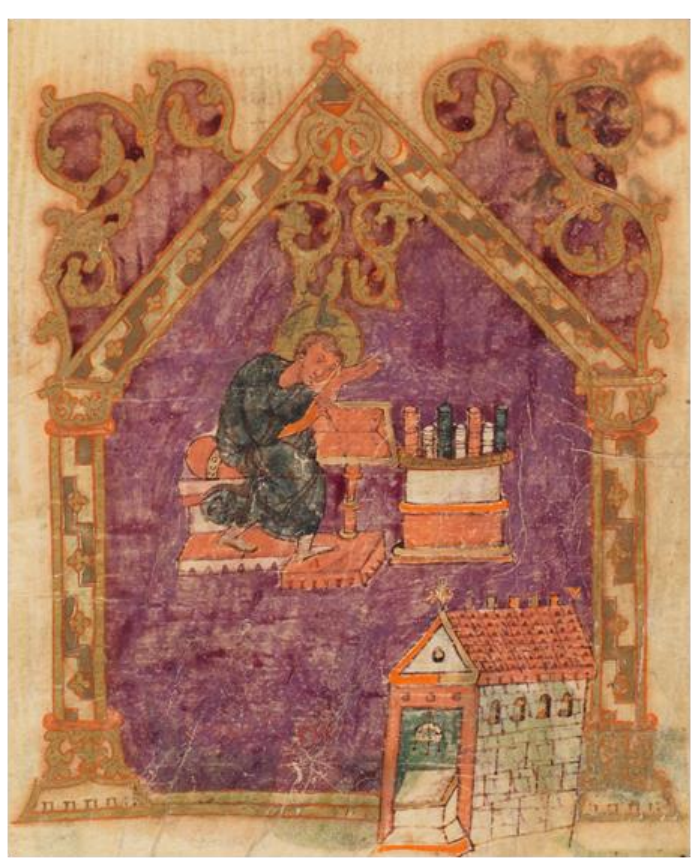

Cod. 264, pág. 67. Siglo X.

Miniatura 7. Invocación de Prudencio (Efigie de Prudencio) 
casos se afirma esta acción. A la luz de la imagen los títulos de los manuscritos Burm.Q.3 y Ms. 9987-91 pueden interpretarse con este sentido, Prudencio ora, pues su actitud de rodilla con las manos extendidas ante un altar muestra que el mismo se encuentra en dicha acción ${ }^{79}$. En el códice de la Biblioteca de Francia el poeta aparece igualmente en actitud orante, sin embargo, la palabra utilizada en este caso es invocatio gius de, designando así que el poeta invoca a Dios como guía.

Las inscripciones que acompañan la efigie del escritor en los códices del siglo X, el Ms. 10066-77 y el Cod. 264 son de especial interés. Aquí nuevamente se ha escrito orat (en el manuscrito de Berna se utiliza el sustantivo oratio) pero en esta ocasión el verbo no puede interpretarse como Prudencio ora, ya que la actitud de la figura del poeta no indica tal acción. En todos estos casos los gestos de las iluminaciones aclaran el sentido de los tituli. Orat, del verbo oro, no sólo se refiere a la acción de orar, sino que también se refiere a la facultad de hablar, de decir palabras, de pronunciar un discurso. Los ademanes del poeta, en el caso del Cod. 264: elevar su mano izquierda y sus palmas abiertas y en Ms. 10066-77 de Brusélas el gesto es más incisivo: la misma mano abierta, pero con el pulgar de esta toca su mentón, indican que la acción la figura es la de hablar o decir algo. En el ejemplo belga además hace como si pasará los folios del códice que sujeta, lo que podría interpretarse como que lee el mismo. Estas dos miniaturas son las más parecidas a los ejemplos de retratos de autores: estos se encuentran sentados inmersos en su oficio, el de escribir. Sin embargo, estas dos imágenes guardan más relación con los retratos de evangelistas, pues incluso llevan nimbo ${ }^{80}$, atributo que en el caso de Prudencio no se explica. Los retratos de evangelistas se documentan ya en los primeros siglos de la cristiandad, por lo menos desde el siglo $\mathrm{V}^{81}$, cronología muy similar al desarrollo de los manuscritos miniados de la Psychomachia. Estos en un

\footnotetext{
${ }^{79}$ SChMitT, Jean-Claude. La raison des gestes: dans l'occident Médiéval. París: Gallimard, 1992. GARNIER, François. Le langage de l'image au Moyen Âge (I)..., p. 223.

${ }^{80}$ Los retratos de los Evangelistas surgen en los manuscritos medievales de la Alta Edad Media. Los retratos de poetas con musas y filósofos de la antigüedad sirvieron de modelos para esta iconografía de los Evangelistas. Ver: FRIEND, Albert M. "Portraits of the Evangelists in Greek and Latin Manuscripts", Art Studies, Nº 5 (1927), pp. 115-147.

${ }^{81}$ FRIEND. "Portraits of the Evangelists..., p. 141.
} 
principio adoptaron como modelos también los retratos de autores en los que se representaba los pergaminos o libros y un atril en el que la figura escribe o se recuesta a pensar ${ }^{82}$. Gracias a ésta similitud de gestos y composición se puede establecer que estas dos efigies de Prudencio también se encuentran en el proceso de composición del poema. Éste no sólo escribe, sino que también pronuncia y a través de la articulación de las palabras se le escucha.

En términos mnemónico, la efigie del poeta es un signo o señal visible que recuerdan a los usuarios de estos cinco manuscritos que quien pronuncia la invocación de los primeros veinte versos y la acción de gracias de los últimos es el poeta, haciendo presente la voz de alguien que no lo está ${ }^{83}$ no sólo por medio de las letras entendidas como signos gráficos, sino también por medio de la imagen. En todos los casos aquí tratados antes de que el lector lea los versos de la plegaria, lee la imagen de Prudencio, funcionando como una señal para indicar y especificar quién es el que pronuncia ambas plegarias. Se guarda o recopila mentalmente aquello dicho por Prudencio en una imagen del autor, funcionando igualmente la miniatura como un marcador de la autoría del ad res del poema ${ }^{84}$. Las imágenes del siglo X van más allá pues además de hacer presente la voz del autor sirven de evidencia para corroborar como era el acto de leer en esta época. Ambas figuras llevan uno o más códices en sus manos, los cuales observan, pero por otra parte el gesto de la mano indica que los mismas están comunicando algo, están leyendo los textos frente a ellos. Queda en el aire la cuestión de si los tituli eran leídos de forma audible o sólo los leía el litteratus o el semi-letrado. Lo que si queda claro es que, en estas cinco miniaturas, no importa los distintos verbos que aparezcan en los títulos, todos indican que se están pronunciando littera.

\footnotetext{
${ }^{82}$ WeITZMANN. Studies in Classical..., pp. 115-116.

${ }^{83}$ IsIDORO DE SEVILLA. Etimologías. Libro I, 3.

${ }^{84}$ CARRUTHERS. The Craft of Thought ..., p. 147.
} 


\subsection{Batalla del alma o Psychomachia: los combates}

La Psychomachia se divide en siete combates o luchas entre una virtud principal y un vicio. Además de las principales siete, en el campo de batalla aparecen otros vicios y virtudes que auxilian a las protagonistas de cada encuentro y el poema culmina con la edificación de un templo en cuyo trono se sienta Sapientia. La estructura de los siete combates es muy similar. En el inicio del mismo siempre se introduce al lector a la virtud que es atacada por un vicio. El vicio arrematé contra su enemiga, pero por su misma condición viciosa encuentra su final, ya sea lastimándose a sí misma o incluso suicidándose, como es el caso de Ira, las virtudes terminan siempre por matar al vicio. Una vez muerto el enemigo, la virtud pronuncia un discurso lleno de referencias bíblicas de como el cumplimiento de la virtud llevó a muchos hombres a perseverar y triunfar. En la mayoría de los casos estos discursos sirven como lugares mnemónicos de recopilación en donde se concatenan las acciones de personajes bíblicos con las acciones de los vicios y las virtudes en cuestión.

\subsubsection{Fides vs. Cultura Deorum}

El combate entre Fides y Cultura Deorum se narra entre los versos 21-39. El mismo cuenta con tres miniaturas que recogen los momentos más memorables del combate: el inicio en el que Cultura deorum ataca a Fides, el momento en que Fides derriba y destroza a Cultura deorum y el final en que Fides corona a los mártires (Miniaturas 8, 9 y 10). Éstas tres miniaturas recogen el ad res de la batalla entre esta virtud y este vicio.

Como anteriormente se había establecido, la imagen introduce al lector a los versos del poema, da a conocer de ante mano los mismos. En la primera miniatura del poema, Cultura deorum ataca a Fides (Miniatura 8), Fides fue plasmada como la describen los versos: con los hombros y brazos descubiertos ${ }^{85}$. En los ejemplos del

\footnotetext{
${ }^{85}$ Prudencio. Psychomachia, vv. 21-23. Obras Completas de Aurelio Prudencio..., pp. 312-313.
} 
siglo X el miniaturista incluso se tomó la molestia de representarla con el cabello largo (intonsa comas). Si bien la descripción de Fides se toma directamente del texto, la de Cultura deorum más que apelar al texto, es onomástica, se vincula directamente con el nombre de ésta. Cultura deorum en algunas traducciones se traduce por idolatría, pero realmente el apelativo de éste vicio se refiere a culto, veneración o adoración a los dioses. En esta primera miniatura la enemiga de Fides aparece armada con el hacha con la que intenta golpear a Fides, pero junto a ésta se incluyó un altar sobre el que se encuentran las cabezas de unas reses, una clara alusión a un sacrificio o una ofrenda. En los manuscritos del siglo X, Ms. 10066-77 y Cod. 264, la alusión al sacrificio, es más evidente. Aquí el bovino aparece detrás del altar en el cual ya arden las llamas y junto al altar sacrificial una imagen devocional que alude a los antiguos ídolos y dioses del mundo pagano, la cual Camille identifica con una estatua del dios Marte ${ }^{86}$.

En las miniaturas siempre se recoge la acción principal del vicio y la virtud. Según el verso 29, Cultura deorum es la primera que hoza en golpear a la virtud, acción que se plasmó en la imagen en la que el vicio levanta su mano para lastimar con un hacha a Fides (Miniatura 8). La composición y gestos Burm.Q.3, Ms. 998791 y Ms. Lat. 8085 es muy similar, sin embargo estilísticamente el códice parisino es distinto. En el mismo Fides lleva nimbo y se cubre completamente. Por otra parte, la vestimenta de su enemiga es distinta, en Lat. 8085 Cultura deorum viste un camisón, calzas y botas. En la siguiente miniatura el camisón de este vicio es más elaborado.

Las escenas en las que las virtudes vencen y matan al vicio la acción de las mismas son más crudas rayando incluso en lo grotesco y mórbido, cualidad necesaria para la creación de imágenes memorables. En la miniatura en la que Fides derriba y destroza a Cultura deorum (Miniatura 9) la virtud se plasma en el momento en el que

${ }^{86}$ CAMILle, Michael. El ídolo gótico. Ideología y creación de imágenes en el Arte Medieval. Madrid: Akal, 2000. pp. 24-25. 


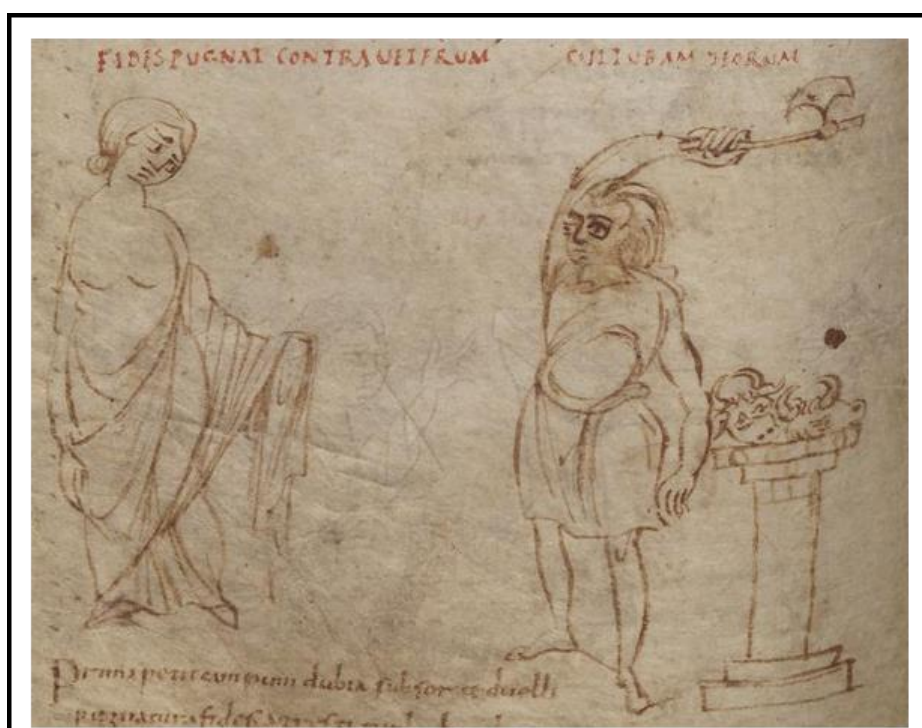

Burm.Q.3, fol. 122v. Siglo IX.

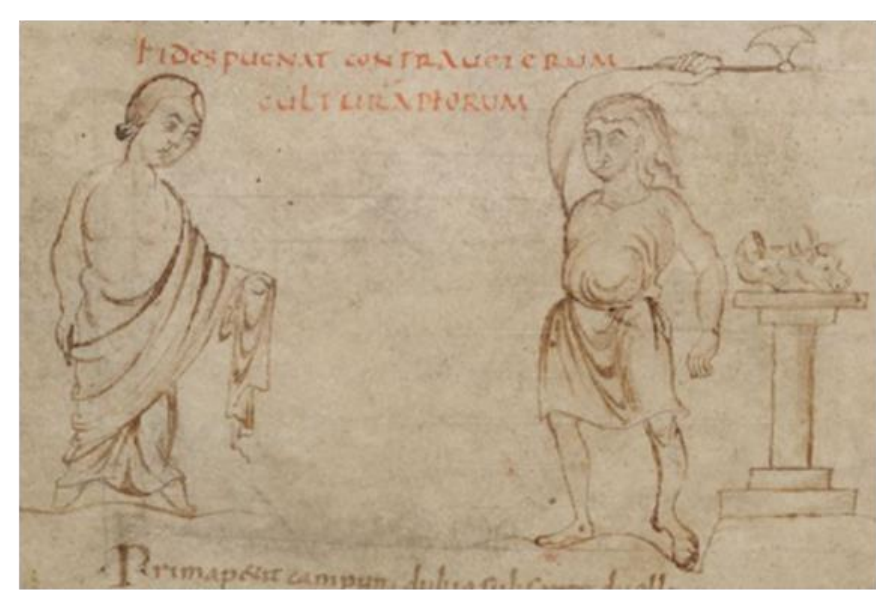

Ms. 9987-91, fol. 120v. Siglo IX.

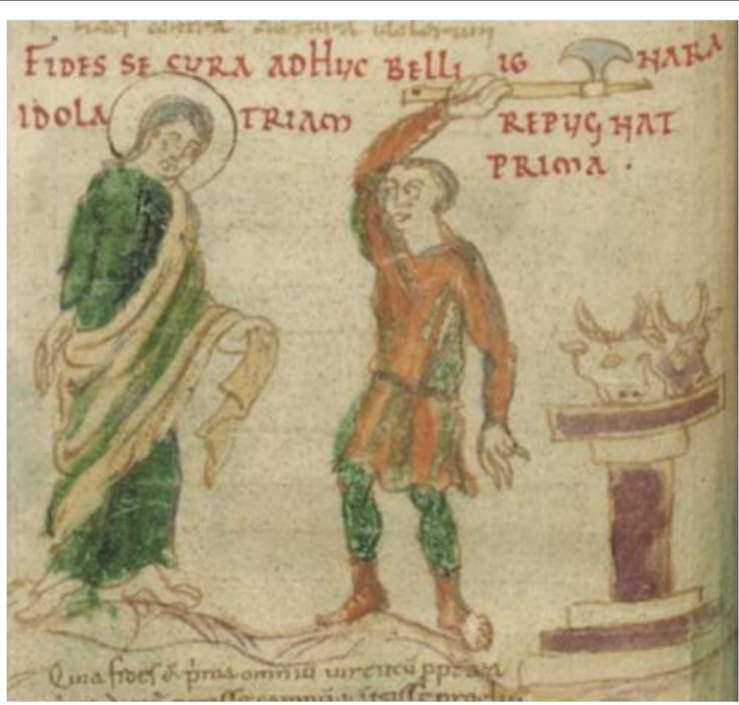

Ms. Lat. 8085, fol. 56vSiglo IX.

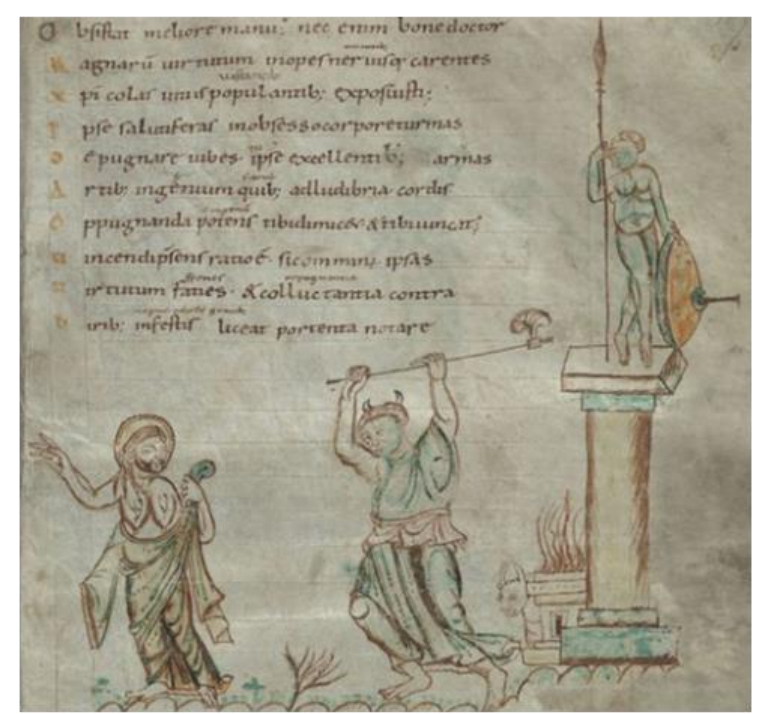

Ms. 10066-77, fol. 115r. Siglo X.

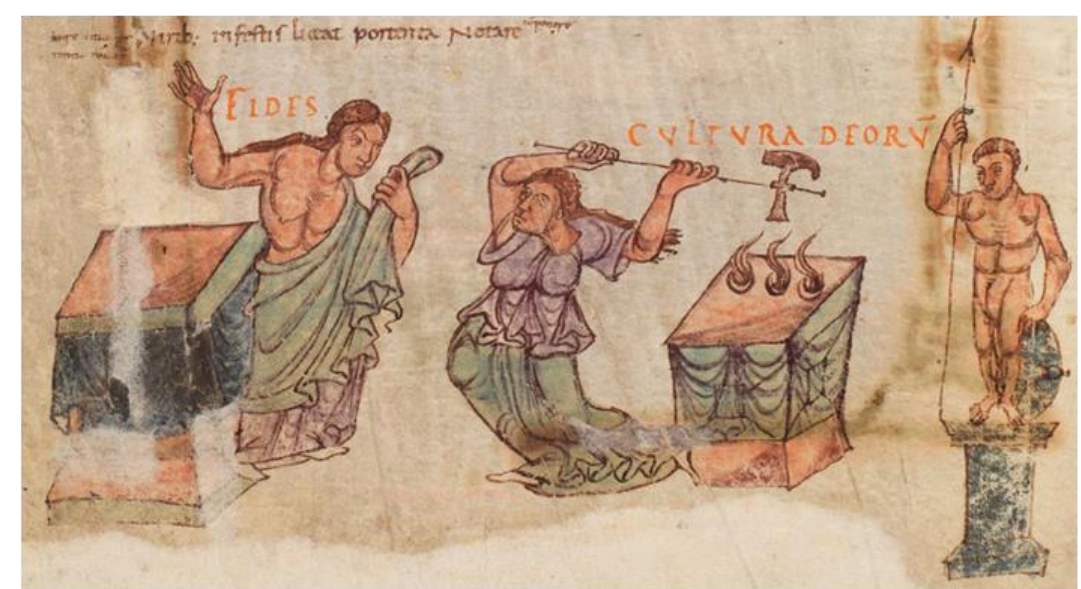

Cod. 264, pág. 68. Siglo X.

Miniatura 8. Cultura deorum ataca a Fides 


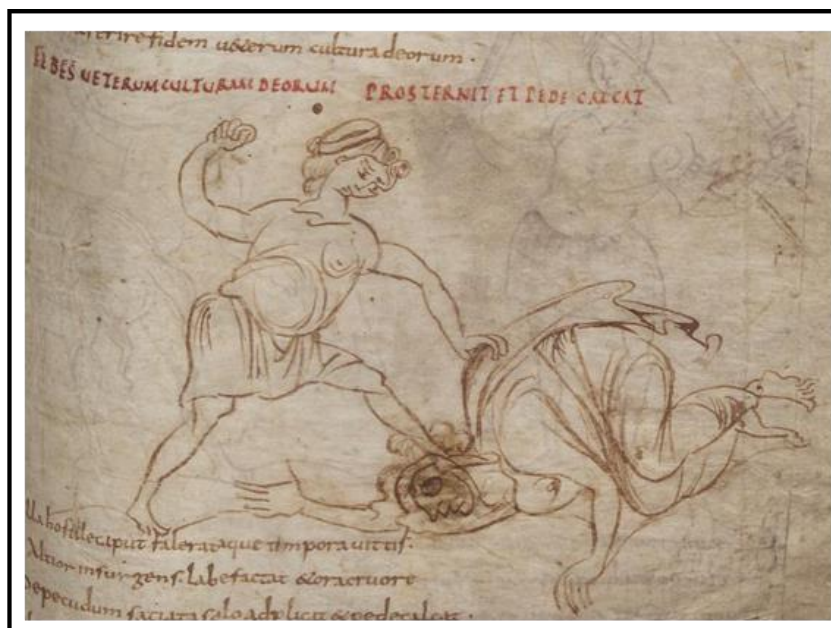

Burm.Q.3, fol. 123r. Siglo IX.

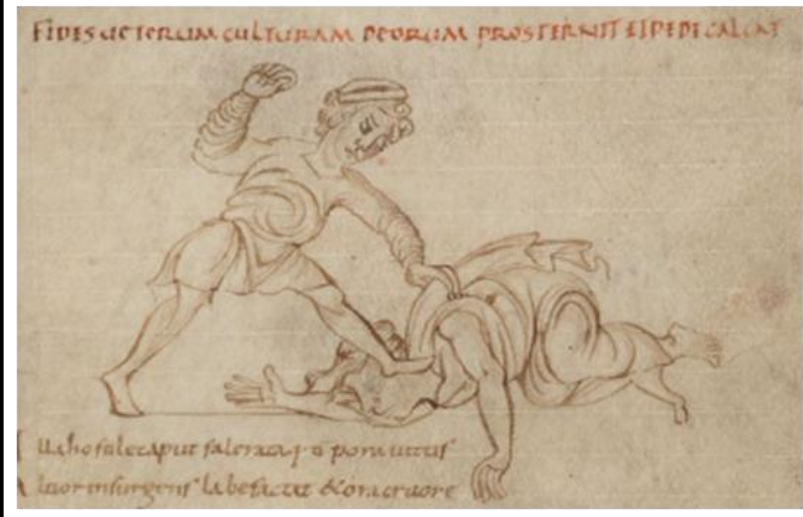

Ms. 9987-91, fol. 103r. Siglo IX.

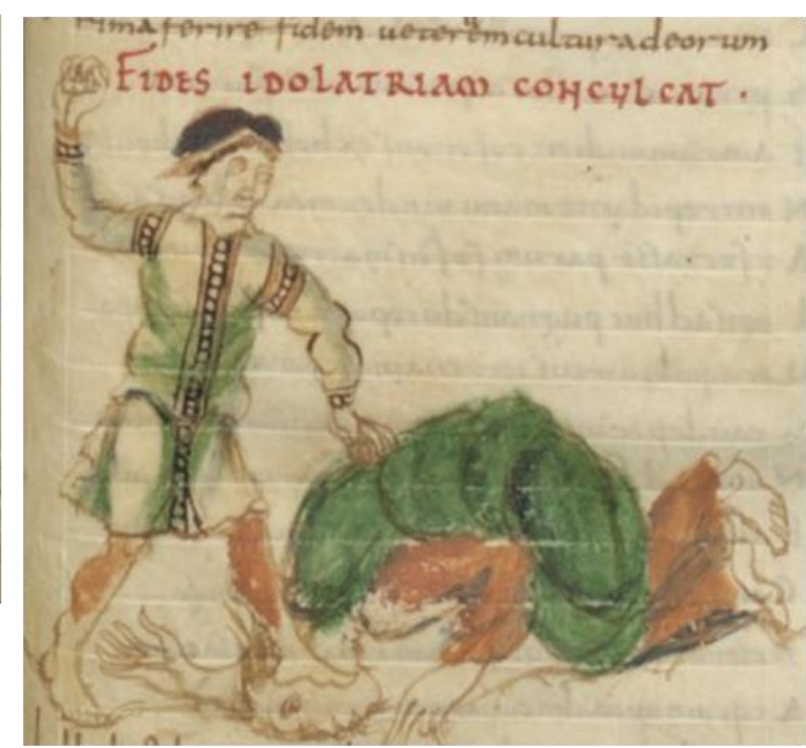

Ms. Lat. 8085, fol. 57r. Siglo IX.

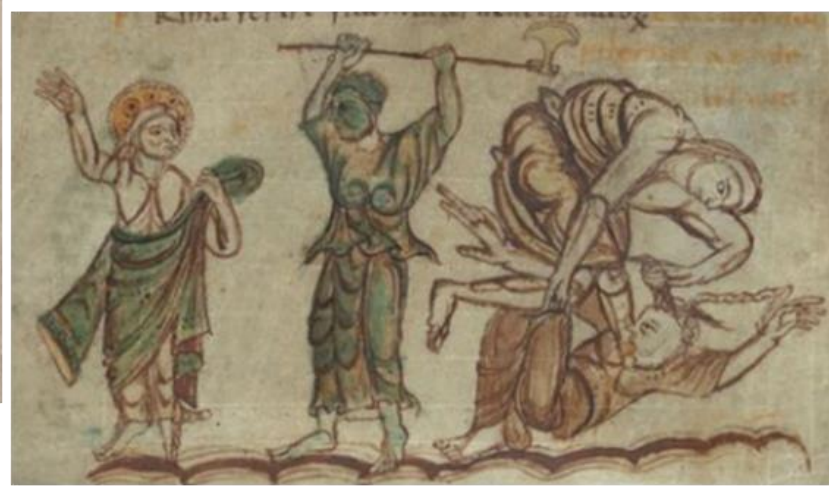

Ms. 10066-77, fol. 115v. Siglo X.

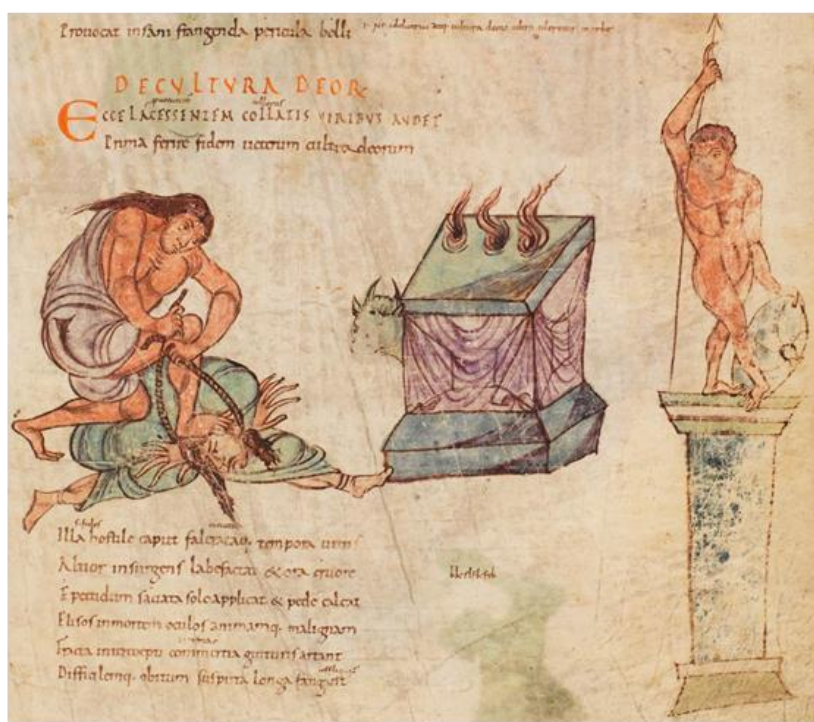

Cod. 264, pág. 69. Siglo X.

Miniatura 9. Fides derriba y destroza a Cultura deorum 


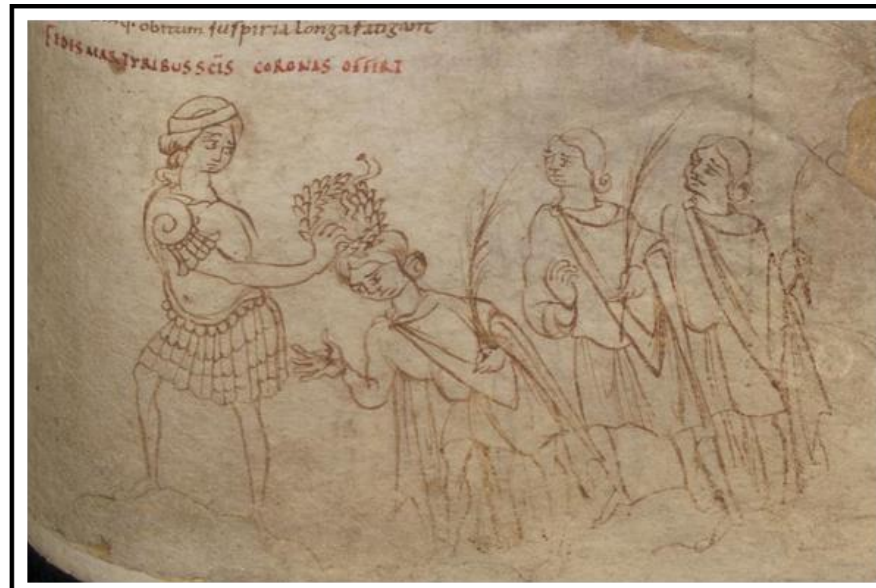

Burm.Q.3, fol. 123r. Siglo IX.
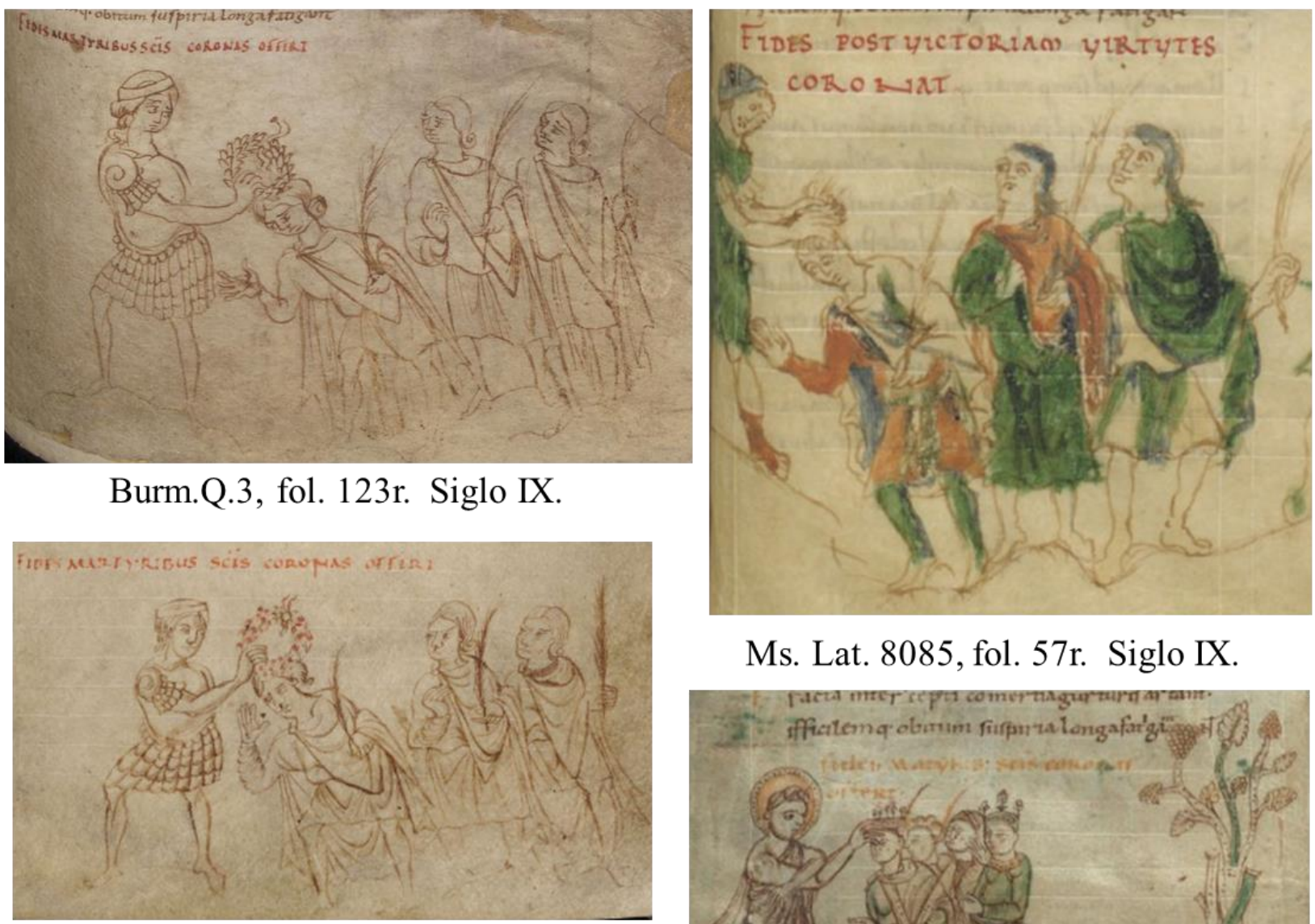

Ms. 9987-91, fol. 103r. Siglo IX.

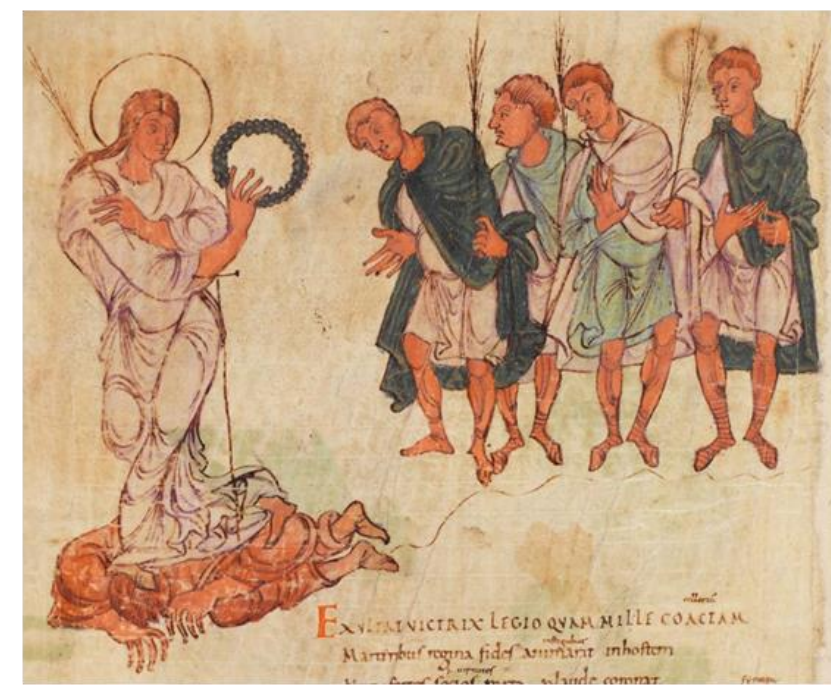

Ms. Lat. 8085, fol. 57r. Siglo IX.

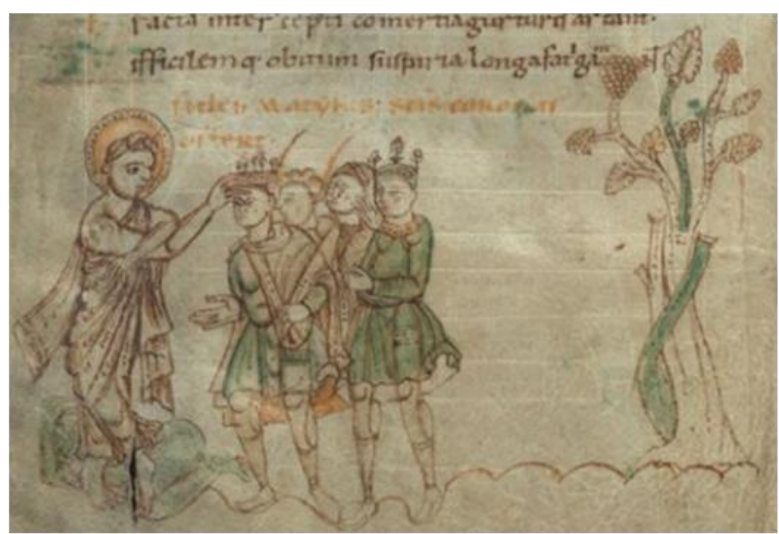

Ms. 10066-77, fol. 115v. Siglo X.

Cod. 264, pág. 70. Siglo X.

Miniatura 10. Fides corona a los mártires 
justamente sujeta al vicio y le aplasta su cabeza contra el suelo. La imagen de Ms. 10066-77 muestra el momento que le sigue, cuando Fides mientras aplasta a Cultura deorum le corta el aliento y ésta expide vapores. La miniatura recoge la noción general de los versos 21-29 en los que se narra el momento en que el vicio es derrotado y sobre todo la acción violenta de aplastar la cabeza contra el suelo.

La última escena del combate entre Fides y Cultura deorum es la victoria de la virtud (Miniatura 10). Según el poema, Fides en su júbilo corona y viste de púrpura a la legión de mil mártires que le acompañaba, y en la miniatura se representa dicho momento. En los códices 10066-77 y Cod. 264 la virtud se representa victoriosa pisoteando al vicio vencido. En otras miniaturas encontraremos imágenes similares de la victoria de las virtudes, no obstante, la forma en la que se plasmó esta escena en estos dos códices se vincula directamente con las imágenes de la Psychomachia en la escultura monumental del sur-oeste de Francia, específicamente de Saintonge y Poitou $^{87}$ (Figs. 11, 12, 13 y 14).

Sobre los atributos que se incluyen en esta última miniatura del encuentro entre Fides y Cultura Deorum, la corona es originalmente un símbolo de fama, honor, gloria y dignidad sobre todo real. Su significado se relaciona con el uso, la forma y los materiales de la misma: se coloca en la parte superior de la cabeza que en contra posición con los pies resalta el carácter trascendental, y que es doblemente realzado a través del uso del círculo, símbolo de la perfección y de los celestial y por último éstas se hacen ya sean de distintos materiales preciosos como el oro y las joyas o de materiales con carácter sacrificial como las hojas o las flores ${ }^{88}$. En las miniaturas del siglo X el significado transcendental y celestial se entiende en contraposición con el vicio muerto debajo de los pies de la virtud. El manto simboliza protección ${ }^{89}$, el color purpura antiguamente era considerado uno de los más bellos y nobles. En el imaginario cristiano medieval representaba la unión de lo terrenal y lo celestial, las

\footnotetext{
${ }^{87}$ KatZenellenbogen. Allegories of the Virtues and Vices in Mediaeval Art..., p. 15.

${ }^{88}$ HeINZ-MoHR, Gerd. Lessico di iconografia cristiana. Milán: Istituto di Propaganda Libraria, 1995. p. 116.

${ }^{89}$ HeINZ-MOHR. Lessico di iconografía..., p. 215.
} 
dos naturalezas de Cristo $^{90}$. El uso de las coronas y el manto purpura, en el texto y en la imagen, es un símbolo de la victoria y el premio y protección que gozan aquellos que siguen la virtud, pero también son elementos mnemónicos que vuelven estas imágenes memorables, son en palabras de Frances Yates "coronas memorables 91 ".

Las imágenes memorables, los phantasmatas, auxilian la memoria en la medida en que estimulan emocionalmente al receptor y esto lo logran a través de la similitud de las mismas con lo real ${ }^{92}$. En éste caso se adornan la imagen de los mártires con elementos utilizados para denotar la victoria. En los manuscritos del siglo IX y en el Cod. 264 las coronas son de materiales sacrificiales, flores y hojas, descripción tomada directamente del verso 39, "coronat floribus". En el códice Ms. 10066-77 se utiliza un modelo mucho más cercano al momento histórico en el que se creó la imagen, es una corona de materiales preciosos. Si bien estos dos atributos con los que Fides premia a los mártires vuelven las imágenes de ésta y la escena en general en una percusivas, que resuena en la memoria del espectador, también evidencia que Prudencio tenía formación en retórica y conocía algunos de los principios de las mnemotecnias del mundo clásico, pues Cicerón en su definición sobre cómo construir imágenes para inscribirlas en la memoria establece que éstas se pueden embellecer por ejemplo "con coronas o vestidos purpuras ${ }^{93 "}$.

Los mártires en esta última escena se representan con su atributo por excelencia, la palma. El texto solamente indica que Fides coronó y vistió a los mártires, pero el miniaturista o los miniaturistas de los distintos códices plasmaron a estos con su atributo por excelencia el ramo de palma. Este atributo posee un carácter anagógico, simbolizando la vitoria, el acenso al renacimiento y la inmortalidad. El mismo se utiliza ya desde los primeros siglos de la cristiandad se utiliza para identificar a aquellos hombres que murieron por su $\mathrm{fe}^{94}$. Se incluyen atributos y

\footnotetext{
${ }^{90}$ HeInZ-MoHR. Lessico di iconografía..., p. 112.

${ }^{91}$ YATES. El arte de la memoria..., p. 125.

${ }^{92}$ YATES. El arte de la memoria..., p. 23.

${ }^{93}$ CICERÓN. Rhetorica ad Herennium. III, 22, 37. Edición consultada: Retórica a Herenio. trad. de S. Núñez. Biblioteca Clásica Gredos, 244. Madrid: Gredos, 1997.

${ }^{94}$ HeINZ-MOHR. Lessico di iconografía..., p. 259.
} 
cualidades cuyas nociones y significados se encuentran bien establecidos cultural y socialmente para plasmar al mártir ${ }^{95}$.

La palma no es el único atributo que se utiliza en estas miniaturas cuyo uso y función dentro del contexto que se estudia está muy bien establecido. En las miniaturas de Ms. Lat. 8085, Ms. 10066-77 y Cod. 264 Fides lleva nimbo, claramente un atributo añadido por el iluminador, pero muy certero para ésta virtud. El poema no menciona el mismo, por lo que se puede deducir que el uso de este atributo resalta la cualidad divina de Fides, después de todo esta es una de las virtudes teologales las cuales sólo pueden ser adquiridas por los hombres a través de la gracia divina. En el manuscrito parisino la primera representación de Fides es distinta a las otras, se le representa con una túnica larga y un manto, que a priori recuerda un poco a la figura de Jesús. En el manuscrito belga del siglo X la asimilación de esta virtud con la figura de Jesús es más obvia. A diferencia del resto, en este códice Fides se representó cuatro veces, la primera miniatura del combate se repitió en el folio subsiguiente. En la imagen que introduce al espectador al poema y al combate entre Fides y Cultura deorum (Miniatura 8), esta virtud se plasmó como una figura andrógina: en su pecho desnudo se dibujaron un par de pechos, pero a la misma vez lleva barba. Una posible explicación sobre este añadido particular a esta única miniatura es que la misma fue dibujada por alguno de los usuarios del manuscrito amparado a la noción paulina de que Jesús es quien trae la obediencia de la $\mathrm{fe}^{96}$.

\subsubsection{Pudicitia vs. Libidinem}

Entre los versos 40 al 108 se recoge el combate entre Pudicitia y Libidinem. Intercalados entre los distintos versos se encuentran seis miniaturas que corresponden a distintos momentos de la batalla: el inicio en el que Libidinem trata de herir a Pudicitia, dos miniaturas que recogen como la virtud se defiende y da muerte al vicio, la virtud increpando o reprendiendo al vicio vencido y dos escenas más que ilustran

\footnotetext{
${ }^{95}$ Belting. Antropología de la imagen..., pp. 23-25. WARBURG. Atlas Mnemosyne..., pp. 3-4.

${ }^{96}$ Romanos 16: 25-27.
} 
cuando Pudicitia lava y purifica su espada en el río Jordán y la ofrece y consagra al templo (Miniaturas 11, 12, 13, 14, 15, y 16). En la primera miniatura de este combate se comienzan a representar las distintas virtudes como guerreras: con armaduras y cascos, similares a los de los soldados romanos ${ }^{97}$. En la miniatura que introduce el combate, Pudicitia aparece con su armadura dispuesta a combatir y Libidinem la ataca con su tea flamante tal y como indican los versos 40 al 45 (Miniatura 11). Si bien la composición de las cinco imágenes es similar: la virtud armada se encuentra a la izquierda y desde la derecha se aproxima el vicio, en los códices del siglo X las armas de las combatientes cambian. La virtud se protege de las teas con un escudo, según Stettiner el escudo es un Amazonenschild (escudo de amazonas) ${ }^{98}$. Este tipo de escudo era utilizado por los peltastas tracios y durante el Renacimiento se empleó en las imágenes de amazonas, motivo por que se conoce como Amazonenschild ${ }^{99}$. El uso de este tipo de escudo explica las armas que porta Pudicitia, las tres lanzas que lleva en la mano izquierda, pues como parte de su armamento dado lo liviano del escudo peltastas, los guerreros podían sujetar un puñado de lanzas o jabalinas ${ }^{100}$. Además de la virtud, el vicio Libidinem también se representa distinta. En las miniaturas de Ms. 10066-77 y Cod. 264 ésta lleva tres teas en lugar de una. Este cambio Stettiner lo atribuye a un error en los versos en los que se describen las armas de Libidinem en estos dos manuscritos ${ }^{101}$. Los miniaturistas de estos dos códices en las dos subsiguientes miniaturas, la 12 y 13, plasmaron las armas de las combatientes de esta manera.

La miniatura 12 recoge visualmente los versos 46 al 49, dependiendo el manuscrito se representa momentos específicos narrados en los versos. En estos se narra cómo Pudicitia golpea con una roca la mano derecha de Libidinem y la antorcha con la que el vicio intentaba atacar a la virtud cae. En los manuscritos del siglo IX la parte pasó a ser el todo y además de la antorcha en el suelo, también el vicio ha sido

\footnotetext{
${ }^{97}$ KATZENELLENBOGen. Allegories of the Virtues and Vices in Mediaeval Art..., p. 7.

${ }^{98}$ STETTINER. Die Illustrierten Prudentiushandschriften..., p. 245.

${ }^{99}$ STÜCKELBERG, Ernst Alfred. Das Wappen in Kunst und Gewerbe. Zúric: E. Cotti, 1901. p. 70.

${ }^{100}$ BEST, Jan. G.P. Thracian Peltasts and their Influence on Greek Warfare. Groninga: WoltersNoordhoff, 1969. pp. 3-4.

${ }^{101}$ STETTINER. Die Illustrierten Prudentiushandschriften..., pp. 244- 245.
} 
derribado. En los códices del siglo X, Ms. 10066-77 y el Cod. 264, se plasma el momento en que Libidinem es golpeada por la roca, y la antorcha y ésta son derribadas. En estos dos ejemplos este instante de la acción es sumamente gestual y sobre todo dramático: la virtud extiende sus manos para lanzar la roca y el vicio se retuerce y encoge en posición fetal. A diferencia de las imágenes del siglo IX, en estas dos la virtud se representa con túnica larga. En el códice belga, 10066-77, no lleva armadura y en el Cod. 264 sí.

Los tituli que anteceden las distintas miniaturas ya discutidas, la 11 y 12, más que describir la acción plasmada en el poema describen a la misma miniatura. En los mismo se utiliza el verbo percutio, golpear, herir, tocar, matar, impresionar. Incluso entre los posibles significados de este verbo se encuentra: hacer una impresión en la mente, tocar, agradar, deleitar, asombrar y conmocionar. El título además de indicar la acción de ambas guerreras, también denota la intención de la imagen: inscribirla en la mente del lector a través de la vigorosidad de la misma, lo que vuelve al título y a la miniatura en una imagen memorable ${ }^{102}$.

La vigorosidad se relaciona directamente con las acciones recogidas ya sea en el título de la imagen o en ésta en sí. En los cinco códices, el texto de la Psychomachia se copió primero y luego se añadieron los tituli y las miniaturas, en Ms. 10066-77 y Cod. 264 se conserva integro el texto del poema, pero no se llegaron a realizar todas las miniaturas como bien se aprecian en varios folios. Woodruff y Stettiner trataron de establecer que se elaboró primero, los tituli o las miniaturas. Woodruff se cuestiona si los títulos de las imágenes pudieron ser escritos por el iluminador o incluso por una tercera mano que no era ni la del copista ni la del miniaturista. En el caso de Ms. Lat. 8085, ésta afirma que se copió el texto, luego las miniaturas y por último se inscribieron los tituli ${ }^{103}$. Si bien este es el caso para el códice parisino, para el resto de los manuscritos no queda tan claro. Lo que si se percibe es una intención por parte de la mano o las manos que elaboraron los títulos de la miniatura 12 en la

\footnotetext{
${ }^{102}$ CARruthers. The Book of Memory..., p. 133.

103 WoOdRUFF. "The Illustrated Manuscripts..., p. 58. STETTINER. Die Illustrierten Prudentiushandschriften..., p. 40.
} 


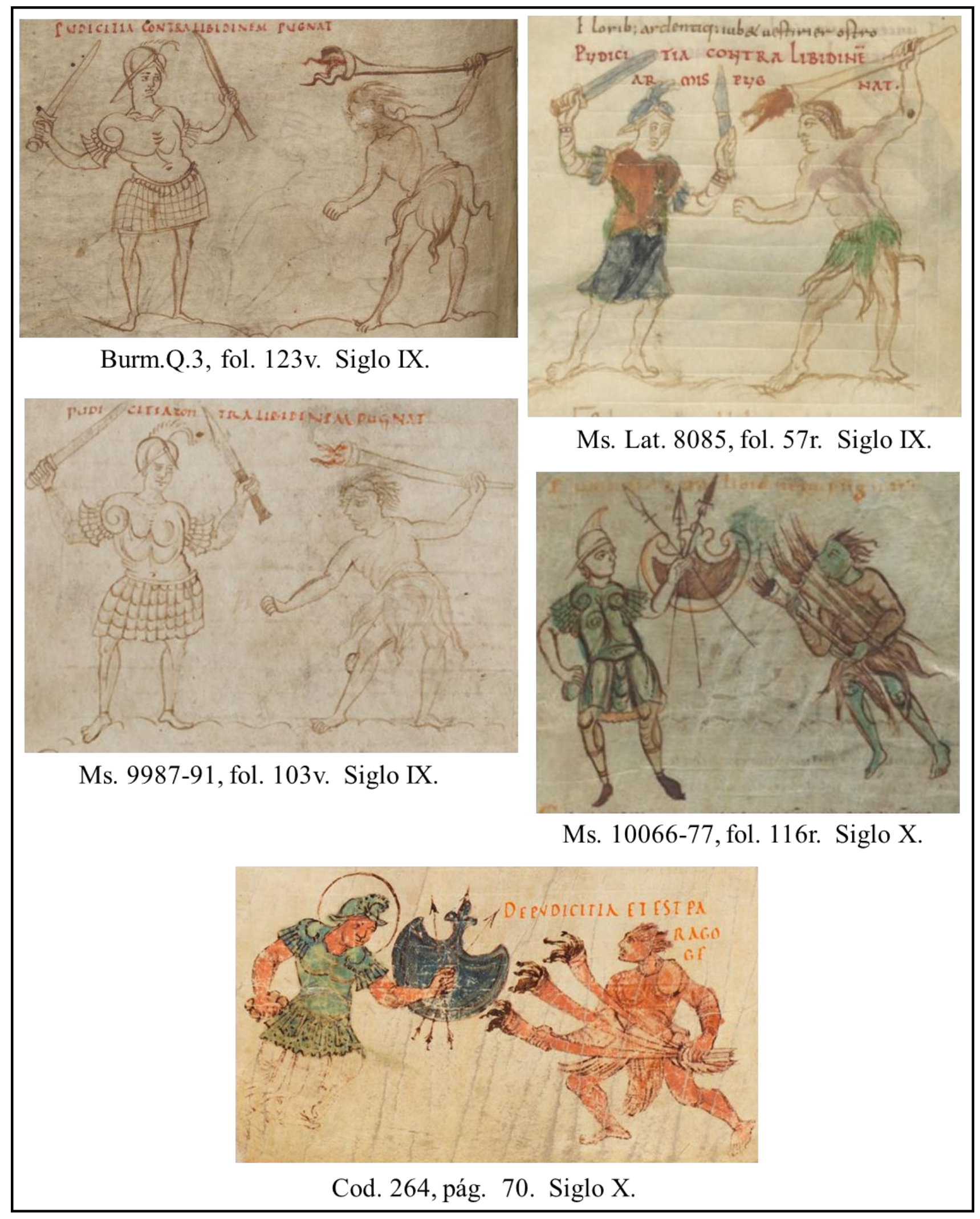

Miniatura 11. Combate de Pudicitia y Libidinem 


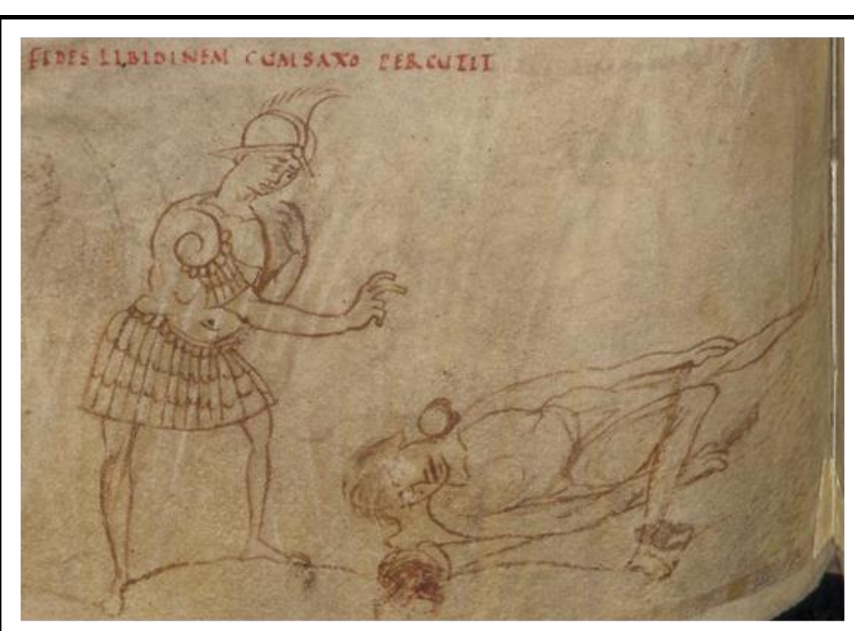

Burm.Q.3, fol. 123v. Siglo IX.

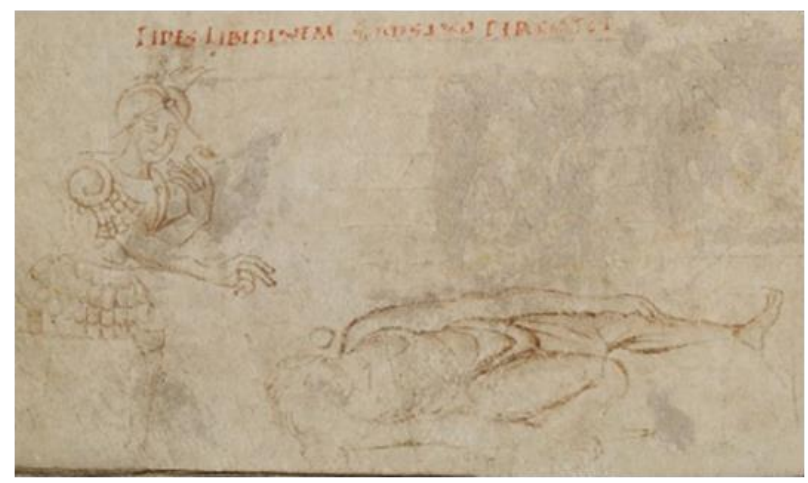

Ms. 9987-91, fol. 103v. Siglo IX.

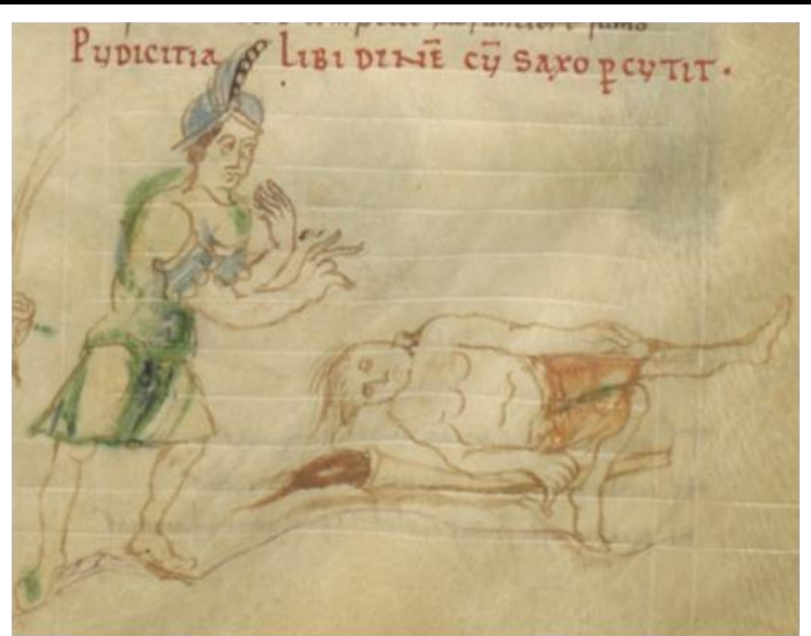

Ms. Lat. 8085, fol. 57r. Siglo IX.

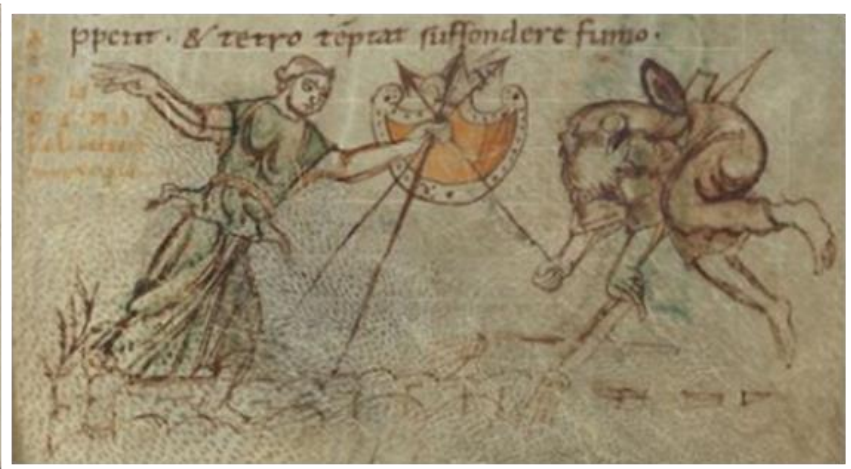

Ms. 10066-77, fol. 116r. Siglo X.

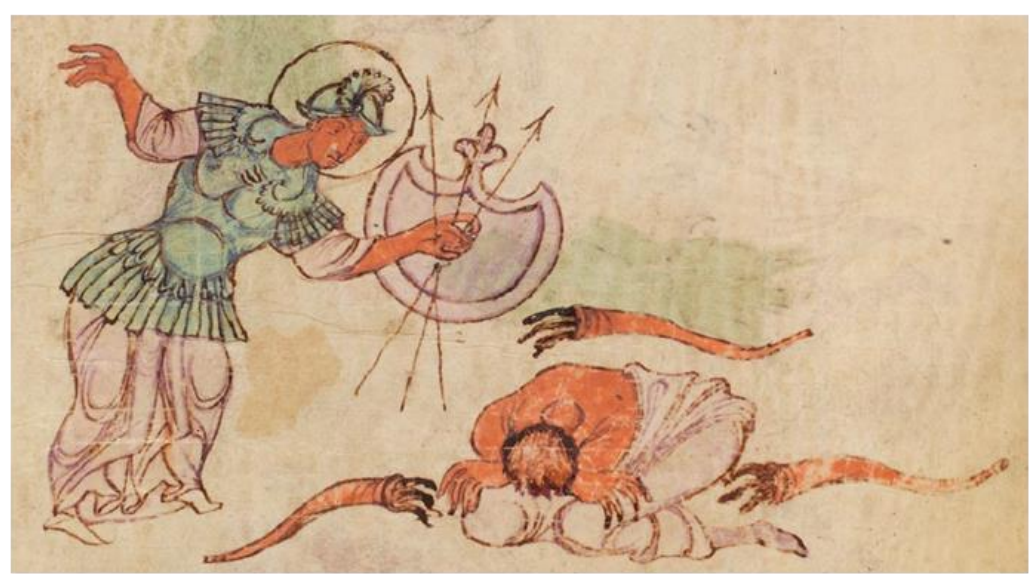

Cod. 264, pág. 71. Siglo X.

Miniatura 12. Pudicitia golpea con una piedra a Libidinem 
que Pudicitia golpea con una piedra a Libidinem, estos optaron por una escena cuya acción en cierto modo exagera la acción narrada en el poema de golpear con una piedra la mano de Libidinem. El uso de las hipérboles contribuye a inscribir en la memoria aquello que se desea recordar, siendo un principio elemental de las mnemotecnias ${ }^{104}$. La hipérbole en este caso no sólo se limita al aspecto literario, sino que también es pictórica sobre todo en las escenas de los manuscritos del siglo $\mathrm{X}$ donde el gesto del vicio apedreado se exagera. Libidinem al ser apedreada deja caer las antorchas y se retuerce.

La miniatura 13 se limita a plasmar gráficamente, a recoger el ad res, de las acciones de los versos 50 al 52. Pudicitia atraviesa con su espada la garganta de Libidenm y ésta vomita sangre. La composición de las imágenes del siglo IX es distinta a las del siglo X. En las tres primeras la virtud se representó al lado izquierdo, inclinada clavando su espada en la cien del vicio muerto. Las iluminaciones de Ms. 10066-77 y Cod. 264 se intercambiaron, en estos dos la virtud se plasmó en el lado derecho y en lugar de inclinarse, pareciera más como si arrematara contra el vicio muerto. La imagen se plasma con mucha crudeza. En todos los manuscritos de la herida y la boca de Libidinem brota sangre. En los manuscritos monocromos, Burm.Q.3 y Ms. 9987-91 se utilizó el color rojo para resaltar la sangre. En Ms. Lat. 8085 y Ms. 10066-77 la imagen del vicio se afeó coloreando el rostro de ésta verde. Estas no son las únicas miniaturas en el poema en el que se resalta la presencia de la sangre o se utiliza el verde para exaltar y asemejar al vicio con un monstruo. Imágenes mnemónicas de los vicios y pecados resultan más fácil de desfigurar que las de las virtudes ${ }^{105}$ y a través de las distintas miniaturas de los cinco códices esto se constata. Si bien el poema indica la presencia de la sangre, la presencia del verde es un añadido del miniaturista. Ambos elementos son mencionados por Cicerón y posteriormente por otros autores como cualidades que hacen de una imagen una memorable, especialmente si estas figuras humanas se encuentran "comprometidas dramáticamente en alguna actividad ${ }^{106}$ ". El dramatismo de esta escena en el códice

\footnotetext{
${ }^{104}$ CARRUTHERS. The Craft of Thought..., p. 117.

${ }^{105}$ RIVERS. Preaching the Memory..., p. 310.

${ }^{106}$ YATES. El arte de la memoria..., p. 23
} 
belga Ms. 10066-77 sobrepasa el del resto de los ejemplos, no sólo por el uso del color en la sangre o para exaltar la fealdad de Libidinem, sino también por la manera en la que las acciones se plasmaron. El vicio lucha por su vida, brazos y piernas extendido y en el mismo instante Pudicitia atraviesa con su espada la nuca de Libidinem, y el fierro sale por la boca de su enemiga.

Tres miniaturas más completan el combate entre Pudicitia y Libidinem. La miniatura 14, Pudicitia reprende a Libidinem, antecede los versos 53-98. Ésta plasma las palabras del verso 53, "exclamat victrix regina". En el texto se utiliza un verbo que expresa la acción de gritar o de "emitir palabras con fuerza o vehemencia para expresar la viveza de un afecto o para dar vigor y eficacia a lo que se dice ${ }^{107}$ ". Sin embargo, en los tituli de los cinco códices se utilizó el verbo increpo, un verbo cuya acción igualmente es la de pronunciar palabras, pero cuyo matiz es distinto. El verbo de los títulos alude al acto de reprimir, reprender o corregir con dureza o severidad y los gestos de Pudicitia aluden a dicha acción, a la de aquel que increpa a alguien. En los manuscritos del siglo IX el gesto de la virtud es un tanto vago, ésta apenas eleva sus manos, una con la palma abierta, y se dirige hacia el vicio vencido tendido en el suelo. En los ejemplos del siglo X el gesto de Pudicitia es más claro: ésta eleva y apunta con su dedo índice, otorgándole a estos dos casos un carácter imperativo, gesto que no sólo manifiesta visualmente la reprimenda de la virtud, sino también su autoridad de Pudicitia sobre Libidinem ${ }^{108}$. En las miniaturas del siglo X la virtud mientras increpa sujeta sus armas. Ésta conserva las tres lanzas ya representadas en las miniaturas 11, 12 y 13, sin embargo, el escudo ha cambiado. No se plasmó el escudo peltastas, sino que vemos un escudo redondo que se continuará utilizando en el resto de las iluminaciones de estos dos códices.

${ }^{107}$ Definición del verbo exclamar tomada del Diccionario de la Real Academia Española de la Lengua. "exclamar", en: Rae.es. Disponible en: http://dle.rae.es/?id=HCXFu0g [Consulta: 21/noviembre/2016]

${ }^{108}$ GARNIER. Le langage de l'image au Moyen Âge (I)..., pp. 167-168. 


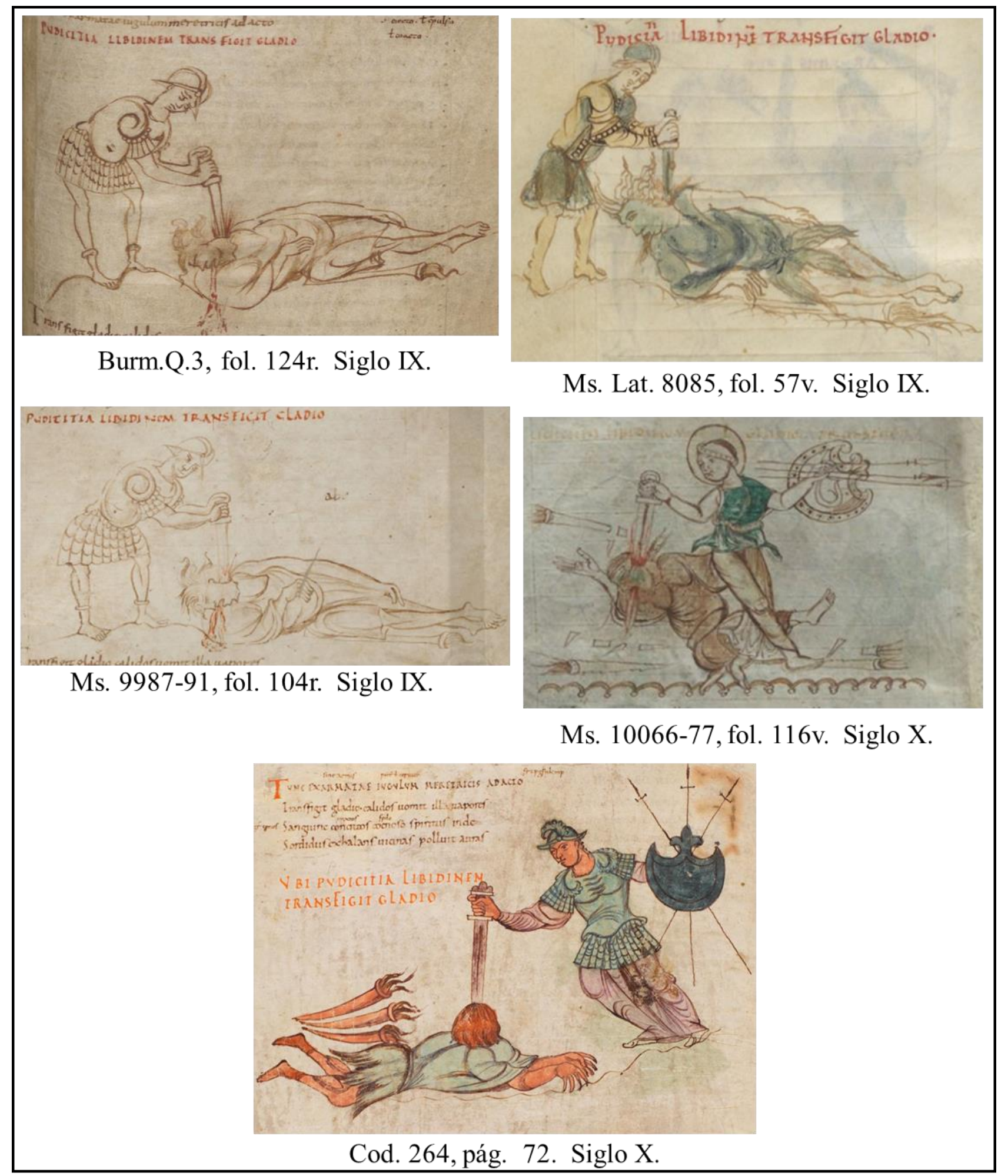

Miniatura 13. Pudicitia atraviesa con su espada la garganta de Libidinem 


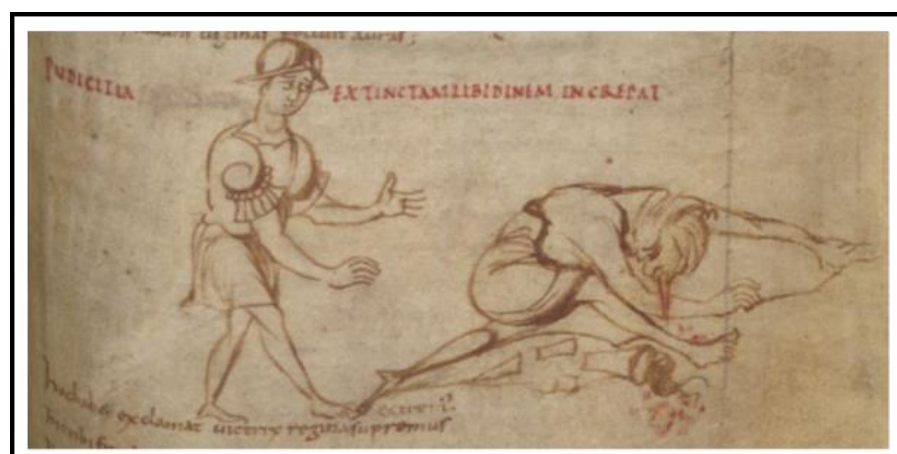

Burm.Q.3, fol. 124r. Siglo IX.

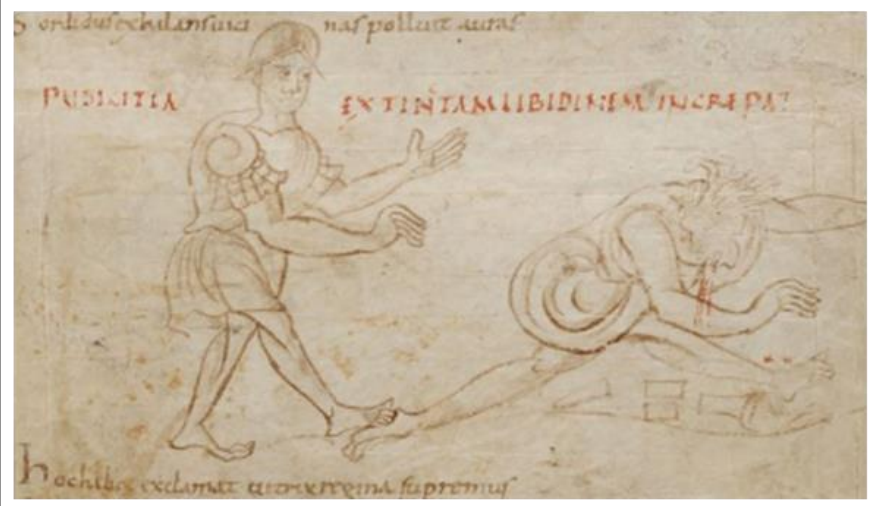

Ms. 9987-91, fol. 104r. Siglo IX.

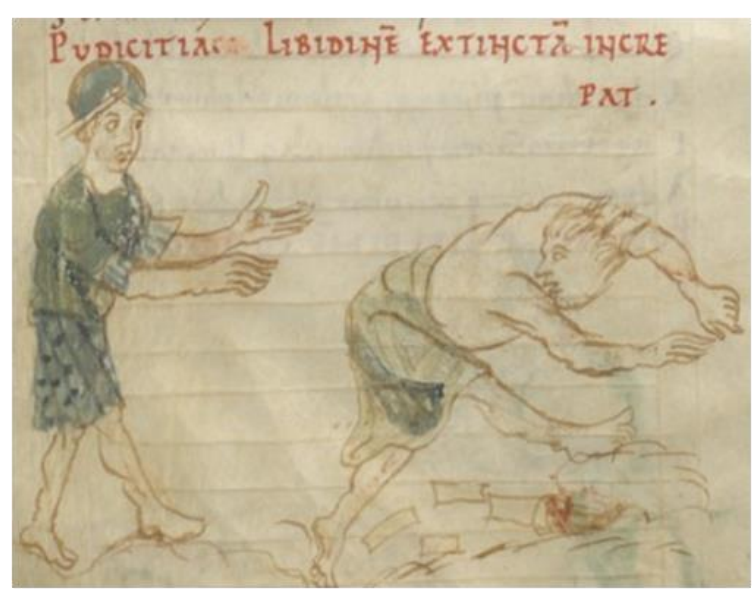

Ms. Lat. 8085, fol. 57v. Siglo IX.

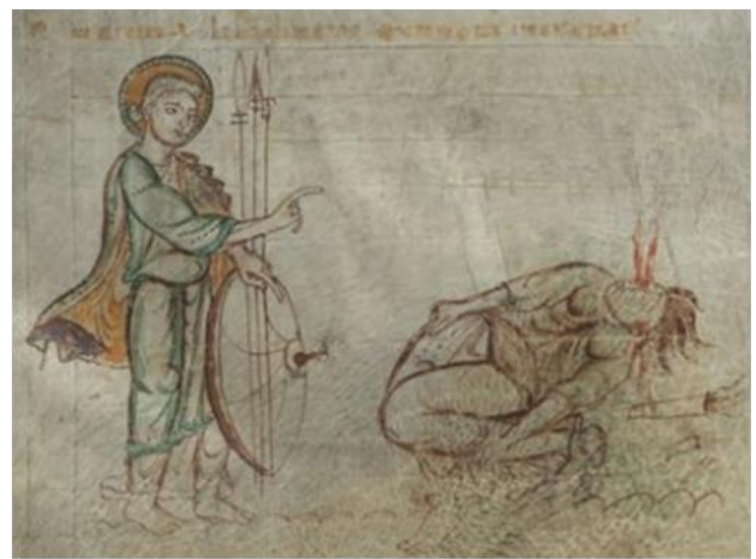

Ms. 10066-77, fol. 116v. Siglo X.

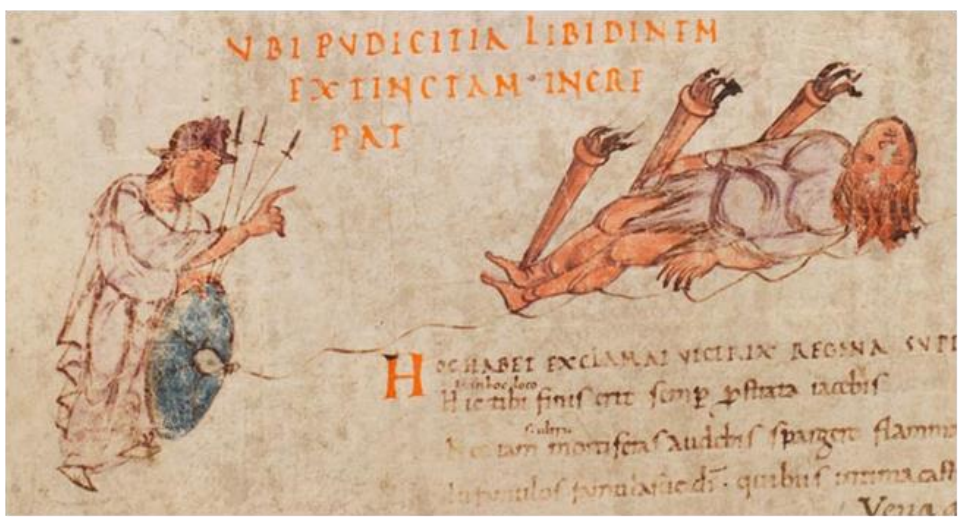

Cod. 264, pág. 72. Siglo X.

Miniatura 14. Pudicitia reprende a Libidinem 
De los cuarenta y cinco versos que siguen a la miniatura de Pudicitia increpando a Libidinem sólo uno se relaciona con la imagen plasmada, el 53: "exclamant victrix regina" (exclama triunfante la reina). El resto consiste en las palabras que la virtud dirigió al vicio vencido. El gesto de Pudicitia acompañado por un verbo que designa la acción de pronunciar palabra se puede apreciar en muchas otras miniaturas del poema, específicamente en aquellas en las que las virtudes reprenden a los vicios vencidos como un indicativo de que se están enunciando litterae. Al igual que en las miniaturas con la efigie del autor, en las distintas escenas en las que las victoriosas virtudes reprochan a los vicios aparecen títulos que clarifican la imagen. En los manuscritos aquí estudiados por lo general se ha inscrito el nombre de la virtud acompañado del verbo increpo y ésta articula el gesto correspondiente de levantar la mano, gesto parecido al de Prudencio sobre todo en los manuscritos del siglo $\mathrm{X}$. A pesar de que el gesto de las distintas virtudes recuerda al del poeta las mismas no son invenciones del iluminador como en el caso de Prudencio, pues estas escenas y títulos han sido tomados en mayor o menor grado directamente del texto. En cada discurso el texto indica que es la virtud tal o cual la que pronuncia la amonestación, por lo tanto, cuando estas escenas eran leídas los receptores tenían muy claro quién era quien hacia el reproche.

El gesto y el verbo increpo utilizados en esta miniatura es un recurso mnemónico que da vigorosidad a la imagen, pero esta no es la única mnemotecnia empleada en esta miniatura. La imagen en la que Pudicitia pronuncia su discurso (Miniatura 14) sirve como un lugar mnemónico de recopilación para otras historias y textos los cuales se asocian entre sí1 ${ }^{109}$. El resto de los versos narran distintas historias bíblicas tomadas del Antiguo y Nuevo Testamento al igual que elementos dogmáticos. Se exaltan la victoria de Judit sobre Holofernes, la inmaculada concepción y virginidad de María, y la doble naturaleza de Jesús. Pudicitia, la figura alegórica de la castidad, se asocia entonces con mujeres ejemplares portadoras y defensoras de esta virtud, como así lo afirma el verso 65, "haciéndose audaz vengadora mía con ayuda del cielo". Judit es una prefiguración de la Virgen e

${ }^{109}$ CARRUTHERS. The Craft of Thought..., p. 19. 
igualmente es símbolo de la castidad y la humildad ${ }^{110}$. Holofernes encarna a la lujuria y el orgullo ${ }^{111}$ y en el poema Libidinem, el vicio del deseo carnal, es vencido de la misma forma: degollado.

Las dos siguientes miniaturas también sirven como lugares, o en este caso imágenes, de recopilación. En la miniatura 15, Pudicitia lava su espada en el río Jordán, se plasma dicha acción al mínimo detalle: la espada manchada con la sangre del vicio derrotado y las aguas del río Jordán. El título de ésta incluso se utiliza el verbo lavo, lavar, recogiendo así la acción a priori. En el poema se utiliza abluo que además de lavar también indica purificar. La virtud lava y sobre todo purifica su espada en el río Jordán para borrar con el bautizo la mancha que había dejado la sangre de Libidinem ${ }^{112}$. Carruthers entiende que la Psychomachia se configura en catenae en donde una escena o elemento se vincula y a la misma vez introduce el siguiente $^{113}$. El origen de los conceptos de virtudes, pero sobre todo de los vicios parte de la concatenación de estos donde la práctica de un vicio principal se torna en terreno fértil para que otros emerjan ${ }^{114}$. La imagen de lavar y purificar en el río Jordán remite el bautismo de Jesús.

En los manuscritos del siglo IX el río se representa como agua brotando de una urna (Miniatura 15). Se utilizó un tema iconográfico conocido procedente de la antigüedad, la personificación de los ríos. En el arte cristiano ya tan temprano como en el siglo IV se encontraban personificaciones de los ríos, incluso del Jordán ${ }^{115}$. El tema igualmente se utilizó en el arte carolingio y uno de los ejemplos más llamativos es la personificación del cuerpo de agua en el salmo 1 del salterio de Utrech. Según Sánchez Ameijeiras la personificación del río en el breviario es una figura retórica

\footnotetext{
${ }^{110}$ RÉAU. Iconografía del arte cristiano. Iconografía de la Biblia. Antiguo Testamento. Tomo 1, Vol. ..., pp. 381-382.

${ }^{111}$ RÉAU. Iconografía del arte cristiano. Iconografía de la Biblia. Antiguo Testamento. Tomo 1, Vol. ..., p. 381.

${ }^{112}$ Prudencio. Psychomachia, vv. 103-104. Obras Completas de Aurelio Prudencio..., pp. 316317.

${ }^{113}$ CARRUTHERS. The Craft of Thought..., p. 146.

${ }^{114}$ NEWHAUSER. The Treatise on Vices and Virtues..., p. 183.

${ }^{115}$ HeINZ-MoHR. Lessico di iconografía..., p. 160.
} 


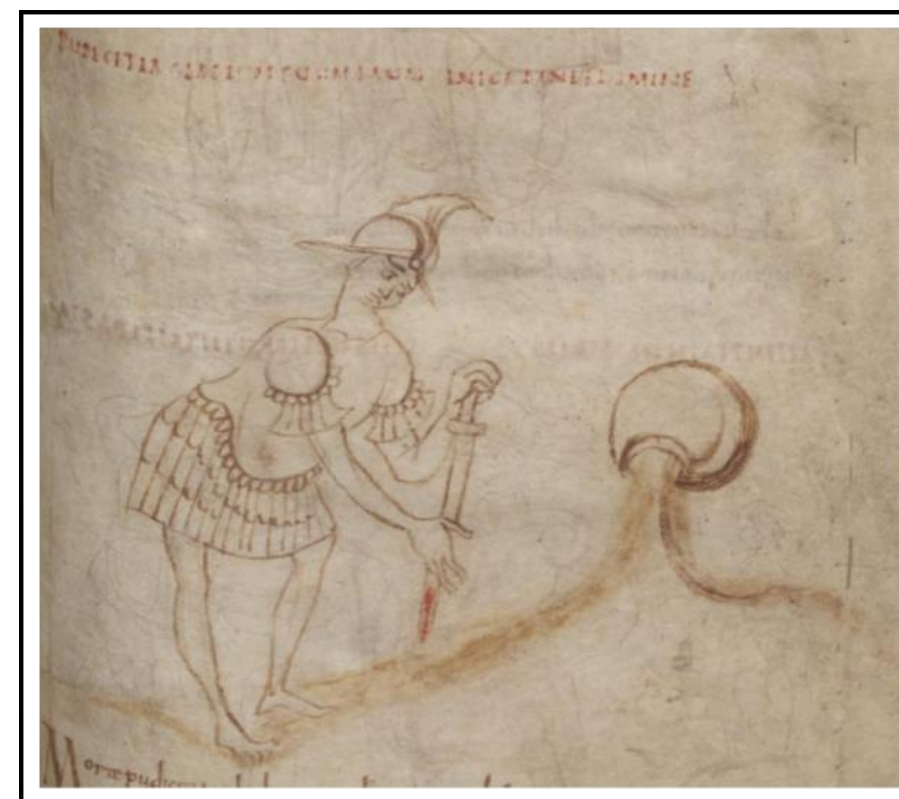

Burm.Q.3, fol. 125r. Siglo IX.

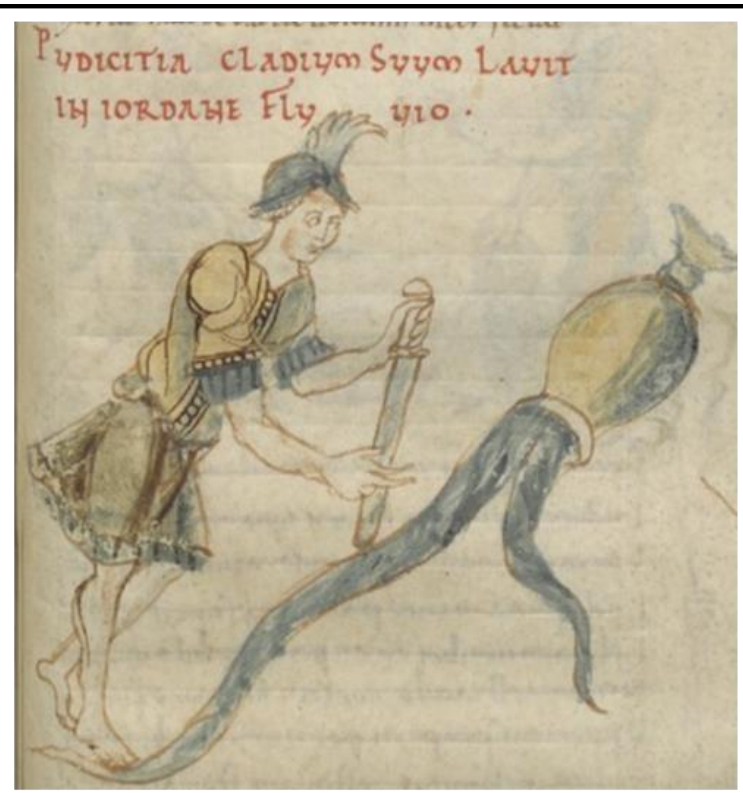

Ms. Lat. 8085, fol. 58r. Siglo IX.
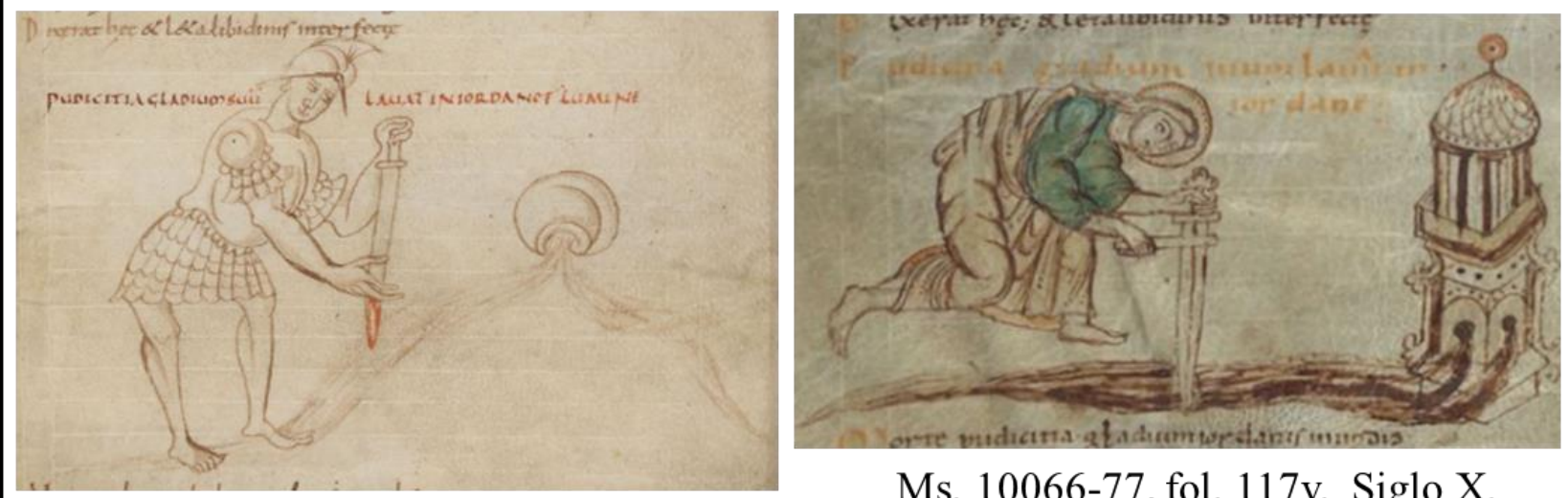

Ms. 10066-77, fol. 117v. Siglo X.

Ms. 9987-91, fol. 105r. Siglo IX.

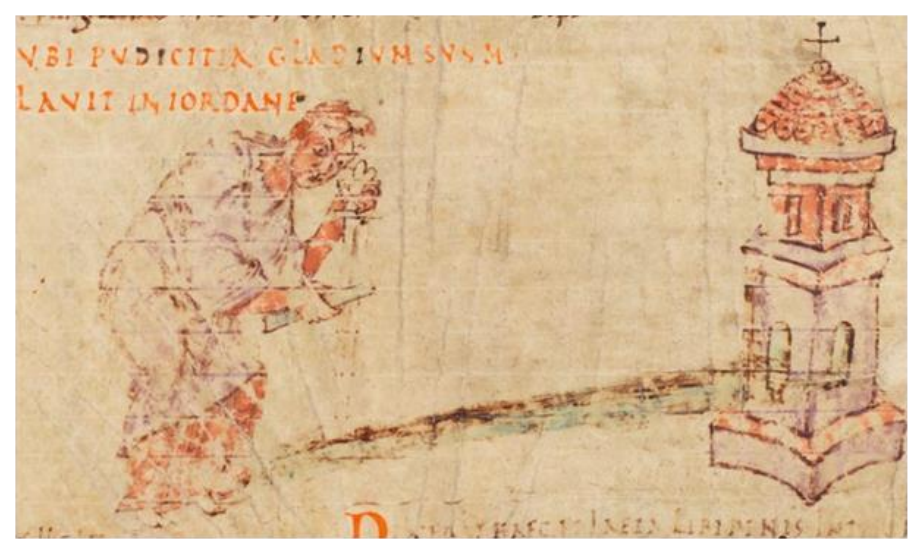

Cod. 264, pág. 74. Siglo X.

Miniatura 15. Pudicitia lava su espada en el río Jordán 


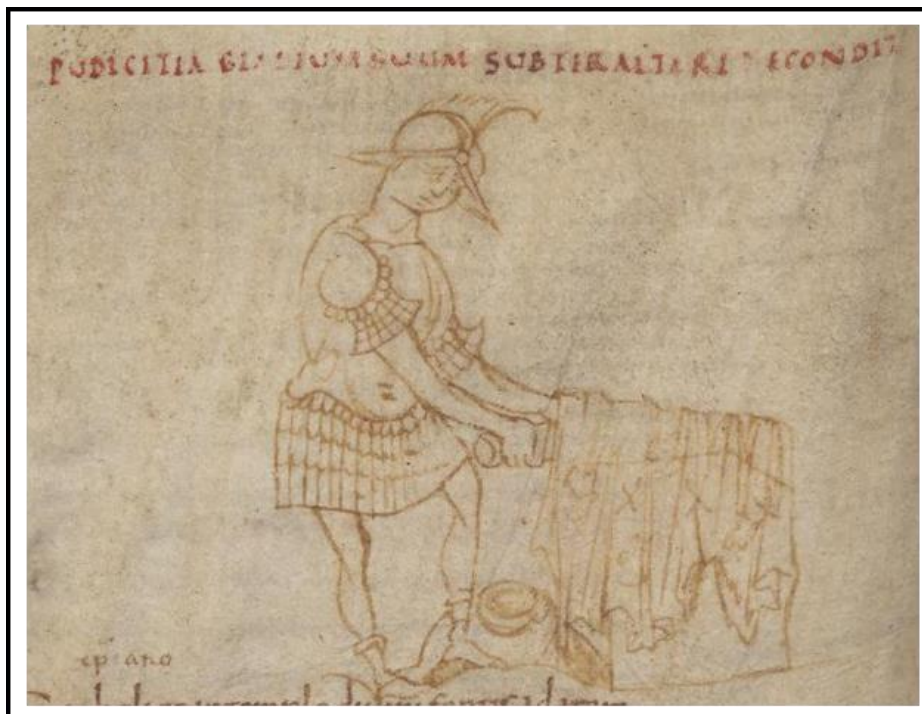

Burm.Q.3, fol. 125v. Siglo IX.

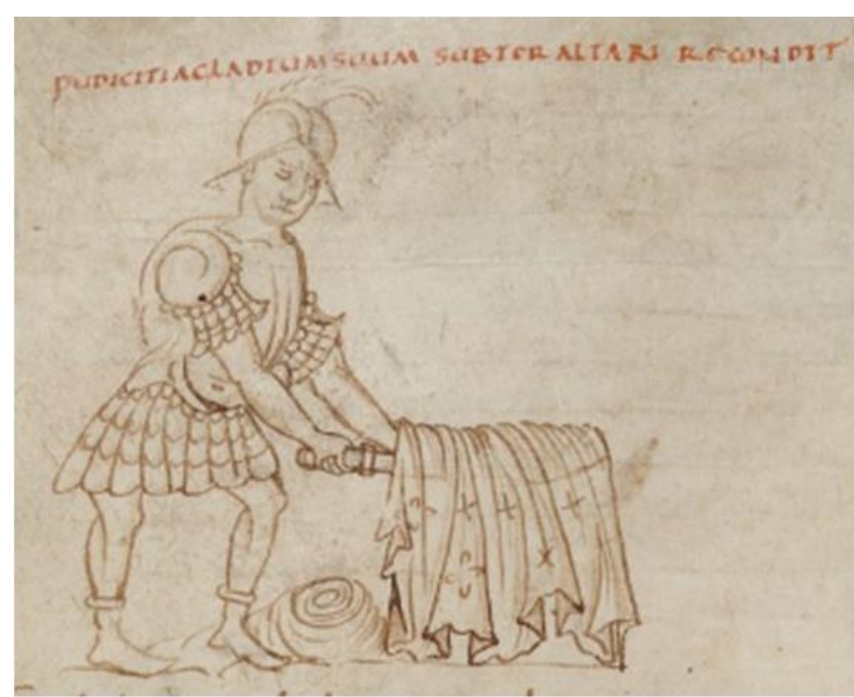

Ms. 9987-91, fol. 105v. Siglo IX.

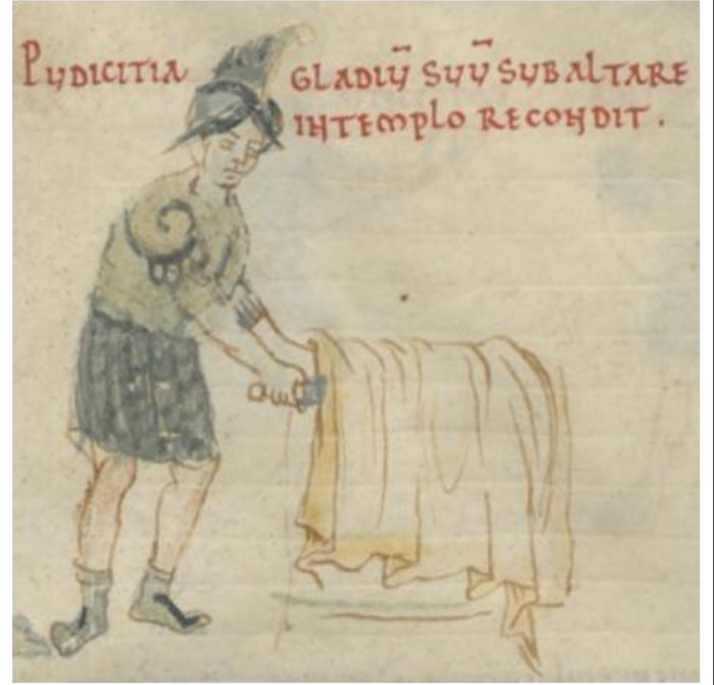

Ms. Lat. 8085, fol. 58r. Siglo IX.

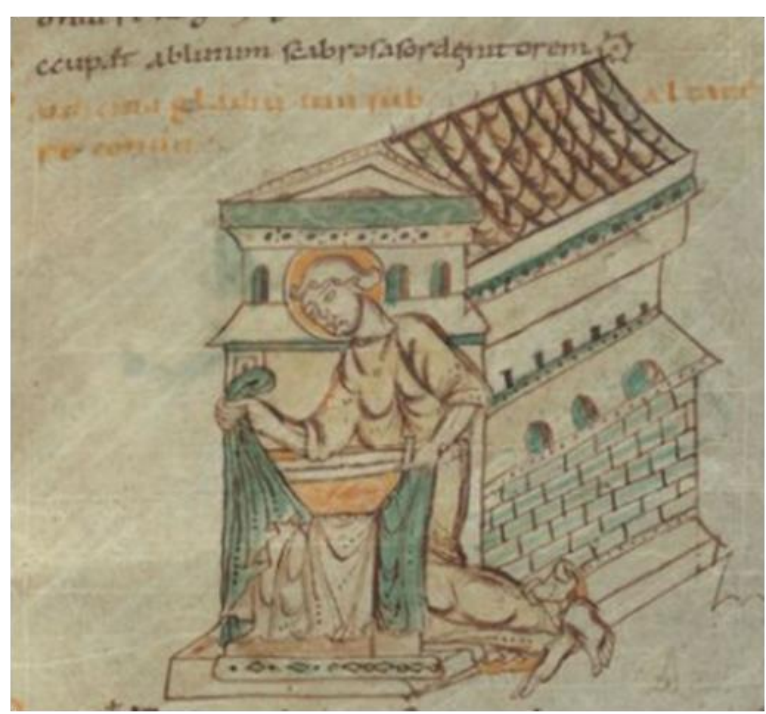

Ms. 10066-77, fol. 118r. Siglo X.

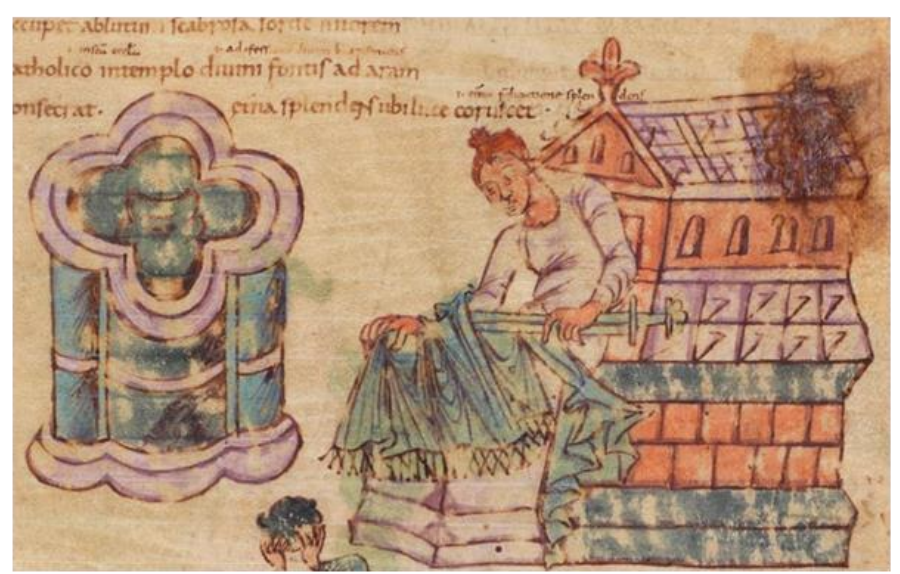

Cod. 264, pág. 75. Siglo X.

Miniatura 16. Pudicitia enfunda su espada y la consagra al templo 
trasladada visualmente y por medio de las mismas además de acceder al sentido alegórico, moral o místico igualmente permiten desentrañar otros sentidos del texto ${ }^{116}$. En los códices del siglo X la plasmación del cuerpo de agua cambió y ahora la urna ha pasado a ser una torre, recordando a una fuente de la que brota el agua. Según Stettiner esta torre es una reminiscencia de las fuentes bautismales rematadas en cruz utilizadas en representaciones tempranas del bautismo de Cristo ${ }^{117}$. En términos mnemónicos si el acto de lavar y purificar en el río Jordán ya remitía al espectador al relato neotestamentario del bautismo de Jesús, en Ms. 10066-77 y Cod. 264 el motivo iconográfico antiguo utilizado para la administración de este sacramento confirma visualmente la relación de la imagen con el acto mismo.

En la última miniatura aparece Pudicitia, la virtud enfunda su espada y la consagra al templo poniéndola junto al altar (Miniatura 16). En ésta, al igual que la miniatura 15, también encontramos diferencias composicionales entre las imágenes del siglo IX y las del X. En las representaciones del siglo IX aparece Pudicitia colocando su espada sobre un altar y ésta queda oculta bajo un manto. En Burm.Q.3 y Ms. 9987-91 este manto se adornó con cruces. En los códices del siglo X la virtud se ha representado junto a una estructura arquitectónica, un templo de planta basilical. Delante de la edificación, la virtud coloca sobre el altar su espada y la cubre con un manto. Estas diferencias en la composición realmente recogen momentos puntuales de los dos versos sobre los que esta miniatura versa. Los elementos ornamentales de las cruces en Burm.Q.3 y Ms. 9987-91 plasman visualmente la descripción de uno de los versos: "aeterna splendens ubi luce coruscet ${ }^{118 "}$ ". De igual modo, la presencia del templo en Ms. 10066-77 y Cod. 264 se remite al verso 107: “catholico in templo divini fontis ad aram consecrat ${ }^{119}$ ". En el códice de Berna visualmente se ofrecen más detalles al espectador, pues en el mismo se dibujó incluso la fuente divina mencionada en el verso 107.

\footnotetext{
${ }^{116}$ SÁNCHEZ AMEIJEIRAS. Los rostros de las palabas..., pp. 190-191.

${ }^{117}$ STETTINER. Die Illustrierten Prudentiushandschriften..., p. 252.

118 "resplandeciente, pueda centellear con luz eternal". PRUDENCIO. Psychomachia, v. 108. Obras Completas de Aurelio Prudencio..., pp. 316-317.

119 "la consagra y pone nunto al altar de la divina Fuente en el templo católico".
} 


\subsubsection{Patientia vs. Ira}

El preámbulo, el combate y la victoria de Patientia contra Ira se narra en los versos 109 al 177. Entre estos sesenta y ocho versos se insertaron doce miniaturas en las que se utilizan los elementos antes mencionados para la creación de imágenes memorables como los vicios como seres afeados y monstruosos. En el Ms. 1006677 se vuelve una constante el representar a los vicios con los rostros verdes. Igualmente encontramos vicios con cuernos, como en la miniatura 17 de Ms. 1006677 y en los códices del siglo $\mathrm{X}$ a la virtud con nimbo.

La primera miniatura del encuentro entre Patientia e Ira, Patientia permenece tranquila entre el ejército de los vicios (Miniatura 17), se introduce a las protagonistas del combate, la misma se limita a transcribir visualmente los versos. En todos los códices en el centro de la composición, inerte, se plasmó a Patientia tal y como lo indica el verso 112 "lenta manebat" (permanecía tranquila o tenaz) que a su vez se recoge igualmente en el título de la imagen: "intrepida stat". La composición de los códices del siglo IX es sumamente similar, la virtud en el centro sobre una especie de montículo es atacada por la izquierda y la derecha por los vicios. Sin embargo, las vestiduras de los vicios en Ms. Lat. 8085 han cambiado y tres de éstas se representaron con el pecho desnudo. En los ejemplos del siglo X el número de vicios que se abalanzan sobre la virtud ha aumentado: en Ms. 10066-77 son cinco y en Cod. 264 aumentó a ocho. En este manuscrito los vestidos de las atacantes son una especie de híbrido de los modelos del siglo IX, como se puede apreciar sobre todo en la parte inferior de los camisones es muy similar a las faldas en forma de lenguas de fuego de Lat. 8085. En el códice de Berna la virtud embestida por todas partes. Este tipo de escena y composición es característico del norte, específicamente de la zona de Reims ${ }^{120}$ de donde surgió el arquetipo grupo II al que pertenecen los cinco códices aquí tratados.

Patientia, la personificación del sufrir, el soportar, el aguantar y la constancia, permanece inmóvil en el campo de batalla mientras su enemiga Ira en diversos versos

${ }^{120}$ WOODRUFF. "The Illustrated Manuscripts..., p. 60. 
y miniaturas arremata contra ella. En la miniatura 18 el vicio golpea con una pica a la virtud. Según el poema Ira desde lo lejos amenaza a Patientia y la zahiere con una pica y con su voz haciendo que el penacho de su yelmo vibre. En las miniaturas de los códices Burm.Q.3, Ms. Lat. 8085 y Ms. 9987-91se aprecia como el vicio con un objeto punzante, con la pica, golpea el yelmo de la virtud. La composición de los códices del siglo X cambia y las protagonistas se han intercambiado, el vicio ahorra arremata a la virtud desde el lado izquierdo de la composición. En el Ms. 10066-77 Ira intenta atacar a la Patientia con lo que parece ser una pértiga de madera y en Cod. 264 con un garrote y los gestos son mucho más articulados y expresivos. En el poema, se utilizan dos verbos para describir la acción de Ira. En el verso 115 lacesso, irritar, desafiar, provocar, atacar, molestar, golpear, turbar y en el 116 peto, dirigirse, atacar, amenazar. En el título de esta imagen en los cuatro manuscritos que se incluyó, se utiliza el verbo percutio, cuyo significado ya se había tratado en el combate entre Pudicitia y Libidinem, específicamente en la miniatura 12 y el principio mnemónico se aplica por igual. El individuo o los individuos encargados en copiar los tituli y hacer las miniaturas interpretaron los versos 113 al 117 según lo establece la imagen y el título: Ira golpeó con su pica el yelmo de Patientia haciendo vibrar éste. El uso de percutio entonces pudo ser deliberado. Del verbo percutit, deriva el sustantivo percussio, choque, golpe, percusión, compás o medida. En la miniatura, el golpe que le profiere Ira con la pica a Patientia en el yelmo es uno percusivo no sólo por la similitud de la imagen con la acción real sino también por su relación con la percusión. Según el verso 117 el golpe en el casco hace ruido: quatiens galeato.

Aquí encontramos una relación etimológica entre un verbo, percutit, y un sustantivo, percusio. Estas asociaciones ya eran utilizadas desde la antigüedad para formar las imágenes mentales de palabras ${ }^{121}$. En el contexto monacal y en relación

${ }^{121}$ YATES. El arte de la memoria..., p. 46. 

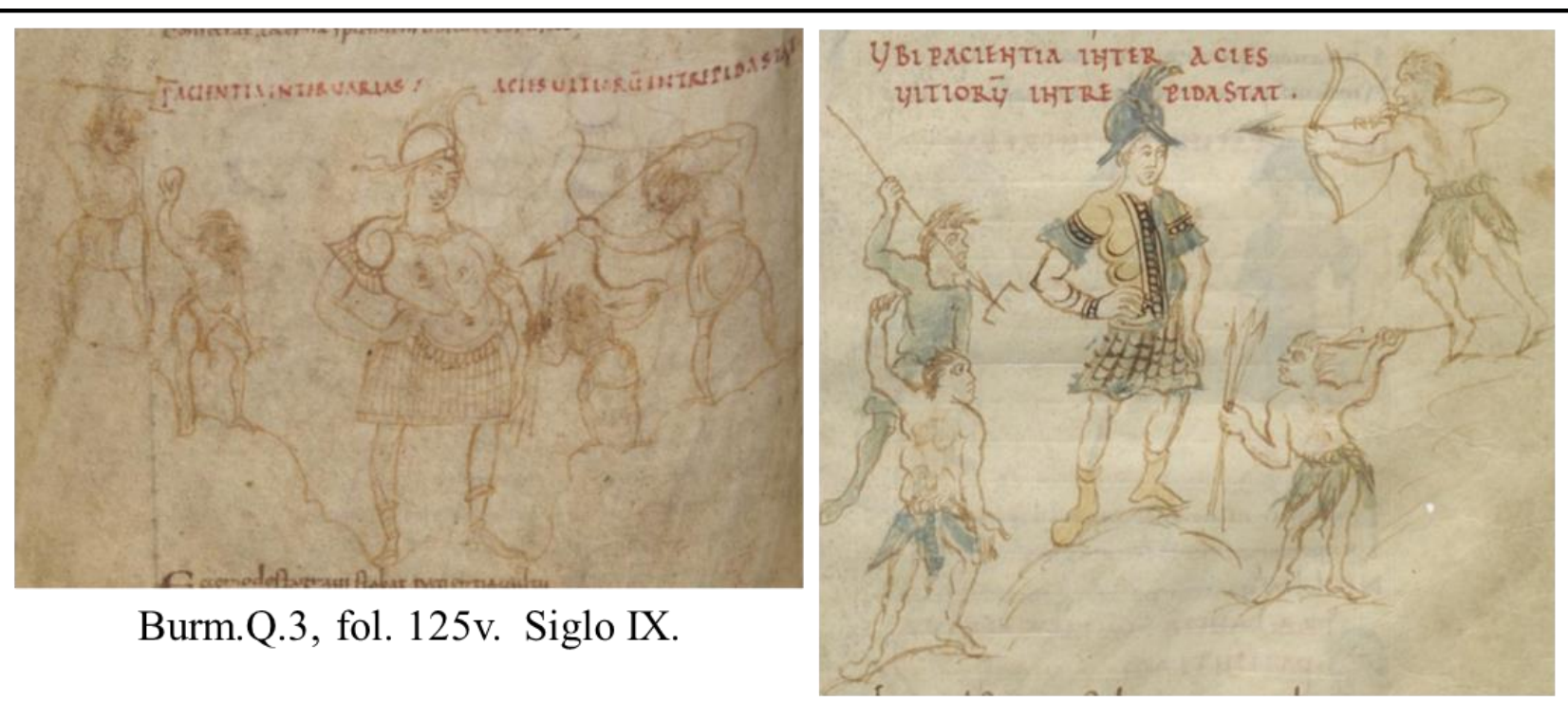

Burm.Q.3, fol. 125v. Siglo IX.

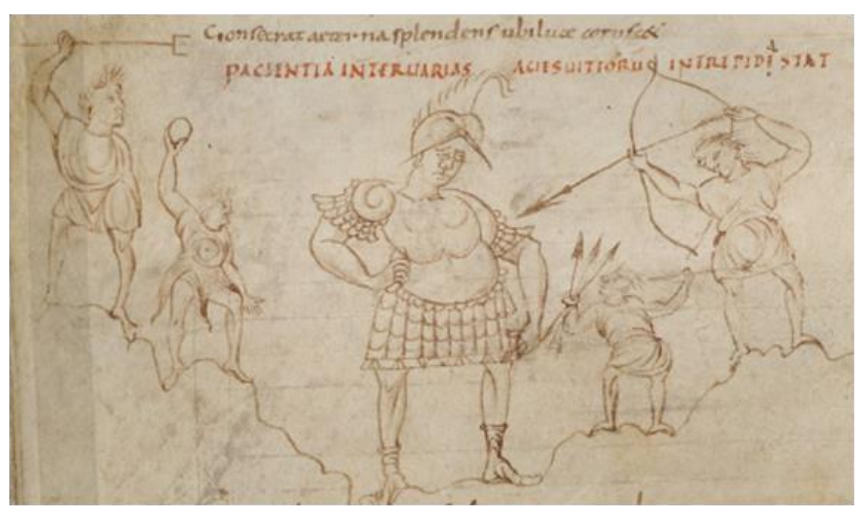

Ms. 9987-91, fol. 105v. Siglo IX.

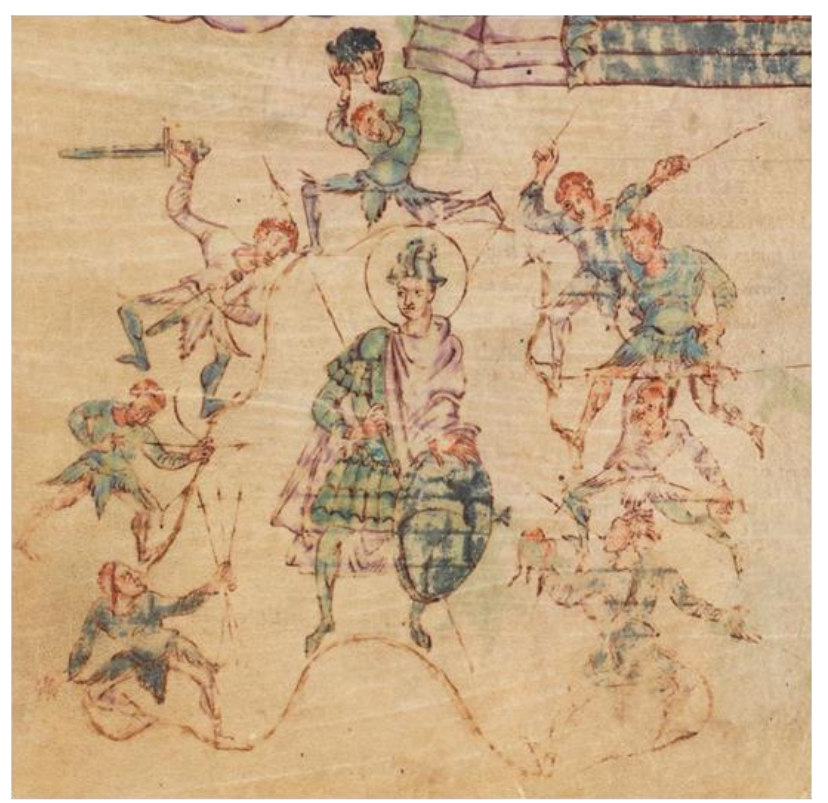

Ms. Lat. 8085, fol. 58r. Siglo IX.

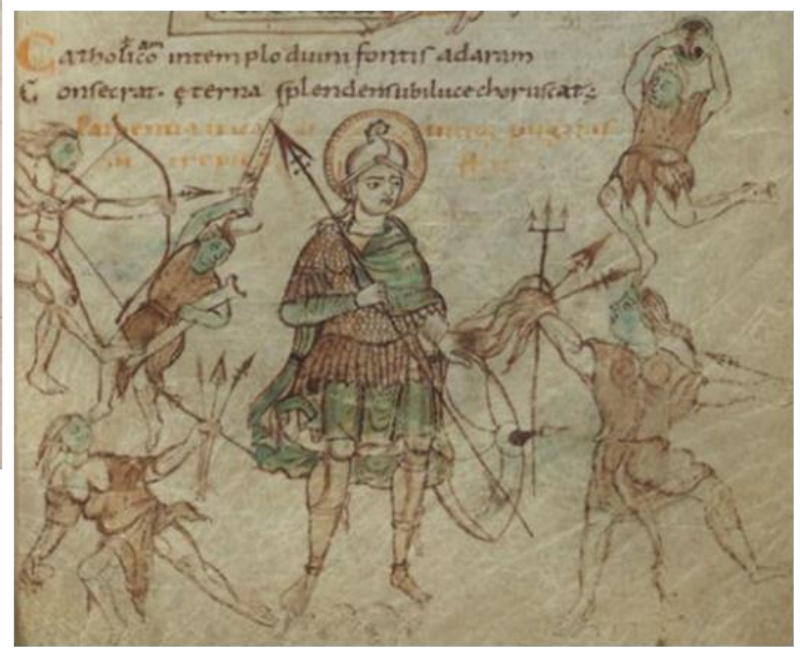

Ms. 10066-77, fol. 118r. Siglo X.

Cod. 264, pág. 75. Siglo X.

Miniatura 17. Patientia permanece tranquila entre el ejército de los vicios 


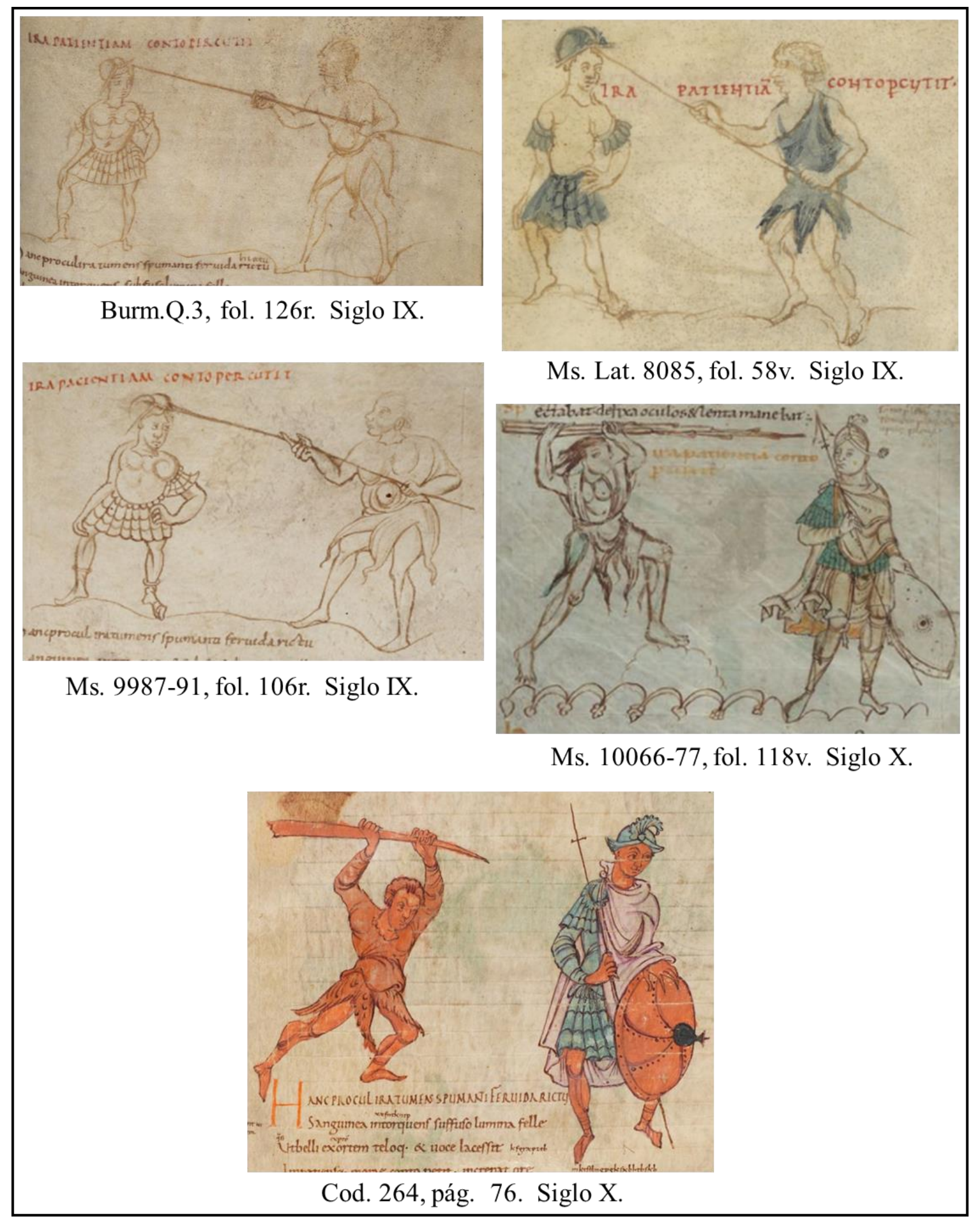

Miniatura 18. Ira golpea con una pica a Patientia 
con la meditación los juegos de palabras eran utilizados como un mecanismo mnemónico por el cual se concatenaban palabras e incluso frases cuya raíz o estructura era igual ${ }^{122}$. La miniatura además de ayudar a crear una imagen mental, junto al título también crea una imagen sonara en la mente del espectador: la del sonido vibrante (percusión) del golpe contra el yelmo, utilizando así la sinestesia como mecanismo mnemónico.

Las siguientes tres miniaturas 19, 20 y 21 recogen el ad res de los versos a los que acompañan. En la 19, Ira increpa a Patientia, se aprecia cómo e vicio se dirige hacia la virtud sujetando varias lanzas. En el título de esta imagen nuevamente se utiliza el verbo increpo para expresar en este caso que el vicio pronuncia palabras. En los cinco manuscritos Patientia lleva un escudo, en los códices del siglo IX la virtud sujeta el mismo con la mano derecha. En los ejemplos posteriores, Ms. 10066-77 y Cod. 264 el escudo se plasmó delante de su portadora, protegiéndola, y en la mano izquierda de una lanza. En esta escena Ira amenaza a la virtud con herirla con sus hierros los cuales en las miniaturas del siglo IX el vicio lleva en las manos, se aprecia la lanza en posición vertical, y en las representaciones del siglo X Ira se dispone a lanzar el dardo, el cual se captó visualmente en posición horizontal.

En la próxima miniatura, la 20, Ira arroja su lanza para herir a Patientiam. Según los versos 121 al 124 la virtud permaneció inmóvil y el vicio arrojo su arma atinando en el estómago de Patientiam, pero su armadura la protegió. La composición de esta escena en los cinco códices es muy similar a la escena de la miniatura 19. La virtud Pudicitia se encuentra a la izquierda, en los códices Burm.Q.3, 9987-91 y Lat. 8085 ya no porta escudo, y es atacada por el vicio Ira que se plasmó en el lado derecho. En esta miniatura el principal cambio es la lanza arrojada con la que el vicio ataca a la virtud, la cual se aprecia entre medio de ambas figuras. La descripción del lugar en donde la misma golpea se ha tenido en cuenta, según el poema el golpe de la misma es bajo el estómago y la dirección a la que

${ }^{122}$ CARruthers. The Craft of Thought..., p. 98. GiBSON-Wood. "The 'Utrecht Psalter' and the Art of Memory..., p. 14. NewhaUSER. The Treatise on Vices and Virtues..., p. 156. 
apunta el dardo en las miniaturas, especialmente las del siglo IX, es hacia la parte baja de la loriga de Pudicitia.

Por último, la miniatura 21 plasma cómo todas las armas con la que Ira intento herir a Patientiam yacen rotas en el suelo tal y como lo indican los versos 125 al 136. En los cinco ejemplos de esta escena aparece en el lado izquierdo de la composición Patientia, con semblante tranquilo sujetando una lanza y un escudo. En Burm.Q.3, Ms. Lat. 8085 y Ms. 9987-97 su mano derecha se eleva un poco. De cara a la virtud se representó Ira, ésta baja su mano derecha, que según el poema se había cansado tras los distintos ataques fallidos a su contrincante. Entre medio de ambas figuras, se plasmaron las distintas armas que utilizó el vicio para atacar a la virtud. Éstas parecen como sin cayeran, y algunas se encuentran rotas.

En los códices del siglo X los gestos de Ira cambian. Ya no se representa su brazo fatigado, sino que los mismos se encuentran en plena acción de lanzar y su mano izquierda todavía sujeta un arma, específicamente un arco que es producto de la interpretación del miniaturista ${ }^{123}$. En Cod. 264 Patientia se protege con el escudo. El lugar de esta escena en Ms. 10066-77 se cambió, la misma en lugar de encontrarse precediendo los versos en los que la misma se narra, 125-136, ésta se incluyó en el folio 120r, antecediendo los versos 145-150.

En la miniatura 22 nuevamente aparece en el título de ésta el verbo percutit, para describir la acción de Ira. Ira golpea con su espada el yelmo de Patientia. En los manuscritos Burm.Q.3, Ms. Lat. 8085, Ms. 9987-91 y Cod. 264 se plasmó el momento en que Ira golpea con su espada el yelmo de Pudicitia inerte. En Ms. 10066-77 es el momento luego del golpe, cuando la espada del vicio se hace pedazos. En este caso el título de la miniatura coincide con el resto de miniaturas, sin embargo, la imagen que se aprecia corresponde más con la escena 23 que corresponde a los versos 137-144 en la que se representa el momento en que la espada de Ira se rompe

${ }^{123}$ STETTINER. Die Illustrierten Prudentiushandschriften..., p. 266. 


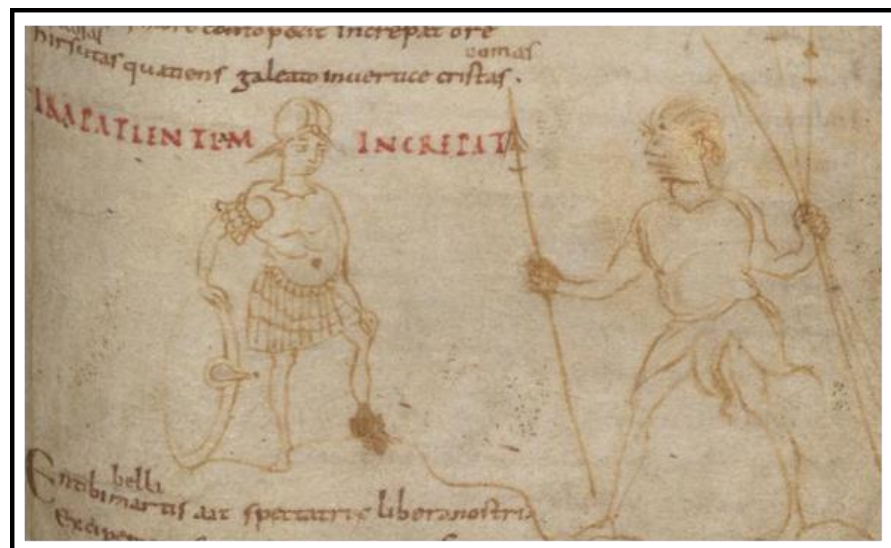

Burm.Q.3, fol. 126r. Siglo IX.

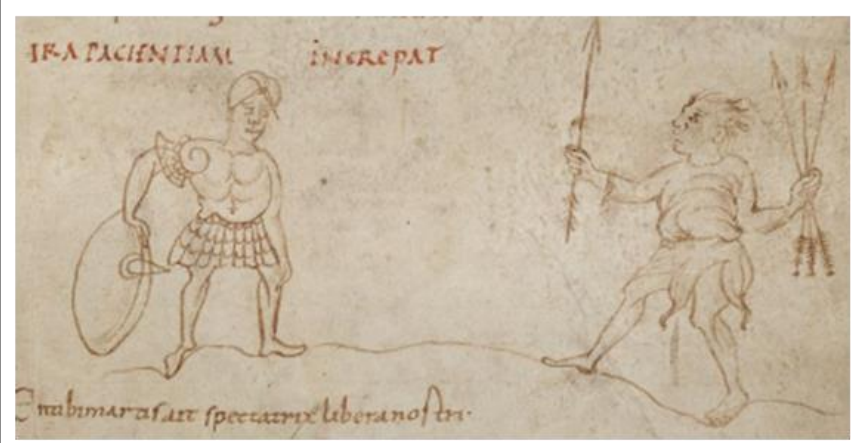

Ms. 9987-91, fol. 106r. Siglo IX.
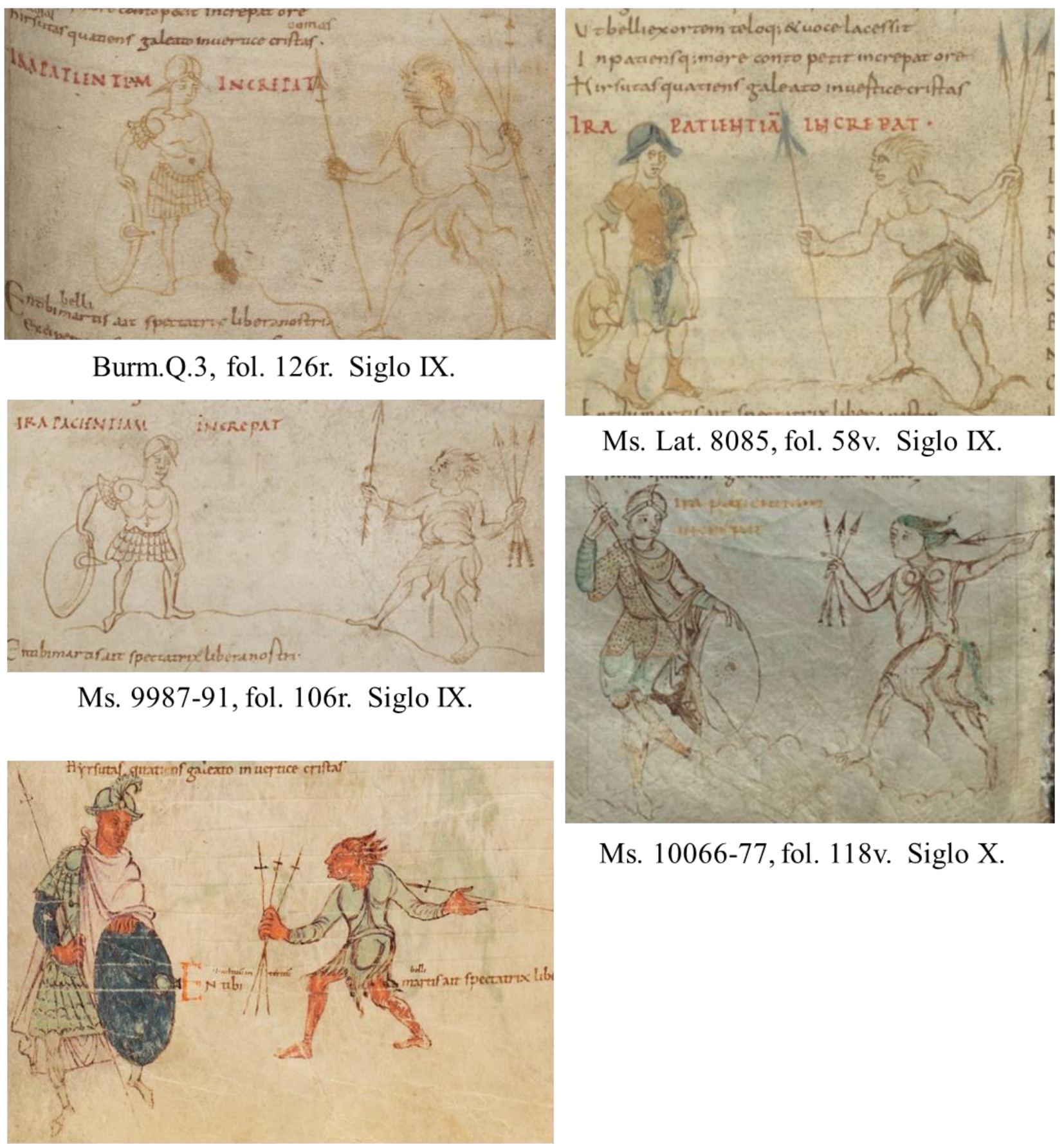

Ms. Lat. 8085, fol. 58v. Siglo IX.

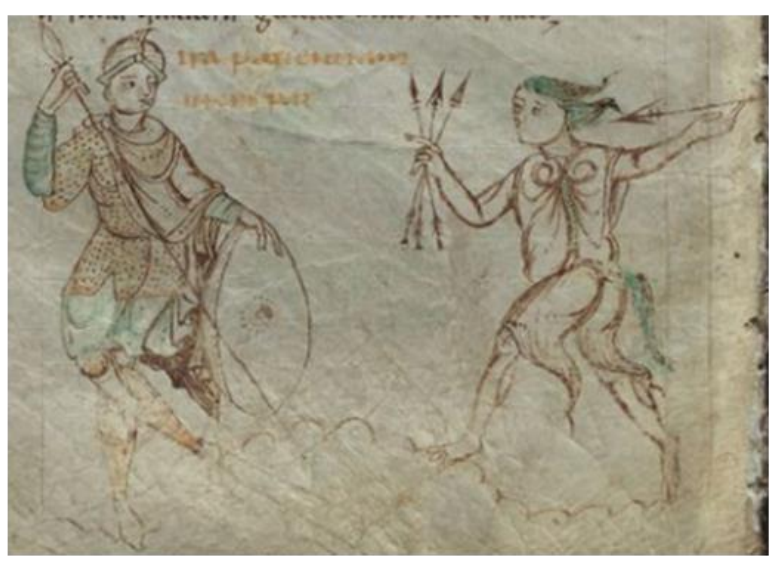

Ms. 10066-77, fol. 118v. Siglo X.

Cod. 264, pág. 76. Siglo X. 


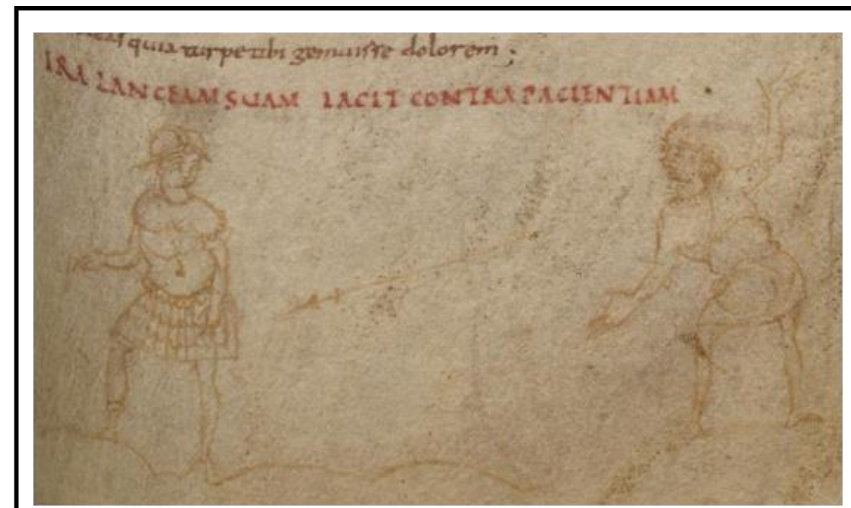

Burm.Q.3, fol. 126r. Siglo IX.

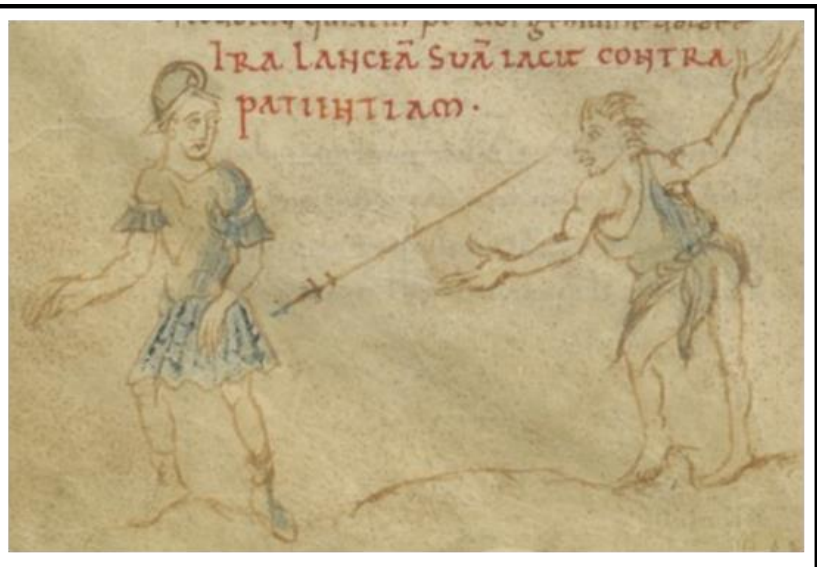

Ms. Lat. 8085, fol. 58v. Siglo IX.

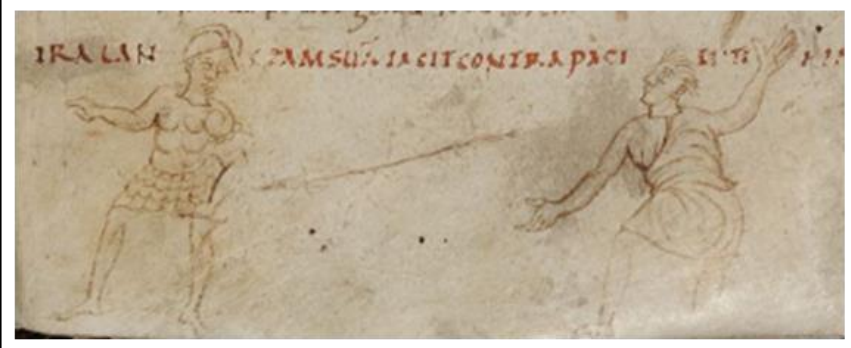

Ms. 9987-91, fol. 106r. Siglo IX.

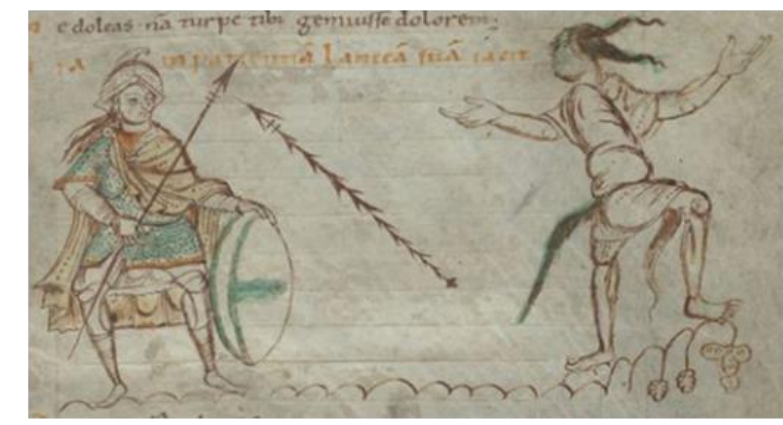

Ms. 10066-77, fol. 119r. Siglo X.

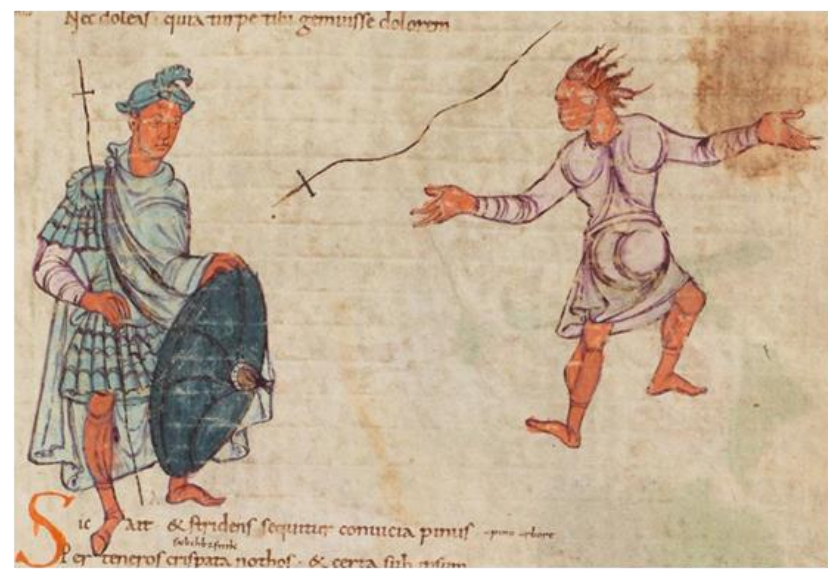

Cod. 264, pág. 77. Siglo X.

Miniatura 20. Ira arroja su lanza contra Patientiam 


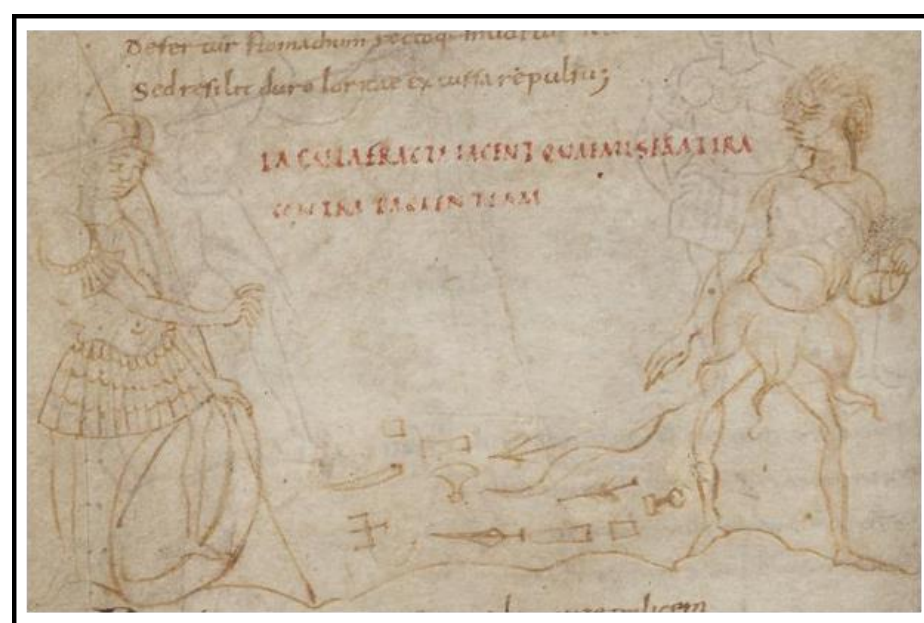

Burm.Q.3, fol. 126v. Siglo IX.

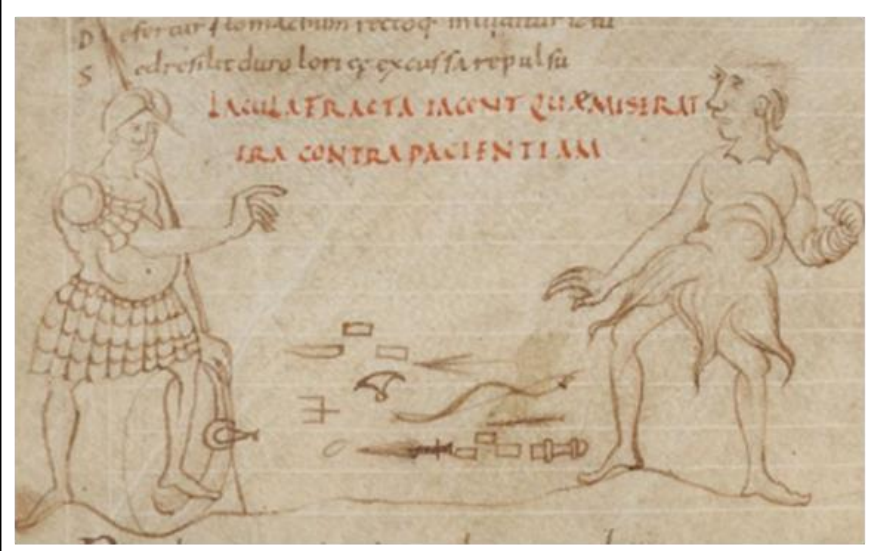

Ms. 9987-91, fol. 106v. Siglo IX.

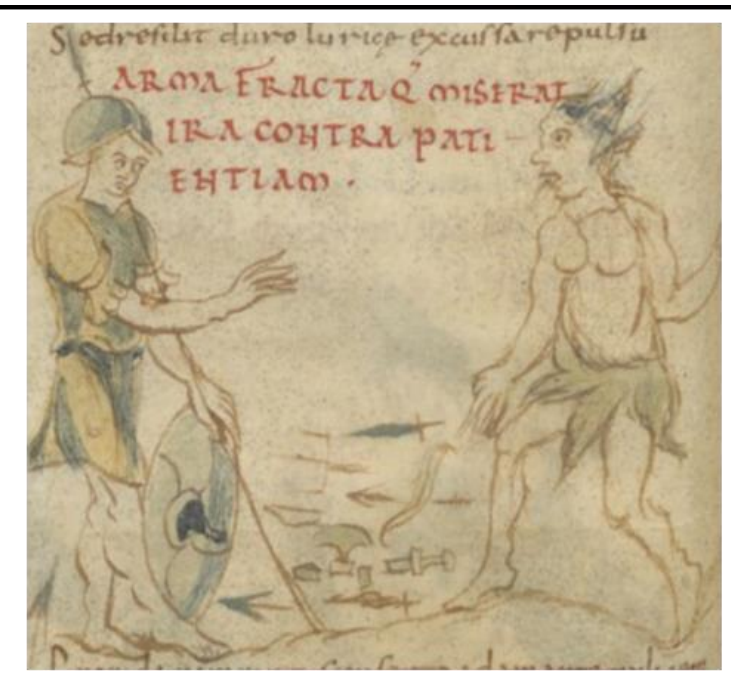

Ms. Lat. 8085, fol. 58v. Siglo IX.

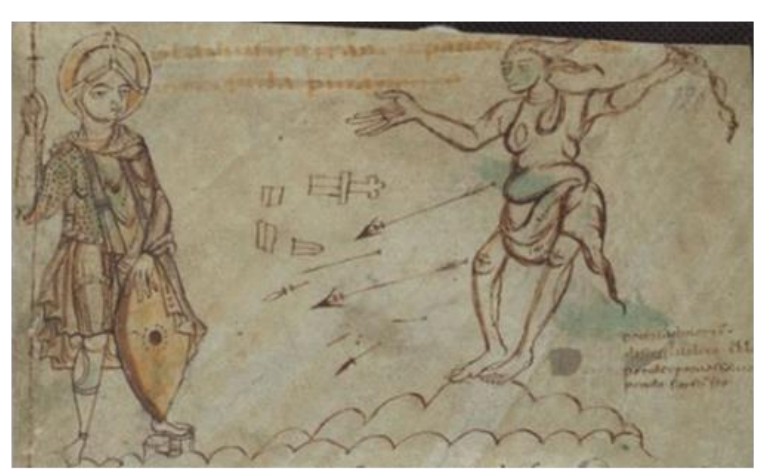

Ms. 10066-77, fol. 120r. Siglo X.

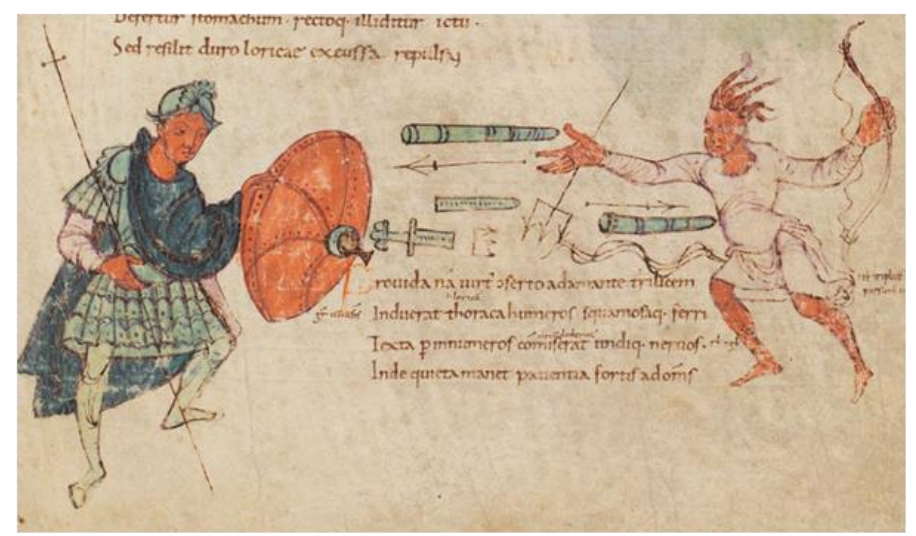

Cod. 264, pág. 77. Siglo X.

Miniatura 21. Rotos yacen los dardos que Ira lanzó a Patientiam 


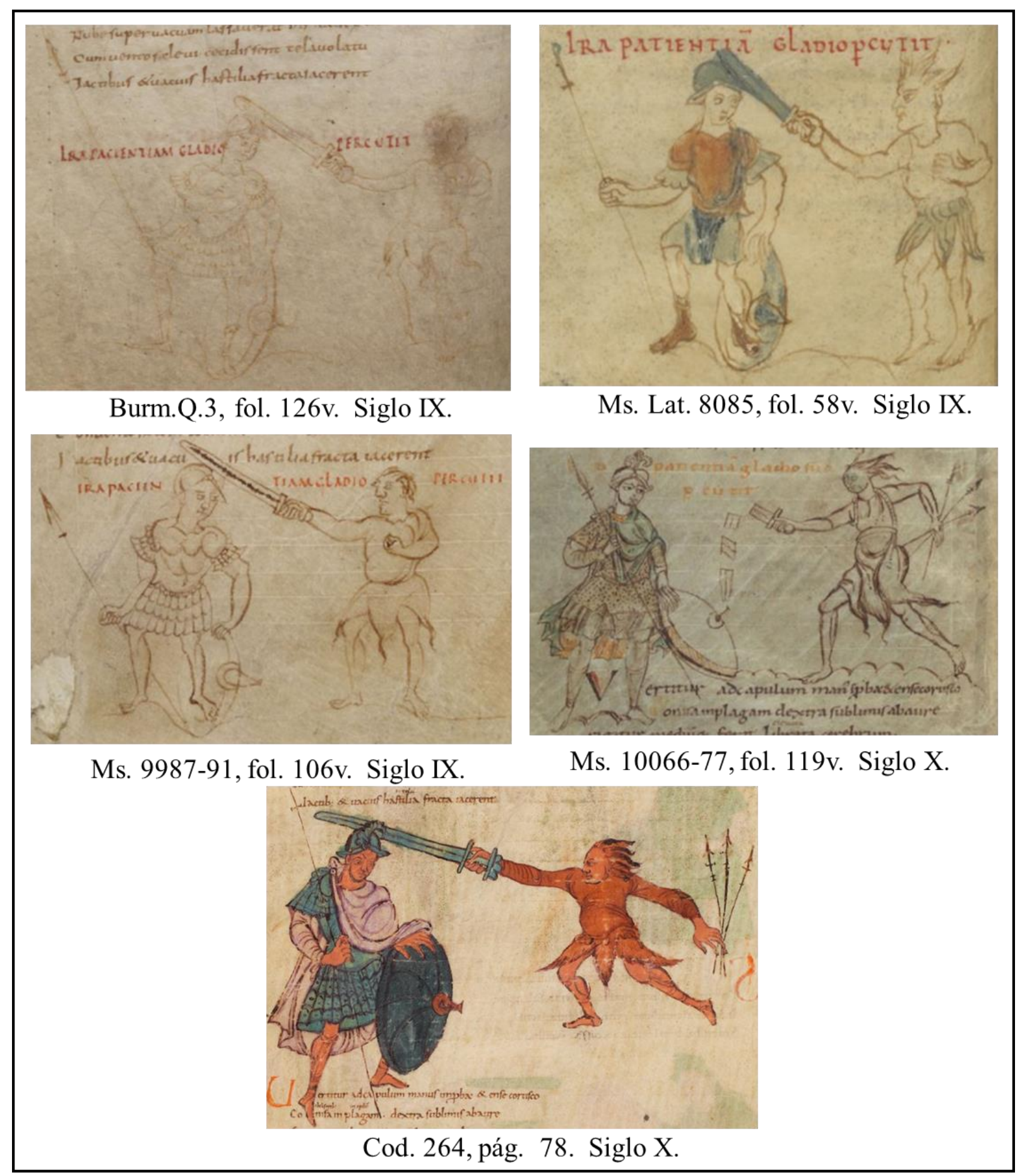

Miniatura 22. Ira golpea con su espada a Patientiam 
y en la mano de ésta sólo queda el pomo de la misma. Al igual que en la miniatura 18 en la que el vicio ataca con su lanza a la virtud, encontramos un juego de palabras en el que el verbo utilizado remite a otro término que enriquece la imagen. El mismo autor en los versos describe esta escena como una percusiva y sonora, Ira golpeo con una espada el yelmo de bronce de Patientia, la misma rebotó produciendo un sonido: "Aerea sed cocto casi foramta metallo / tinnitum percussa refert aciemque retundit $^{124}$ ". La acción plasmada en la miniatura junto al título recuerda al espectador el sonido de la espada contra el yelmo. La creación de recuerdos depende de las impresiones sensoriales, la memoria almacena desde imágenes hasta sonidos, siendo las impresiones percibidas por el ojo y el oído las que se recuerdan con mayor facilidad $^{125}$. Las letras, y por ende las palabras formadas con éstas, son la señal gráfica de un sonido $^{126}$. El uso de percussus en el poema y de percutit en el título activan el recuerdo no sólo de una acción sino del resultado de ésta, el sonido o tintineo de las dos piezas de metal que chocan. En cuatro de los cinco manuscritos se plasmó el momento justo en el que la espada de Ira toca el yelmo de Patientia, la misma crea la sensación de sinestesia pues la imagen visual igualmente activa la sensación sonora en el espectador. La sinestesia entre lo visual y lo verbal o auditivo fue utilizada con mucho ímpetu en el contexto monacal para la memorización ${ }^{127}$.

Tras el golpe la espada de Ira se quebró y el vicio permaneció sujetando el pomo de ésta. La miniatura 23 se limita como otras a recoger la acción principal, el ad res, que se narra en los versos 145-150. En las miniaturas de Burm.Q.3, Ms. Lat.

\footnotetext{
${ }^{124}$ Prudencio. Psychomachia, vv. 140-141. Obras Completas de Aurelio Prudencio..., pp. 318319.

125 Fentres, James et. Chris WiCKHAM. Memoria social. Madrid: Cátedra, 2003. p. 51. CARruthers. The Craft of Thought..., p. 69. SAN Agustín. Confesiones, X.viii.12. Edición consultada: Obras de San Agustín, Las confesiones. Texto Bilingüe, Tomo II. Edición de: Ángel Custodio Vega. Madrid: Biblioteca de Autores Cristianos, 1973. ARISTÓTELES. De memoria et reminiscentia, 449b 9-19, 450a 25-35. Edición consultada: Acerca de la generación y la corrupción. Tratados breves de historia natural, traducción de: E. La Croce y A. Bernabé Pajares. Madrid: Editorial Gredos, S.A., 1987. PlATón. Teeteto, 191d. Edición consultada: Diálogos V. Parménides, Teeteto, Sofista, Político. Biblioteca Clásica Gredos, 117. Madrid: Editorial Gredos, S.A., 1988.

${ }^{126}$ CARruthers. The Craft of Thought..., p. 136. CARRUTHERS. The Book of Memory..., p. 111. CAMILLE. "The Gregorian Definition, ..., p. 92. IsIDORO DE SEVILla. Etimologías, Libro I, iii. 1.

${ }^{127}$ CARRUTHERS. The Craft of Thought ..., p. 3.
} 
8085, Ms. 8897-91 y Cod. 264 se aprecia a mano izquierda la figura de Patientia inerte, sujetando un escudo y una lanza. Delante de ésta se plasmó el vicio, Ira, ésta se abalanza hacia la virtud. En su brazo derecho se encuentra el pomo de su espada y cayendo los trozos rotos de ésta. Con la mano izquierda Ira sujeta la funda de su arma. En Ms. 10066-77 esta escena se unió la 21 en la que el vicio intenta herir a la virtud con los dardos que lanza e Ira sujeta el arco que utilizó para lanzar los dardos.

Una de las escenas más memorables en el combate entre Patientia e Ira es la muerte del vicio (Miniatura 24). Ésta al ver que no podía ganarle a la virtud en su desesperación coge una de las puntas de las tantas lanzas que yacían en el campo de batalla, la clava en el suelo y se atraviesa con ésta, se suicida. En la miniatura se plasmó el momento en que Ira se atraviesa con la lanza. En los manuscritos Burm.Q.3, Ms. 9987-91 y Lat. 8085 al vicio se le representó de lado, permitiendo que el espectador pueda contemplar el cuerpo y el rostro de ésta, y en el momento justo en el que la lanza entra en el pecho del vicio y su sangre brota de su herida. El dramatismo en las iluminaciones del siglo $\mathrm{X}$ es mayor y esto se logra a través del arreglo de la composición. Ira aparece de frente al espectador retorcida por el golpe auto-infligido, sólo se aprecia la coronilla de su cabeza y de su espalda sale la punta de la lanza con la que se ha suicidado. Si ya de por sí, la forma en la que Ira se aniquila es memorable y se representa de tal manera, en las distintas miniaturas no falta el elemento de la sangre.

Ira perece por su propio frenesí, como lo indica Patientia en los versos que siguen a la miniatura 25. La composición de esta escena en Burm.Q.3, Ms. Lat. 8085, Ms. 9987-91 y Ms. 10066-77 es muy similar a la de la escena 14 en la que Pudicitia reprende a Libidinem. Nuevamente el vicio se representa tendido en el suelo en una posición un tanto extraña y en el lado opuesto a ésta la virtud. Aquí particularmente se continúa representado a Patientia como se ha hecho en las escenas anteriores, con sus vestiduras militares, escudo y lanza. Ésta eleva su mano derecha y el gesto de la misma es el de hablar. En Cod. 264 la miniatura muestras ciertas diferencias con respecto a las otras cuatro. Si bien en las anteriores en el lado izquierdo de la composición se encuentra la virtud y en el derecho el vicio, en este caso se han 
intercambiado los lugares. La virtud toca con la punta inferior de su lanza el cuerpo inerte del vicio. Tal vez uno de los muchos significados del verbo increpo explica la acción de ésta, la de aguijar con impaciencia a su contrincante. Según el poema la virtud dice un discurso, pero en los tituli de los distintos códices de la miniatura 25 se utilizó nuevamente el verbo increpo. En la miniatura se aprecia a la virtud con el gesto de increpar, y delante de ésta la virtud muerta tendida en el suelo. Como elementos mnemónicos de esta miniatura cabe resaltar el gesto de proferir de Patientia e igualmente la extraña posición en la que se representa el cuerpo de Ira. En Ms. 10066-77 el vicio se plasmó con su cara y extremidades pintadas de verde resaltando su aspecto monstruoso.

En la miniatura anterior en la que la virtud increpa al vicio, y en las próximas, en los discursos de las victoriosas se incluyen distintas historias bíblicas. En el caso particular del triunfo de Patientia sobre Ira no sucede esto, pues en el campo de batalla aparece un personaje bíblico que encarna esta virtud: Job. La figura de Job es una prefiguración de la Pasión de Jesucristo y de la persecución de la Iglesia e igualmente es la encarnación de la virtud de la paciencia ${ }^{128}$. Si en el combate de Pudicitia vs. Libidinem el discurso de la virtud vencedora alude a Judit y a la Virgen María, aquí no sólo en el poema, sino también en dos de las miniaturas aparece la figura de Job (Miniaturas 26 y 27). Ambas acumulan visualmente el ad res. La miniatura 26, Patientia atraviesa con Job el campo de batalla, se incluyó en los cinco manuscritos precediendo los versos 162 al168. En las del siglo IX se han representado tres planos distintos. En el centro del segundo plano están las figuras de Patientia, a la derecha de la composición, y a la izquierda la de Job vestido con túnica como suele representarse a las figuras bíblicas. Los distintos gestos de sus manos indica que ambas figuras se encuentran en pleno dialogo. En el primer y tercer plano se representan los ejércitos que éstas atraviesan a través de distintas figuras con armas. En estos tres ejemplos se utilizan los distintos planos para establecer la acción

\footnotetext{
${ }^{128}$ RÉAU. Iconografía del arte cristiano. Iconografía de la Biblia. Antiguo Testamento. Tomo 1, Vol. ..., pp. 360 y 362.
} 


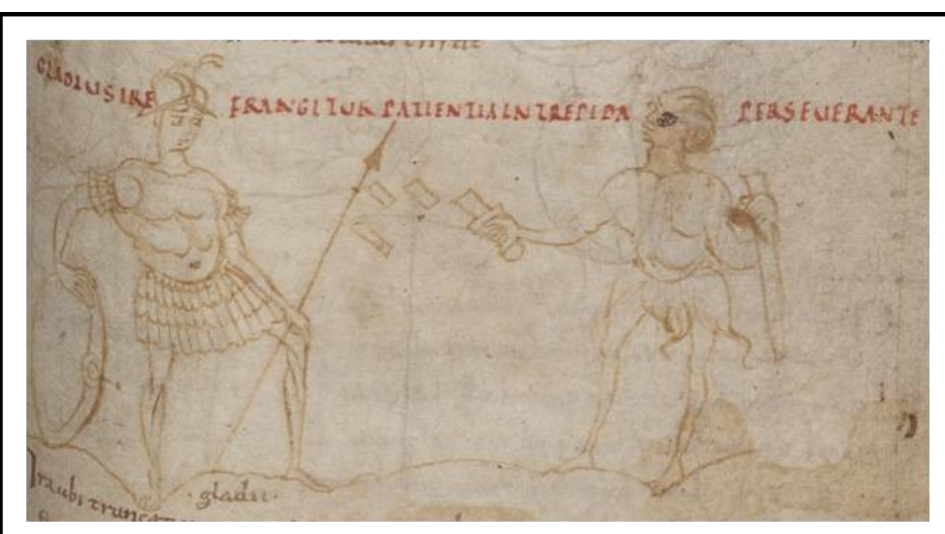

Burm.Q.3, fol. 127r. Siglo IX.

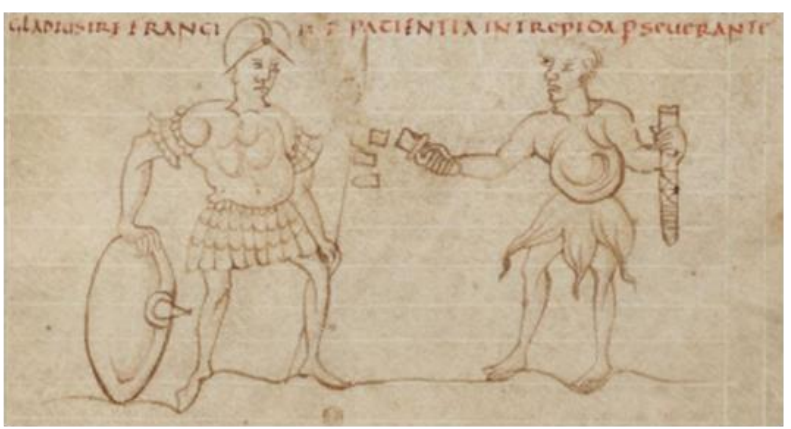

Ms. 9987-91, fol. 107r. Siglo IX.

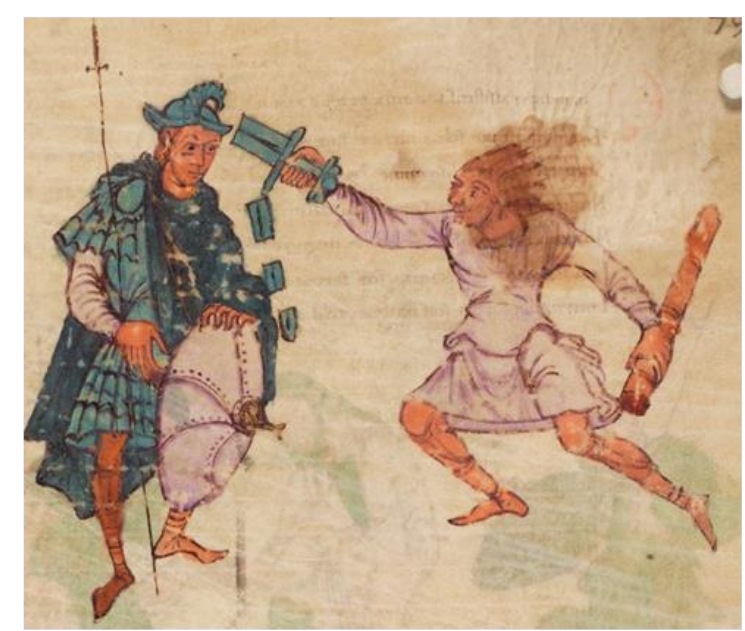

Cod. 264, pág. 79. Siglo X.

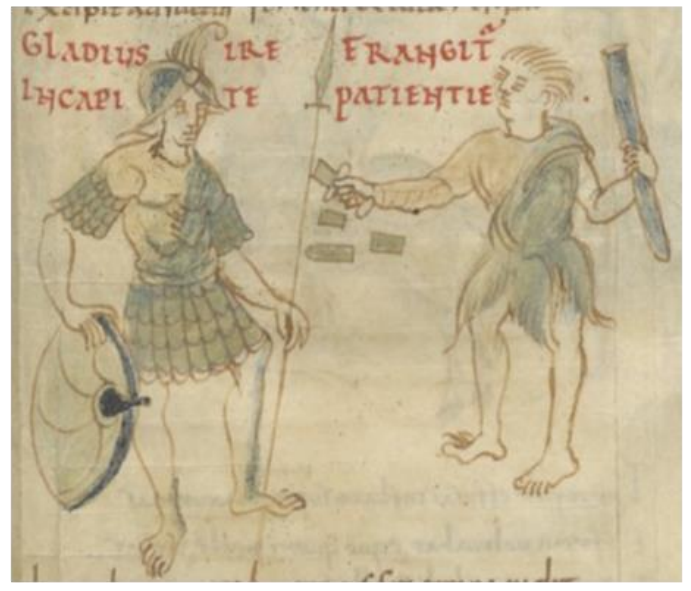

Ms. Lat. 8085, fol. 59r. Siglo IX.

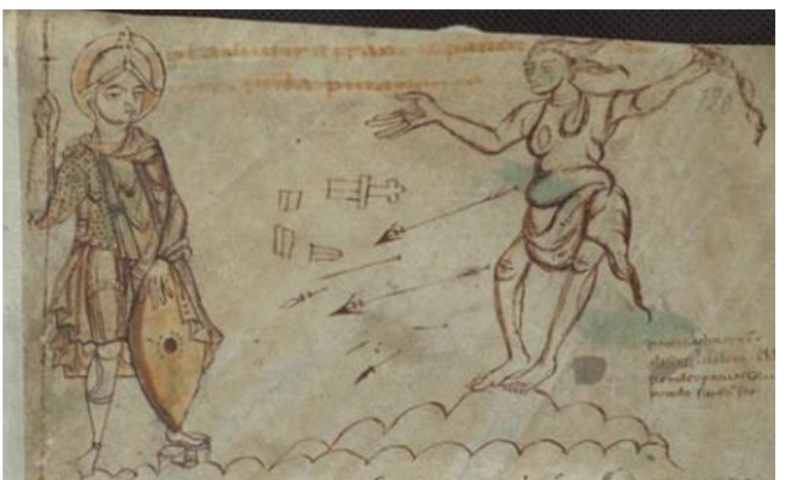

Ms. 10066-77, fol. 120r. Siglo X.

Miniatura 23. La espada de Ira se quiebra y Patientiam tranquila persevera 


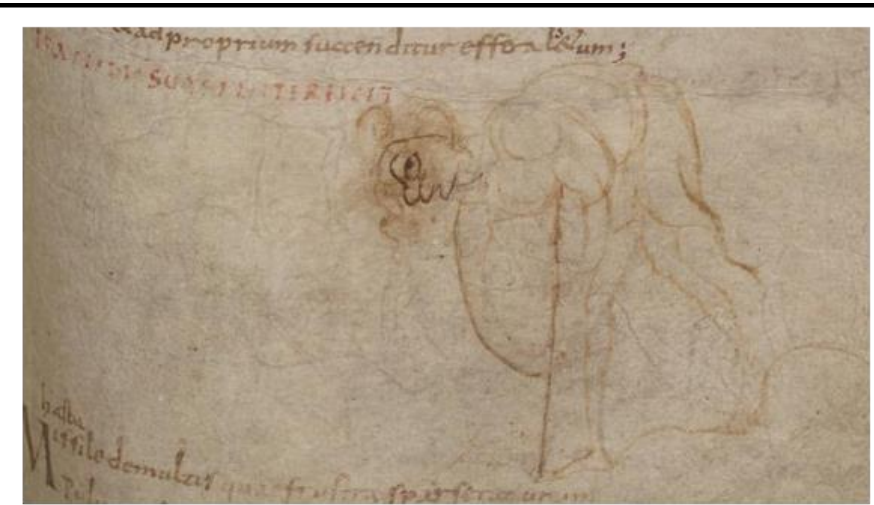

Burm.Q.3, fol. 127r. Siglo IX.

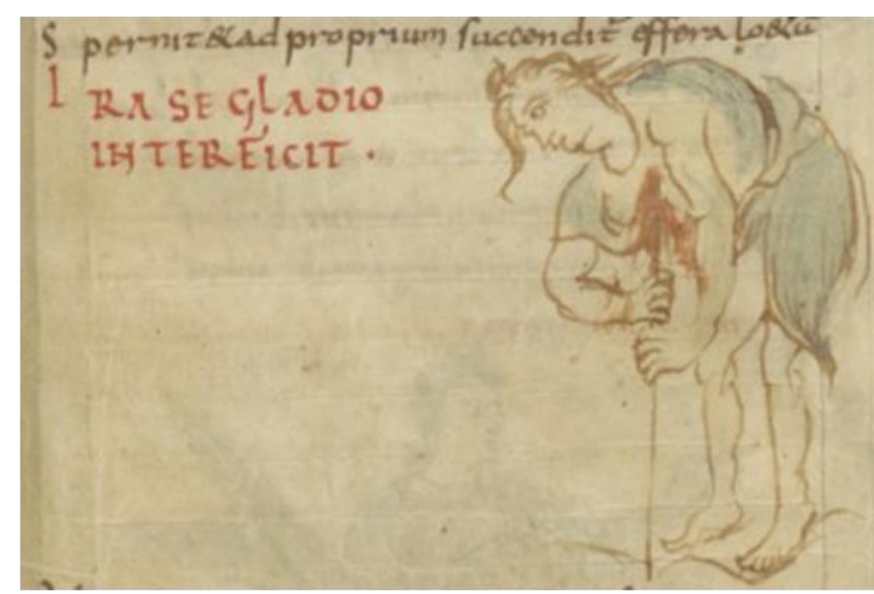

Ms. Lat. 8085, fol. 59r Siglo IX.

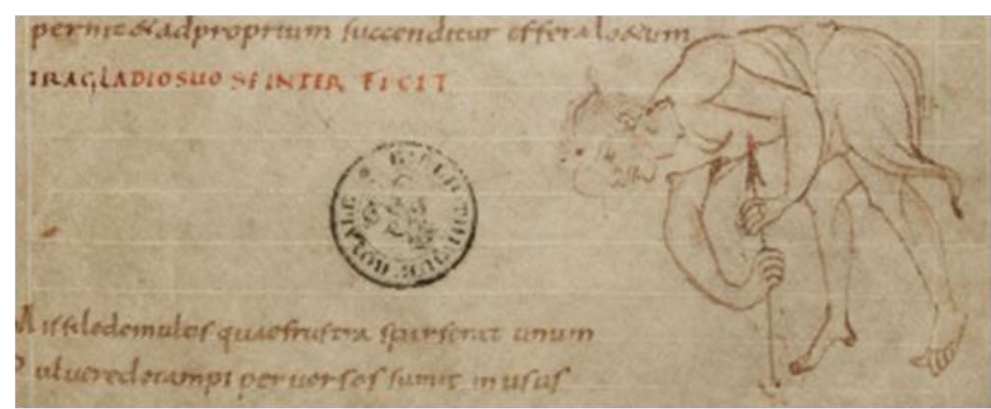

Ms. 9987-91, fol. 107r. Siglo IX.

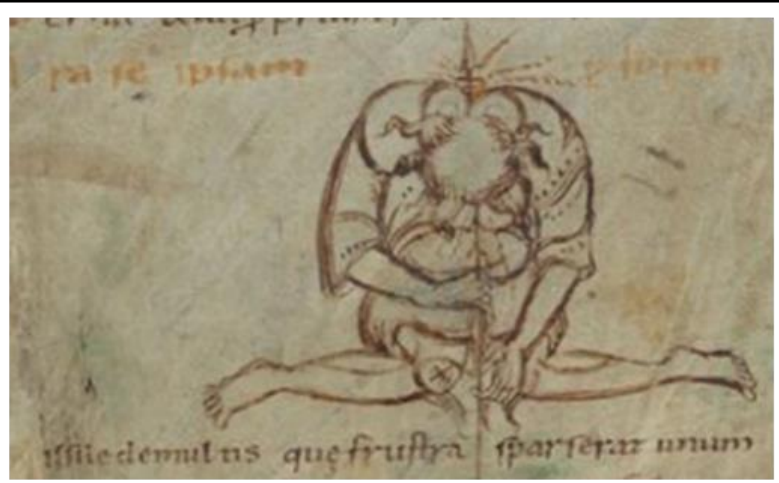

Ms. 10066-77, fol. 120r. Siglo X.

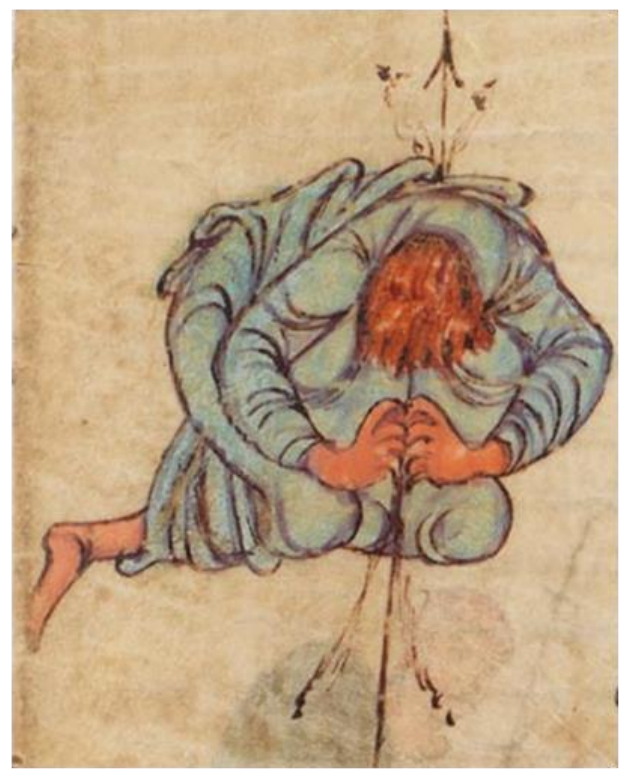

Cod. 264, pág. 79. Siglo X.

Miniatura 24. Ira se suicida 


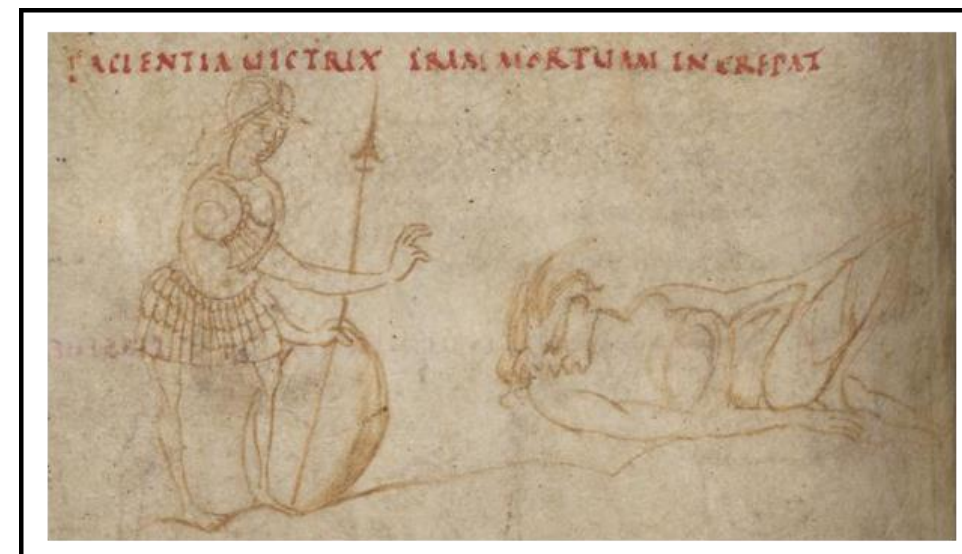

Burm.Q.3, fol. 127`v. Siglo IX.

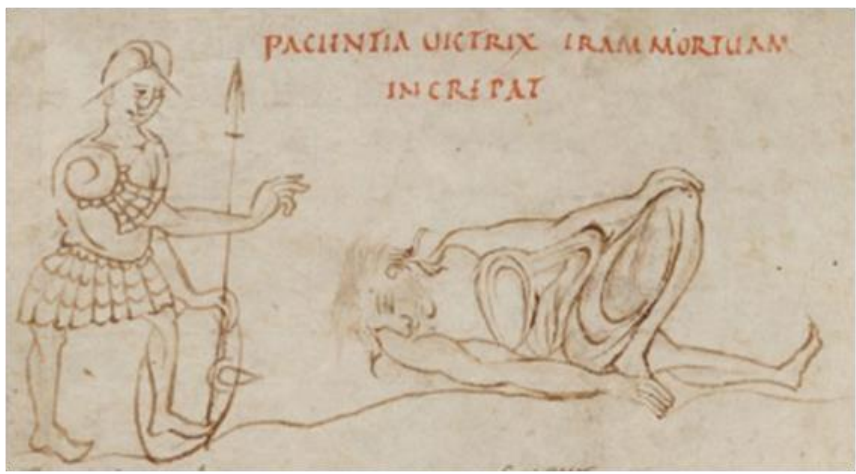

Ms. 9987-91, fol. 107rv Siglo IX.

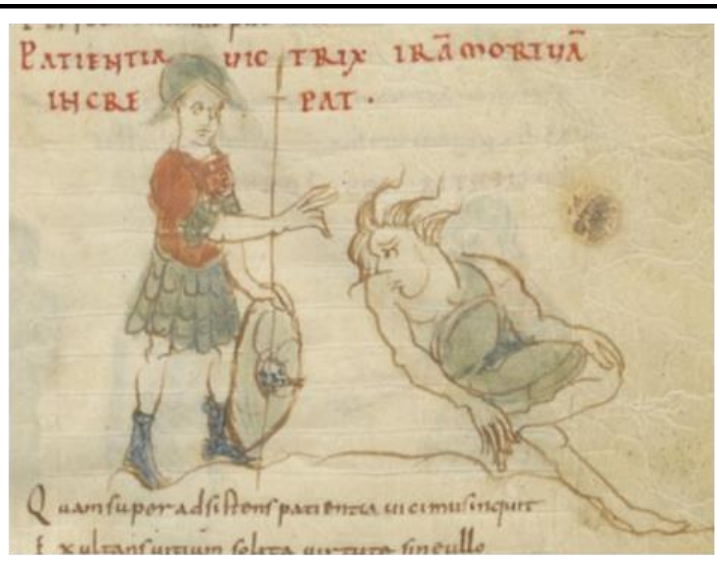

Ms. Lat. 8085, fol. 59r Siglo IX.

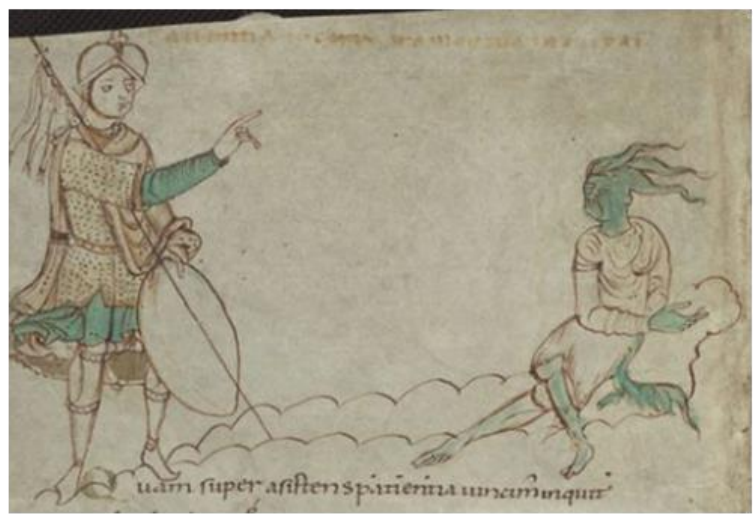

Ms. 10066-77, fol. 120v. Siglo X.

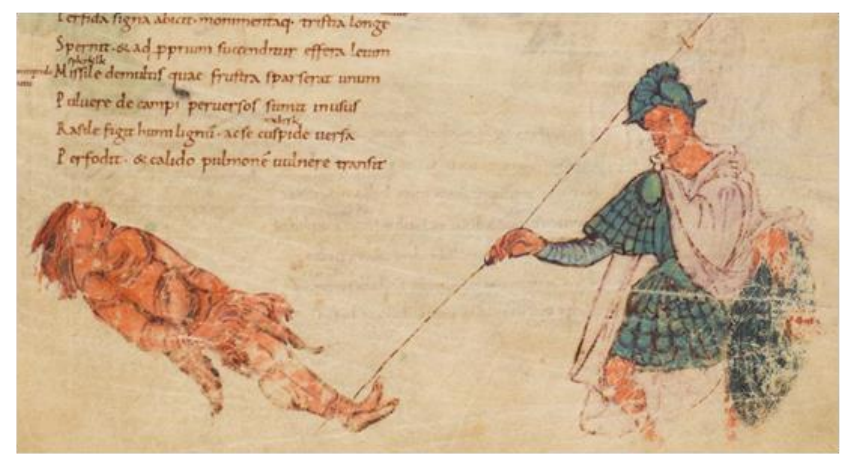

Cod. 264, pág. 79. Siglo X.

Miniatura 25. La victoriosa Patientiam increpa a la Ira muerta 


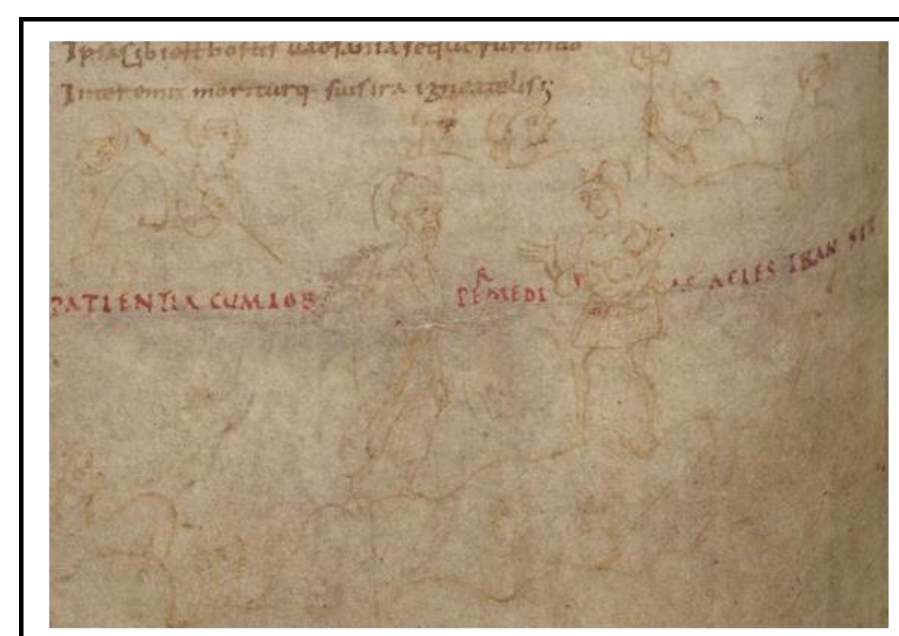

Burm.Q.3, fol. 127v. Siglo IX.
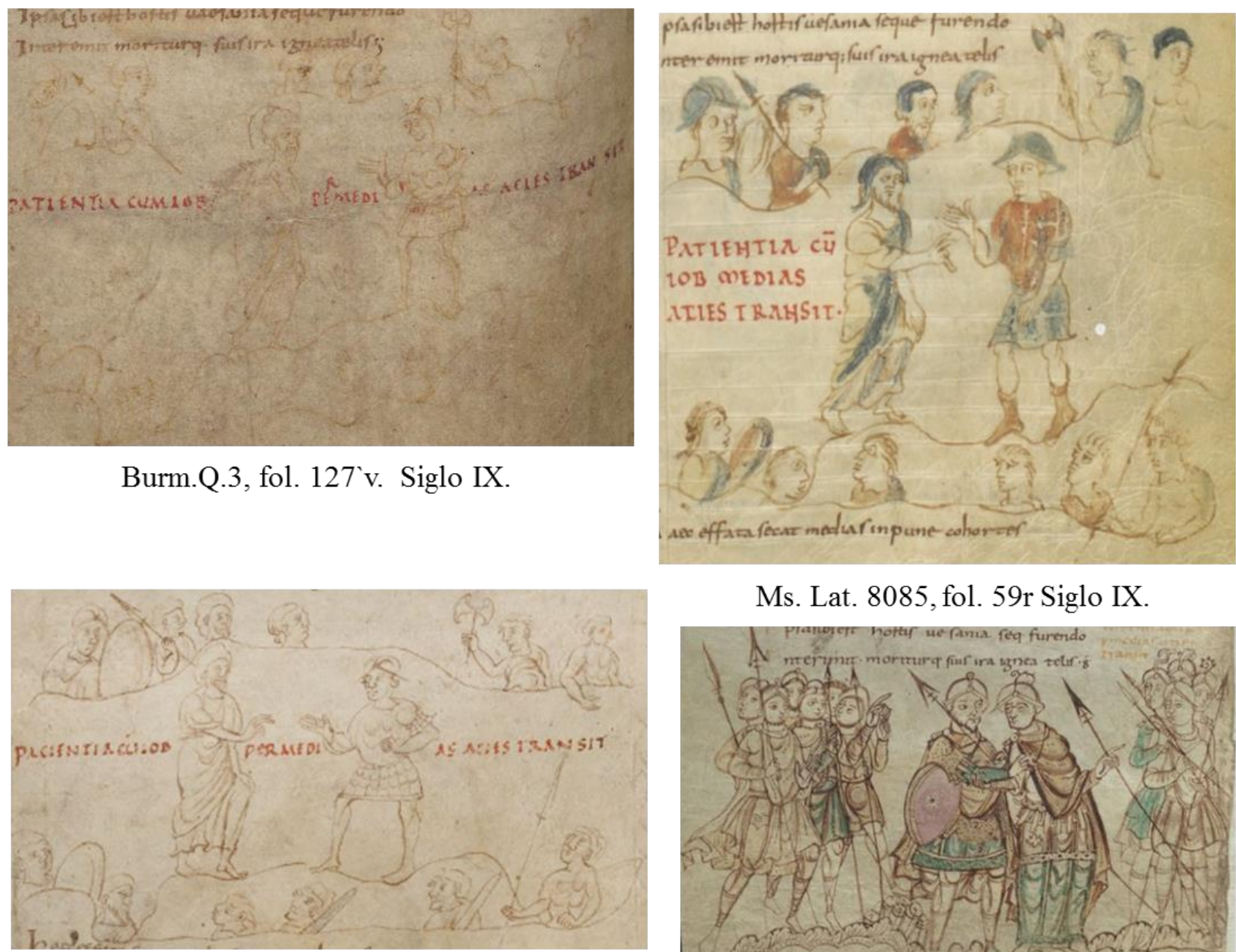

Ms. 9987-91, fol. 107rv Siglo IX.

Ms. Lat. 8085, fol. 59r Siglo IX.

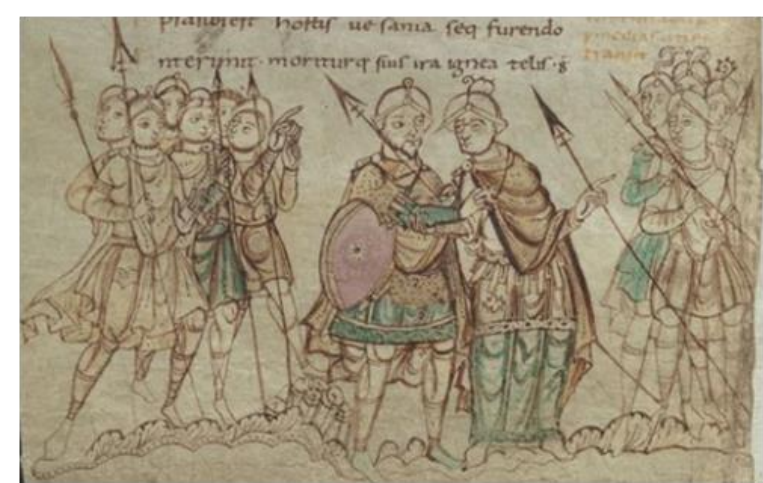

Ms. 10066-77, fol. 120v. Siglo X.

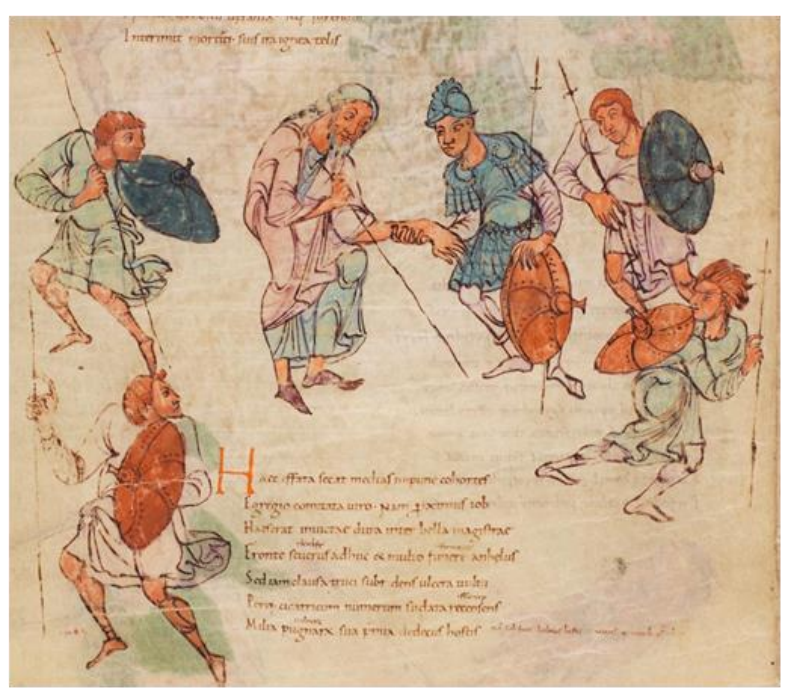

Cod. 264, pág. 80. Siglo X.

Miniatura 26. Patientia atraviesa con Job el campo de batalla 
de la virtud y Job, la de atravesar los ejércitos. En los manuscritos del siglo X la composición cambió para indicar la misma acción. En Ms. 10066-77 la disposición de las figuras se vincula con los modelos del Grupo ${ }^{129}$.

Por otra parte, el arreglo composicional de la escena 26 en Cod. 264 da la sensación de que los protagonistas de esta escena se aproximan al espectador. En todos los ejemplos Job viste túnica, vestimenta usual para los personajes bíblicos, sin embargo, en Ms. 10066-77 la vestimenta de éste es similar a la de la virtud, la principal diferencia entre Job y Patientia es que la segunda lleva una túnica larga debajo de su cota y Job ha sido representado con barba.

La siguiente miniatura, Patientia habla con Job (Miniatura 27) aparece únicamente en cuatro de los cinco manuscritos. En Burm.Q.3, Ms. Lat. 8085 y Ms. 9987-91 en el lado izquierdo, con su armadura, Patientia y delante de ésta vestido con una túnica Job. Los gestos de los mismos indican que dialogan y son similares a los de la miniatura 26. En término de composición, las figuras de Job y Patientia se han intercambiado y ahora se encuentran solos. En el poema, la virtud ordena a Job ir a descansar y llevar consigo las riquezas necesarias para no perecer jamás.

En el Cod. 264 la composición cambia bastante. Ambas figuras se encuentran sentadas y conversan en esta posición. Junto a Patientia se incluyó la representación de una construcción arquitectónica cuya parte trasera recuerda a la torre de la que brota el torrente de agua que plasma al río Jordán en la miniatura 15 y la estructura delantera al templo de planta basilical en la miniatura 7 y 16 de este mismo códice. En Ms. 10066-77 antecediendo los versos 169-171 hay un espacio en blanco el cual muy probablemente estaba destinado a la ilustración de esta escena.

La actuación de Patientia en el combate culmina con ésta uniéndose y prestando su ayuda a todas las virtudes, pues "ninguna virtud traba el combate incierto sin esa virtud, pues vacía está de fuerzas toda aquella a la que no sostiene

${ }^{129}$ WOODRUFF. "The Illustrated Manuscripts..., p. 63. 
la Paciencia ${ }^{130}$ ". A estos versos les acompaña una miniatura 28 en la que Patientia dialoga con su ejército mientras es atacada por el ejército contrario. Al igual que en la miniatura 27, la escena de Patientia jutno a las virtudes somete a los vicios (Miniatura 28) sólo se representó en cuatro y en Ms. 10066-77 a pesar de no encontrarse, sobre los versos correspondientes a la escena dejó un espacio en blanco de pergamino el cual pudo estar destinado a la miniatura de esta escena. En Burm.Q.3, Ms. Lat. 8085 y Ms. 9987-91 en el centro de la composición se encuentra Patientia, su cuerpo se dirige hacia el lado derecho y eleva sus brazos, gesto que indica que la misma habla. Delante de ésta, a menor escala y vestida con túnicas se representaron varias figuras que corresponden al ejercito de las virtudes. En el lado opuesto cuatro figuras con arma se aproximan a las virtudes, plasman al ejercito de los vicios, a las que Patientia les da la espalda.

En el Cod. 264 la composición de la miniatura se intercambió, los elementos recogidos a la derecha ahora están a la izquierda. Los distintos ejércitos en este códice visten cota de malla, cambio sustancial en relación con las imágenes del siglo IX $^{131}$. En el lado izquierdo de la composición se encuentran seis figuras dialogando entre sí. Gracias a las miniaturas anteriores es posible identificar a Pudicitia con la figura que sujeta el escudo y la lanza. Detrás de éstas seis figuras se aprecia una pequeña escena de combate, en la misma la figura con lanza y escudo ataca a una figura con espada, el ejército de los vicios. El miniaturista se inspiró directamente en el poema e ilustra los versos 172 al 174 "Ella misma deshace las cerradas filas de las legiones y las tropas que cargan en combate, avanzando sin rasguño entre nubes de dardos heridos ${ }^{132}$ ". Los versos que preceden a la miniatura 28 en los cinco códices el poeta describe en los versos que la virtud deshizo las filas de las tropas y atravesó ilesa el

\footnotetext{
${ }^{130}$ Prudencio. Psychomachia, vv. 176-177. Obras Completas de Aurelio Prudencio..., pp. 320321.

${ }^{131}$ WoODRUFF. "The Illustrated Manuscripts..., pp. 61 y 63.

${ }^{132}$ StetTiner. Die Illustrierten Prudentiushandschriften..., p. 277. PrUdencio. Psychomachia, vv. 172-174. Obras Completas de Aurelio Prudencio..., pp. 320-321.
} 


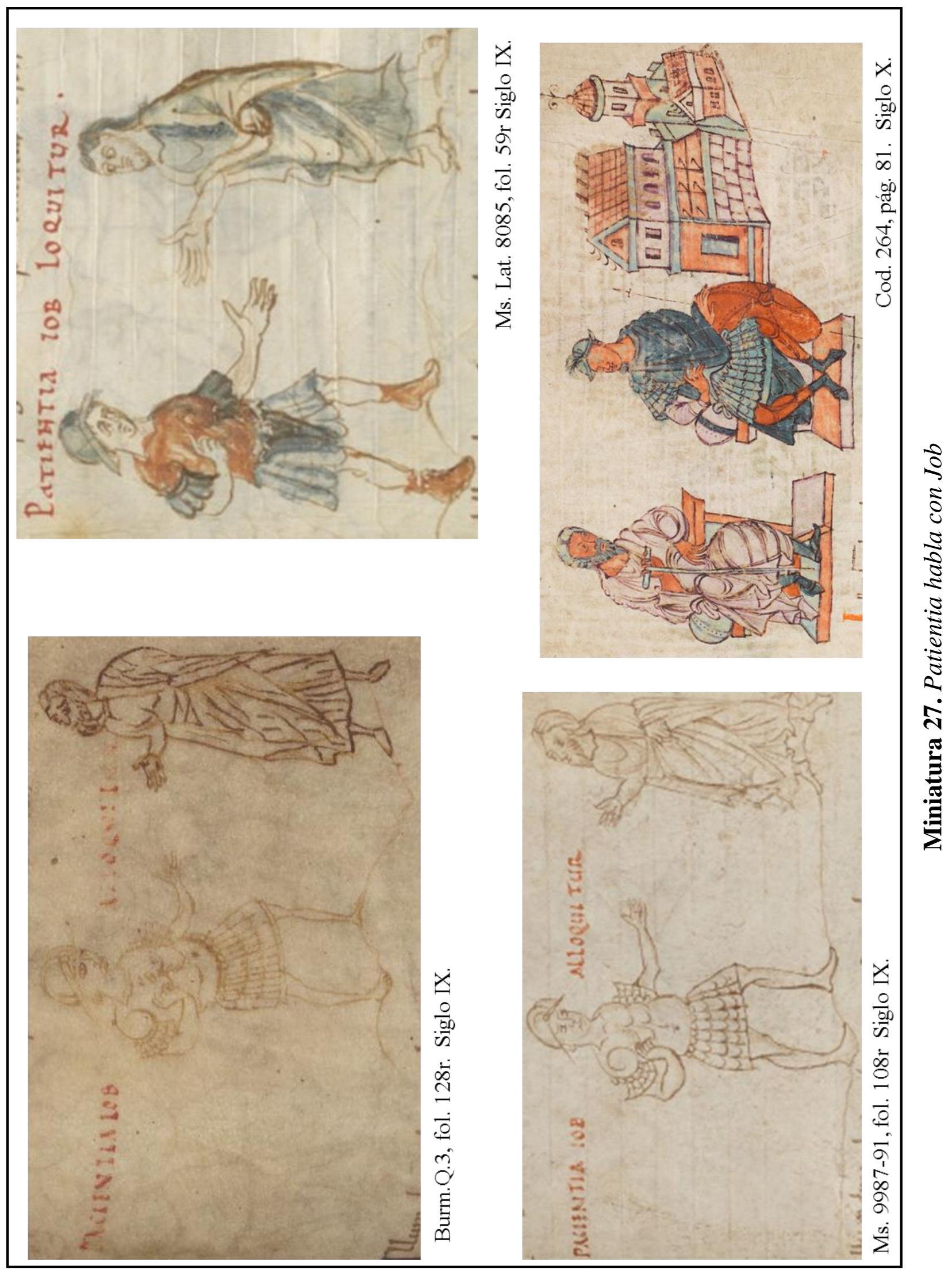




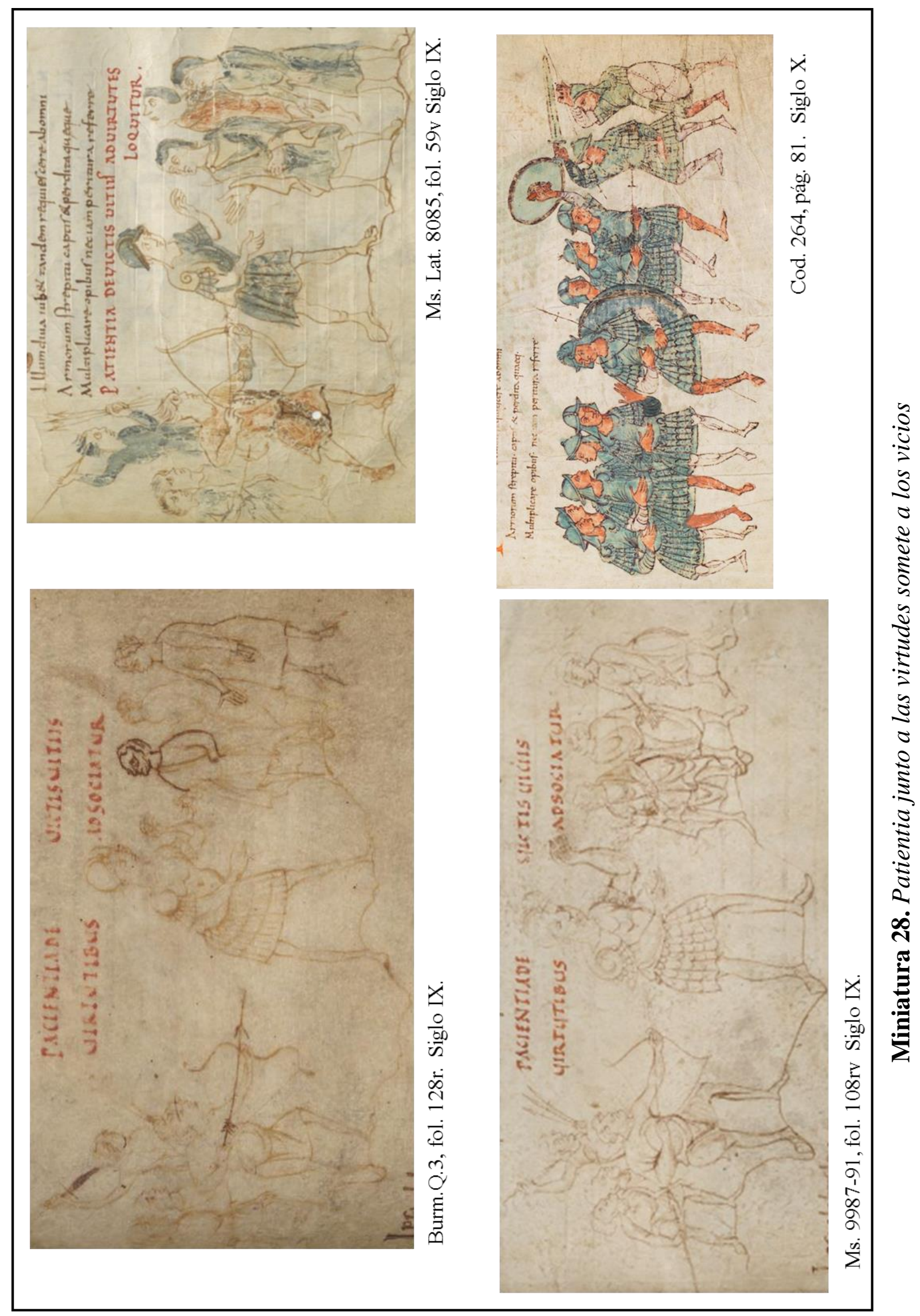


campo de batalla a pesar de las nubes de dardos que atravesaban el mismo. En términos mnemónicos esta miniatura se limita a expresar en imagen el ad res de los versos 172 al 177.

\subsubsection{Humilitas vs Superbia}

El combate entre Superbia y Humiltas abarca los versos 179 al 309. Entre estos ciento treinta versos se incluyeron once miniaturas que recogen los momentos más memorables de dicha batalla. Todas estas imágenes plasman visualmente el ad res de los distintos versos que anteceden. La mayoría de estas iluminaciones corresponden a lo narrado en dos o tres versos, realmente denota un interés particular por parte de los copistas e iluminadores en las imágenes que se representan. Por ejemplo, las primeras tres imágenes, las miniaturas 29, 30 y 31, introducen al espectador a la figura de Superbia tal y como la describe el poema: altiva, vestida con un manto fino que colgaba de su cuello y con los cabellos entrelazados en lo alto de su cabeza para verse más altanera.

Con la miniatura 29, Superbia se pavonea entre los escuadrones en su caballo indomable, inicia el cuarto combate de la Psychomachia. La misma se representó en tres de los cuatro manuscritos estudiados: Burm.Q.3, Ms. Lat. 8085, Ms. 9987-91 y Cod. 264. En los primeros tres ejemplos en el centro de la miniatura aparece Superbia montada en su caballo. Varios detalles del poema se traducen en imagen. Según el texto el vicio revoloteaba de un lado a otro (volito). Esta acción se plasma a través de la capa que revolotea. Igualmente se aprecia en lo alto de su cabeza los bucles ensortijados con los que según el relato ésta decoró su melena. A ambos lados de la figura a caballo se representa un grupo de tres figuras, todas con apariencia desconcertada. En el Cod. 264 la imagen de Superbia se representó en el lado derecho dirigiéndose hacia las distintas figuras desconcertadas a la derecha. El iluminador de este manuscrito tubo mucho más cuidado con los detalles del vicio, en la escena además de apreciar la fulgurante capa o los ornamentos que ésta colocó en su cabeza, 
se ha incluido la piel de león con la que Superbia había revestido su caballo. En las miniaturas del siglo $\mathrm{X}$ en las que aparece este vicio se mantienen estos detalles.

En la siguiente miniatura, la 30, el vicio aparece sólo en su corcel. El equino gira su cabeza en dirección contraria a la posición de su cuerpo, que en conjunto con el movimiento de la capa y el brazo extendido de Superbia en una imagen estática trasmite la acción de inestabilidad e impaciencia del corcel a la que alude el poeta en los versos 190 y $191^{133}$. Las miniaturas de los manuscritos del siglo X visualmente son mucho más ricas. Superbia sujeta un hacha y el caballo se representa con sus patas extendidas para hacer hincapié en que corre velozmente.

En cuanto a la miniatura 31, Superbia amenaza a la muchedumbre, Humilitas y Spes permanecen tranquilas, la composición de esta escena en los manuscritos del siglo IX es muy similar a la de la escena 29 en la que Superbia se pavonea montada en su caballo entre los escuadrones. Aquí el vicio aparece montado en su caballo entre los distintos ejércitos representados a través de los grupos de tres figuras a cada lado de Superbia. La principal diferencia de esta miniatura con la 29, es que en el lado derecho se incluyen dos figuras vestida con armadura y yelmos: Humilitas y Spes. En los códices Ms. 10066-77 y Cod. 264 se introducen leves cambios. En el manuscrito de la Bibliotea Real de Bélgica las virtudes portan lanza y escudo. En el códice de la Biblioteca de Berna la muchedumbre amenazada se representa huyendo del galopar furioso de Superbia y se suprimieron las figuras de las virtudes. Stettiner entiende que esta multitud despavorida es una representación del pobre ejército de Humilitas descrito en los versos 196 al $198^{134}$.

En estas tres miniaturas que introducen a la figura de Superbia los rasgos físicos con los que constantemente el poeta describe a ésta se adaptan a la descripción visual. En las miniaturas 29, 30 y 31 el vicio se plasma con el manto colgándole y

133 "Nec minus instabili sonipes feritate superbit inpatiens madidis frenarier ora lupatis". Prudencio. Psychomachia, vv. 190-191. Obras Completas de Aurelio Prudencio..., pp. 322-323. ${ }^{134}$ STETTINER. Die Illustrierten Prudentiushandschriften..., pp. 283-284. 


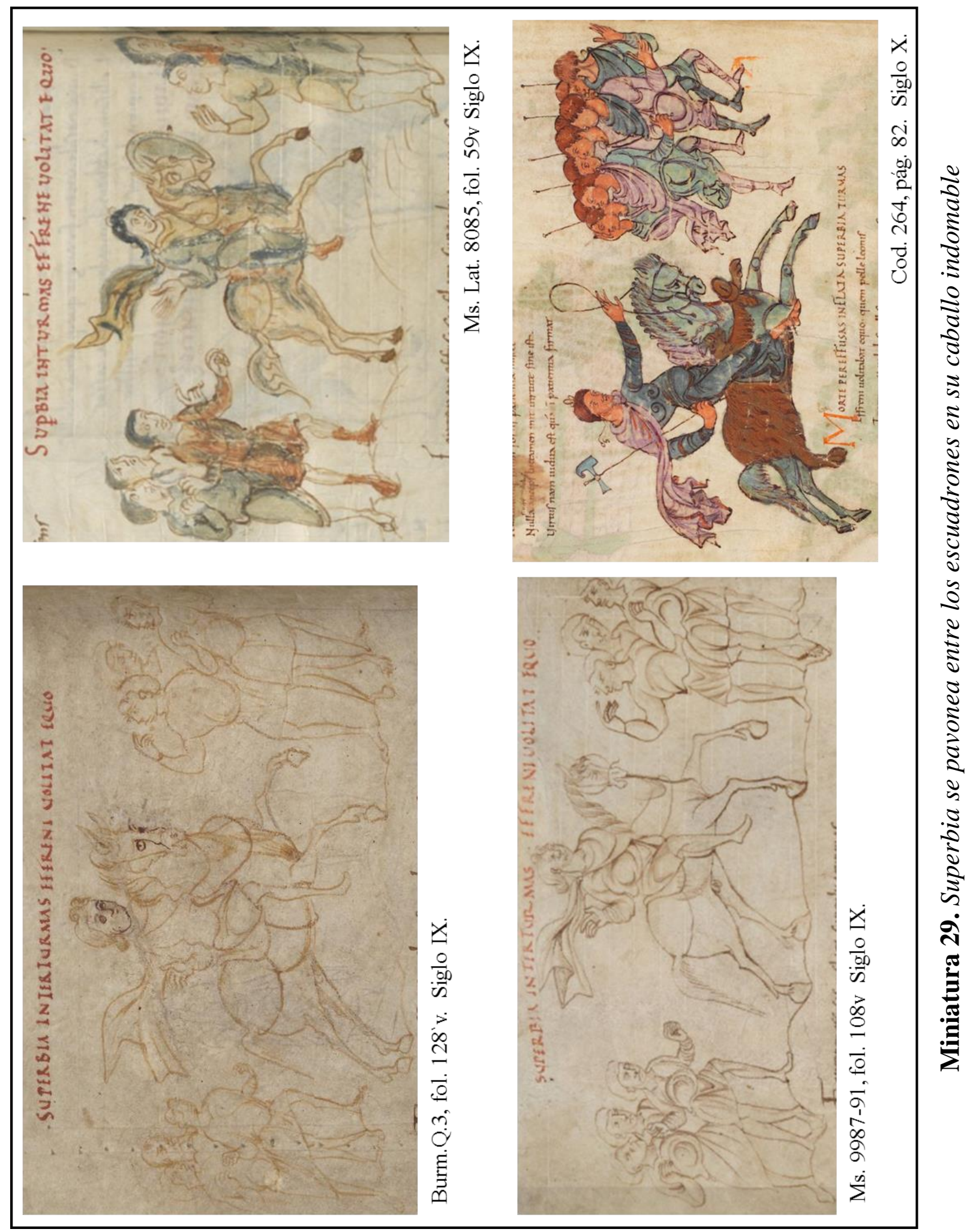




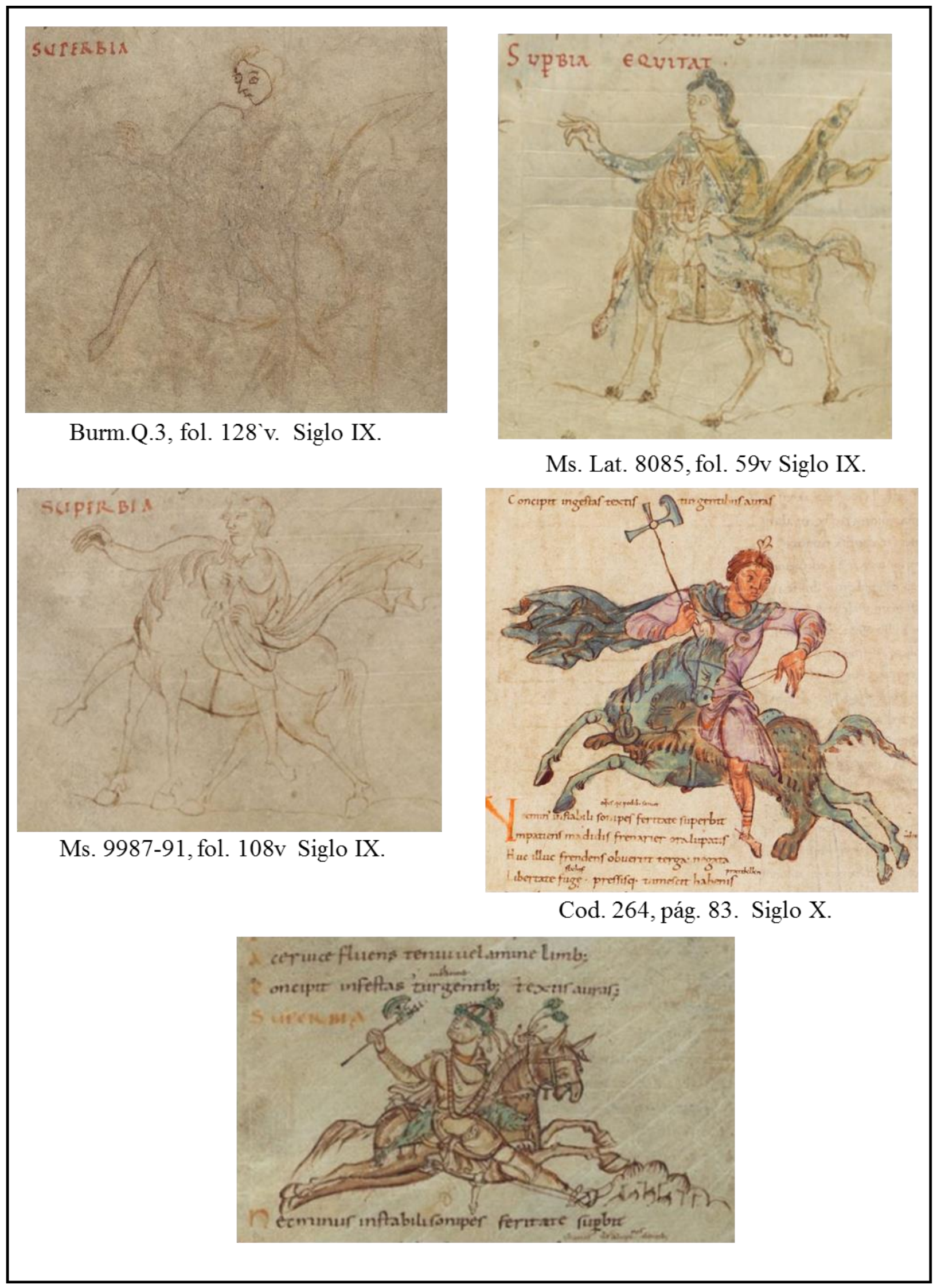

Miniatura 30. Superbia cabalga 


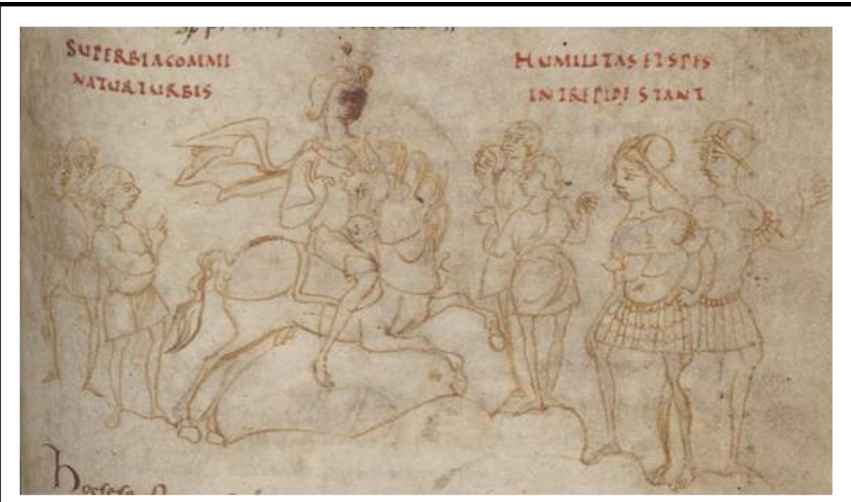

Burm.Q.3, fol. 129r. Siglo IX.

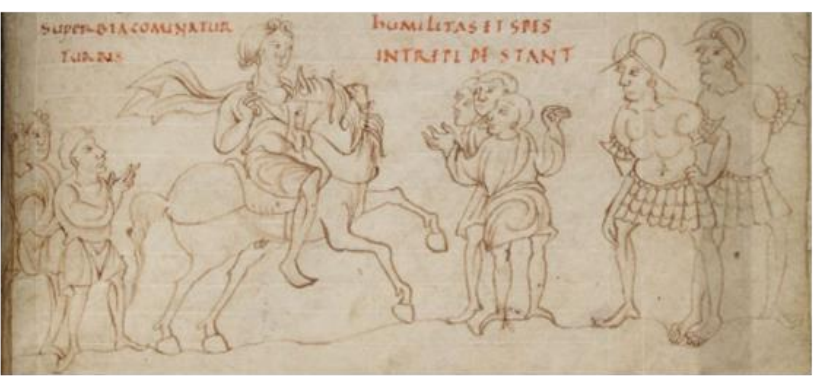

Ms. 9987-91, fol. 109r Siglo IX.

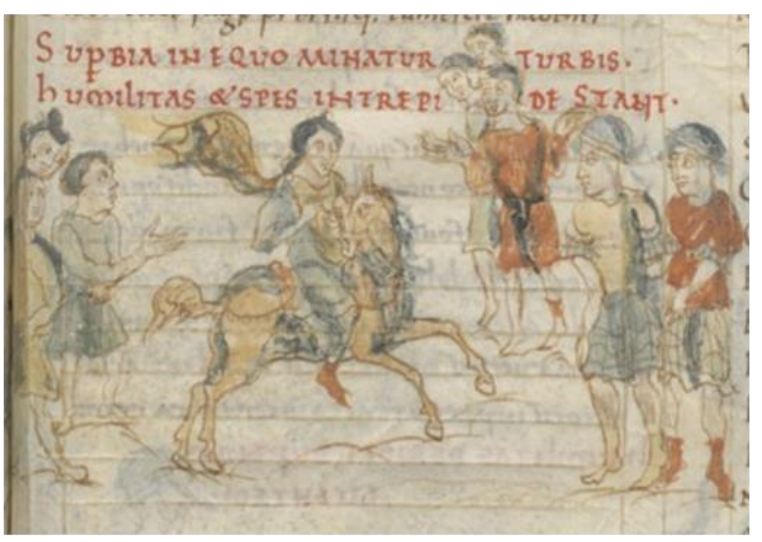

Ms. Lat. 8085, fol. 60r Siglo IX.

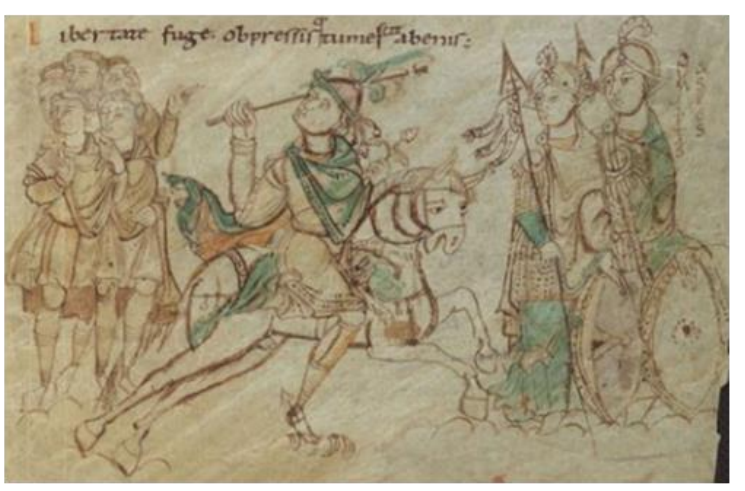

Ms. 10066-77, fol. 122r. Siglo X.

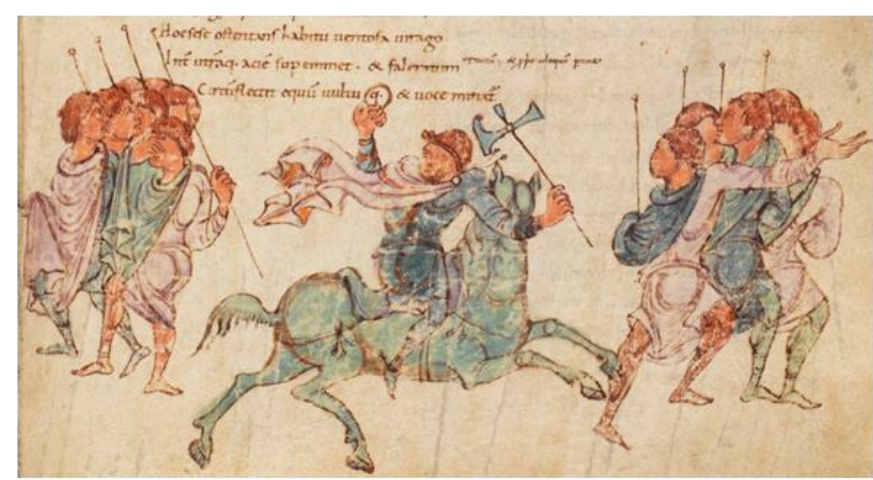

Cod. 264, pág. 83. Siglo X.

Miniatura 31. Superbia amenaza a la muchedumbre, Humilitas y Spes permanecen tranquila 
revoloteando y con los adornos en la cabeza. En cuanto al tocado de ésta, en los códices del siglo IX se plasmó según los versos, con sus melenas ensortijadas formo una especie de torre en lo alto de su cabeza ${ }^{135}$. Prudencio indica que el vicio había revestido su corcel con la piel de un león ${ }^{136}$ y ésta se incluye en las representaciones del siglo X. La piel del león es el premio de Hércules tras haber luchado con éste y posteriormente será utilizado por la virtud de la Fortaleza equiparada con el héroe de la antigüedad, no obstante, el hecho de que sea uno de los vicios la portadora de la misma le otorga un significado negativo a este animal ${ }^{137}$. Por su misma naturaleza salvaje y potente es una fuerza negativa y amenazante a la que se ha de vencer, igual que a Superbia. En el Antiguo Testamento algunos de los enemigos políticos poderosos eran descritos como el león y las fuerzas demoniacas del demonio eran equiparadas con este animal ${ }^{138}$.

La descripción del autor parte de la creación de imágenes mentales según el principio mnemónico de que éstas deben ser cercanas a la realidad. Al describir a Superbia, una figura alegórica, con adjetivos que podrían aplicar bien a un individuo real la figura de ésta se acerca a la realidad lo que garantiza que la rememoración de la misma se logre de manera efectiva como las coronas y los mantos púrpuras de los mártires al final del combate entre Fides y Cultura Deorum (Miniatura 10). El manto, la piel de león o el tocado de Superbia no sólo se vinculan con la similitud, sino que también manifiestan la misma naturaleza del vicio, después de todo Superbia encarna la soberbia, la altanería, la arrogancia, la insolencia y el orgullo. La composición y el mayor empeño en los detalles por parte de los iluminadores de los manuscritos 10066-77 y Cod. 264 realzan dando más vigorosidad a las imágenes cualidad que las

\footnotetext{
${ }^{135}$ Prudencio. Psychomachia, vv. 183-185. Obras Completas de Aurelio Prudencio..., pp. 322323.

136 "quem pelle leonis". PRUDENCIO. Psychomachia, v. 179. Obras Completas de Aurelio Prudencio..., pp. 320-321.

${ }^{137}$ KatZenellenbogen. Allegories of the Virtues and Vices in Mediaeval Art..., p. 56. RÉAU. Iconografía del arte cristiano. Introducción general..., p. 222. MÂLE, Emile. L'art religieux de la fin $d u$ Moyen Âge en France. Étude sur l'iconographie du Moyen Âge et sur ses sources d'inspiration. 2da edición. París: Librairie Armand Colin, [1908] 1922. p. 322.

${ }^{138}$ HeINZ-MoHR. Lessico di iconografía ..., pp. 197-198.
} 
vuelve aún más memorables. El mejor ejemplo de esto es la muchedumbre que huye en la miniatura 29 y 31 del códice de Berna.

Estas tres miniaturas a priori son muy similares, sin embargo, las mismas llevan a cabo muy bien su función: recopilar o resumir las acciones más importantes de los versos a los que responden. Esto se logra por medio de sutilezas visuales recogidas en los gestos o las figuras plasmadas. El combate entre Superbia y Humlitas inicia con el vicio pavoneándose sobre su caballo en medio de las tropas. La miniatura que precede los versos con esta información, la 28, muestra a la altanera Superbia en medio de una muchedumbre que personaliza a las tropas. La miniatura 30 muestra al vicio sobre su caballo. Según los versos, el caballo igual de altivo que su dueña se agita de un lado para otro y ni el freno puede controlarlo ${ }^{139}$. En los manuscritos Burm.Q.3, Lat. 8085 y 9987-91 la vigorosidad del caballo se captura plasmando al mismo girando su cabeza en dirección contraria a la posición de su cuerpo mientras que a causa del movimiento el manto de la virtud revolotea. La imagen de Cod. 264 provee mucha más información sobre la acción del equino. En ésta se aprecia el cabalgar de la bestia y a Superbia sujetando las riendas.

Es en la miniatura 31, Superbia amenaza a la muchedumbre, Humilitas y Spes permanecen tranquilas, donde por fin aparece la virtud Humilitas, acompañada por Spes, ambas con armaduras y cascos. Superbia continúa revoloteando y pavoneándose entre la multitud, pero esta vez amenaza e insulta a sus contrincantes. En Burm.Q.3 y Ms. 9987-91 el iluminador se tomó la molestia de representar al vicio con el gesto que ya anteriormente se ha vinculado para la articulación de palabras. El gesto de Superbia hace de lugar de recopilación para la figura de Adán, quien por consejo de este vicio pecó y perdió el paraíso terrenal ${ }^{140}$. Otra sutileza visual pero que resulta ser igualmente un recuso mnemónico son las figuras representadas de forma genérica. Éstas no sólo captan visualmente la muchedumbre descrita por el

\footnotetext{
${ }^{139}$ Prudencio. Psychomachia, vv. 190-193. Obras Completas de Aurelio Prudencio..., pp. 322323.

${ }^{140}$ Prudencio. Psychomachia, vv. 225-227. Obras Completas de Aurelio Prudencio..., pp. 324325. CARRUTHERS. The Craft of Thought ..., p. 19.
} 
autor, sino que el número representado en los códices Burm.Q.3, Lat. 8085, 9987-91 y 10066-77 corresponde a los cinco soldados que Humilitas había reunido: Iustitia, Honestas, Sobrietas, Ieiunia, Pudor y Simplicitas.

Las miniaturas 32, 33, 34, 35, 36 y 37 recopilan la batalla entre Superbia y Humilitas y la derrota del vicio. Al igual que las tres imágenes que introducen a las protagonistas del combate, estas ilustraciones recopilan las principales acciones narradas en los versos a los que aluden. La acción de la miniatura 32 narra visualmente lo descrito en los versos 253 al 256: Superbia se precipita sobre Humilitas y Spes para derribarlas con su escudo y caballo. En los tres manuscritos del siglo IX, se aprecia la figura de Superbia sobre su corcel cabalgando en dirección a Humilitas y Spes. En los tres ejemplos sujeta con una mano un escudo y en Burm.Q.3 también lleva una lanza. En los códices del siglo X levanta su brazo izquierdo para golpear a las virtudes con el hacha de guerra que lleva. En el Cod. 264 la miniatura de esta escena es la primera representación de Humilitas y Spes que aparece en el códice. Las mismas son figuras femeninas vestidas con túnicas y mantos. El dramatismo de la escena se amplía en los códices Burm.Q.3, 10066-77 y Cod. 264, pues el vicio blandea una lanza o un hacha sobre las virtudes. Las virtudes permanecen inmóviles al ataque del vicio, cuyo intento por herir a Humilitas es fallido ya que termina cayendo de cabeza junto a su caballo en una fosa que había cavado Fraus $^{141}$. A partir de este momento el cuerpo inerte de Superbia y del equino se reproducen en los códices de forma sumamente patética, claramente apelando a la creación de imagines agentes por medio de la desfiguración (Miniaturas 33, 34, $35,36,37)^{142}$.

El fin de Superbia se recoge en los veros 278 al 283. Entre estos seis versos se insertaron tres iluminaciones que plasman visualmente lo descrito por Prudencio, o sea, cada una de estas tres miniaturas corresponde a dos versos del poema. En comparación con combates o escenas anteriores, por ejemplo, el combate entre Fides

\footnotetext{
${ }^{141}$ Prudencio. Psychomachia, vv. 257-273. Obras Completas de Aurelio Prudencio..., pp. 326327.

${ }^{142}$ YATES. El arte de la memoria..., p. 22.
} 
y Cultura deorum cuyos 19 versos se ilustran con tres miniaturas (Miniaturas 8, 9 y 10), claramente ser percibe una disparidad entre versos e imágenes. Las imágenes entonces no se ubican de acuerdo a un número de versos en concretos. El orden o el sistema que guía el lugar de las miniaturas dentro del poema responde a los aspectos más memorables y llamativos descritos por Prudencio.

La miniatura 33 es la primera en la que se representa a Superbia muerta. En las tres imágenes de los ejemplos del siglo IX se aprecia en el lado derecho de la composición a Humilitas y Spes contemplando cómo Superbia cae en la fosa. La fosa se representa a través de una figura ovalada dentro de la cual se aprecia al vicio y su equino. En los ejemplos del siglo $\mathrm{X}$ el lugar de las figuras se ha intercambiado. Las virtudes aparecen en el lado izquierdo y el vicio en la derecha. En Ms. 10066-77 y Cod. 264 también se utiliza la figura ovalada para ilustrar la fosa, la principal diferencia es que en estos sólo se aprecia parte del cuerpo de Superbia y de su caballo. Mientras que en Burm.Q.3, Ms. 9987-91 y Ms. Lat. 8085 dentro de la fosa se aprecia el cuerpo completo de Superbia y su corcel, en Ms. 10066-77 y Cod. 264 no.

En la miniatura 34, Humilitas se burla de la derribada Superbia, también se representa a Superbia muerta, sin embargo, los gestos y la composición de las imágenes responde a las acciones descritas en los versos 274 al 277: Humilitas se aproxima al borde de la fosa a ver a su enemiga se alegra, pero luego vacila y viene a su ayuda Spes. En los códices del siglo IX, la composición es la misma, y en el Cod. 264 del siglo X la disposición de las figuras es similar. En el lado izquierdo tumbada en el suelo yace Superbia y su caballo. A pesar de que el poema indica que aún se encuentran en la fosa, en estos cuatro manuscritos ésta no se ilustró. La miniatura de Ms. 10066-77 es distinta, en el lado izquierdo se representa Humilitas sola con un escudo, elevando su brazo de forma parecida a las escenas en las que se plasma el gesto de increpat. Delante de la virtud dibujaron los cuerpos muertos del equino y Superbia e inspirado en el texto, se ilustran dentro de la fosa. Si bien los rostros de las figuras no representan el sentimiento que ésta manifiesta, el título de la imagen recuerda al espectador el mismo. En los cuatro casos que aparecen los tituli se utilizó el verbo derideo, burlarse de. 


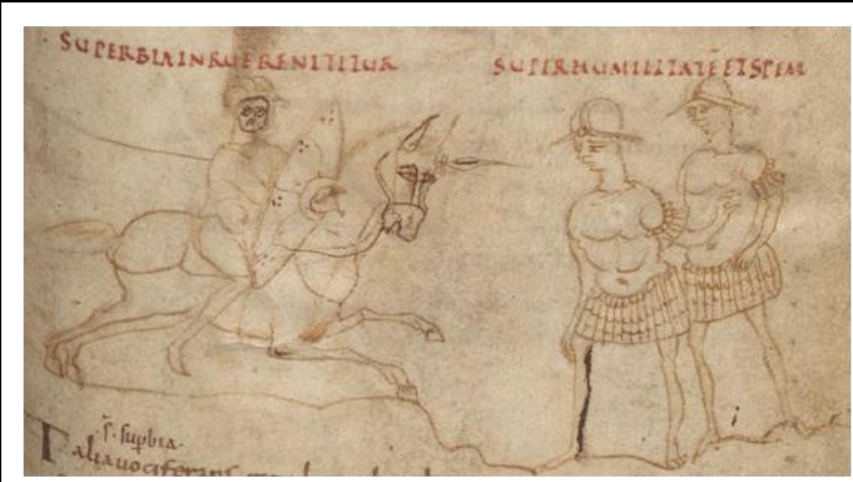

Burm.Q.3, fol. 130r. Siglo IX.

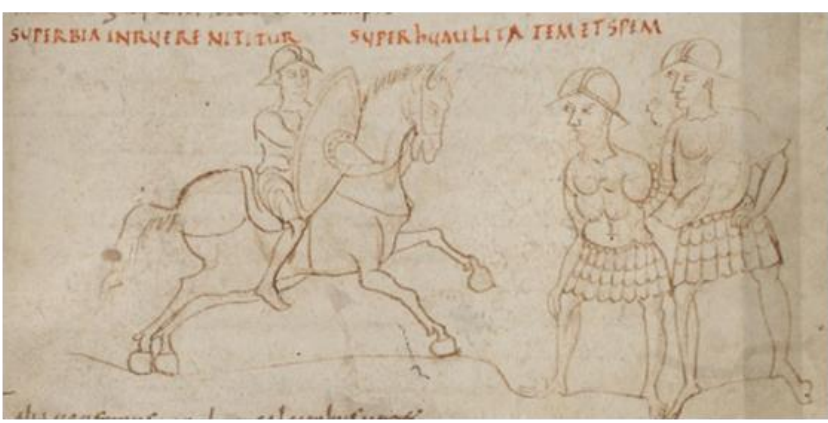

Ms. 9987-91, fol. 110r Siglo IX.

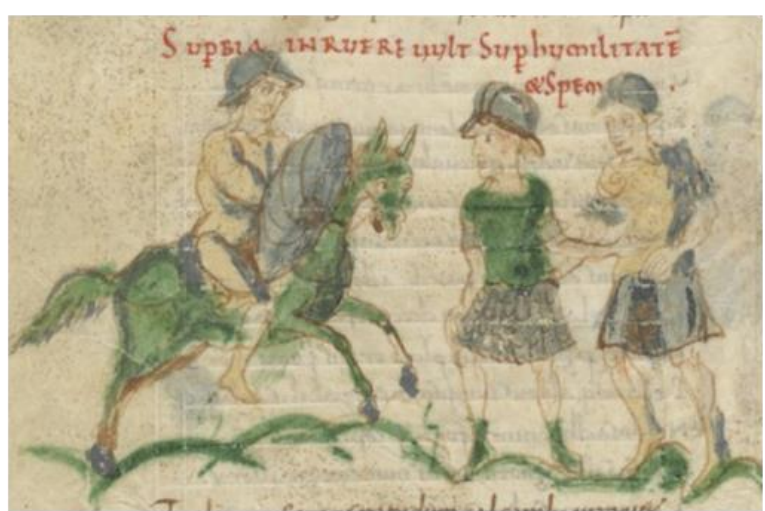

Ms. Lat. 8085, fol. 60v Siglo IX.

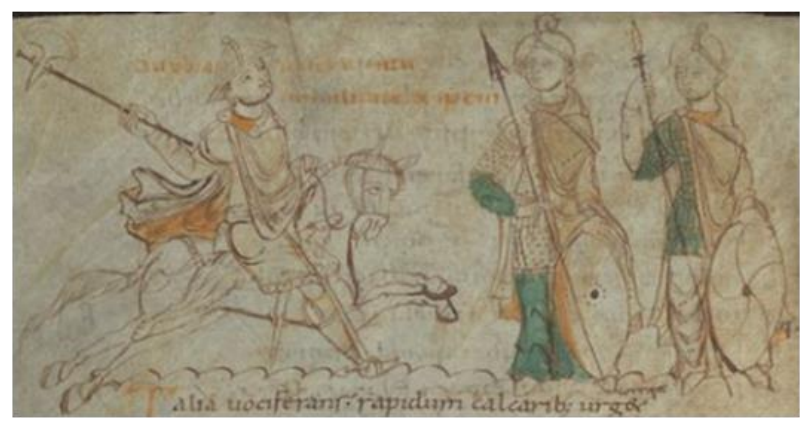

Ms. 10066-77, fol. 123v. Siglo X.

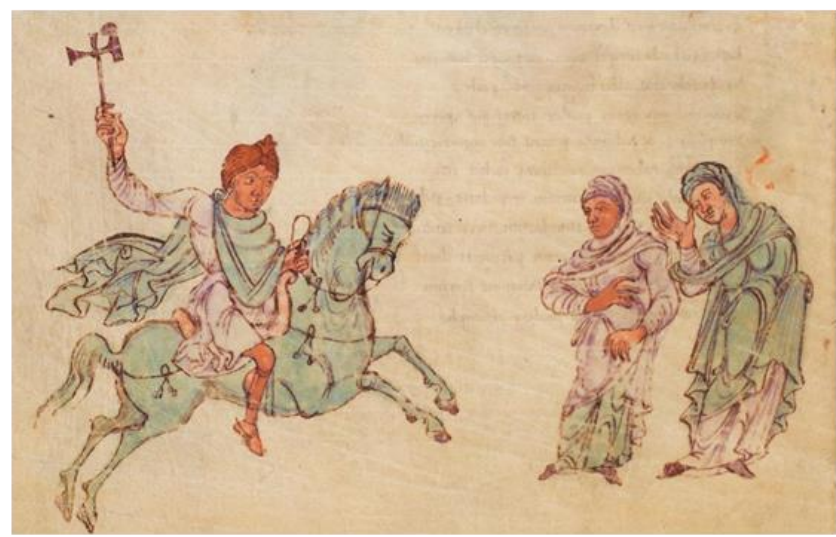

Cod. 264, pág. 86. Siglo X.

Miniatura 32. Superbia se precipita sobre Humilitas y Spes 


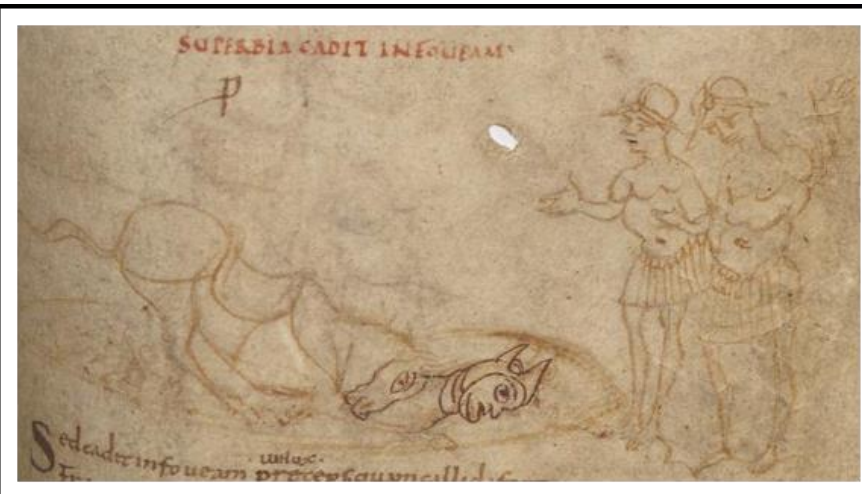

Burm.Q.3, fol. 130r. Siglo IX.

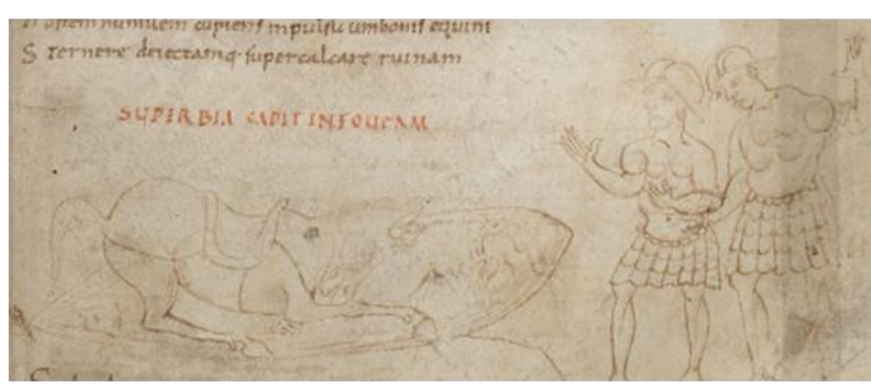

Ms. 9987-91, fol. 110r Siglo IX.

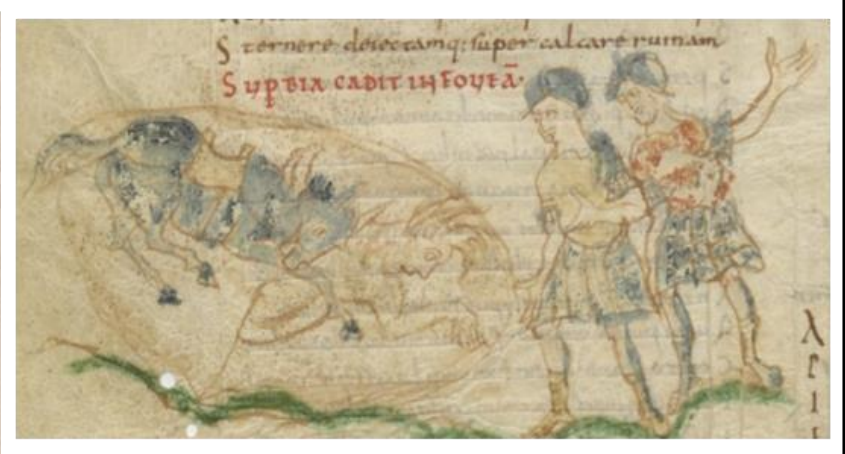

Ms. Lat. 8085, fol. 60v Siglo IX.

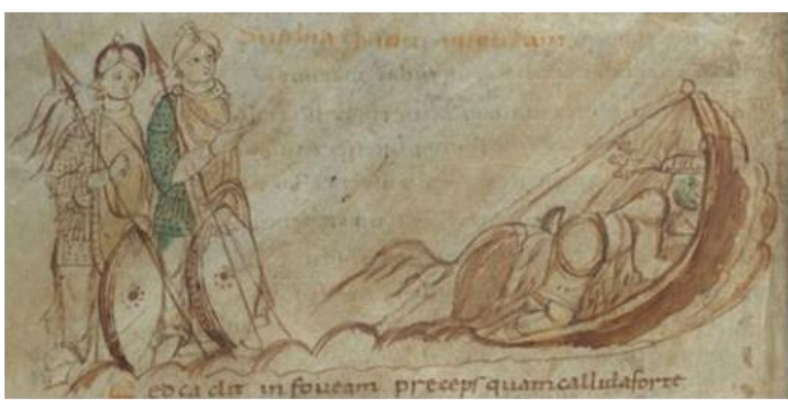

Ms. 10066-77, fol. 123v. Siglo X.

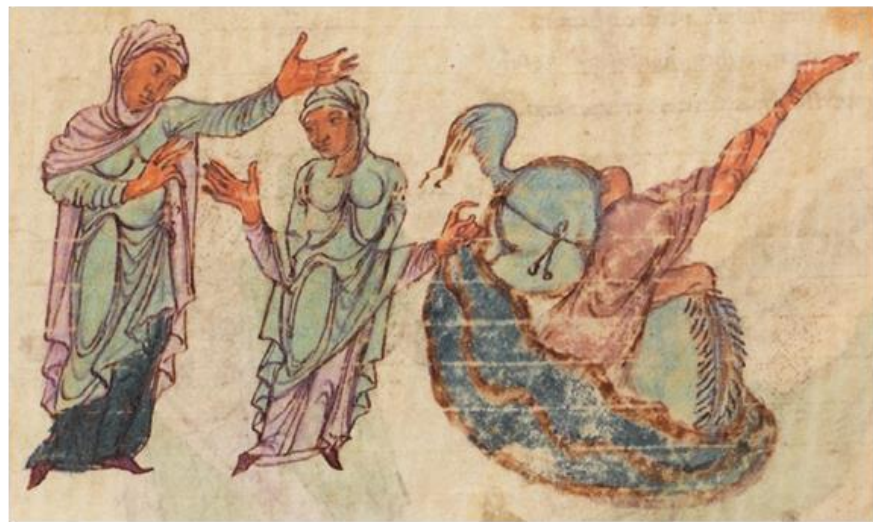

Cod. 264, pág. 87. Siglo X.

Miniatura 33. Superbia cae en una fosa 


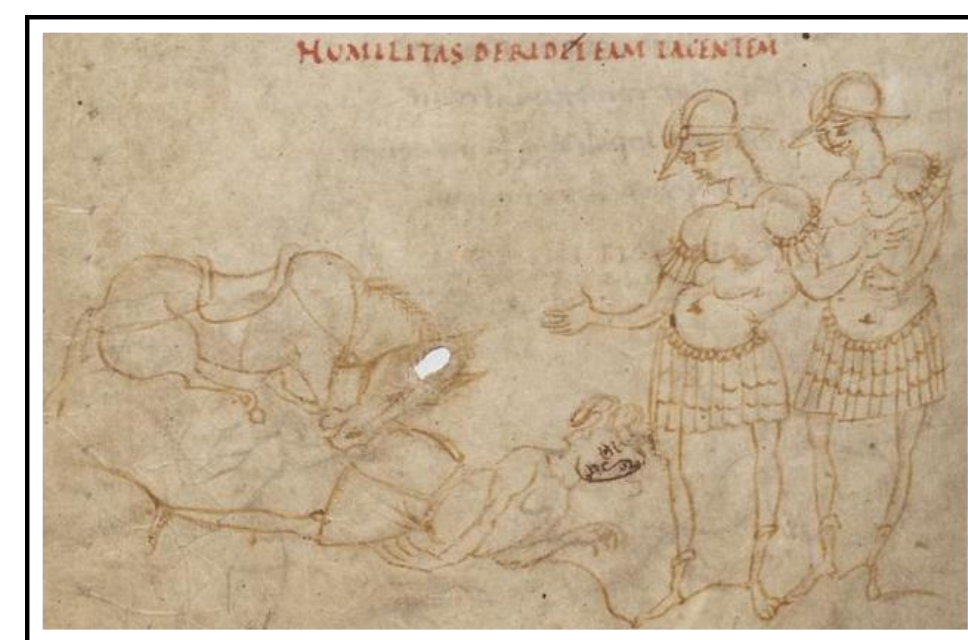

Burm.Q.3, fol. 130v. Siglo IX.

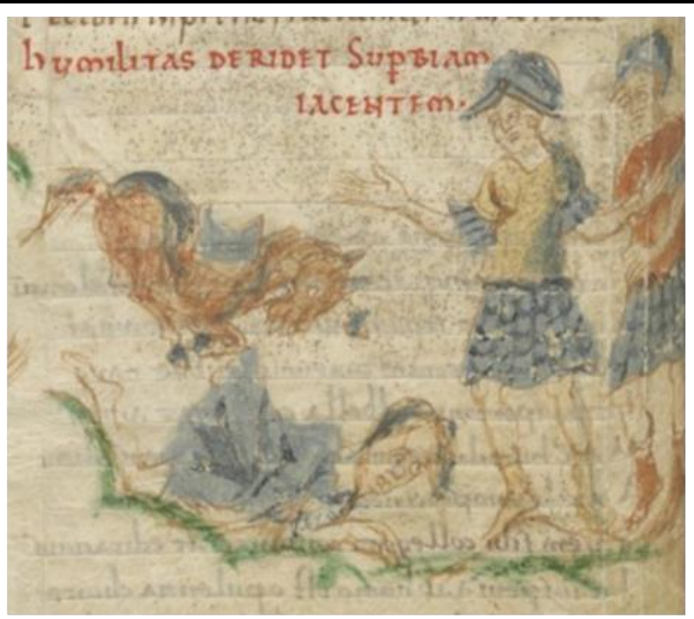

Ms. Lat. 8085, fol. 60v Siglo IX.

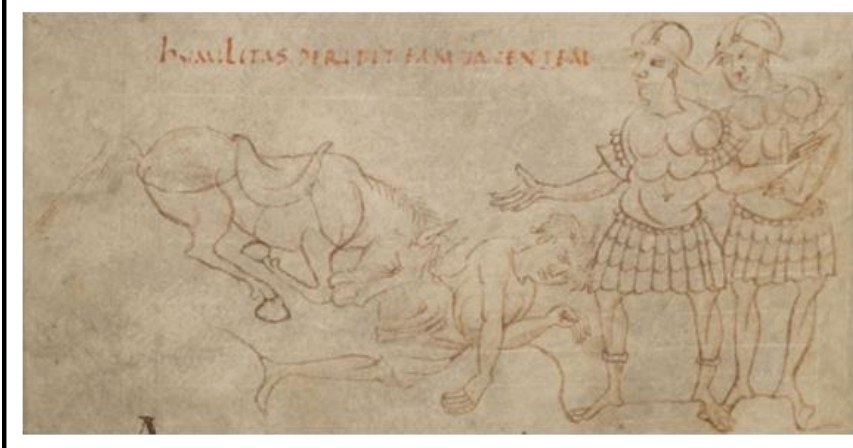

Ms. 9987-91, fol. 110v Siglo IX.

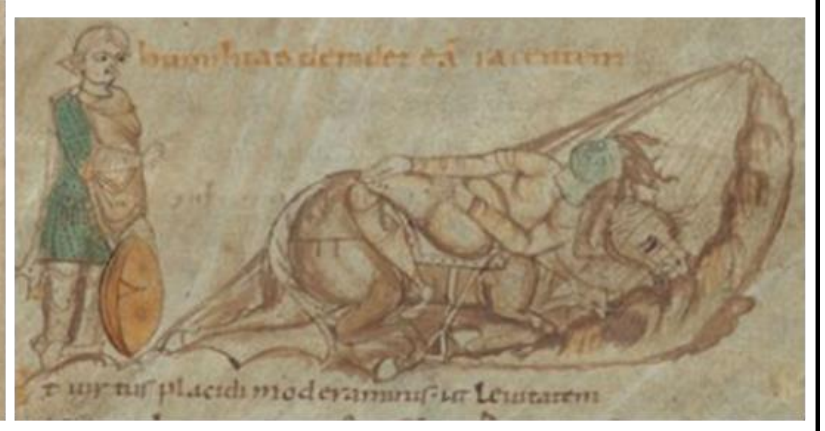

Ms. 10066-77, fol. 124r. Siglo X.

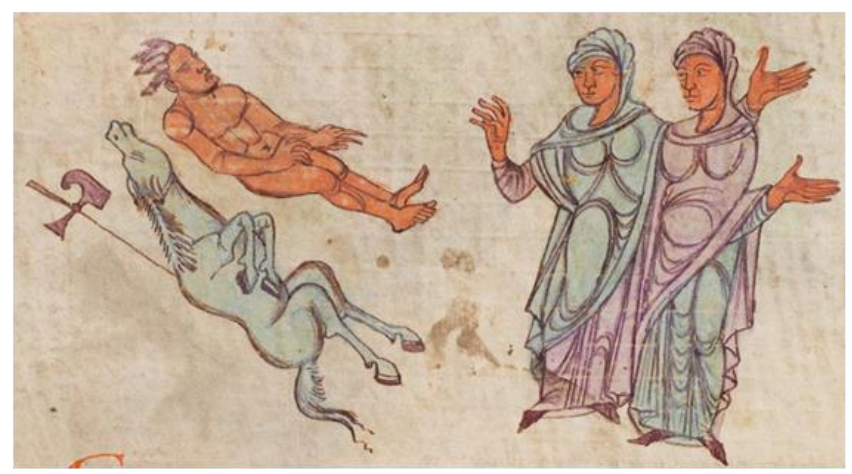

Cod. 264, pág. 88. Siglo X.

Miniatura 34. Humilitas se burla de la derribada Superbia 
La miniatura 35 se vincula con las escenas de la derrota de Superbia y en la misma se recoge visualmente le momento en que Spes ofrece su espada a Humilitas. Esta escena se incluyó en los cinco manuscritos estudiados antecediendo los versos 278 al 279. La composición de las imágenes sigue muy de cerca el arreglo de la miniatura 34, Superbia y su caballo tendidos en suelo ocupan el lado izquierdo mientras que en el lado derecho están Humilitas y Spes. El mayor cambio son los gestos de las dos virtudes y es a través de estos que se lee la imagen y el espectador se ubica en el momento preciso del poema. En los mismos se aprecia como Spes, extiende sus brazos y ofrece su espada a Humilitas y como ésta igualmente alza su brazo para recibir el arma de su compañera. Los códices del siglo X ofrecen más información visual, en Ms. 10066-77 Spes ofrecece su espada enfundada y en Cod. 264 la espada acaba de ser desenfundada por Spes. El el códice de Berna la posición de Superbia es distinta, ahora viste una túnica y su cuerpo inerte cuelga de forma extraña. Más que pender es como si estuviera tendido en el suelo y el miniaturista lo representó de tal forma que el espectador pueda contemplarlo completo.

En las miniaturas 36 y 37 se narra visualmente como las virtudes se disponen a decapitar a Superbia. Si bien el título de las miniaturas 36, utiliza el verbo amputo para indicar que Humilitas corta la cabeza de Superbia, en las distintas imágenes de esta escena se representa lo narrado en los versos 280 al 281, Humilitas coge con la mano izquierda por los cabellos a su enemiga. En Ms. 10066-77 la acción es mucho más violenta y la virtud además de agarrar al vicio por los cabellos se abalanza y pisotea al mismo. Los gestos representados en las cinco imágenes de esta escena crean un ritmo visual y la acción plasmada de elevar el brazo con la espada para cercenar la cabeza de Superbia nos introduce a la acción de los próximos versos y por consiguiente de la miniatura 37.

El brazo con la espada a punto de cortar la cabeza en la miniatura 37 ya realizó dicha acción, Humilitas cortó la cabeza de Superbia y mientras chorrea sangre se la ofrece a Spes. Las tres miniaturas de los códices del siglo IX muestran una composición similar. A la izquierda el cuerpo inerte del caballo y el decapitado de Superbia. En el lado derecho se aprecia Humilitas sujetando la cabeza de su enemiga 
y a Spes con los brazos abiertos. En los ejemplos del siglo $\mathrm{X}$ los gestos cambian un poco. En estos se eliminó el cuerpo del corcel y sólo queda el del vicio. Humilitas continúa sujetando la cabeza cercenada de Superbia, pero en estas dos miniaturas extiende su brazo para ofrecérsela a su compañera Spes y ésta reciproca el gesto para recibirla. Hay un claro interés en los manuscritos Lat. 8085, 10066-77 y Cod. 264 de resaltar lo grotesco de la situación. En estas tres imágenes particularmente se plasmó la sangre que chorrea de la cabeza y del cuerpo de Superbia. Con anterioridad habíamos apuntado a que este líquido es una de los elementos más llamativos en la creación de imágenes memorables.

Cómo en los combates anteriores, en el encuentro entre Superbia y Humilitas se incluye una escena de increpat y se representa en la miniatura 38. A pesar de que las protagonistas de esta es la lucha son Humilitas y Superbia y es esta virtud la que mata al vicio, según los versos del poema la que pronuncia el reproche al vicio muerto es Spes, la fiel compañera de Humilitas. La imagen de esta escena sólo se incluyó en los manuscritos del siglo IX y en Cod. 264. La composición de Burm.Q.3, Ms. 998791 y Ms. Lat. 8085 es muy similar. A la izquierda el cuerpo del caballo y de Superbia, y junto a estos la cabeza cercenada del vicio. A la derecha las dos virtudes victoriosas, Spes con un brazo extendido y Humilitas con la espada que puso fin a las injurias del vicio.

A través de la vestimenta es muy difícil identificar en estos cuatro ejemplos que figura es Humilitas y cual es Spes. A través de las sutilezas es que el espectador familiarizado con el poema puede identificar las mismas. Humilitas es la figura que lleva la espada con la que fulminó a Superbia ${ }^{143}$. A través de esta acción, como en la miniatura anterior, se mantiene el ritmo visual. Por defecto, la otra imagen entonces representa a Spes, sin embargo, el gesto de ésta ayuda igualmente a corroborar su identificación. El ademán de las manos de esta figura es sumamente similar a los de otras escenas en las que las virtudes increpan al vicio derrotado como: en la victoria de Pudicitia sobre Libidinem (Miniatura 14) o la victoria de Patientia sobre Ira

${ }^{143}$ STETTINER. Die Illustrierten Prudentiushandschriften..., p. 298. 
(escena Miniatura 25). El ejemplo del códice del siglo X la composición se intercambió, el equino muerto se eliminó y los gestos de las virtudes son mucho más obvios, indicando que éstas dialogan. Spes en su discurso menciona el combate entre David y Goliat y cómo la actitud soberbia del gigante le llevó a su perdición y cómo la humildad y la esperanza de David le ayudó a vencer. Aquí la escena de increpat igualmente se asocia con individuos portadores de las virtudes y vicios protagonistas del combate y la imagen de Spes increpando a Superbia se vuelve un lugar mnemónico de recopilación que conecta con las historias bíblicas.

David es una prefiguración de Jesús e igualmente es uno de sus antepasados directos ${ }^{144}$. La lucha y victoria de éste contra Goliat ha sido interpretada como Cristo dando muerte al diablo, una prefiguración de la victoria de Cristo sobre Satán. Réau vinculó las figuras de David y Goliat con la batalla de los vicios y las virtudes. Para este historiador del arte, Goliat personifica la cólera ${ }^{145}$, lectura más apropiada para representaciones posteriores sobre todo del siglo XIV y XV. Las protagonistas del cuarto combate de la Psychomachia son imágenes antropomorfas de los conceptos de la humildad (Humilitas) y el orgullo y la soberbia (Superbia). Ya tan temprano como en el siglo V Prudencio en su poema concatenó estos conceptos morales con las figuras de David y Goliat. San Agustín, contemporáneamente, también relaciona tropológicamente estas dos figuras veterotestamentarias con estos vicios y virtudes: "David es figura de Cristo, como Goliat del diablo; y como David decapitó a Goliat, así Cristo mató al diablo. Y ¿qué significa que Cristo mató al diablo? Que la humildad mató a la soberbia ${ }^{146 "}$. Del mismo modo que Prudencio, el texto de este padre de la Iglesia ofrece al lector una imagen mental donde los personajes veterotestamentarias encarnan los conceptos morales. La concatenación de sucesos

\footnotetext{
${ }^{144}$ RÉAU. Iconografía del arte cristiano. Iconografía de la Biblia. Antiguo Testamento. Tomo 1, Vol. ..., p. 300.

${ }^{145}$ RÉAU. Iconografía del arte cristiano. Iconografía de la Biblia. Antiguo Testamento. Tomo 1, Vol. ..., p. 307.

${ }^{146}$ SAn Agustín. Enarrationes in Psalmos, 33, s.1, 4. Edición consultada: Obras de San Agustín, Enarraciones sobre los Salmos (1 parte). Edición bilingüe, Tomo XIX. Edición de: Balbino Martín Pérez. Madrid: Editorial Católica, S.A., 1964. p. 474.
} 


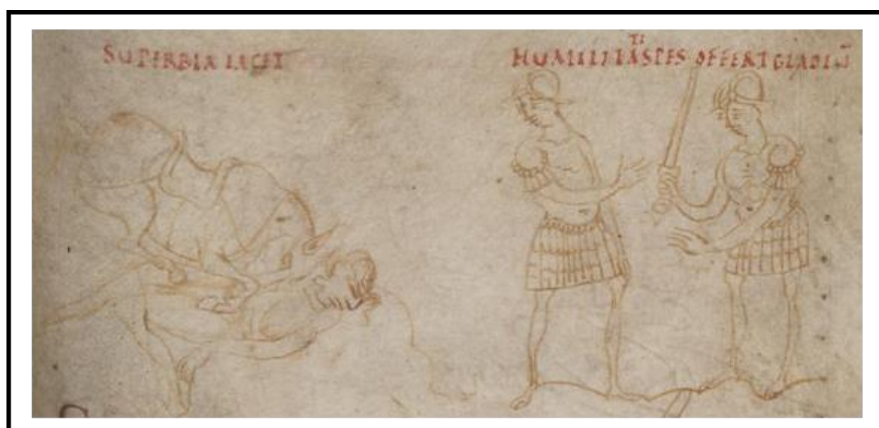

Burm.Q.3, fol. 131r. Siglo IX.

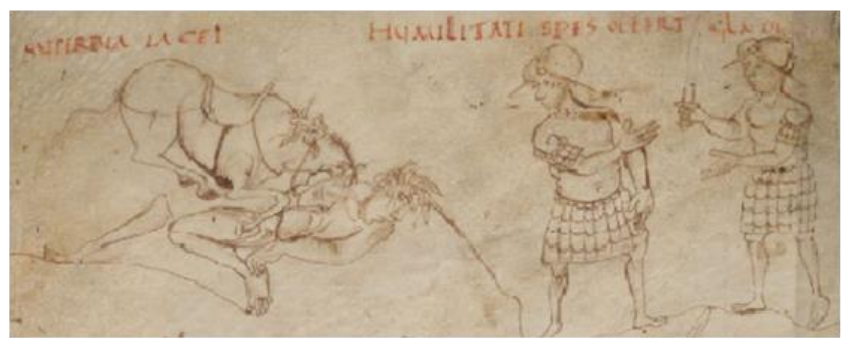

Ms. 9987-91, fol. 111r Siglo IX.
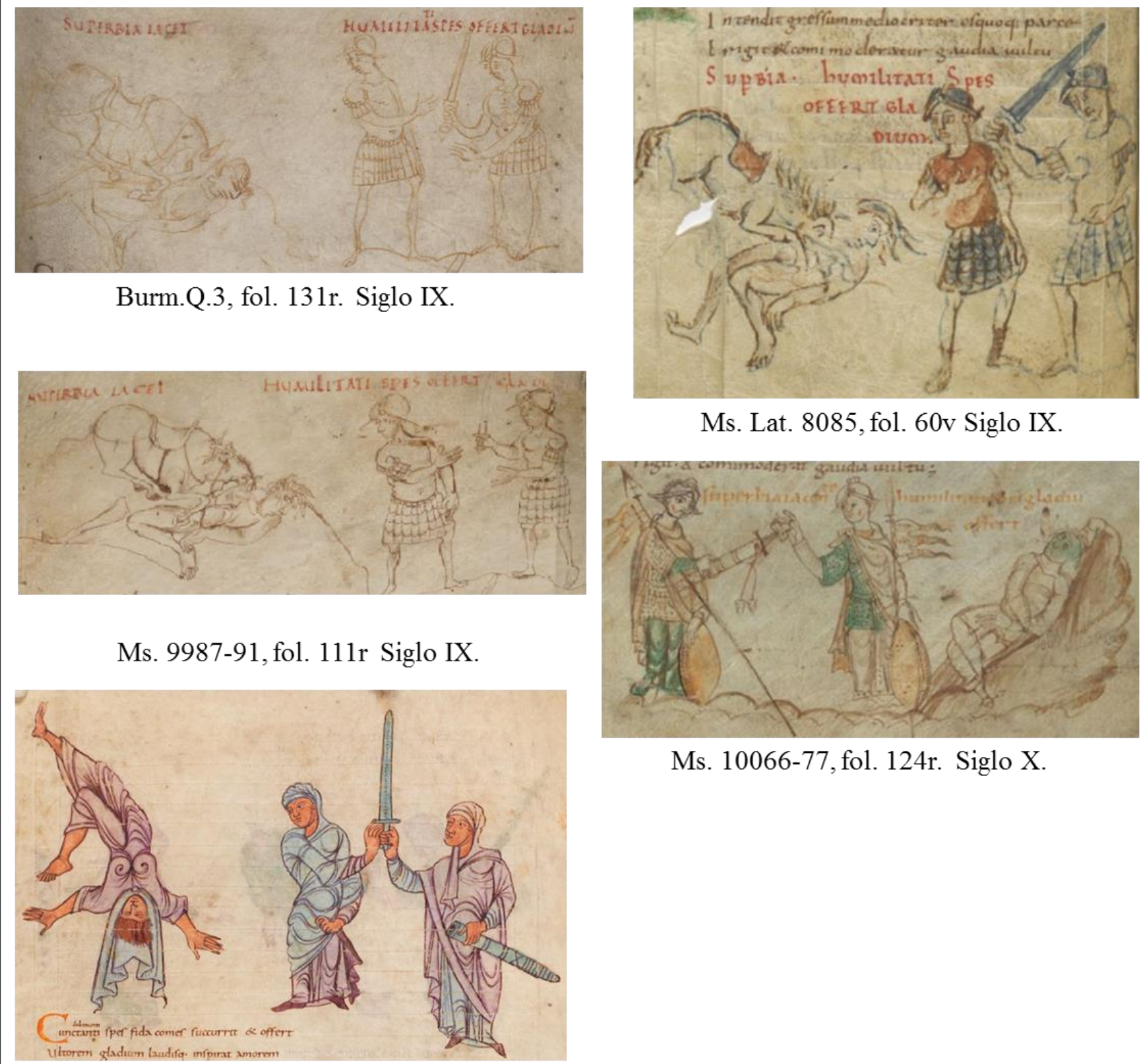

Ms. Lat. 8085, fol. 60v Siglo IX.

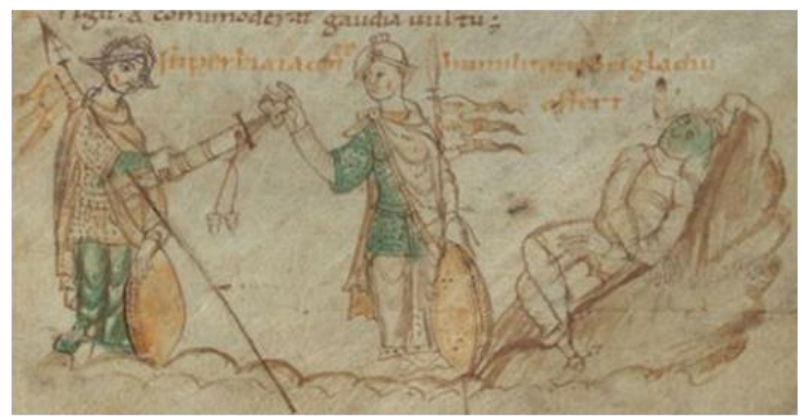

Ms. 10066-77, fol. 124r. Siglo X.

Cod. 264, pág. 89. Siglo X.

Miniatura 35. Spes ofrece su espada a Humilitas 


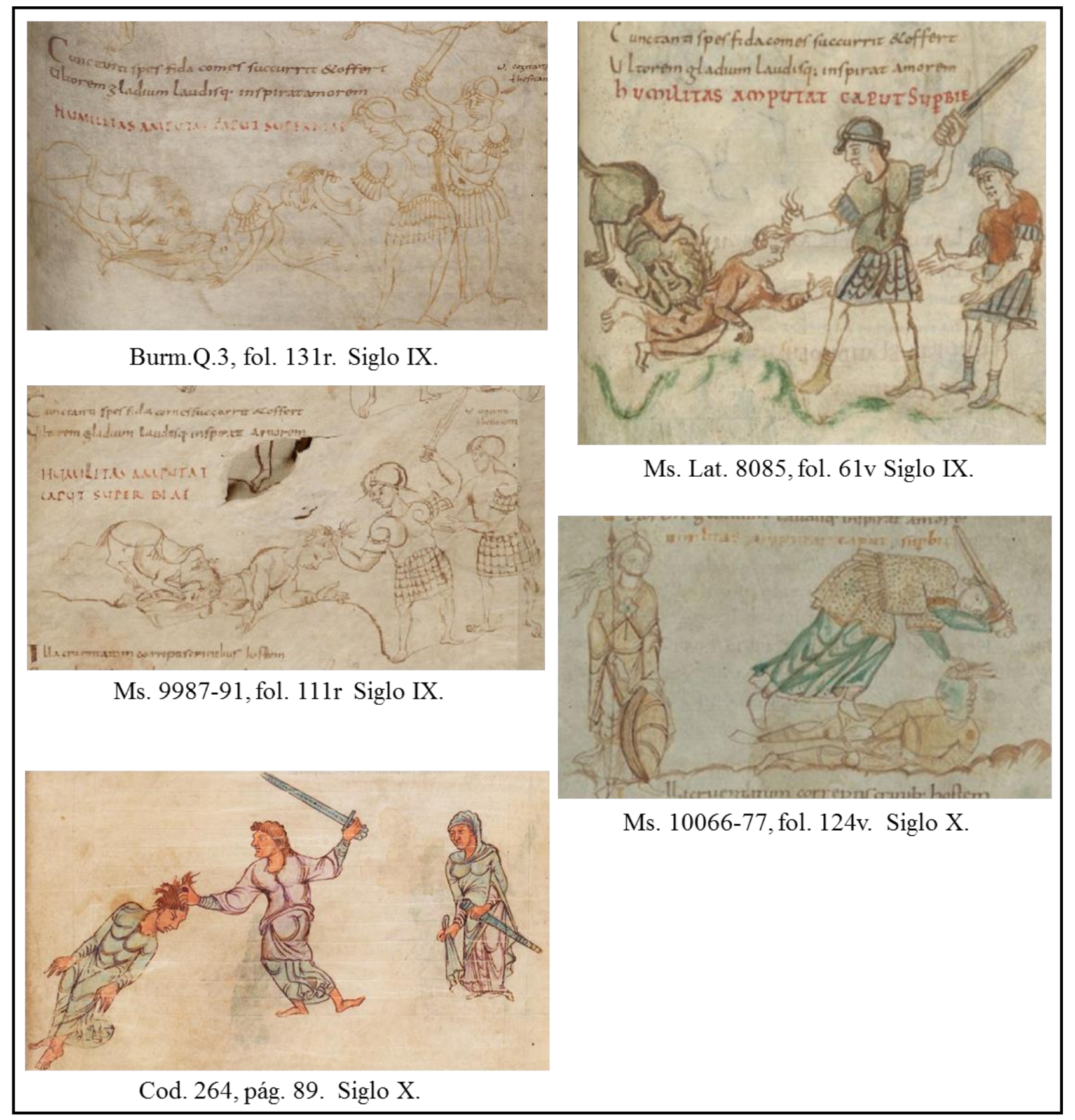

Miniatura 36. Humilitas decapita a Superbia 


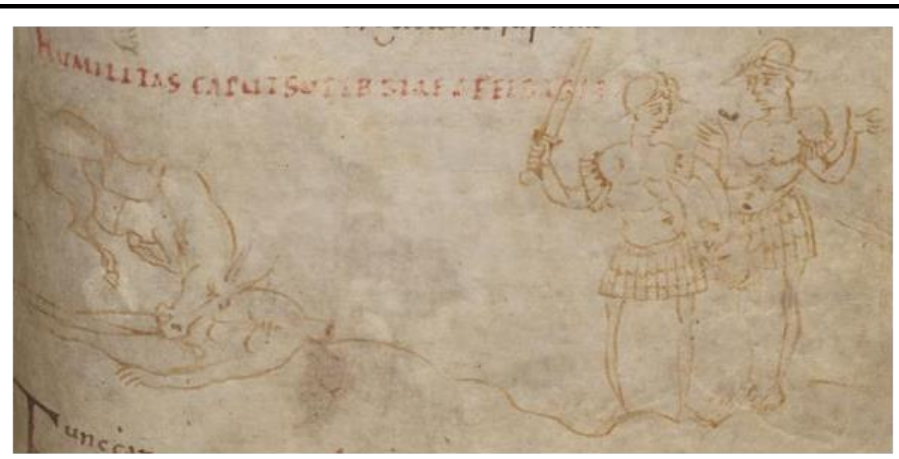

Burm.Q.3, fol. 131r. Siglo IX.

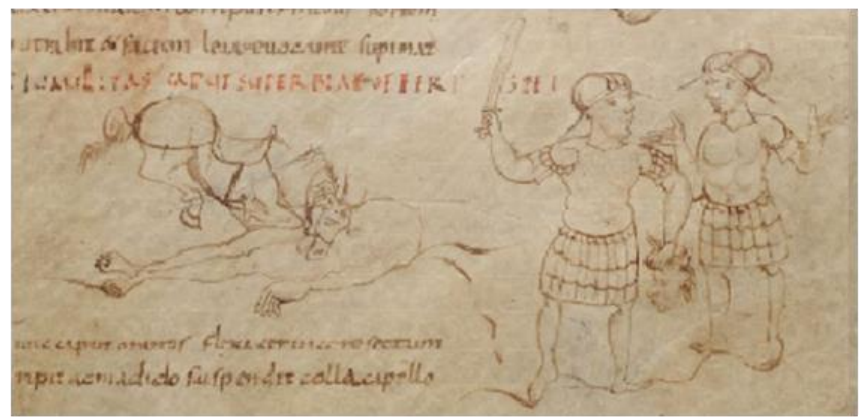

Ms. 9987-91, fol. 111r Siglo IX.

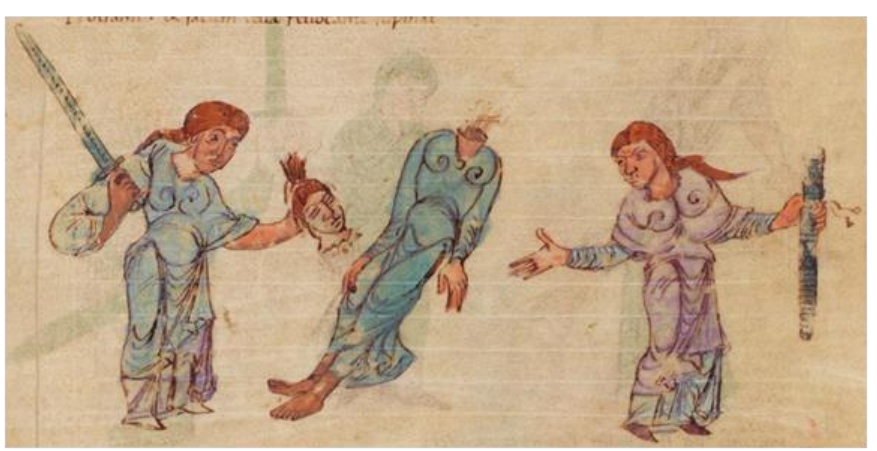

Cod. 264, pág. 90 . Siglo $X$.

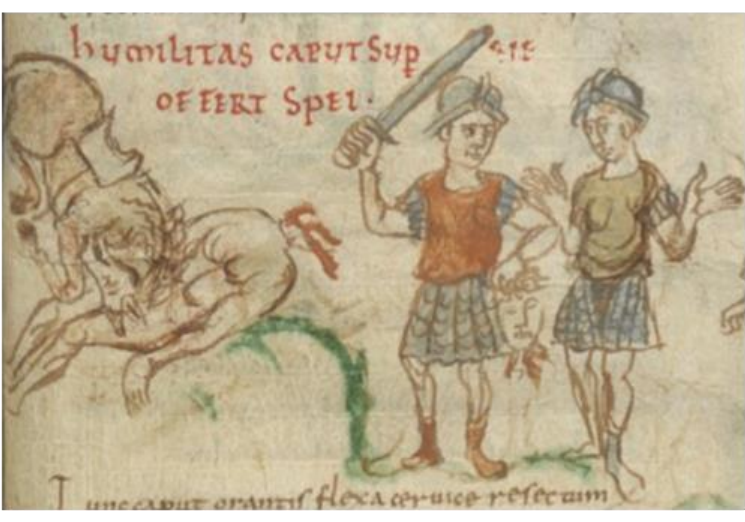

Ms. Lat. 8085, fol. 61v Siglo IX.

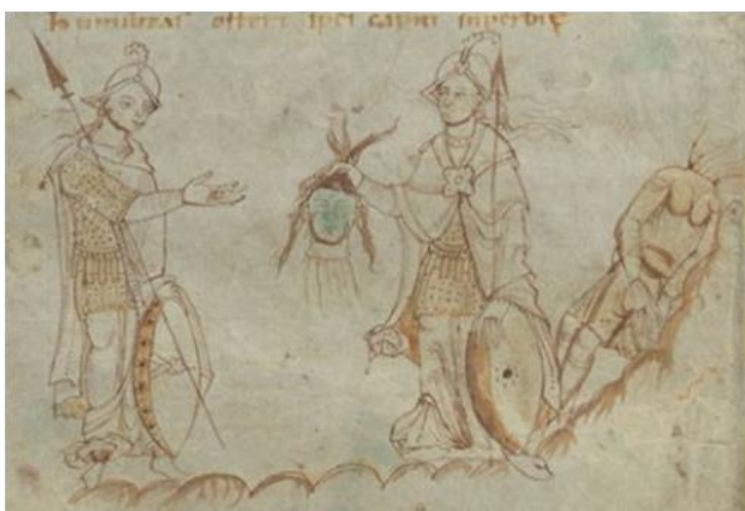

Ms. $10066-77$, fol. 124v. Siglo X.

Miniatura 37. Humilitas ofrece a Spes la cabeza de Superbia 
igualmente se extiende a la derrota de Superbia, después de todo Humilitas y David cortaron la cabeza de su enemigo.

Spes una vez pronunciado su discurso se eleva a los cielos y los miembros de su ejército contemplan como ésta sube. En esta última miniatura, la 39, Spes lleva alas tal y como la describe Prudencio en el verso 305, "auratis praestringens aëra pinnis". Esta escena aparece únicamente en los manuscritos del siglo IX. En la misma, al lado izquierdo de la composición se aprecia Spes. La representación de ésta concuerda con los versos, pues en los mismos se indican que posee alas (verso 305). En Burm.Q.3 y Ms. Lat. 8085 ésta con su mano bendice al ejército de las virtudes. En el lado derecho y de cara a Spes se encuentran tres figuras que contemplan a la virtud alada, sus gestos son lo de sorpresa y admiración. De los tres ejemplos, hay que resaltar que la imagen de Ms. Lat. 8085 es mucho más fluida, efecto que en gran parte se logró a través del manto de Spes. En el manuscrito belga claramente la mano que iluminó esta miniatura es otra, muy parecida al ejecutor de las imágenes del prefacio de este códice.

El poeta utiliza uno de los atributos o características más comúnmente de los ángeles ${ }^{147}$ para describir la acción abstracta de la virtud de ascender al cielo y el mismo se transporta a la miniatura para recrear dicha acción. El título de esta miniatura tiene un error, pues a pesar de que en el poema establece que es Spes la que asciende en el cielo, el mismo dice que es Humilitas ${ }^{148}$. A pesar del error en los títulos de la miniatura 39, cabe destacar que los títulos de las once iluminaciones que acompañan el combate de Humilitas y Superbia, especialmente en los manuscritos del siglo IX, están tomados directamente de los versos, sobre todo los verbos que describen las acciones. Esto en conjunto con las imágenes denota un gran interés por parte del individuo que elaboró los títulos y las imágenes de que ambas recojan el ad res de los distintos versos del poema.

\footnotetext{
${ }^{147}$ HeINZ-MoHR. Lessico di iconografía..., p. 32.

148 WOODRUFF. "The Illustrated Manuscripts..., p. 76. STETTINER. Die Illustrierten Prudentiushandschriften..., pp. 298-299.
} 


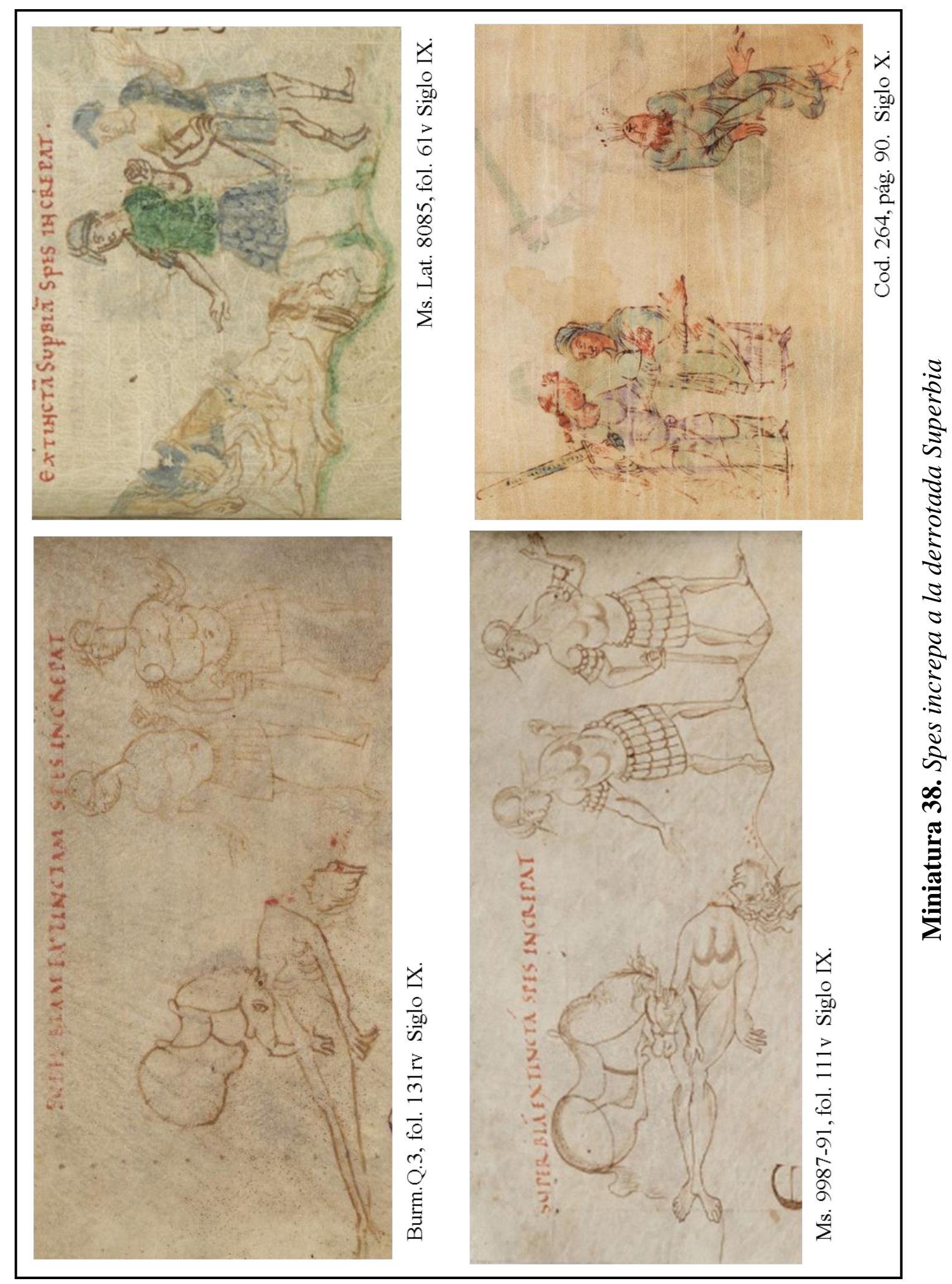




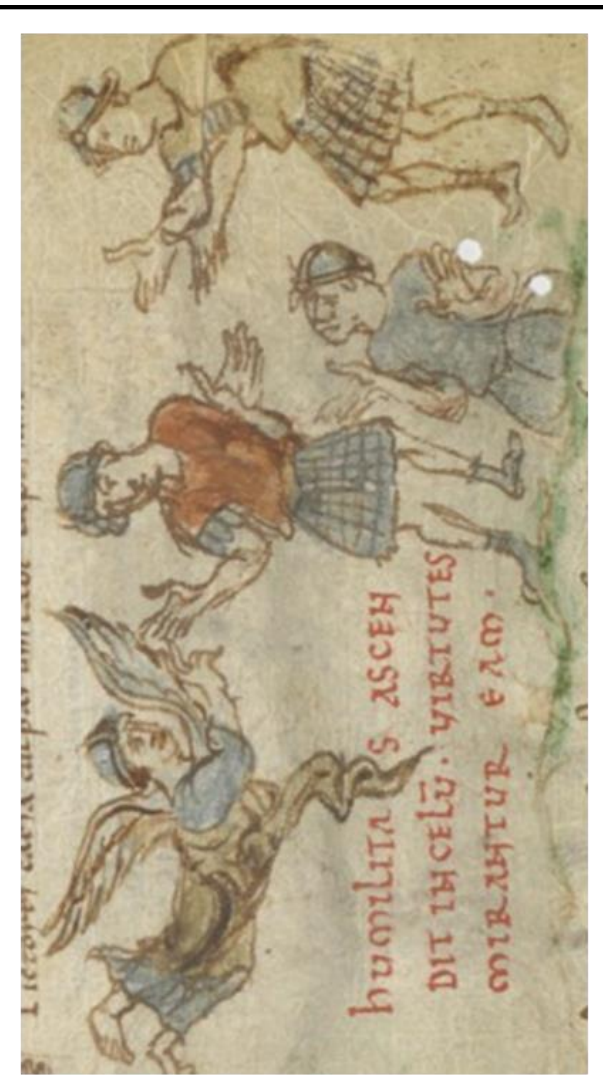

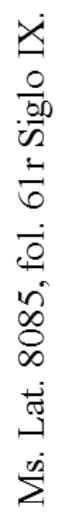
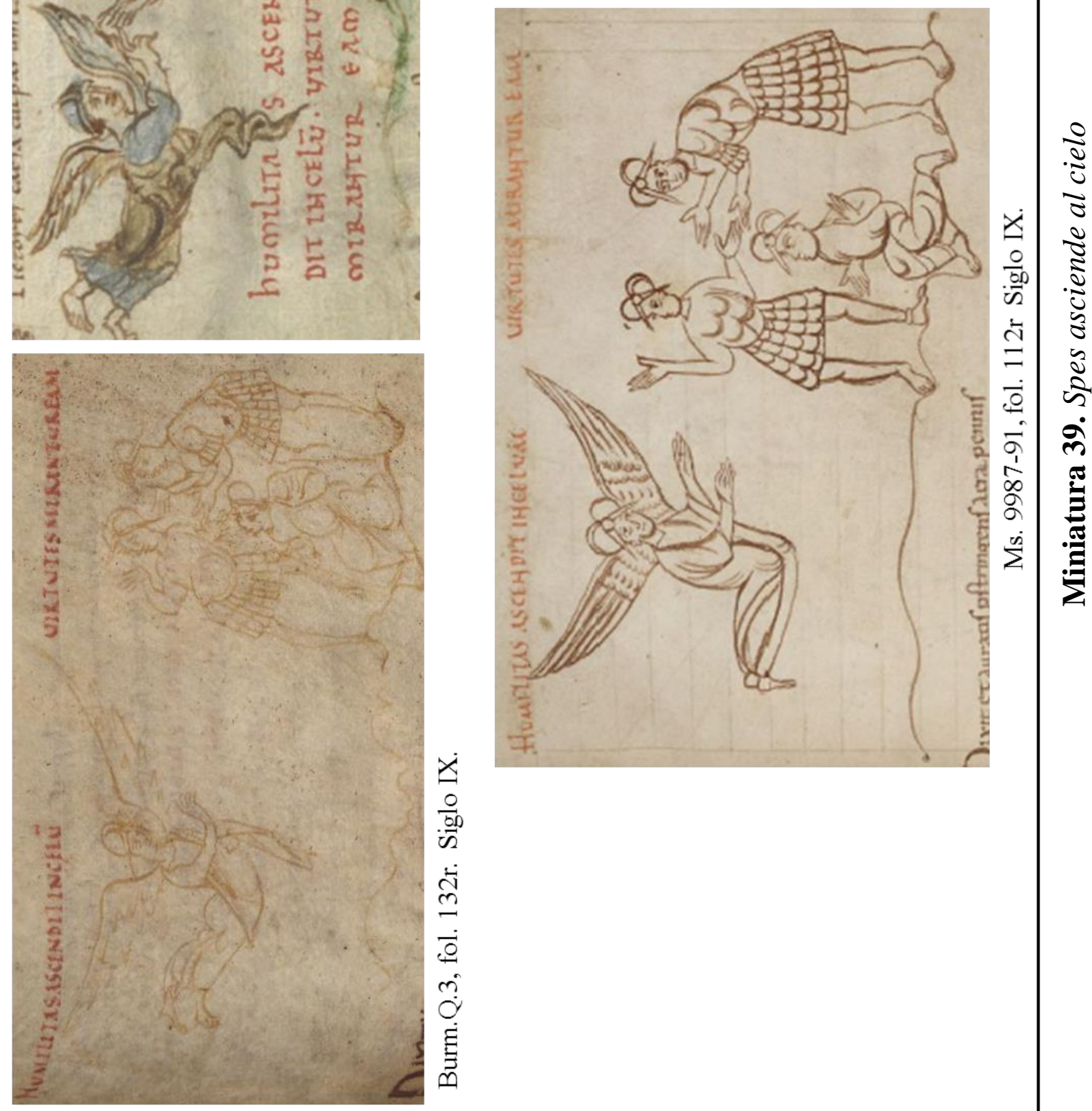

X

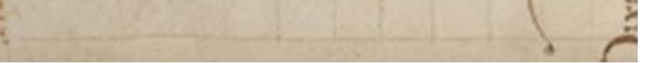

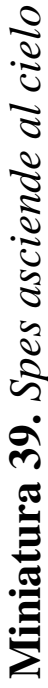

$\frac{0}{60}$

ते

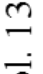

D

i்

हี 


\subsubsection{Sobrietas vs. Luxuria}

A partir del combate entre Sobrietas y Luxuria se aprecia un incremento en los versos y las miniaturas que acompañan a estos. Este aumento responde a la vivacidad y el detalle con el que Prudencio plasmó los distintos episodios del combate entre este vicio y esta virtud. Las miniaturas entonces recogen la acción principal, el ad res, de los versos a los que preceden y para lograrlos en las mismas se plasmaron visualmente los distintos detalles y elementos dados por el autor. Las primeras seis miniaturas de esta batalla (Miniatura 40, 41, 42, 43, 44 y 45) introducen al espectador a la figura de Luxuria, la personificación de la exuberancia, el exceso, la demasía, la suntuosidad, el lujo excesivo, la sensualidad y el desenfreno. En estas seis imágenes, siguiendo lo narrado en los versos, se captó a éste vicio manifestando alguna de sus facetas. En la miniatura 40, aparece el vicio abandonada a las delicias con sus cabellos alborotados. Con ésta miniatura abre el quinto combate de la Psychomahcia y sólo se incluyó en los códices del siglo IX. La disposición de las figuras es muy parecida. En el lado izquierdo se encuentra recostada junto a una mesa Luxuria con cabellos alborotados. Sobre ésta mesa hay varios objetos. El cuidado con el que el miniaturista del manuscrito belga 9987-91 permite identificar un cuchillo y varios cuencos. Junto a Luxuria se colocaron tres figuras, dos ofrecen al vicio sedente un cuerno y la tercera toca uno de estos. En el manuscrito parisino una de las figuras también lleva unos címbalos. Si bien esta miniatura acompaña los versos 310-315 en los que se introduce la figura de este vicio al lector, la imagen realmente recoge visualmente los versos 316-318. En ésta imagen se plasma un banquete descrito en los versos 316-318 que acompañan a la miniatura 41.

Este intercambio entre miniaturas y versos se repite igualmente en la 41. En la imagen de Luxuria corre al combate al escuchar las trompetas el vicio se ubica en el lado izquierdo, y ha sido dibujada con sus cabellos sueltos y sus brazos extendidos sujetando unas ramas o brotes. En Ms. 9987-91 se aprecian formas vegetales en el suelo. Delante de ésta se encuentran dos figuras tocando los cuernos que le dan la señal a Luxuria para salir al combate. Estos elementos vegetales están tomados directamente de la descripción del poema, sin embargo, los mismos aparecen en los 
versos 326-327 los cuales acompañan a la miniatura 43, a pesar de que los versos que acompañan a la escena 41 son los 316-320.

La discrepancia entre miniaturas y versos realmente tiene que ver con el hecho de que el miniaturista colocó en orden cronológico las imágenes, pues estos versos indican que antes de que Luxuria saliera al combate, "cansada eructaba el prologando festín de toda la noche, porque al rayar el alba, aún recostada junto a la $m e s a^{149}$ ". El vicio continuaba ebrio y al escuchar el sonido de las trompetas corre entre los bálsamos al combate ${ }^{150}$. Como parte de los recursos mnemónicos, en estos dos versos se insertan dos imágenes sensoriales no visuales: una auditiva y la otra olfativa. Éstas se plasman en la miniatura 41, y por medio de la sinestesia, la representación visual recuerda las mismas. El sonido de las trompetas se figuró visualmente a través de las dos figuras que llevan a su boca un instrumento de viento con la forma de un cuerno, claramente un lituus, una trompeta de guerra utilizada desde la antigüedad. La acción de las figuras en la imagen evoca el sonido. En los tres manuscritos en los que se incluyó esta miniatura Luxuria sujeta en sus manos unas ramas. Éstas evocan los bálsamos, después de todo esta sustancia aromática se obtenía de la resina de la corteza de ciertos árboles. En el manuscrito 9987-91 se recogen más elementos de los versos. En éste se aprecian formas vegetales en el suelo, son las flores que Luxuria ebria pisoteaba según el verso 320.

En las otras cuatro escenas que introducen a Luxuria los principales recursos mnemónicos que se identifican residen en la atención con la que se plasma los distintos detalles descritos en el poema que vuelven las diferentes escenas memorables, o sea, fáciles de memorizar. En la miniatura 42, Luxuria en su carro asombraba a los hombres se plasma la acción de los versos. En los tres ejemplos en los que se inserta esta escena de izquierda a derecha primero se aprecian las figuras aquellos que quedaron cautivados y asombrados tras el paso de Luxuria. Inmediatamente le sigue la figura de Luxuria montada sobre una carroza tirada por

\footnotetext{
${ }^{149}$ Prudencio. Psychomachia, vv. 316-318. Obras Completas de Aurelio Prudencio..., p. 329.

${ }^{150}$ Prudencio. Psychomachia, vv. 319-320. Obras Completas de Aurelio Prudencio..., pp. 328329.
} 
dos corceles. Ms. Lat. 8085 el vicio lleva una fusta y el carro se ha representado con las ruedas en la parte de atrás en lugar de la parte delantera como en Burm.Q.3 y Ms. 9987-91. Este tipo de vehículo es un vestigio tardo antiguo que aparece en los manuscritos y se puede encontrar en muchos mosaicos y relieves romanos ${ }^{151}$. Esta miniatura, particularmente, recoge más el sentido del título que de los versos. En el poema se emplea una metáfora para establecer el asombro de los hombres, metáfora que fue simplificada por el copista del título y plasmada así en la miniatura.

Las miniaturas 43, Luxuria con halagos engaña a las virtudes, y 44, Los hombres arrojan sus armas contemplando la carroza de Luxuria, expresan visualmente particularidades de los versos. Luxuria no lucha con los medios tradicionales, sino que arroja al ejército de las virtudes violetas, pétalos de rosas y canastillas de flores. Con éstas ablanda y seduce los corazones de sus enemigos (Miniatura 43) $)^{152}$. En los tres códices en los que se representa esta escena se aprecia la figura de Luxuria arrojando brotes y flores como indica el poema. Delante de ésta se encuentran cinco figuras con aspecto desconcertado, los miembros del ejército de las virtudes que fueron seducidos por Luxuria. El miniaturista del códice belga dibujó con más empeños las formas vegetales para que éstas sean reconocidas como las flores del verso 326. En el ejemplo parisino las mismas se realzan a través del uso del color verde.

En la siguiente imagen, la miniatura 44, Luxuria aparece nuevamente montada en su carro. La composición de esta imagen en los tres manuscritos que se incluyó es muy similar a la de la escena 42 en la que Luxuria aparece en su carro y asombra a los hombres. En el Ms. Lat. 8085 incluso ésta se plasmó sujetando la fusta. El cambio principal en la composición que indica al espectador que se trata de otra escena se aprecia en las figuras de la extrema izquierda, pero en la miniatura 44

${ }^{151}$ Katzenellenbogen. Allegories of the Virtues and Vices in Mediaeval Art..., pp. 5- 6. WOODRUFF. "The Illustrated Manuscripts of Prudentius"...,p. 70.

${ }^{152}$ Prudencio. Psychomachia, vv. 323-331. Obras Completas de Aurelio Prudencio..., pp. 328329. 

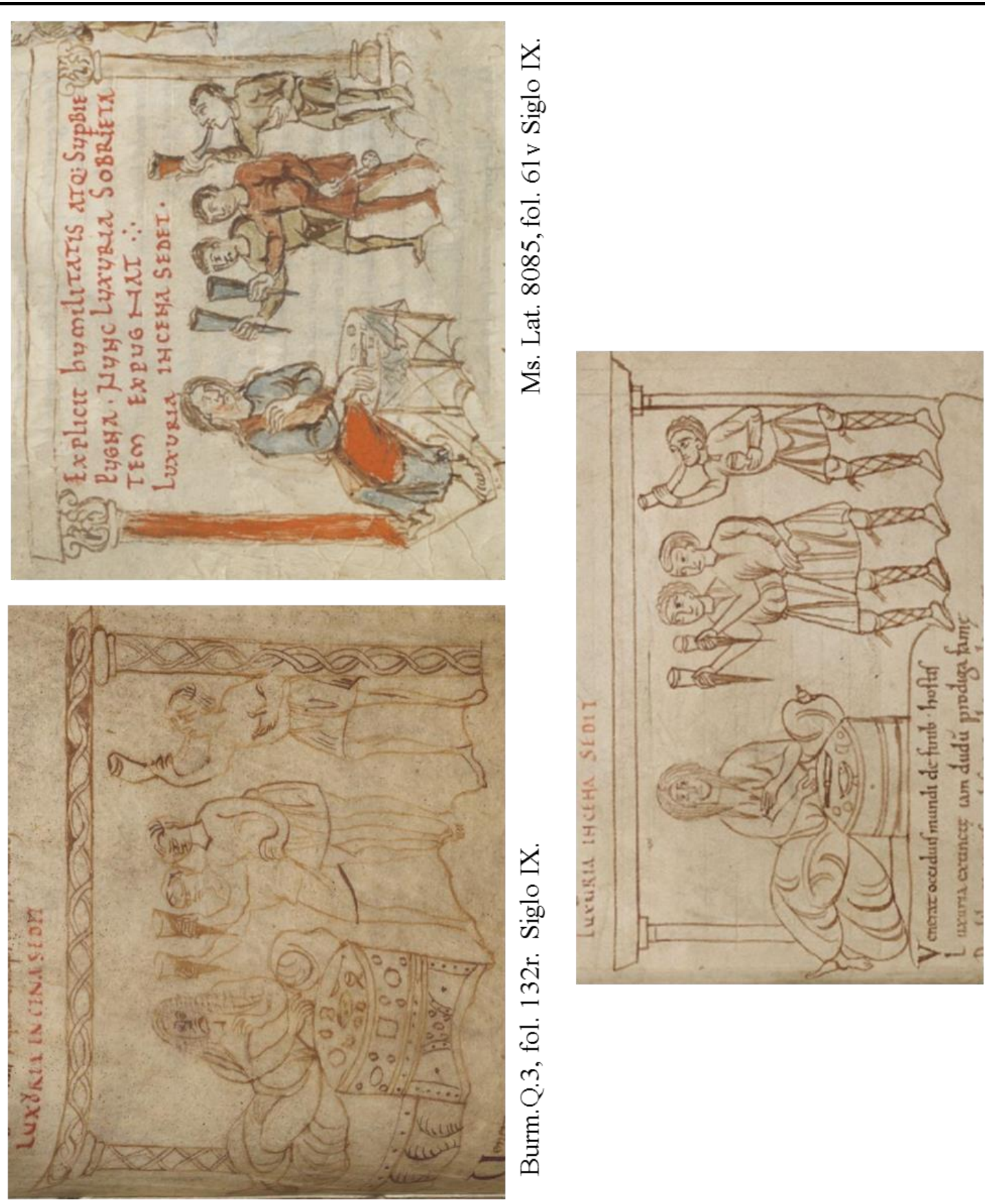

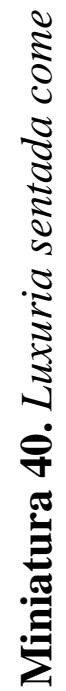




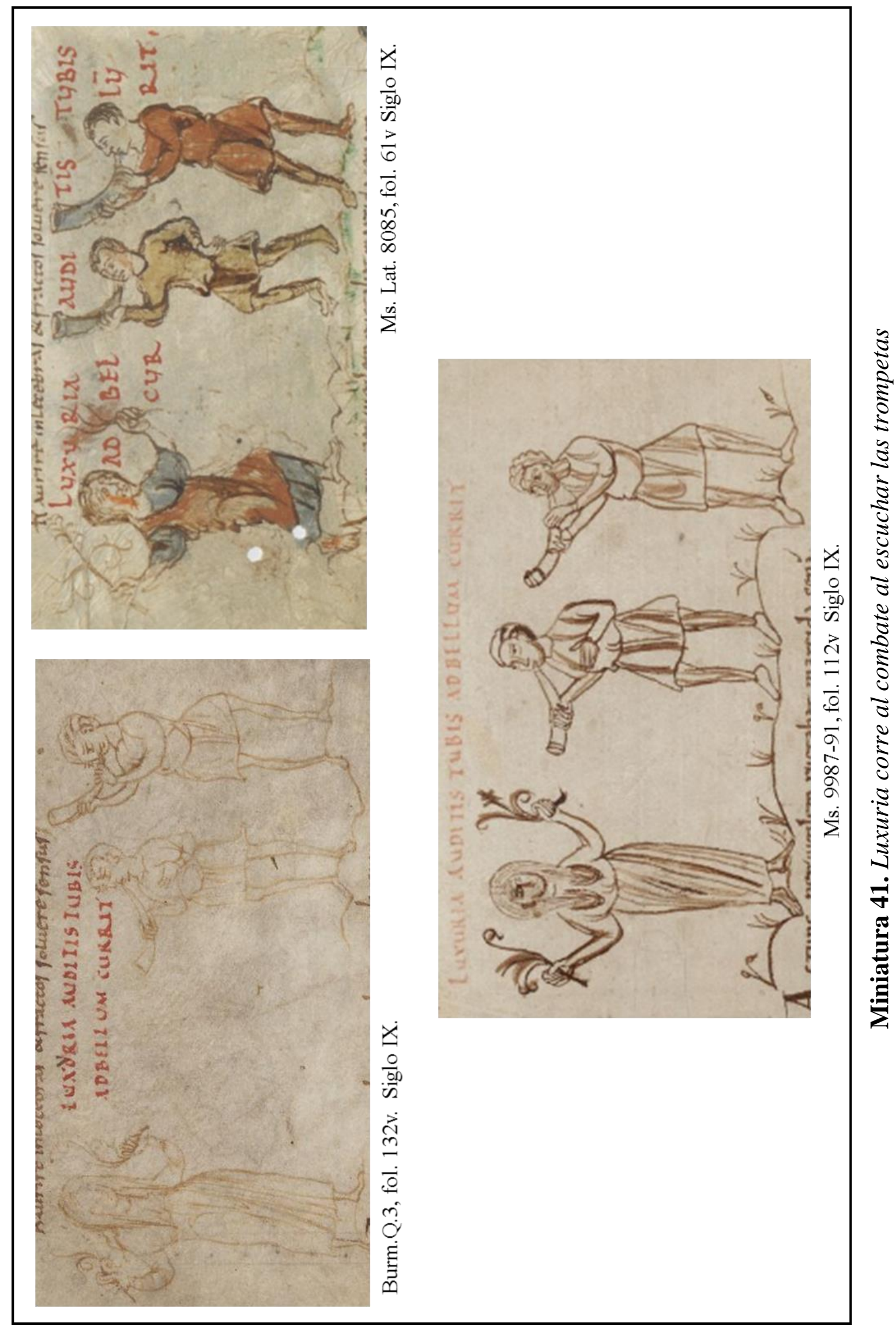



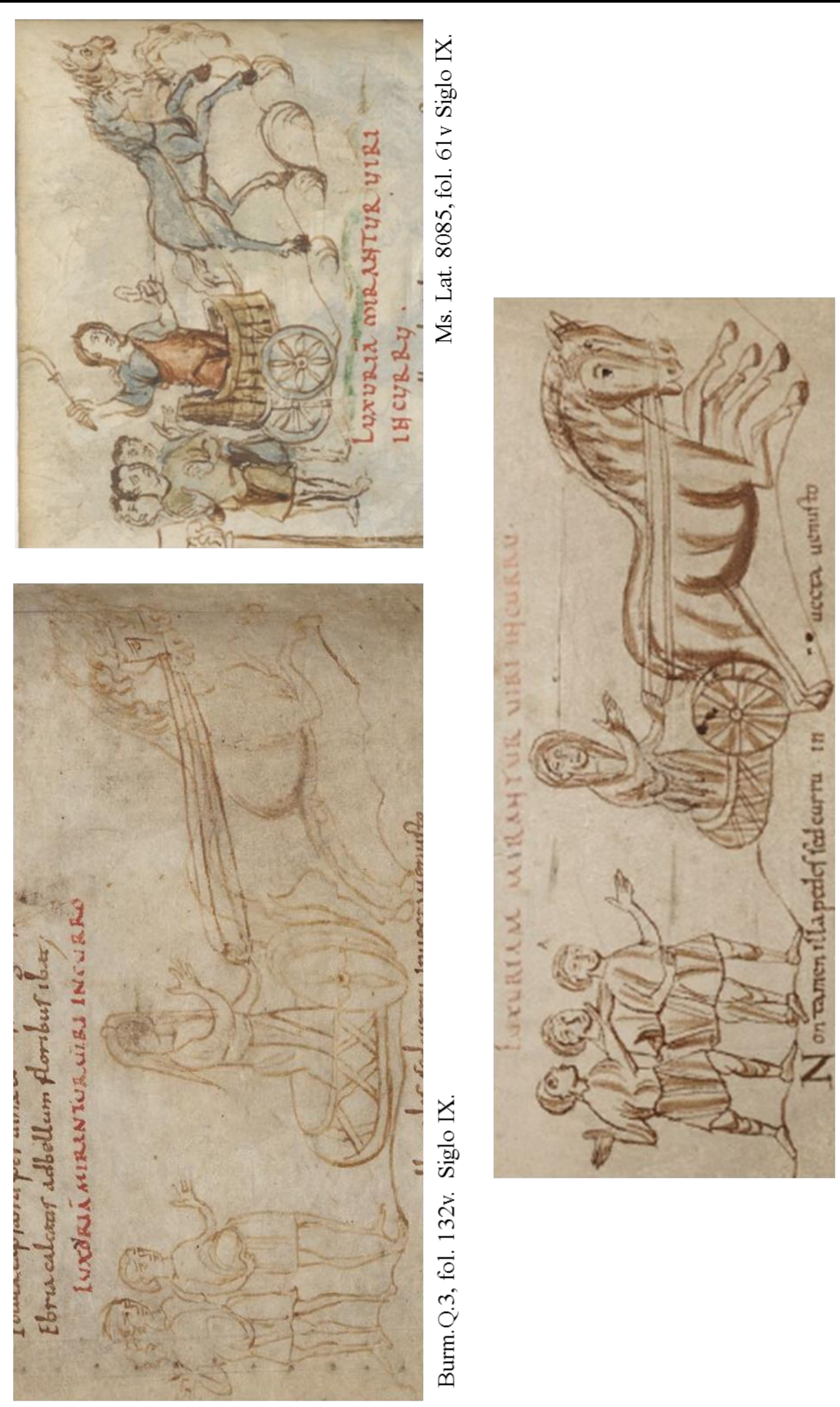

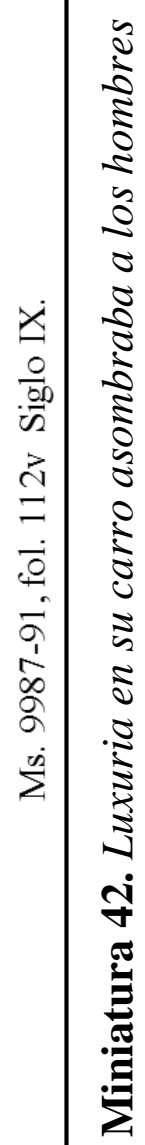

$\frac{x}{\frac{x}{00}}$

ते

$\div$

(4)

$\stackrel{m}{\circ}$

官 


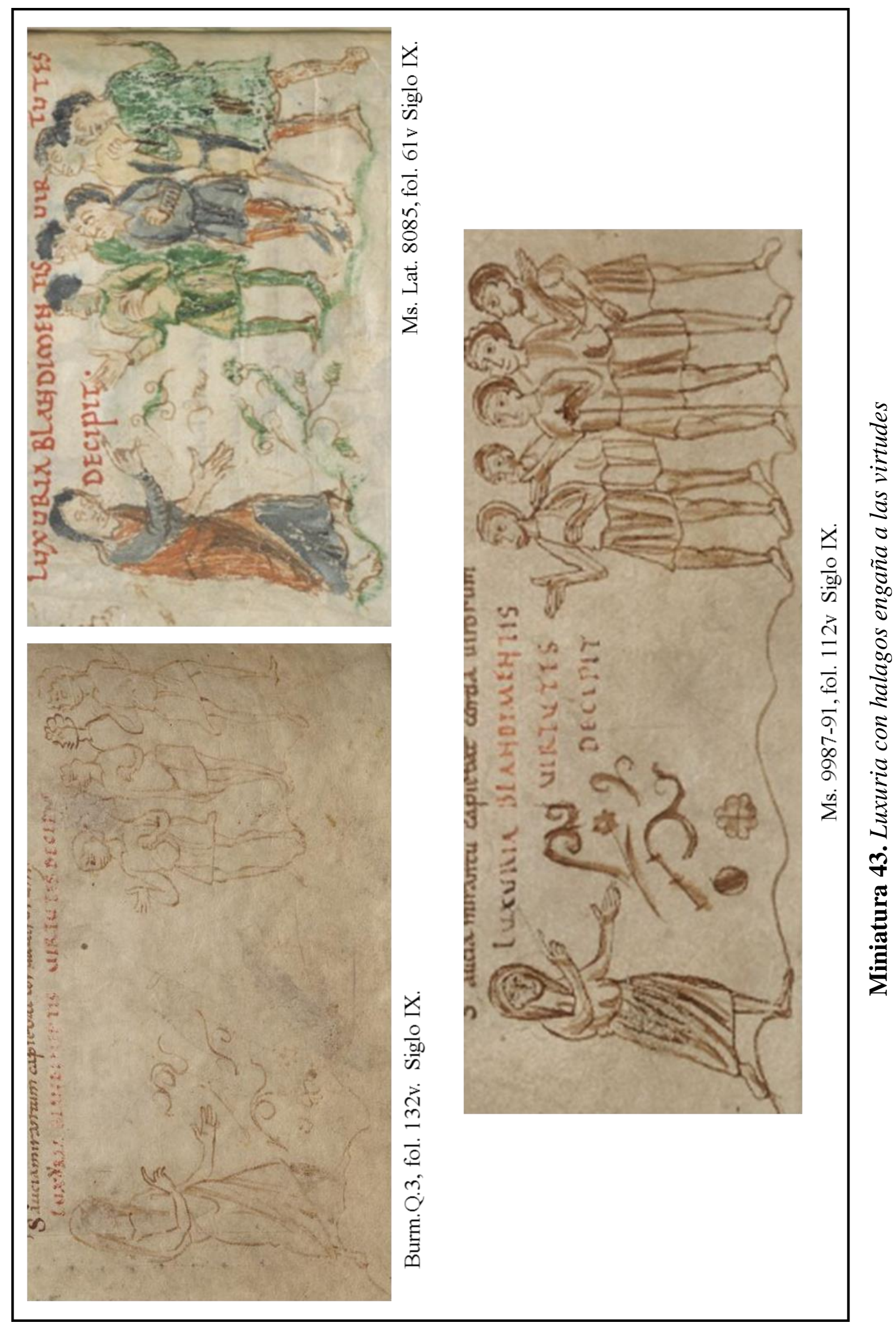


sujetan sus armas: lanza y una espada enfundada las cuales según los versos 332-339 al ver los encantos de su enemiga abandonarán.

A simple vista las miniaturas 44 y 45 son similares: en ambas, a la izquierda se aprecian los hombres cautivados y a la derecha a Luxuria en su carro. La miniatura 45, Todo el ejército se rinde y pasa al lado traidor, se diferencia en que la primera figura a la izquierda de la composición sujeta un banderín. Éste es el signo de la traición, perfida signi, pues el ejército rendido a los encantos del vicio abandona sus estandartes para dejarse a los placeres de Luxuria ${ }^{153}$. Signum además de traducirse por signo también puede utilizarse para referirse a bandera. En el caso de la imagen se juega con el doble significado de la palabra y la bandera es el signo visual de la acción de traicionar.

Si bien Sobrietas es la virtud protagonista de este combate y la heroína del mismo, en comparación con Luxuria y otros vicios, las representaciones de ésta son menos, limitándose a cinco miniaturas de las quince que ilustran este combate. La primera imagen en la que aparece Sobrietas es una de increpat (Miniatura 46). En la escena de Sobreitas advierte a su ejército de no seguir a Luxuria, en los tres códices que se incluyó, la virtud se representó en el lado derecho, de pie, sujetando con su mano derecha una férula que remata en cruz. Si bien el poema establece que ésta coloco en la punta de su lanza un estandarte con la cruz, en la miniatura esto se condensó a través de la férula. Delante de Sobrietas se encuentra el ejército al que ésta arenga plasmado a través de cuatro figuras. La vestimenta de la virtud en Ms. 9987-91 comparte ciertas similitudes con la de Ms. Lat. 8085. A diferencia del resto de las imágenes de increpat, que en los encuentros anteriores la virtud reprime al vicio derrotado, en la miniatura 46 y en los versos que le acompañan no sucede esto. En esta escena particularmente la virtud amonesta a su hueste tal y cómo se aprecia en la miniatura. A pesar de que aquí el discurso de la virtud no es para amonestar al vicio vencido, el mismo sirve igualmente como un un lugar mnemónico de recopilación que se concatenan a partir del estandarte de la cruz que ésta sujeta. En

${ }^{153}$ Prudencio. Psychomachia, vv. 340-343. Obras Completas de Aurelio Prudencio..., pp. 330331. 
el poema por medio de otros acontecimientos bíblicos e incluso de las batallas ya sucedidas se plasman conceptos anagógicos. Se vincula la acción de comer, el convite presentado en la miniatura 40 con el banquete del que ya participan las huestes, la Eucaristía, por medio de la protección concedida por Fides a través del Bautismo. Para resaltar estos sacramentos se parten de dos sucesos de la vida de Moisés: la fuente que hizo brotar de la roca y la caída del maná. Incluso la acción de Moisés, golpear la roca con su vara, Sobrietas la evoca al clavar en el suelo la cruz.

El encuentro entre ambas fuerzas se limita a dos imágenes que visualmente expresan el ad res de los versos 407 al 431. En este encuentro, Sobrietas de la misma forma que se plantó ante su ejército, se presentó ante la cuadriga de Luxuria. La miniatura 47 se incluyó en los manuscritos del siglo IX y en el códice 10066-77 del siglo X. La disposición de las figuras en los ejemplos más antiguos es la misma, n el lado izquierdo aparece Sobrietas vestida como guerrera sujetando la férula. Justo delante de ésta se encuentra el vicio en su carro tirado por los dos caballos desenfrenados. Dentro del carro hay dos figuras, la cochera que pierde el control de las riendas de los fieros y Luxuria cayendo de espaldas y sus cabellos arrastrados por el suelo. En Ms. 10066-77 esta es la única representación de Luxuria y Sobritas. En la misma aparece Sobrietas en la parte superior de la composición, y con la férula le impide el paso a su enemiga, haciendo que los caballos huyan cada uno en sentido contrario y el vicio cae del carro. Para Katzenellenbogen la composición particularmente de Sobrietas cayendo de su carro es muy similar a los relieves de sarcófagos romanos en los que se representa la caída de Faetón de su carruaje ${ }^{154}$.

En la miniatura 47, claramente sobresalen las acciones más memorables del episodio: los caballos descontrolados y Luxuria cayendo patéticamente de la carroza. En el códice 10066-77 se plasma a Sobrietas activamente según los mismos versos: pone el madero de la cruz en las bridas del caballo. En esta iluminación el miniaturista se tomó la libertad de adornar la cruz con unos rayos que brotan de ésta. La derrota de Luxuria se plasmó en la miniatura 48 y tal y cómo indican los versos la

${ }^{154}$ KatZenellenbogen. Allegories of the Virtues and Vices in Mediaeval Art..., p. 6. 

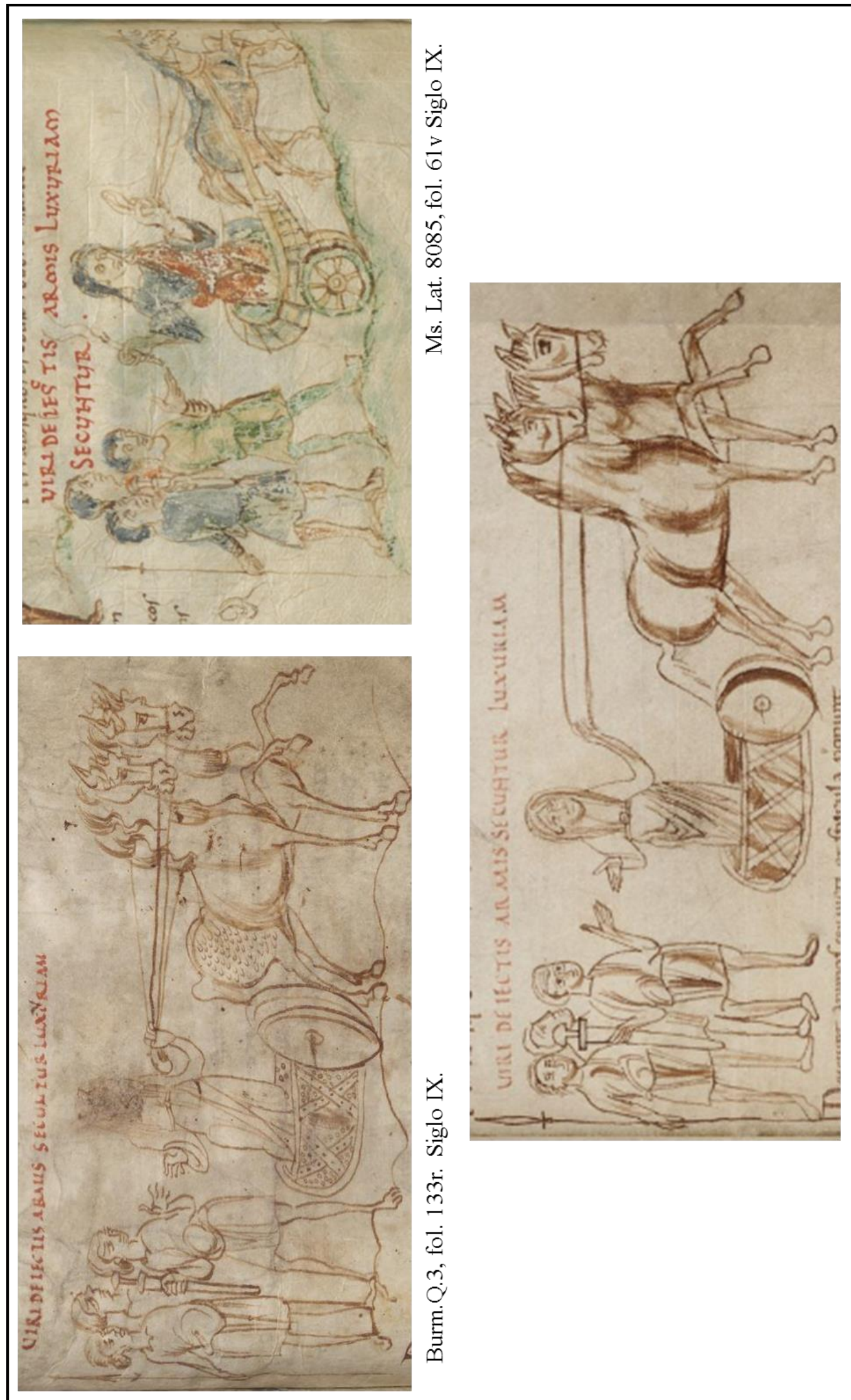

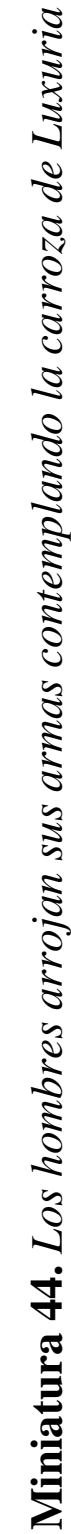

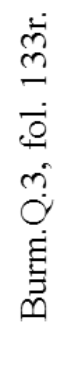




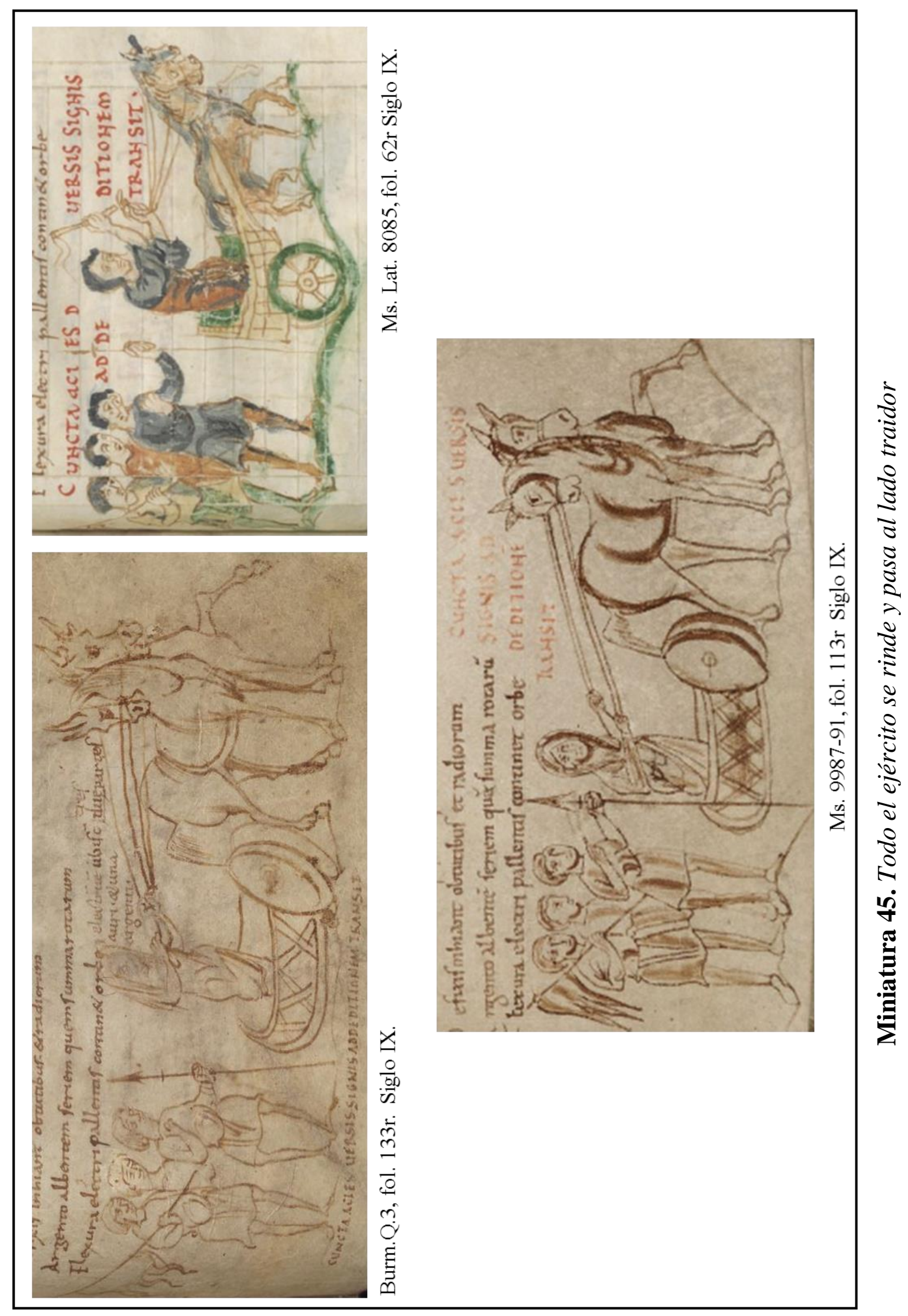




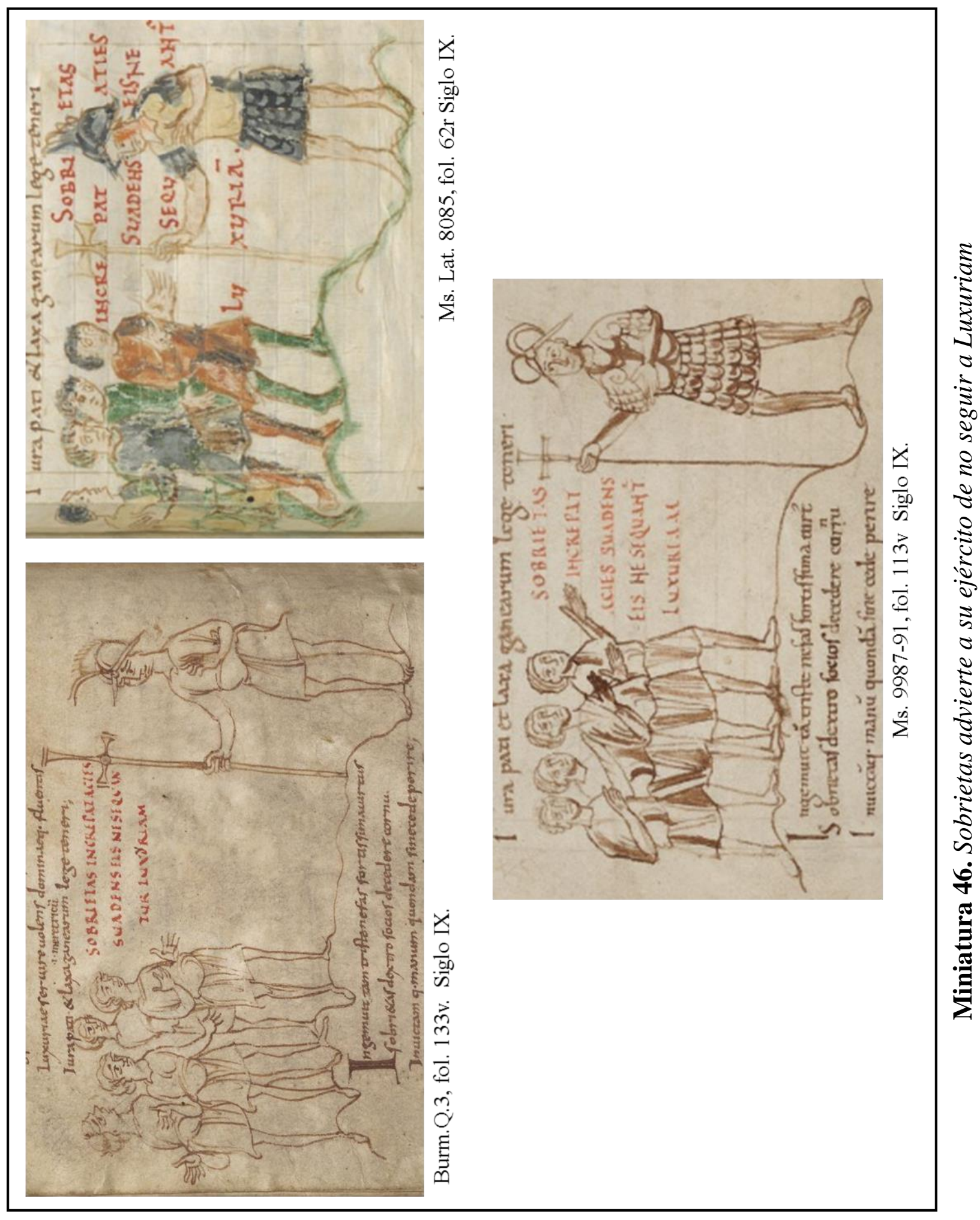




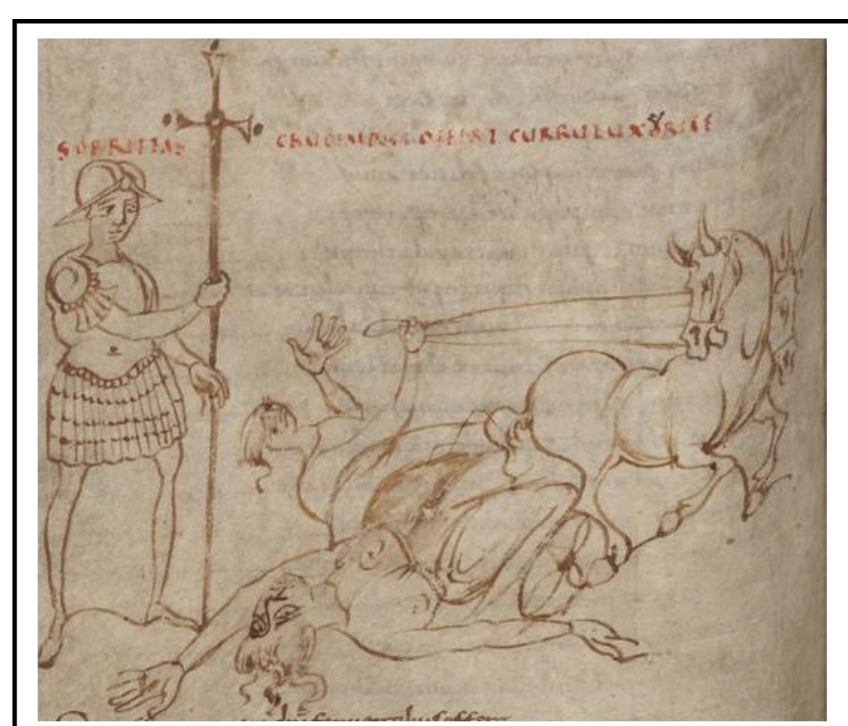

Burm.Q.3, fol. 134v. Siglo IX.

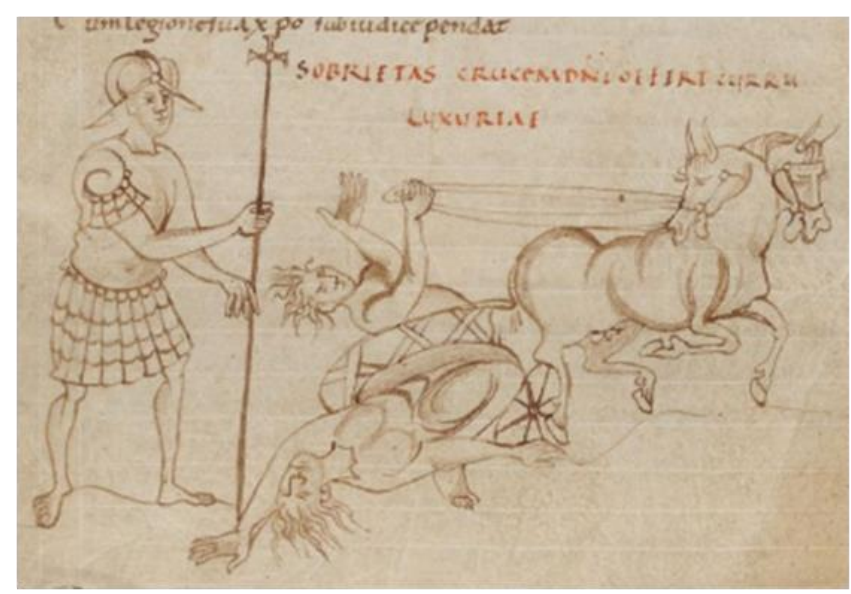

Ms. 9987-91, fol. 114v Siglo IX.

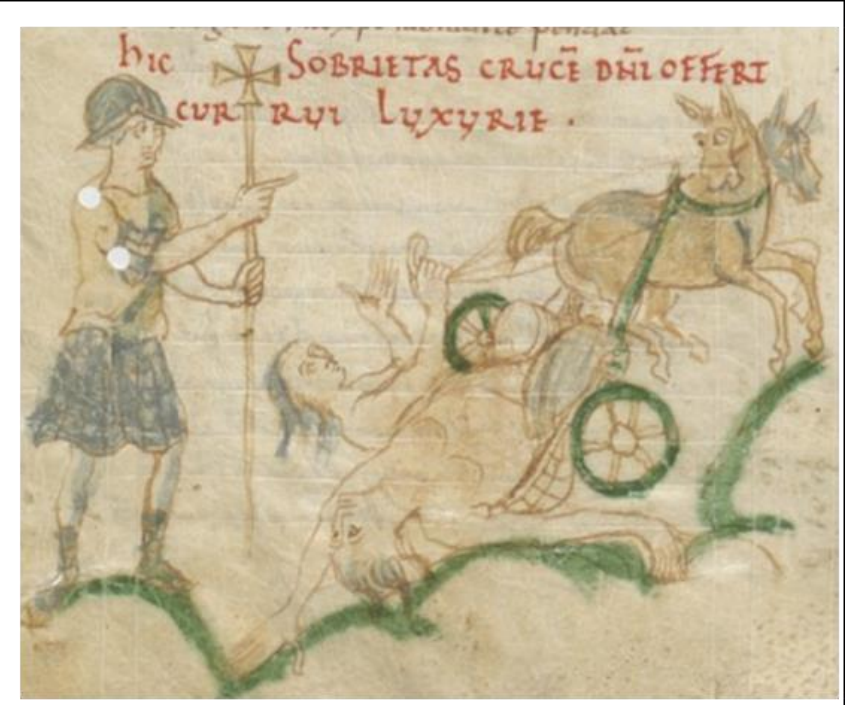

Ms. Lat. 8085 , fol. 62v Siglo IX.

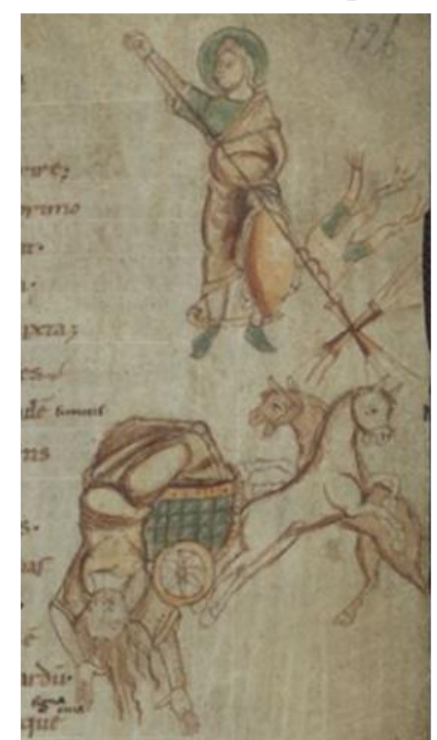

Ms. 10066-77, fol. 126r. Siglo X.

Miniatura 47. Sobrietas con la cruz del Señor sale al encuentro del carro de Luxuria 
virtud le arrojó una roca que atinó en la boca del vicio y le cortó la respiración. En los tres códices que se incluyó esta escena se aprecia el momento en el que Sobrietas coge la roca para golpear a su enemiga. En Ms. 9987-99 en esta escena se representó la causa y el efecto, pues la virtud sujeta la roca con la que golpeará al vicio, pero también se incluyó el momento en que la piedra golpea la boca de Luxuria.

A priori, la miniatura 48 y la 49 parecerían ser las mismas, es a través de las sutilezas de los ademanes que las acciones de éstas se diferencian. En la miniatura 48, Sobreitas lanza una piedra y hiere la boca de Luxuria, la virtud en los tres manuscritos del siglo IX se dispuso a la extrema izquierda elevando su mano izquierda y justo delante de ella aparece tumbada en el suelo el vicio. En la miniatura 49, Sobrietas increpa a Luxuria ya muerta, encontramos una composición muy parecida: la virtud a la extrema izquierda con el brazo alzado y tumbada en el suelo inerte Luxuria. Si bien en ambas iluminaciones Sobrietas levanta su extremidad, en la primera escena (Miniatura 48) es la mano de siniestra la que esta eleva y en los códices Burm.Q.3 y Ms. 9987-91 igualmente eleva la derecha y sujeta un objeto ovalado, la piedra que lanza para herir a su enemiga. La acción de la virtud en la miniatura 48 es, por lo tanto, la de alguien que se dispone a arrojar algo motivo por el que ambas extremidades se alejan del cuerpo. En Ms. 9987-91 igualmente lleva la roca en su mano con la pequeña diferencia de que también se ha incluido una piedra tocando la boca de Luxuria. Estas acciones corresponden a los versos 417 al 426 en los cuales Sobrietas coge una piedra y se la lanza a Luxuria, golpeándole la boca y cortándole la respiración y rompiéndole los labios y dientes.

En la siguiente imagen, la miniatura 49, el brazo izquierdo de Sobrietas se representó pecado a su cuerpo indicando que el mismo no realiza acción alguna y aquí la mano que levanta es la derecha, claramente es el ademan de increpar sumamente similar sobre todo a la imagen de increpat en la miniatura 25 . El vicio inerte en el suelo en esta escena en los tres manuscritos que se insertó lleva en la boca el objeto ovalado que en la escena anterior Sobrietas sujetaba en su mano derecha: la piedra. En esta escena gracias al gesto de la virtud y a los tituli el espectador sabe que nuevamente se encuentra ante una escena de increpat, y al igual que en los 
combates anteriores una vez derrotado el vicio la virtud reprende a su enemigo. Luxuria termina de la misma forma en la que fue introducida al poema: comiendo y bebiendo, lo único es que ahora come y bebe sus dientes y su sangre como bien le recuerda Sobrietas en el verso 427 al 431. Dentro de un texto la repetición de una acción similar es un recurso textual que permite la memorización del mismo ${ }^{155}$. La miniatura 49, Sobrietas increpa a Luxuria ya muerta, es una escena de increpat, sin embargo, la misma se limita al reproche de la virtud al vicio y no se concatena con las Sagradas Escrituras. La diferencia que presenta esta escena de increpat con las ya analizadas se puede apreciar a simple vista en el manuscrito. El tamaño de estos códices es aproximadamente el mismo que el de un cuaderno con folios A4. Al igual que en el cuaderno, las imágenes y versos de éste se circunscriben al campo visual del espectador, permitiendo que el mismo aprecie todo el conjunto sin la necesidad de que su vista divague mucho. Las iluminaciones de increpat que además guardan un discurso lleno de referencias a las Sagradas Escrituras cómo las 10, 21 y 34 se estructuran de manera distinta a la miniatura 49. En estas primeras imágenes de reprimenda le sigue todos los versos en los que se recoge el discurso pronunciado, la extensión de los mismos es mucho mayor que la del resto de las escenas suponiendo una diferenciación visual que se aprecia a simple vista. Por lo tanto, el monje que estuviera utilizando estos manuscritos al encontrarse con una imagen de increpat seguida de una amplia extensión de texto podía establecer que la imagen era un lugar de recopilación en el que se almacenaban otros sucesos. En el caso de Sobrietas increpa a Luxuria ya muerta (Miniatura 49) el espectador inmediatamente después de los cinco versos del reproche se encuentra con otra miniatura.

Las cinco miniaturas que completan el relato del encuentro entre Sobrietas y Luxuria plasman los distintos sucesos que ocurren tras la muerte del vicio, con un particular interés en detalles. Entre los versos 432 al 449 Prudencio narra cómo tras la muerte de Luxuria todo el ejército de ésta huye, el autor describe algunos de los

${ }^{155}$ BURNS. "La répétitions et la mémoire du texte", Jeux de mémoire..., p. 65. 

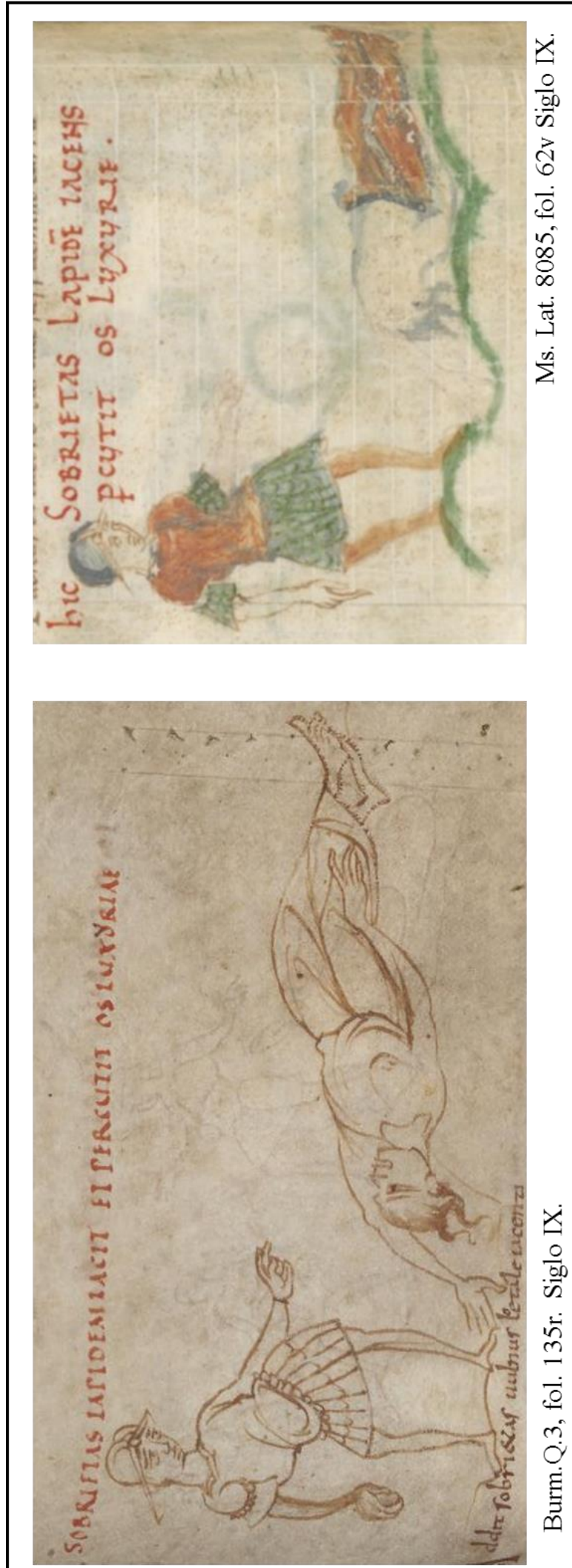

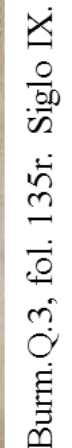

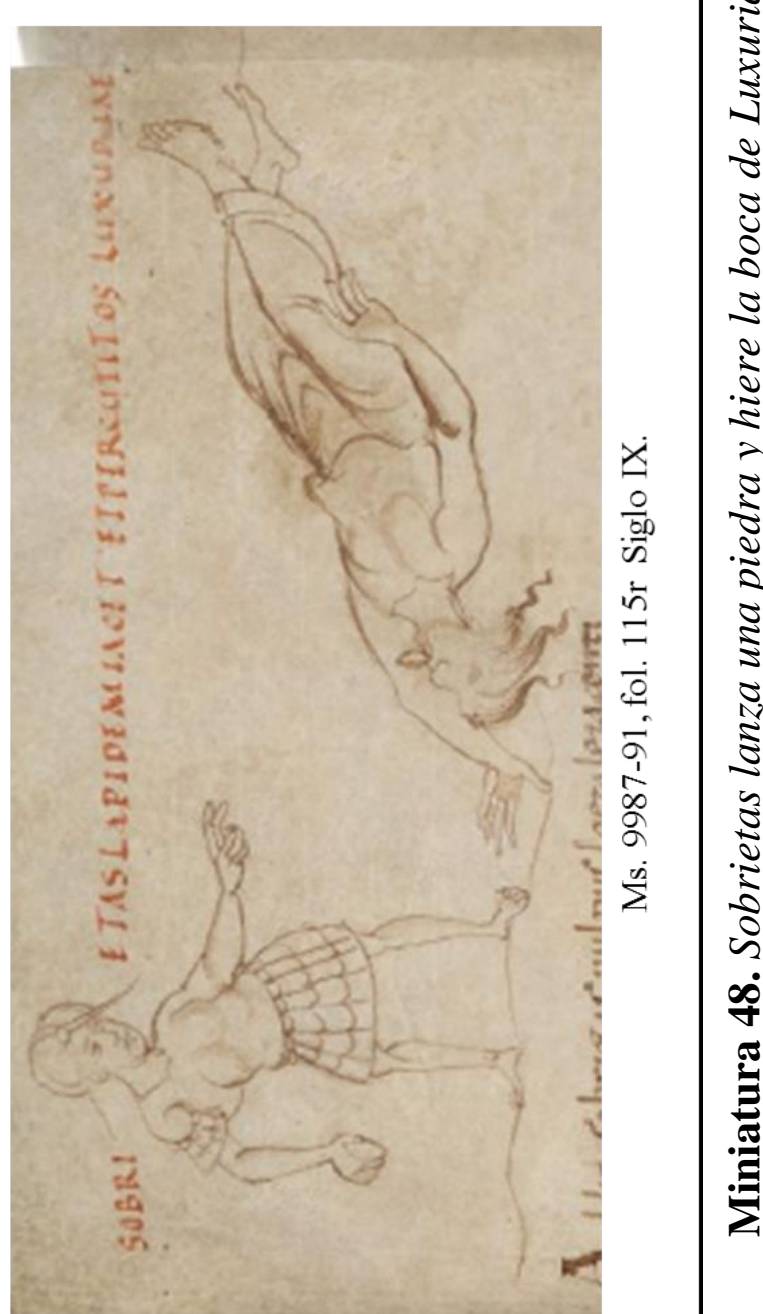




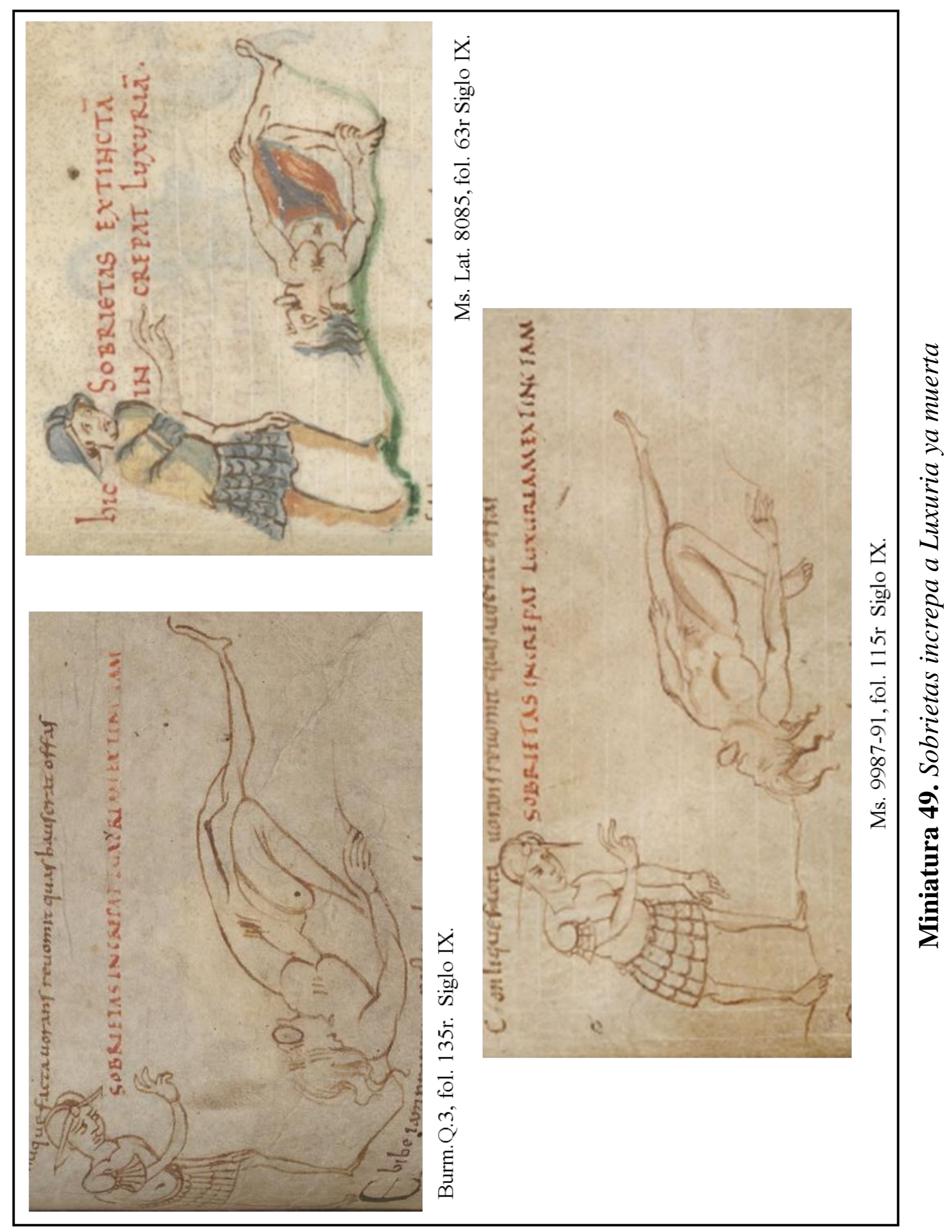




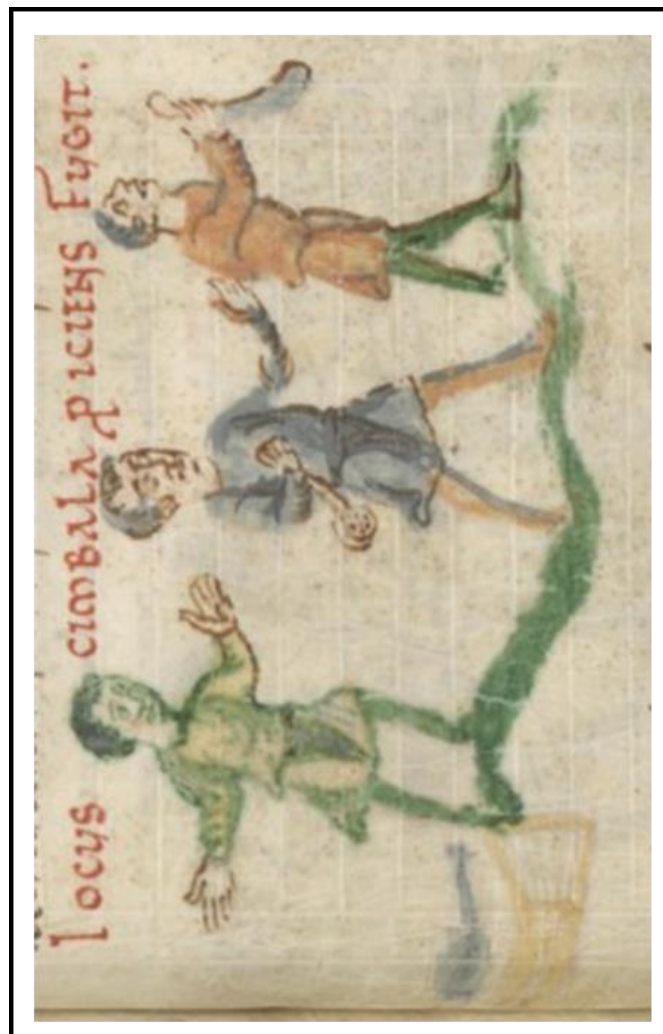

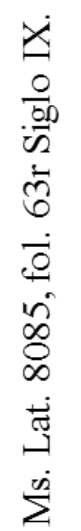
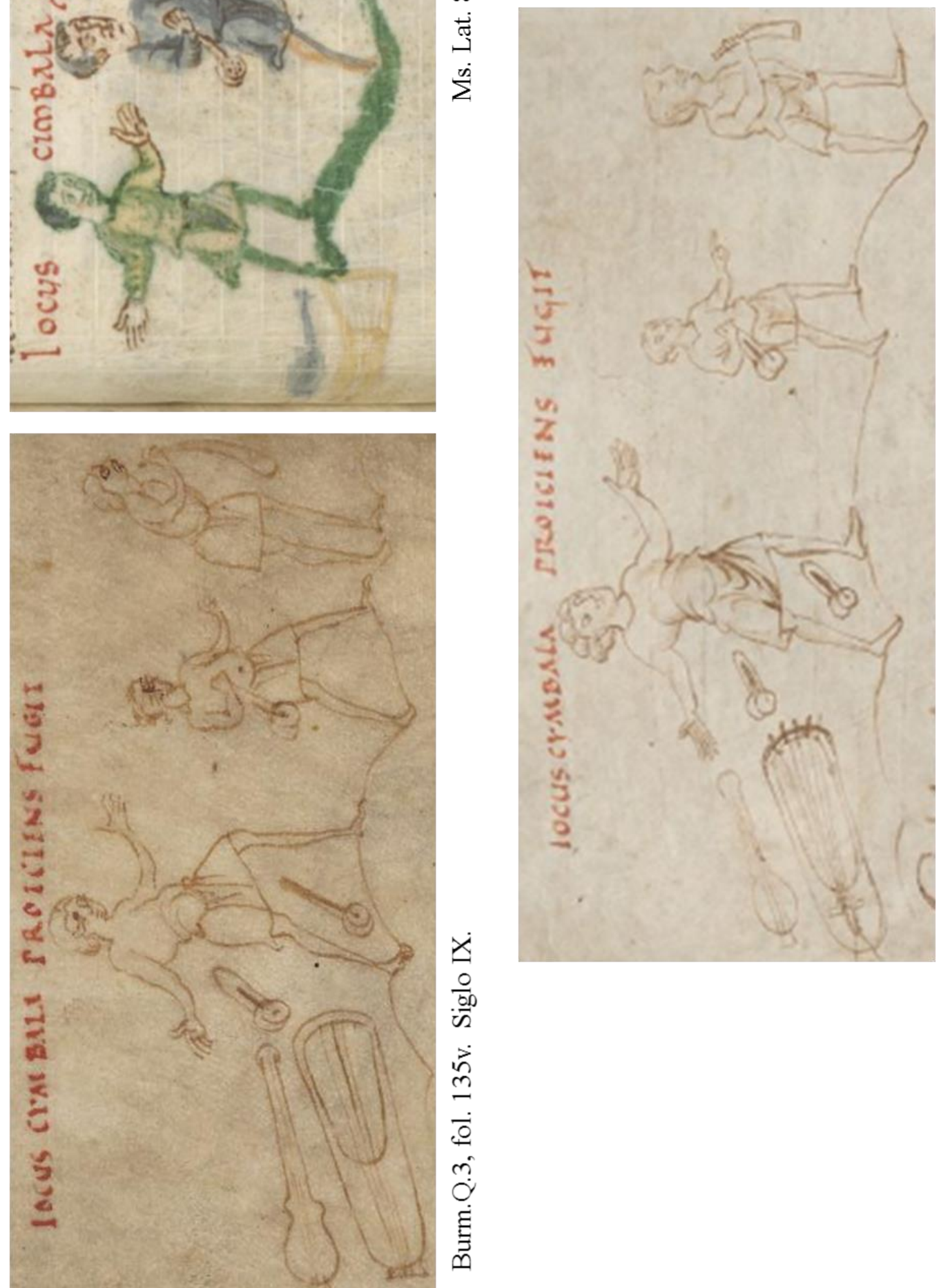

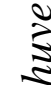

文

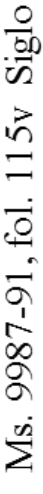

齐

$\frac{w}{2}$

$\frac{0}{200}$
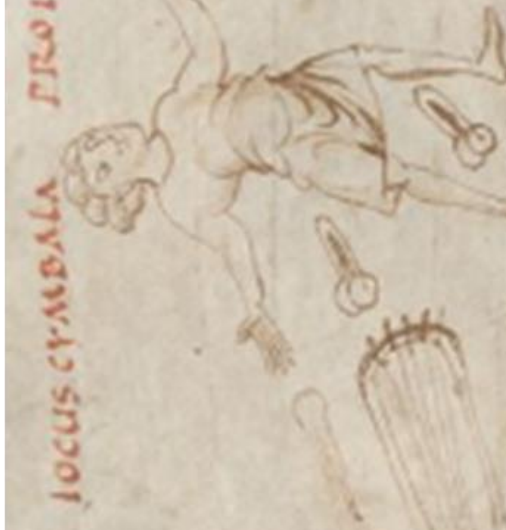

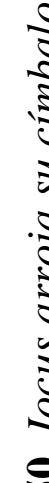

的 


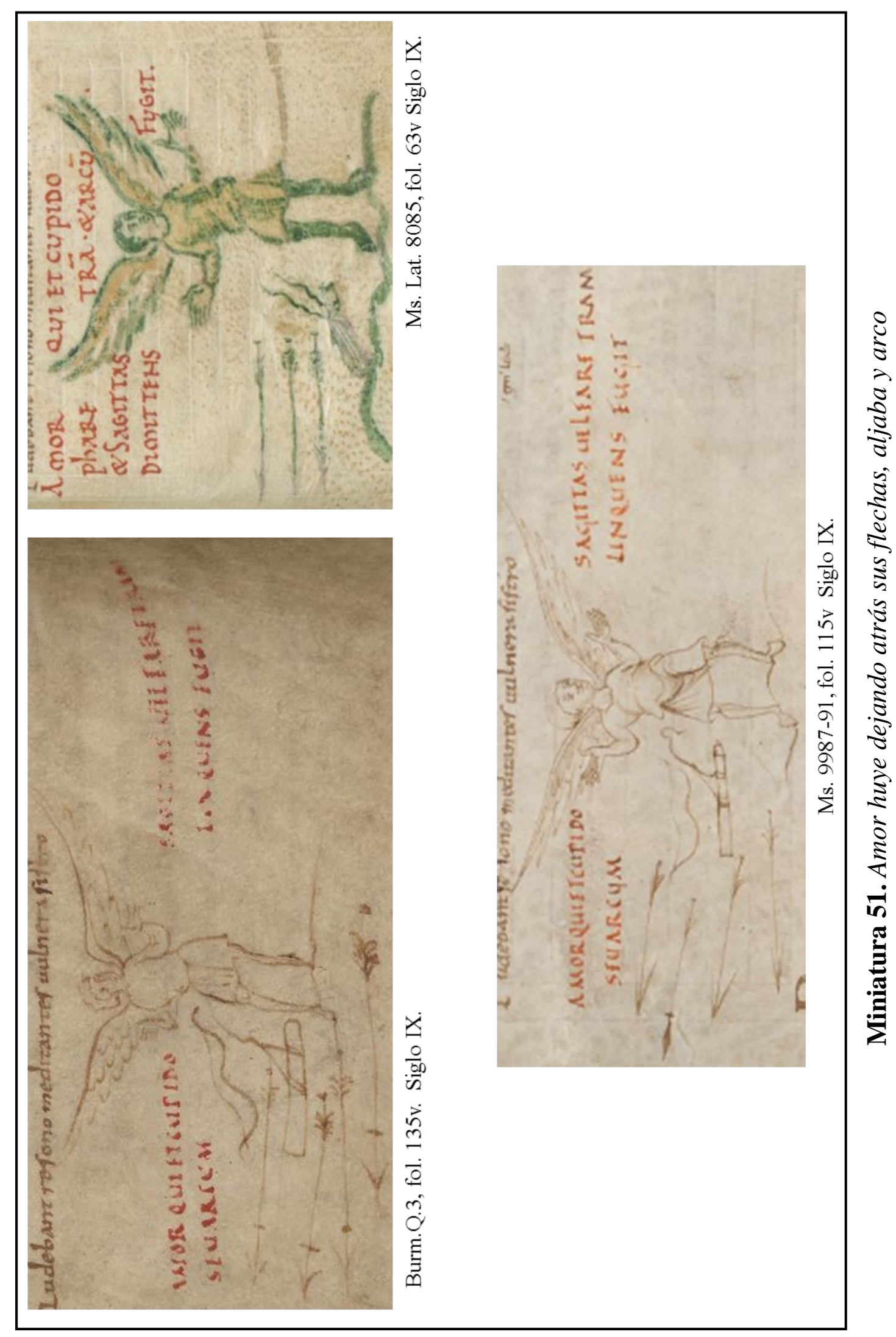


acompañantes de éstas y las distintas armas o atributos que llevaban. Los miniaturistas plasmaron estas singularidades descritas en los versos. En la miniatura 50, a pesar del que en el título sólo se menciona a un vicio, a Iocus, en la imagen se incluyeron dos figuras con címbalos, Iocus y Petulantia cómo indica el verso 33. Puesto que la figura con los brazos abiertos se ha representado con mayor dimensión y considerando el título que aparece en los tres ejemplos, Iocus cymbala proiiciens fugit, la esta figura podría identificarse como Iocus. La tercera figura lleva en sus manos un cuerno. Junto a Iocus se han representado otros dos instrumentos de cuerdas los cuales muestran muchas similitudes con una lira y un laúd. Prudencio no menciona los instrumentos de cuerda ni al trompetista dibujados en los manuscritos del siglo IX, sin embargo, el poeta describe otro instrumento, un sistro. La forma de este instrumento antiguo a simple vista es un poco similar a la de la lira, pues consistía en una pieza con forma de herradura atravesada horizontalmente por varillas de metal en las que se colocaban platillos metálicos. El miniaturista del manuscrito que sirvió de modelos para estos -estema de Stettiner copia carolingia del año 800 y estema de Woodruff arquetipo R- pudo haber interpretado la imagen del sistro como la de un instrumento más familiar al siglo IX, volviendo así la imagen en una más cercana a la realidad de los monjes de los monasterios en los que estos códices se realizaron y fueron utilizados ${ }^{156}$. En Ms. 9987-91 los detalles de los instrumentos son muchos más claros, sobre todos los de la lira en la que además del cuerpo y las cuerdas de ésta, el miniaturista también dibujó las clavijas que sujetan las cuerdas o el puente sobre el que pasan las cuerdas. La presencia del trompetista puede ser la traducción visual de la acción de resonar recogida en el verso 435 con el verbo resono, después de todo el cuerno en muchas ocasiones pasó a ser un símbolo de la voz y el sonido ${ }^{157}$.

En la miniatura 51 el que huye es Amor. En los tres manuscritos que se insertó la escena se aprecia una figura alada, vestida con túnica corta y los brazos extendido gesto de desconcierto. Al lado izquierdo de la figura se aprecian las armas de este miembro de la legión de Luxuria, las flechas, la aljaba y el arco. Los mismos parece

\footnotetext{
${ }^{156}$ CARRUTHERS. The Craft of Thought..., p. 16. YATES. El arte de la memoria..., p. 23.

${ }^{157}$ GARNIER. Le langage de l'image au Moyen Âge (II)..., pp. 190-191.
} 
que se suspenden en el aire y es porque se plasmó el momento en el que la protagonista de la imagen los deja caer para huir tal y como indica los versos 436 al 438 y el título de la imagen, en Burm.Q.3 y Ms. 9987-91: “Amor qui et cupido sagittas vel faretram seu arcum linquens fugit" y en Ms. Lat. 8085 "Amor qui et cupido pharetram et arcum et sagittas dimittens fugit", Amor huye dejando todas sus armas. La figura de Amor en esta miniatura se representó en los tres códices con alas, a pesar de que Prudencio no la describió así. El hecho de que lleve alas lo equipara con Cupido, el dios del deseo, y en este caso Amor es uno de los vicios que acompaña a Luxuria, personificando el deseo y la pasión. La referencia a Cupido en un texto de época carolingia no es rara, ya que en este período las imágenes clásicas fueron utilizadas y su forma y contenido original se unió a otros significados ${ }^{158}$. "El miniaturista se servía de modelos antiguos que encajaban en la clasificación del lenguaje figurado ${ }^{159}$ ", En el caso de Amor, plasmar visualmente la connotación negativa del amor: deseo y pasión personificados en la figura de Cupido.

A Amor, le sigue Pompa y el momento en el que ésta huye se recoge en los versos 439-442 que acompañan a la miniatura 52. La composición de los tres códices es muy similar, en el centro una figura extiende su brazo derecho y alrededor de ésta se aprecian una serie de objetos. En el códice parisino el pigmento de los objetos se ha perdido y estos apenas se pueden apreciar. La figura de Pompa en Burm.Q.3 y Ms. 9987-91 lleva el cabello largo y suelto. La imagen sigue los dos versos del poema en los que indica como esta seguidora de Luxuria mientras huye se despoja de sus ornamentos, junto al cabello de la figura de Pompa el objeto circular alude a la diadema descrita en el verso 441.

El último miembro del ejército de Luxuria en escapar es Voluptas. En la miniatura 53 se captó el momento en que ésta escapa sobre los matorrales de espina, lastimando sus pies y dejando sus despojos entre los que se encuentran un pañuelo ${ }^{160}$.

\footnotetext{
${ }^{158}$ PANOFSKY, Erwin. Renacimiento y renacimientos en el arte occidental. Madrid: Alianza, 1988. p. 134.

${ }^{159}$ SÁNCHEZ AMEIJEIRAS. Los rostros de las palabas..., p. 191-192.

${ }^{160}$ Prudencio. Psychomachia, vv. 443-449. Obras Completas de Aurelio Prudencio..., pp. 334337.
} 
La composición de los tres ejemplos de esta escena es muy similar, sin embargo, encontramos que en el códice Lat. 8085 la vestimenta del vicio cambia, a diferencia de los otros dos casos, aquí lleva túnica larga de color azul y sobre ésta otra pieza de ropa más corta de color rojo. Debajo de los pies de Voluptas se aprecian unas figuras curvas y torcidas, estos son los matorrales de espinas descritos por Prudencio en el verso 443. El iluminador de Burm.Q.3 se tomó la molestia de incluir más detalles visuales, en este caso los pies heridos del vicio al caminar por los matorrales espinosos, por medio del uso del color rojo.

El episodio entre Luxuria y Sobrietas culmina con la miniatura 54, Sobrietas y el resto de las virtudes se abstienen de tocar los despojos, se aprecia a la victoriosa virtud vestida de guerrera ante su ejército. Si bien la disposición de las figuras en los tres ejemplos es la misma, el estilo de éstas es muy distinto. En todas se aprecia en la extrema izuqierda de la composición la figura de Sobrietas vestida con su armadura, eleva ambos brazos gesto de conversar el cual es retribuido por cuatro figuras al lado contrario de éstas que representan su ejército. En Burm.Q.3 y Ms. Lat. 8085 se plasmaron cuatro individuos para representar las huestes de la virtud. La figura de la extrema derecha mira en dirección contraria a sus compañeros, este gesto ha sido interpretado por Stettiner como uno de disconformidad producto de la conversación con su líder ${ }^{161}$. El grupo de cuatro en Ms. 9987-91 fue representado con más torpeza y a pesar de haber cuatro cabezas sólo se aprecian los cuerpos de tres figuras. En Ms. Lat. 8085 el estilo de las cinco figuras es muy distinto al resto de las miniaturas de este códice. Aquí se aprecia una mayor definición de los contornos y de la aplicación de los colores, pero igualmente se aprecian notables diferencias con la forma de dibujar las extremidades, las cuales son más grandes y gruesas que en el resto de ejemplos.

${ }^{161}$ STETTINER. Die Illustrierten Prudentiushandschriften..., p. 326. 


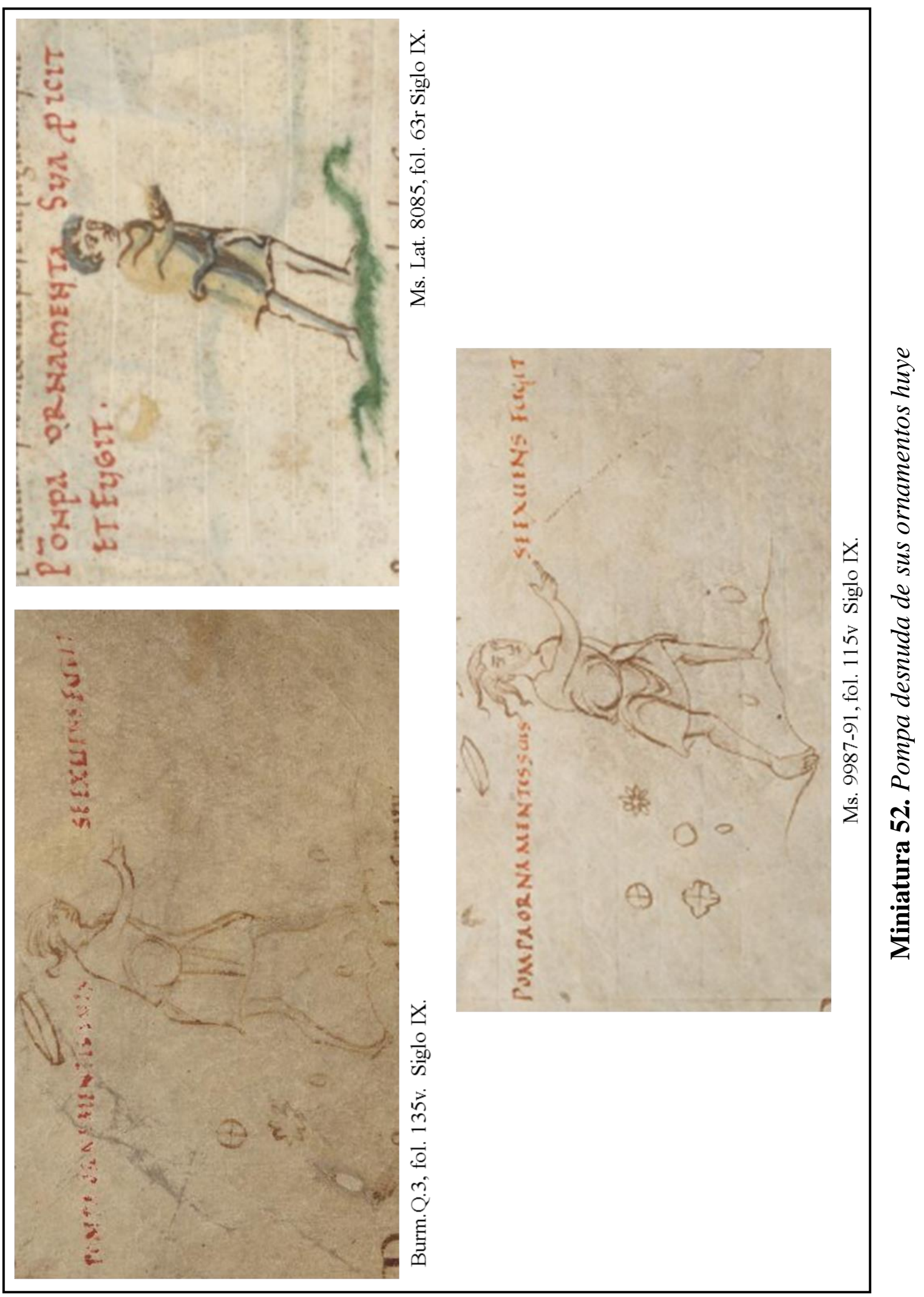




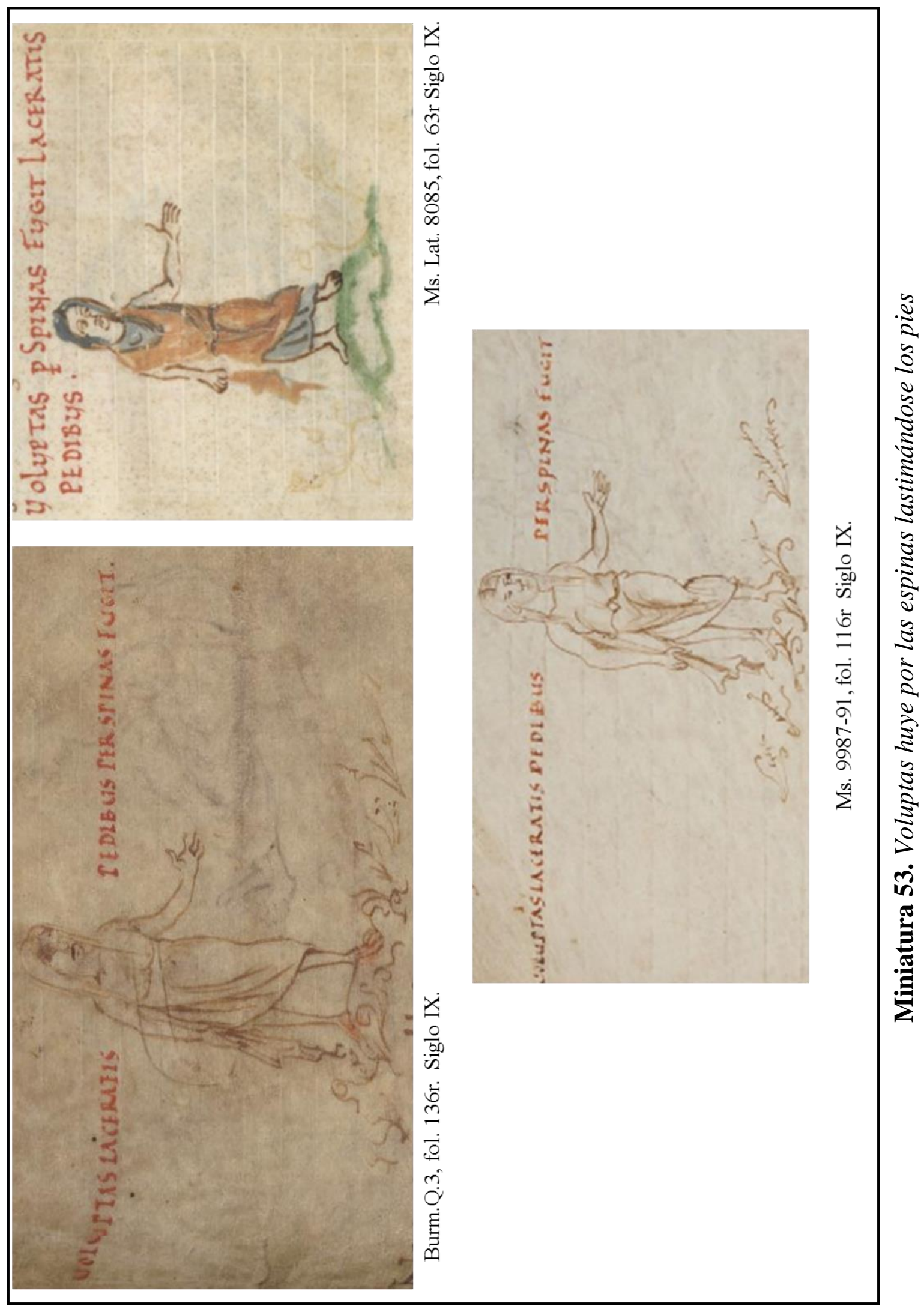




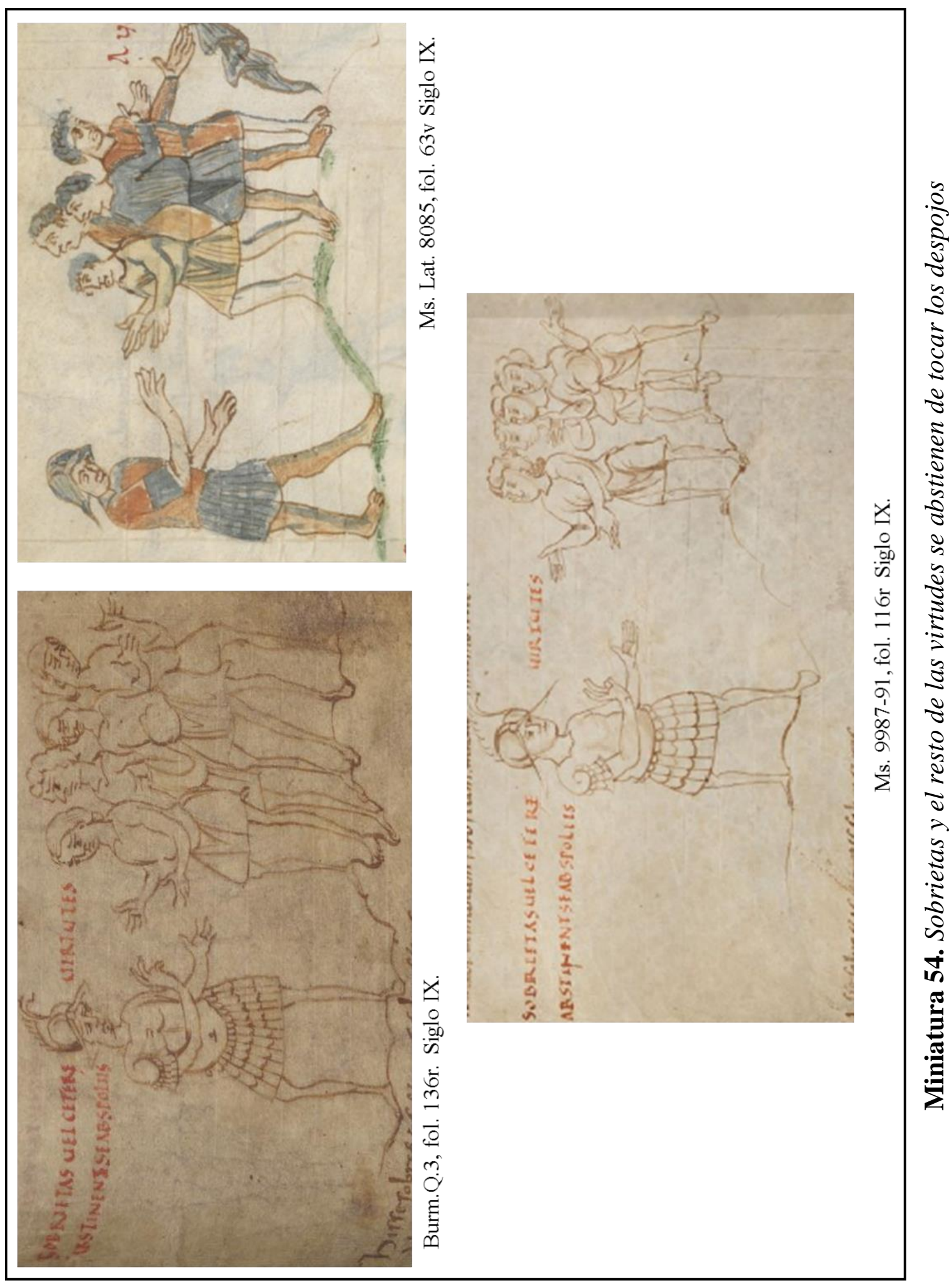


Sobre el gesto de la virtud en esta miniatura particular, la misma se plasmó conversando con sus huestes, repitiendo el gesto de increpar que se utiliza las virtudes que reprenden a los vicios vencidos en las miniaturas 14, 25 y 38. Si bien se repite el gesto, por la extensión de los versos que siguen al poema y el título que le acompañan el gesto de Sobrietas se refiere a la advertencia que ésta les hace a sus compañeras de abstenerse a tocar los despojos enemigos.

\subsubsection{Largitas vs. Avaritia}

El combate entre Avaritia y Largitas es el que cuenta con el mayor número de miniaturas. En diecinueve imágenes se recogen los ciento noventa versos de esta batalla. El desarrollo de las imágenes sigue el mismo esquema del combate entre Luxuria y Sobrietas. Las primeras diez miniaturas se introduce al vicio y las distintas formas en las que ésta obra, luego aparece Largitas y se muestra la lucha entre ambas fuerzas contrarias y por último la victoria de la virtud.

Avaritia personifica el afán desmedido de poseer y adquirir riquezas para atesorarlas y Prudencio introduce a ésta envuelta en su afán por la fortuna. En las primeras dos imágenes, las miniaturas 55 y 56, Avaritia se representa tal y como indica el poeta, por ende, recogiendo el ad res. La primera escena (Miniatura 55) además de plasmarse en los manuscritos del siglo IX también se incluyó en el Ms. 10066-77. En todos los códices Avaritia se representó sentada en el suelo junto a un torrente de agua y adentra su mano derecha en este mientras que reposa su mano izquierda sobre su falda. A través de esta posición visualmente se manifiesta la acción recogida en el poema, según el cual: Avaritia hizo una bolsa ancha con su vestido para recoger todos los objetos preciosos abandonados e igualmente los fragmentos de oro que habían caído en la arena ${ }^{162}$. Cabe decir que la representación en Burm.Q.3 y Ms. 9987-91 es muy escueta, en el primero apenas se representa un pequeño objeto para indicar las piezas de oro. A pesar de lo parco de estos dos casos,

${ }^{162}$ PrudenCiO. Psychomachia, vv. 454-457. Obras Completas de Aurelio Prudencio..., pp. 336337. 
que en ambos se aprecia otro gesto que aporta más información vinculada directamente con el poema, y es que la figura de Avaritia lleva la boca abierta, como indica el verso 457 ore inhians. En el manuscrito parisino (Ms. Lat. 8085) se recurre nuevamente al uso de la urna para plasmar el cuerpo de agua como en la miniatura 15 en la que Pudicitia purifica su espada en el río Jordán, para Stettiner la presencia de la urna es producto de un error en el que Avaritia fue confundida con un río lo que llevo a proyectarla como la personificación de un cuerpo de agua ${ }^{163}$. En la miniatura del códice del siglo X se mantuvo este elemento, y la urna que representa el torrente se dibujó con forma de un rostro. En este manuscrito la imagen de Avaritia cambio, ésta continúa sentada en el suelo, pero lleva su pecho al descubierto y sólo viste de la cintura para abajo, que se encuentra adornada con un nudo. Se incluyeron las piezas de oro en el torrente y aquí el gesto del vicio es muy claro, se aprecia como las reagrupa no sólo en su falda sino también en las tres urnas junto a ella.

Junto con la miniatura 55, la 56 también introduce al monje usuario del códice a la figura de Avaritia y a su proceder. Esta miniatura acompaña los versos 458 al 463, en los que el vicio también llena bolsas con los despojos hallados en el campo de batalla y los oculta con su mano izquierda con una tela. En la ilustración de los tres códices del siglo IX la disposición de la figura de Avaritia es sumamente parecida, ésta se plasmó de lado caminando, sujeta con su mano izquierda una bolsa que acerca a su cuerpo y en su mano derecha lleva una tela, la que utilizará para ocultar lo recogido. En Ms. Lat. 8085 si bien la figura acerca su mano izquierda a su pecho, no se representó la bolsa. En Ms. 10066-77 la imagen cambia, ahora el vicio se representa de cara al espectador, y utiliza su falda como la bolsa. Lleva el pecho vestido no como la anterior miniatura. De su mano caen unos objetos, los despojos que ha recogido ${ }^{164}$. Con la miniatura 56 del códice belga 10066-77 comenzamos a ver cambios sustanciales en la composición de las miniaturas de este manuscrito en relación con los del siglo IX.

\footnotetext{
${ }^{163}$ STETTINER. Die Illustrierten Prudentiushandschriften..., p. 328.

${ }^{164}$ STETTINER. Die Illustrierten Prudentiushandschriften..., p. 331.
} 
El afán desmedido por las riquezas materiales como se plasma en las anteriores miniaturas no es la única característica o acción con la que Prudencio describe a Avaritia. Ésta nutre a otros vicios y utiliza diversas artimañas para hacer que los hombres caigan y enriquecerse. El mismo autor indica que Avaritia con su leche negra alimenta a Cura, Famis, Metus, Anxietas, Periuria, Pallor, Corruptela, Dolus, Commenta, Insomnia y Sordes, para que comentan crímenes devastadores por todo el campo ${ }^{165}$. Ésta escena se plasmó de forma distinta en los manuscritos del siglo IX y X (Miniatura 57). En los más antiguos, específicamente en Burm.Q.3 y Ms. 998791, se integraron en la miniatura los detalles más importantes, recordándole al espectador que Avaritia nutre con su leche por medio de la figura de ésta con un pecho expuesto, y los vicios a los que nutre por medio de las once figuras que le acompañan. En los tres casos las figuras de los vicios se representan melenudos y la parte inferior de sus vestimentas recuerdan lenguas de fuego. El miniaturista, como ya hemos visto a lo largo del poema ilustrado, utiliza estos elementos como cualidad memorable de la imagen de los vicios feos y monstruosos. En el códice parisino en lugar de once vicios sólo se proyectaron siete, esto en gran parte pudo ser una reducción del grupo por el limitado espacio para reproducir la escena, ya que este es el códice que se distribuyó en dos columnas.

La disposición de Avaritia en Ms. 10066-77 es distinta. Ésta se encuentra sentada en el suelo con sus pechos al aire, amamantando a dos figuras pequeñas. Aquí se continua el ritmo visual de la miniatura 55 de este códice en el que el vicio aparece sentado de forma similar ${ }^{166}$. Las dos figuras de menores dimensiones que recuerdan niños hace hincapié en la idea de nutrir con su leche del verso 469. En las miniaturas más antiguas el miniaturista resaltó el número de vicios que Avaritia nutre, dándole importancia y recordándole al monje el cuidado, el hambre, el miedo, la ansiedad,

\footnotetext{
${ }^{165}$ PRudencio. Psychomachia, vv. 464-479. Obras Completas de Aurelio Prudencio..., pp. 336337.

${ }^{166}$ STETTINER. Die Illustrierten Prudentiushandschriften..., p. 332.
} 


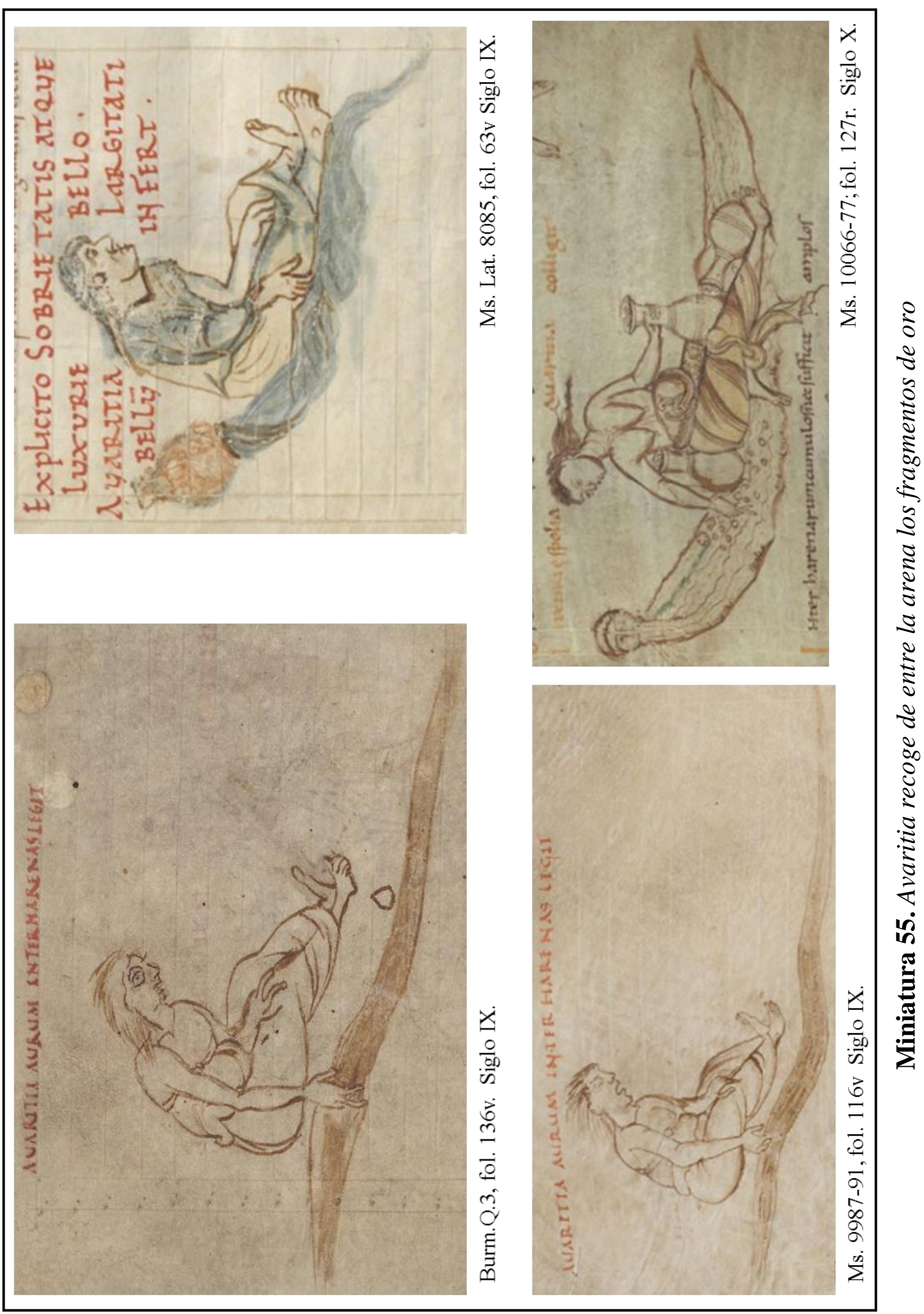




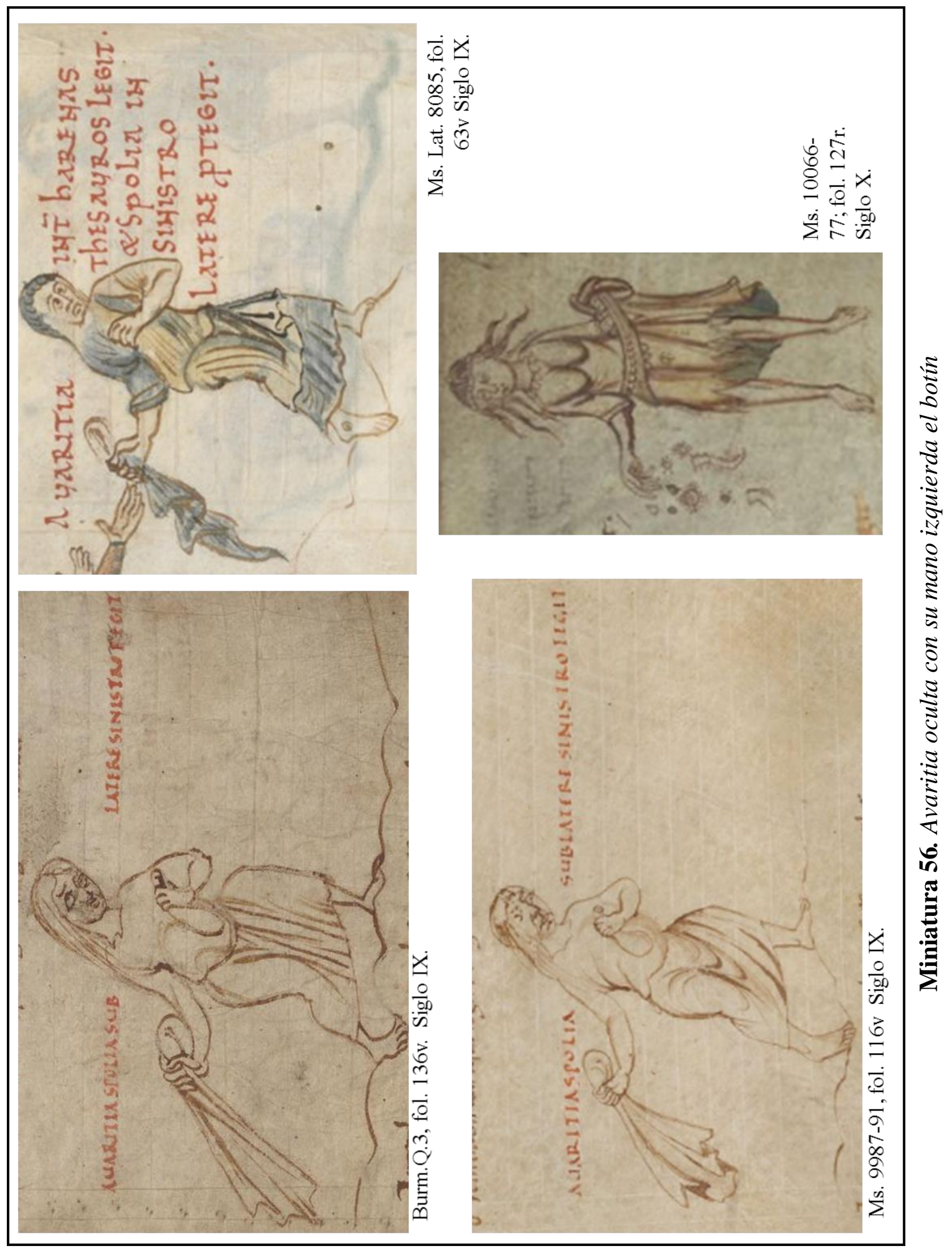



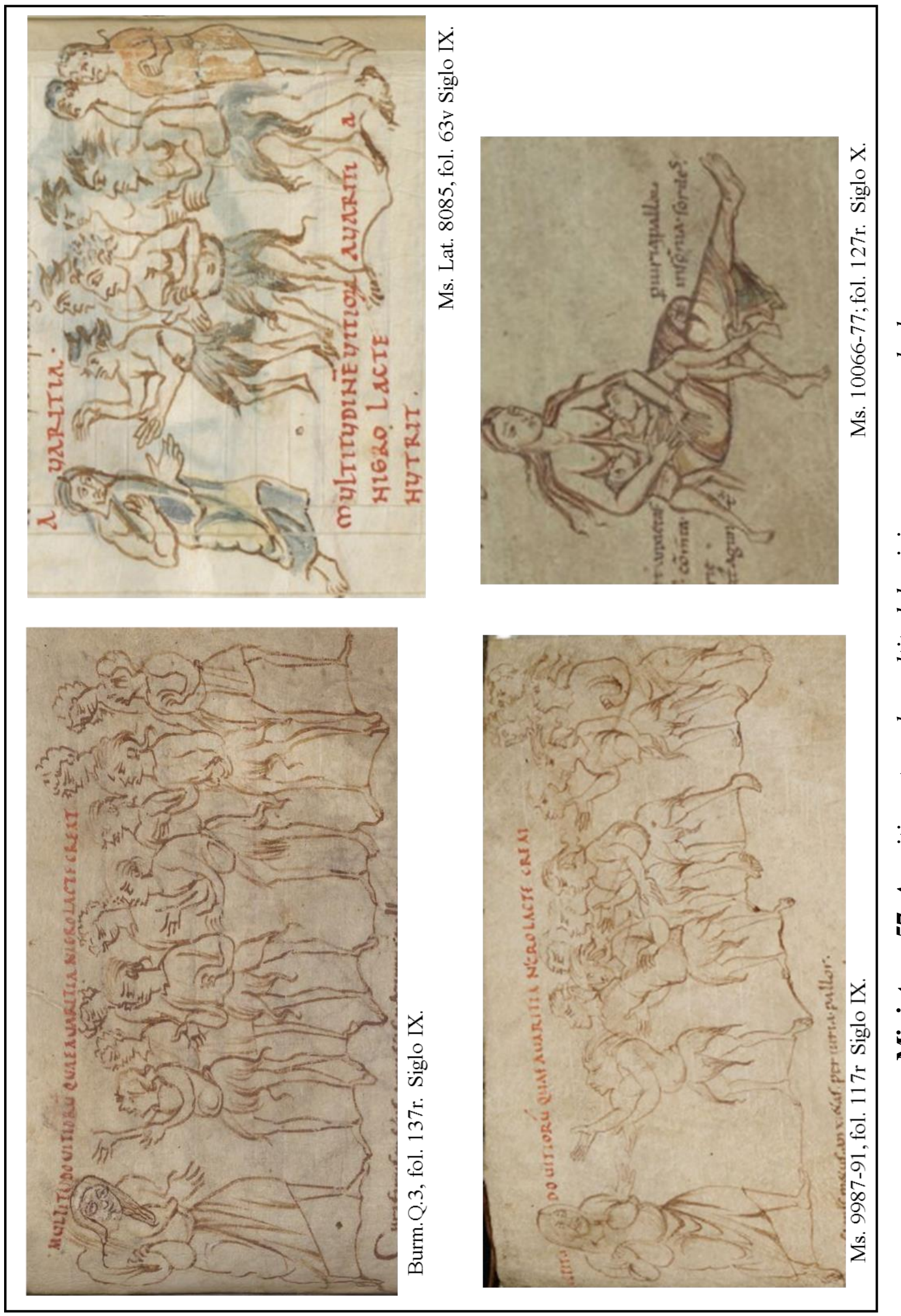

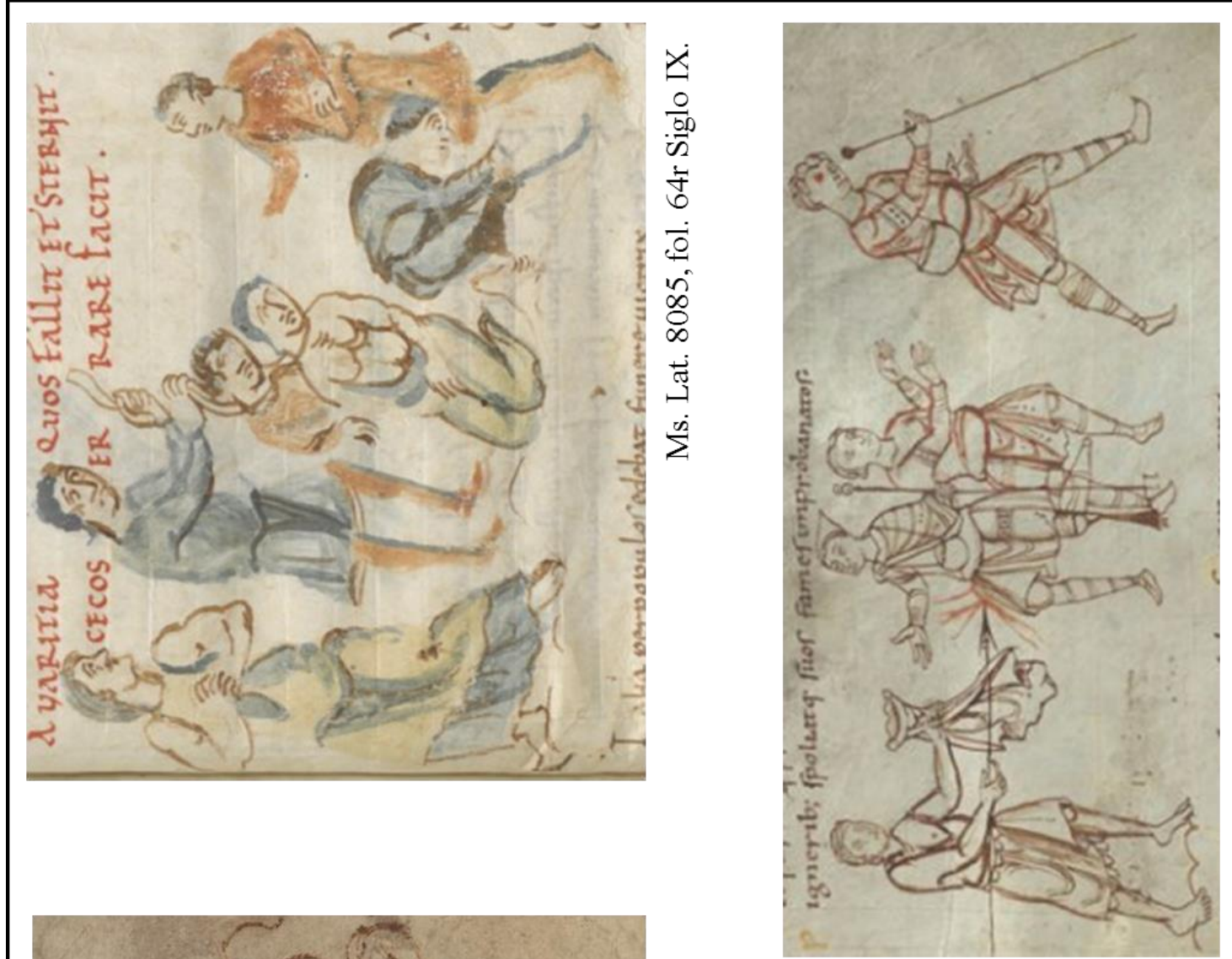

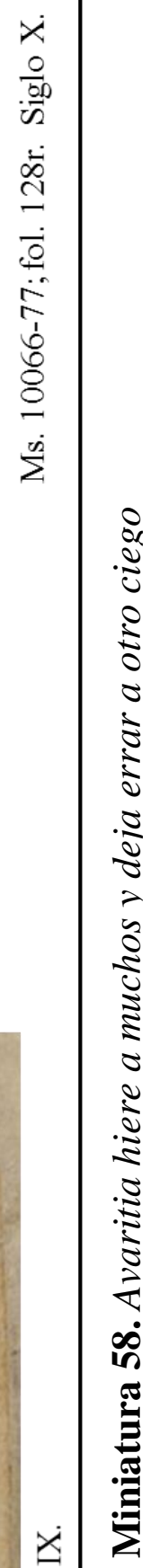
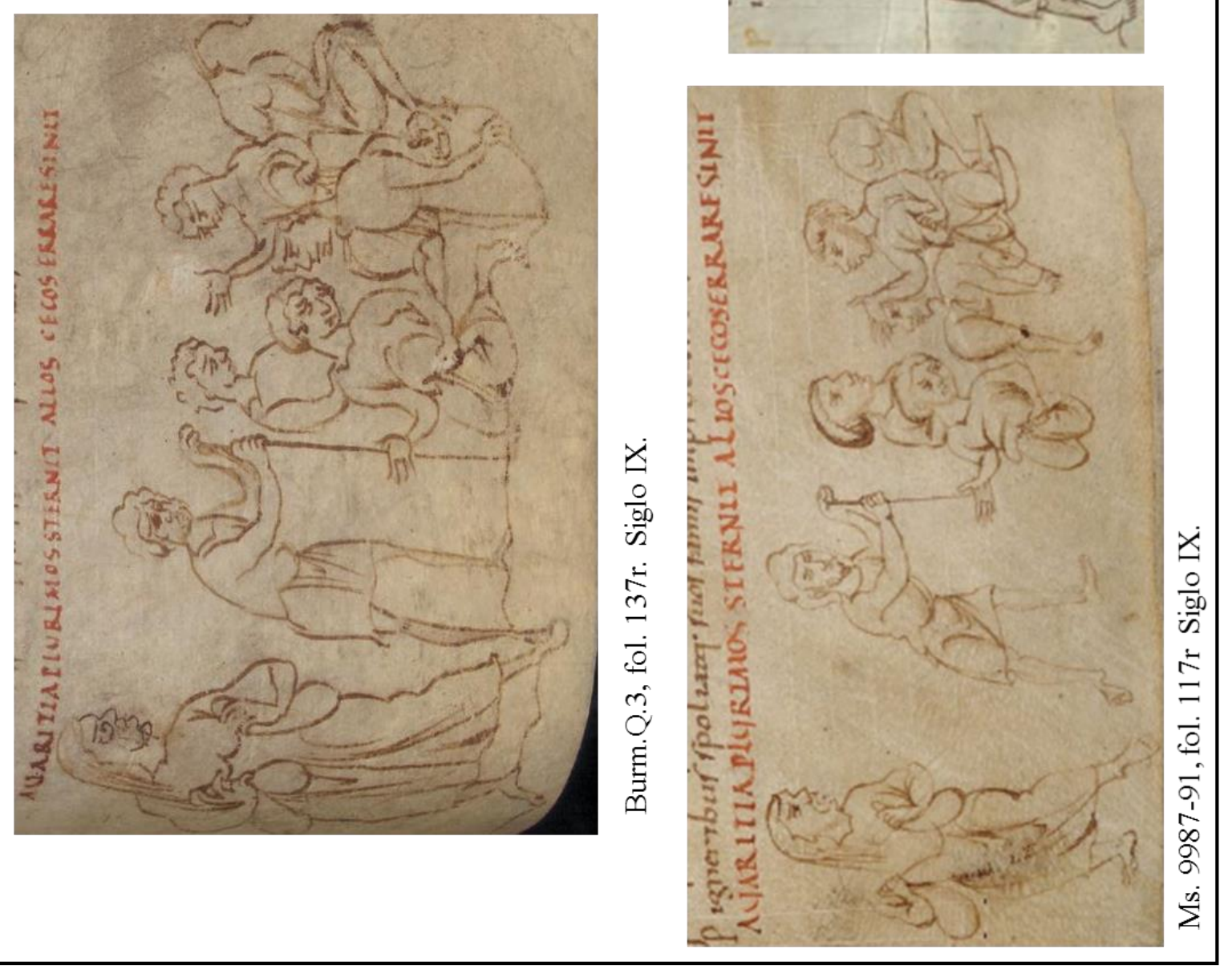
el perjurio, la palidez, la corrupción, el dolor, las mentiras, los insomnios y la mezquindad son vicios que se nutren del acto de avaricia ${ }^{167}$. En el códice del siglo X se resalta el acto mismo de nutrir, Avaritia es la causante de otros males.

Avaritia tiene distintas mañas para engañar y derribar a los hombres, las cuales además de ser enumeradas en el poema visualmente se recogen en las miniaturas 58 a la 64. La miniatura 58 responde a los versos 480 al 485, los cuales indican que Avaritia iba sembrando la muerte por todo el mundo, hiriendo y derribando a miles de hombres; a uno le sacó los ojos y le dejó errar entre muchos tropiezos. En las miniaturas de los manuscritos del siglo IX el Avaritia se plasmó en la extrema izquierda, de pies, sujetando dos bolsas y las figuras de la derecha son los hombres heridos que ésta dejó. El grupo de figuras de los heridos y las acciones de estos en Ms. Lat. 8085 son distintas a las de Burm.Q.3 y Ms. 9987-91. En el ejemplo del códice parisino, uno de los personajes fuerza a otros contra el suelo mientras tira de la soga del cuello de uno. Según Woodruff la miniatura 58 de Lat. 8085 es la que visualmente sigue más de cerca el poema, y el verbo sterno -hacer caer- en el verso 481 se puede interpretar como la acción plasmada ${ }^{168}$.

En Burm.Q.3 y Ms. 9987-91 entre el grupo de heridos el primero que llama la atención es el hombre con el bastón, un cuerpo sin cabeza, otro se retuerce en el suelo y otro sujeta una flecha o la punta de una lanza. El hombre con la vara es la plasmación visual del hombre al que Avaritia le sacó los ojos y dejó errar del verso 483. Si bien el texto establece que el vicio dejó errar sin vara alguno para no poder zafarse de los peligros que les esperan, los miniaturistas los plasmaron con este objeto. Se utilizó un símbolo u atributo por excelencia vinculado con la ceguedad para visualmente referirse a la privación total de la vista de este hombre fruto del ataque de Avaritia. La composición de esta miniatura en el códice del siglo X es distinta. En el códice del siglo X, Ms. 10066-77 esta escena se unión a la imagen de

167 "Famis Metus Anxietas Periuria Pallor / Corruptela Dolus Commenta Insomnia Sordes,/ Eumenides". PRUdEnCIO. Psychomachia, vv. 464-465. Obras Completas de Aurelio Prudencio..., pp. 336-337.

${ }^{168}$ WOODRUFF. “The Illustrated Manuscripts of Prudentius"...,p. 56. 
la escena 59. Las dos figuras del lado derecho representan la acción del hombre ciego que erra y el ojo derecho de éste se plasmó ensangrentado.

En términos mnemónicos, la acción de Avaritia en estas miniaturas, especialmente en las del siglo IX se concatenan visualmente con la representación de este vicio en las miniaturas 56 y 57, creando un ritmo visual a través de las bolsas que el ésta sostiene. Otro recurso que auxilia a la memoria es el uso de imágenes memorables, específicamente en los heridos por Avaritia. Estos se plasmaron de forma muy cruda: tumbados agonizandos, decapitados, ahorcados y el ciego en Burm.Q.3 y Ms. 10066-77 por ojos tiene dos manchones de sangre, que le quedaron al vicio habérselos arrancados.

Avaritia utiliza cualquier método para herir a los hombres, y el engaño es uno de estos. Esta acción se recoge en la miniatura 59. En los cuatro manuscritos que se incluyó esta imagen la misma se representó de forma similar. La diferencia que presenta Ms. 10066-77 es porque esta escena se representó junto con la miniatura 58. En el lado izquierdo de los cuatro casos aparece Avaritia, con su mano izquierda sujeta un paño a manera de cebo y en la derecha, como si quedara ocultó detrás de la tela su lanza dispuesta a herir a su víctima. A la derecha aparece el hombre seducido por el engaño de ésta. El mismo extiende las manos como si fuera a recibir el paño que Avaritia sujeta. Aquí se plasma visualmente los versos en los que este vicio engaña a un hombre mostrándole algo glorioso, el individuo se precipita hacia el vicio y cae en su trampa y es herido con uno de los dardos del enemigo ${ }^{169}$. Las sutilezas de los gestos representan momentos precisos. En los manuscritos del siglo IX gracias a las acciones sabemos que se recoge visualmente el momento en Avaritia engaña a su víctima según lso versos 486 y 487 y en el ejemplo del siglo X el momento en el que el hombre cayó en la trampa de Avaritia y es herido por su lanza según indican los versos 488 y 489. En Ms. 10066-77 esta miniatura se representó junto a la número

${ }^{169}$ PRUdenCiO. Psychomachia, vv. 486-489. Obras Completas de Aurelio Prudencio..., pp. $338-$ 339. 
58 de éste manuscrito y la narración de la misma se invierte. A priori parece como si el vicio hiriera al hombre y luego éste errara.

En las distintas escenas en las que Avaritia hiere a alguien, sobre todo en las del manuscrito 10066-77 se utiliza el color rojo, el cual contribuye a que estas imágenes sean memorables, para sobresaltar las heridas causadas por el vicio y las artimañas utilizadas por ésta. En la miniatura 58, Avaritia hiere a muchos y deja errar a otro ciego, los ojos heridos del hombre son manchones de este color. En la 59, Avaritia muestra algo y hiere con su lanza a uno de los hombres, aparece la sangre de la herida. En la miniatura 60, Avaritia precipita a muchos al fuego, este es el color para exaltar las llamas que quemaran a las víctimas del vicio. Esta escena se representó en los cuatro manuscritos con una distribución muy similar. En la extrema izquierda se encuentra la figura de Avaritia, la cual es posible identificar gracias a sus cabellos sueltos. Ésta empuja a otras tres figuras hacia una figura en forma de caja de la cual brotan llamas. En el ejemplo del siglo X la caja en llama se ha representado con la forma de un edificio de cuyas puertas y vanos salen las llamas. Algunas de los gestos de las victimas lanzadas al fuego son de resistencia.

El objeto en llamas en los manuscritos del siglo IX claramente es un fogón. En el centro del lado frontal se aprecian unas llamas, el orificio por el que se inserta la leña y en la parte superior vemos como brotan cuatro llamas más vivas. Por otra parte, el edificio representado en la miniatura de Ms. 10066-77 se presta para múltiples lecturas. Bien podría ser un simple edifico en llamas o a pesar de su forma de edificio podría representar un horno o incluso ser el edificio destinado para hornear, el horno del panadero. La presencia del fogón en tres de las imágenes y la de la construcción en llamas responde a distintas interpretaciones de los versos 490 al 492, específicamente del sustantivo focus, el mismo hace referencia al fogón u hornillo, pero igualmente se utiliza para referirse a la casa, el hogar, o altar. En Burm.Q.3, Ms. 9987-91 y Ms. Lat. 8085 las llamas abiertas, cómo las del brasero donde arde el oro, a las que Avaritia precipita a los hombres se representan con dicho 

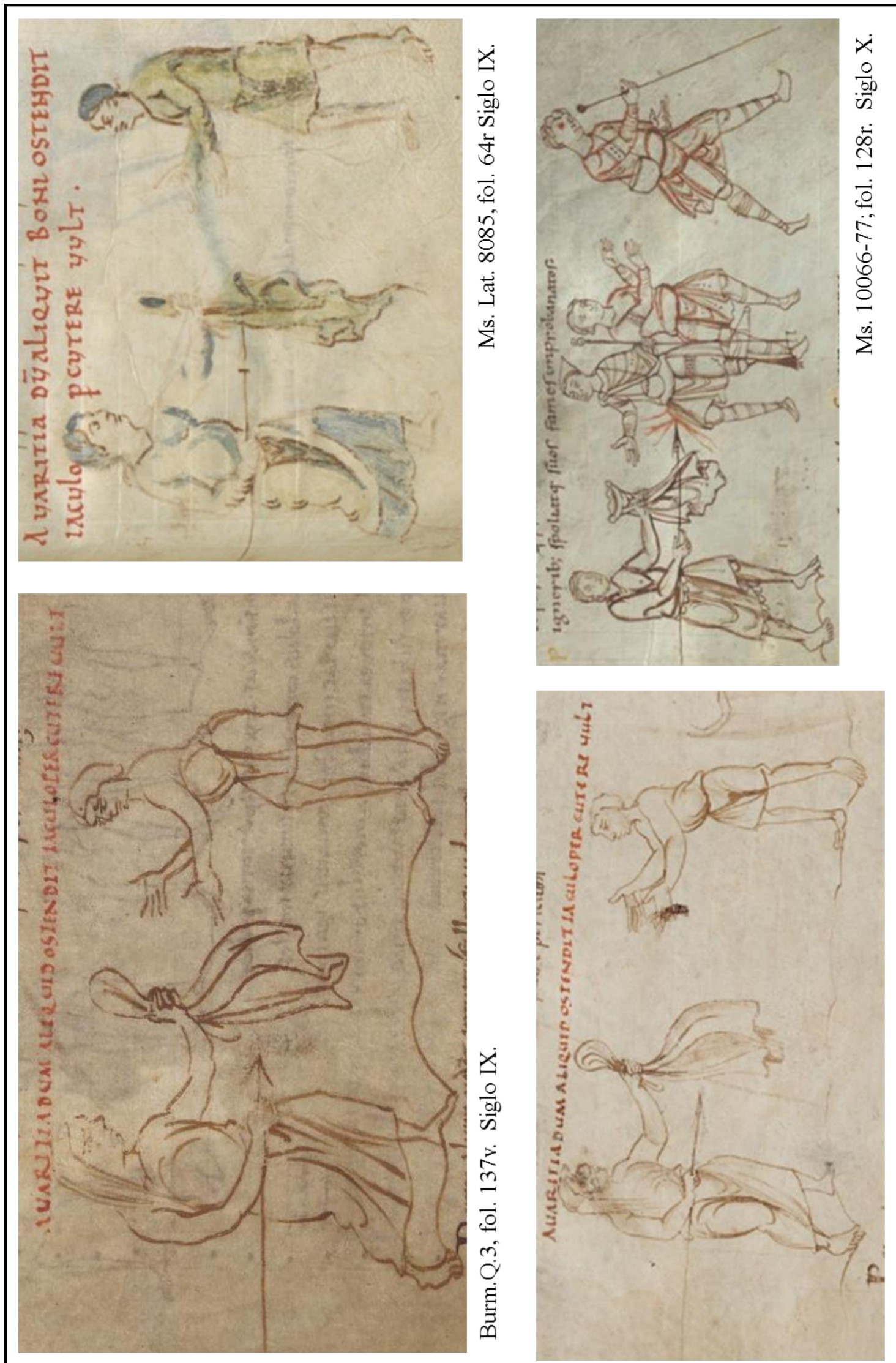

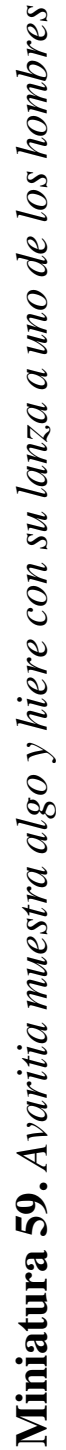




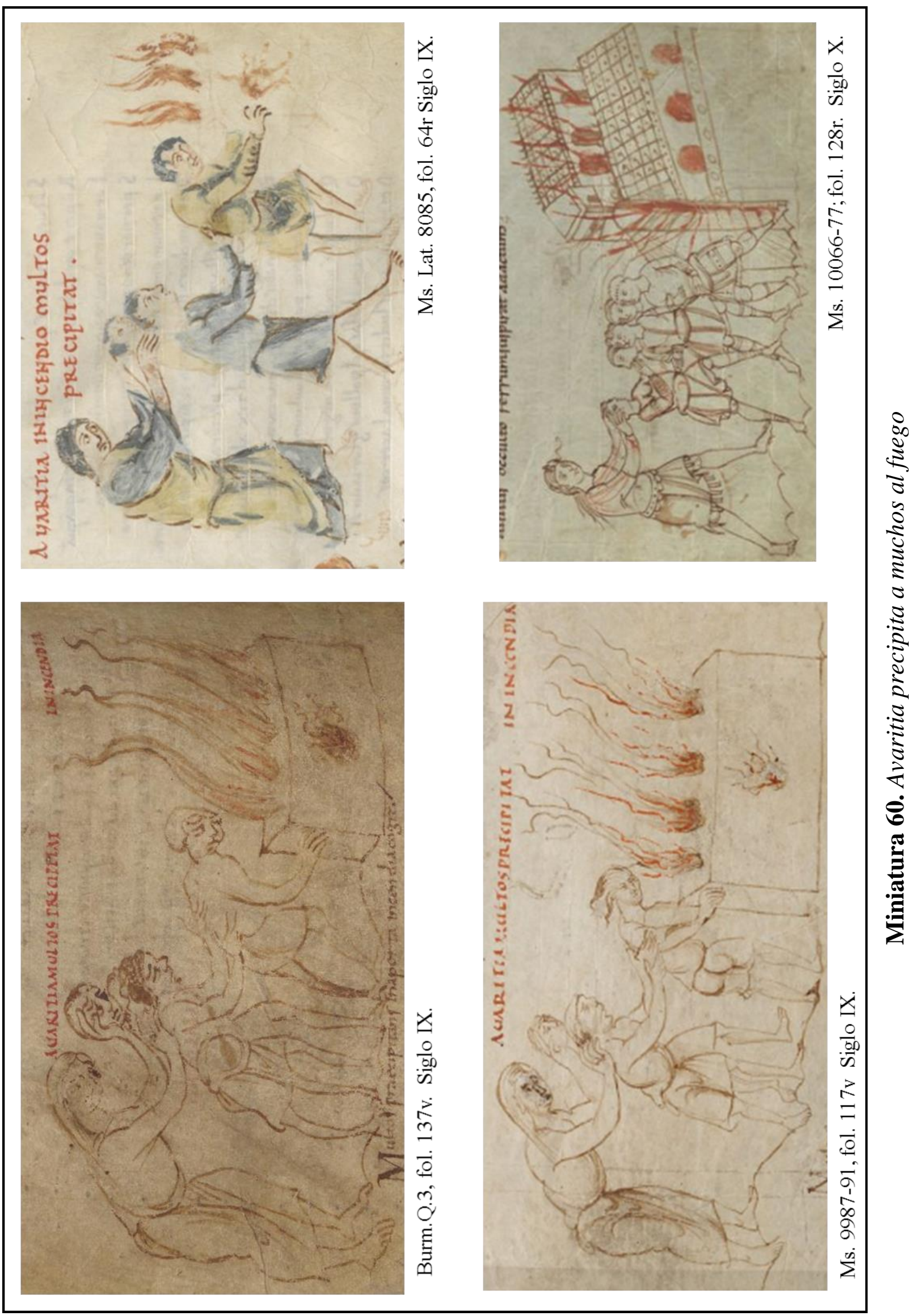




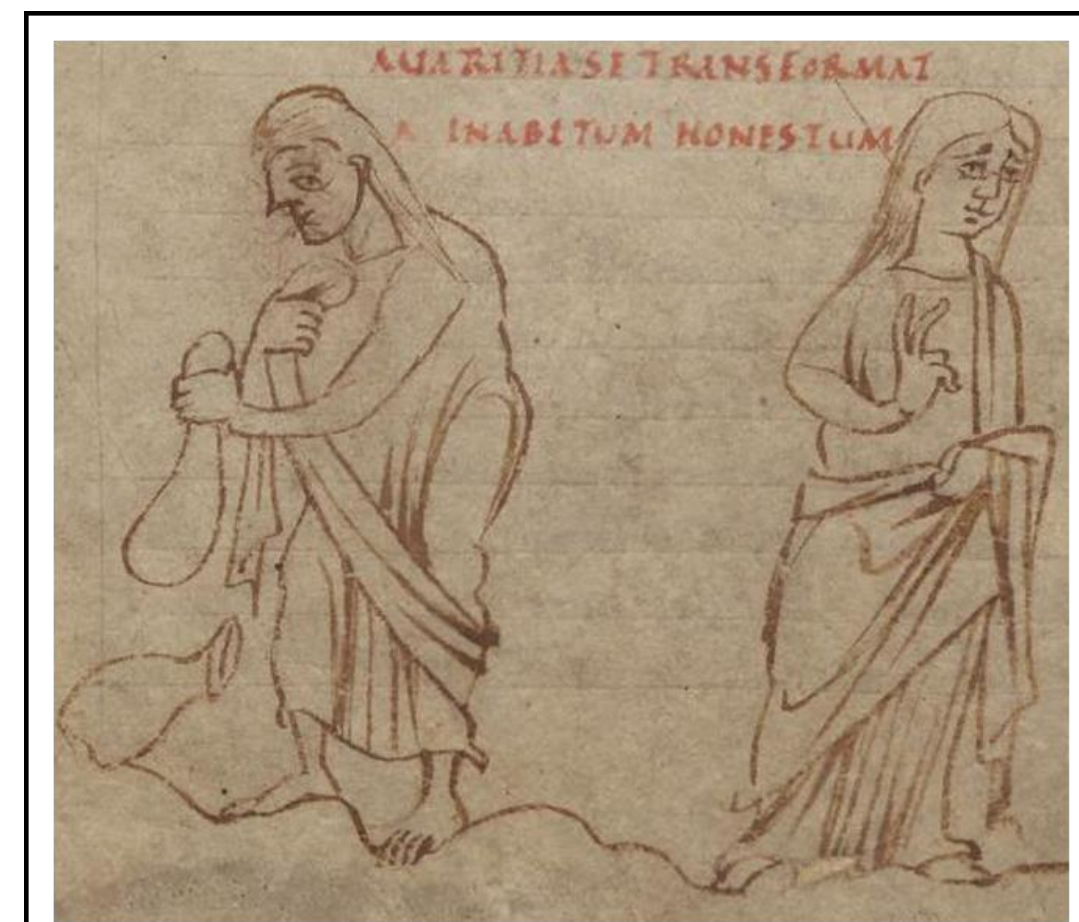

Burm.Q.3, fol. 138v. Siglo IX.

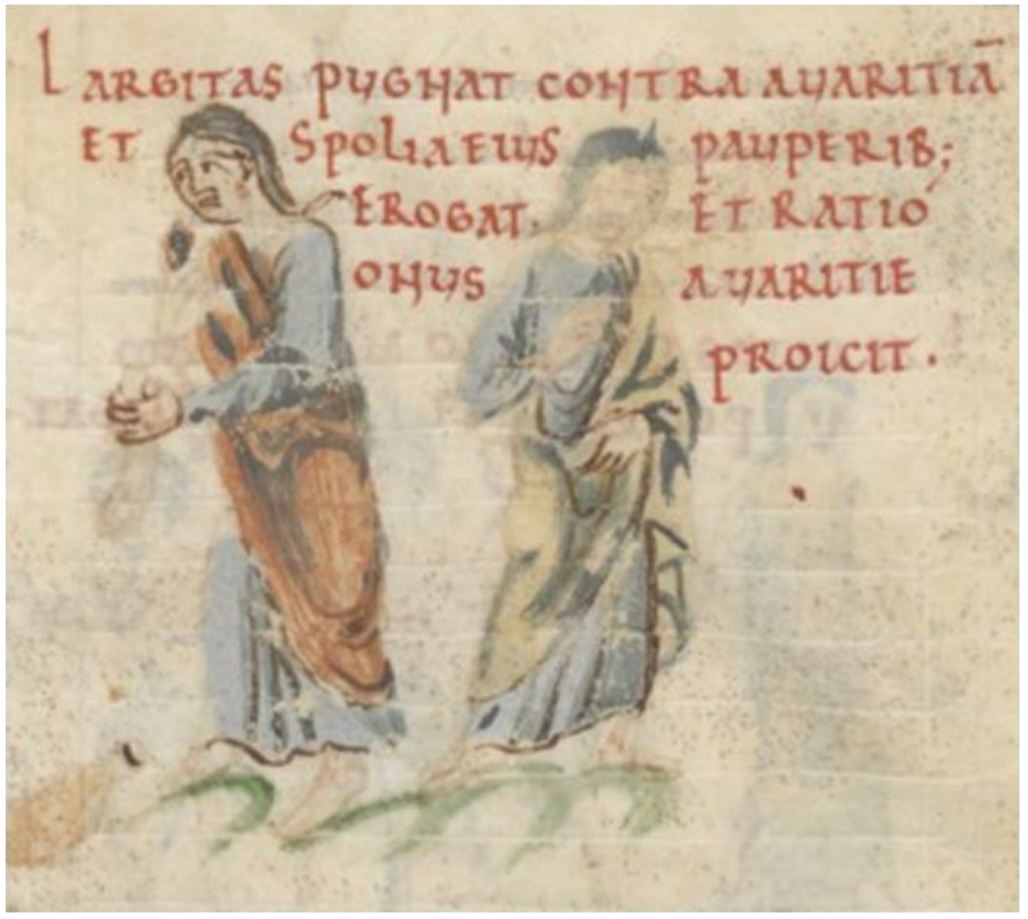

Ms. Lat. 8085, fol. 65r Siglo IX.

Miniatura 61. Avaritia transforma su aspecto a uno honorable 


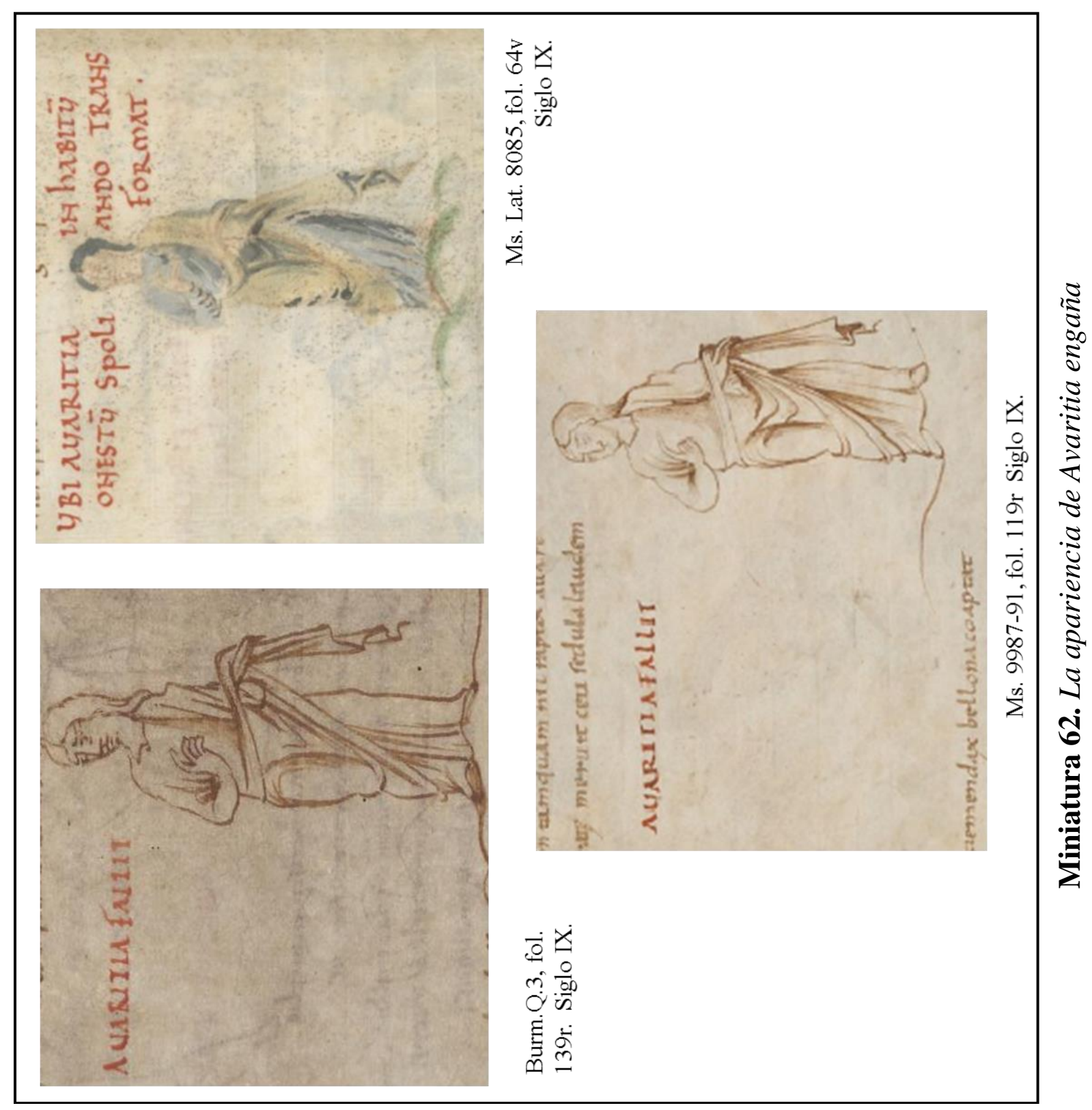


objeto. En Ms. 10066-77 las llamas abiertas salen de una casa conforma de basílica ${ }^{170}$ apelando al segundo significado de focus.

La miniatura 61, Avaritia transforma su aspecto a uno honorable, sólo se representó en dos de los manuscritos, en Burm.Q.3 y Lat. 8085. En ambos casos aparece a la izquierda de la composición una mujer encorvada de torvo aspecto al parecer desvistiéndose, y junto a ella unas bolsas, que recuerdan contienen los despojos que Avaritia recogió y que en las miniaturas 56, 57, 58 se ha utilizado como atributo de ésta. A la derecha del vicio, mirando en dirección contraria se dibujó una mujer de rostro dulce que hace el gesto de bendecir. El miniaturista presenta aquí cómo Avaritia cambia su apariencia, y se hace pasar por la virtud Frugi, para engañar a las huestes de las virtudes, recogiendo visualmente los versos 551-556. La representación de esta escena es sumamente interesante. El miniaturista para poder plasmar visualmente la acción descrita en el poema se sirvió de una doble silueta ${ }^{171}$, a la izquierda Avaritia se despoja de sus vestimentas y a la derecha aparece con su nuevo aspecto. Ya a finales del siglo XIX Stettiner se había percatado de esto ${ }^{172}$. En la miniatura de Burm.Q.3 se hace hincapié en la diferencia estética entre el aspecto feo y encorvado de Avaritia tal cual es y la figura de mejor apariencia por la que se hace pasar. Durante el resto del combate Avaritia será representada con su nueva apariencia.

En los códices del siglo IX se insertó una imagen interesante, la miniatura 62, La apariencia de Avaritia engaña. Aquí se aprecia una figura femenina tocándose el pecho. En comparación con las anteriores, muestra un aspecto más dócil. Esta mujer es Avaritia bajo su nueva apariencia. Los versos que acompañan a esta miniatura describen todo lo que hace Avaritia para ocultar su vil apariencia y pasarse por una más de las virtudes. El gesto de ésta, apuntarse al pecho con el dedo índice, es el gesto de designar. Según François Garnier, este gesto designa aquello a lo que se

\footnotetext{
${ }^{170}$ STETTINER. Die Illustrierten Prudentiushandschriften..., p. 340.

${ }^{171}$ François Garnier se refiere a las representaciones de dos figuras que representan al mismo individuo como doble silueta (doublé silhouetté). GARNIER. Le langage de l'image au Moyen Âge (II)..., pp. 67-72.

${ }^{172}$ STETTINER. Die Illustrierten Prudentiushandschriften..., pp. 343-344.
} 
señala ${ }^{173}$, en este caso Avaritia disfrazada de una virtud se auto designa, afirmando que ella es una más de las virtudes.

La nueva apariencia de Avaritia engaña a los hombres, los cuales la siguen pues la tienen por una de las virtudes. Ésta se aprovecha de la situación y los hace prisioneros como se aprecia en la miniatura 63 y Prudencio describe en los versos 564 al 567. En los tres manuscritos en la extrema derecha aparecen tres figuras con las manos atadas y a la extrema izquierda la figura de Avaritia con el mismo aspecto afable de las dos miniaturas anteriores, sujetando a los prisioneros con lo que parece ser una cuerda, a pesar de que en el verso 567 Prudencio especifica que estos fueron apresados con esposas (manicis). Los versos del poeta y la traducción visual realmente lo que hacen es realzar la noción de que las apariencias engañan y podemos volvernos prisioneros de éstas. Esta interpretación se confirma en la próxima miniatura, la 64, en la que vemos a los mismos personajes, el grupo de tres a la izquierda y Avaritia en la extrema derecho, pero ya no se encuentran atados o esposados. Si bien la composición de esta escena no cambió con respecto a la anterior, los gestos de los protagonistas sí. Los hombres prisioneros ahora elevan sus manos con las palmas hacia arriba. Este gesto se vincula con el diálogo, pero sobre todo con la pregunta y confusión como indica el título: Avaritia llena de dudas al batallón de las virtudes (Virtutum acies dubitat Avaritiam non plene cognoscens). En cuanto a la figura del vicio, en esta miniatura los gestos de ésta se vuelven más discretos, ahora acerca sus brazos al cuerpo y con la mano derecha se señala de la misma forma que en la miniatura 62. Como se ha ido corroborando a lo largo del análisis de las distintas imágenes, la repetición de gesto sirve para confirmar ciertas acciones, como es el caso de las imágenes de increpat, por lo tanto, Avaritia a través de este ademán se auto designa, afirmándole en esta ocasión a los hombres conturbados que ella es una más de las virtudes. En el códice belga, 9987-91, de la mano derecha del vicio cae un objeto redondo. Este detalle se repitió en el códice parisino, a pesar de que apenas aprecia. El mismo podría ser una de las piezas del

\footnotetext{
${ }^{173}$ GARNIER, François. Le langage de l'image au Moyen Âge (I). Signification et symbolique. París: Le Léopard d'Or, 1982. pp. 165-166.
} 
despojo que al inicio del encuentro recogió Avaritia, la forma redonda recuerda la de una moneda, pudiendo interpretarse la misma como una representación visual el verso 572, en el que al vicio se describe con una imagen dudosa de dos caras.

La miniatura 65, Largitas lucha contra Avaritia y reparte su botín a los pobres, introduce al espectador a la virtud Largitas. La plasmación se limita a recoger los detalles más memorables de los versos 573 al 583. Esta miniatura se incluyó en los tres manuscritos del siglo IX. En la misma, en el centro de la composición se aprecia la figura de la virtud Largitas. Con la mano izquierda sujeta una lanza y de la mano derecha caen los objetos del botín. A diferencia de sus compañeras en los combates anteriores, ésta no lleva armadura, y esto se repetirá en el resto de imágenes en las que aparece esta virtud, descripción visual tomada directamente del texto del poema según el cual para combatir esta se había despojado de sus vestimentas ${ }^{174}$. Sobre la acción de Largitas, la manera de combatir de ésta es repartiendo a los pobres y necesitados las riquezas y tesoros que llevaba, pues Largitas es la personificación de la generosidad y la caridad.

A la extrema derecha tres figuras de pie levantan sus manos con las palmas hacia arriba, en el lado contrario un segundo grupo de hombres extienden las manos para recibir alguno de los bienes que reparte la virtud. Para Stettiner este primer grupo se limita a plasmar visualmente el asombro de los hombres ${ }^{175}$. Los ademanes de estos expresan dicha emoción, sin embargo, estos no son un conjunto aleatorio de figuras. Estos tres personajes se concatenan directamente con los tres individuos inciertos de la miniatura 64, ya que es justo en el momento en el que Avaritia llena de dudas a los hombres cuando Largitas salta en medio del campo de batalla a auxiliar a sus aliados ${ }^{176}$. Sobre el segundo grupo junto a la virtud, el mismo representa a los débiles y pobres que auxilió ésta. En el título de esta miniatura, en los tres manuscritos en los que se insertó, se utilizó el sustantivo pauperibus para referirse a

\footnotetext{
${ }^{174}$ PrudenCiO. Psychomachia, vv. 577-578. Obras Completas de Aurelio Prudencio..., pp. 342343.

${ }^{175}$ STETTINER. Die Illustrierten Prudentiushandschriften..., p. 351.

${ }^{176}$ Prudencio. Psychomachia, vv. 573-576. Obras Completas de Aurelio Prudencio..., pp. $342-$ 343.
} 
los pobres, sin embargo, en el poema se utiliza inops que además de referirse a pobre también se traduce por: indigente, necesitado, impotente, débil, desamparado. La imagen incluye estos diversos significados en las distintas figuras junto a Largitas, con particular énfasis en el impotente y débil el cual fue representado a través de la figura pequeña junto a los pies de la virtud, un lisiado al cual se le puede identificar gracias a los dos objetos junto a él los cuales son unas especies de muletas. Este personaje ya había aparecido en la miniatura 58 como una de las víctimas e Avaritia sujetando una de sus muletas y volverá a repetirse en la miniatura 69 arrastrándose en el suelo con la ayuda de estos objetos. El uso de pauperibus en el título probablemente se utilizó por ser una palabra más conocida para los jóvenes aprendices que se estaban familiarizando con el latín ${ }^{177}$.

La miniatura 66, Avaritia se encuentra aturdida y agotada, solamente se dibujó en Burm.Q.3 y Ms. 9987-91. En la misma se plasmaron dos figuras, una a cada extremo de la composición. La mujer de la extrema derecha viste túnica larga y lleva el cabello largo suelto, muy similar a como se ha plasmado a Avaritia cuando se hace pasar por una virtud. A la izquierda de la composición una figura con túnica corta, similar a la de Largitas en la miniatura 65, extiende sus brazos. Esta imagen acompaña los versos 584 al 588 según los cuales Avaritia al ver la forma en la que la virtud combatía, presa de la locura quedó paralizada. A pesar de que en los versos solamente se establece que el vicio quedó aterrado ante su enemiga, en la miniatura se incluyó a Largitas, para establecer que ante su presencia Avaritia quedó paralizada $^{178}$.

El encuentro entre las fuerzas contraria de este combate se recoge en dos miniaturas: 67, Largitas estrangula a Avaritia, y 68, Largitas sujeta con sus pies y rodillas a Avaritia, las cuales muestran en sucesión el conflicto de estas fuerzas contrarias. En la primera miniatura, la 67, se aprecia de pies la figura de Largitas, ésta sujeta a su enemiga por el cuello y la estrangula como se narra en los versos 589

\footnotetext{
${ }^{177}$ GIBSON-WoOD. "The 'Utrecht Psalter' and the Art of Memory..., p. 14.

${ }^{178}$ STETTINER. Die Illustrierten Prudentiushandschriften..., p. 353.
} 

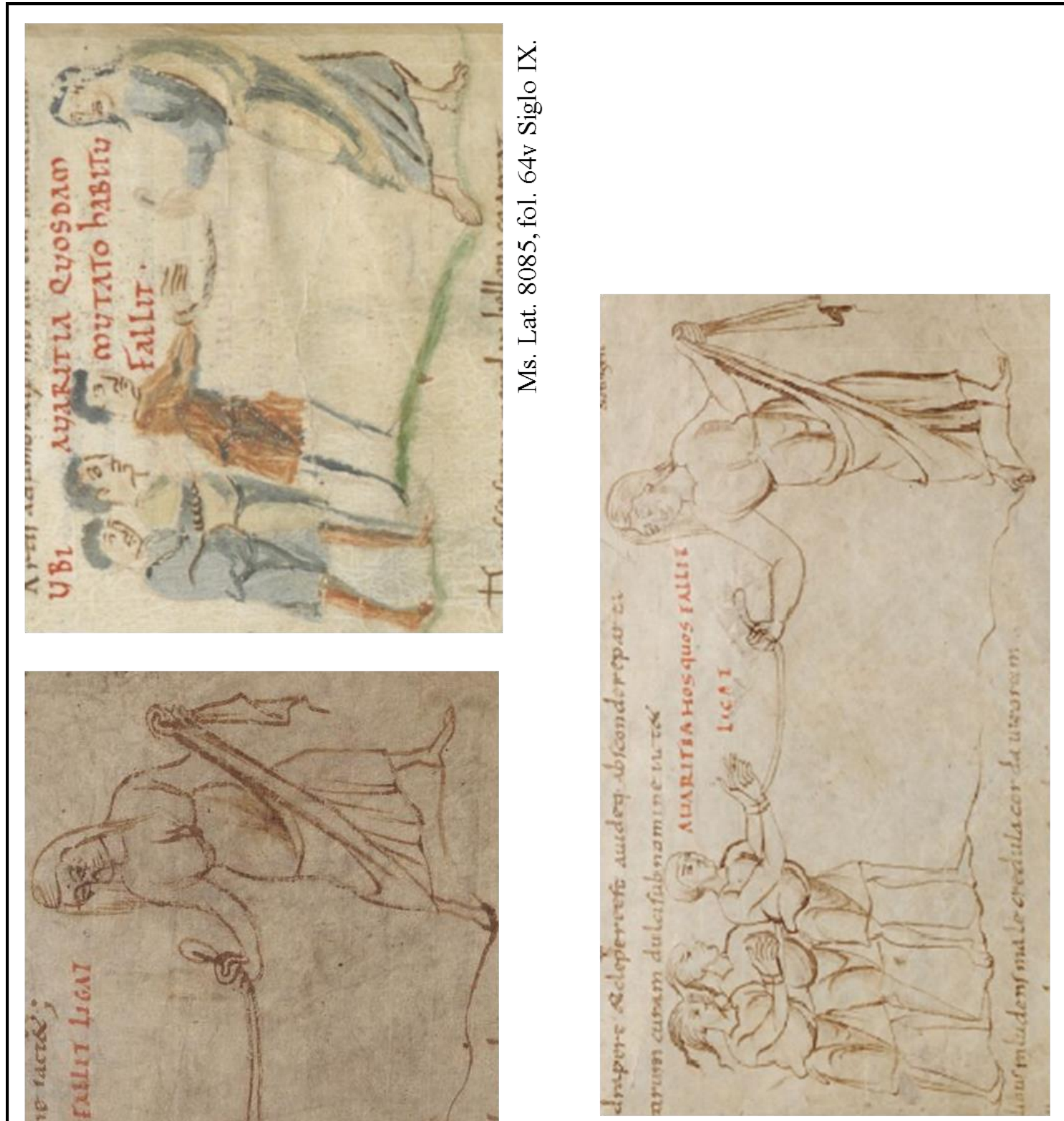

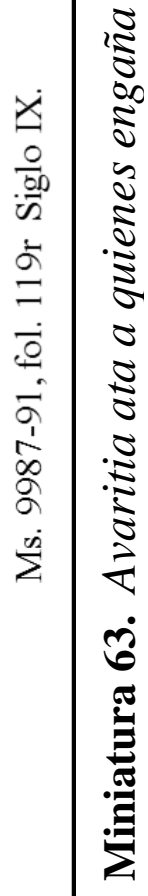

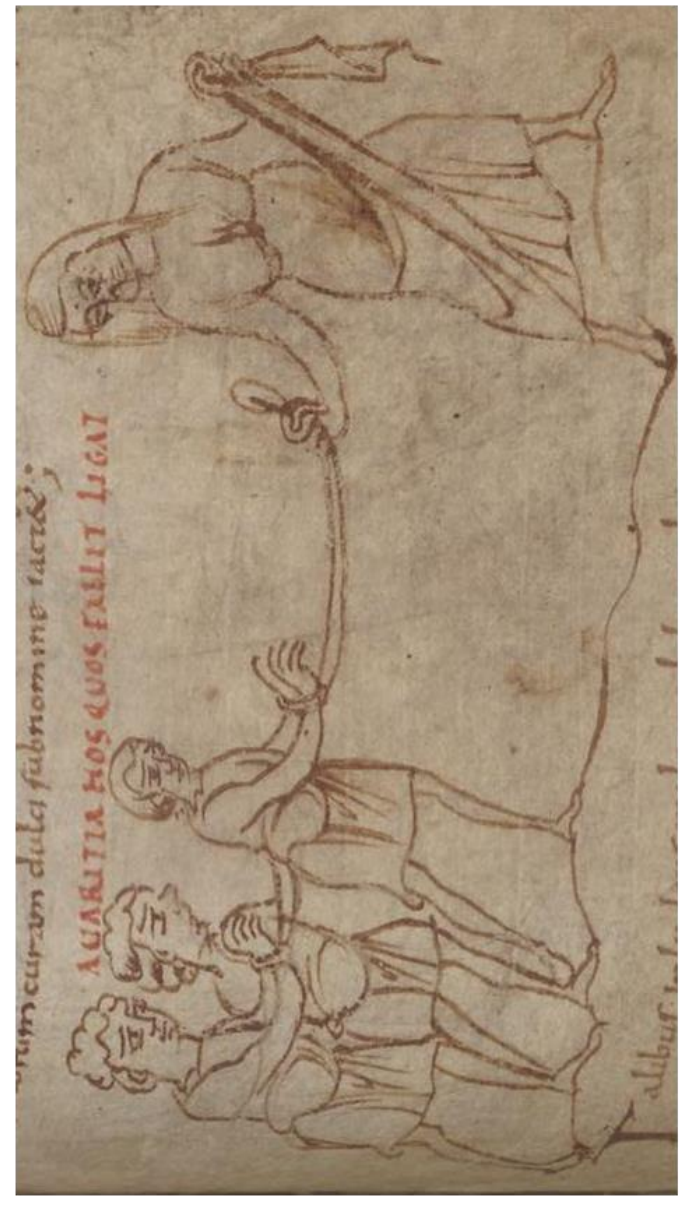

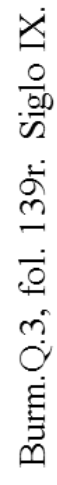




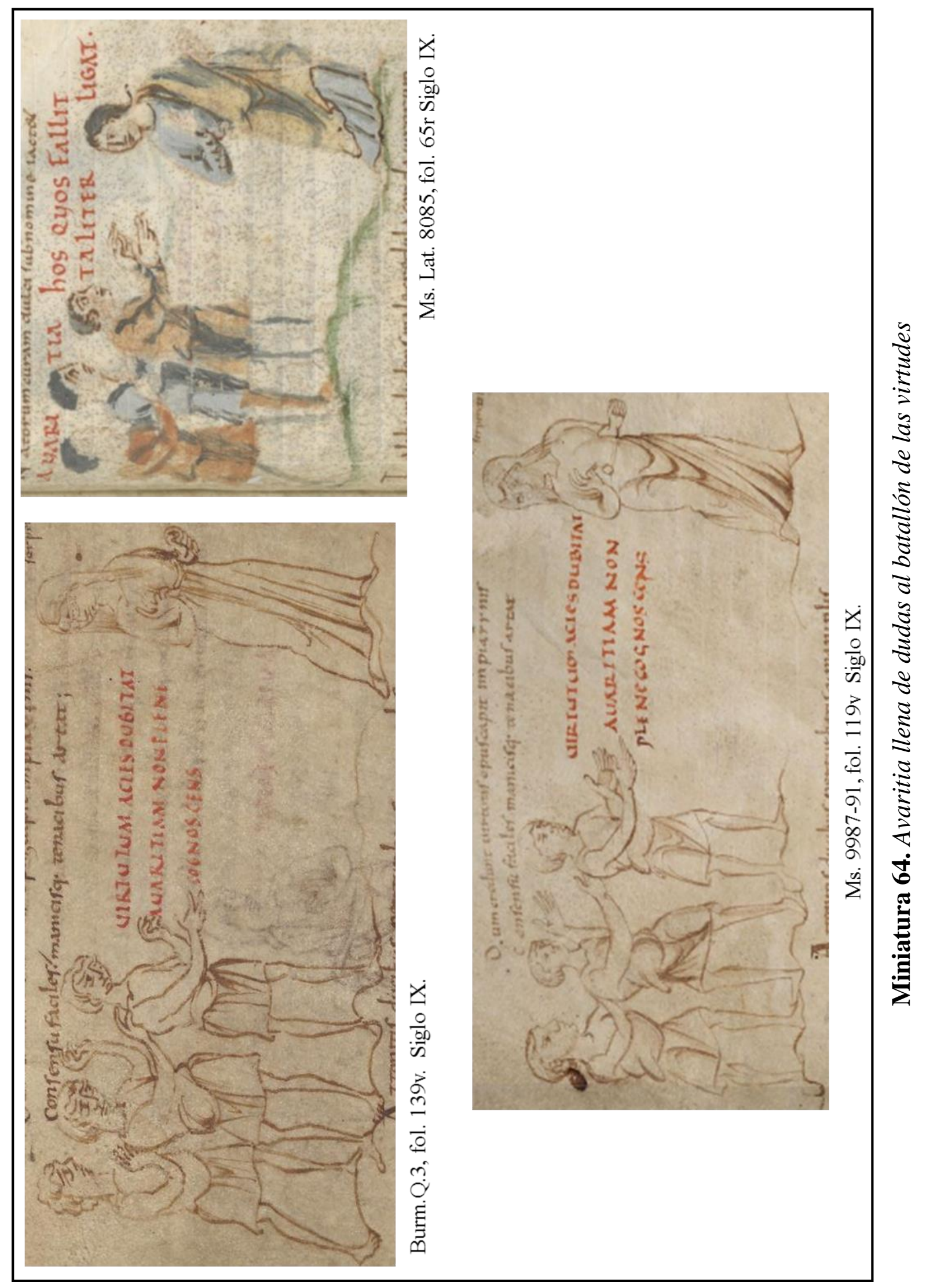



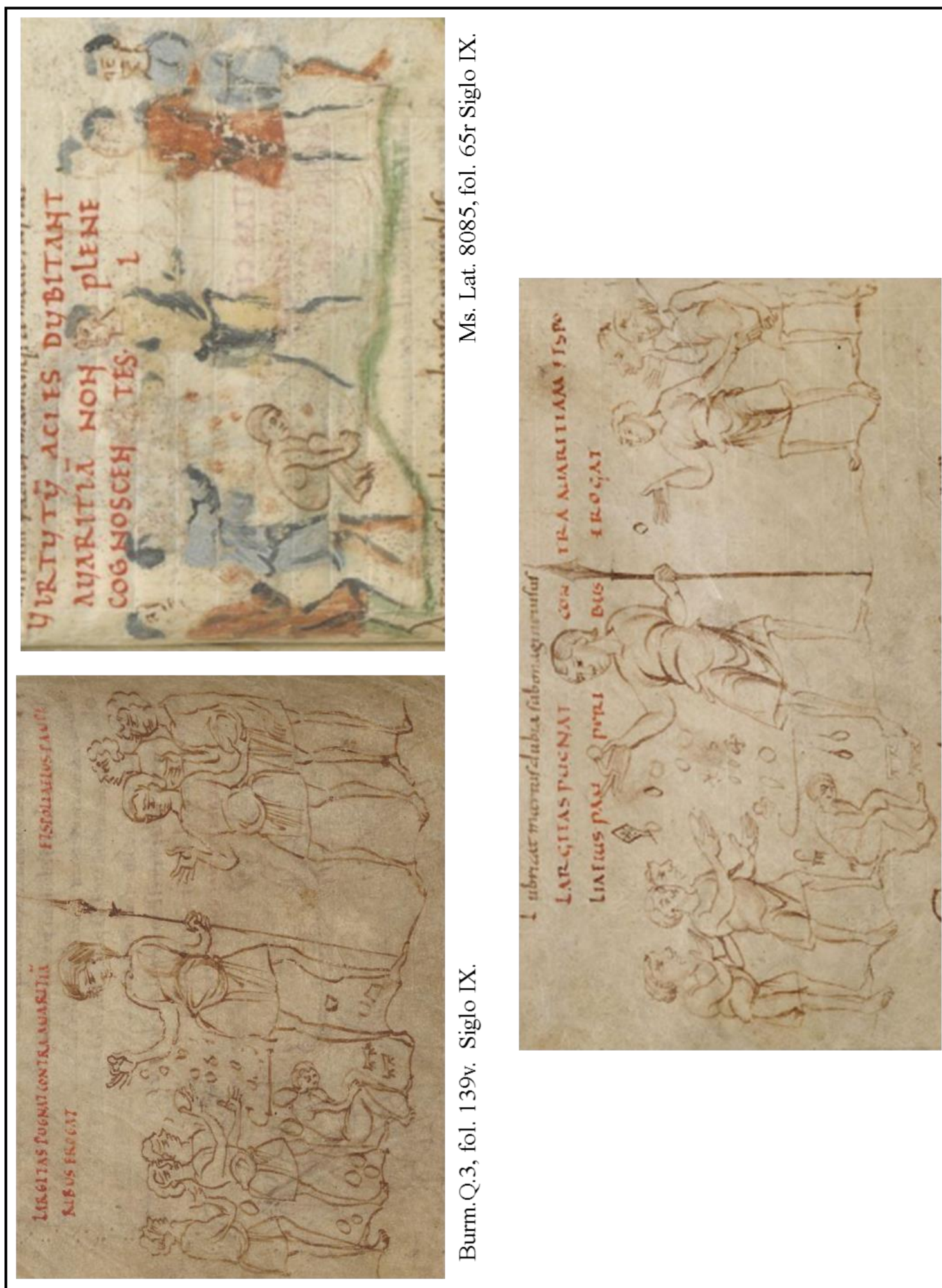

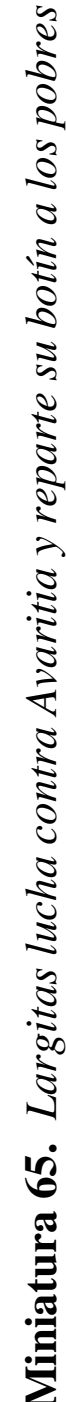




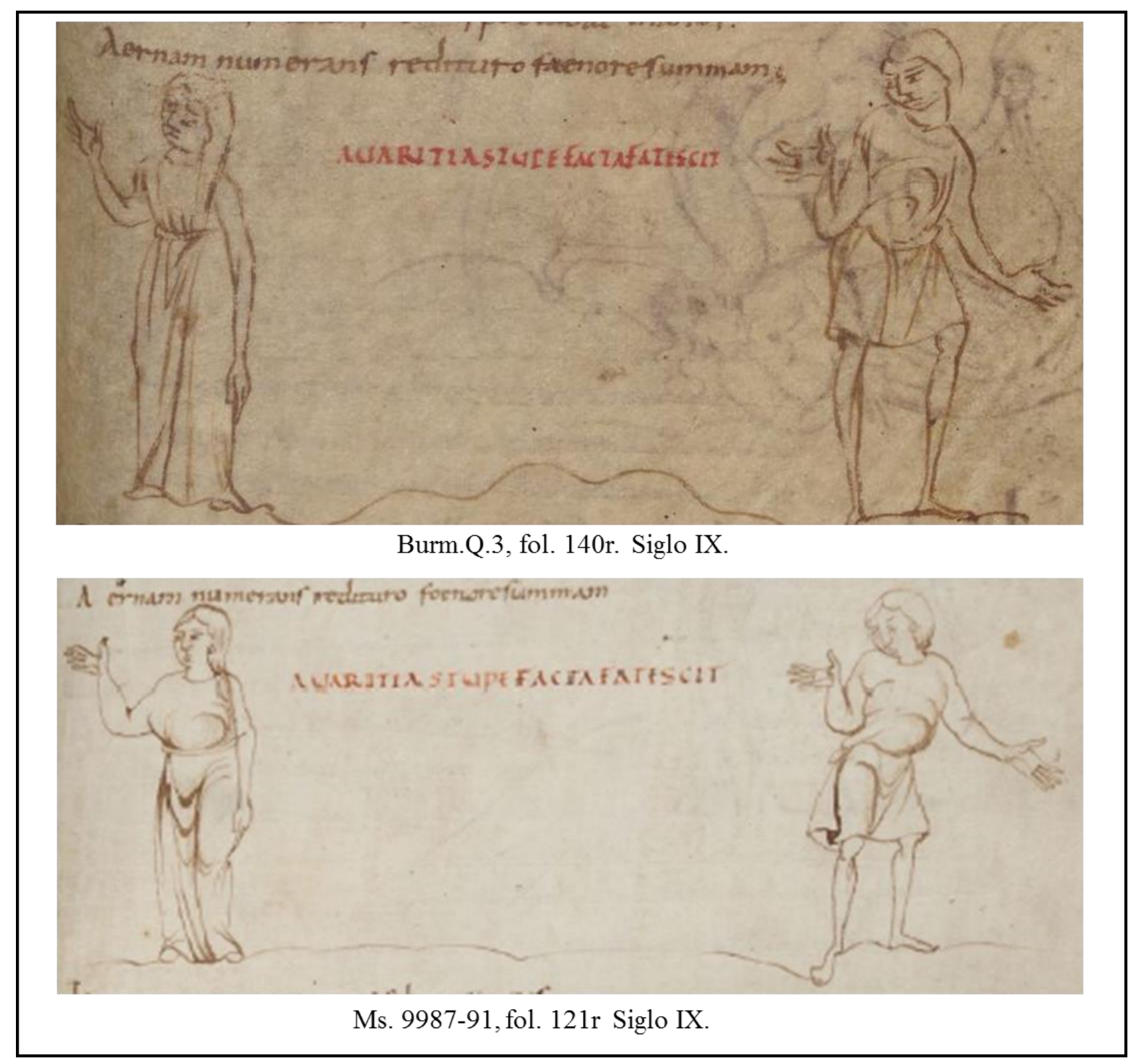

Miniatura 66. Avaritia se encuentra aturdida y agotada 
al 595. Los gestos del vicio en Burm.Q.3 y Ms. 9987-91 son mucho más expresivos. Avaritia extiende los brazos mientras levanta la cabeza. En el códice belga unas líneas se dibujaron saliendo de la boca de ésta, alusión a que le cortan la respiración. Los tituli de esta miniatura utilizan el verbo ligo, indicando que Largitas ata, aprieta o sujeta a Avaritia. La imagen recoge el sentido completo de la acción narrada en los versos. Largitas extangula a Avaritia: conpressa ligantur vincla lacertorum y se incluye en la imagen el instrumento con el que se realiza esta acción, la cuerda, correa o atadura (vinclum).

En la siguiente escena (Miniatura 68) se plasma visualmente los versos en los que Avaritia se resiste a Largitas, pero la virtud la aprieta con sus pies y rodillas hasta romperle las costillas y dejarla sin aliento ${ }^{179}$. En la miniatura la virtud aprieta con sus pies y rodillas al vicio contra el suelo mientras sujeta con la mano derecha parte de la túnica de Avaritia y con la izquierda la atadura con la que le amarró sus manos. El vicio vencido en esta miniatura recupera su aspecto turbio y vuelve a ser representado con los cabellos melenudos. En Ms. Lat. 8085 incluso se aprecia que lleva el torso desnudo. En cuanto a la postura de Largitas, el poema establece que la virtud rompe las costillas del vicio, pero en los tres códices Largitas aprieta con su rodilla la boca del vicio, la plasmación visual de rumpit anhela (interrumpió su aliento).

La victoria de Largitas se plasmó en dos miniaturas. En la miniatura 69 se aprecia a la virtud quitándole al cadáver del vicio piezas de oro y bolsas para repartirla entre los pobres y débiles, según los versos 598 al 603. Esta escena se representó en los tres códices del siglo IX y en el Ms. 10066-77 del siglo X. La composición de los ejemplos más antiguos es semejante, en la izquierda el cuerpo inerte de Avaritia, junto a ésta se aprecian las bolsas en las que había guardado los tesoros encontrados en el campo de guerra, y que a lo largo del encuentro han sido utilizadas como atributo de este vicio, y desperdigados objetos redondos que no son otra cosa que las piezas de oro (En Ms. Lat. 8085 estos son de color amarillento). Arrodillada junto al cuerpo muerto de Avaritia, se colocó a Largitas y ésta con su mano derecha sujeta el cuello

${ }^{179}$ PrudenCIO. Psychomachia, vv. 596-597. Obras Completas de Aurelio Prudencio..., pp. 344345. 
del vicio y con la izquierda ofrece una de las piezas a las tres figuras de la izquierda. Estos tres hombres son la plasmación visual de los débiles según el poema, o pobres según los títulos y explicaremos más adelante.

En Ms. 10066-77 a Largitas se dibujó de pies sobre el vicio. En este códice esta forma de ilustrar la victoria de la virtud había sido utilizada, específicamente en la miniatura 10 donde se plasmó el triunfo de Fides sobre Cultura deorum. En el códice belga esta es la primera representación de Largitas, no lleva armadura, sino una túnica como en los ejemplos del siglo IX, pero aquí es larga. En lugar de las bolsas de los despojos, se incluyeron las urnas que había llenado de piezas de oro el vicio en la miniatura 55 de este códice. Sobre el paño anudado que ofrece la virtud a los pobres, Stettiner y Woodruff lo mencionan ${ }^{180}$, pero no ofrecen explicación sobre el mismo. Entendemos que éste puede ser parte de la vestimenta del Avaritia que Largitas igualmente reparte a los pobres y débiles. La imagen del lisiado cambió, en este ejemplo se encuentra de pie, lleva una pata de palo y con su mano izquierda sujeta su muleta.

En los tituli de las miniaturas del siglo $\mathrm{X}$ nuevamente encontramos que se utilizó la palabra pauperibus para referirse a los pobres, pero la imagen representa a los débiles y necesitados (egenits et tenues) de los versos 602 al 603. En los códices del siglo IX, entre los débiles y necesitados a los que Largitas reparte los despojos de Avaritia se incluyó la figura del lisiado o discapacitado que utiliza los objetos en las manos para arrastrarse hasta la virtud. En el manuscrito 10066-77 el cojo tiene una pierna de palo. En los dos manuscritos belgas (Ms. 10066-77 y Ms. 9987-91) a este personaje no se le dibujo un pie, representado de forma muy gráfica el motivo de su debilidad.

La siguiente miniatura, la 70 Largitas con júbilo arenga a la muchedumbre, los gestos de la victoriosa virtud son los de pronunciar o dialogar, similares a los de las imágenes anteriores de increpat. En Burm.Q.3, Ms. 9987-91 y Ms. Lat. 8085 en

\footnotetext{
${ }^{180}$ WoODRUFF. "The Illustrated Manuscripts of Prudentius"...,p. 60. STETTINER. Die Illustrierten Prudentiushandschriften..., pp. 357-359.
} 
el centro se dibujó la figura de Largitas con los brazos extendidos y el ademan de la mano derecha es el mismo que con anterioridad se ha utilizado en otras miniaturas para indicar la acción de increpar. En el lado derecho de la composición un grupo de cuatro figuras y en el lado contrario un grupo de dos: estos dos grupos constituyen el millar de hombres a los que con alegría la virtud se dirige. Con relación al gesto de Largitas, en este caso particular, en lugar de increpar al vicio vencido, la virtud arenga -cómo indica el título alloquitur- o grita -cómo indica el verso 605 clamat- a su ejército. En monje que utilizara este manuscrito además de por los gestos de la virtud, también por la extensión de los versos que separan cada miniatura de antemano sabía que estos versos corresponden a las palabras pronunciadas por la virtud. Al igual que en otras imágenes en las que la virtud se representa con los gestos propios de pronunciar palabras, aquí el discurso se ve acompañado por la exaltación de las cualidades morales que personifica la heroína. En el discurso de Largitas se exhorta al cuidado del alma sobre el del cuerpo y a que el creyente recuerde que Dios siempre les acompaña, pues Él es generoso. El discurso de la virtud es muy acertado para la práctica del ascetismo. A pesar de que el texto de Prudencio es más antiguo que la regla Benedictina en ésta se enfatizan el descanso moderado, y vestimenta y alimento sencillo para para practicar la virtud de la generosidad y la humildad ${ }^{181}$.

La composición de la miniatura 70 en el manuscrito 10066-77 es distinta. La virtud se representó de pies sobre el vicio derrotado, como en la 69 del mismo códice, pero aquí lleva su cota de malla, yelmo y armas. Una segunda lanza se encuentra en el suelo, ésta hace hincapié en las palabras pronunciadas por Largitas expresadas en el verso 606: "discedite ab armis!" "182. A pesar de las diferencias composicionales con el resto de las miniaturas de esta escena, la función es la misma, continúa siendo un lugar mnemónico de recopilación del discurso pronunciado por la virtud.

\footnotetext{
${ }^{181}$ Ver los capítulos 7, 55 y 67 de la Regla benedictina. SAN BENITO. San Benito: su vida y su regla. dirección e introducciones del Padre Dom García M. Colombas, versiones del Padre Dom León M. Sansegundo, comentarios y notas del Padre Dom Odilón M. Cunill. Madrid: Editorial Católica, S.A., 1954. pp. 370-393, 596-603, 666-669.

${ }^{182}$ STETTINER. Die Illustrierten Prudentiushandschriften..., p. 362.
} 


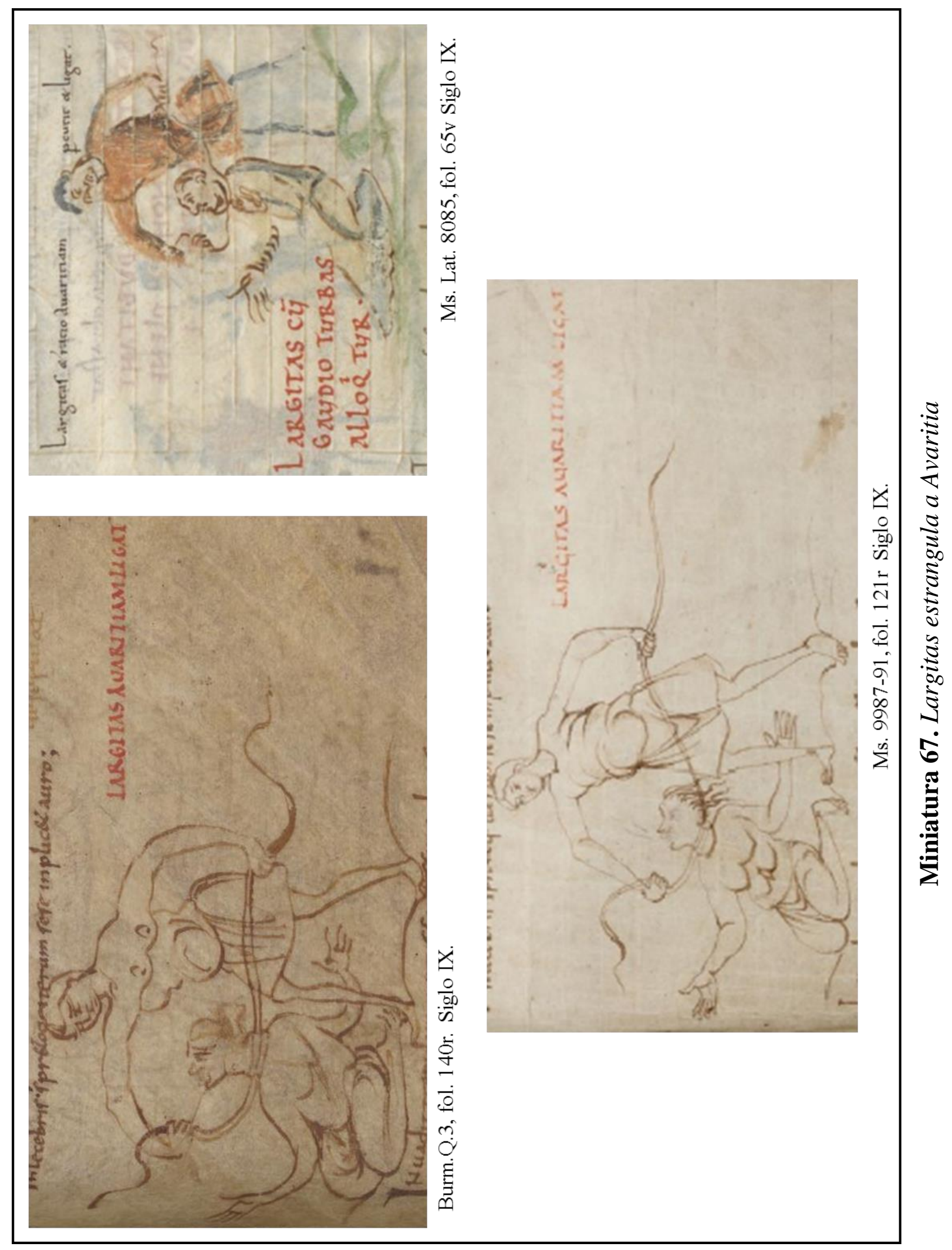




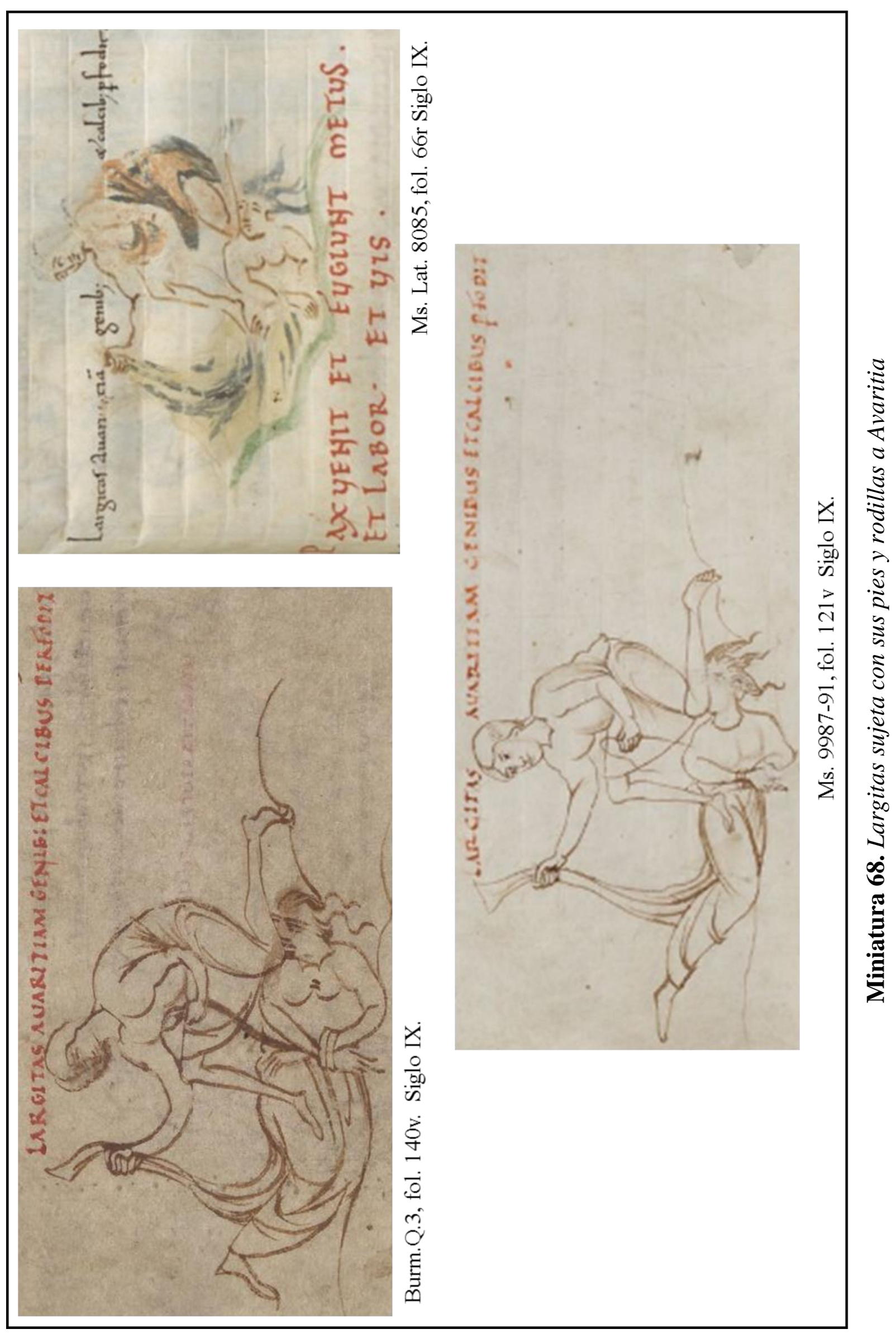




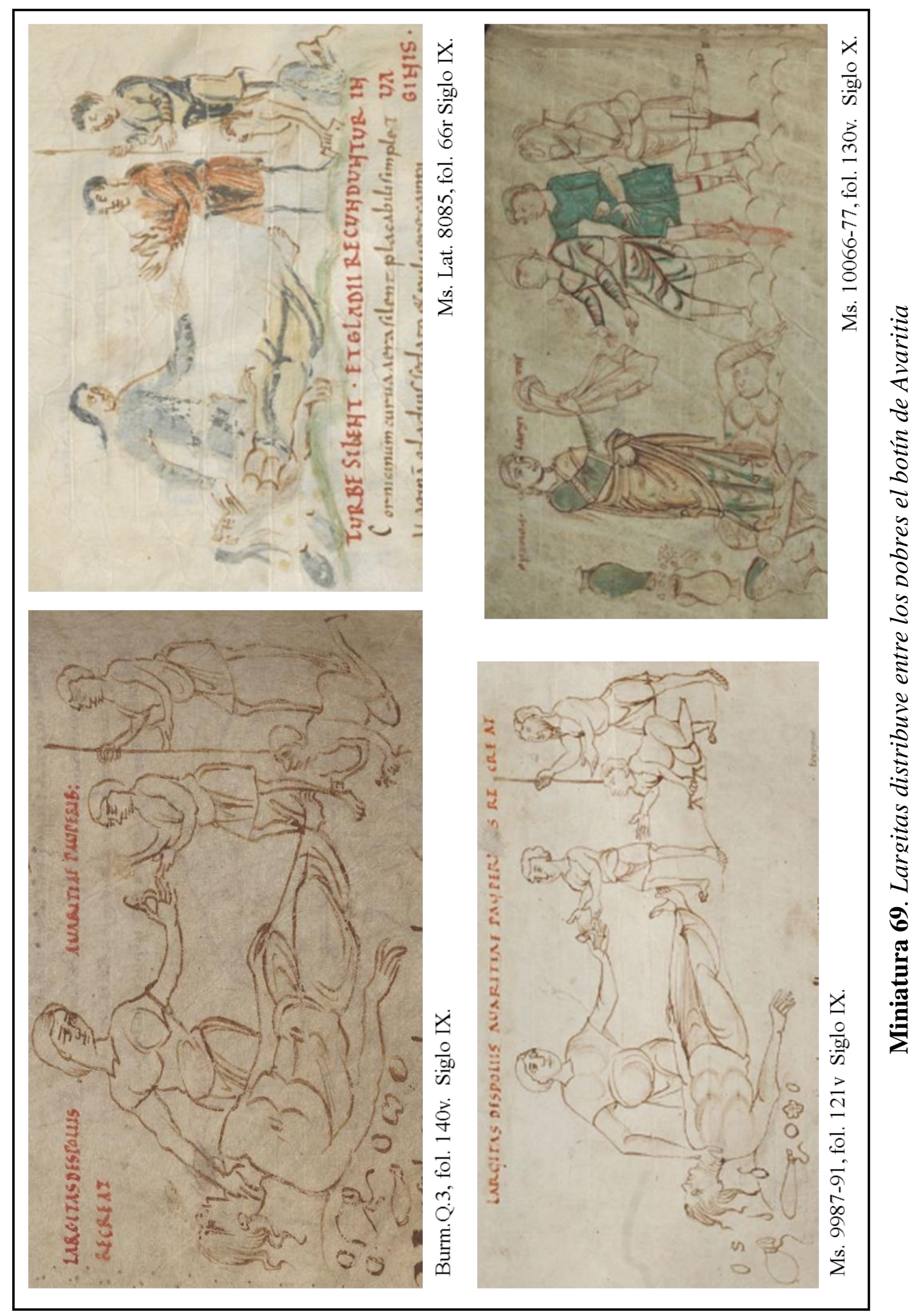



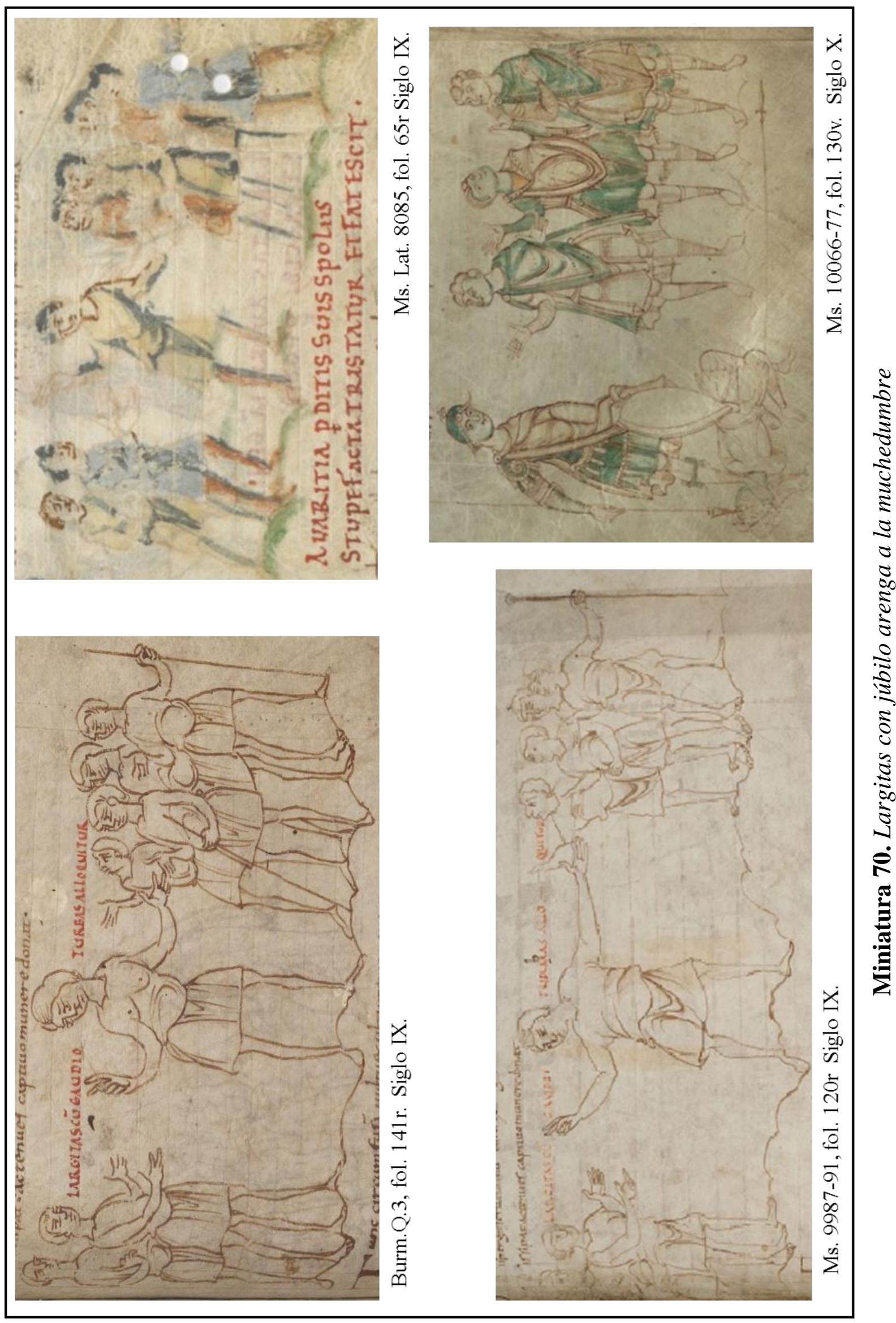
Tras la derrota de Avaritia y la victoria de Largitas, aparece en el campo de batalla otra virtud, Pax. Ésta se plasmó en las miniaturas 71, Pax llega y huyen Metus, Labor, Vis, y 72, Se silencian las trompetas y las espadas se enfundan. Ambas recogen el ad res. La primera (Miniatura 71) en los tres códices que se insertó antecede los versos 629 al 635 en los cuales el poeta describe como Pax llegó a poner fin a la guerra y ella y las huestes de despojan de sus armaduras y a la misma vez el ejercito de la derrotada Avaritia, compuesto por Metus, Labor, Vis, Scelus y Fraus, huye al escucharla. Pax se dibujó en la extrema izquierda y viste una túnica alarga. De su cintura penden dos tiras que sujeta con ambas manos. Este gesto es el de desceñirse tal como indica el verso 632, discingitur. Se incluye la figura de Pax como una reminiscencia de los versos anteriores, de que ella es la que detiene y pone fin a la guerra. De espalda a ésta, se representaron cinco figuras con faldas en forma de lenguas de fuego y cabellos alborotados. Como en la miniatura 57, Avaritia nutre a la multitud de vicios con su negra leche, nuevamente aquí se utiliza de nuevo la fealdad y la monstruosidad (proyectada por medio de las melenas) para plasmar un número específico de vicios al servicio de uno principal, cualidad visual que a la misma vez convierte la imagen en una memorable.

La miniatura 72 es una prolongación de la victoria de Largitas, y reproduce visualmente la narrativa de los versos 636 al 638 en los que el ejército invicto de las virtudes silencia sus trompetas y enfunda sus espadas. En el centro de la composición de aprecia la figura de la virtud, con la mano derecha bendice y con la mano izquierda sujeta un objeto redondo que lleva a su corazón, en Ms. 9987-91 en el centro de éste se dibujó una cruz. La presencia de Pax en esta miniatura concatena visualmente la miniatura anterior con ésta, ya que los hombres enfundaron sus espadas y silenciaron su trompeta ante la presencia de la virtud. Los personajes de los laterales son los que expresan plásticamente los versos que acompañan. A la izquierda de la composición dos figuras bajan sus cuernos, en señal de que los silencias. En el lado opuesto dos personajes sujetan la funda y el pomo de sus espadas, gesticulando el acto de enfundar sus armas. La disposición de los títulos en Burm.Q.3 y Ms. 9987-91 es un poco distinta al resto de las iluminaciones. Aquí encontramos que el texto se divide y 

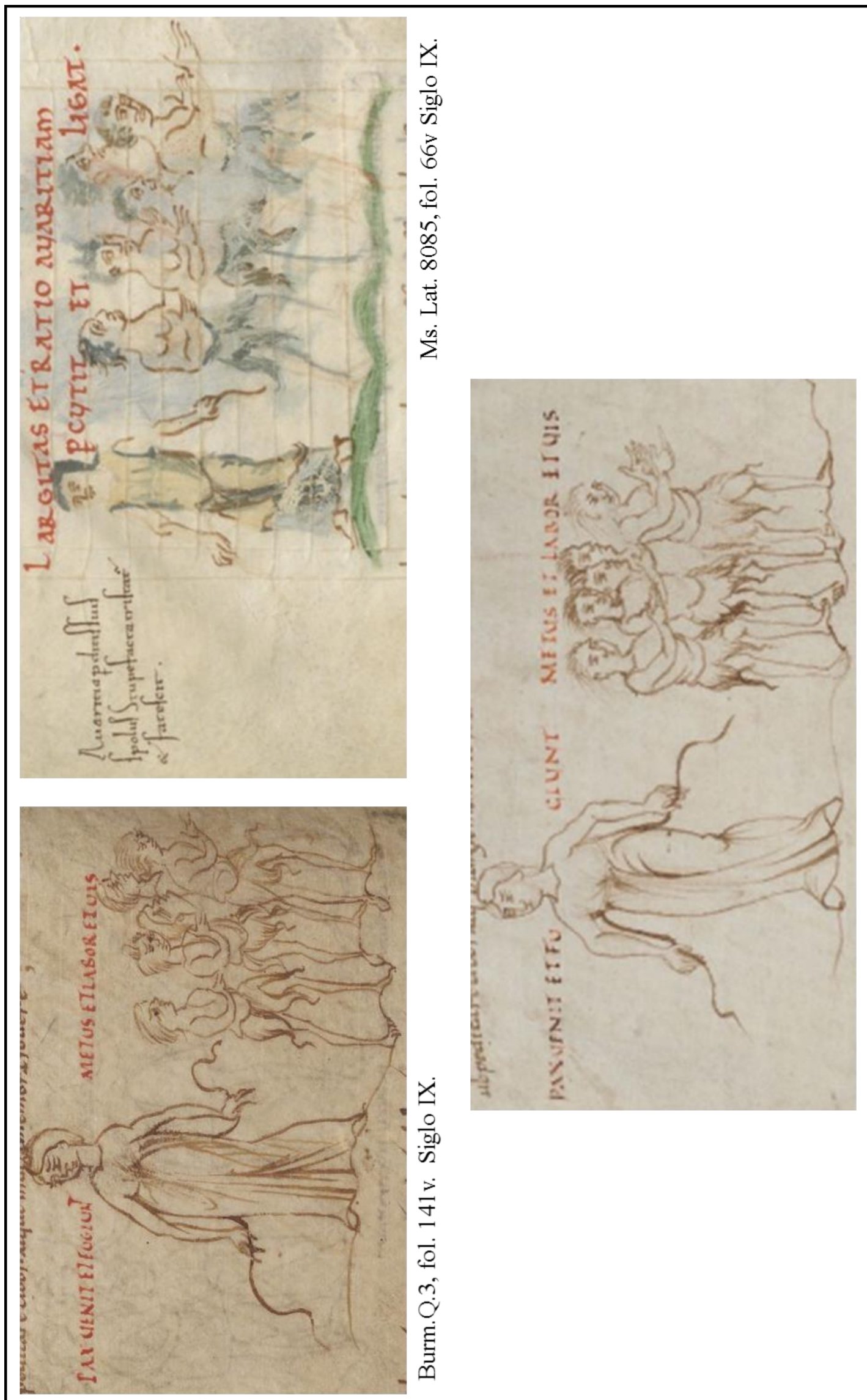

$i$

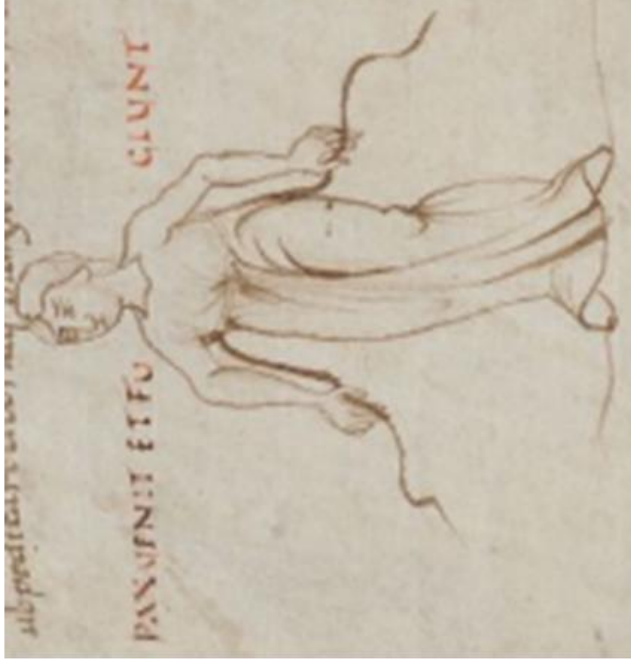

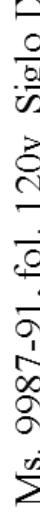

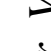

ธั

$\frac{1}{3}$ 


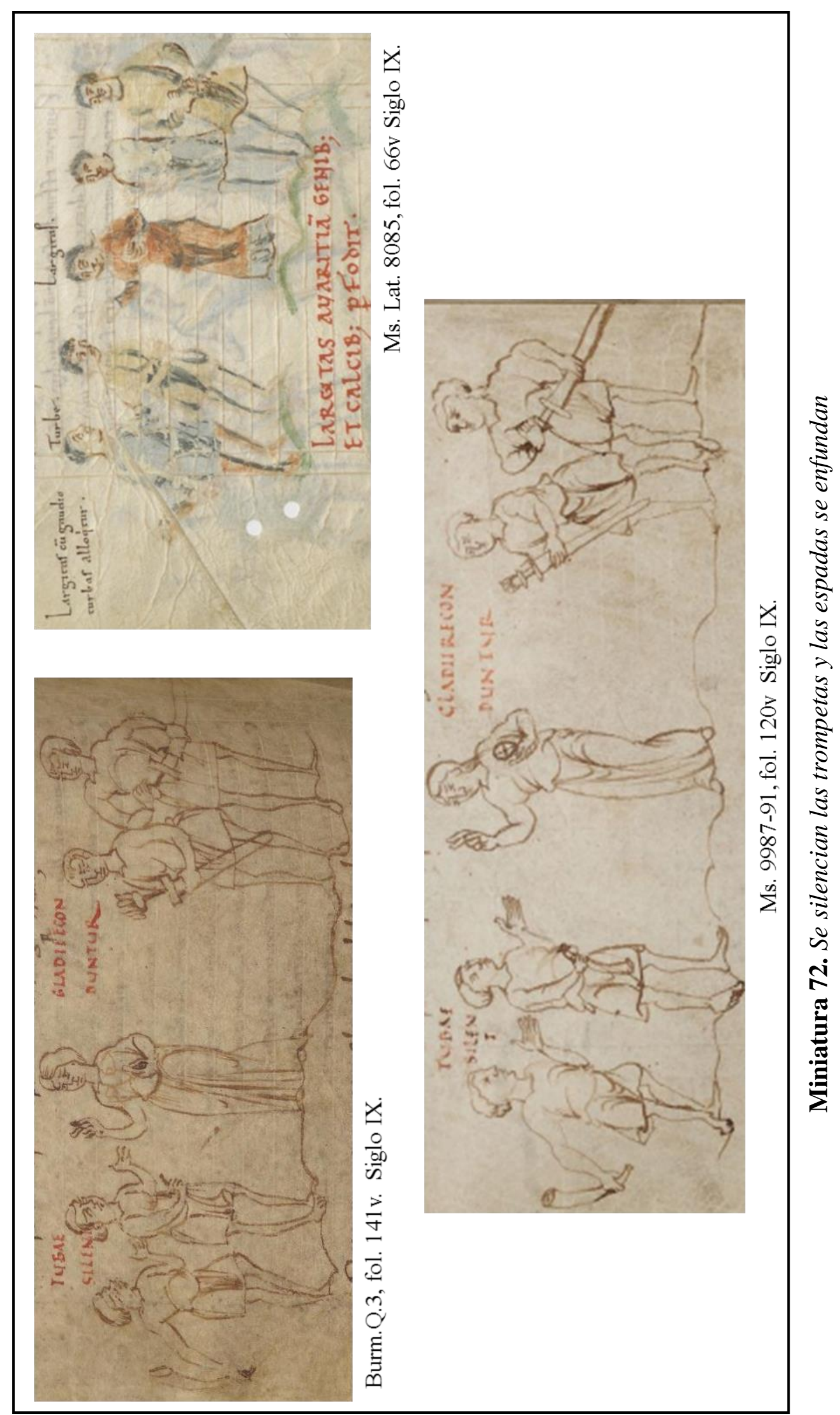




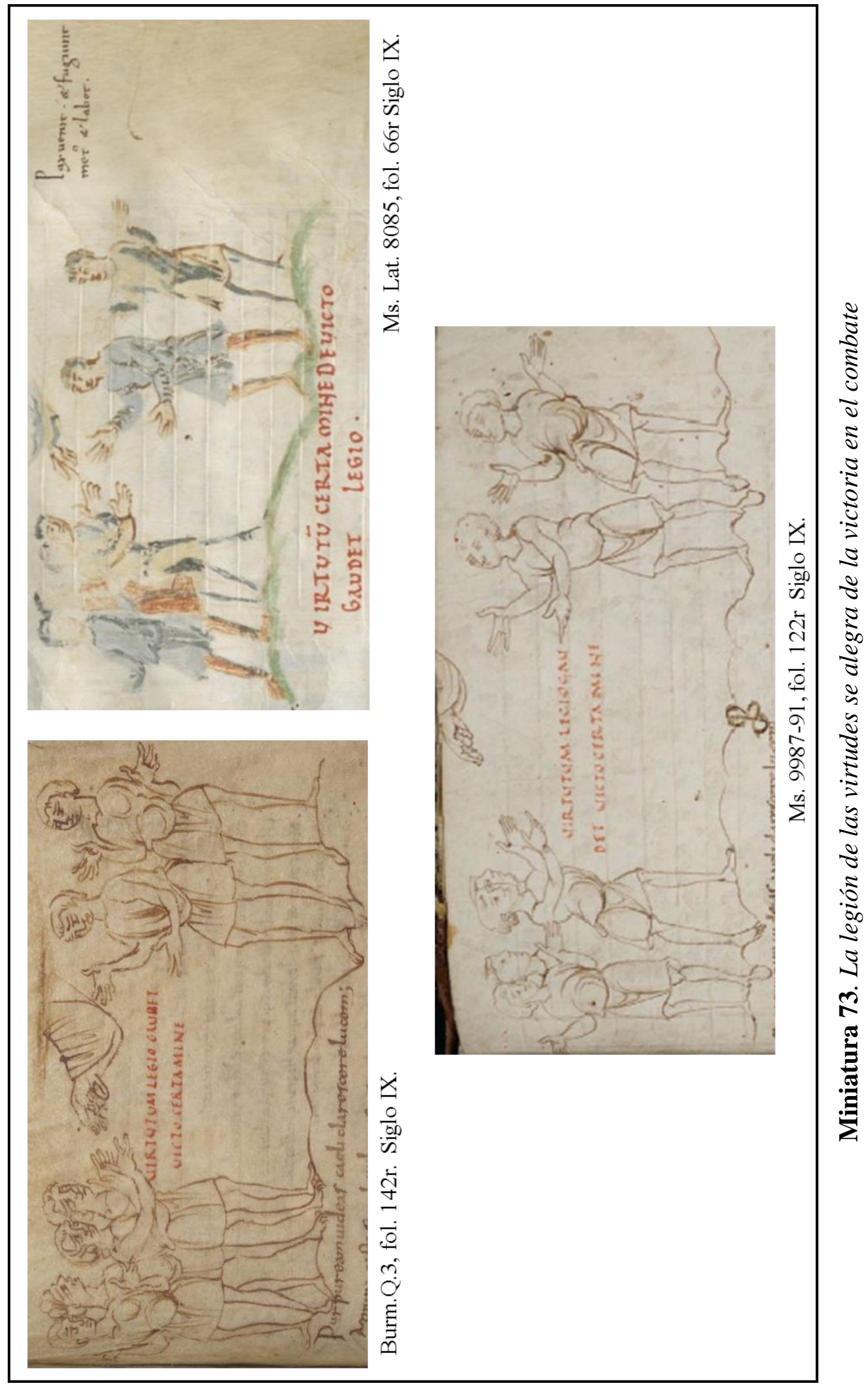


corresponde a cada uno de los grupos representados. Entre los hombres con trompetas se inscribió tubae silent y junto a los que llevan espadas gladii reconduntur, clarificando las acciones que llevan a cabo los personajes.

Con la miniatura 73, La legión de las virtudes se alegra de la victoria en el combate, finaliza al encuentro entre Avaritia y Largitas. Esta miniatura igualmente recopila visualmente las acciones de los versos 639-643: los escuadrones felices de terminar la victoria sintieron que el rostro de Dios les sonreía. En el centro de la imagen se dibujó una mano, brota del cielo y su gesto es el de bendecir. Al igual que en la miniatura 1, Sacrificio de Isaac, para representar a Dios, la parte representa al todo, captando visualmente todo su poder y actividad ${ }^{183}$. La legión se plasmó en dos grupos de figuras, cuyo número es el mismo utilizado en la miniatura 70 pero invertido, ahora son dos figuras las que se representan a la derecha y cuatro a la izquierda. El gesto de los soldados indica que estos reciben o aceptan ${ }^{184}$, y con relación al poema, lo que reciben es el camino que Cristo les ha otorgado a la casa de su Padre ${ }^{185}$.

\subsubsection{Concordia vs. Discordia}

El último encuentro entre las virtudes y los vicios es el de Concordia y Discordia. Este posee un número sustancial de miniaturas que acompañan los distintos versos. Sin embargo, la estructura de este combate no sigue el mismo orden de los anteriores, en los que suele aparecer el vicio, arremata contra la virtud, la virtud lucha con éste, le vence y pronuncia un discurso. El autor a la primera que presentó en este combate fue a la virtud, Concordia, personificación de la concordia, la armonía, la unión. En las primeras tres miniaturas se recogen las distintas acciones llevadas a cabo por ésta. La primera representación de esta lucha, la miniatura 74,

\footnotetext{
${ }^{183}$ HEINZ-MOHR. Lessico di iconografía..., p. 214.

${ }^{184}$ GARNIER. Le langage de l'image au Moyen Âge (I)..., p. 174.

${ }^{185}$ Prudencio. Psychomachia, vv. 642-643. Obras Completas de Aurelio Prudencio..., pp. 346347.
} 
Concordia da la señal de volver al campamento, acompaña a los versos en los que esta virtud da la señal para que las legiones vuelvan con sus banderines victoriosos al campamento $^{186}$. A la extrema derecha de la composición se plasmó la figura de Concordia, se incluyó el yelmo para indicar visualmente, a través de la parte, que viste armadura. La virtud eleva su mano derecha, ademán que se vincula con la pronunciación de palabras y que particularmente en esta plasmación manifiesta visualmente la orden que ésta da al ejército ${ }^{187}$. Delante de Concordia, se dibujaron dos figuras que caminan hacia una tienda. La primera de izquierda a derecha, en los tres manuscritos, eleva su mano diestra de forma similar a la virtud. Ambos personajes con la mano izquierda sujetan unos banderines. La presencia del banderín se vincula directamente con un sustantivo del verso 645, en este Prudencio el término que utilizó para designar los banderines fue aquilas, que, si bien también se traduce por águila, aquí claramente es un vestigio del momento en el que el poeta escribió, pues este animal era el enseña o estandarte más importante de las legiones romanas. Aquila fue interpretado por el miniaturista como estandarte o banderín, plasmando a los soldados con estos objetos, pero el iluminador del códice más antiguo, el Burm.Q.3 captó ambos sentidos pues los estandartes que llevan las dos figuras en este caso particular la forma con la que se coronan recuerdan mucho la cabeza de un águila.

La siguiente miniatura, la 75, a pesar de que se relaciona con Concordia, ésta no aparece en la misma y el motivo de esto es porque se quieren destacar las acciones más importantes del texto. Los versos a los que esta imagen pertenece narran cómo Concordia dirige al ejército, marchando en doble columna de un lado la infantería entonando salmos y al otro la caballería cantando himnos ${ }^{188}$. En la imagen se aprecian claramente dos grupos de hombres: a la izquierda dos hombres montan dos equinos representan a la caballería del verso 649. En el lado contrario, tres hombres de pies

\footnotetext{
${ }^{186}$ Prudencio. Psychomachia, vv. 644-645. Obras Completas de Aurelio Prudencio..., pp. 346347.

${ }^{187}$ GARNIER. Le langage de l'image au Moyen Âge (I)..., pp. 167-168,174-175.

${ }^{188}$ Prudencio. Psychomachia, vv. 646-664. Obras Completas de Aurelio Prudencio..., pp. 346347.
} 
recogen visualmente la infantería tal y como indica el verso 648. La gestualidad de todos los personajes en esta miniatura es la misma, elevar las manos con las palmas abiertas, al igual que en casos anteriores el gesto manifiesta la pronunciación de palabras, aquí se auxilia la acción visual por medio de las palabras escritas en los tituli. En las imágenes de los tres manuscritos se utilizó el verbo psallo, tocar la cítara, cantar salmos, salmodiar, para enriquecer y precisar el significado de los gestos. El uso de psallo en el título de la miniatura es muy acertado, pues a través del uso de un solo verbo se expresan las dos acciones indicadas en los versos 648 y 648: la infantería cantaba al son de la cítara y la caballería entonaba himnos ${ }^{189}$.

En las representaciones de Las tropas a caballo y andando entonan himnos (Miniatura 75), a pesar de que las mismas plasmas al ejército, se buscó diferenciar a los grupos que componen al mismo. La marcada división entre las cuadrillas resalta la descripción de dispoistis bifida agmina longe ${ }^{190}$. Esta miniatura sirve como un lugar de recopilación, al igual que aquellas en las que las virtudes increpan, y la cantidad de versos que acompañan a la misma son el detonante visual que indican al monje o usuario del códice esto. En este caso, Prudencio equiparó las acciones de las virtudes y sus ejércitos con la huida de los israelitas de Egipto. Los himnos que entonan las huestes de las virtudes recuerda el cántico de júbilo del pueblo de Israel al salir de las tierras del faraón. La marcha del ejército en dos columnas recuerda cómo el mar Rojo se abrió en dos.

Las virtudes se disponían a descansar y entran a la ciudad. Este momento se plasmó en dos miniaturas. La primera escena, la 76, plasma el momento en el que las virtudes atraviesan la entrada de la muralla. Las dos figuras sobre equinos concatenan visualmente esta imagen con la miniatura 75. Para indicar que las figuras entran, a uno de los caballos sólo se le dibujó la parte trasera, lo mismo se hizo con el jinete, cuya pierna y manos no se incluyeron. En Burm.Q.3, la construcción arquitectónica se compone de un arco, dos torres o pilastras adosadas a un muro el

189 "peditum psallente caterva, / ast alia de parte equitum resonantibus hymnis." PRUDENCIO. Psychomachia, vv. 648-649. Obras Completas de Aurelio Prudencio..., pp. 346-347.

${ }^{190}$ Prudencio. Psychomachia, v. 646. Obras Completas de Aurelio Prudencio..., pp. 346-347. 

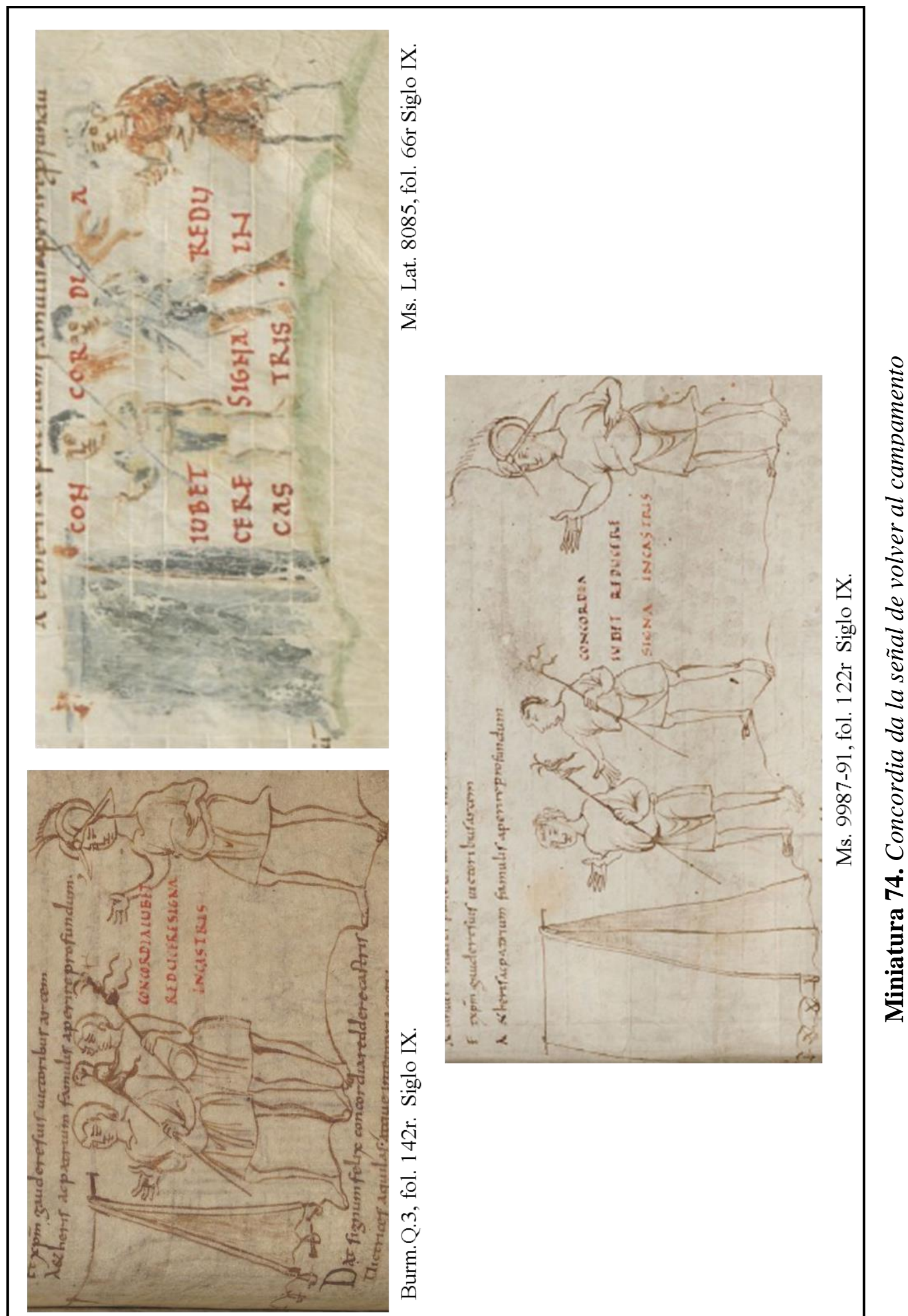

$\frac{6}{b}$

ปั่

웅

$\stackrel{\leftrightarrow}{\dot{\alpha}}$

空 


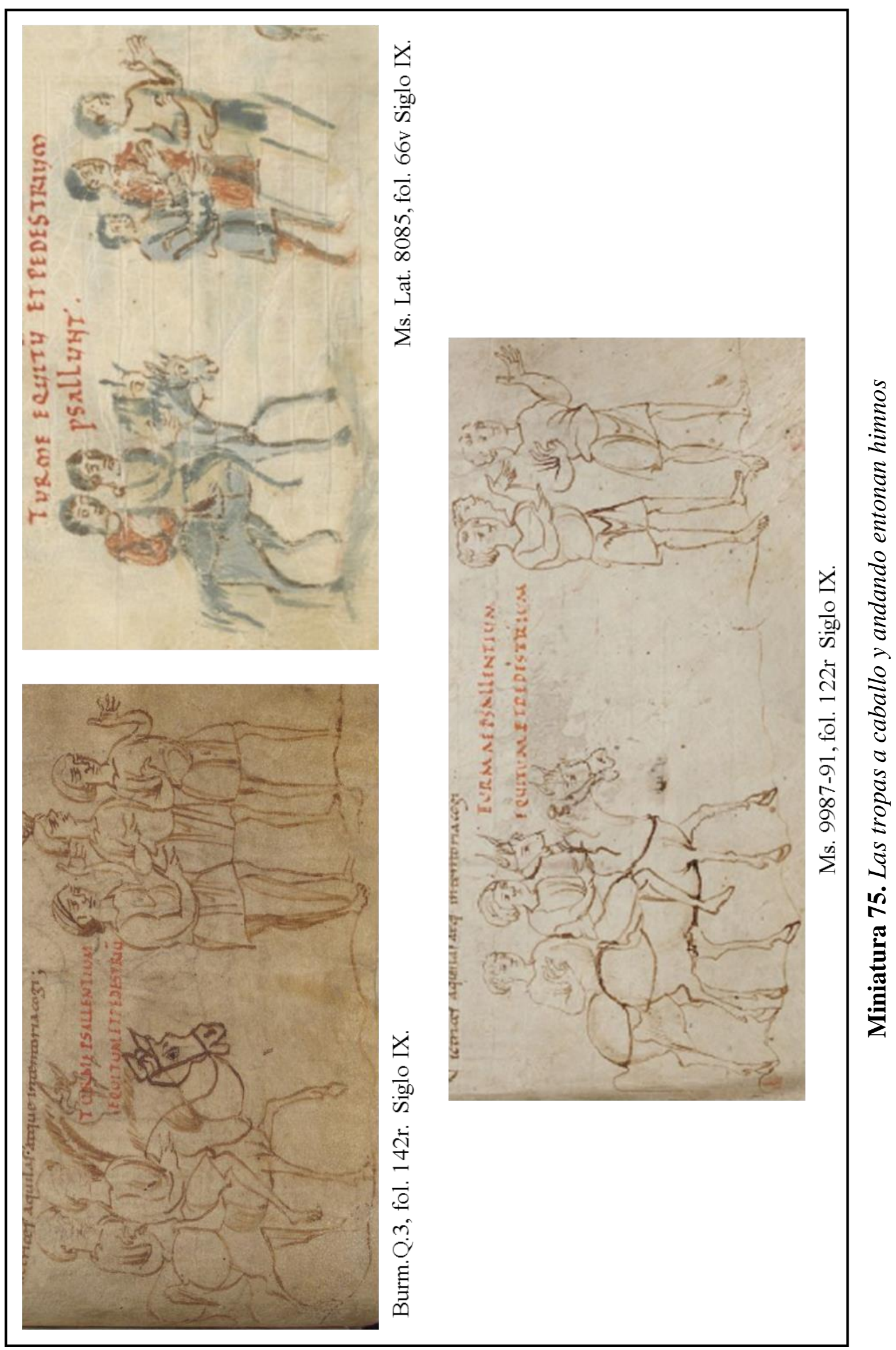



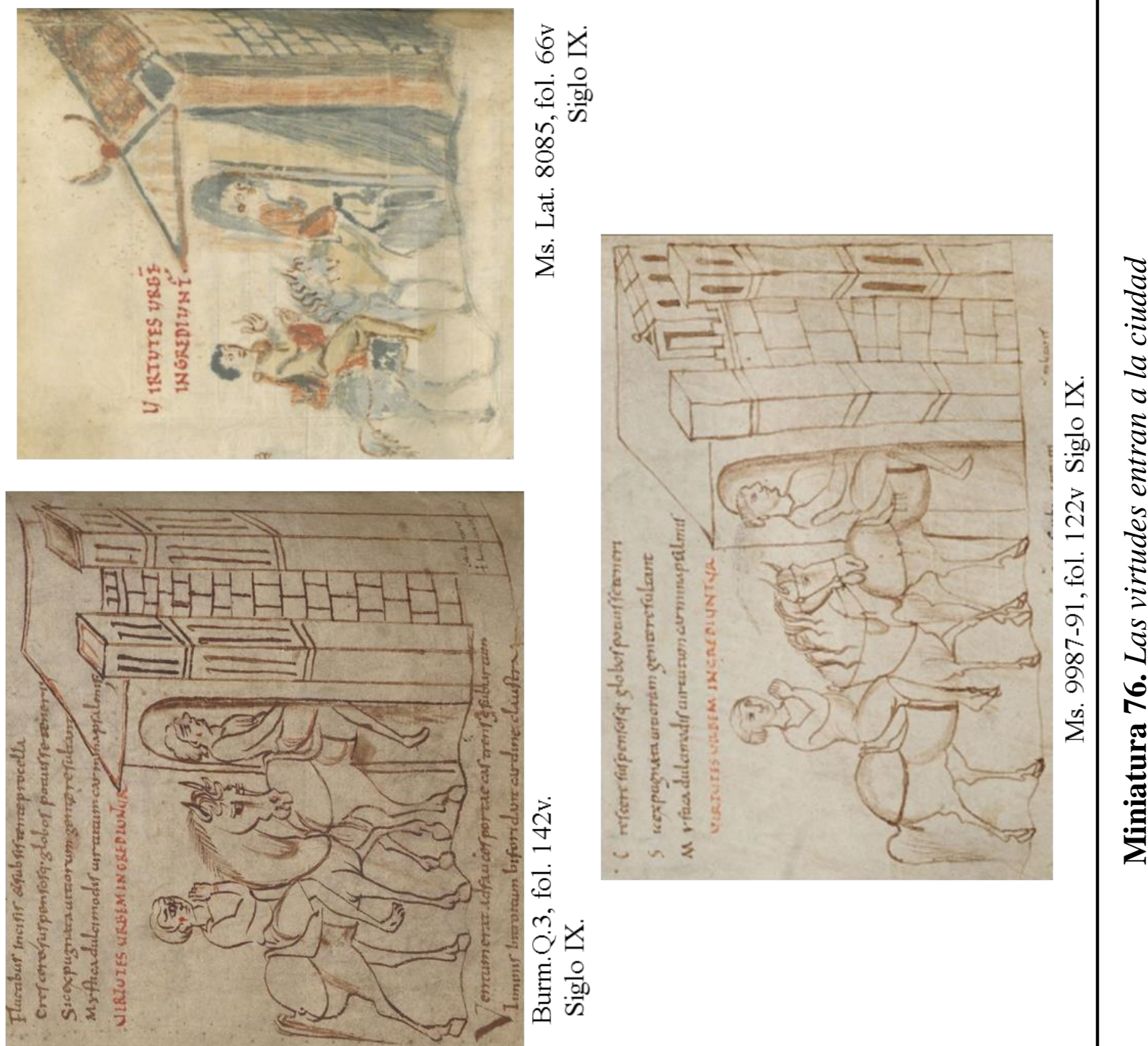

m.

$\stackrel{m}{\circ} \dot{x}$

官 을

$\vec{n}$ 


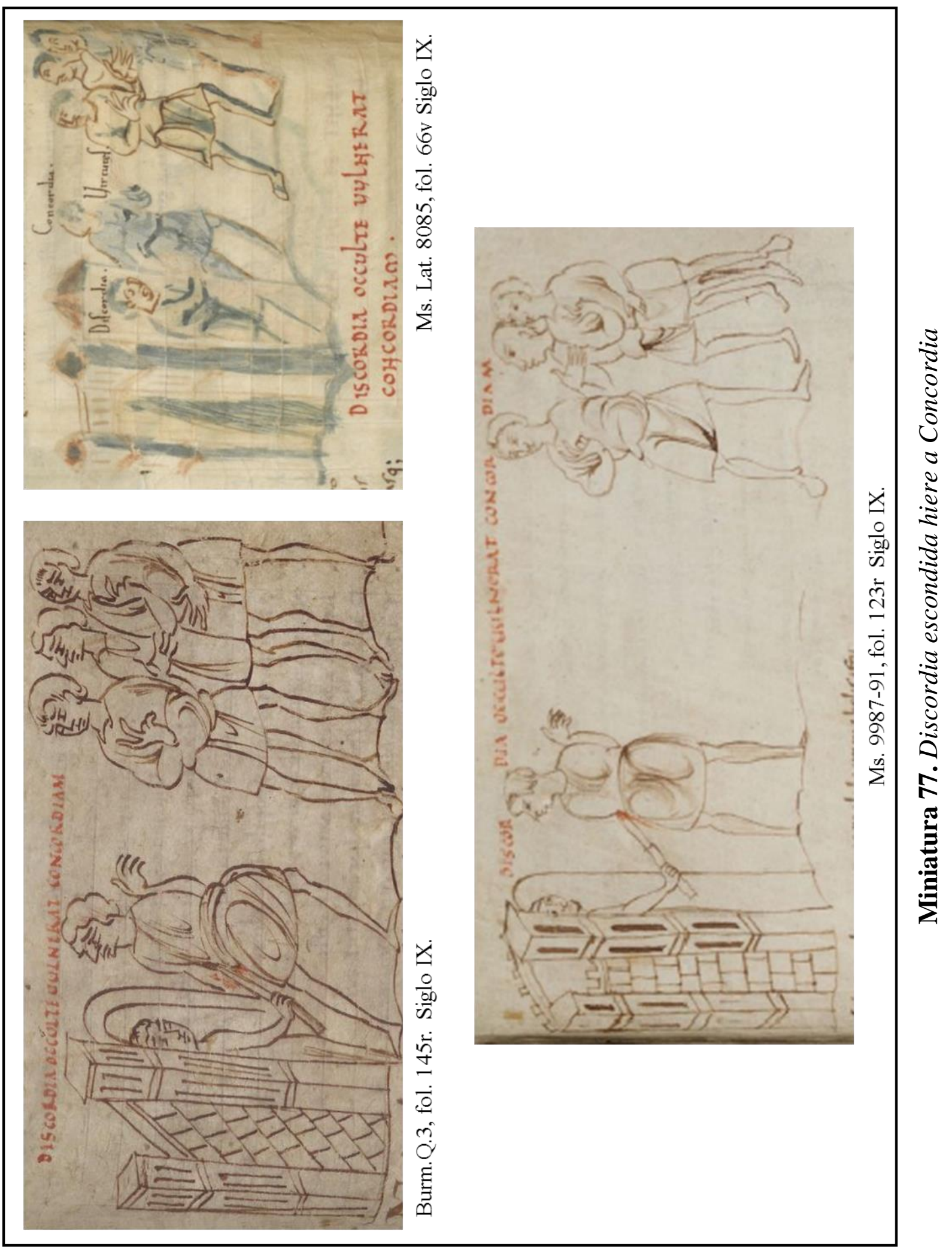


cual el miniaturista se tomó la libertad de dibujar la mampostería. La composición de Ms. 9987-91 es similar, sin embargo, el muro remata en almenas y sobre estas se incluyó un pequeño edificio de planta basilical. En el códice parisino la construcción fue dibujada como una basílica a la que se le adjunto una torre ${ }^{191}$. En los tres códices se dibujaron incluyeron pictóricamente los elementos arquitectónicos que Prudencio menciona; la puerta (portae) y el muro (claustra).

El ductus del poema, particularmente de la entrada de las virtudes a la ciudad continua en la miniatura 77. Ésta no solamente se concatena visualmente con las acciones de la escena 76, sino que es el momento en el que se introduce al vicio Discordia. En los tres manuscritos que se dibujó se plasmó el instante en el que Concordia puso un pie dentro de la muralla y Discordia la hirió. Esta escena muestra como el vicio sale de la puerta a herir a la virtud. Aquí la urbe se dibujó siguiendo el esquema de la miniatura anterior. Incluso en el códice parisino se adoptó el modelo de Burm.Q.3 y Ms. 9987-91: el arco, las dos torres y el muro. La ubicación de la misma dentro de la composición se cambió, ahora se plasmó en la extrema izquierda. De la puerta surge una figura, de la que solamente se contempla su rostro un brazo con un objeto alargado con el que toca a la figura que tiene delante. En Ms. Lat. 8085 el miniaturista representó el cuerpo completo. Es el momento en el que Discordia hiere a Concordia. Como en combates anteriores, aquí también se utiliza el color rojo para resaltar la herida que le causó, claramente un elemento mnemónico ${ }^{192}$. Las tres figuras con túnica corta a dispuesta a la extrema derecha de la imagen tienen la misma lectura que en otras representaciones con personajes adicionales, son la plasmación visual de la legión de la virtud principal del combate, en este caso de Concordia. En el manuscrito parisino, además de los títulos de las imágenes, al lado de cada uno de los protagonistas se inscribió el nombre de éste. En los mismos se leen: Discordia, Concordia y junto al grupo de tres virtutes. La presencia de las huestes se vincula directamente con el poema, específicamente con en el verso 670 en el que se narra que la virtud entraba a la ciudad rodeada por sus batallones. La

\footnotetext{
${ }^{191}$ STETTINER. Die Illustrierten Prudentiushandschriften..., p. 372.

192 Rivers. Preaching the Memory..., p. 310. CARRUTHERS. The Book of Memory..., p. 133. YATES. El arte de la memoria..., p. 30.
} 
presencia de estos tres personajes, además de guardar una relación estrecha con el texto de Prudencio también es un conector visual que introduce al espectador a las acciones de la miniatura 78 .

La miniatura 78, Discordia aprovecha el momento propicio para acechar y acercarse a las virtudes, es una de ad res. Recopila visualmente las distintas acciones narradas en los versos 681 al 704. En este caso específicamente se plasman visualmente las distintas maniobras que lleva a cabo Discordia para infiltrarse dentro del ejército de las virtudes y acercarse a Concordia. Esta imagen se lee de izquierda a derecha y en la misma encontramos que se dibujó tres veces al vicio para plasmar visualmente las distintas acciones que ésta realizó para terminar hiriendo a la virtud $^{193}$. A la extrema derecha de la composición en los tres códices se aprecia una figura encorvada junto a dos cuerpos decapitado. Este plasma el momento en el que el Discordia deja su látigo entre medio de los derrotados, siguiendo los versos 685 al 686, específicamente la descripción de Prudencio sobre los vencidos. El poeta utilizó el sustantivo strage, el cual se traduce por masacrados, asesinados, matanza o carnicería. El miniaturista conservó y plasmó en la imagen el sentido que el autor expresa, pues los cuerpos entre los que Discordia merodea, han sido decapitados. El autor y el iluminador utilizaron el elemento grotesco, claramente una característica que vuelve esta escena y estas imágenes en memorable, para que sea más fácil para los jóvenes aprendices inscribir en sus mentes estos versos.

El grupo de figuras en el centro de la composición son los batallones entre los que Discordia se mezcla con apariencia de aliada ${ }^{194}$. Este es el conjunto de personas que visualmente conecta la miniatura anterior, la 77, con ésta. En Bur.Q.3 y Ms. 9987-91 se dibujaron tres figuras con túnica corta, en Ms. Lat. 8085 se introdujo una cuarta que no se integra al dialogo gestual de las otras tres, y mira hacia la izquierda. Ésta, tal y como indica la inscripción sobre su cabeza, es Discordia mezclada entre los batallones de las virtudes como describe Prudencio en el verso 683. En el códice

\footnotetext{
${ }^{193}$ STETTINER. Die Illustrierten Prudentiushandschriften..., pp. 375-376.

194 "Nam pulsa culparum acie Discordia nostros intrarat cuneos sociam mentita figuram". Prudencio. Psychomachia, vv. 683-684. Obras Completas de Aurelio Prudencio..., pp. 348-349.
} 
Burm.Q.3 sólo se dibujó la cabeza de la intrusa. El último personaje en la extrema izquierda de la composición corresponde a la tercera representación del vicio, quien sujeta una espada y con su cuerpo trata de ocultarla de las miradas los otros hombres. Esta imagen de Discordia en esta miniatura también se vincula con el texto, según el cual ésta "esconde el puñal debajo de la túnica195".

El título de esta miniatura en los tres manuscritos, Discordia virtutibus insidiatur et capitur, más que responder al texto resume el sentido de la imagen, pues el mismo hace énfasis en dos acciones específicas llevada a cabo por el vicio para lograr su cometido contra Concordia, acechar aguardando el momento propicio y arrebatar algo al enemigo. Los tituli aportan información adicional al usuario, clarifican las acciones de las imágenes, corroboran las acciones memorables, facilitando así el proceso de memorización del contenido, del ad res, de la misma.

Si bien las protagonistas de este combate son Concordia y Discordia, esta virtud no lucha contra su enemiga. En primera instancia, son todas las virtudes indignadas y airadas las que acorralan al vicio, acción narrada en los versos 705 al 714 y plasmada visualmente en la miniatura 79, Las virtudes rodean a Discordia con sus espadas. Esta escena además de insertarse en los manuscritos del siglo IX se incluyó en el códice del siglo X 10066-77. El esquema composicional de Burm.Q.3, Ms. 9987-91 y Lat. 8085 es similar. En el centro, con los brazos extendidos y túnica larga se dibujó a Discordia. Varias figuras rodean a la pérfida, en Burm.Q.3 y Ms. Lat. 8085 son cinco, dos a la derecha una con dardos y la otra con la espada y a la izquierda tres, dos de éstas portan las mismas armas que las del lado contrario y la tercera simplemente se abalanza hacia el vicio. En Ms. 9987-91 sólo se representaron los personajes armados. Al parecer la tercera figura iba a ser dibujada, pero sólo se ve el contorno del rostro de ésta. Los ademanes en los distintos actores son los mismos: levantar la mano o las manos con las palmas hacia arriba. El gesto de pronunciar palabras en este caso responde a la demanda que las huestes de Concordia

${ }^{195}$ Prudencio. Psychomachia, v. 689. Obras Completas de Aurelio Prudencio..., pp. 348-349. 


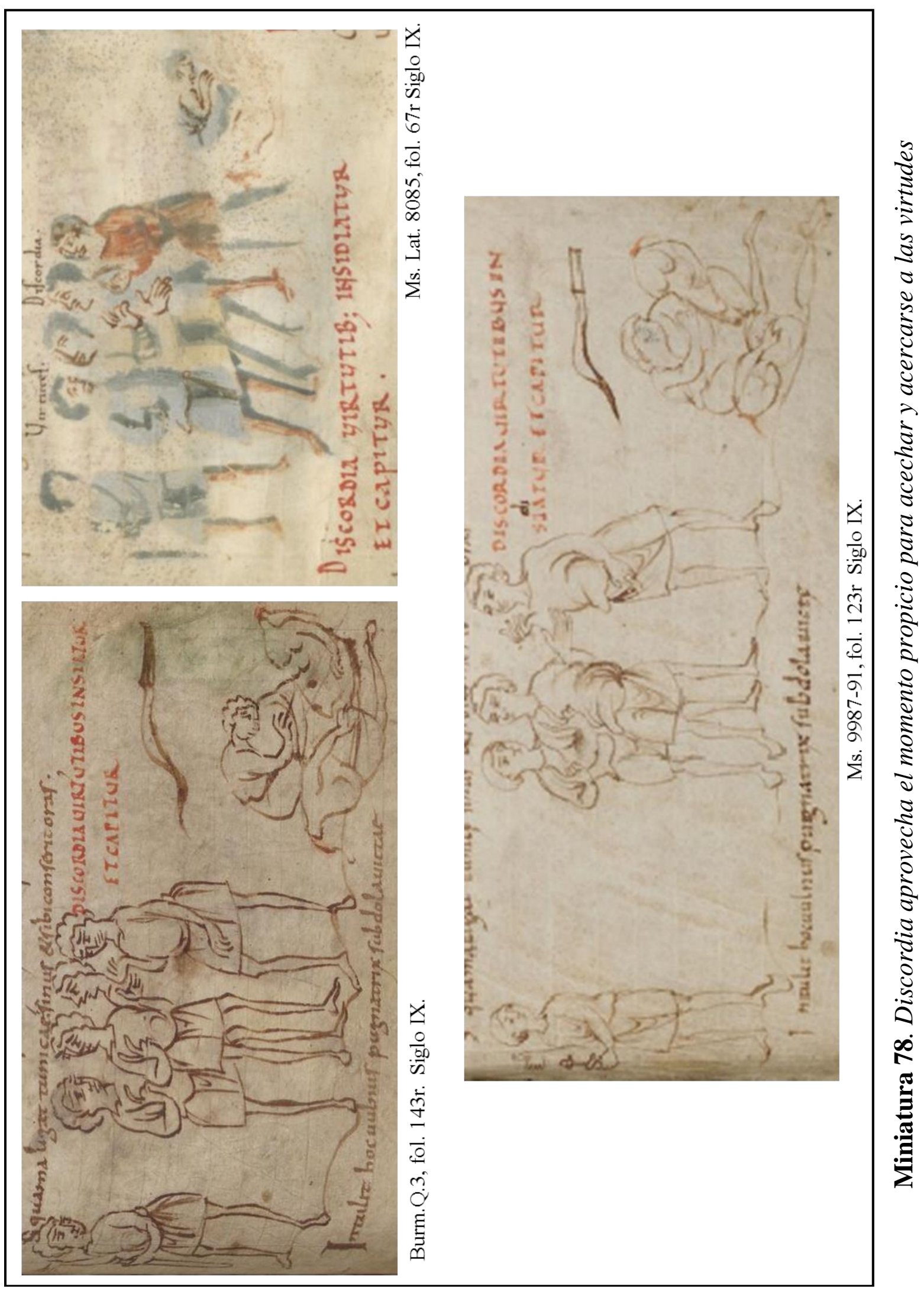




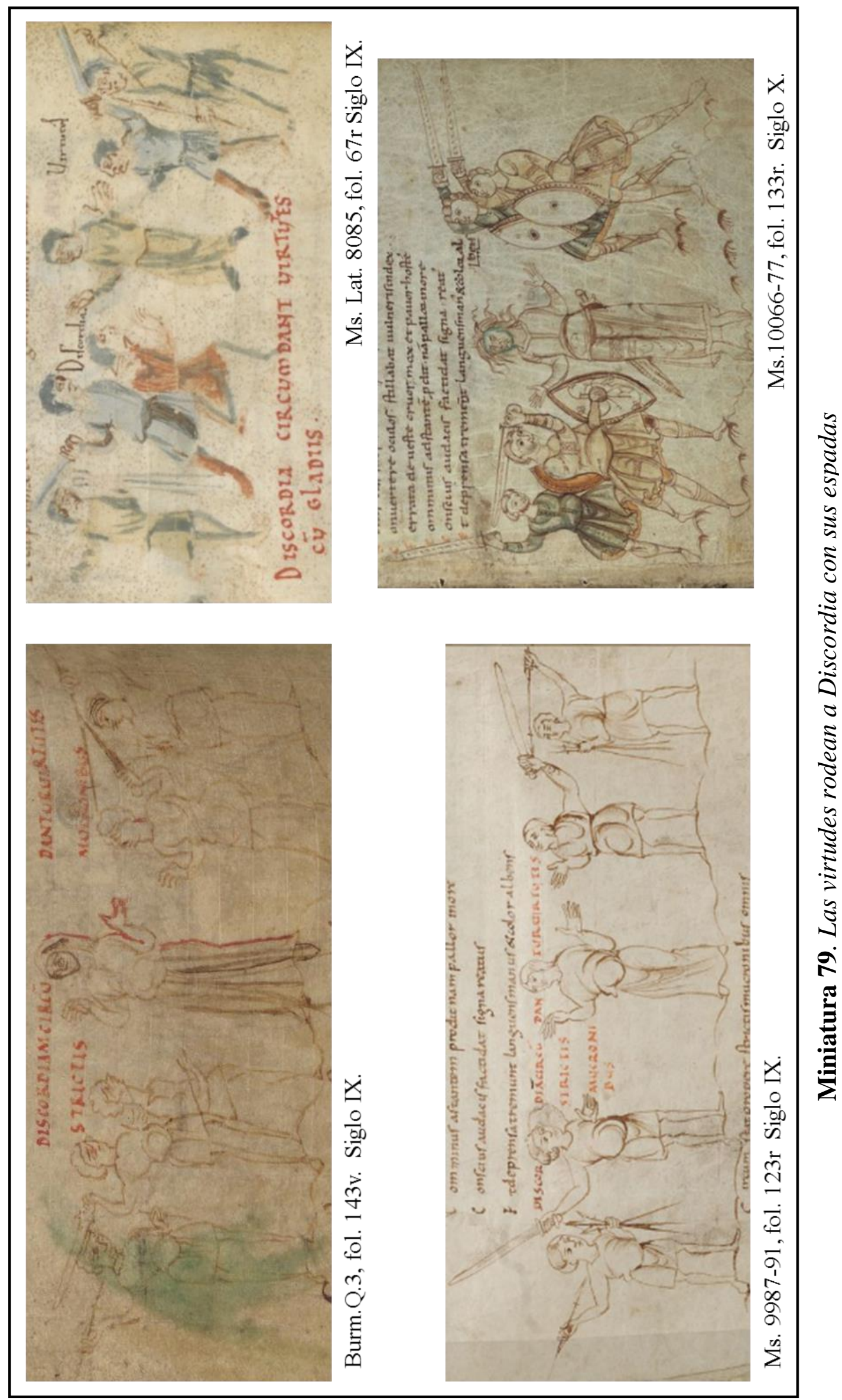




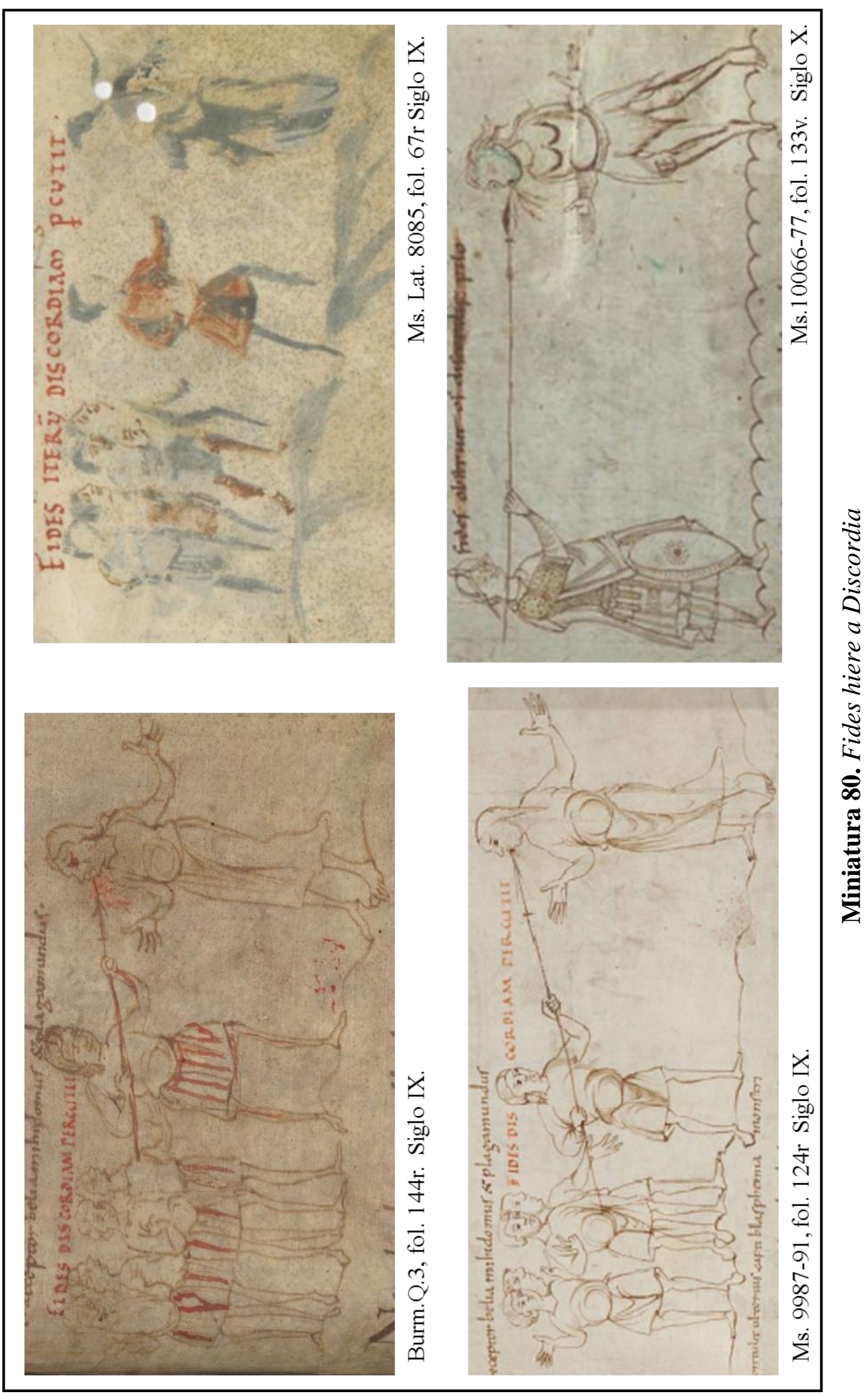


se hacen a Discordia: le exigen su nombre, su patria y su fe ${ }^{196}$. El vicio realiza el mismo gesto, pues replica a los cuestionamientos de sus enemigos.

En Ms. 10066-77 el arreglo de la composición de la miniatura 79 es sumamente similar a los ejemplos del siglo $\mathrm{X}$, sin embargo, estilísticamente se aprecian ciertas diferencias. Esta imagen visualmente es mucho más rica. El vicio continua en el centro, lleva túnica larga y realiza los mismos gestos, sin embargo aquí se ha plasmado siguiendo el modelo que a lo largo de este códice se ha utilizado: su melena suelta y descontrolada y el rostro de color verde para resaltar la monstruosidad del vicio Discordia. En la cintura lleva la espada, arma que había utilizado para herir a Concordia y desató el coraje del ejército de las virtudes motivo por el que la rodearon, aquí ya no la cuestionan simplemente van por ella, la atacan. Las cuatro figuras en túnica corta que plasman a las huestes de Concordia llevan espadas y escudos.

Las protagonistas de este último combate son Discordia y Concordia, sin embargo, la que pone fin y derrota a este vicio es la virtud con la que el poema de la Psychomachia inició, Fides. Según los versos 715 al 718 Fides tras todas las blasfemias e injurias de Discordia, le atinó el primer golpe con su lanza la que le traspasó su garganta y la hizo callar. Este momento descrito en el poema se recoge visualmente en la miniatura 80. En los códices del siglo X encontramos una composición más abigarrada en comparación con la represntación de Ms. 10066-77. En Burm.Q.3, 9987-91 y Lat. 8085 la acción principal que corresponde a los versos e igualmente resume el título se plasmó en el lado derecho, Discordia viste túnica larga como en las miniaturas anteriores extendiendo sus brazos, justo delante de ésta se aprecia una figura vestida con túnica corta, sujetando una lanza que toca la boca del vicio, Fides. A pesar de que al espectador al inicio del poema se le había introducido a la imagen de esta virtud, aquí no se aprecian de esa primera imagen de Fides. En el ejemplo parisino los pigmentos se han desgastado y la lanza ya no se aprecia. Además de las protagonistas de esta escena, aquí también encontramos un

${ }^{196}$ PrudenCIO. Psychomachia, vv. 707-708. Obras Completas de Aurelio Prudencio..., pp. 350351. 
grupo de figuras. La disposición y los gestos del mismo recuerdan al representado en la miniatura anterior. En los versos que corresponden a la escena de Fides hiere a Discordia no mencionan a las huestes, sin embargo, por los versos anteriores y subsiguientes queda implícito que éstos se encuentran cerca. La presencia del grupo de figuras que plasma el ejército de las virtudes en los manuscritos, como hemos afirmado anteriormente, concatena o conecta visualmente las distintas miniaturas. En el caso del grupo de la 80, vincula la escena principal del ejemplo en cuestión con la escena que le precede, pero igualmente con la escena y las acciones de la siguiente.

El miniaturista del códice de la biblioteca de Berna se limitó a plasmar solamente las acciones de los versos a los que la miniatura corresponde, el momento en el que Fides atina con su lanza la boca de Discordia. Al igual que en los ejemplos más antiguos, la representación de la virtud no corresponde con la imagen de ésta al inicio del poema en las miniaturas 8,9 y 10, sino con la del resto de las virtudes de este manuscrito que llevan armadura, escudo, yelmo y una capa. En este códice, al igual que en Burm.Q.3 y 9987-91 el iluminador se tomó la molestia de plasmar la sangre que brota de la boca herida de Discordia en rojo, color que ya hemos establecido se utiliza para resaltar y hacer de las imágenes unas memorables. La presencia de la sangre en la miniatura 80 es un añadido del autor hacer de la misma una más grotesca y vigorosa. Los tituli de los distintos ejemplos utilizan un verbo ya anteriormente utilizado para aludir a la acción de golpear o herir, percutio, verbo con el cual ya debían estar familiarizado a lo largo del poema los monjes que leyeran el mismo.

La miniatura 81, Las virtudes desmiembran el cuerpo muerto de Discordia, es una de las imágenes más memorables de todo el poema ${ }^{197}$. En la misma se recopilaron visualmente las acciones narradas en los versos 719 al 725, el ejército de las virtudes desgarra en pedazos el cuerpo del vicio y los trozos se reparten a animales inmundos: cuervos y perros. En las miniaturas del siglo IX nos encontramos con el grupo de figuras, las huestes, de pie. De las cinco figuras, cuatro llevan espada.

197 CARruthers. The Craft of Thought..., p. 148. STETTINER. Die Illustrierten Prudentiushandschriften..., pp. 380-381. 
Inmediatamente delante de éstas vemos pies y manos, los trozos del cuerpo desmembrado de Discordia. En Ms. Lat. 8085 los pigmentos de este dibujo se han perdido. Se incluyeron en la imagen varios animales: dos aves que llevan algo en su pico. Una de éstas vuela y la otra se encuentra al lado izquierdo de los restos del vicio. En el lado derecho un can. Estos son los cuervos (corvis) y perros (canibus) a los que ofrecen los miembros desgarrados del vicio ${ }^{198}$. El segundo integrante, de derecha a izquierda, del batallón de las virtudes, sujeta en su mano izquierda la cabeza cercenada de Discordia. En Burm.Q.3 y Ms. 9987-91 el siguiente personaje, junto al cuervo volando, con su mano izquierda sujeta algo, en el códice belga es una de las manos del vicio.

La composición de Ms. 10066-77 muestra ciertas diferencias. Aquí el ejército de las virtudes que ataca a Discordia se compone de dos individuos. Éstos sujetan al vicio desnudo por las piernas y alzan sus espadas para atacarle. Dos canes se acercan al cuerpo inerte de la pérfida, uno muerde su rostro y el otro le tira de un brazo. En la extrema izquierda se representó otro can en cuya boca se aprecia el brazo izquierdo que le ha sido cortado al vicio y en la extrema derecha un ave volando, el cuervo, con su pico y garras ensangrentadas.

Las sutilezas composicionales y sobre todo gestuales denotan ciertos momentos del poema. Las miniaturas de los códices del siglo IX plasman las acciones de los últimos dos versos: "Todo el cadáver, hecho pedazos, se reparte entre animales inmundos, y, destrozados sus miembros, perece la horrenda Herejía ${ }^{199}$ ". Mientras en el códice 10066-77 se plasmó el momento que antecede estas acciones, justo cuando el vicio es atrapado y comienza a ser desmembrada por las virtudes. Los animales que aparecen en la imagen son los que menciona el poeta en el verso 721: perros (canibus) y cuervos (corvis). Si ya de por si la imagen descrita por Prudencio es mórbida, los miniaturistas mantuvieron esta cualidad en las representaciones visuales de los versos. En los cuatro ejemplos se aprecian el cuerpo desmembrado y

\footnotetext{
${ }^{198}$ Prudencio. Psychomachia, v. 721. Obras Completas de Aurelio Prudencio..., pp. 350-351.

199 "Discissum foedis animalibus omne cadaver dividitur, ruptis Heresis perit horrida membris." Prudencio. Psychomachia, vv. 724-725. Obras Completas de Aurelio Prudencio..., pp. 350-351.
} 
troceado del vicio, una virtud sujeta una mano, la otra la cabeza preparada para dársela a los animales. En Ms. 10066-77 uno de los perros se lleva uno de los brazos. En Burm.Q.3 y Ms. 9997-91 esparcidos se encuentran el resto de las extremidades hecha trozos. En los distintos ejemplos no puede faltar la sangre, y en Burm.Q.3 particularmente se resalta como ésta brota de los distintos miembros del vicio hechos pedazos. Una vez más se puede relacionar el final del vicio con las acciones que le caracterizan. Discordia, la personificación de la discordia, desunión y el desacuerdo terminó desmembraba, separada y hecha pedazos.

Los combates o encuentros entre las virtudes y los vicios, culminan con la muerte de Discordia disfrazada de Heresis. El resto de las miniaturas se centran en la victoria de Concordia y de todas las virtudes. A priori, las miniaturas 82 a la 86 son muy similares. En éstas se representa una tribuna y las distintas virtudes, por una parte, estas similitudes crean un ritmo visual que concatena las distintas escenas siguiendo la narración de los versos, y los gestos de las huestes y a los tituli de las imágenes determinan los momentos específicos representados. La primera de estas miniaturas, Las virtudes construyen una tribuna (Miniatura 82), recoge el ad res de los versos 726 al 733, como y donde se construyó una tribuna. Esta escena se incluyó únicamente en los códices del siglo IX. La disposición de las distintas figuras es muy similar, gira en torno a la figura arquitectónica en el centro de la composición: la tribuna. Las huestes de las virtudes se distribuyen en distintos niveles de la composición, Burm.Q.3 y Ms. 9987-91 muestran mucha similitud con arreglos similares en el salterio de Utrecht. Básicamente en las tres imágenes en cada una de las esquinas de la composición se incluyó un grupo de tres o cuatro figuras cuyos gestos son los de dialogar. Son las figuras centrales, junto a la tribuna las que plasman visualmente las acciones de los versos. Dos llevan los materiales para construir la edificación, la figura de la izquierda con un martillo y cincel labra una piedra, pieza que el resto de las figuras ofrecen a la virtud cobijada bajo la cubierta de la tribuna, y se dispone a utilizar para su construcción. Las acciones y gestos de los distintos miembros del ejército son muy vívidas, cualidad que ya tan temprano como en el 
1895 Stettiner había resaltado ${ }^{200}$ y que como a lo largo de nuestro trabajo hemos resaltado es necesaria para la creación de imagines agentes.

Las acciones representadas en la miniatura 80 son claras, pero el título de ésta: - Virtutes aedificant tribunal en Burm.Q.3, Ms. 9987-91 y Virtutes edificant tribunal et cum fidutia erigunt en Ms. Lat. 8085 corrobora las acciones de forma más eficaz y sencilla. En el poema se utilizó el verbo extruso para indicar que se levanta, erige, construye o edifica la tribuna. El título en las tres miniaturas se utilizó aedifico, construir, un verbo que probablemente era más fácil de entender y recordar para los jóvenes aprendices que pudieron haber utilizado estos manuscritos.

En la miniatura 83 igualmente se incluyó la imagen de la tribuna, sin embargo, los personajes dentro de ésta han cambiado y la disposición y los gestos de las huestes también. En el interior de la construcción se aprecian dos figuras vestidas con túnicas largas y manto, en posición sedente y por sus ademanes en actitud de diálogo, las dos virtudes que han protagonizado el octavo combate contra los vicios: Fides y Concordia. En el plano por debajo de estas dos se incluyeron siete personajes, con gestos vigorosos. El título de las miniaturas indica que las virtudes suben en la tribuna, pero en la imagen estás ya se encuentran en el interior. La imagen plasma los versos 738 al 739 en el que las protagonistas de la miniatura ordenan a las tropas a acercarse.

La miniatura 80 en Ms. 10066-77 es distinta. Aquí en lugar de la tribuna se representó una muralla poligonal, decorada con cinco torres y la centra posee un arco. En el centro se aprecian de pies dos figuras femeninas, con los cabellos trenzados. Visten túnicas largas y manto y en sus manos llevan una lanza y escudo. Justo al lado de cada una de las virtudes se incluyó el nombre de éstas: Fides y Concordia. La presencia de las coronas al parecer es un añadido por parte del iluminador tomada de directamente de los versos 716 y 830 en los que se alude a Fides como Regina y el

${ }^{200}$ STETTINER. Die Illustrierten Prudentiushandschriften..., p. 382. 


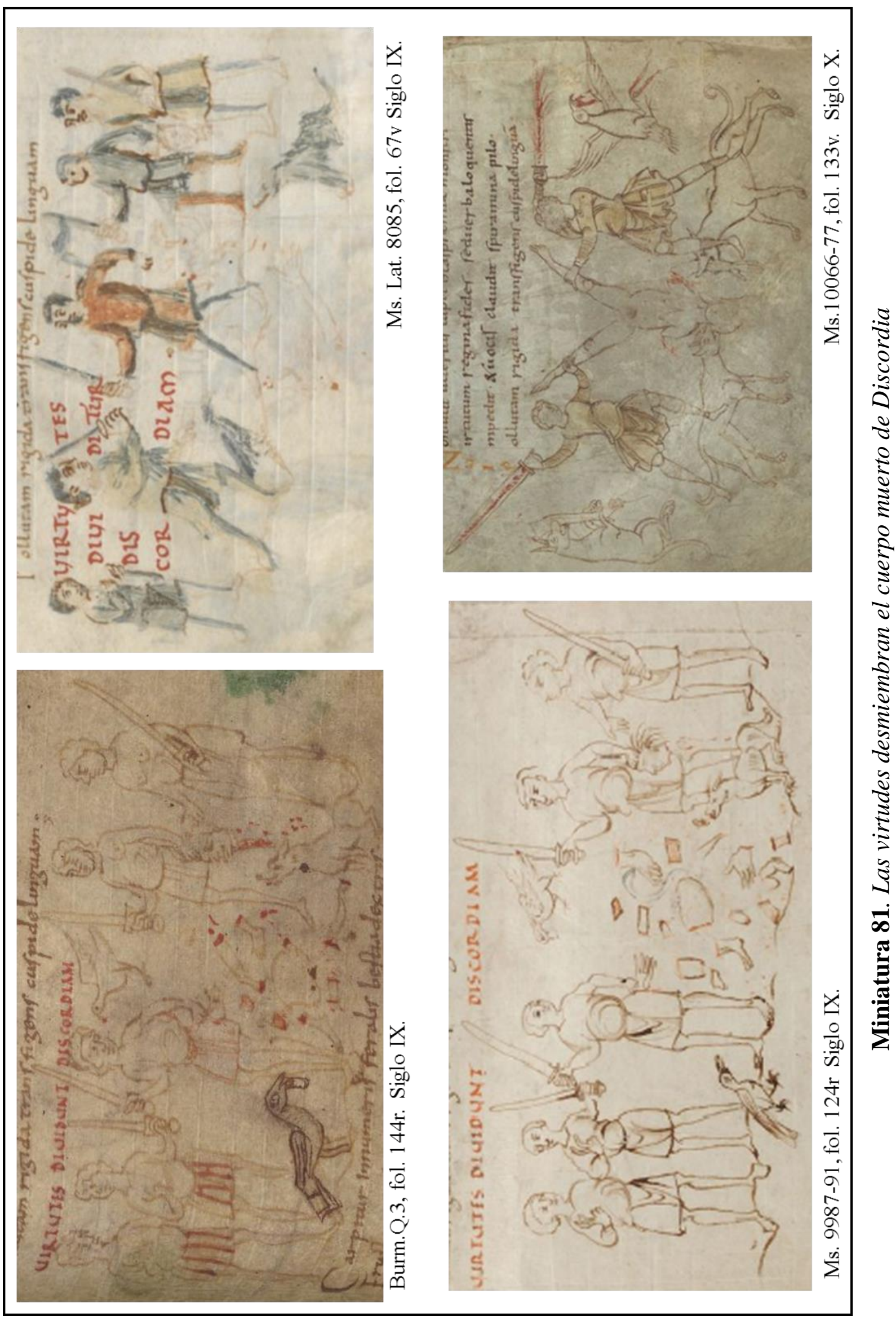



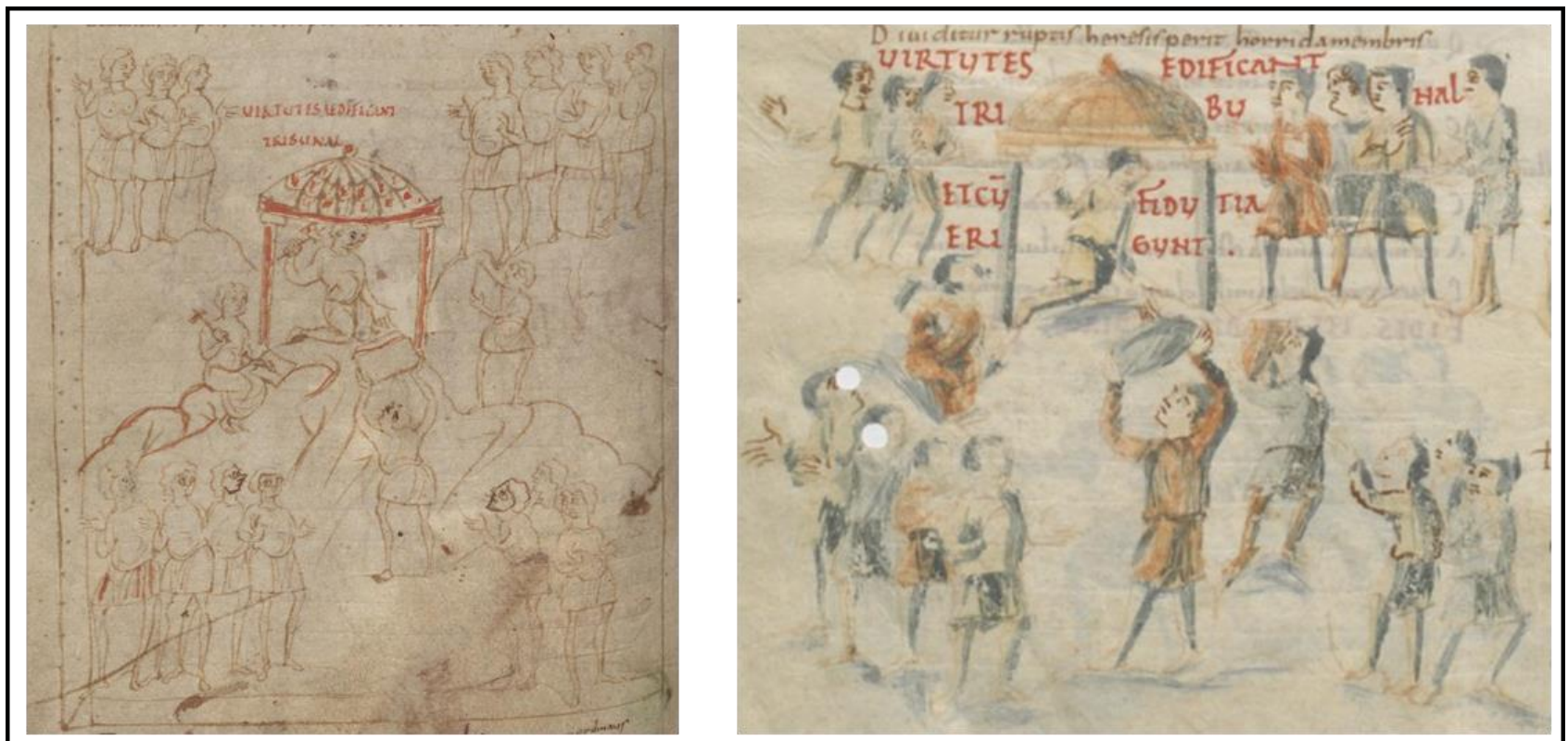

Burm.Q.3, fol. 144v. Siglo IX.

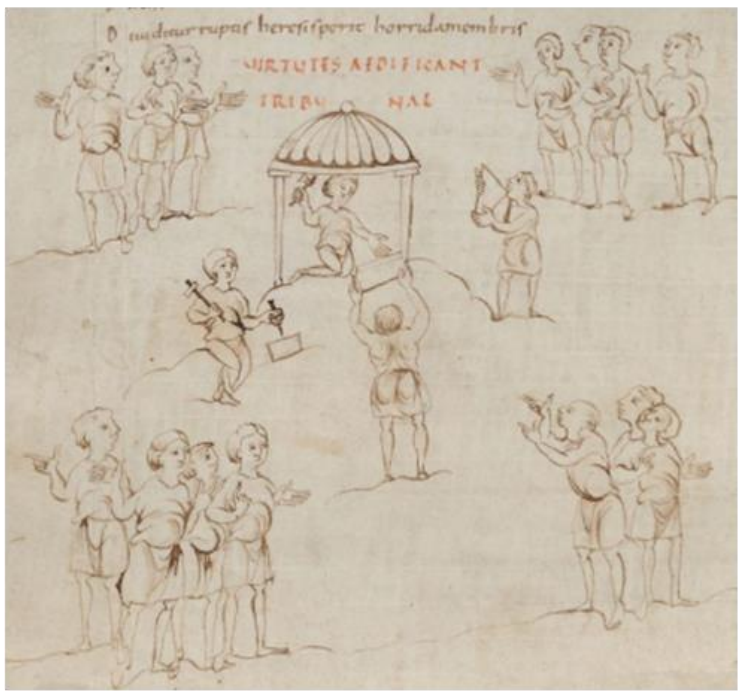

Ms. Lat. 8085 , fol. 67v Siglo IX

Ms. 9987-91, fol. 124v Siglo IX.

Miniatura 82. Las virtudes construyen una tribuna 


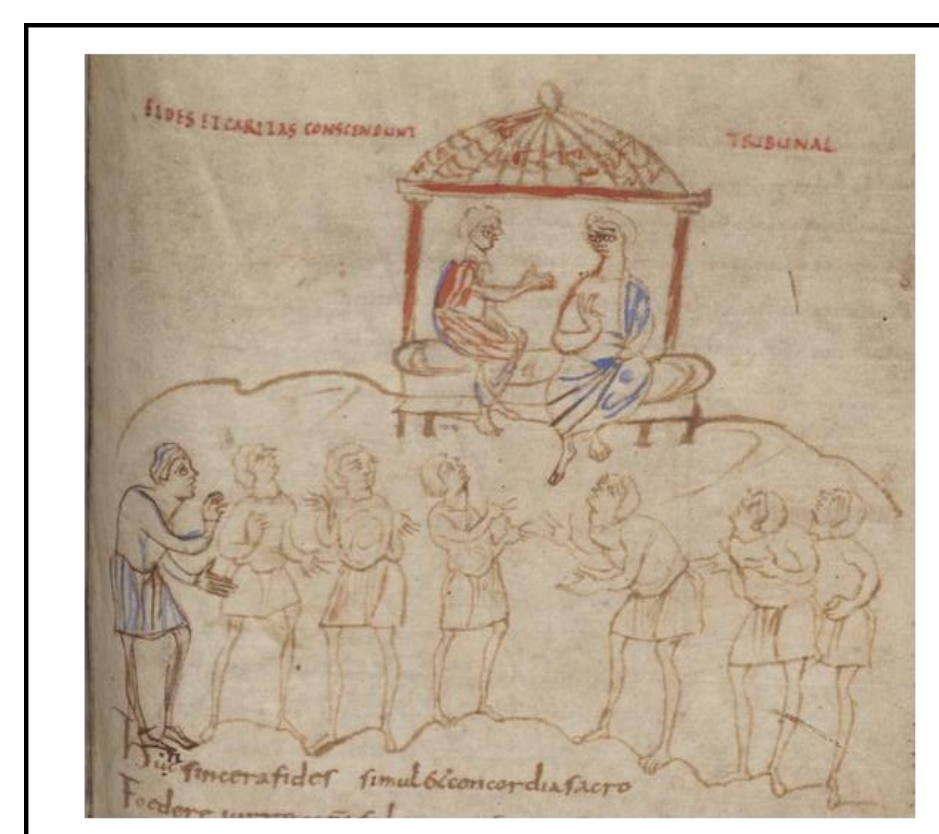

Burm.Q.3, fol. 145r. Siglo IX.

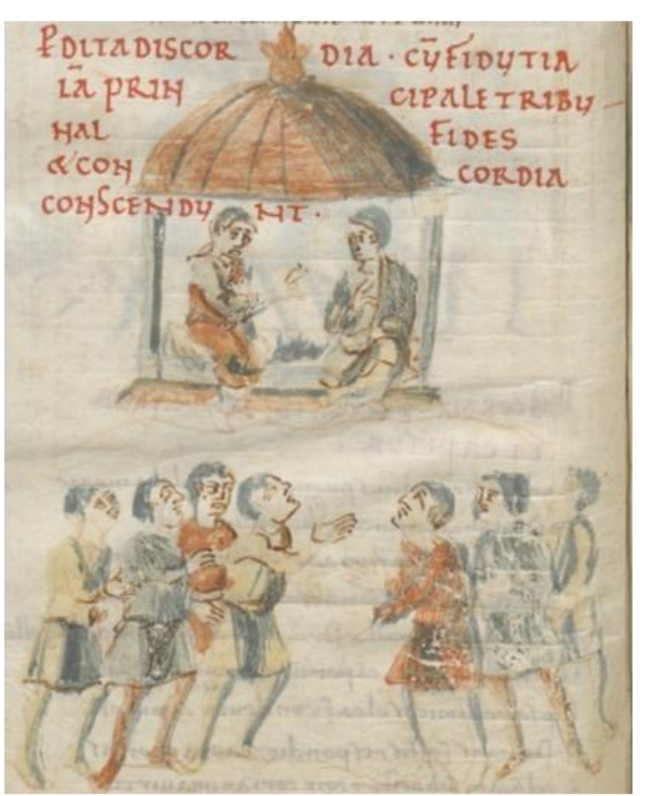

Ms. Lat. 8085, fol. 67v Siglo IX.

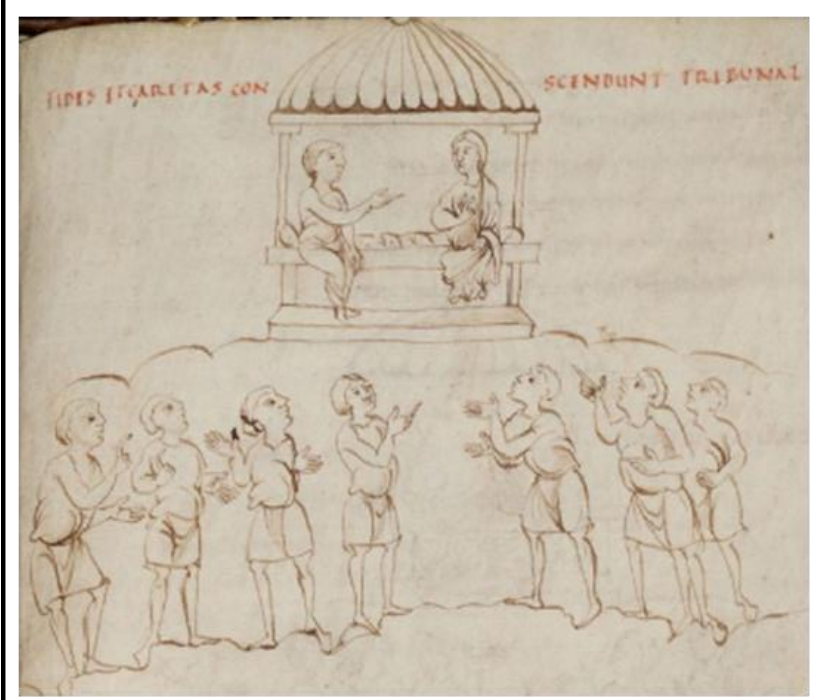

Ms. 9987-91, fol. 125r Siglo IX.

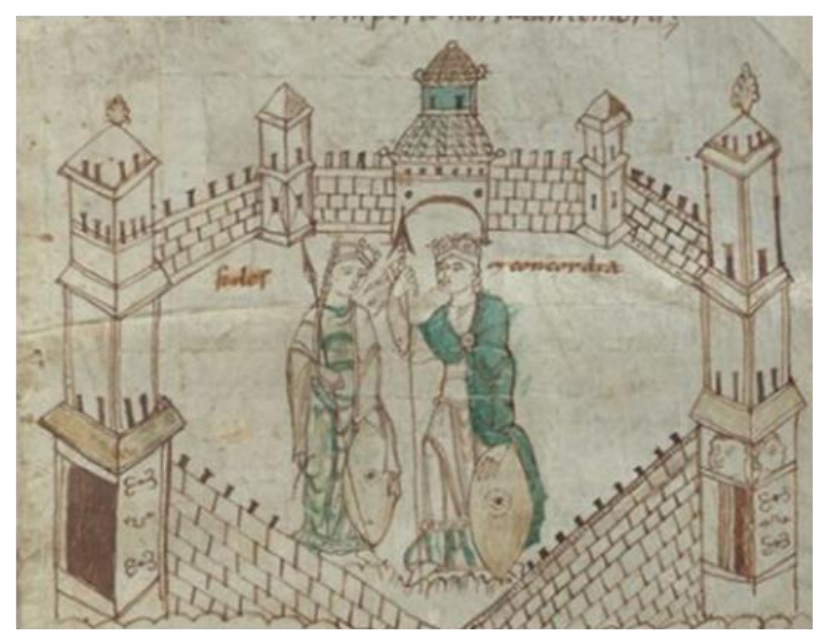

Ms.10066-77, fol. 134r. Siglo X.

Miniatura 83. Fides y Concordia suben a la tribuna 
747 en el que Concordia es llamada princeps $^{201}$. En este códice particular esta miniatura acompaña se insertó antecediendo los versos de la miniatura 82, y el lugar de esta escena acompañando los versos 734 al 739 se dejó en blanco. En cuanto al muro en lugar de la tribuna, Stettiner había vinculado la representación del mismo con el dibujo arquitectónico de miniaturas 89 con la que cierra la descripción de los combates $^{202}$.

La tribuna en la que se colocan Fides y Concordia en las miniaturas anteriores, conectan la narración visual con la escena 84 en la que Todos acuden desde el campamento. En Burm.Q.3 y Ms. 9987-91 la estructura de la tribuna y las figuras sedentes de Fides y Concordia siguen el esquema composicional utilzado en la escena 83. En el códice parisino el dibujo de la cubierta de la tribuna cambió y pasó a representarse con el frontón de una basílica. Como se estableció anteriormente, son las sutilezas gestuales y los detalles los que diferencias estas distintas imágenes. Aquí en el plano más próximo al espectador, por debajo de Fides y Concordia, en cada extremo se incluyeron dos tiendas, las cuales al igual que en la miniatura 74 se utilizan para designar visualmente la representación del campamento. Se aprecia como los miembros del ejército salen de éstas, por medio de ésta acción el miniaturista hace hincapié en el hecho de que las tiendas se dejaron abiertas para que ninguno de los que esté adentro quede aletargado ${ }^{203}$.

La composición de las miniaturas 85 y 86 es muy similar. En ambas se aprecian a Concordia y Fides dentro de la tribuna, dialogando mientras que sus ejércitos contemplan. La primera de estas escenas, la 85 antecede los versos 746 al 798 en los que Concordia se dirige al ejército. La principal diferencia que la diferencia de la miniatura 86 es el número de figuras utilizado para representar el ejército. En Concordia dirige la palabra al ejército de las virtudes el ejército se compone de siete miembros divido en tres grupos, dos de tres y el último en la derecha

\footnotetext{
${ }^{201}$ STETTINER. Die Illustrierten Prudentiushandschriften..., p. 386.

${ }^{202}$ STETTINER. Die Illustrierten Prudentiushandschriften..., p. 386.

${ }^{203}$ PrudenCIO. Psychomachia, vv. 743-744. Obras Completas de Aurelio Prudencio..., pp. 352353.
} 
uno solo. Además, en esta escena la virtud en el lado izquierdo eleva su mano, gesto que expresa visualmente la acción de que se dirige hacia las huestes, lo que permite identificarla con Concordia. En Ms. Lat. 8085 la tribuna ahora tiene la forma de una basílica de tres naves, con un pórtico de dos arcos. Este tipo de construcción fue utilizada únicamente en esta miniatura.

La miniatura 85 se incluyó igualmente en el códice 10066-77 con un arreglo composicional muy distinto a las representaciones del siglo IX o a la miniatura anterior de este manuscrito, la 83. En este ejemplo Concordia y Fides, vestidas con su armadura y portando sus armas, se encuentran de pies sobre una serie de edificios y los ademanes de éstas indican que se dirigen al resto de los personajes. Aquí el número de figuras que componen el ejército de las virtudes aumentó, ahora encontramos once divididas en tres grupos de tres y uno de dos. A diferencia de en Burm.Q.3, Ms. Lat. 8085 y Ms. 9987-91 sólo encontramos una miniatura que recoge el diálogo y las acciones de Fides y Concordia. El número de soldados incluso alude a esto, pues es como si el número total de soldados dibujados en la miniatura 85 y 86 de los códices del siglo IX, once, en el caso del códice belga se aglomeraron en una sola imagen.

En la miniatura 86, Fides también dirige la palabra al ejército de las virtudes, el ejército ahora se representa a través de dos grupos compuestos de tres figuras y la virtud identificada como Concordia ya no eleva su brazo. La similitud composicional en gran medida se puede vincular con el hecho de que en ambas escenas se recoge la misma acción, la de hablar y dirigirse a las huestes, pues después de todo esta miniatura antecede los versos 799 al 822 en los que se narra cómo también Fides se dirigió al ejército victorioso. En la miniatura 85 y 86 los tituli ayudan a identificar en gran medida la virtud protagonista de la escena.

En Ms. 10066-77 la imagen que antecede a los versos 799 al 822 en los códices del siglo IX es otra. En este códice en el centro de la composición se aparece una edificación arquitectónica muy similar a la plasmada en la miniatura 83 de este manuscrito. Vemos una serie de figuras en plena faena constructiva, portando los 
distintos materiales de construcción para terminar la estructura. En la extrema izquierda aparece vestida con armadura, túnica larga, yelmo y lanza una de las virtudes, extendiendo su mano. Si el edificio que construyen las huestes de las virtudes es similar al de la escena 83, cabe destacar igualmente que las acciones de las figuras, especialmente la que sostiene la roca sobre su cabeza en la parte izquierda de la composición recuerda a las acciones del ejército en la miniatura 82 de los ejemplos del siglo IX, siendo una posibilidad que se hayan transpuesto las imágenes en Ms. 10066-77. En relación con la miniatura 86, Stettiner afirma que en este códice la miniatura 86 se plasmó así para representar el discurso de Fides, apelando específicamente a lso versos 814 al 815en el que esta virtud exhorta a la construcción de un templo, evitando así la monotonía visual de las miniaturas 85 y 86 en los cosos del siglo $\mathrm{IX}^{204}$.

Las miniaturas 85 y 86, en los cuatros manuscritos poseen la misma función, las mismas sirven como lugares mnemónicos de recopilación pues recogen los discursos de estas dos virtudes. El primero es el de la protagonista de este combate, Concordia, en el que exhorta a todos a la práctica de la concordia y la unión en pensamiento y actos, en alma y cuerpo; pues sólo así se puede alcanzar la Paz, obra perfecta de la virtud y cumbre final de los trabajos ${ }^{205}$. La miniatura 86, Fides también dirige la palabra al ejército de las virtudes, antecede los versos que recogen el discurso de Fides, en el que ésta exhorta a los ejércitos a estar alegres y luego a seguir los pasos de Salomón. Aquí se interpola la victoria de las virtudes ante los pérfidos vicios con la tarea de Salomón de devolver la gloria a su linaje, y en el momento de paz construyó un templo al Señor. El templo es la gloria de todo el reino.

\footnotetext{
${ }^{204}$ STETTINER. Die Illustrierten Prudentiushandschriften..., p. 392.

205 "Pax plenum virtutis opus, pax summa loburum..." PRUDENCIO. Psychomachia, vv. 769-770. Obras Completas de Aurelio Prudencio..., pp. 352-353
} 


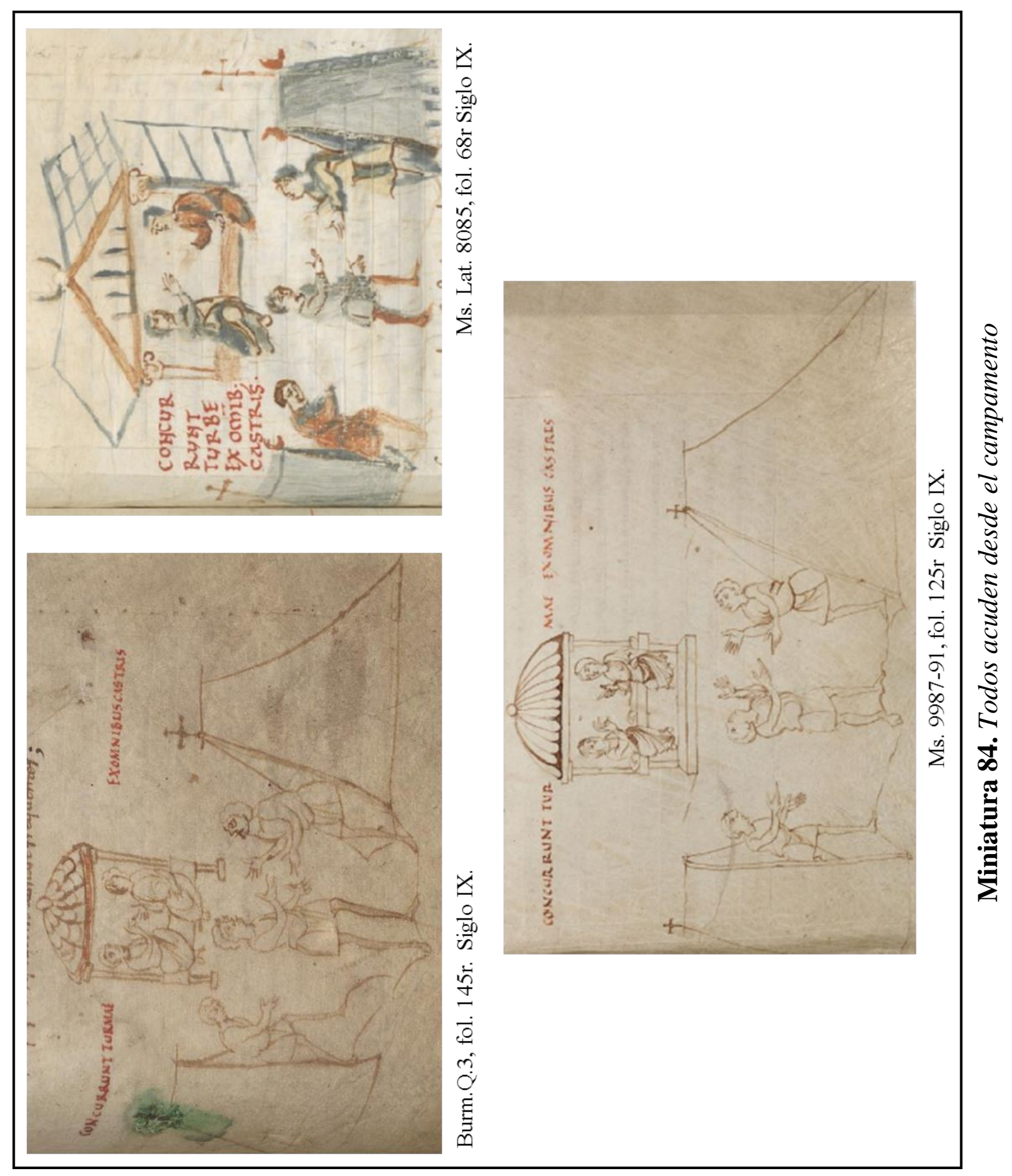




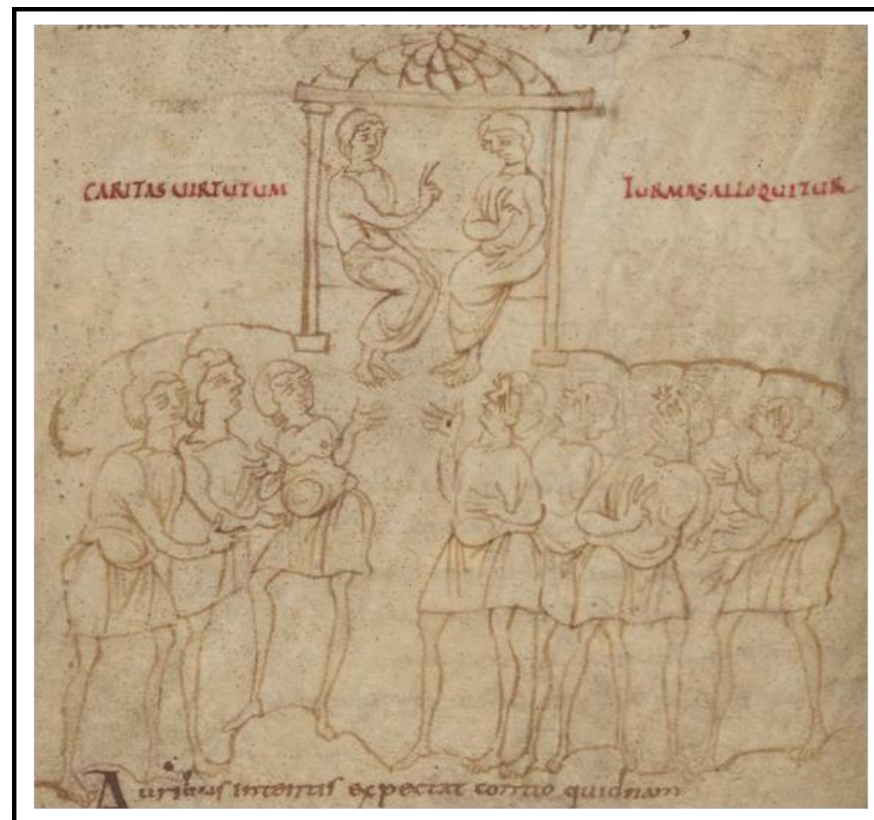

Burm.Q.3, fol. 145v. Siglo IX.

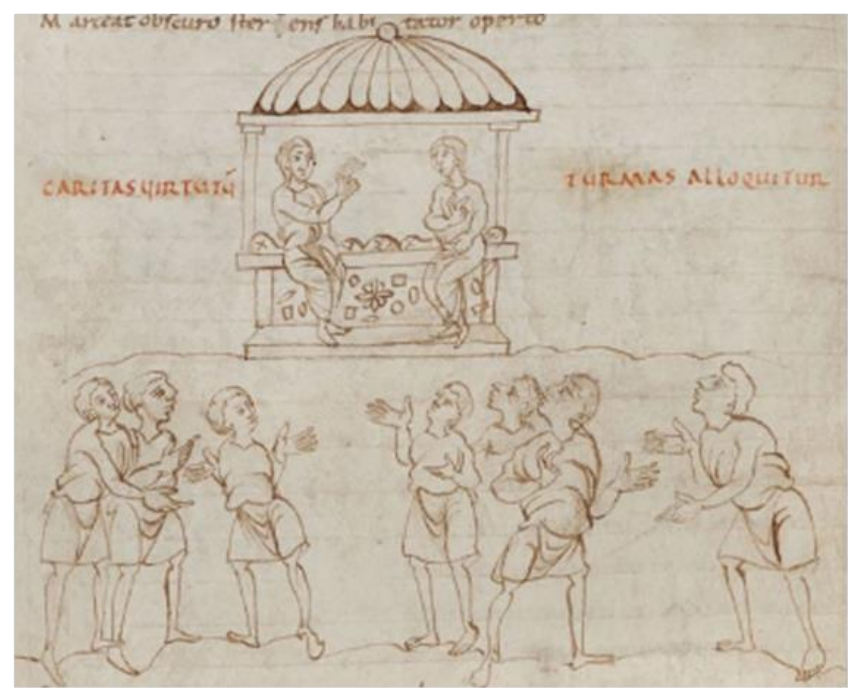

Ms. 9987-91, fol. 125v Siglo IX.

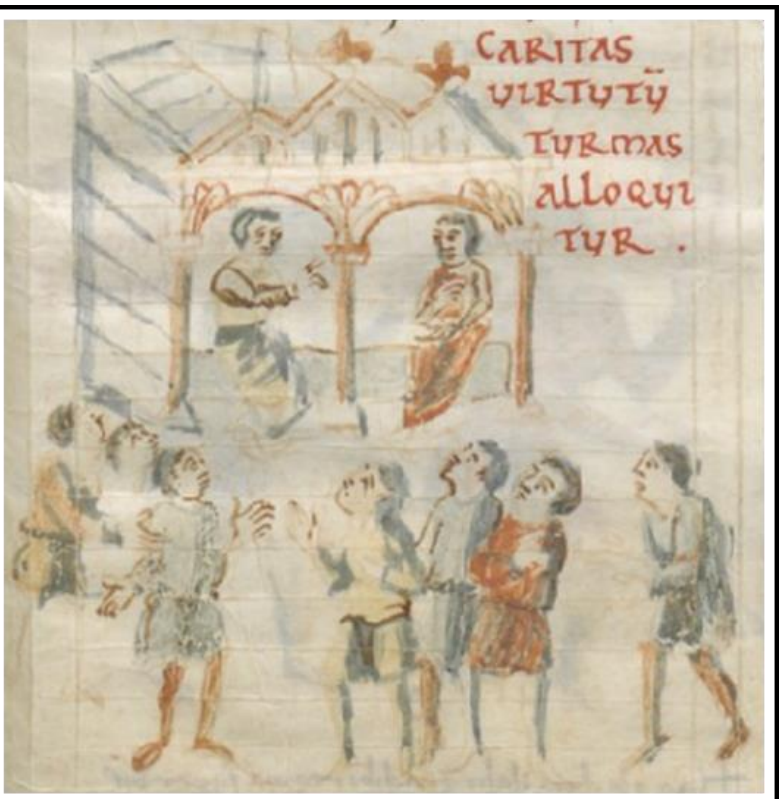

Ms. Lat. 8085, fol. 68r Siglo IX.

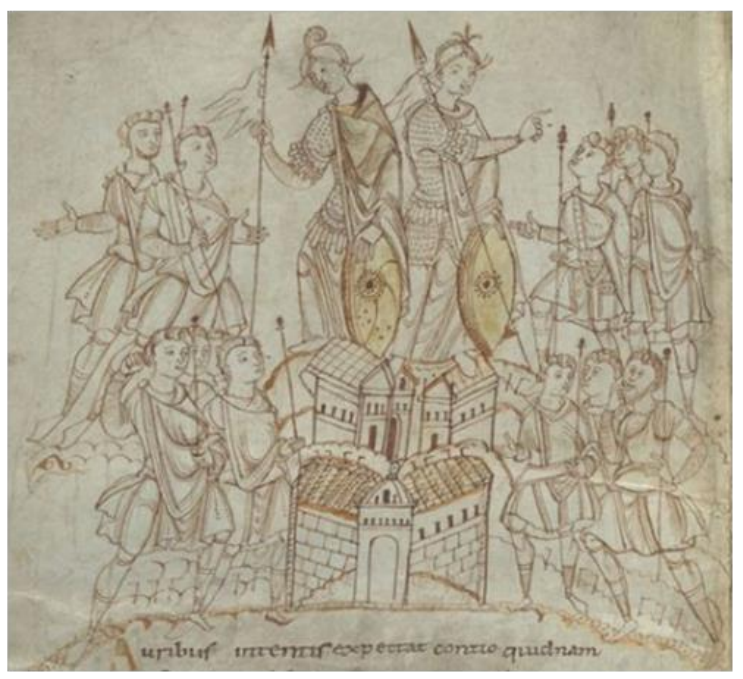

Ms.10066-77, fol. 135v. Siglo X.

Miniatura 85. Concordia dirige la palabra al eiército de las virtudes 


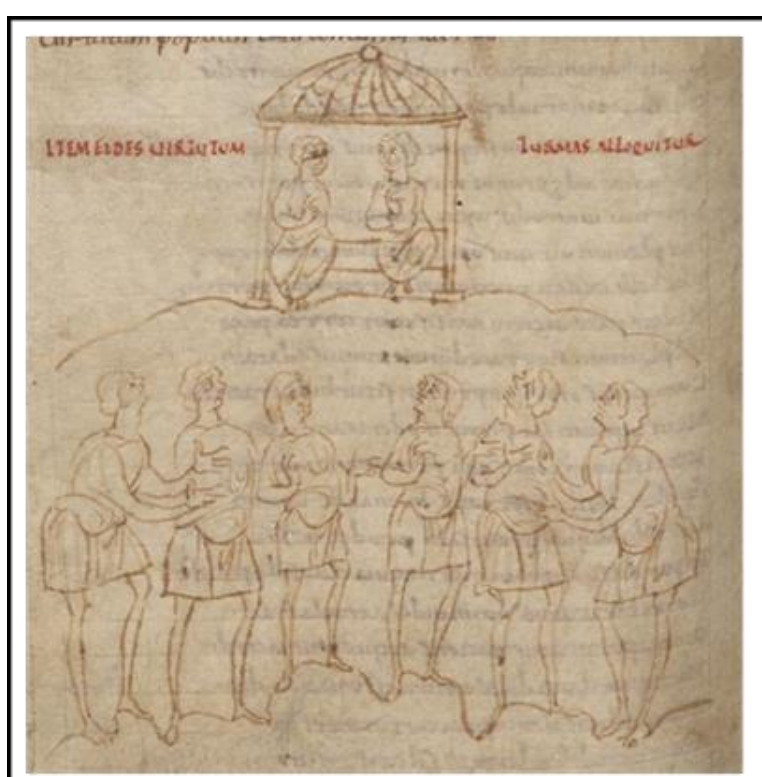

Burm.Q.3, fol. 146v. Siglo IX.

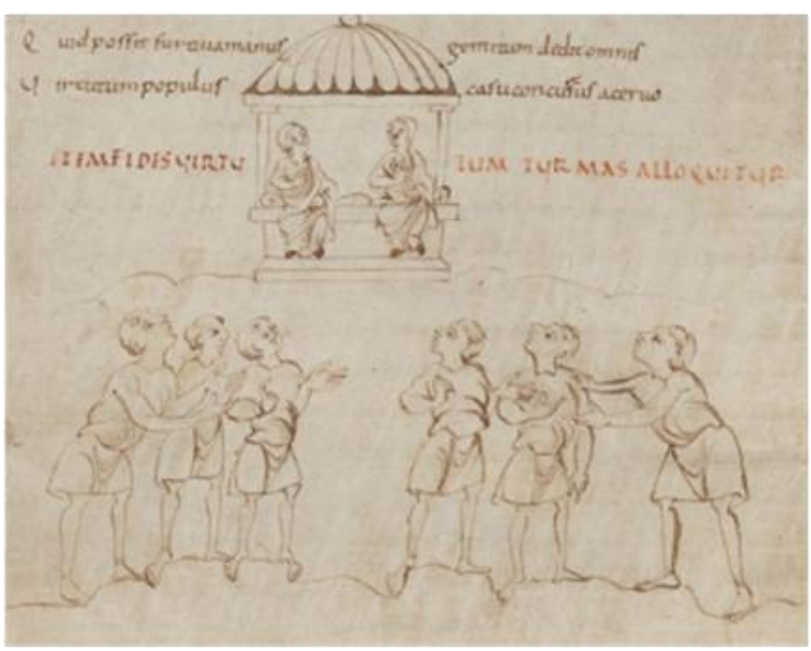

Ms. 9987-91, fol. 126v Siglo IX.

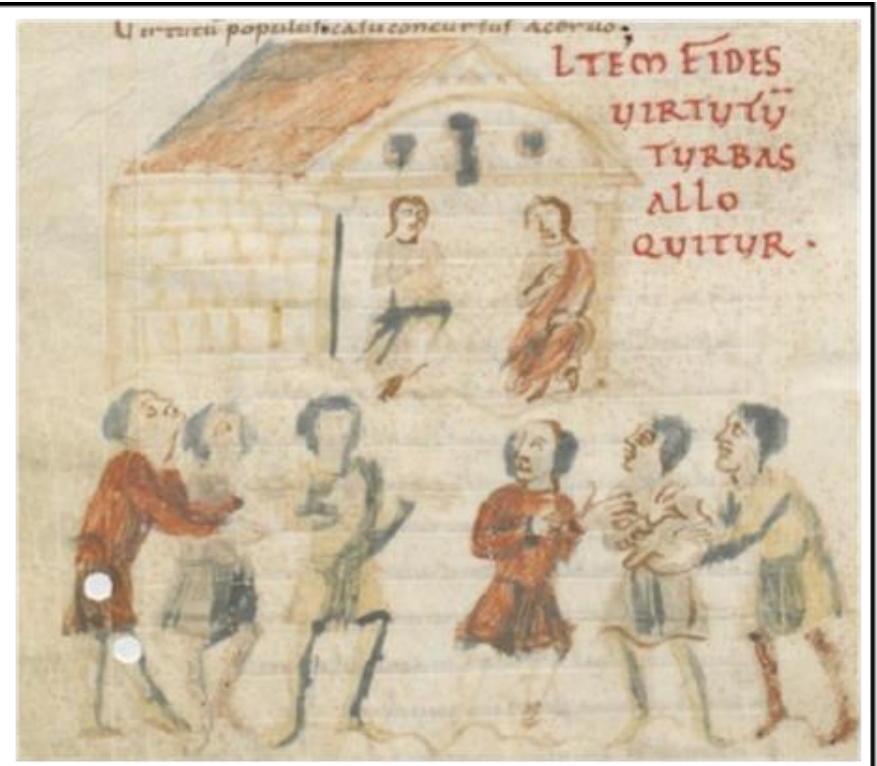

Ms. Lat. 8085, fol. 68v Siglo IX.

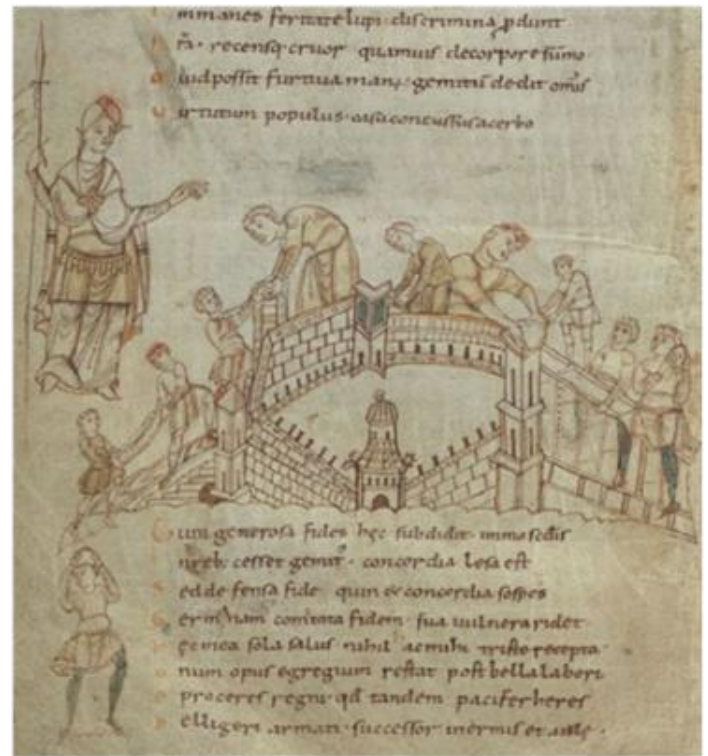

Ms. 10066-77, fol. 136v Siglo X.

Miniatura 86. Fides también dirige la palabra al ejército de las virtudes 


\subsubsection{Construcción del templo de Sapientia}

El poema de la Psychomachia termina con la construcción del templo de Sapientia por iniciativa de Fides. La edificación del mismo se recoge entre los versos 830 al 887 y se representa con tres miniaturas. La primera miniatura en torno a la construcción del templo es la 87, en ésta aparecen Concordia y Fides y realizan las acciones que establecen los versos que le siguen: bajan de la tribuna y con una regla de oro miden y ponen los cimientos para la construcción del templo ${ }^{206}$. La disposición de las figuras en Burm.Q.3, Ms. Lat. 8085 y Ms. 9987-91 es similar. En la misma se dibujaron a las dos virtudes con túnica corta. La de la derecha sujeta un objeto largo, la caña de oro (aurea harundo) ${ }^{207}$. Los ademanes de ambas son los propios para indicar el computo, pues estas miden el espacio. Stettiner asocia las dos figuras con las de un maestro arquitecto y su asistente, e identifica a la figura de la izquierda con Fides y la de la derecha con Concordia. Los tituli además de clarificar la acción que éstas llevan a cabo, Fides et Caritas metiuntur locum ubi templun Domini aedificetur (Fides y Concordia miden en lugar donde construirán el templo del Señor) también ayudan a identificar a cada virtud, pues las mismas se representaron en el orden en el que aparecen en el título, que sigue igualmente el orden del poema. En el códice parisino los gestos de Fides y Concordia son los mismos, sin embargo, aquí no encontramos rastros de la caña, y asea porque los pigmentos de la misma se perdieron como ha pasado con muchos detalles de este manuscrito o bien porque simplemente el miniaturista no la dibujó.

En Ms. 10066-77 las dos virtudes visten túnica larga y ambas fueron representadas con la caña. Al parecer, el miniaturista intentó sobresaltar este objeto, en el caso de la figura de la izquierda, por medio de unos trazos ondulados, y el de la derecha, por medio del uso del color rojo, tal vez una forma de representar que no es una caña cualquiera. Los gestos igualmente cambiaron, ahora la figura de la izquierda, Fides, ordena y la figura de la derecha, Concordia, se dispone a medir.

\footnotetext{
${ }^{206}$ Psychomachia, vv. 823-829. Obras Completas de Aurelio Prudencio..., pp. 356-357.

${ }^{207}$ Psychomachia, v. 826. Obras Completas de Aurelio Prudencio..., pp. 356-357
} 
La siguiente miniatura, la 88, presenta el templo del Señor, cómo lo establecen los tituli: Templum Domini. La misma sólo se insertó en los códices del siglo IX y consiste en una muralla con un vano de entrada, tres torres y en el interior de esta una tribuna similar a la que se plasmó en las miniaturas 82, 83, 84, 85 y 86 de estos manuscritos, y un edificio de planta basilical. Esta escena corresponde a los versos 830 al 867 en los que se recoge cómo fue la construcción del templo. La descripción del mismo es claramente una alusión a la Jerusalén Celeste descrita por Juan en Apocalipsis 21: 15-26. Al igual que la Jerusalén celestial, el templo construido por las virtudes se mide con una caña de oro para que sus medidas sean exactas y armoniosas. En cada uno de sus muros posee triple puerta, y sobre éstas se escriben los nombres de los Apóstoles. El templo se ornamenta de igual manera con distintas piedras preciosas que son mencionadas en el texto de Juan ${ }^{208}$. La representación del templo parece ser una imagen genérica de un templo que introduce al lector a la edificación, sin embargo, no recoge los detalles de éste mencionados en los versos.

Es la última miniatura, la 89, la que sí capta visualmente la descripción del templo ${ }^{209}$. En Burm.Q.3, Ms. Lat. 8085 y Ms. 9987-91 el perímetro del templo se divide por medio de doce torres y en cada muro la triple puerta que describen los versos 830 al 834. En el centro de esta construcción, sobre una esfera y cobijada bajo un templete de siete columnas se incluyó una figura sedente cuyo gesto de la mano derecha que lleva al pecho es el de bendecir. Esta imagen además de captar visualmente la descripción del Templum Domini, igualmente plasma la descripción de los versos que antecede, en los que se describe la construcción de la cámara interior del templo del Señor y cómo en el interior de este sobre el trono se sienta Sapientia ${ }^{210}$ En la miniatura de Ms. 10066-77 se prestó más cuidado a la representación de Sapientia entronizada. Según Stettiner en Ms. 10066-77 también se incluyeron las

\footnotetext{
${ }^{208}$ Prudencio. Psychomachia, vv. 857-865. Obras Completas de Aurelio Prudencio..., pp. 358359. Apocalipsis 21: 19-20.

${ }^{209}$ STETTINER. Die Illustrierten Prudentiushandschriften..., p. 397.

${ }^{210}$ PrudenCiO. Psychomachia, vv. 868-887. Obras Completas de Aurelio Prudencio..., pp. 358361.
} 
siete columnas, tres a cada lado y la séptima en el centro ${ }^{211}$, no obstante, la identificación de las mismas resulta un poco complicado.

Según el poema, debajo de la bóveda se colocó una perla que había comprado Fides y Sapientia la utilizó como trono. En los cuatro códices se ve la figura de Sapientia sentada sobre un objeto redondo que alude a la perla, símbolo de Cristo, de la iluminación, del renacimiento espiritual e igualmente de la inmaculada concepción de María $^{212}$. En los ejemplos del siglo IX, Sapientia lleva su mano derecha a su pecho. Si bien este gesto es muy parecido al de Avaritia en la miniatura 62, en el que ésta se señala para indicar su presencia, aquí se relaciona con el verso 878, Sapientia en el fondo de su corazón retiene las leyes para salvaguarda de los hombres (tutandique hominis leges sub corde retractat). En el manuscrito más antiguo, el Burm.Q.3 la mano de Sapientia se posa sobre un objeto rectangular, probablemente un códice para representar gráficamente la ley ${ }^{213}$.

En la miniatura del códice del siglo $X$, la virtud en cada mano muestra una filacteria desenrollada. La filacteria presentada por un personaje entronizado significa la posesión de la verdad y la sabiduría ${ }^{214}$, en este caso significado muy propio para Sapientia la personificación de estas cualidades. Ambas filacterias llevan un texto, la de la izquierda pone "venite et discite" y la de la derecha "transite ad me omnes". El texto de éstas no ha sido tomado del poema. Los mismos son una exhortación que hace Sapientia: venid y aprended (o estudiad), pasad por mi todos.

\footnotetext{
${ }^{211}$ STETTINER. Die Illustrierten Prudentiushandschriften..., p. 398.

${ }^{212}$ HeINZ-MOHR. Lessico di iconografía..., p. 280.

${ }^{213}$ HeINZ-MoHR. Lessico di iconografía ..., pp. 200-201.

${ }^{214}$ GARNIER. Le langage de l'image au Moyen Âge (II)..., p. 230.
} 


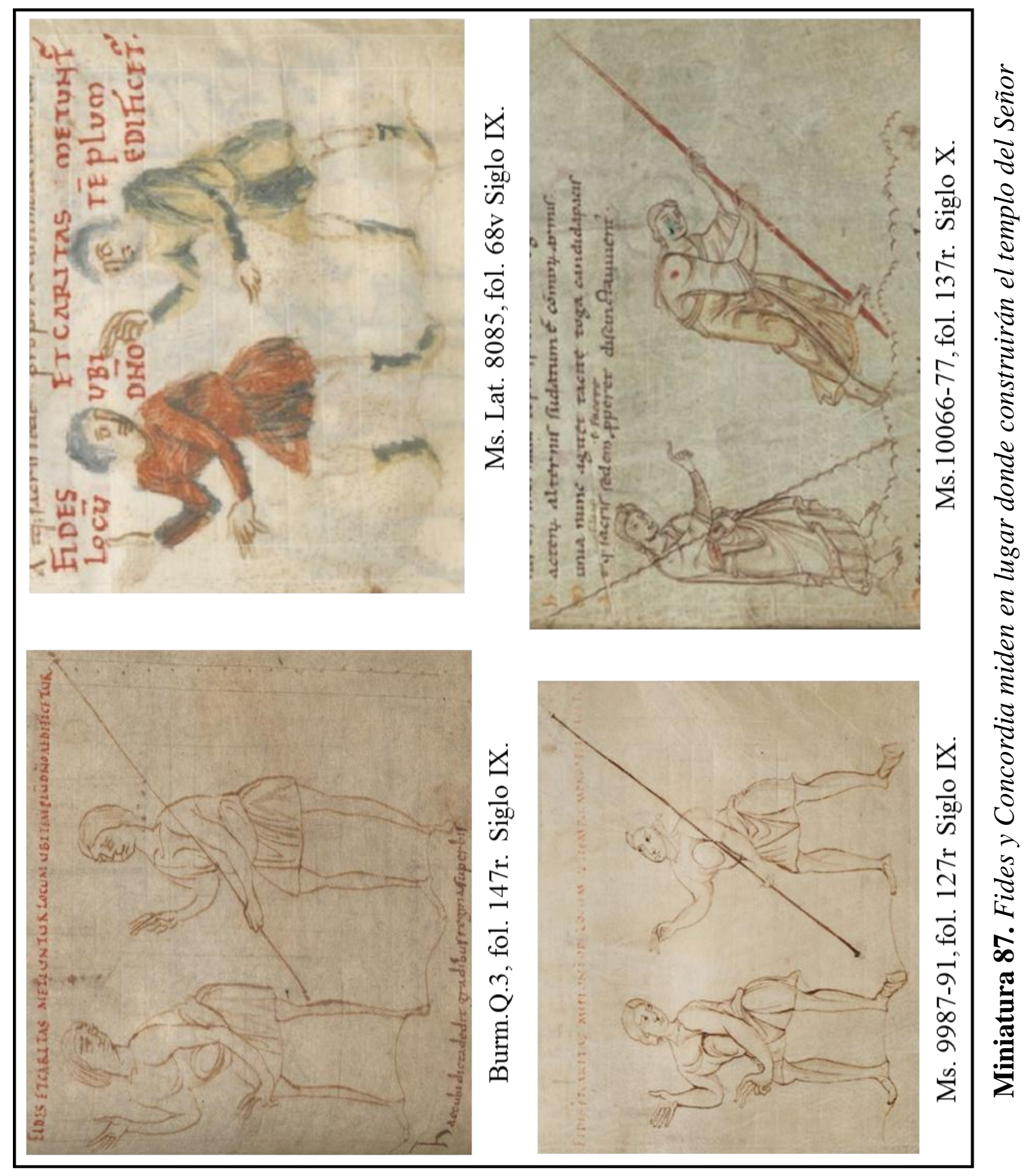




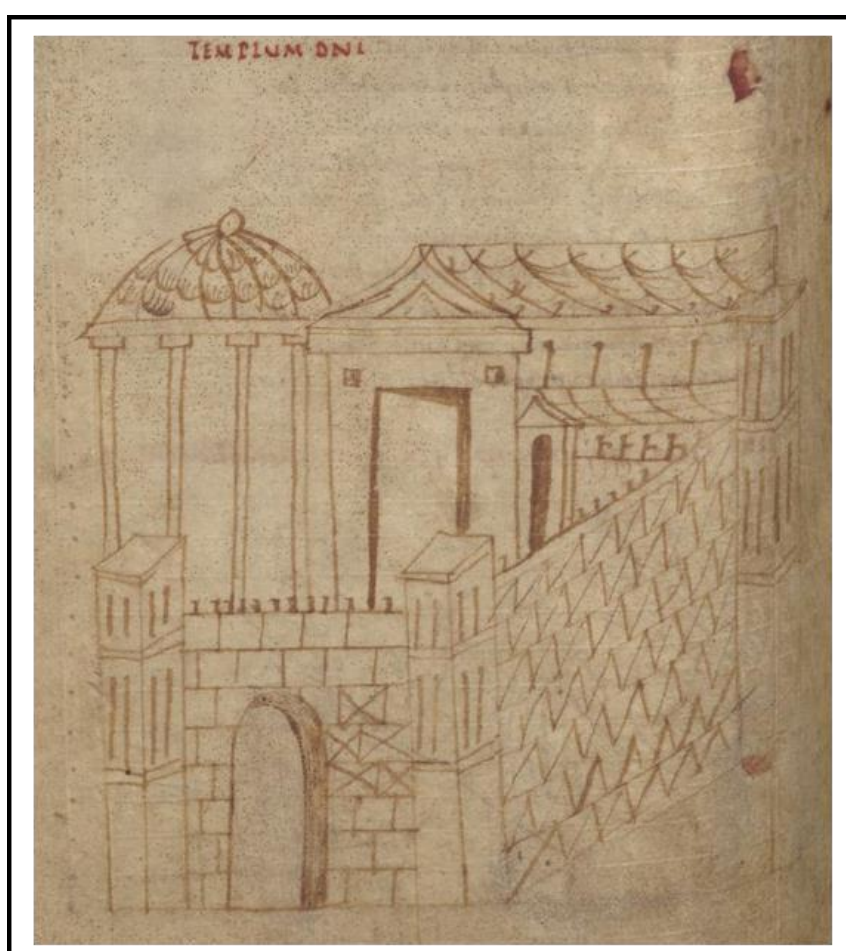

Burm.Q.3, fol. 147v. Siglo IX.

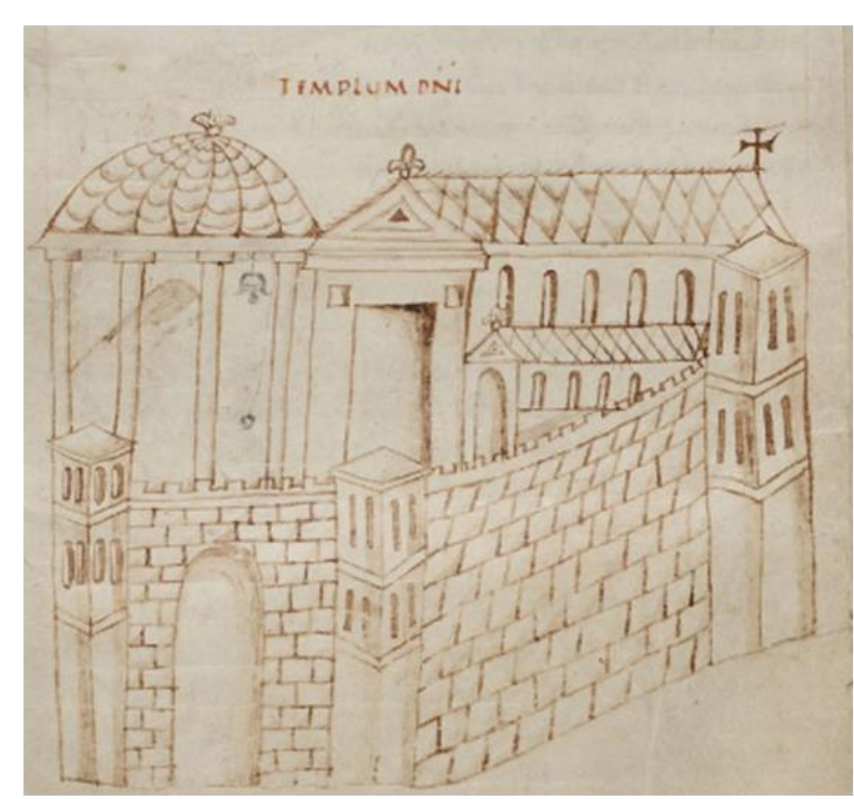

Ms. 9987-91, fol. 127v Siglo IX.

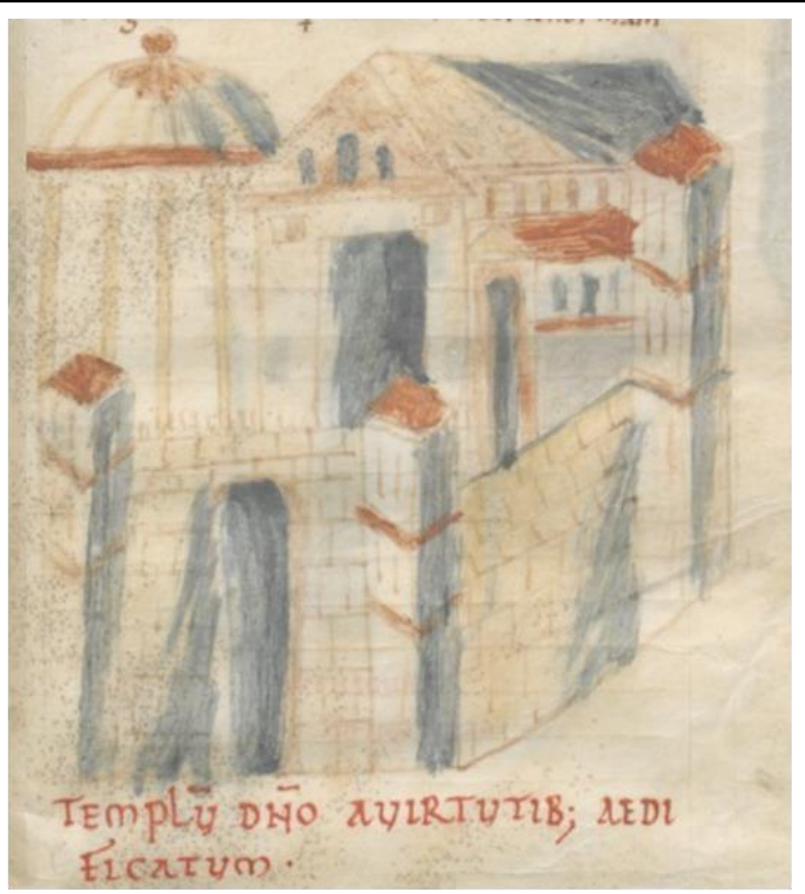

Ms. Lat. 8085, fol. 69v Siglo IX.

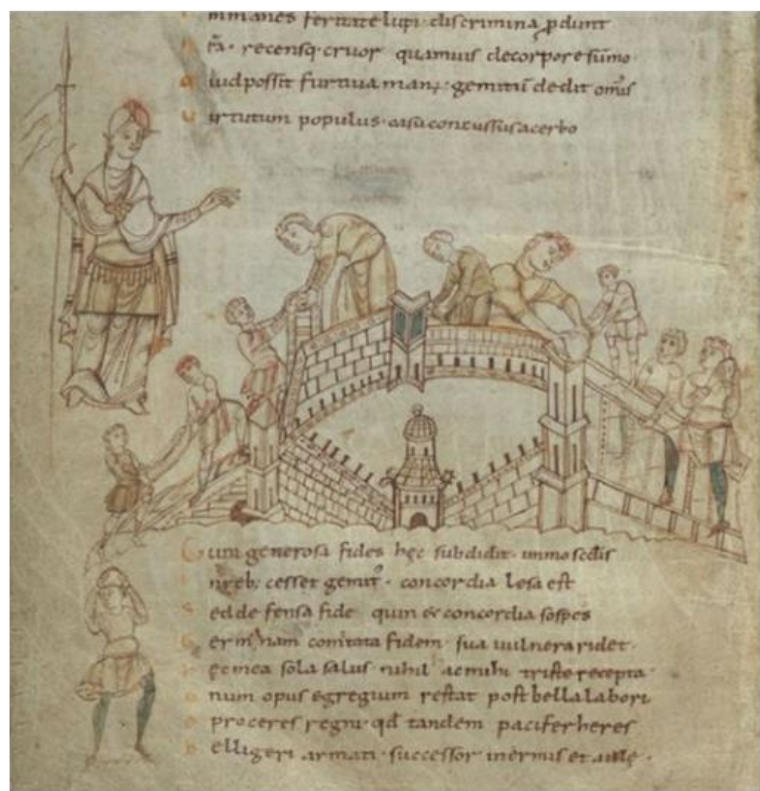

Ms.10066-77, fol. 136v. Siglo X.

Miniatura 88. Templo del Señor construido por las virtudes 


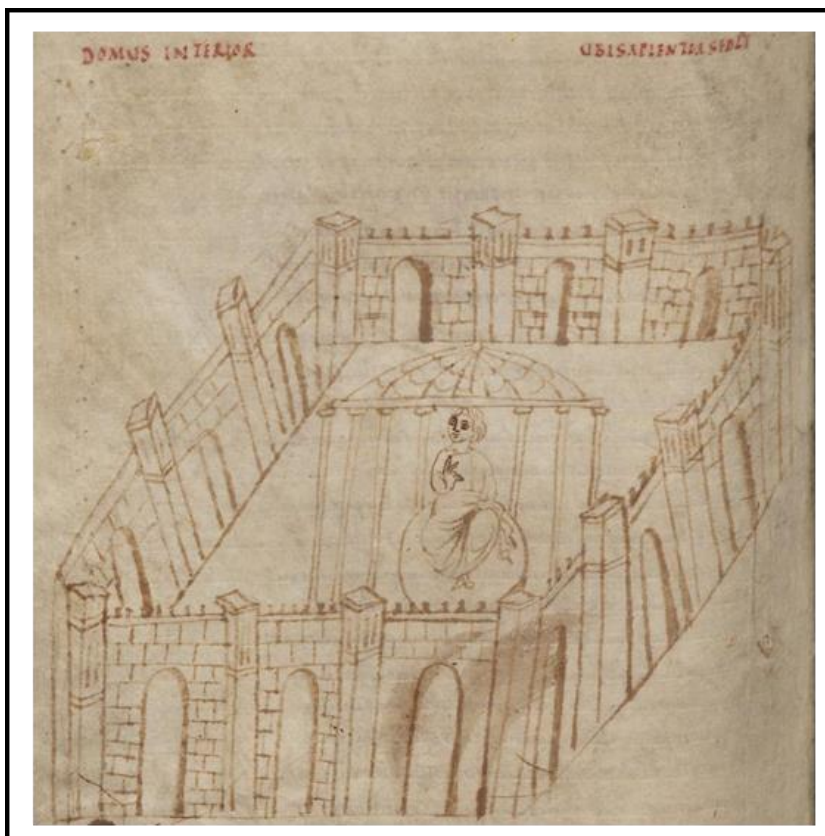

Burm.Q.3, fol. 148v. Siglo IX.

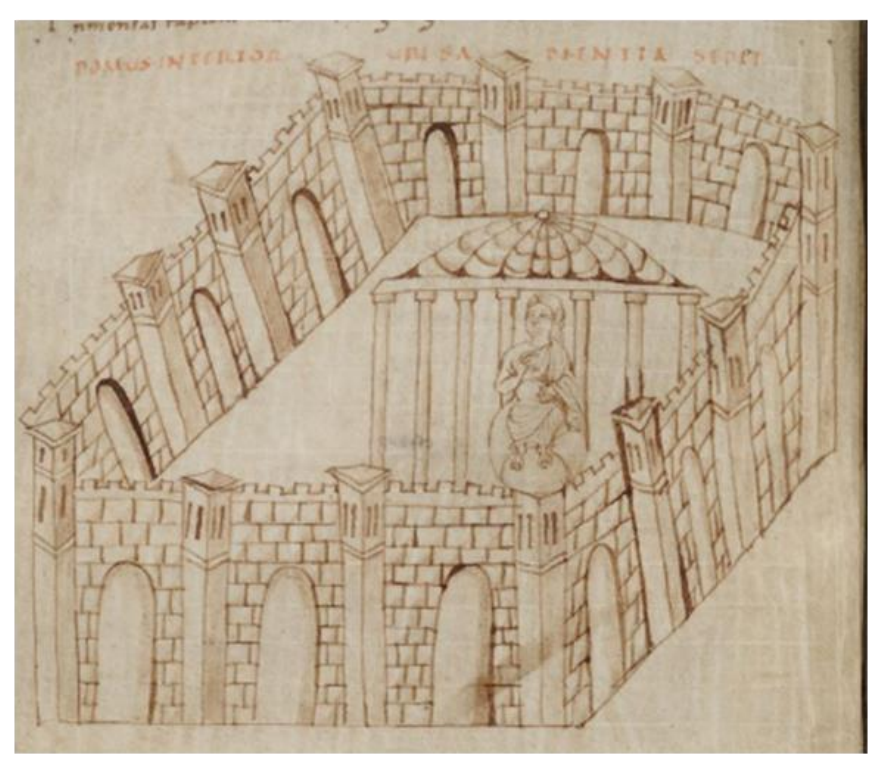

Ms. 9987-91, fol. 128v Siglo IX.

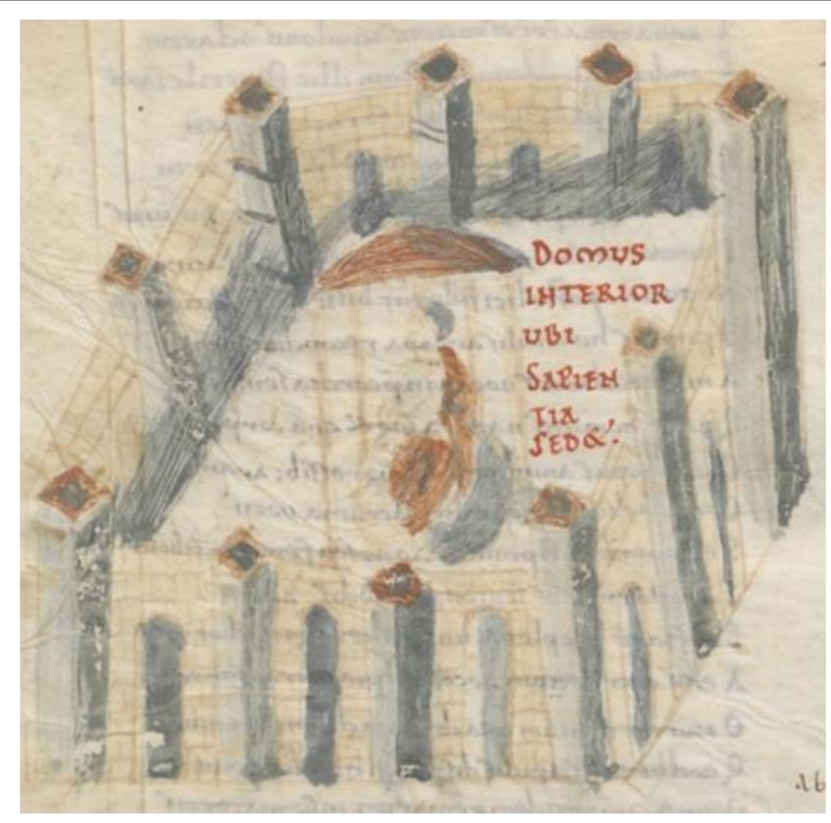

Ms. Lat. 8085, fol. 69v Siglo IX.

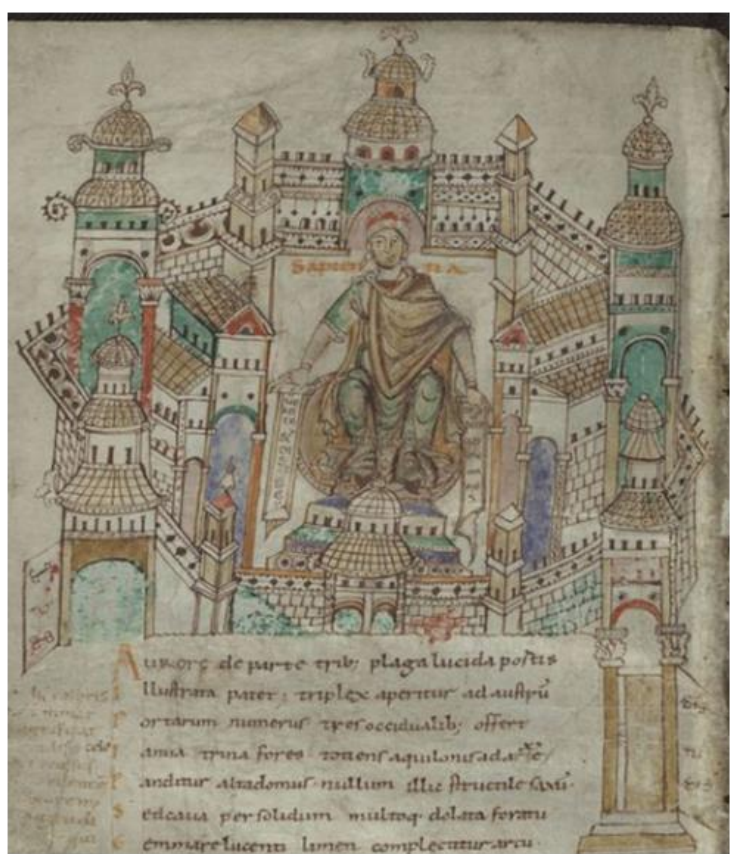

Ms.10066-77, fol. 137v. Siglo X.

Miniatura 89. Sapientia se sienta en un trono en el interior del edificio 


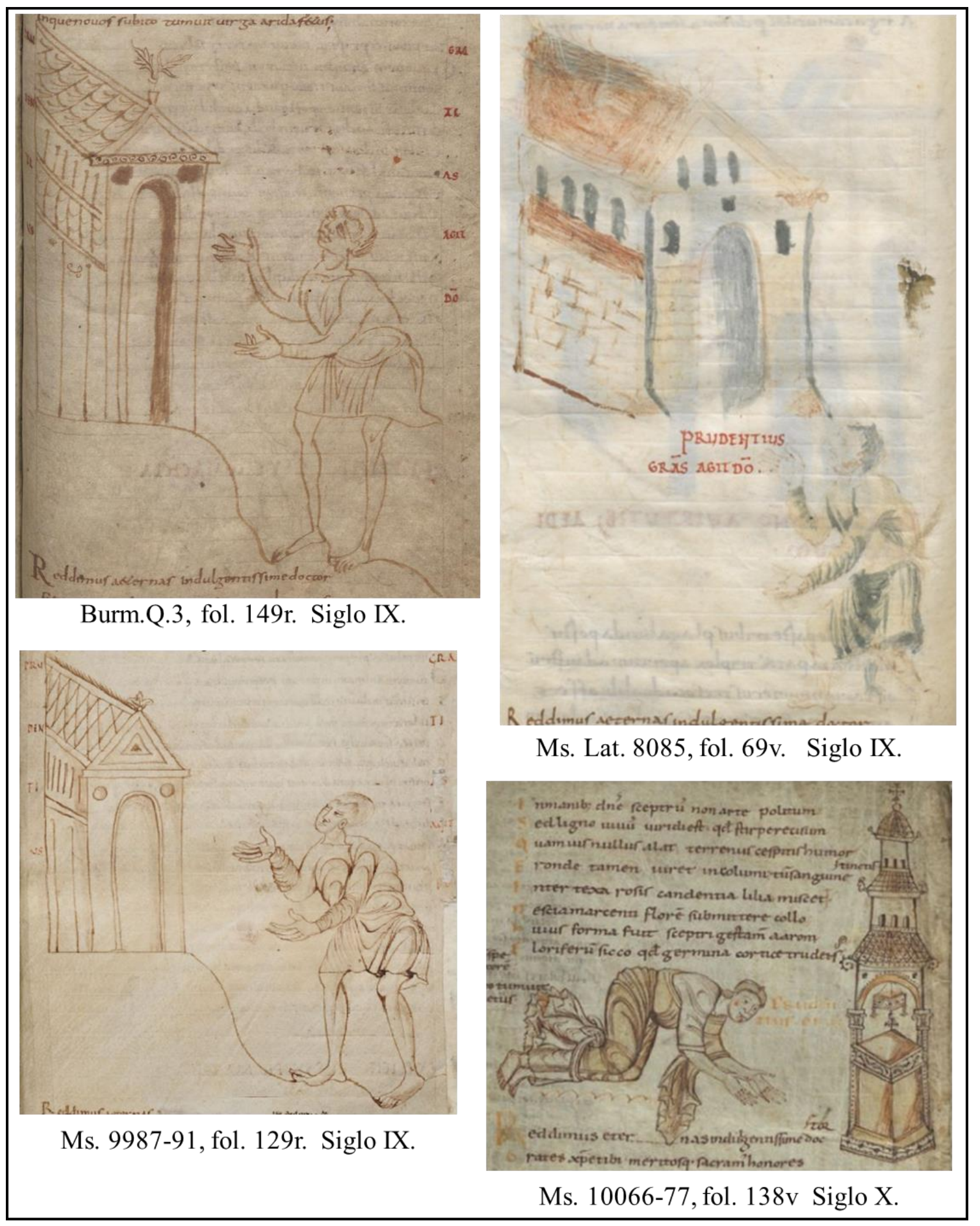

Miniatura 90. Prudencio da gracias a Dios 


\subsection{Ascenso a la sabiduría: consideraciones finales sobre los combates}

El poema de la Psychomachia finaliza con la virtud Sapientia entronizada, seguida de la oración de gracia de Prudencio. De la misma manera, la representación visual de estos versos culmina con estas dos imágenes. El encuentro entre los vicios y las virtudes, además de su carácter combativo, también recuerdan un peregrinar: el lector tiene que ir pasando a través de los distintos combates descritos en el poema para poder alcanzar la sabiduría, que en la Edad Media es la figura de Cristo mismo. Esta virtud se manifiesta en el texto de la obra de dos formas: en términos educativos, es alcanzar el conocimiento sobre todo de las materias del trivium; en términos espirituales, a través de la práctica de la meditación profundizar en la figura de la sabiduría encarnada: Jesús. Por lo tanto, las miniaturas se encuentran estrechamente relacionadas con las principales actividades que se llevadas a cabo en un monasterio del siglo IX y X: el estudio y la meditación.

A finales del siglo VIII Carlomagno a través de la Admonitio Generalis estableció una reforma educativa y eclesiástica que afectó los distintos cenobios que se encontraban dentro de su territorio y el conquistado. Los mismos debían adoptar como regla monástica la de san Benito e igualmente debían establecer escuelas en las que se enseñarían las distintas materias del trivium y el quadrivium. Los cenobios a los que pertenecieron los cinco códices miniados de la Psychomachia aquí estudiados, San Amand, San Denis, San Remi, San Laurent, San galo y Reichenau, no fueron la excepción y en los mismos se adoptó e implementó la capitular del emperador $^{215}$.

Un siglo más tarde, época en que se iluminaron los ejemplares más antiguos de la Psychomachia (Burm.Q.3, Ms. 9987-91, Ms. Lat. 8085) se puede corroborar que las disposiciones de la Admonitio Generalis se continuaban ejecutando, y las escuelas monásticas de estos cenobios mantenían su actividad intelectual. En las

\footnotetext{
${ }^{215}$ Platelle, Henri. Le temporel de l'abbaye de Saint-Amand des origines a 1340. París: Librairie d'Argences, 1962. p. 65. Clark, J. M. The Abbey of St. Gall as a Centre of Literature and Art. Cambridge: Cambridge University Press, 1926. p. 93. D'AYZAC, Félicie-Marie-Emilie. Histoire de l'abbaye de Saint-Denis en France. Tome Premier. Paris: Imprimerie Impériale, 1860. p. 61.
} 
mismas se recibían jóvenes para ser instruidos en gramática, cálculo y música. Dos hijos de Carlos el Calvo, quien era nieto de Carlomagno, se educaron en la abadía de San Amand ${ }^{216}$. Durante este período igualmente se aprecia cómo muchos de los maestros o scholars (erudito o sabio) de estos centros visitaban otros como parte de su proceso de formación para exponerse a nuevos conocimientos por medio de la consulta de los distintos códices ${ }^{217}$. El desplazamiento de individuos no sólo enriquecía a estos personalmente, sino que igualmente permitía el intercambio intelectual por medio de la enseñanza, pero también a través de los manuscritos que bien éste podía aportar al nuevo monasterio como regalo o para ser copiados, o recabar ejemplares su monasterio. Y es que es de conocimiento pleno que estas abadías poseían scriptoriums cuya producción de códices se encontraba destinada a satisfacer la exportación, pero sobre todo las necesidades de la escuela y la biblioteca del propio monasterio ${ }^{218}$.

La copia de manuscritos para uso de las escuelas y las bibliotecas monacales es producto de una demanda: la necesidad de obras que sirvan en el proceso de instrucción de los jóvenes alumnos e igualmente de los monjes de la comunidad y además los mismos proveían los textos utilizados para la práctica de la meditación. Es así como se identifican en estos distintos monasterios, a parte de las Sagradas Escrituras, textos de autores clásicos, de los padres de la iglesia y de poetas cristianos tardo antiguos como Prudencio ${ }^{219}$.

Las obras de los autores clásicos y los poetas tardo antiguos, en conjunto con el salterio eran esenciales para la enseñanza de las materias del trivium. El primer

\footnotetext{
${ }^{216}$ PlATELLE. Le temporel de l'abbaye de Saint-Amand..., p. 65.

${ }^{217}$ FrIEND, A.M. "Carolingian Art in the Abbey of St. Denis", Art Studies; Medieval, Renaissance and Modern Vol. 1 (1923), p. 73. Platelle. Le temporel de l'abbaye de Saint-Amand..., p. 65. Clark. The Abbey of St. Gall as a Centre..., p. 10.

${ }^{218}$ MCKITTERICK. "Script and Book Production", Carolingian Culture: Emulation and..., pp. 242243.

${ }^{219}$ O'Sullivan. Early Medieval Glosses..., p. 11. Platelle. Le temporel de l'abbaye de SaintAmand..., p. 68. CLARK. The Abbey of St. Gall as a Centre..., pp. 91-124. Poussin, Clovis (Abbé). Monographie de l'abbaye et de l'église de St-Remi de Reims, précédée d'une notice sur le saint apôtre des Francs d'après Flodoard. Reims: Lemoine-Canart, 1857. Pp. 70-71. D'AYZAC. Histoire de l'abbaye de Saint-Denis..., p. 15.
} 
paso en la instrucción de los niños en estos cenobios era aprender de memoria los rudimentos de la fe: el credo, el Padre Nuestro y los salmos. Esto lo lograban por medio de la asistencia diaria al oficio divino y la repetición constante de los mismos. Una vez memorizadas estas oraciones e himnos, se les enseñaba a leer y escribir en latín, adentrándolos así a la gramática. En la antigua Roma, las fábulas de Esopo eran utilizadas como el texto primario para aprender a leer. En el mundo cristiano, éstas fueron remplazadas por el salterio y por las obras de Prudencio, como fue el caso en monasterio de San Galo lugar en el que se iluminó el Cod. $264^{220}$. Los elementos rítmicos de los textos escritos en verso facilitan la memorización de los mismos, auxiliando así la memoria del individuo ${ }^{221}$. A esto se ha de sumar el hecho de que los eran leídos en voz alta, por lo cual se resaltaba la musicalidad de los versos, incidiendo así en la experiencia sensorial del receptor.

Con relación a Prudencio, se ha de señalar el corpus de su obra se compone de una serie de poemas que versan sobre distintas rememoraciones importantes del mundo cristiano como la Natividad o la Epifanía y la vida de distintos santos y mártires. La Psychomachia es su única obra con un carácter alegórico cuyos protagonistas son personificaciones de conceptos abstractos. De los cinco manuscritos iluminados con copia de la Batalla del alma, en cuatro se incluyeron otros de los poemas de Prudencio. La presencia del resto de las obras en verso del este poeta, en conjunto con listas de palabras contemporáneas a la obra de dicho autor - como en Ms. 10066-77-, o un tratado de gramática -como en Burm.Q.3- reafirma el vínculo de los escritos de éste con el aprendizaje de la lectura, escritura y la gramática.

En los cinco manuscritos que hemos mencionado, a pesar de incluir otros textos de Prudencio, sólo se iluminaros los versos del poema alegórico. En Ms. 10066-77 ocurre algo muy peculiar, y es que se incluyen imágenes en otro texto cuyo contenido tienen un marcado interés alegórico: el Physiologus. Por lo tanto, se puede

\footnotetext{
${ }^{220}$ GIBSON-WOOD. "The 'Utrecht Psalter' and the Art of Memory..., p. 11. Clark. The Abbey of St. Gall as a Centre..., p. 101.

${ }^{221}$ RICHE, Pierre. "Le rôle de la mémoire dans l'enseignement médiéval", Jeux de mémoire. Aspects de la mnémotechnie médiévale. dirección de: Bruno Roy y Paul Zumthor. Montréal: Presses de l'Université de Montréal, 1985. p. 143.
} 
afirmar que únicamente se incluyen plasmaciones visuales en aquellas obras cuyo contenido abstracto podría ser más complicado de aprender. Los elementos visuales de estas obras literarias, sobre todo las miniaturas, ayudaría al lector a tener una mayor comprensión del texto, transmitiendo de forma más eficiente el significado de las palabras e incluso permitiendo la memorización de las mismas con mucha mayor facilidad $^{222}$.

El análisis de las distintas miniaturas del prefacio y el poema de la Psychomachia revelan un marcado interés por el detalle y ciertos elementos, cómo lo son las acciones y gestos de las distintas protagonistas. A través de los mismos se realzan las distintas particularidades que convierten las miniaturas en imagines agentes, imágenes memorables cercanas a la realidad que por medio de sus particularidades exaltan los sentidos, pues solamente a través de su cualidad memorable podrían las mismas inscribirse en la mente de una persona. Al observar las diversas miniaturas, a primera instancia podemos pensar que muchas son sumamente parecidas. No obstante, si observamos con detenimiento, vemos que, por medio de los gestos, es posible hacer una lectura más certera de las acciones plasmadas, coincidiendo las mismas con los tituli e igualmente con los versos, conservando visualmente así la esencia del poema. Cabe resaltar que en las distintas miniaturas hay un marcado interés por los detalles, no sólo a través de los gestos, sino también de los objetos u personajes necesarios para transmitir el ad res de los versos que acompañan. Esto incluso sucede en los códices del siglo IX cuya calidad estética, en comparación con los del siglo $\mathrm{X}$, es inferior. Es así como en la escena con la captura de Lot se plasman los reyes captores, en los distintos encuentros entre vicios y virtudes se dibujan las armas descritas en el poema: ya bien sean una lanza, o espada, Superbia como si de un atributo se tratara se representa con su corcel y Avaritia con las monedas y la bolsa de los despojos.

Las miniaturas de los manuscritos del siglo $\mathrm{X}$ en cuanto a la plasmación de particularidades trascienden las de los códices más antiguos. En Ms. 10066-77 y Cod.

\footnotetext{
${ }^{222}$ MCKITTERICK. "Script and Book Production”, Carolingian Culture: Emulation and..., pp. 225 y 231. CAMILLE. "Seeing and Reading..., p. 38.
} 
264 los miniaturistas prestaron mayor cuidada a la plasmación de detalles y sobre todo de la exaltación de la fealdad, lo grotesco y la monstruosidad, denotando así un particular interés en la exaltación de los sentidos en el individuo que contemplara las imágenes de estos dos códices. En estos dos manuscritos encontramos leves diferencias gestuales y composicionales con relación a las miniaturas de los códices Burm.Q.3, Ms. 99987-91 y Ms. Lat. 8085. Esta diferencia estriba principalmente en la elección de unos versos en lugar de otros, prefiriéndose en la mayoría de los casos el momento de mayor tensión o morbosidad, mejor expresado en la miniatura 81 en el que se representó justamente el instante en el que Discordia está siendo desmembrada. A esto se ha de añadir que en estas iluminaciones se utilizan los elementos estéticos, sobre todo el uso del color y la línea, para resaltar las distintas cualidades que hacen de estas representaciones unas memorables.

El interés por recoger visualmente el ad res de los versos lleva a la integración de la sinestesia, en donde por medio de la imagen de la miniatura se insertan detalles que evocan a otros sentidos, particularmente la audición y el olfato. Si bien esto no es nobel, -puesto que el mismo Prudencio en el poema utiliza la sinestesia para crear una impresión en el espectador como es el caso del verbo percutio para referirse al golpe proferido en el yelmo, y el cual a la misma vez evoca el sonido producido por el mismo-, el miniaturista tradujo visualmente dicho recurso y ahora no son las palabras las que evocan el sonido o el olor, sino la imagen captada por la visión.

Las distintas miniaturas que narran visualmente el poema se insertaron intercaladas con el propio texto. El alumno o monje que utilizara estos códices no solamente leería las palabras de los versos, sino que igualmente leería la imagen. En el capítulo anterior afirmamos que en estos manuscritos existe una relación intrínseca entre palabra-imagen-memoria. Este vínculo cognitivo a priori se aprecia por medio del mise-en-page; y sin embargo, trasciende el mismo. El interés para que el contenido del poema se memorice, aparte de manifestarse en las representaciones, también se aprecia en los distintos tituli que acompañan las mismas. Identificamos algunos casos en los que una acción queda unificada en el título por medio del uso repetitivo del mismo verbo. El ejemplo más contundente es el de increpat, palabra 
utilizada en las distintas imágenes donde las acciones de los protagonistas indican que pronuncian palabras, especialmente con relación a una reprimenda o amonestación, a pesar de que la misma no es la que utilizó Prudencio en el poema. Encontramos que algo similar ocurre con el verbo alloquitur, el cual se utiliza para establecer que los personajes dicen algo, pero con un carácter positivo. La repetición de los mismos términos serviría a los alumnos en formación a aprender y recordar con mucha más facilidad estas palabras.

La unificación de palabras e imágenes no sólo ocurre con verbos, asimismo hemos identificado sustantivos como es el caso del término pauperibus en las miniaturas 65 y 69 . Los términos utilizados por el poeta en los versos correspondientes a estas dos imágenes para designar a los pobres y necesitados son: inopes y egenis. En los tituli de los tres códices del siglo IX el copista de estos optó por utilizar una palabra muy conocida dentro del contexto monacal de corte benedictino, pues la práctica de la limosna y la caridad a los pauperis era una práctica habitual promovida por la misma regla de san Benito. Para transmitir la noción principal, en el ad res de estos versos, se utilizó el sustantivo que probablemente resultaba más familiar para aquellos en proceso de aprendizaje.

Con relación a los tituli y las miniaturas, por último, cabe destacar que en muchas de las imágenes en los títulos de éstas se utilizan verbos y adjetivos diferentes a los empleados por Prudencio en los versos. Cuando esto ocurre, nos hemos percatado de que la palabra utilizada por el copista posee un significado más profundo, pudiendo referirse a dos o más acciones o descripciones descritas en los versos. Cuando se intercambian vocablos ocurre también que los empleados en el título expresan con mayor viveza el ad res de lo expresado en el poema. Algunas miniaturas en las que esto ocurre son la: 12, 14, 17, 21, 24, 26, 36, 43 y 78.

El poema de la Psychomachia en sí mismo emplea un sin número de elementos propios de las mnemotecnias clásicas. Al fin y al cabo, el mismo Prudencio, gracias a su formación en retórica, debía conocer los principios de las técnicas para resaltar la memoria artificial, las mnemotecnias. Por medio del análisis de las miniaturas, 
hemos podido identificar cómo muchos de estos recursos mnemónicos se tradujeron a la imagen. Ahora sólo nos queda contestar, ¿cómo entonces podrían haber memorizado el poema?

La exposición de Carol Gibson-Wood sobre el uso de las mnemotecnias en el salterio de Utrecht nos brinda un acercamiento a como pudo haber sido este proceso. Esta historiadora del arte trató de reconstruir cómo el texto de este salterio pudo haber sido aprendido de memoria a través de las miniaturas del mismo. Ella entiende que el usuario del texto, debía estar familiarizado al menos con los rudimentos del vocabulario latino. El individuo debía leer y repetir cada verso del salmo que estuviera memorizando para así inscribir en su mente las palabras, comenzando entonces por la memorización ad verba. Tras repetir las palabras, contemplaría la imagen correspondiente al salmo, identificando en ella cada uno de los versos del texto. Por medio de este ejercicio quedaría fijada en su mente las distintas figuras de las miniaturas. En el proceso de memorización, se comenzaba por la memorización ad verba de un texto, pero éste se perfeccionaba a través de la memoria rerum ${ }^{223}$. En el salterio de Utrecht, esto se logra en la medida en que el individuo intenta a partir de la imagen, y sin mirar el texto, pronunciar el salmo correspondiente a la miniatura $^{224}$.

${ }^{223}$ CARRUTHERS. The Craft of Thought..., p. 31.

${ }^{224}$ Carol Gibson-Wood utiliza los versos y la miniatura del salmo 95 para reconstruir el proceso de memorización: "I would hypothesize that the Psalter was meant to be used in something like the following manner. One or more young novices in the schoolroom of a Carolingian monastery is at a point in his studies at which he has mastered the rudiments of Latin words but is still working on his reading, the Psalter being the book from which he learns to recognize and pronounce Latin words. At the same time, he is trying to commit to memory the words of the Psalms. After reading and repeating each line, he looks at the corresponding image. "Elevaverunt flumina domine, elevaverunt flumina vocem suam, 'he reads, and fixes in his mind the amusing figures of the river gods raising their voices. So he proceeds, then tries to repeat the whole psalm without looking at the words, but with the illustrations still before him. The figure of Christ with his attributes helps get him started, reminding him to include that hard world praecinscit, while the memorable river gods and figures in boats make him remember that this is the psalm in which lines about floods and voices lifting up are repeated in several variations, and so on. Finally, he closes the book and recites the psalm completely from memory, the lively images now before his mind's eye, where they help trigger recall of those words with which he had become used to associate them." GIBSON-WOOD. "The 'Utrecht Psalter' and the Art of Memory..., p. 14. 
Un proceso similar se pudo haber dado con la Psychomachia. Cómo se ha discutido anteriormente, éste texto formaba parte del currículo de enseñanza de los jóvenes oblatos y aspirantes a monje de los distintos monasterios en los que se elaboraron o utilizaron. Los mismos códices corroboran la importancia de la obra de Prudencio para la educación del trivium, específicamente la enseñanza de la gramática. Por lo tanto, los usuarios de los mismos ya debían poseer rudimentos en latín y muy probablemente conocían el salterio de memoria.

En el caso de los salmos estos debían memorizarse palabra por palabras, pues eran necesarios para el rezo del oficio divino. Sin embargo, en el caso de la Psychomachia, por su contenido tropológico es mucho más probable que los jóvenes memorizaran el ad res, las nociones generales del mismo. Un procedimiento semejante al que Gibson describe, entonces, pudo haber ocurrido con la memorización del poema. Los jóvenes aprendices leerían los versos del poema que acompañaban a tal o cual miniatura. Es sumamente probable que la lectura fuera de tipo audible. Luego de leer los versos, pasarían a leer los tituli. Una vez familiarizados con las imágenes de las palabras, con los versos y títulos, procederían a la contemplación de la miniatura, identificando en ésta el verso o versos que recogen la imagen, que en última instancia es la plasmación visual de la noción general, del ad res de esos versos. Una vez dominado este ejercicio, pasarían a la etapa en que, a través del título de la miniatura y la imagen, los jóvenes serían capaces de recordar la esencia del poema, pues al final, recordar cosas, la memorización ad res, significa recordar las palabras principales del argumento, la esencia del texto o la historia ${ }^{225}$.

La memorización de la Psychomachia únicamente no auxiliaría la mente de aquellos que se encontraban aprendiendo a leer y escribir, sino que asimismo asistirían a los monjes en el ejercicio de la meditación. Al inicio de esta sección establecimos que la batalla de los vicios y las virtudes muestra un carácter de peregrinar espiritual, a través del cual el lector debe ir venciendo los diversos obstáculos que le permitirán en última instancia obtener la sabiduría. En la discusión

${ }^{225}$ CARRUTHERS. The Book of Memory..., p. 73. 
sobre el contexto histórico de la Psychomachia, expuesta en el capítulo 3, sacamos a colación el hecho de que el público al que Prudencio dirigió sus obras se desconoce. Sin embargo, el análisis de las miniaturas y la estructura del poema apuntan a que este poema debió estar dirigido a individuos que practicaban el ascetismo, ya que el mismo poeta al final de su vida se retiró y llevó una vida ascética. El primer encuentro entre un vicio y una virtud, el combate entre Fides y Cultura Deorum consta de 39 versos los cuales se ilustraron con tres miniaturas. En el siguiente combate vemos un incremento, el encuentro entre Pudicitia y Libidinem se plasma visualmente con seis miniaturas intercaladas en los sesenta y nueve versos. El detalle con el que se plasman las subsiguientes batallas es más minucioso, el número de versos y de miniaturas de estos aumenta. Los últimos tres combates: Sobrietas vs. Luxuria, Largitas vs. Avaritia y Concordia vs. Discordia, son los que poseen el mayor número de imágenes. Prudencio y los miniaturistas presentaron especial cuidado a la hora de describir las artimañas con las que se presentan Luxuria, Avaritia y Discordia. O sea, presenta a lector las distintas maneras en las que éste puede ser seducido por la lujuria o suntuosidad, la codicia o avaricia, y la discordia. El autor, al inició del poema, indica al lector que el modo de vencer los monstruosos vicios ésta al alcance nuestro si se pueden describir dichas figuras ${ }^{226}$. En la oración de gracia al final del poema se recuerda nuevamente al lector la importancia de que éste conozca "los peligros que se ocultan en la envoltura del cuerpo y los azares de la lucha del alma 227 ".

El orden de los combates y la extensión de los mismos se organiza según el grado de dificultad de los vicios a vencer. Esto no es un recurso único de Prudencio, pues como se estableció anteriormente, Evagrio utilizó un sistema parecido, en el que organizó los vicios de acuerdo al grado de dificultad que suponía cada uno a la hora de conquistar el mismo, y eventualmente este modelo fue utilizado por Casiano y Gregorio Magno. Las últimas batallas, específicamente aquellas en contra de Luxuria

\footnotetext{
${ }^{226}$ Prudencio, Aurelio. Psychomachia, vv. 18-20. Edición consultada: Obras Completas de Aurelio Prudencio, traducción de: A. Ortega, introducción general de: I. Rodríguez. Ed. bilingüe. Biblioteca de Autores Cristianos 427. Madrid: Editorial Católica, 1981.

227 "Tu nos corporei latebrosa pericula operti luctantisque animae voluisti agnoscere casus". Psychomachia, vv. 891-892. Obras Completas de Aurelio Prudencio..., pp. 360-361
} 
y Avaritia, responden a aquellos vicios que resultaban más dificultosos de vencer para aquellos que llevaban una vida asceta, puesto que el ascetismo consiste en la renuncia a los bienes materiales, la carne y el cuerpo, y dedicación a la vida espiritual, el cultivo del alma. Ya Katzenellenbogen se había percatado del cuidado particular que prestó Prudencio a los combates contra estos dos vicios y sobre todo el hecho de que en algunas instancias del combate estas fuerzas perniciosas por corto periodo logran establecerse con éxito ${ }^{228}$. Eventualmente, estos dos vicios en las portadas de los templos románicos, serán plasmados en los Juicios Finales, junto a los condenados. En contraposición, si estos vicios son los más dificultosos de vencer, también se exhorta al individuo a la práctica de las cualidades virtuosas de las virtudes que les vencen: Sobrietas, la sobriedad y Largitas la generosidad.

El último combate también se encuentra en este ascenso a la virtud, sobre todo a aquellos que habitan en comunidad. En el mismo la Discordia se infiltró entre las huestes de las virtudes para herir a la Concordia y sembrar la discordia y la desunión entre el ejército. A pesar de lograr haber lesionado a la virtud, el vicio es capturado y vencido. La muerte de este vicio es la más mórbida y por ende memorable de todos los vicios, como si recordara al espectador el fin de todo aquel que ose sembrar este mal dentro de la claustra, sustantivo que en el contexto en el que se escribió el poema se refiere a los muros de la ciudad, pero que en el contexto monacal en el que fueron utilizado también puede interpretarse como la clausura y el claustro en sí. Por lo tanto, el monje, para obtener la sabiduría y alcanzar el conocimiento de Cristo, debía primeramente conocer los vicios que podían afectar su alma y vencer los mismos. Sólo así podría contemplar a Sapientia en su trono.

Como parte del currículo de enseñanza de los distintos cenobios a los que pertenecieron nuestros cinco códices, se encontraba la enseñanza de la retórica. En el contexto monacal, esta materia se vinculó con la moral, y las técnicas de la misma, sobre todo aquellas que mejoraban y aumentaban la memoria artificial, fueron

228 "Prudentius had already given an impressive picture of the dangerous misrule of Luxuria and Avaritia, who succeed for a certain time in establishing themselves successively as tyrants". Katzenellenbogen. Allegories of the Virtues and Vices in Mediaeval Art..., p. 58. 
utilizadas por los religiosos de estas comunidades para memorizar los conceptos morales por los cuales sus vidas debían regirse. El almacenamiento de estos conocimientos brindaba a los monjes las bases por las cuales estos debían ejercer los juicios morales.

El poema de la Psychomachia claramente tiene un carácter tropológico. Por lo tanto, el aprender de memoria la obra de Prudencio brindaba al individuo de las herramientas necesarias para que estos conocieran y pudieran combatir las fuerzas perniciosas a las que en lo más adentro de su ser se enfrentaban, reproduciendo así en sus vidas los comportamientos que las erradicarían. El mismo autor afirma en el prefacio del poema que las imágenes dibujadas en la Psychomachia son el modelo de vida a seguir por el fiel ${ }^{229}$.

El conocimiento de los conceptos morales tratados en el poema de Prudencio en el contexto monacal serviría para el ejercicio de la meditación, pues permitiría el desarrollo de pensamientos creativos en torno a Dios. Al fin y al cabo, el fin del poema es alcanzar a Sapientia, virtud que en la Edad Media es Cristo. Estos pensamientos creativos se servían de las imágenes mentales, fruto de las experiencias ya vividas, de los conocimientos obtenidos y almacenados en lo más profundo del ser: el alma. Anteriormente, hemos establecido cómo estos saberes se almacenaban a través de la elaboración de imágenes mentales contenedoras de la esencia, el ad res, de los mismos. Sin embargo, el acervo de tropos también se nutría de imágenes reales, las cuales facilitaban y aceleraban el proceso de memorización pues el religioso no tenía que elaborar una complicada imagen mental, sino que ya tenía a su disposición una representación que resumía el contenido de lo que deseaba aprender de memoria ${ }^{230}$.

Los distintos elementos mnemónicos de las miniaturas de los vicios y las virtudes en estos manuscritos, identificados a lo largo de todo este capítulo facilitaron a los monjes recordar con facilidad el contenido de la obra. En el proceso de

229 "Haec ad figuram praenotata est línea / quam nostra recto vita resculpat pede". PRUDENCIO. Praefatio vv. 51-52. Obras Completas de Aurelio Prudencio..., p. 310.

${ }^{230}$ YATES. El arte de la memoria..., p. 103. 
meditación, es muy probable que estos con anterioridad hubieran leído en voz alta el poema, y los mismos ya debían encontrarse familiarizados con su contenido. Una vez retirados para el ejercicio de la meditación, estos sólo tendrían que pensar en las imágenes provistas en el códice. Sus mentes tendrían un referente visual de las artimañas de las que se sirve el vicio: Luxuria es dada a los excesos, Avaritia a la acumulación de aquello que no es de ella, y de los comportamientos que contrarrestan los mismos: la avaricia y el exceso se vence imitando el comportamiento de Largitas, por medio de la caridad a los más necesitados.

El componente afectivo es muy importante para el proceso de memorización. Los distintos elementos antes mencionados que hacen de estas imágenes unas agentes y memorables tienen como fin exaltar las emociones para que el espectador conecte con lo plasmado en la página del códice y lo inscriba en su mente. A esto se ha de sumar el uso por parte de los miniaturistas de temas iconográficos, símbolos y atributos ya conocidos, los cuales por su familiaridad facilitan al individuo la fijación de la imagen en su mente. En última instancia estas imágenes debían ser memorizadas por los jóvenes aprendices para avanzar en su aprendizaje, el cual le proveería de las herramientas necesarias para poder desentrañar las Sagradas Escrituras y tener un mejor entendimiento de la palabra de Dios. En términos morales, la memorización de la Batalla del alma proveía al individuo, tal y como lo indica el mismo poeta, de un referente literario y visual sobre aquellos males que afectan el caminar en la fe. El proceso de meditación tiene un elemento contemplativo. En este caso, el monje no sólo meditaría en torno a los versos del poema, sino que las imágenes en los manuscritos le llevarían a contemplar concretamente la lucha interna abstracta en lo más profundo de su alma, recordándole como si de un signo o señal se tratará de que sólo a través de la conquista de las pasiones, venciendo a los vicios, se podría alcanzar a Sapientia. 


\section{Capítulo 5}

\section{PSYCHOMACHIAS EN PIEDRA}

Las obras de Prudencio, especialmente la Psychomachia, fueron sumamente famosa dentro del contexto monacal. La popularidad de los textos de este poeta resultó en la copia y difusión de los mismos por todo el continente. También sirvió como modelo e inspiración para la creación de nuevos textos sobre el tema de los vicios y las virtudes. La Psychomachia de Prudencio no sólo es la primera obra literaria que trata el tema, sino que también es en ésta donde por primera vez se encuentran representaciones gráficas de estos conceptos abstractos. Este poema además de suscitar la creación de otras obras literarias, las miniaturas de los códices ilustrados también sirvieron para la creación de nuevas imágenes inspiradas en el poema y las miniaturas.

El tema de la batalla de los vicios y las virtudes de los manuscritos iluminados a principios del siglo XII pasó a representarse en la escultura monumental, específicamente en las fachadas de templos. El cambio de medio requirió igualmente un cambio del lenguaje icónico, y para que esto fuera posible los escultores románicos simplificaron y sintetizaron el poema en un momento específico de la narrativa: el final del combate y el triunfo de las virtudes sobre los vicios ${ }^{1}$. En las arquivoltas de las portadas de iglesias románicas, usualmente en números pares que responden al resto del programa iconográfico, se aprecian las virtudes vestidas como guerreras: con cota de malla, espada o lanza y escudo, aplastando a los vicios vencidos.

\footnotetext{
${ }^{1}$ En su revisión al trabajo de Paul Deschamps, Pierre Bouffard coincide con éste y admite que dada las limitaciones del medio los escultores tuvieron que simplificar el tema. BOUFFARD, Pierre. "La Psychomachie sur les portails romans de la Saintonge" Zeitschrift Für Schweizerische Archäologie Und Kunstgeschichte = Revue Suisse D'art et D'archéologie = Rivista Svizzera D'arte E D'archeologia = Journal of Swiss Archeology and Art History, Vol. 22 №. 1-3 (1962), p. 19. DESCHAMPS, Paul. Le combat des vertus et des vices sur les portails romans de la Saintonge et du Poitou. Caen: Henri Delesques, Imprimeur-Éditeur, 1914. p. 4.
} 
El tema de la Psychomachia en la escultura románica gozó de mucha popularidad en el sur-oeste de Francia, zona en la que se encuentran los primeros ejemplos pertenecientes a las primeras décadas del siglo XII². Según Katzenellenbogen el ejemplo más temprano, con fecha de 1130, se encuentra en las arquivoltas del arco de una ventana del transepto sur de la iglesia de St. Pierre d'Aulnay (Fig. 16) ${ }^{3}$. En éste y otros ejemplos en los arcos de las ventanas de algunos templos como en la iglesia de Gripperie-Saint-Symphorien (Fig. 17) o Saint-Nazaire de Corme-Royal (Fig. 18), la arquivolta con las virtudes triunfantes está acompañada por otras arquivoltas con elementos decorativos ${ }^{4}$. Las representaciones en piedra de la Psychomachia en esta región suelen plasmarse en números de cuatro, seis u ocho que responden al programa iconográfico del espacio en el que se ubican e igualmente se vinculan directamente con la simetría de la portada. Paul Deschamps explica la presencia de pares de virtudes de la siguiente manera: "Des nécessités d'harmonie dans la décoration leur imposaient l'obligation de rendre le symbolisme uniforme ${ }^{5}$ ".

Las virtudes victoriosas galas siguen un modelo bien establecido en el que éstas se encuentran en posición hierática, visten túnicas, llevan sobre su cabeza un casco y sujetan las armas con las que han vencido a sus enemigas: espada o lanza y escudo. Se plasman de pies pisoteando a los vicios. Estas fuerzas perniciosas se representan como seres monstruosos, desfigurados, retorciéndose de dolor, plasmación que sigue muy de cerca la descripción de Prudencio ${ }^{6}$. A pesar de que los vicios y las virtudes de esta región siguen en mayor o menor grado este modelo,

\footnotetext{
${ }^{2}$ Bouffard. "La Psychomachie sur les portails romans..., p. 19. KATZENELLENBOGEN, Adolf. Allegories of the Virtues and Vices in Mediaeval Art, from Early Christian Times to the Thirteenth Century. New York: W.N. Norton \& Company, Inc., 1964. p. 58. DESCHAMPS. Le combat des vertus et des vices sur les portails romans..., p. 3.

${ }^{3}$ Katzenellenbogen. Allegories of the Virtues and Vices in Mediaeval Art..., p. 17. Deschamps. Le combat des vertus et des vices sur les portails romans..., pp. 5-6.

${ }^{4}$ Bouffard apunta al carácter sumamente decorativo del tema en la iglesia de St. Pierre d'Aulnay. Según el: "Le parti décoratif est ici très clair et l'itégration dans l'architecture est telle que ces figures ont perdu toute grâce, toute élégance et toutes les subtilités plastiques...". BOUFFARD, Pierre. "La Psychomachie sur les portails romans..., p. 20.

${ }^{5}$ DESCHAMPS. Le combat des vertus et des vices sur les portails romans..., p. 4.

${ }^{6}$ Bouffard, Pierre. "La Psychomachie sur les portails romans..., p. 19. DESCHAMPS. Le combat des vertus et des vices sur les portails romans..., p. 4.
} 
encontramos que el lenguaje pictórico de los ejemplos más tardíos muestra leves variaciones. La iglesia de St. Pierre d'Aulnay es uno de los mejores ejemplos para entender estas diferencias (Figs. 16 y 19).

En la iglesia de Aulnay la Psychomachia se representó dos veces. Las figuras de los vicios y las virtudes más antigua de este templo, en las arquivoltas de la ventada del arco del transepto y aproximadamente de 1130, son robustas y en las mismas dominan las líneas rectas integrándolas por completo a la arquitectura (Fig. 16). La segunda representación en St. Pierre se plasmó 10 años más tarde en la fachada occidental del templo (Fig. 19) ${ }^{7}$. En lugar de cuatro, aquí se insertaron seis virtudes las cuales han perdido la actitud desafiante de las cuatro de la ventana. La composición sigue siendo la misma, la virtud armada se posa sobre el vicio vencido, no obstante, el lenguaje pictórico ha cambiado. Continúan portando las armas y los cascos de sus antecesoras, pero las mismas son figuras largas estilizadas, efecto que se consigue a través de los pliegues de sus túnicas y mantos. Las virtudes que se encuentran en la clave del arco sujetan una corona, corona que las vincula directamente con el resto del programa iconográfico de la portada, elemento notorio que no encontramos en las representaciones más antiguas.

Ya Bourffard había resaltado que estas primeras Psychomachias en los arcos de vanos de templos románicos, como la de St. Pierre d'Aulnay, Gripperie-SaintSymphorien o Saint-Nazaire de Corme-Royal (Figs. 16, 17 y 18), tienen un carácter sobre todo "decorativo" 8 ". Sin embargo, cuando el tema se inserta en las fachadas de estos templos lo acompañan otros motivos iconográficos, cómo los Ancianos del Apocalipsis, el Cordero con ángeles, las vírgenes sabias y necias, el zodiaco o temas apocalípticos ${ }^{9}$.

\footnotetext{
7 "The figured archivolts of the west porch of St. Pierre at Aulnay, which was built about ten years later than the south transept...". KATZENELLENBOGEN. Allegories of the Virtues and Vices in Mediaeval Art..., p. 18.

${ }^{8}$ BOUFFARD, Pierre. "La Psychomachie sur les portails romans..., p. 20.

${ }^{9}$ Katzenellenbogen. Allegories of the Virtues and Vices in Mediaeval Art..., p. 18. DesChAMPS. Le combat des vertus et des vices sur les portails romans..., pp. 5 y 9.
} 
La mayoría de estas representaciones de las virtudes triunfantes se insertan en la fachada de templos que se encuentran en la ruta de peregrinación a Santiago de Compostela. Dada su monumentalidad, su ubicación no sólo en relación con el templo, sino también geográficamente, cabe suponer que éstas gozaron de un público numeroso. Para Katzenellenbogen, "special function of the triumph of the virtues is now that of encouraging the faithful, even before they enter the church, to emulate the virtues in view of the coming Judgment Day ${ }^{10 " . ~ P a r a ~ J o a n n e ~ N o r m a n ~ l a ~ b a t a l l a ~}$ en el alma del hombre, la Psychomachia, igualmente es una lucha espiritual que se da en los más adentro del ser, lucha que también se experimenta en el peregrinaje ${ }^{11}$. Para el caso de las representaciones del tema en el arte románico del sur-oeste de Francia, esta autora vínculo las mismas con la batalla interior experimentada por los peregrinos en dirección a Santiago ${ }^{12}$. Por ende, las Psychomachias plasmadas en las fachadas de estos templos responde a la circunstancia particulares de los peregrinos que las contemplan. A pesar de que el tema en la escultura románica abunda en las fachadas de las iglesias románicas ${ }^{13}$ también existen casos en el contexto monacal.

A través de nuestra investigación se han logrado identificar dos Psychomachias en piedra en claustros de abadías: la abadía de Saint Aubin d'Angers (norte de Francia) y el monasterio de Sant Cugat del Vallès (España). Las imágenes se vinculan directamente con los espectadores, es a través de los individuos que éstas

\footnotetext{
${ }^{10}$ KAtZenellenbogen. Allegories of the Virtues and Vices in Mediaeval Art..., p. 18.

${ }^{11}$ NORMAN, Joanne S. Metamorphoses of an Allegory: The Iconography of the Psychomachia in Medieval Art. New York: P. Lang, 1988. p. 29.

${ }^{12}$ NoRman. Metamorphoses of an Allegory: The Iconography of the Psychomachia..., p. 5.

${ }^{13}$ A través de la bibliografía consultada se han identificado 17 iglesias románicas en Francia en las que en algunas de sus portadas se plasmaron la victoria de las virtudes sobre los vicios. Estos templos son: 1) Saint-Gilles d'Argenton-les-Vallées, 2) Saint-Pierre d'Aulnay, 3) Abadía Saint-Maurice en Blasimon, 4) Notre Dame de Castelvieil en Aquitania, 5) Saint-Martin de Chadenac, 6) iglesia de la Madeleine en Châteaudun, 7) Saint-Nicolas de Civray, 8) Saint-Nazaire de Corme-Royal, 9) SaintEsprit de Fenioux, 10) Saint-Martin de Fontaines-d'Ozillac, 11) Saint-Hilaire de Melle-sur-Béronne, 12) Notre-Dame-de-la-Couldre en Parthenay, 13) Saint-Pierre de Pérignac, 14) Saint-Pierre de Pontl'Abbé-d'Arnoult, 15) iglesia de Saint-Pompain, 16) iglesia de Saint-Symphorien de SaintSymphorien, 17) Saint-Germain de Varaize. Ver: HouriHANE. Virtue \& Vice... Norman. Metamorphoses of an Allegory..., pp. 27-47. BOUFFARD. "La Psychomachie sur les portails romans... KatZEnellenbogen. Allegories of the Virtues and Vices in Mediaeval Art..., pp. 1719. DESCHAMPS. Le combat des vertus et des vices sur les portails romans....
} 
reciben un sentido vivo y un significado ${ }^{14}$. En el caso de las esculturas de la batalla del alma en las portadas de las iglesias ya hemos indicado poseen una relación estrecha con los diversos peregrinos que visitaban los templos. Anteriormente establecimos que las imágenes de los vicios y las virtudes en los manuscritos iluminados de la Psychomachia se encontraban dirigidas a los distintos miembros de la comunidad de religiosos en los que estos códices se elaboraron o a los que pertenecieron. Los mismos se entrelazan directamente con el currículo de enseñanzas de las distintas abadías. Las representaciones en piedra de la Batalla del alma en el interior de cenobios debieron tener una función similar.

Los dos ejemplos identificados muestran ciertas diferencias, además de encontrarse en zonas geográficas distantes, la composición las Psychomachias en claustro de Saint Aubin y Sant Cugat es muy distinta. En el caso francés, las virtudes victoriosas sobre los vicios son seis, se incluyeron en un arco y siguen el modelo ya antes mencionado típico de la escultura románica del sur-oeste de Francia. En Sant Cugat siete virtudes victoriosas coronadas sobre siete vicios vencidos antropomorfos se labraron en tres de las cuatro caras de un capitel de la galería sur. Estas representaciones de la Psychomachia no son imágenes aisladas de conceptos morales, sino que responden a un programa iconográfico complejo comprendido en toda el área del claustro.

${ }^{14}$ Belting, Hans. Antropología de la imagen. Madrid: Katz, 2007. p. 71. 


\subsection{Saint Aubin d'Angers}

Hoy en día los únicos espacios de época medieval que sobreviven de la abadía de Saint Aubin d'Angers son la torre y el claustro. Esto se debe a que a finales del siglo XIX la mayor parte del cenobio antiguo se destruyó para edificar una plaza. Esta reconstrucción decimonónica integró el claustro al edificio de la prefectura de gobierno de Angers. Entre los relieves y esculturas románicos que se conservan se encuentra el arco con la Psychomachia.

La historia de este cenobio se remonta al siglo VI, cuando fue fundado por el hijo de Clovis, Childeberto I. En época de Carlomagno la iglesia de Saint Aubin ya gozaba del título de abadía y estaba compuesta por un abad y cincuenta canónigos. En el siglo X el obispo de Angers y el conde de Anjou introdujeron la regla benedictina al cenobio. A partir del siglo XI la abadía gana notoriedad a tal punto que el obispo de Angers tras su nombramiento debía dirigirse al cenobio y luego a la catedral. La posición privilegiada de la que disfrutó la comunidad de Saint Aubin no sólo se manifiesta en su vínculo fundacional con las monarquías francas o su cercana relación con el obispado. El mismo también se corrobora en el propio programa escultórico del claustro ${ }^{15}$.

Los únicos vestigios de la clausura medieval que se conservan son: la arcada de la sacristía, y la puerta y arcos de la sala capitular en la galería este y el arco de la puerta del refectorio en el ala sur. La reforma románica del cenobio se realizó entre 1127 y 1154 por mandato del abad Robert de La Tour-Landry, no obstante, estudios

\footnotetext{
${ }^{15}$ Ver: De Broussillon, Bertrand. Cartulaire de l'abbaye de Saint-Aubin d'Angers. Tomo I. Angers : Germain et Grassin, Imprimeurs-Libraires, 1903. pp. 21-30. HERBECOURT, Pierre d'. Anjou roman. La Pierre-qui-Vire (Yonne): Zodiaque, 1959. pp. 150-170. FANG-CHEN, Wu. "Les Arcades du cloître de l'abbaye Saint-Aubin d'Angers (1128-1151)," Histoire de l'Art: bulletin d'information de l'Institut national d'histoire de l'art, No. 3, 1988, pp. 37-46. TCHERIKOVER, Anat. High Romanesque Sculpture in the Duchy of Aquitaine, c. 1090-1140. Oxford: Clarendon Press, 1997. p. 88. MCNEILL, John. "The East Cloister Walk of Saint-Aubin at Angers: Sculpture and Archeology”, Anjou: Medieval Art, Architecture and Archaeology. Ed. John McNeill y Daniel Prigent. Leeds: British Archaeological Association, 2003. pp. 111-137. The Grove Encyclopedia of Medieval Art and Architecture, Vol. 1. Ed. Colum P. Hourihane. Oxford; Nueva York: Oxford University Press, 2012. p. 75.
} 
más recientes sobre la escultura de claustro afirman que estas fechas son dudosas y especulativas no teniendo un dato contundente al respecto ${ }^{16}$. Los arcos de este primer espacio, específicamente los de la sacristía y la puerta de la sala capitular, tienen un carácter principalmente decorativo en el que predominan el follaje, criaturas monstruosas y motivos geométricos ${ }^{17}$.

Los arcos de la sala de capítulos también se diferencian entre sí. Con relación al arco de la portada, estudios recientes han traído a la luz que el estilo artístico de la misma podría remontarse a los motivos decorativos del arte merovingio, con el propósito de constatar y resaltar el vínculo histórico del cenobio con estos monarcas $^{18}$. Es en dos de los doble arcos de esta estancia antigua sala capitular donde encontramos varios temas iconográficos tomados de las Sagradas Escrituras. El primero, en el dintel que forman los dobles arcos hay un relieve de la Virgen en Majestad, encerrada en una mandorla y flanqueada por dos ángeles. El programa de Angers conjuga pintura y escultura, pues las distintas esculturas del claustro estaban coloreadas y hoy en día se aprecian rectos de pigmentos, pero igualmente el discurso icónico se completa por medio de la pintura. Debajo de la Virgen entronizada, en los doble arcos, se pintaron escenas del ciclo de la Natividad que incluye a los tres reyes Magos y la Masacre de los Inocentes ${ }^{19}$. En el dintel del doble arco contiguo labrado en la piedra David luchando contra Goliat y luego el momento en el que el joven cercena la cabeza del gigante. Aquí desafortunadamente no se conservó la pintura mural de los arcos inferiores.

\footnotetext{
${ }^{16}$ En relación con la cronología ver: MCNEILL, John. "The East Cloister Walk of Saint-Aubin at Angers: Sculpture and Archeology", Anjou: Medieval Art, Architecture and Archaeology. Ed. John McNeill y Daniel Prigent. Leeds: British Archaeological Association, 2003. p. 112. HERBECOURT. Anjou roman. p. 170.

${ }^{17}$ HeRBECOURT. Anjou roman..., p. 172.

${ }^{18}$ MCNEILL. "The East Cloister Walk of Saint-Aubin at Angers..., p. 123.

${ }^{19}$ TCHERIKOVER, Anat. High Romanesque Sculpture in the Duchy of Aquitaine, c. 1090-1140. Oxford: Clarendon Press, 1997. p. 132.
} 


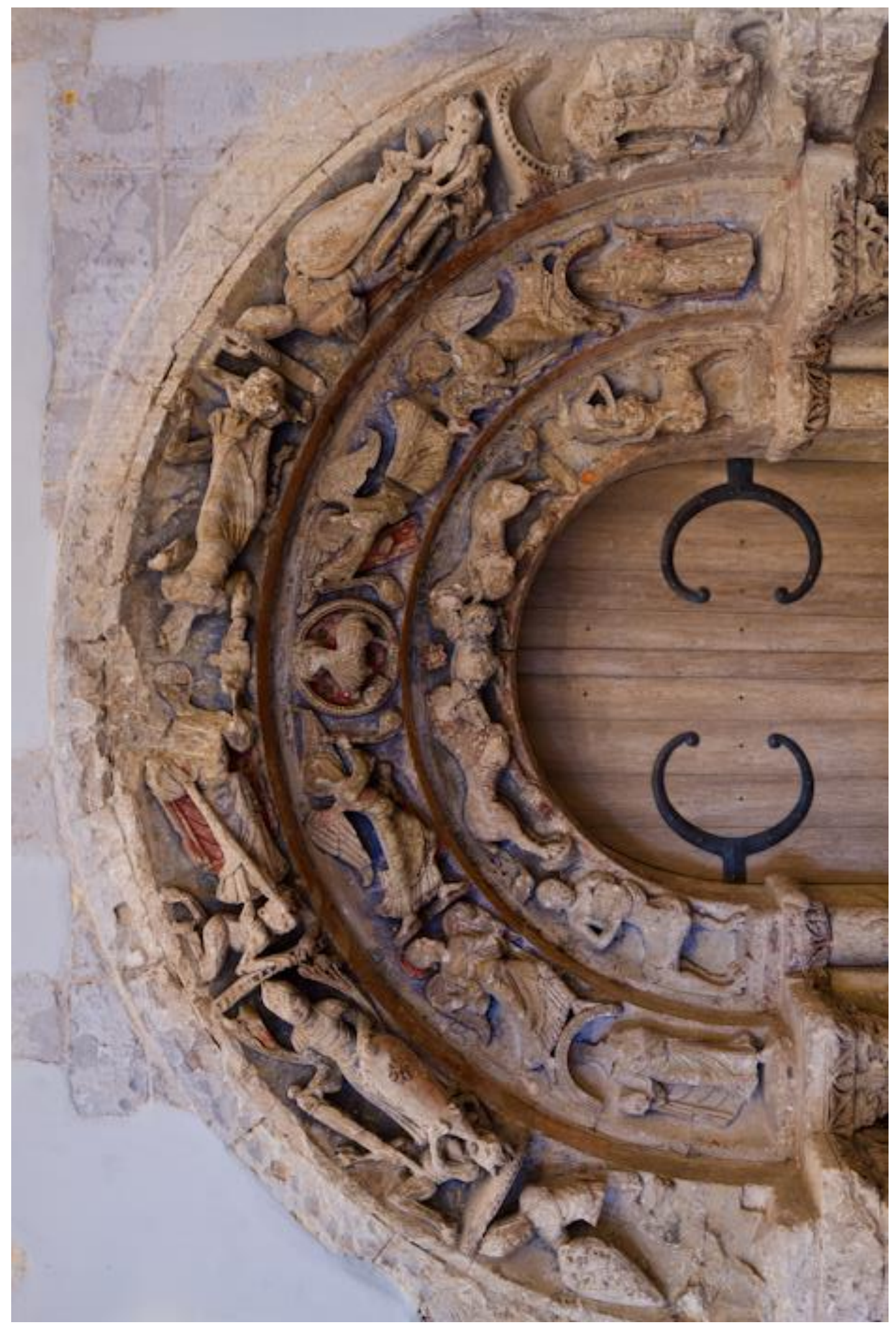

章

क

空

ส $\frac{\pi}{\pi}$

क्ञ

夏的

4

递完

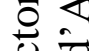

造

전

过

ชิ

نे

二

륭

$\exists$

(

.

¿ ¿

ई

ड़े

2

ले

3

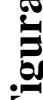


El tema de la Psychomachia se insertó en el arco de la puerta que daba acceso al refectorio (Fig. 31). Diferencias estilísticas con la galería de levante han llevado a determinar que la fecha de ejecución de la misma es posterior ${ }^{20}$. En el arco exterior se representaron seis virtudes venciendo a seis vicios con forma de demonio siguiendo el modelo francés de Saintonge y Poitou ${ }^{21}$. Al igual que sus homologas en las fachadas de templos románicos, junto a la batalla se incluyeron otros temas iconográficos. En el arco central el Agnus Dei encerrado en un círculo flanqueado por dos ángeles turíferos a los que le siguen dos ángeles más. Las figuras inferiores del arco central han sido identificadas como Moisés con las tablas de la ley al lado izquierdo y a la derecha Aarón ${ }^{22}$. En el arco interior encontramos más escenas de lucha entre animales y hombres. En el centro dos leones devoran un jabalí y debajo de estos una doble representación de Sansón luchando con el león.

El contenido alegórico y moral representado en estas tres arquivoltas es evidente. La batalla del alma no sólo se plasma a través de las virtudes, sino que también se utilizan las luchas de animales o Sansón contra el león para enfatizar la misma, después de todo Sansón contra el león prefigura a Cristo contra el Demonio. La figura victoriosa de Cristo aparece a través del Agnus Dei. Las virtudes que ya han triunfado sobre los vicios, corona a éste. Los ángeles le exaltan y como base de todo el conjunto la figura de Moisés con las tablas de la ley.

La historia de la abadía medieval de Saint Aubin ha sido una desafortunada. A lo largo de la historia los espacios del cenobio cambiaron, esto ya fuese respondiendo a los gustos estéticos de las distintas épocas o por necesidad. En el siglo XIV la bóveda del claustro fue rehecha en estilo gótico. En el siglo XVII guerras

\footnotetext{
${ }^{20}$ MCNEILL. "The East Cloister Walk of Saint-Aubin at Angers..., p. 131.

${ }^{21}$ The Grove Encyclopedia of Medieval Art and Architecture, Vol. 1. Ed. Colum P. Hourihane. Oxford; Nueva York: Oxford University Press, 2012. p. 75. MCNEILL. "The East Cloister Walk of Saint-Aubin at Angers..., pp. 111-137. TCHERIKOVER. High Romanesque Sculpture in the Duchy of Aquitaine..., p. 157. DESCHAMPS. Le combat des vertus et des vices sur les portails roman..., p.7.

22 “Au départ de l'archivolte, sus des arcs décorés d'un rinceau ou de dents de scie, on remarque debout, à gauche, Moïse tenant les tables de la loi, à droite (mutilé) sans doute Aaron". HERBECOURT. Anjou roman..., p. 175.
} 
religiosas afectaron el cenobio y este debió ser reconstruido. En 1790 la abadía fue desamortizada, pasando el edificio a manos de la administración departamental y entre esta fecha hasta 1812 gran parte de la misma fue demolida para construir la actual plaza y el edificio de la prefectura de gobierno de Angers ${ }^{23}$. Estos distintos eventos han trastocado de tal manera el claustro de Saint Aubin, siendo prácticamente imposible reconstruir el discurso icónico del mismo.

Por otra parte, la segunda Psychomachia en piedra identificada muestra un panorama distinto al de Saint Aubin, pues las peripecias de la historia han hecho que el discurso icónico del claustro medieval del monasterio de Sant Cugat del Vallès se conserve en su totalidad. La batalla del alma se plasmó en un capitel de la galería sur del claustro del cenobio catalán el cual no se encuentra aislado. Junto a éste encontramos otros chapiteles labrados con temas tomados de las Sagradas Escrituras y la vida en cenobio. El capitel en cuestión sirve de conector de los distintos temas tratados en el claustro y se vincula directamente, al igual que los manuscritos iluminados ya tratados, con el currículo de enseñanza y la meditación, respondiendo directamente a los distintos miembros de la comunidad de religiosos.

Gracias al buen estado de conservación en el que se encuentra la Psychomachia de Sant Cugat del Vallès, y el hecho de que la misma se conserva hoy en día en el lugar para el que fue proyectada con el resto del conjunto escultórico nos proponemos a reconstruir el discurso iconográfico del mismo y el vínculo de estos chapiteles labrados, sobre todo los de la batalla del alma, con las técnicas de mnemónicas necesarias para el currículo de enseñanza y la meditación. Para el análisis de los códices miniados de la Batalla del alma fue un imperativo reconstruir el entorno en el que se crearon y fueron utilizados, pues el mismos permitió profundizar en el proceso de educación de estos distintos cenobios y el uso de la obra de Prudencio como parte del currículo de enseñanza. Si bien no contamos con una extensa bibliografía como con los monasterios del mundo carolingio, hasta el día de hoy se han conservados diversas fuentes primarias y secundarias que permiten

\footnotetext{
${ }^{23}$ HeRBeCOURT. Anjou roman..., pp. 150-173.
} 
entender la fundación del cenobio catalán y el período histórico en el que se construyó el claustro de éste, e igualmente las distintas actividades que se realizaban en su interior como la enseñanza y la meditación.

\subsection{Sant Cugat del Vallès}

\subsubsection{De san Cucufato a Saint-Denis: fundación y vinculación del cenobio con el mundo carolingio}

El edificio que hoy en día se conserva del monasterio de Sant Cugat del Vallès es producto de distintas empresas llevadas a cabo a lo largo de los siglos IX al XIV. No obstante, la historia del enclave de Sant Cugat del Vallès se remonta a la tardía antigüedad. Este se construyó sobre la antigua fortaleza romana Castrum Octavianum. La elección de lugar se debe al hecho de que fue aquí donde san Cucufato (Sant Cugat en catalán) fue martirizado y sepultado. Prudencio en uno de los himnos del Peristephanon recoge uno testimonios más antiguos sobre el martirio de Cucufato ${ }^{24}$. Como mucho de los templos o lugares de culto cristiano tardo antiguos o alto medievales, se erige un edificio para albergar, custodiar y sobre todo rememorar la memoria del santo por medio de las reliquias de éste. A lo largo de los siglos distintas comunidades se congregaron en este lugar ${ }^{25}$.

A partir del siglo VIII la historia del monasterio se entrecruza entre la dinámica del obispado de Barcelona, la monarquía franca, específicamente carolingia, y las invasiones sarracenas. Distintos autores a través de la historia han afirmado que

\footnotetext{
${ }^{24}$ PRUDENCIO. Peristephanon, Hymnus 4, vv. 34-35. Edición consultada: Obras Completas de Aurelio Prudencio. Traducción de A. Ortega, introducción general de: I. Rodríguez. Ed. bilingüe. Biblioteca de Autores Cristianos 427. Madrid: Editorial Católica, 1981.

${ }^{25}$ VILlanueVA, Jaime. Viage literario a las iglesias de España. Tomo XIX, Viage á Barcelona y Tarragona. Madrid: Imprenta de la Real Academia de la Historia, 1851. p. 21. MoXO Y DE FRANCOLI, Benito. Memorias históricas del real monasterio de San Cucufate del Valles. Barcelona: Francisco Suriá y Burgada, Impresor, 1790. p. 72.
} 
Carlomagno último cuarto del siglo VIII fundó el cenobio ${ }^{26}$. Si bien Carlomagno no fue el fundador de éste, entre los siglos IX y X se desea resaltar y constatar la relación entre el Sant Cugat y la monarquía carolingia ${ }^{27}$, como demuestra el precepto de Carlos el Calvo confirmando al abad Ostrofredo las posesiones del monasterio (875-877) y el precepto de Lotario confirmando al monasterio de San Cugat todos sus bienes, su inmunidad y la libre elección del abad $(986)^{28}$.

El vínculo del monasterio con la monarquía carolingia, a parte de los preceptos firmados por los distintos descendientes de Carlomagno, se puede constatar a través de la datación cronológica de muchos de los documentos del cenobio. Para fechar los mismos se utilizaba la cronología de los reyes de Francia ${ }^{29}$. El monasterio poseía varias listas con éstas cronologías, y hoy en día se conservan dos en el Archivo de la Corona de Aragón, fechados entre los siglos XII y XIII ${ }^{30}$. Según Rius Serra la cronología francesa se utilizó en los documentos anteriores al 1180, sin embargo, el folio con la lista de los monarcas francos del Ms. 47 es del siglo XIII.

También se ha encontrado una relación indirecta entre el monasterio de Sant Cugat del Vallès y la abadía de Saint-Denis. En el siglo VIII el abad Fulrad de SaintDenis y también consejero de Carlomagno, como parte de su testamento donó a su monasterio varías reliquias de mártires que se encontraban en su poder, entre éstas

\footnotetext{
${ }^{26}$ MoXo y DE FrAnCOLI. Memorias históricas del real monasterio de San Cucufate..., p. 1. PujAdES, Gerónimo. Crónica universal del principado de Cataluña. Tomo V. Barcelona: Imprenta de José Torner, [1609] 1829. p. 306. BEUTER, Pere Antoni. Segunda parte de la Coronica general de España y especialmente de Aragon, Cathaluña y Valencia: donde se tratan las obranças destas tierras de poder de moros por los inclytos Reyes de Aragon y Condes de Barcelona... Valencia: en casa de Ioan de Mey, Flandro, 1551. fol. xxxiir.

${ }^{27}$ ZimmermanN, Michel. Écrire et lire en Catalogne (IXe-XIIe siècle). Tomo II. Madrid: Casa de Velázquez, 2003. pp. 982-1001.

${ }^{28}$ Doc. 1 y Doc. 173. RiUs SerRA, José (ed.). Cartulario de Sant Cugat del Vallés. Vol. III. Barcelona: Consejo Superior de Investigaciones Científicas, Sección de Estudios Medievales de Barcelona, 1945-1947.

${ }^{29}$ Rius Serra en el Prólogo a su edición del Cartulario de Sant Cugat del Vallés discute este punto. RIUS SERRA. Cartulario de Sant Cugat del Vallés. Vol. I..., p. XLIV

${ }^{30}$ Fol. 225v, Ms. Sant Cugat 63 y fol. 159v Ms. Sant Cugat 47 (Archivo de la Corona de Aragón).
} 
las de san Cucufato ${ }^{31}$. No queda muy claro cómo éstas reliquias llegaron a manos del abad Fulrad. Según Moxo, el mismo abad visitó el monasterio y se llevó una reliquia del cuerpo del santo para enriquecer su monasterio de Vosgo ${ }^{32}$. Para algunos autores Carlomagno fue quien trasladó la reliquia del monasterio del Vallès y se la dio a Fulrad, mientras que otros especulan el emperador las recibió del papa Adriano y se las entregó a su consejero ${ }^{33}$.

A pesar de lo difusa que es la información sobre el traslado de una reliquia de san Cucufato hasta la abadía de Saint-Denis, la única información certera es que el abad Fulrad en su testamento dispuso que estas reliquias se custodiaran y veneraran en la iglesia de Saint-Denis. En ésta además del culto a su santo titular, san Dionisio, también se recordaba la memoria de Cucufato siendo uno de los nombres de santos venerados en el templo que aparecen en el Sacramentarium Sancti Dionysii ${ }^{34}$. Este códice de finales del siglo IX fue realizado en el scriptorium de Saint Amand, no obstante, la liturgia, el calendario y las letanías del mismo fueron adaptadas para los usos litúrgicos de Saint-Denis ${ }^{35}$. Además del sacramental a mediados del siglo XIII se erigió y consagró una capilla en el ábside al mártir san Cucufato ${ }^{36}$.

Estos distintos documentos y testimonios denotan un particular interés por resaltar el vínculo con el mundo carolingio. Incluso las diferentes teorías de la travesía de parte de los restos de san Cucufato a París igualmente pueden interpretarse como una conexión y un interés por vincular el cenobio catalán con el mundo

\footnotetext{
${ }^{31}$ StOCLET, Alain J. Autour de Fulrad de Saint-Denis (v. 710-784). École pratique des hautes études (France). Section des sciences historiques et philologiques. Ginebra: Champion, 1993. p. 7. FÉLIBIEN. Histoire de l'abbaye royale de Saint-Denys en France..., p. 60.

${ }^{32}$ Moxo y de Francoli. Memorias históricas del real monasterio de San Cucufate..., p. 30.

${ }^{33}$ StOCLET. Autour de Fulrad de Saint-Denis..., pp. 7-9. FloREZ, Enrique. España sagrada. Tomo XXIX. Madrid: Imprenta de José Rodríguez, [1747] 1859. pp. 339-341. PUJADES. Crónica universal del principado de Cataluña. Tomo VI..., p. 49.

${ }^{34}$ FrIEND, A.M. "Carolingian Art in the Abbey of St. Denis", Art Studies; Medieval, Renaissance and Modern Vol. 1 (1923), p. 70.

${ }^{35}$ Ms. Lat. 2290 (Biblioteca Nacional de Francia). "Sacramentarium Sancti Dionysii [Sacramentaire de Saint-Denis", Bibliothèque nationale de France. Disponible en: http://gallica.bnf.fr/ark:/12148/btv1b8423836x/f358.item.r=ms.zoom [Consulta: 31 de octubre de 2016]

${ }^{36}$ FÉLIBIEN. Histoire de l'abbaye royale de Saint-Denys en France ..., pp. 531, 535.
} 
carolingio pues algún religioso miembro de un cenobio francés fue quien visitó Sant Cugat y ciertamente dicha visita no debió ser inadvertida. Al parecer la relación del monasterio de del Vallès con la cultura carolingia fue una indirecta, no obstante, lo suficiente para constatar ciertos datos históricos. Al igual que en las abadías a las que pertenecieron los manuscritos iluminados de la Psychomachia también tenemos constancia de que ciertas prácticas: como la donación de niño, la presencia de una escuela, el estudio del quadrivium pero sobre todo del trivium formaban parte del quehacer de Sant Cugat. Por lo tanto, aquí, como en San Amand, San Denis, San Laurent o San Galo, se emplearon técnicas mnemónicas partiendo el uso de imágenes para el proceso de enseñanza y sobre todo de meditación.

\subsubsection{Schola, magistri et alumni: enseñanza y aprendizaje en el cenobio}

A través de los distintos documentos como el cartulario, el costumari, los manuscritos y los relatos posteriores por viajeros o miembros de la misma comunidad del monasterio es posible establecer que en el monasterio de Sant Cugat de Vallès se enseñaban y estudiaban algunas de las materias del trivium y el quadrivium ${ }^{37}$ además $^{-}$ de los principios de la fe. La conexión con el mundo carolingio introduce en el cenobio la regla benedictina, regulando así las horas de trabajo, estudio y oración de la comunidad ${ }^{38}$.

A finales del siglo XVIII el abad de Sant Cugat encargó a uno de sus monjes, Benito de Moxo y de Francoli recopilar la historia del monasterio, la cual se publicó en 1790 bajo el título Memorias históricas del real monasterio de San Cucufate del Valles. A pesar de que la obra de Moxo es posterior a la época medieval, la misma resulta interesante para reconstruir la biblioteca y el currículo de enseñanza del monasterio entre los siglos VIII al XII. Según el monje, tan temprano como en el siglo IX en Sant Cugat se cultivaban las matemáticas, la astronomía, la filosofía y la

\footnotetext{
${ }^{37}$ ZiMMERMANN. Écrire et lire en Catalogne, Tomo I..., p. 604.

${ }^{38}$ LAWRENCE, Clifford Hugh. Medieval Monasticism: Forms of Religious Life in Western Europe in the Middle Ages. Londres; Nueva York; Longman, 1989. p. 38. MOXO Y DE FRANCOLI. Memorias históricas del real monasterio de San Cucufate..., pp. 12-13.
} 
teología y en el mismo se custodiaban escritos de los más famosos padres de la Iglesia $^{39}$. Además de cultivarse estos distintos saberes en el cenobio se educaban a niños. Estos en muchas ocasiones eran ofrecidos como oblatos por sus padres y dentro del monasterio un monje que hacía de maestro, magister, estaba a cargo de ellos ${ }^{40}$. Gran parte de la información dada por Moxo se puede constatar a través de distintos documentos que aún perviven.

Según el Costumari de Sant Cugat en el monasterio existía una escuela (scola) a la que pertenecían niños y allí se les educaba. Éstos formaban parte importante de distintos servicios litúrgicos: cantaban en el oficio divino y en las celebraciones importantes como la vigilia de Navidad, la Cena del Señor o la solemnidad de los Santos Inocentes estos participaban activamente en las procesiones, el servicio litúrgico e incluso leían textos bíblicos en la celebración ${ }^{41}$. El Costumari fue escrito en el primer cuarto del siglo XIII por un miembro de la comunidad, Pere Ferrer ${ }^{42}$ y el mismo recoge las distintas fiestas litúrgicas, tareas y celebraciones llevadas a cabo en el monasterio. El mismo es de época posterior a la construcción de la primera fase del claustro, sin embargo, es contemporáneo de la segunda etapa en la que se construyó la galería sur con un rico programa iconográfica. Se puede suponer que su autor recopiló distintas prácticas y reglas que ya se celebraban con anterioridad. Es muy probable que la gran cantidad de niños que pertenecían a la scola fueran oblatos como indica Moxo. En el Cartulario entre 1154 y 1208 se registraron veintisiete casos en los que padres u algún otro pariente ofrecieron algún hijo o individuo al monasterio ${ }^{43}$. El Costumari constata la presencia de más de un magister y específica las tareas de los maestros, entre las cuales destacan estar a cargo de los alumnos no

\footnotetext{
${ }^{39}$ MoXo y De Francoli. Memorias históricas del real monasterio de San Cucufate..., p. 10.

${ }^{40}$ Ver nota alcalce 13. MOXO Y DE FRANCOLI. Memorias históricas del real monasterio de San Cucufate..., pp. 12-13.

${ }^{41}$ El costumari del monestir de Sant Cugat del Vallès. Introducción y transcripción de Efrem E. Compte, prefacio de Anscari M. Mundó. Barcelona: Institut d'Estudis Catalans, 2009. pp. 70, 173, 244.

${ }^{42}$ El costumari del monestir de Sant Cugat del Vallès..., p. 11.

${ }^{43}$ Ver documentos: 996, 998, 1006, 1010, 1014, 1017, 1022, 1039, 1057, 1082, 1088, 1092, 1096, 1101, 1119, 1126, 1149, 1150, 1155, 1167, 1168, 1181, 1221, 1222, 1240 y 1269 . RIUS SERRA. Cartulario de Sant Cugat del Vallés. Vol. III...,
} 
sólo en el proceso de educación, sino en las distintas actividades en las cuales los niños participaban ${ }^{44}$.

Moxo en el siglo XVIII identificó alguno de los manuscritos de época medieval que todavía en su tiempo formaban parte de la biblioteca: el Martirologio de Adón, la Regla de San Benito, obras antiguas y textos realizados por antiguos magistri $^{45}$. Muchos documentos y textos se perdieron por causa de las distintas invasiones sarracenas y tras el saqueo de Al-Mansur en el 985 la biblioteca de Sant Cugat tuvo que ser completamente reconstituida ${ }^{46}$. La mayor parte de los manuscritos que pertenecieron y/o se realizaron en el monasterio de Sant Cugat actualmente se custodian en el Archivo de la Corona de Aragón. Hoy en día sobreviven doce manuscritos de los siglos XI al XIII ${ }^{47}$. Entre los textos que se recogen en estos códices están: el Martirologio de Adón, la Regla de San Benito, textos de san Clemente, san Martín de Braga, Gregorio Magno, san Agustín y san Jerónimo.

A través del estudio de estos manuscritos y el resto de los documentos que se conservan, Michel Zimmermann afirma que la cultura religiosa de Sant Cugat más que enfocarse en el análisis especulativo, se centra principalmente en dos áreas: la espiritualidad y el estudio de los textos bíblicos incluyendo los comentarios de los mismos (homilético) ${ }^{48}$. La mayor parte de los textos de época medieval que se conservan son sobre todo las Sagradas Escrituras, especialmente distintos evangelios

\footnotetext{
${ }^{44}$ El costumari del monestir de Sant Cugat del Vallès..., pp. 352-353. ZIMMERMANN. Écrire et lire en Catalogne, Tomo II..., p. 877.

${ }^{45}$ MoXo y DE FRANCOLI. Memorias históricas del real monasterio de San Cucufate..., pp. 12 y 108.

${ }^{46}$ ZimMERMANN. Écrire et lire en Catalogne, Tomo I..., p. 604. VillanUEVA. Viage literario a las iglesias de España. Tomo XIX..., p. 21. MOXO Y DE FRANCOLI. Memorias históricas del real monasterio de San Cucufate..., p. 72.

${ }^{47}$ Manuscrito número: 12, 17, 21, 22, 24, 47, 55, 57, 69, 74, 86, 90. MiQUEL RoselL, Francesc X. Catalèg dels llibres manuscrits de la Biblioteca del Monestir de Sant Cugat del Vallès existents a l'Arxiuu de la Corona d'Aragó. Barcelona: Imprenta de la Casa de Caritat, 1937.

${ }^{48}$ ZIMMERMANn. Écrire et lire en Catalogne, Tomo I..., p. 604
} 
glosados. A partir del siglo XII se revela un mayor interés por las obras literarias de corte ascético entre estos, tratados sobre vicios y sobre el infierno y el pecado ${ }^{49}$.

El principal método de enseñanza en este cenobio y otros de la zona, cómo el monasterio de Santa María de Ripoll, fue el comentario. El maestro se apoyaba sobre el texto de una obra en particular, sirviéndole el mismo para explicar el sentido y la naturaleza de las palabras y definir las reglas gramaticales, abordando así el estudio de la dialéctica y la gramática. Dependiendo el texto escogido por el magister, el comentario versaría en historia, moral o teología. Esto permitía la introducción de referencias bíblicas o patrísticas. Los trabajos de los autores clásicos igualmente nutrían el comentario ${ }^{50}$. El uso de las obras clásicas para nada difería con las obras cristianas, pues la finalidad de ésta era complementaria a los textos de autores cristianos; el estudio de los poetas latinos aportaba los modelos de la prosodia latina y los cristianos familiarizaban al estudiante con la versificación ${ }^{51}$.

La educación depende principalmente de la memoria, por esto la importancia de las mnemotecnias. Un aspecto significativo en la educación y la enseñanza en estos monasterios, y al cual Zimmermann dedica un apartado de su estudio, son las mnemotecnias. Anteriormente, específicamente en el capítulo 3, se estableció la importancia de la memoria y las distintas técnicas que realzan, mejoran y aumentan la capacidad de la memoria artificial con el proceso de aprendizaje del trivium y el quadrivium. Al igual que en los cenobios carolingios, en Sant Cugat se empleaban técnicas de memorización para auxiliar la memoria. Las memorias de los estudiantes eran entrenadas a través de la memorización de definiciones retóricas y etimológicas y de exhaustivos inventarios ${ }^{52}$. Estos eran auxiliados a través de los elementos

\footnotetext{
${ }^{49}$ El Ms. 17 incluye un tratado titulado De conflictu vitiourum atque virtutum, atribuido a san Agustín y el Ms. 90 Diadema Monachorum de Smaragde. MiQuel Rosell. Catalèg dels llibres manuscrits de la Biblioteca del Monestir de Sant Cugat..., pp. 36 y 140. ZIMMERMANn. Écrire et lire en Catalogne, Tomo I..., p. 605

${ }^{50}$ ZIMMERMANN. Écrire et lire en Catalogne, Tomo II..., p. 897.

${ }^{51}$ ZIMMERMANN. Écrire et lire en Catalogne, Tomo II..., p. 900.

52 "Il est clair que ce commentaire nous transmet la liste de exercices imposés aux élèves; leur mémoire est entraînée à la rigueur des définitions rhétoriques et étymologiques comme à l'exhaustivité des inventaires". ZIMMERMANN. Écrire et lire en Catalogne, Tomo II..., pp. 902-903.
} 
prosódicos como la rima y el ritmo, o en el caso de los inventarios el uso de cifras numéricas como signos bajo los cuales se almacenaba la información a memorizar. El esfuerzo de la memoria se sostiene a través de los artificios de la composición literaria. Los términos a aprender preferiblemente se integran en los elementos del ritmo, la puntuación, rima o aliteración ${ }^{53}$. El énfasis en estas técnicas vinculadas directamente con el verso se debe al particular gusto por los monjes de la zona por los versos leoninos, el cual se tradujo a la inscripción en piedra en el claustro de Sant Cugat, en el epígrafe que recoge el artífice del claustro ${ }^{54}$.

No obstante, estas no fueron las únicas mnemotecnias empleadas. Técnicas mnemónicas utilizadas en el mundo carolingio igualmente se emplearon en los monasterios catalanes en el momento histórico al que nos circunscribimos. Entre estas se encuentran el uso de listas y glosarios de palabras para la enseñanza de la gramática, similares a las de los manuscritos antes estudiados. También la idea tratada por Carruthers de dividir el texto o material a memorizar en trozos manejables para retener el ad res del mismo. De particular interés también se encuentran la concatenación de ideas. En esta práctica de memorización particularmente Zimmermman afirma que se utilizaba en la enseñanza de la gramática, formando cadenas de concordancia entre las diversas palabras con raíces similares, pero igualmente la idea de la catena se empleaba para el estudio de las escrituras pues los distintos prólogos de los diferentes libros de la Biblia, principalmente del Antiguo Testamento entrelazan con otras historias bíblicas, conceptos dogmáticos, gramaticales, autores clásicos, etc. Entre los ejemplos que brindan Zimmermman, se encuentra el prólogo al Génesis en el cual se insertan distintas referencias históricas y filológicas a partir de la historia de la traducción de la Biblia, el prólogo a Reyes en el que desde la simbología de los nombres se integra el estudio del alfabeto hebreo y el prólogo del libro de Job se transforma en una historia de la poesía lírica grecolatina $^{55}$. El uso de estas mnemotecnias se aplicó a las imágenes de los capiteles del

\footnotetext{
${ }^{53}$ ZimMERMANN. Écrire et lire en Catalogne, Tomo II..., p. 905.

54 “[...] et c'est à l'aide des deux vers léonins que les sculpteur Arnau Gatell (ou Catell) signe son cuvre dans le cloûtre de Sant Cugat". Écrire et lire en Catalogne, Tomo II..., p. 909.

${ }^{55}$ Zimmermann. Écrire et lire en Catalogne, Tomo II..., pp. 901-902.
} 
claustro como recurso cognitivo complementario al método de enseñanza del cenobio, el comentario, con la finalidad de que los miembros de la comunidad adquirieran todos los conocimientos necesarios para formar parte de la misma y poder así adentrarse en el proceso de meditación. En el caso de los monasterios benedictinos este proceso se daba a través de la práctica de la Lectio Divina la cual se divide en cuatro partes esenciales: la lectura, la meditación, la oración y la contemplación. La ejecución de la misma se hace en silencio y contemplativamente ${ }^{56}$. El papel del claustro en estas actividades es esencial, pues es en este espacio donde se llevan a cabo las mismas.

${ }^{56}$ ColombAs, García M. "Introducción general”, en: San Benito: su vida y su regla. dirección e introducciones del Padre Dom García M. Colombas, versiones del Padre Dom León M. Sansegundo, comentarios y notas del Padre Dom Odilón M. Cunill. Madrid: Editorial Católica, S.A., 1954. pp. 100-101. 


\section{CAPítulo 6}

\section{DUCTUS EN EL CLAUSTRO: EL USO DE LAS MNEMOTECNIAS EN EL PROCESO DE EDUCACIÓN Y DE MEDITACIÓN}

El claustro de un monasterio constituía una parte integral en el desarrollo del diario vivir de la comunidad de religiosos que allí habitaba. Además de su función principal, como conector de las distintas estancias y paso a las mismas también en estos se realizaban un sin número de tareas que de cierto modo resumían todo el quehacer social, cultural y económico del cenobio. Las tareas que se realizaban en estos espacios iban desde la conservación de la producción agropecuaria, trabajos artesanales y manuales, hasta el estudio la escritura, la enseñanza ${ }^{1}$ o la práctica de la meditación, y el claustro de Sant Cugat no fue la excepción.

El claustro bajo del cenobio catalán es de época medieval. Son las galerías de esta sección las que se encuentran adornadas con capiteles labrados y las que conectaban con la iglesia, la sala capitular, el refectorio, la cocina y la bodega. Estas alas igualmente eran utilizadas por los monjes para llevar a cabo otras tareas cotidianas. La profesora Inmaculada Lorés a través del estudio de la escultura de los capiteles y el Costumari ha identificado alguna de las actividades que se llevaban a cabo en las distintas galerías del claustro, especialmente aquellas que se relacionan con la vida cotidiana cómo el lavado de los pies. Diariamente en el cenobio, se alimentaban a tres pobres y como parte del acto caritativo también se le lavaban los pies. Además, semanalmente, específicamente los sábados, los

\footnotetext{
${ }^{1} \mathrm{Al}$ respecto de las tareas de producción que se realizaban en los claustros hispanos desde el siglo XI hasta el XIX ver: GARCÍA ÁlvAREZ-Busto, Alejandro. "Al servicio del claustro. Análisis de los espacios de trabajo en los monasterios hispánicos (siglos XI-XIX)", en: Hispania Sacra Vol. 68 N ${ }^{\text {o. }} 137$ (2016), pp. 145-178. KNOWLES, David. El monacato cristiano. Madrid: Ediciones Guadarrama, S.A., 1969. p. 100.
} 
hermanos de la comunidad se lavaban los pies entre ellos ${ }^{2}$. La presencia del episodio en el que Jesús lava los pies a sus discípulos (Fig. 65) en uno de los capiteles de la galería oriental ha llevado a la profesora Lorés a identificar este lado del claustro como el espacio donde se realizaba el Mandatum, la celebración por la cual los miembros de la comunidad rememoraban el momento en el que Jesús le lavó los pies a sus discípulos ${ }^{3}$.

Otra práctica vinculada directamente con la vida de los monjes que se realizaba en los predios del claustro es la de afeitarse. Según Lorés, la presencia de la escena en la que los monjes se afeitan en el capitel NI 06 (Fig. 61) apela al acto mismo llevado a cabo por los miembros de la comunidad en la galería en la que se insertó la imagen, la norte. Esto era una práctica normal dentro del contexto monacal y en los costumarios de otros cenobios, como Cluny, la misma se recoge $\mathrm{e}^{4}$. A pesar de que el Costumari de Sant Cugat no registra el acto comunal de afeitarse, Lorés si ha logrado identificar en el mismo evidencia de que los monjes se afeitaban en la galería norte del claustro, esto a través del hecho de que parte de las labores del camarero consistían en suministrar los materiales necesarios para el lavado de los pies y el afeitado ${ }^{5}$.

En palabras de David Knowles, el claustro "servía como zona de estudio, escritura y enseñanza", En el Costumari de Sant Cugat encontramos numerosos testimonios sobre el ejercicio de la escritura y la lectura, los monjes al salir de la iglesia, se dirigían al claustro. Allí tomaban un libro del armario y leían el mismo

\footnotetext{
${ }^{2}$ Ver: "Quod ordine fiat mandatum pauperum" y "Quomodo faciunt mandatum in die sabbati". El costumari del monestir de Sant Cugat del Vallès. Introducción y transcripción de Efrem E. Compte, prefacio de Anscari M. Mundó. Barcelona: Institut d'Estudis Catalans, 2009. pp.120 y 342.

${ }^{3}$ LORÉS I OTZET, Immaculada. "La vida en el claustra: iconografia monàstica als capitells de Sant Cugat del Vallès i el Costumari del monestir", Butlletí del Museu Nacional d'Art de Catalunya, $\mathrm{N}^{\mathrm{o}} 6$ (2002), pp. 36-37.

${ }^{4}$ Ver nota 38. LORÉS I OTZET. "La vida en el claustra..., p. 46.

${ }^{5}$ Ver: "De officio camerarii". El costumari del monestir de Sant Cugat del Vallès..., p. 349. LORÉS I OTZET. "La vida en el claustra..., pp. 36-37.

${ }^{6}$ KNOWLES. El monacato cristiano..., p. 100.
} 
en silencio ${ }^{7}$. Además de leer, gracias al Costumari, se puede establecer que en el claustro también se escribía y sobre todo se llevaba a cabo una de las principales tareas de la vida asceta: se meditaba ${ }^{8}$. El capitel con la imagen de los monjes que leen y escriben en la galería sur (Fig. 43) puede interpretarse como una señal o signo que indica que esta zona del claustro se encontraba sobretodo destinada al estudio 9 .

En muchos monasterios en otras zonas de Europa el tramo del claustro adosado a lo largo de la iglesia solía ser el área que gozaba de mayor luminosidad y durante los meses de invierno el que más cálido permanecía, condiciones que hacían de este espacio uno idóneo para la lectura y la escritura e igualmente aquí se amontonaban los libros utilizados por los monjes ${ }^{10}$. En Sant Cugat el ala sur también pudo haber sido utilizada con este propósito por las mismas cualidades geográficas y climatológicas. A esto se ha de añadir otro fin práctico, este es el tramo con el acceso más cercano a la iglesia. Si como establece el Costumari, los monjes cuando terminaban los oficios procedían al claustro a leer, la cercanía de esta galería agilizaba dicho desplazamiento. Este era el espacio en el que igualmente se almacenaban los libros utilizados por los religiosos, tal como lo indica el Costumari: "librum unum de armariolo" $11 "$

En el capítulo anterior se discutía la enseñanza y el aprendizaje en el monasterio de Sant Cugat del Vallés. El estudio y la lectura de los distintos manuscritos por consiguiente se realizaban en la galería sur, galería con el mayor

\footnotetext{
7 "Die dominico vel festive egredientibus omnibus de capitulo, cum silentio vadant sedera in claustro, et primo egrediantur iuniores, et postea seniors, post quos etiam domnus 〈abbas〉 vel prior. Accedentibus omnibus ad claustrum, accipiat unusquisque librum unum de armariolo, et sedeant ordinatim secundum ordinem prioratus sui, et legant cum silentio...”. El costumari del monestir de Sant Cugat del Vallès..., p. 76.

${ }^{8}$ El costumari del monestir de Sant Cugat del Vallès..., p. 115.

${ }^{9}$ LORÉS I OTZET. "La vida en el claustra..., p. 40.

${ }^{10}$ CARruthers, Mary. The Craft of Thought. Meditation, Rhetoric, and the Making of Images, 400-1200. Cambridge: Cambridge University Press, 1998. p. 112. KNOWLES. El monacato cristiano..., p. 100.

${ }^{11}$ El costumari del monestir de Sant Cugat del Vallès..., p. 76.
} 
número de capiteles historiados y cuyo programa iconográfico entonces no sería arbitrario, sino que se encontraría en función de los distintos quehaceres vinculados con la lectura, la escritura y la meditación. Las imágenes plasmadas en los capiteles de esta galería se vinculan directamente con el currículo de enseñanza del cenobio. Las distintas alas se conforman de dieciocho pares de capiteles que dan al interior y exterior. En el caso del lado sur, en catorce de los capiteles se plasmaron distintas historias, doce tomadas directamente del Antiguo y Nuevo Testamento, una vinculada con la Virgen María y la última con un tema de corte tropológico, la victoria de las virtudes sobre los vicios.

El capitel con la Psychomachia (Figs. 49 y 50) en la galería sur es clave para entender el programa iconográfico del claustro de Sant Cugat y reafirma el vínculo del mismo con el currículo de enseñanza del cenobio. Como se ha podido corroborar a través del estudio de los manuscritos iluminados de la Psychomachia, la meta es conquistar los vicios que acechan el alma mediante la práctica de las virtudes para así poder alcanzar la sabiduría. En el ala sur de Sant Cugat el fin es igualmente alcanzar la sabiduría, en este caso por medio del conocimiento de los textos bíblicos, cuya plasmación pictórica antecede al capitel con las virtudes y todo el material complementario que se almacena bajo la imagen de estos. Una vez logrado estos pasos, el individuo sería poseedor no sólo del conocimiento de las Sagradas Escrituras, sino que también tendría las armas necesarias para vencer los vicios que corrompieran su alma y la capacidad para emitir los juicios morales que le ganarían el cielo ${ }^{12}$.

De igual manera, este capitel y la exaltación a la sabiduría que se hace por medio del mismo, como estudiaremos más adelante, se vincula con el resto del programa iconográfico el cual recoge los distintos pasos de todos los individuos que aspirarán a quedarse como religiosos de la comunidad. A pesar de que la

\footnotetext{
${ }^{12}$ CARruthers. The Craft of Thought..., p. 145. CARruthers, Mary. The Book of Memory: A Study of Memory in Medieval Culture. Cambridge Studies in Medieval Literature. Cambridge: Cambridge University Press, 1992. pp. 28, 43 y 68. PrUdENCIO. Praefatio vv. 1-19. Obras Completas de Aurelio Prudencio..., p. 310.
} 
galería sur fue la última en construirse, es a partir de ésta que puede entenderse el ductus del claustro de Sant Cugat. Ductus en la manera en que una obra conduce a alguien a través de sí misma, esta cualidad en los patrones formales de una obra atrae a la audiencia y luego pone al espectador en movimiento dentro de sus estructuras, una experiencia más cercana a viajar por etapas a lo largo de una ruta que la de percibir un objeto entero. Por medio del ductus se analiza la experiencia de la forma artística como un proceso continuo y dinámico más que como el examen de un objeto estático ${ }^{13}$.

La galería meridional fue la última en construirse, sin embargo, esta no era la práctica habitual. Según la profesora Lorés esto en gran parte sucedió porque la cabecera del nuevo templo no había sido terminada, y probablemente se continuaba utilizando la nave del edificio anterior la cual ocupaba parte de la galería sur del claustro del siglo $\mathrm{XI}^{14}$. Si se tiene en cuenta esto, se puede establecer que la cronología del discurso icónico del espacio responde a un fin práctico: hasta que el muro en común entre la galería meridional y la iglesia no estuviera construido, no era factible culminar el claustro.

El currículo del monasterio se centraba principalmente en la espiritualidad y en el estudio de textos bíblicos por medio del comentario. Los manuscritos de Sant Cugat que hoy en día se conservan corroboran el interés particular por estos temas. Entre los doce manuscritos de época medieval que pertenecieron al monasterio, se identifican manuscritos con libros del Antiguo Testamento, con

\footnotetext{
13 "Ductus and its synonyms analyse the experience of artistic form as an ongoing, dynamic process rather than as the examination of a static or completed object. Ductus is the way by which a work leads someone through itself: that quality in a work's formal patterns which engages an audience and then sets a viewer or auditor or performer in motion within its structures, an experience more like travelling through stages along a route than like perceiving a whole object." CARRUTHERS, Mary. "The concept of ductus, or, journeying through a work of art", en: Rhetoric Beyond Words. Cambridge University Press, 2010. p. 190. CARRUTHERS. The Craft of Thought..., p. 78.

${ }^{14}$ LORÉS I OTZET, Immaculada. "La escultura del claustre i de l'eglésia", en: Catalunya románica, Tomo XVIII. El Vallès occidental. El Vallès Oriental. Barcelona: Enciclopèdia Catalana, S.A., 1991. p. 177.
} 
textos del Nuevo Testamento e igualmente comentarios de los padres de la iglesia. El manuscrito número 3 es un ejemplo del interés por los textos veterotestamentario y el mismo recopila los libros de: Isaías, Jeremías, Lamentaciones, Baruch, Ezequiel, Daniel, Oseas, Joel, Amós, Abdías, Jonás, Miqueas, Nahúm, Habacuc, Sofonías, Ageo, Zacarías, Malaquías, Macabeos 1 y 2 y Reyes ${ }^{15}$. Ejemplos neotestamentarios son los manuscritos números 57 , con los evangelios de Lucas y Juan, y el número 74 con el evangelio de Mateo ${ }^{16}$. En el tema de la patrística, varios códices con textos de san Agustín como la enarración al salmo 63 (Ms. 3) o su tratado sobre el evangelio de Juan (Ms. 21), san Gregorio los comentarios al libro de Job y varias homilías (Mss. 17 y 22) y varias epístolas de san Jerónimo (Ms. 17). Los textos de corte asceta y tropológico ganan fama a partir del siglo XII, fecha en la que se inicia la construcción del claustro bajo de Sant Cugat ${ }^{17}$. Ejemplo de estos son el tratado De conflictu vitiorum atque virtutum, atribuido a San Agustín (Ms. 17) o la Diadema Monachorum de Esmaragdo de Saint-Mihiel (Ms. 90).

En los textos bíblicos se corrobora la predilección por el comentario para el estudio. Los distintos libros, específicamente los del Antiguo Testamento recogidos en el códice 3, inician con dos prólogos, el primero es de san Jerónimo

\footnotetext{
${ }^{15}$ Francesc Miquel Roseel catalogó este códice como el número 12, no obstante, hoy en día la numeración del mismo utilizada por el Archivo de la Corona de Aragón es otra, identificándose con el manuscrito número 3. "Libri prophetici et historici", en Archivo de la Corona de Aragón. Disponible en: http://pares.mcu.es/ParesBusquedas/servlets/Control_servlet?accion=3\&txt_id_desc_ud=24509 $\underline{32 \& \text { fromagenda }=I \& t x t \_p r i m e r C o n t i e n e}=1$ [Consulta : 6 febrero 2017]. MIQUEL ROSELL, Francesc X. Catalèg dels llibres manuscrits de la Biblioteca del Monestir de Sant Cugat del Vallès existents a l'Arxiuu de la Corona d'Aragó. Barcelona: Imprenta de la Casa de Caritat, 1937. p. 28.

${ }^{16}$ MiQuel Rosell. Catalèg dels llibres manuscrits de la Biblioteca del Monestir de Sant Cugat..., pp. 28, 100 y 123.

${ }^{17}$ ZIMMERMANN. Écrire et lire en Catalogne, Tomo I..., p. 605.
} 
y el segundo de san Isidoro. En el caso de los tres evangelios conservados, estos todos poseen glosas del abad de Reichenau, Walafrido Strabo ${ }^{18}$.

Si bien es difícil determinar que los textos de estos distintos códices sirvieron como base para la plasmación escultórica de los capiteles del claustro, no se puede descartar la relación temática que existe entre los mismos. Por ende, los capiteles historiados principalmente de la galería sur servirían como complemento al currículo de enseñanza a la vez que funcionaban como señales o signos mnemónicos los cuales además de permitir la memorización ad res de la historia plasmada, igualmente éstas se concatenaban con otros conocimientos. El principal método de enseñanza en Sant Cugat era el comentario de un texto, éste permitía a partir de un escrito específico integrar otros conocimientos. En términos mnemónico, la obra literaria sobre la cual versaría el resto del comentario, tiene la función de un locus, ubicación o espacio mental en el que se almacenan por medio de la asociación o concatenación el resto de las ideas ${ }^{19}$. Cada uno de los capiteles se dedica única y exclusivamente a tratar un relato bíblico, por lo tanto, estos son trozos específicos de ciertas historias ${ }^{20}$. Los mismos también funcionan como loci en donde la historia plasmada almacena y concatena el sentido literal del mismo con otros conocimientos.

El ejercicio de las catenae igualmente se puede aplicar a los capiteles de la galería sur. En los manuscritos, el prólogo a algún libro de la Biblia se entrelaza con temas similares. En el caso de la escultura, encontramos varios casos que el arreglo o la composición de las figuras en la cara con la que culmina tal o cual narración se repite en la escena con la que inicia el siguiente capitel (Figs. 37, 38 y 39). Se crea un ritmo visual que ayuda al espectador a identificar el principio y el fin de tal o cual capitel, pero este ductus también forma un camino o peregrinar dentro del mismo claustro, cuya meta es la memorización de los diversos

\footnotetext{
${ }^{18}$ Rosell. Catalèg dels llibres manuscrits de la Biblioteca del Monestir de Sant Cugat..., pp. 100 y 123.

${ }^{19}$ CARruthers. The Craft of Thought..., p. 60.

${ }^{20}$ CARRUTHERS. The Craft of Thought..., pp. 63-64.
} 
conocimientos y por último ser capaz de dominar el ejercicio de la meditación, para formar parte de la comunidad.

El ductus, el recorrido del claustro, manifiesta los distintos pasos o niveles por los que debía pasar cualquiera que aspirara a la vida religiosa dentro de la comunidad. La galería sur, alcanzar la sabiduría de las escrituras para la práctica de la meditación, la práctica de la Lectio Divina, la galería oeste con sus imágenes del trabajo en la tierra y animales resalta este aspecto importante de la vida monacal; estos dos lados del claustro recogen la idea de San Benito de orat et labora. La galería norte además de recoger visualmente escenas de la vida en el monasterio, también exalta uno de los rituales de iniciación para formar parte de la comunidad: la tonsura, seguido el mismo por el acceso al templo para el oficio divino. Por último, los tres capiteles historiados de la galería de levante exaltan la práctica de dos virtudes importantes dentro de la vida religiosa, especialmente de aquellos que seguían la regla benedictina: la humildad y obediencia, completando así el peregrinar del individuo.

\subsection{Los capiteles de Sant Cugat del Vallès}

El claustro del monasterio de Sant Cugat del Vallès tiene dos plantas, la baja es de época medieval y la alta es producto de una reforma posterior del siglo XVI. Es en la planta baja donde la mayoría de los estudiosos del claustro se han concentrado. El análisis escultórico y la donación de Guillermo de Claramunt han llevado a los historiadores del arte de la escultura del claustro de San Cugat a fechar el inició de la construcción del mismo en la última década del siglo XII ${ }^{21}$. El actual

\footnotetext{
${ }^{21}$ LORÉS I OTZET, Imma. "La escultura del claustre i de l'eglésia”, en: Catalunya románica, Tomo XVIII. El Vallès occidental. El Vallès Oriental. Barcelona: Enciclopèdia Catalana, S.A., 1991. p. 170. Testamento de Guillermo de Claramunt, 27 abril 1190, documento no. 1182. RIUS SERrA. Cartulario de Sant Cugat del Vallés. Vol. III..., p. 319.
} 
claustró se edificó siguiendo el perímetro de un claustro anterior posiblemente del siglo $\mathrm{XI}^{22}$.

Según Moxo, el claustro se construyó en 1013 bajo el mandato del abad Witardo y así lo confirma un documento del monasterio el cual el autor consultó y trascribió ${ }^{23}$. Este documento recoge una transacción en la cual el dinero de la venta de unas propiedades del cenobio al Conde de Barcelona sería destinado para la edificación del claustra. El documento no ofrece más información al respecto, por ende, el significado de claustra no queda claro, y bien podría referirse al claustro o a la clausura como apunta Rius Serra ${ }^{24}$.

El claustro actual de estilo románico se comenzó a finales del siglo XII y se concluyó en las primeras décadas del XIII. Uno de los elementos más emblemáticos son los 144 capiteles labrados repartidos en las cuatro galerías. La mayoría de los capiteles llevan motivos ornamentales de aves, o vegetales, grifos, guerreros, etc. Estos capiteles los hemos identificados en la figura 32, (Distribución capiteles claustro de Sant Cugat del Vallès) bajo el color gris. Los chapiteles labrados con motivos no ornamentales han sido divididos en cinco grupos dependiendo la temática de los mismos. En la figura 32 se identificaron en rojo todos aquellos capiteles historiados cuyas imágenes están tomadas directamente de las Sagradas Escrituras, salvo el SI 16 y SI 17 en los que se representaron la Dormición de la Virgen y la Psychomachia. En color marrón encontramos cuatro capiteles que se vinculan directamente con los miembros de la comunidad de religiosos y han sido catalogados como vida en el monasterio. La

\footnotetext{
${ }^{22}$ LORÉS I OTZET. "La escultura del claustre i de l'eglésia..., p. 170.

${ }^{23}$ El documento que Moxo cita y transcribe corresponde al documento número 456 del Cartulario de Sant Cugat. Rius SerRa. Cartulario de Sant Cugat del Vallès, Vol. II..., p. 103. MoXo Y DE FRANCOLI. Memorias históricas del real monasterio de San Cucufate..., pp. 7, 84-86.

24 “El abad Guitart y los monjes del Monasterio venden a Ramón Borrell, conde de Barcelona, y a su esposa Ermesinda, y a Longobardo, canonigo de Barcelona, unas propiedades sitas en los términos de Tarrasa, Ullastrell, Castellar y "Nespola", por veinticinco onzas de oro, para terminar la obra del claustro o la clausura". RIUS SERRA. Cartulario de Sant Cugat del Vallès, Vol. II..., p. 103.
} 
galería oeste muestra la mayor diversidad de temas. En esta se recogieron cinco escenas de campesinos identificadas por medio del color verde, seis luchas entre hombres identificadas en azul, cinco capiteles con animales que apelan al ganado y etiquetadas por medio del amarillo y dos escenas tomadas directamente de las Sagradas Escrituras.

Si bien las galerías este, norte y oeste cronológicamente son las más antiguas, anteriormente se expuso el hecho de que el discurso icónico del claustro inicia en el ala sur. Para la reconstrucción del ductus, y el análisis de la función mnemónica de los distintos capiteles y su vinculación con el currículo y las galerías se abordarán siguiendo el mismo. Este, como se recoge en la figura 32, comienza en el ala sur tras salir de la iglesia, y en orden de las manecillas del reloj recorre las galerías oeste, norte y este. En los distintos capiteles se tratarán las posibles lecturas de los distintos temas plasmados.

Las historias del Antiguo y Nuevo Testamento plasmadas en los capiteles de las galerías sur y este se insertaron en las distintas caras estos. Los esquemas de las figuras 33, 34, 35 y 64 recogen la distribución de las distintas escenas o detalles que se recogen en los distintos lados de los chapiteles en los que se incluyeron historias veterotestamentarias y neotestamentarias. 


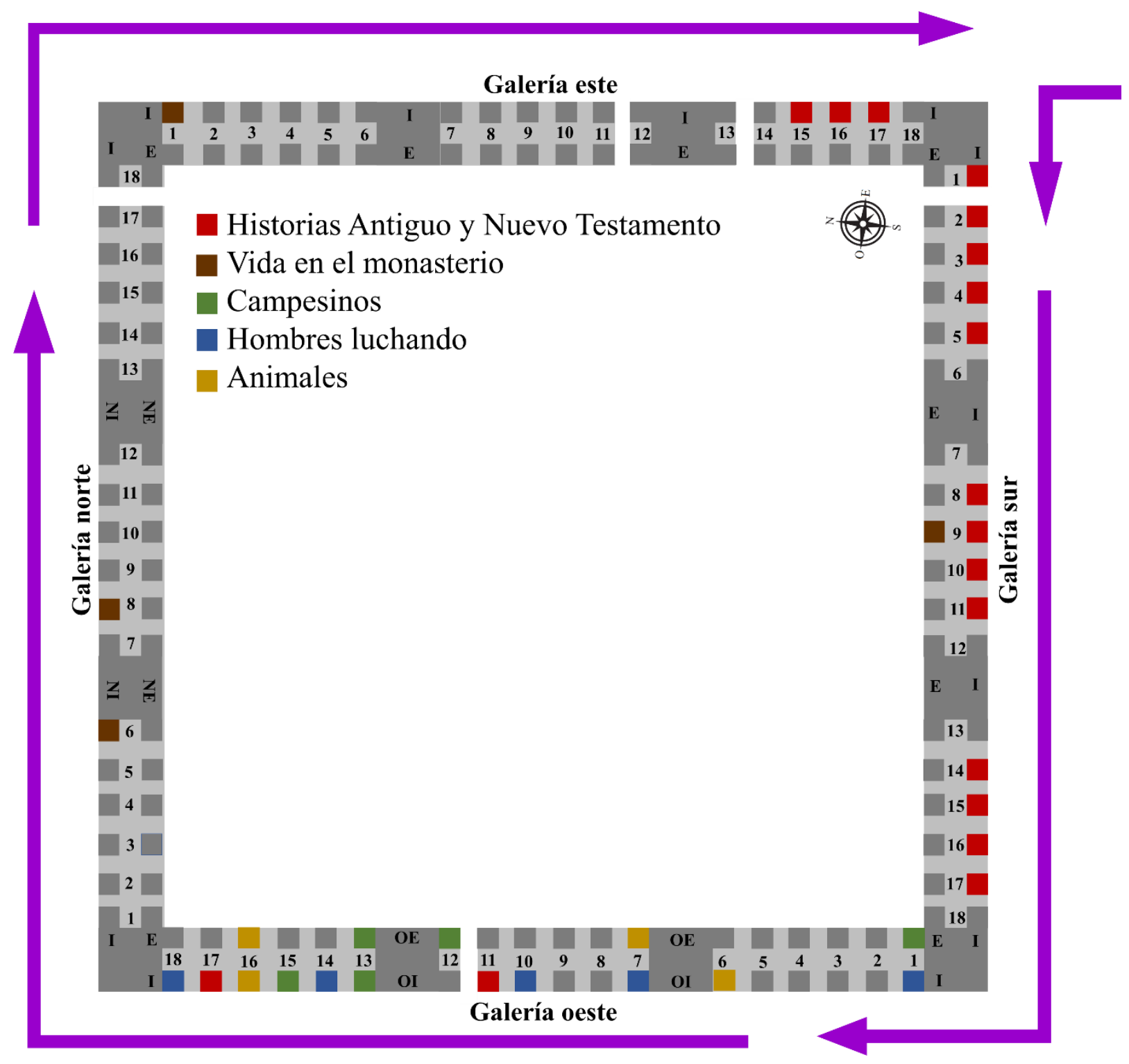

Figura 32. Distribución capiteles claustro de Sant Cugat del Vallès. 


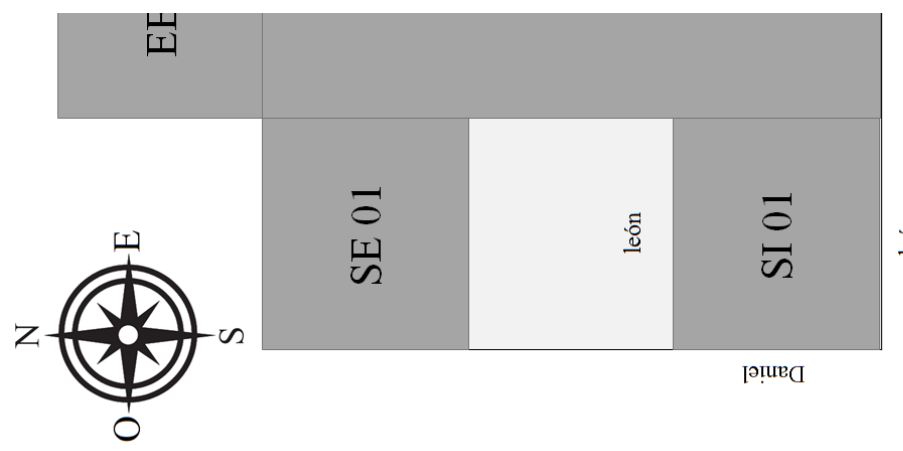

$\ddot{0}$

i

๘)

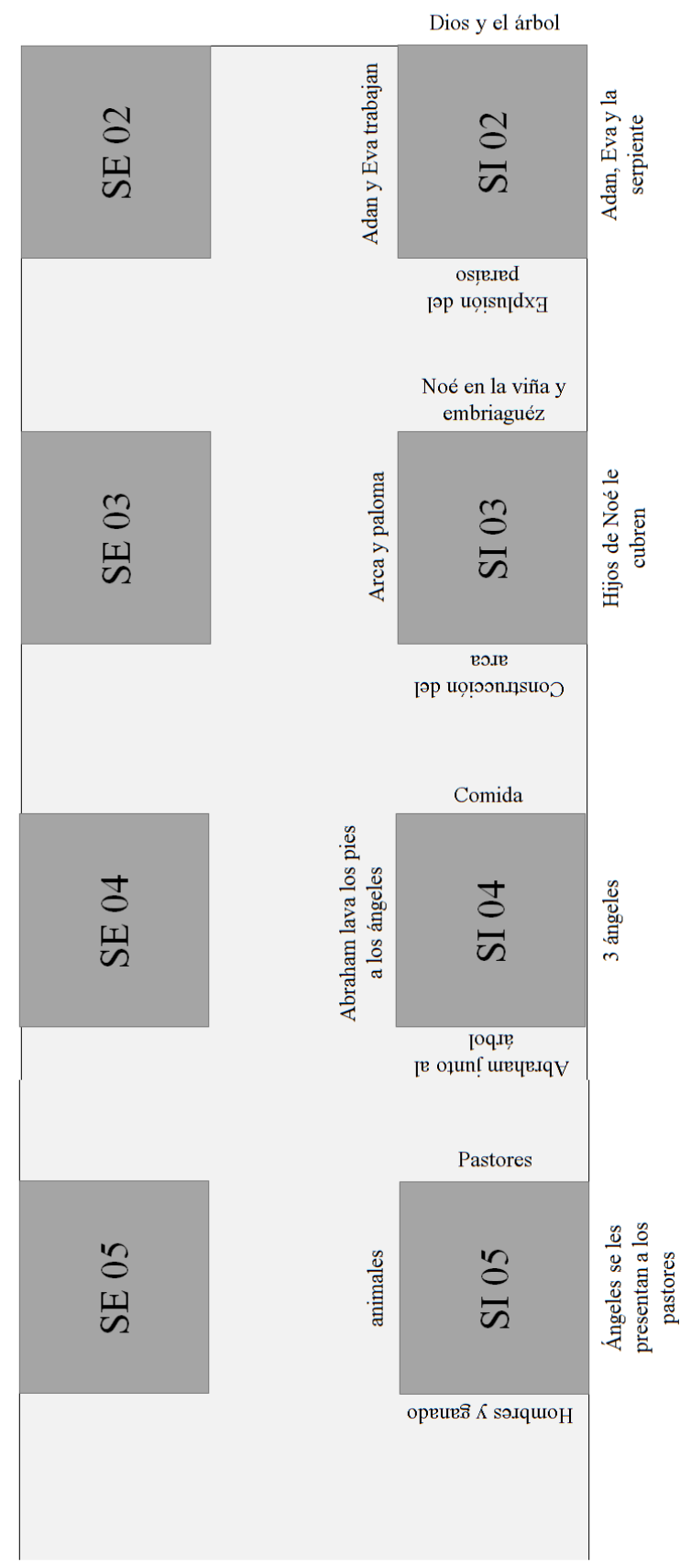

ฮ่

$\bar{\sigma}$

$\frac{\infty}{0}$

Uี

$\stackrel{5}{3}$

$\stackrel{2}{2}$

$\frac{a}{0}$

$\dot{0}$

$\frac{2}{2}$

3
5
5

:

ఏ

ริ

5
0
0
0
0
0
0
0

లై 


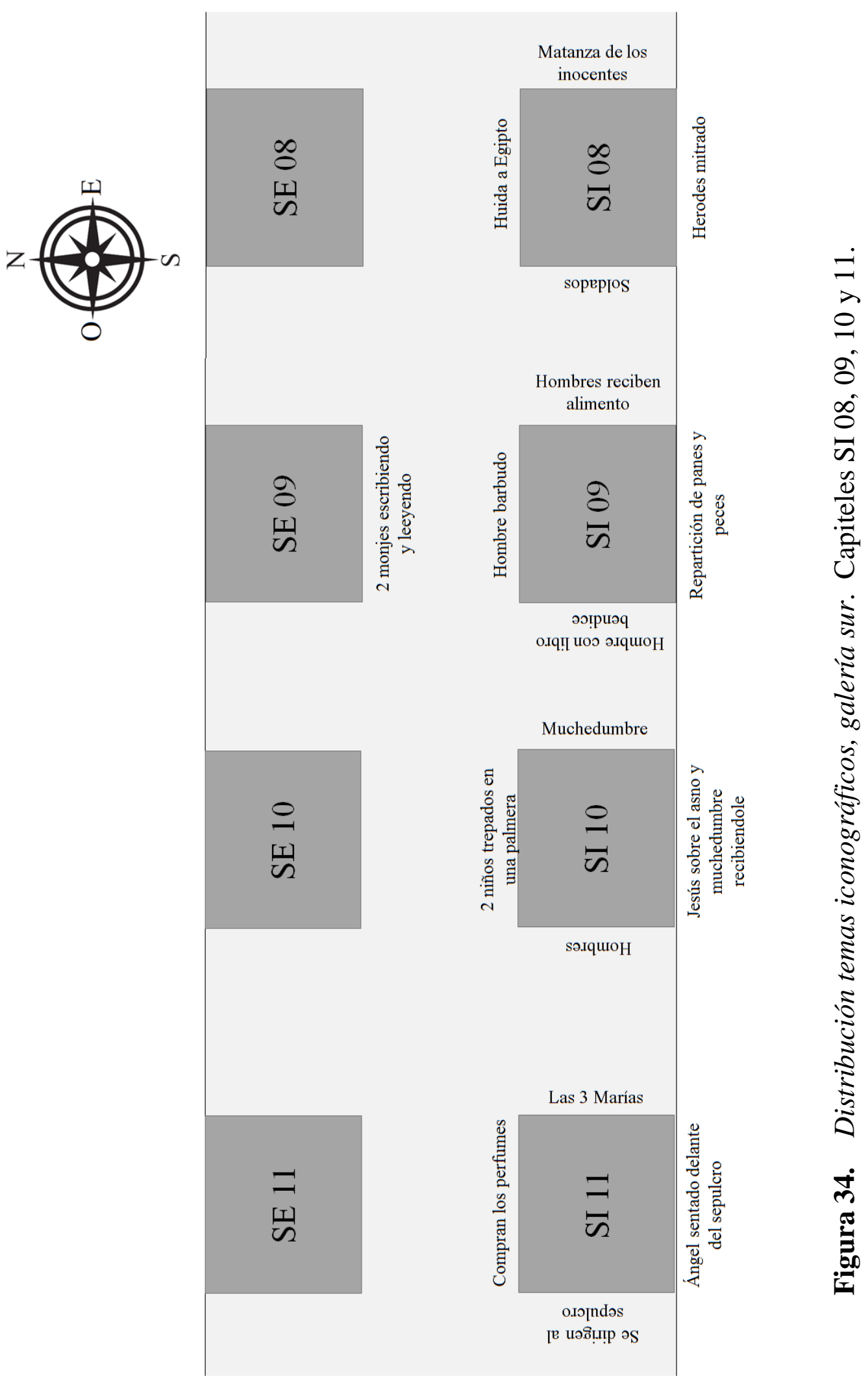




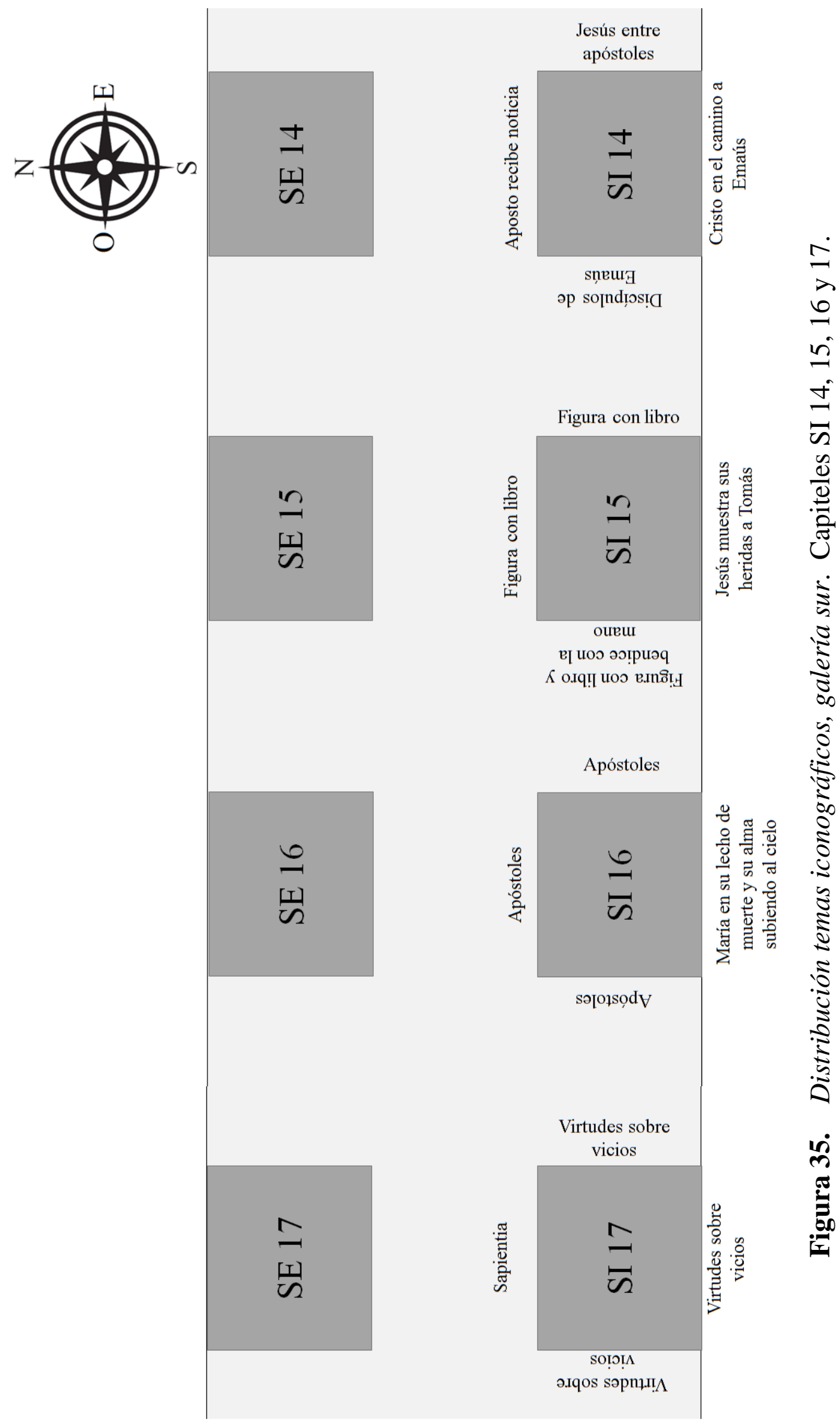




\subsubsection{Galería sur}

A pesar de que la galería sur fue el último tramo del claustro que se construyó, y que estilísticamente muestras ciertas diferencias con el resto de los temas como bien apunta la profesora Lorés, para la reconstrucción del ductus es un imperativo comenzar la discusión iconográfica por esta ala de la clausura. Se realizó durante la primera mitad del siglo XIII y es la que cuenta con el mayor número de capiteles historiados o figurativos en los que se sintetizan historias del Antiguo y Nuevo Testamento. En las figuras 33, 34 y 35 hemos recogido la disposición de los distintos temas iconográficos tratados en los capiteles y su respectiva ubicación con respecto al claustro. Por medio de estas imágenes constatamos que el tema principal se plasmó en la cara que se proyecta al interior del claustro, sin embargo, esta cara no siempre coincide con el orden cronológico de la historia. El inicio de la historia suele plasmarse en los laterales, lo que nos lleva a pensar que los monjes podían sentarse entre las distintas columnas del claustro y cómodamente contemplar la imagen labrada que daría paso en el proceso de meditación al resto de la historia. Esto es posible ya que la altura a la que se ubicaron estos distintos capiteles es muy accesible para cualquier espectador sentado o de pies y el espacio entre capiteles es el suficiente como para no agobiar el campo de visión.

Anteriormente se planteó que al tener en cuenta el currículo de enseñanza y estudio del monasterio, y a la misma vez el orden de las distintas historias plasmadas en los capiteles es un imperativo comenzar la lectura del claustro en esta galería. Los capiteles de este lado se encuentran en orden, comenzando por historias y personajes del Antiguo Testamento y finalizan con temas del Nuevo Testamento. Este recorrido parte de la puerta que conecta el claustro a la iglesia, el eje oeste-sur del claustro y siguiendo la dirección con las manecillas del reloj. 


\subsubsection{Historias del Antiguo Testamento}

En este andar en el claustro, en el primer capitel historiado, el SI 01, se aprecia una figura masculina. Éste con su mano derecha bendice y con la izquierda sujeta un libro y se encuentra flanqueado por un par de leones. La presencia de estos dos animales ha llevado a identificar a la figura sedente con Daniel en el foso de los leones (Fig. 36) 25 . Daniel es considerado una prefiguración de Cristo y el episodio de su vida aquí representado remite a la Resurrección de Jesús, por lo tanto, es un símbolo de la salvación del alma ${ }^{26}$. El libro de Daniel es uno de los textos de época medieval que se conservan de Sant Cugat. La presencia de este profeta y toda su significación exalta el ciclo de la Resurrección plasmado en los últimos tres capiteles de la galería meridional y que más adelante serán discutidos.

En el siguiente (SI 02) aparecen Adán y Eva (Fig. 37). El orden del ciclo no está muy claro. A pesar del mal estado de la cara que da al interior de la galería, en ésta se puede reconocer los restos de un árbol que se encuentran en el centro de la composición, y a la izquierda una figura masculina desnuda. Claramente en este lado del capitel se representó el momento en el que Adán y Eva comen de la fruta prohibida, el momento en el que pecan. En la cara contraria a ésta, en la norte, se plasmó el castigo de ambos, la condena al trabajo. La identificación de las escenas en los laterales es un tanto más complicada, esto se debe como ya había apuntado Baltrusaitis al hecho de que la composición de ambas es muy similar. Para la profesora Lorés, el relato del génesis comienzas en la cara este en la que se plasma Dios sujetando el brazo de Adán y detrás de éste Eva, se recoge la creación ${ }^{27}$. Ya con anterioridad Baltrusaitis había determinado que esta escena con la expulsión de Adán y Eva del paraíso y la escena en la cara este con la admonición de Dios ${ }^{28}$.

\footnotetext{
${ }^{25}$ LORES I OTZET. "La escultura del claustre i de l'eglésia..., p. 177. BALTRUSAITIS, Jurgis. Les Chapiteaux de Sant Cugat del Vallès. Paris: Librairie Ernest Leroux, 1931. p. 84.

${ }^{26}$ RÉAU, Louis. Iconografía del arte cristiano. Iconografía de la Biblia. Antiguo Testamento. Tomo 1, Vol. 1. Barcelona: Ediciones del Serbal, 1999. p. 459.

${ }^{27}$ LORÉS I OTZET. "La escultura del claustre i de l'eglésia..., p. 177.

${ }^{28}$ Baltrusaitis. Les Chapiteaux de Sant Cugat ..., pp. 78-79.
} 
Si se observan con detenimientos los distintos gestos de los personajes, especialmente de la figura de Dios, la lectura de Baltrusaitis es la más probable. En la cara este se labró igualmente un árbol el cual Dios con su mano derecha señala, gesto que vincula a los personajes directamente con el objeto señalado, el árbol. De igual forma las sutilezas del lenguaje corporal en la cara oeste también sirven para entender mejor el momento aquí plasmado. Con su mano izquierda Dios sujeta la muñeca derecha de Adán y eleva la derecha cuyo gesto se ha perdido. Detrás de Adán se esconde Eva. Este gesto es uno de intimidación, subyugación o sometimiento. Garnier establece que el agarrar la muñeca de otro es un gesto por el cual una persona afirma el poder que tiene o posee o desea poseer sobre otro hombre. No se trata de un gesto cualquiera de amistad o simpatía. La naturaleza de esta verdadera posesión depende de cada uno de los personajes envueltos en la situación y de los gestos complementarios, es la manifestación corporal del poder físico o moral que se tiene sobre otro ${ }^{29}$. Puesto que la otra mano de la figura de Dios se perdió sólo se pueden establecer conjeturas sobre el gesto complementario, por la posición elevada podría ser uno de reprimenda. Según Louis Réau, existen ejemplos en donde Dios es quien al expulsar a Adán y Eva del Paraíso les otorga una túnica de piel y las herramientas de trabajo al que están condenados ${ }^{30}$.

A parte de la sutileza de los gestos, otro elemento permite identificar la cara oeste como el inicio de la historia, y es la ubicación del capitel con respecto al claustro y la galería ${ }^{31}$. Como se aprecia en las figuras 32 y 33, este capitel se encuentra entre uno de los puntos que conecta las distintas galerías del claustro al

\footnotetext{
29 "La tenue du poignet est un geste par lequel une personne affirme le pourvoir qu'elle a, qu'elle prend ou qu'elle veut prendre sur un autre homme. Il ne s'agit pas d'une quelconque marque d'amitié, de sympathie. La nature de cette véritable possession dépend de la condition de chacun des personnages en relation, et des gestes complémentaires. Manifestation corporelle d'une puissance physique ou morale...". GARNIER, François. Le langage de l'image au Moyen Âge (I). Signification et symbolique. París: Le Léopard d'Or, 1982. p. 199.

${ }^{30}$ REAU. Iconografía del arte cristiano. Iconografía de la Biblia. Antiguo Testamento. Tomo 1, Vol. 1..., p. 112.

31 "Composition begins with clearly and deliberately locating oneself in a place..." CARRUTHERS. The Craft of Thought..., p. 73.
} 


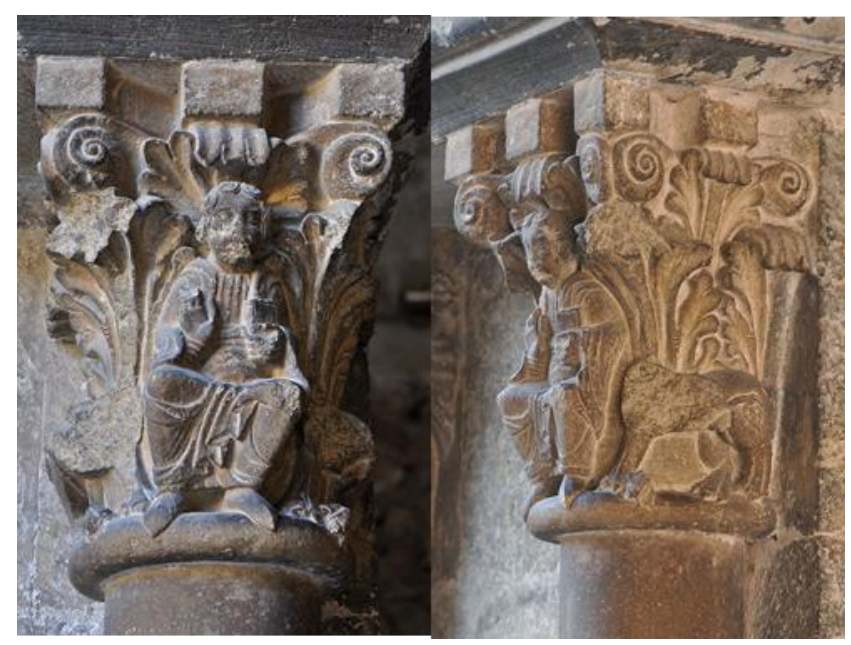

Figura 36. Daniel en la fosa. Capitel SI 01. (Siglo XIII) Galería sur. Monasterio de Sant Cugat del Vallès.

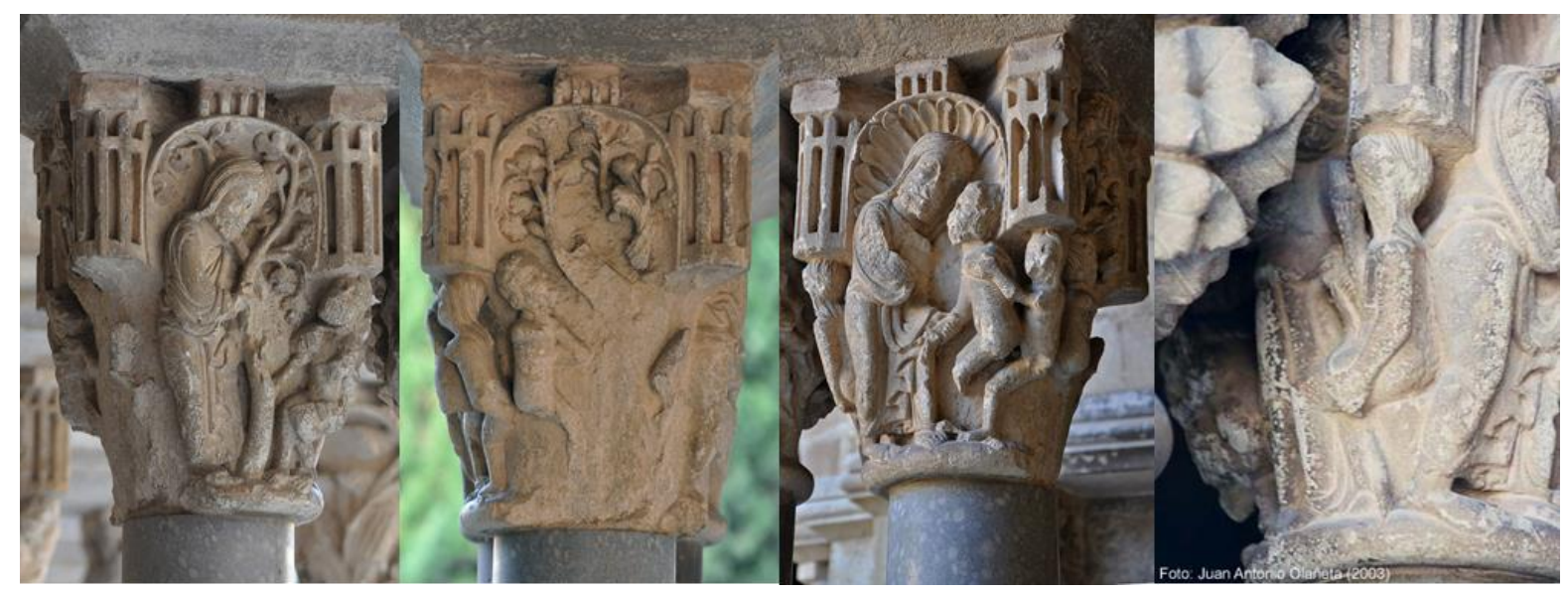

Figura 37. Ciclo de Adán y Eva. Capitel SI 02. (Siglo XIII) Galería sur. Monasterio de Sant Cugat del Vallès.

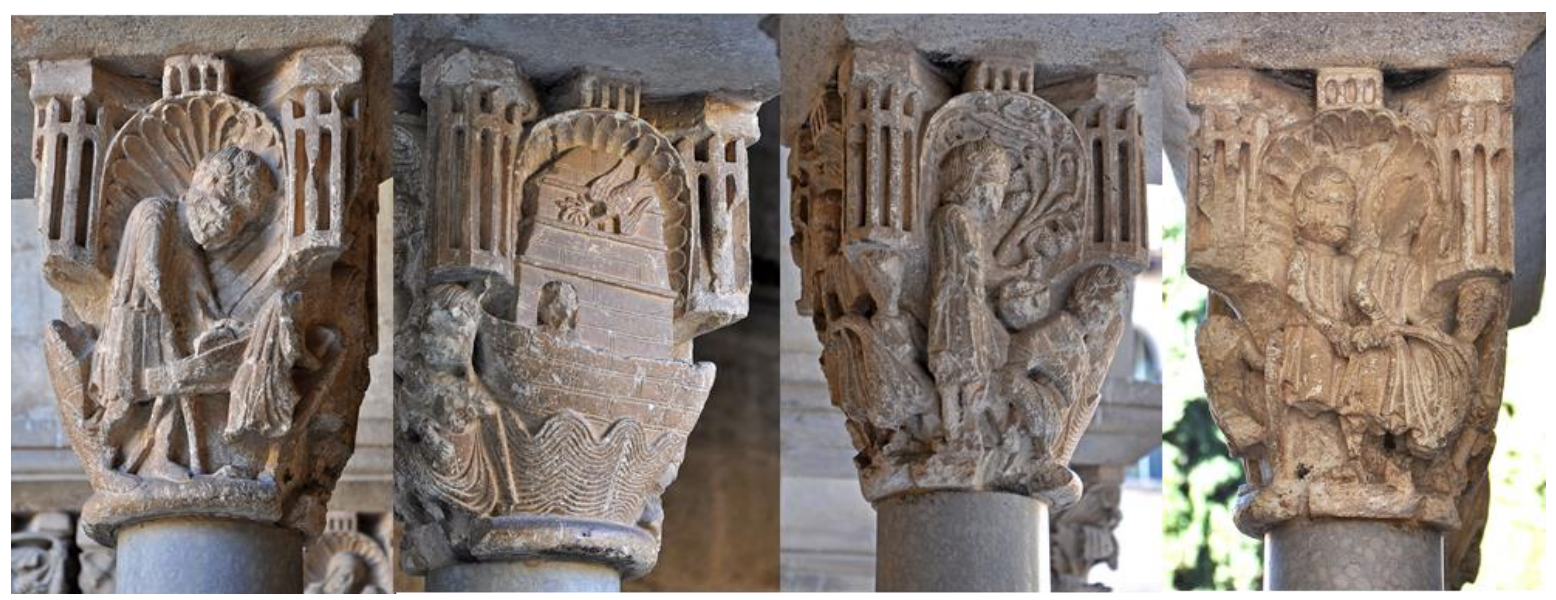

Figura 38. Ciclo de Noé. Capitel SI 03. (Siglo XIII) Galería sur. Monasterio de Sant Cugat del Vallès. 
patio de ésta. A esto se ha de añadir que esta galería enlaza directamente con la puerta de acceso al templo, lo que significa que los monjes cuando salían del templo y transitaban por esta galería el primer capitel con el que se encontraban era éste y la primera cara que apreciaban era la este, la que se recoge la amonestación a Adán y Eva de no comer del árbol prohibido.

El capitel SI 02 (Fig. 37) con el ciclo de los protoplastos Adán y Eva sirve como signo o señal de un lugar mnemónico de recopilación que evoca los distintos sentidos de las escrituras. Las figuras de Adán y Eva son prefiguraciones de Jesús y la Virgen María, la "nueva Eva". Eva introdujo el pecado en el mundo y a través de María llegó la salvación y la redención ${ }^{32}$. No sólo las figuras humanas en esta representación se imbuyen de una serie de significaciones, sino que también los elementos como el árbol o el mismo sitio el cual según el relato bíblico tiene lugar la escena también gozan de diversas interpretaciones que enriquecen la imagen. Elemento esencial en el relato de Adán y Eva es el árbol de la ciencia. Éste por una parte en muchas zonas es una plasmación de la vegetación del entorno geográfico en la que se representa el tema. En Bizancio e Italia la tendencia fue plasmar una higuera o un naranjo, en Francia un manzano y en países vitícolas una vid. Además de informarnos sobre los frutos propios de tal o cual zona, el árbol de la ciencia del que comieron Adán y Eva ha sido entendido como una prefiguración de la cruz, la muerte vino del árbol, la vida de la cruz ${ }^{33}$, por lo tanto, prefigura la Crucifixión de Jesús y en términos anagógico la salvación y la redención.

Este capitel se vincula directamente con el último de la galería meridional, el SI 17 (Figs. 49 y 50), en el que se representan las virtudes victoriosas sobre los vicios derrotados. La escena del capitel del ciclo de Adán y Eva es el pecado original, la cual se plasmó en la cara meridional que da al interior de la galería, en

\footnotetext{
${ }^{32}$ RÉAU. Iconografía del arte cristiano. Iconografía de la Biblia. Antiguo Testamento. Tomo 1, Vol. 1..., p. 102.

${ }^{33}$ RÉAU. Iconografía del arte cristiano. Iconografía de la Biblia. Antiguo Testamento. Tomo 1, Vol. 1..., p. 109.
} 
contraposición a la imagen con la que concluye el ciclo la cual exalta la práctica de las virtudes. En este sentido, el inculcar en la mente de los religiosos la virtud y la eliminación del vicio eran indispensables para reparar las heridas del alma causadas por el pecado original ${ }^{34}$.

La escena con la que culmina este capitel y comienza el siguiente se concatenan visualmente por medio de la composición de la misma. Esto podría interpretarse como una especie de rima o ritmo visual que se repite en los tres chapiteles subsiguientes. Una parte esencial que permite el flujo del ductus en una obra literaria son los modus o color, o sea los ornamentos retóricos provistos por las figuras y tropos del lenguaje. En este caso, la repetición y concatenación de escenas por medio de la composición de la imagen permite un flujo visual entre capiteles. La escena con la que finaliza el ciclo de Adán y Eva es la del castigo de esto, la condena al trabajo. En la cara norte del chapitel se aprecian ambas figuras en plena faena, siendo esta el lado que concatena con el inicio del ciclo de Noé en el capitel SI 03 (Fig. 38).

La historia de Noé inicia con en la cara de levante, en donde se plasmó a este personaje en plena faena construyendo el arca. El relato continua en la cara norte donde la paloma vuelve con la rama de olivo para notificarle a Noé que la tierra se está secando. En el resto de las caras se relata visualmente la embriaguez de Noé y sus hijos que se acercan a cubrirle. En la oeste se recogen dos escenas, la primera es Noé recogiendo las uvas, junto a ésta figura se aprecia una segunda representación de éste, esta vez tumbado junto a la vid. En la cara sur aparecen tres figuras, una de ésta lleva un manto, claramente es el momento en el que Cam llama a sus hermanos y estos se acercan a cubrir a su padre.

Como lugar mnemónico de recopilación, locus, este capitel evoca la rememoración no sólo de las escenas plasmadas en las distintas caras del mismos,

${ }^{34}$ RiVERS, Kimberly A. Preaching the Memory of Virtue and Vice. Memory, Images, and Preaching in the Late Middle Ages. Turnhout: Brepols, 2010. p. 247. 
sino también las sutilezas implícitas de la historia. Si ya bien se tocó la relación visual entre la composición de la escena del ciclo de Adán y Eva y el inicio de la historia de Noé, dicha correlación no es meramente compositiva, sino que incluso es genealógica. Según el Génesis, Noé, nieto de Matusalén, desciende de Set, hijo de Adán ${ }^{35}$. A propósito de las sutilezas implícitas, el arca flotando sobre las aguas en la cara norte, imagen que resume toda la historia, además de evocar el final del diluvio recuerda al espectador el castigo de Dios, castigo que igualmente nos remite a la expulsión del Paraíso y la condena al trabajo.

Noé igualmente es una prefiguración de Cristo, "el hombre justo salvador de la humanidad ${ }^{36}$ " . La embriaguez de éste, recogida en la cara de oriente fue considerada una prefiguración de la Pasión de Cristo, específicamente con el momento en que los despojan de sus vestimentas. El diluvio y el arca poseen un sentido sacramental y escatológico. El navío construido por Noé se asimila con la nave de la iglesia, la barca es el templo y Noé es Cristo, el diluvio prefigura el bautismo por el cual se purifican los individuos del pecado original, pero a la misma vez la destrucción producto del mismo recuerda al hombre el Juicio Final ${ }^{37}$. La imagen con el arca recoge el momento en el que la paloma regresa con el ramo de olivo, prefiguración de la venida del Espíritu Santo sobre los Apóstoles ${ }^{38}$, y que a la misma vez evoca el sacramento de la confirmación, siendo éste junto al bautismo uno de los sacramentos de iniciación cristiana, el cual antiguamente se solía administrar junto al bautismo.

Durante la Edad Media la imagen e idea del arca se vinculaba directamente con la memoria. Ésta desempeñaba un papel importante con las mnemotecnias, ya

\footnotetext{
${ }^{35}$ Génesis 5: 1-32.

${ }^{36}$ GONZÁlez HeRnANDO, Irene. "El diluvio universal", en: Revista Digital de Iconografía Medieval, Vol. 3, No. 6 (2011), p. 44.

${ }^{37}$ HeINZ-MOHR, GERD. Lessico di iconografia cristiana. Milán: Istituto di Propaganda Libraria, 1995. pp. 50, 242. RÉAU. Iconografía del arte cristiano. Iconografía de la Biblia. Antiguo Testamento. Tomo 1, Vol. 1.., p. 130.

38 HeINZ-MoHR. Lessico di iconografía..., p. 243. RÉAU. Iconografía del arte cristiano. Iconografía de la Biblia. Antiguo Testamento. Tomo 1, Vol. 1.., p. 137.
} 
la imagen, real o mental, de ésta servía como un locus. Los teólogos y pensadores medievales asignaron esta función mnemónica al arca partiendo de la propia función de ésta en las Sagradas Escrituras ${ }^{39}$, pues no sólo se remiten al navío construido por Noé, sino también al arca de la Alianza. Ambos son contenedores de algo, la primera de los distintos seres vivos que habitaban la tierra según el relato del Génesis:
"Entrarás en el arca tú y tus hijos, tu mujer y las mujeres de tus hijos contigo. Y de todo ser viviente, de toda carne, meterás en el arca una pareja para que sobrevivan contigo. Serán macho y hembra. De cada especie da aves, de cada especie de ganados, de cada especie de sierpes del suelo entraran contigo sendas parejas para sobrevivir ${ }^{40}$ "

la segunda almacenaba las tablas de la Ley con los diez mandamientos que Dios entregó a Moisés en el monte Sinaí: “En el arca pondrás el Testimonio que yo te voy a dar ${ }^{41}$ ".

A partir de esta idea del arca como contenedor, durante el período en el que nos circunscribimos, surge la noción de la mente y la memoria como arca sapientiae, en donde se diseñan y construyen las memorias y recuerdos en base a los talentos, oportunidades y energías del individuo. Esta noción se vincula directamente con la lectura bíblica, el estudio y la meditación ${ }^{42}$ : prácticas que como anteriormente se ha discutido se realizaban en el claustro de Sant Cugat.

La última historia veterotestamentaria que se aprecia en esta galería se centra en torno a Abraham y la visita de los tres ángeles, capitel SI 04 (Fig. 39). El relato inicia como en los capiteles anteriores, en la cara oeste con Abraham junto a la encina de Mambré y continua en el interior de la galería con la aparición

\footnotetext{
${ }^{39}$ CARruthers. The Craft of Thought..., p. 246. CARruthers. The Book of Memory..., p. 43.

${ }^{40}$ Génesis 6: 18-20.

${ }^{41}$ Éxodo 25: 16.

${ }^{42}$ RIVERS. Preaching the Memory..., p. 133. CARRUTHERS. The Book of Memory..., p. 43.
} 


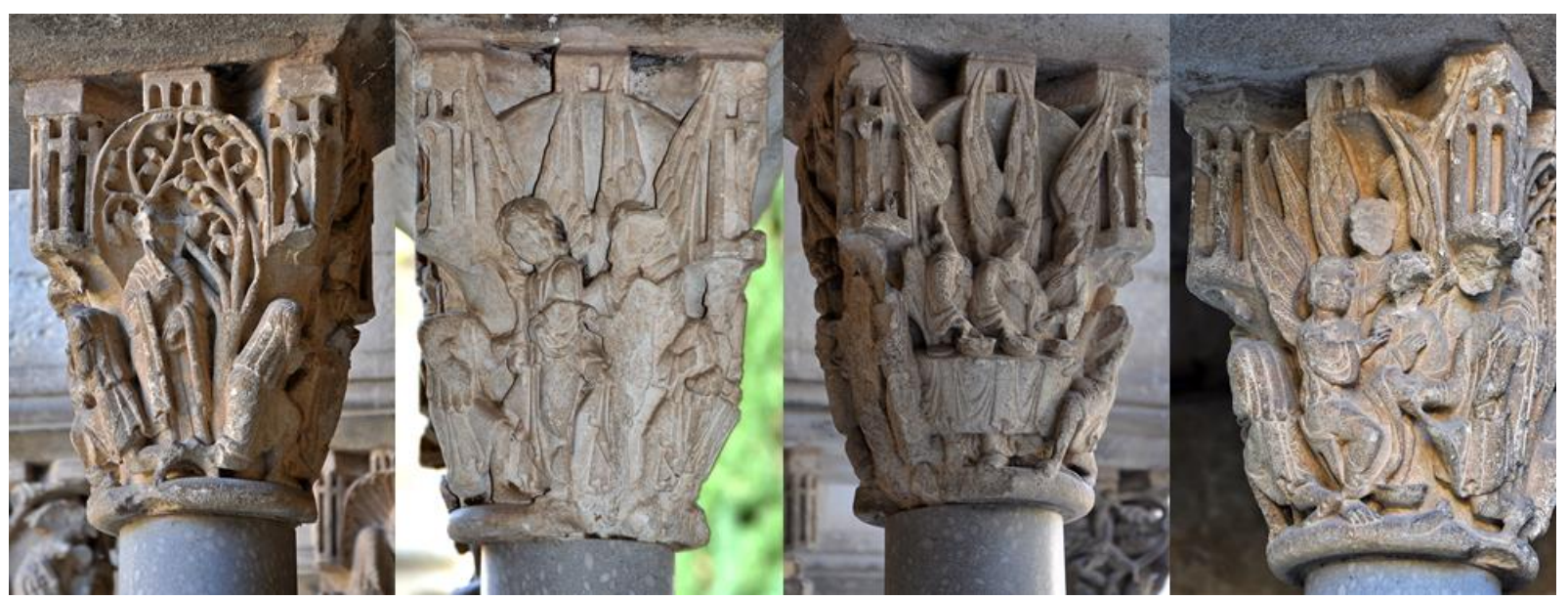

Figura 39. Ciclo de Abraham. Capitel SI 04. (Siglo XIII) Galería sur. Monasterio de Sant Cugat del Vallès.

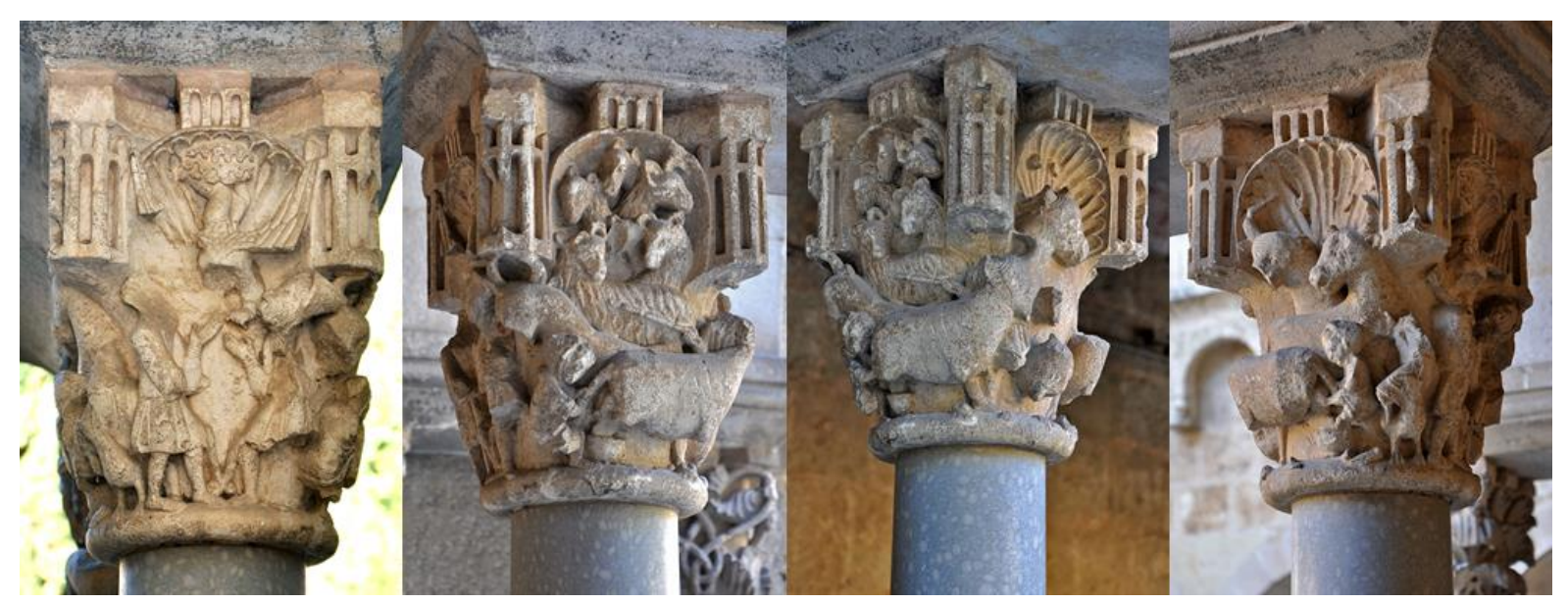

Figura 40. Anunciación a los pastores. Capitel SI 05. (Siglo XIII) Galería sur. Monasterio de Sant Cugat del Vallès.

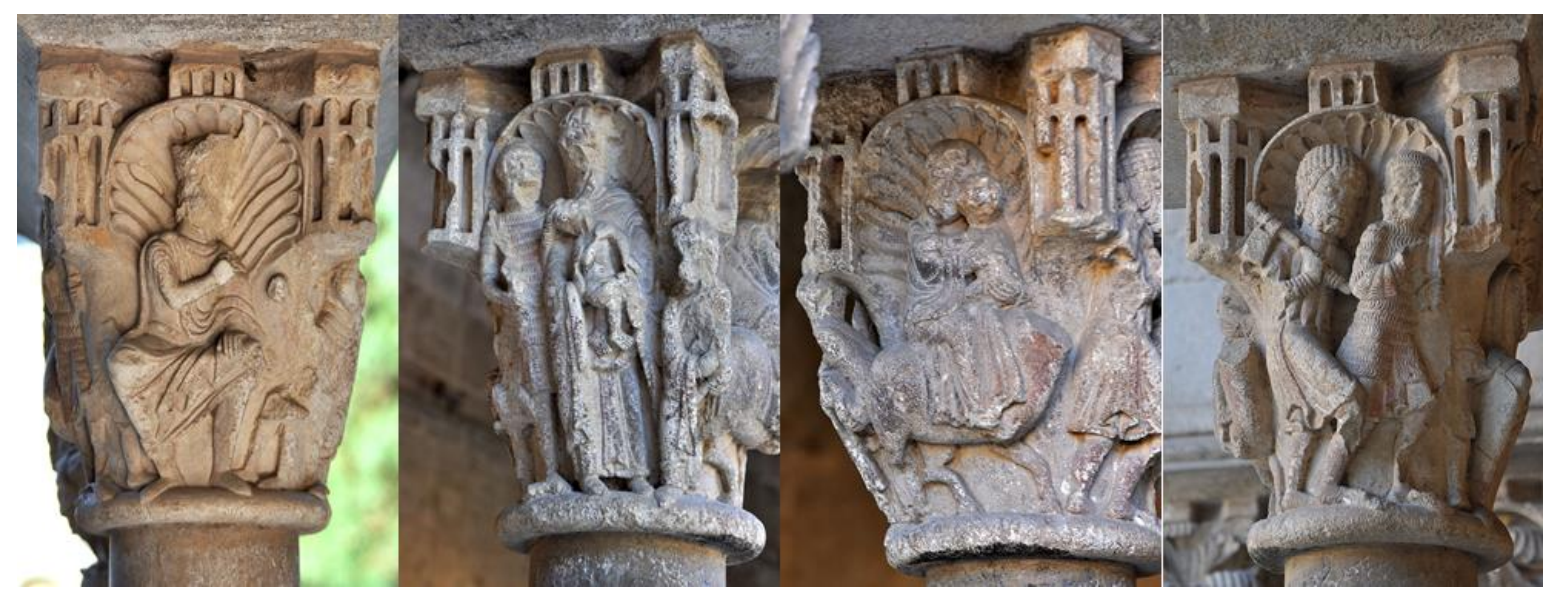

Figura 41. Huida a Egipto. Capitel SI 08. (Siglo XIII) Galería sur. Monasterio de Sant Cugat del Vallès. 
de los tres ángeles. En la cara norte se plasmó a Abraham lavándole los pies a los invitados y en la cara oeste el convite que les preparó.

El capitel de Noé visualmente se concatena con el de Abraham. El ciclo de Noé concluye con la imagen de éste junto a la vid y el momento en que sus hijos le encuentran. El ciclo de Abraham inicia en el momento en que estando el patriarca descansando junto a la encina de Mambré los tres ángeles se le aparecen. Como en el capitel anterior, aquí encontramos una doble representación del protagonista. En la cara de poniente al lado de la higuera se aprecia de pie la figura de Abraham, y una segunda figura en posición de genuflexión. La segunda imagen del patriarca se arrodilla ante la presencia de los tres seres enviados por Dios, ante los tres ángeles. La repetición composicional la vemos en la doble representación del protagonista junto a un árbol y luego la presencia de otras figuras. En el caso de Noé, éstas responden a sus hijos, en el caso de Abraham son los ángeles. Se mantiene el ritmo visual entre los capiteles.

También este capitel se vincula por medio de la genealogía con la historia de Noé, ya que Abraham desciende de Sem, el hijo mayor de Noét3. En la escultura el tema que más suele representarse es el del Sacrificio de Isaac, principalmente en la entrada de los templos, prefiguración del sacrificio de Cristo. El capitel de Sant Cugat con el ciclo de Abraham, más que ser un ciclo, realmente representa un episodio particular de la vida de éste narrado en el capítulo 18 del Génesis, la visita de los tres ángeles también conocida como la filoxenia u hospitalidad de Abraham. La visita de los tres ángeles antecede el sacrificio de Isaac, sin embargo, son estos los que le anuncian a Abraham el nacimiento de su hijo Isaac, prefiguración de la Anunciación a la Virgen. En Bizancio, los tres ángeles en la mesa de Abraham son el símbolo de la Trinidad ${ }^{44}$.

\footnotetext{
${ }^{43}$ Génesis 11: 10-32.

${ }^{44}$ RÉAU. Iconografía del arte cristiano. Iconografía de la Biblia. Antiguo Testamento. Tomo 1, Vol. 1..., p. 162.
} 
Los temas representados suelen responder a los contextos y las audiencias de los mismos. Anteriormente se explicaba que, en la escultura en relación con la vida de Abraham, el momento por excelencia a representarse es el Sacrificio. En este capitel se plasmó un tema más común en manuscritos, como se puede apreciar en la miniatura 6 de los códices de la Psychomachia. En este caso la representación de la Filoxenia de Abraham puede vincularse directamente con la exaltación y la práctica de la hospitalidad en el contexto monacal. Parte importante de la Regla benedictina es la recepción de huéspedes en el cenobio. En los capítulos 53 y 61 se exalta la práctica de la hospitalidad, especialmente con los peregrinos y otros monjes de otras comunidades ${ }^{45}$. Estos debían ser recibidos como al mismo Cristo, saliendo a su encuentro el superior y los monjes ${ }^{46}$.

\subsubsection{Historias del Nuevo Testamento}

En dos capiteles de la galería sur se insertaron escenas vinculadas a la infancia de Jesús. Es con una de éstas que se introducen las historias neotestamentarias. En el capitel SI 05 se plasmó una escena vinculada directamente con la Natividad, la Anunciación a los pastores (Fig. 40). El momento que da nombre al capitel se encuentra representado en la cara sur, en el que se aprecia como del cielo desciende una figura alada, un ángel, y los pastores con las manos abiertas reciben el mensaje de éste. En las caras este, norte y oeste se aprecian los distintos animales que cuidan los pastores. El único evangelio que recoge este evento es el de Lucas.

\footnotetext{
${ }^{45}$ SAn Benito. Regla benedictina LIII y LXI. Edición consultada: San Benito: su vida y su regla. dirección e introducciones del Padre Dom García M. Colombas, versiones del Padre Dom León M. Sansegundo, comentarios y notas del Padre Dom Odilón M. Cunill. $\quad$ Madrid: Editorial Católica, S.A., 1954. pp. 585-591, 633-635.

46 "A todos los huéspedes que llegan al monasterio recíbaseles como al mismo Cristo, pues Él ha de decir: Huésped fui y me recibisteis. [...] Por tanto, en seguida que sea anunciado algún huésped, le saldrán al encuentro el superior y los monjes con la más obsequiosa caridad..." Regla benedictina LIII, 1 y 3. San Benito. San Benito: su vida y su regla..., pp. 359 y 587.
} 
Según Louis Réau, la representación de la Anunciación a los pastores es el motivo primitivo que a partir del siglo XV será remplazado por la plasmación de la Adoración de los pastores ${ }^{47}$. La escena recogida en el capitel de Sant Cugat responde al momento que antecede la adoración de los magos. Es en este instante en el que se les revela a los hombres la venida de su salvador. En términos tropológicos, la Anunciación a los pastores puede ser entendida como una exaltación a la virtud de la humildad, la buena nueva se anuncia primero a los pequeños, y no a los poderosos. Esto se infiere si se considera el contexto histórico y social en el que este evento tuvo lugar. En la época de Jesús, los pastores se encontraban en el estrato más bajo del campesinado. A través del mensaje del ángel, se exalta y enaltece al humilde ${ }^{48}$.

Más adelante, en el capitel SI 08 (Fig. 41) se representa la matanza de los inocentes y la huida a Egipto. En la cara sur que da al interior de la galería se plasmó la figura de Herodes dando la orden de matar a los niños menores de dos años de edad. En la cara este un soldado le arrebata el niño a una mujer. En el lado opuesto al de Herodes, en la cara norte se aprecia la escena de la huida a Egipto y sobre el asno la Virgen con el Niño. En la cara oeste se insertaron otras figuras cuya identificación resulta más complicada. Para Baltrusaitis y Lorés éstos forman parte del sequito de la Virgen, el Niño y José ${ }^{49}$. Sin embargo, la vestimenta de una de estas figuras es sumamente similar a la del soldado que agarra al niño en la cara de levante, además ambas figuras llevan armas por lo tanto las mismas en lugar de formar parte del séquito de la Sagrada Familia, realmente serían soldados de Herodes saliendo a cumplir el mandato de éste.

\footnotetext{
${ }^{47}$ RÉAU. Louis. Iconografía del arte cristiano. Iconografía de la Biblia. Nuevo Testamento. Tomo 1, Vol. 2. Barcelona: Ediciones del Serbal, 2008. p. 243.

${ }^{48}$ GREEN, Joel B. The Gospel of Luke. Grand Rapids; Cambridge: William B. Eerdmans, cop., 1997. pp. 130-131.

${ }^{49}$ LORES I OtZET. "La escultura del claustre i de l'eglésia..., p. 178. BALtrusaitis. Les Chapiteaux de Sant Cugat..., p. 84.
} 


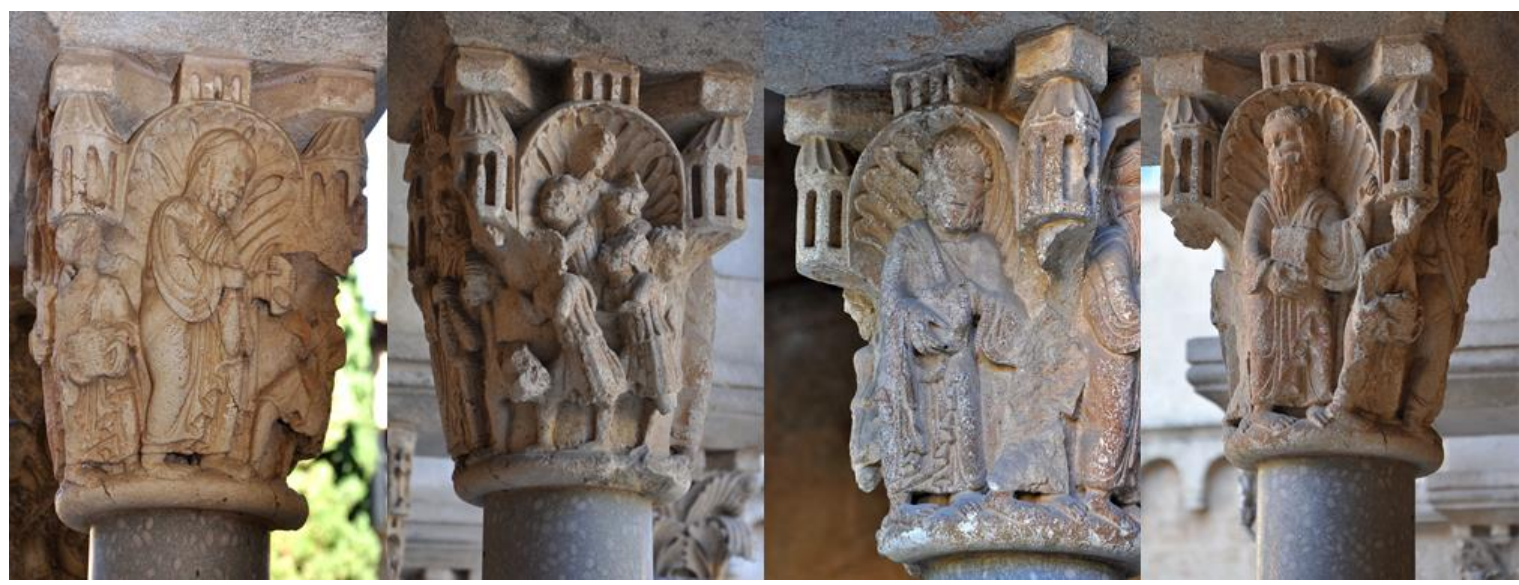

Figura 42. Multiplicación de los panes y peces. Capitel SI 09. (Siglo XIII) Galería sur. Monasterio de Sant Cugat del Vallès.

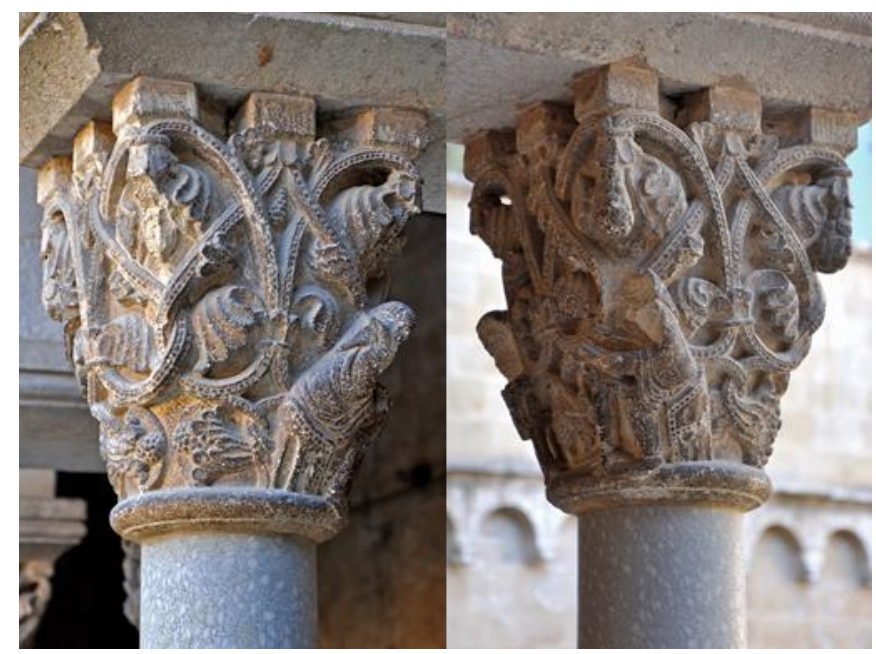

Figura 43. Monjes estudiando. Capitel SE 09. (Siglo XIII) Galería sur. Monasterio de Sant Cugat del Vallès.

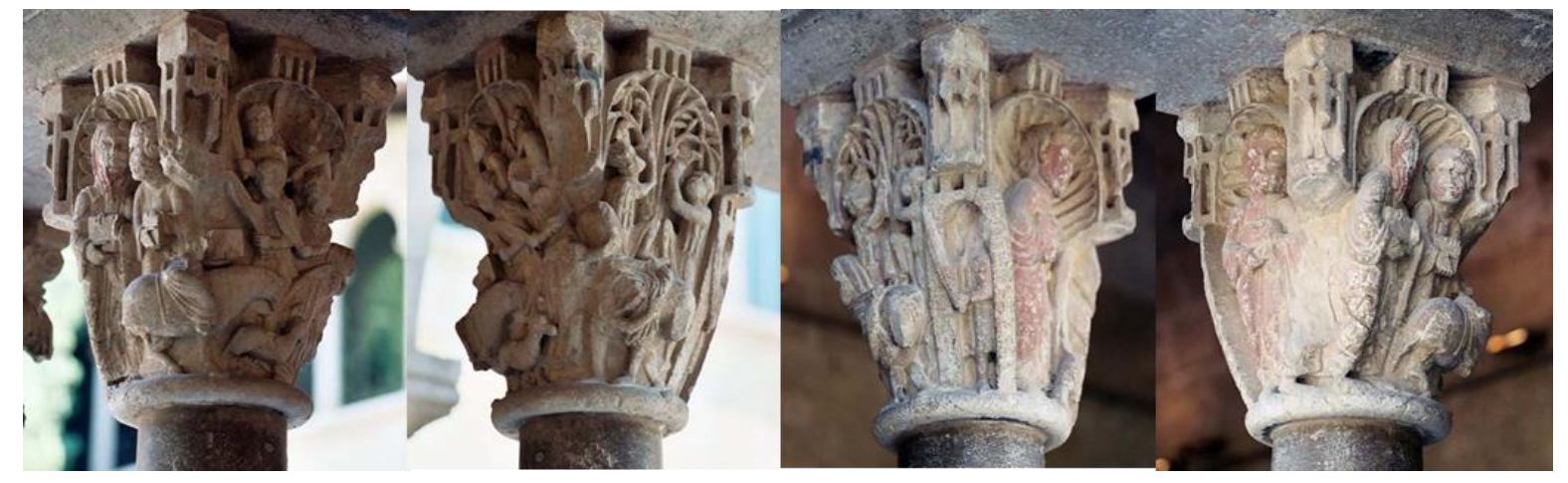

Figura 44. Entrada a Jerusalén. Capitel SI 10. (Siglo XIII) Galería sur. Monasterio de Sant Cugat del Vallès. 
En este capitel se recogen dos historias neotestamentarias, específicamente del evangelio de Mateo, la Huida a Egipto y la Masacre de los Inocentes. Según el evangelista, José al ser avisado en sueño por un ángel huye con María y el Niño a Egipto y luego es que sucede la matanza de los inocentes. A la hora de representar esta historia, el orden se invertía, plasmando en primer lugar a Herodes dando la orden de matar a los niños y como consecuencia de esta acción la Sagrada Familia huye ${ }^{50}$. Los sucesos aquí recopilados visualmente en el calendario litúrgico dieron paso a la festividad de los Santos Inocentes. Esta fiesta se celebraba en el monasterio con especial cuidado, tal como lo indica el costumari $^{51}$.

El siguiente capitel historiado, el SI 09, introduce al espectador a la vida pública de Jesús y específicamente un milagro de éste, la multiplicación de los panes y peces (Fig. 42). En las caras sur y este se recoge el momento en el que Jesús reparte el alimento a la muchedumbre y detrás de éste una figura, la cual ha perdido la cabeza, sujeta una cesta llena de panes. En las otras dos caras se representan figuras barbudas con libros, algunos de los apóstoles ${ }^{52}$. Este capitel $a$ priori plasma el milagro bíblico, sin embargo, como lugar mnemónico de recopilación son más los conocimientos que el espectador puede desprender del mismo. La multiplicación de los panes y peces rememora los milagros consumados por Moisés, la recogida del maná y la lluvia de codornices, y Eliseo, la multiplicación del aceite y pan $^{53}$. Este milagro junto con el del vino en las Bodas de Caná es un símbolo eucarístico ${ }^{54}$.

\footnotetext{
${ }^{50}$ RÉAU. Iconografía del arte cristiano. Iconografía de la Biblia. Nuevo Testamento. Tomo 1, Vol. 2..., p. 278.

51 "De offitio festivitatis Sanctorum Innocentum". El costumari del monestir de Sant Cugat del Vallès..., pp. 179-180.

${ }^{52}$ LORÉS I OTZET. "La escultura del claustre i de l'eglésia..., p. 178. BALTRUSAITIS. Les Chapiteaux de Sant Cugat..., p. 85.

${ }^{53}$ RÉAU. Iconografía del arte cristiano. Iconografía de la Biblia. Nuevo Testamento. Tomo 1, Vol. 2..., p. 377.

${ }^{54}$ RÉAU. Iconografía del arte cristiano. Iconografía de la Biblia. Nuevo Testamento. Tomo 1, Vol. 2..., p. 383.
} 
Junto a este capitel, se aprecia otro historiado, el SE 09. Este es el único ejemplo de los chapiteles exteriores en el que no se representan solamente motivos ornamentales de tipo vegetal. Aquí se incluye una escena de la vida en el claustro, los monjes estudiando los cuales se plasmaron en la cara sur, cara que se aprecia sin problema alguno desde el interior de la galería. Ambos monjes se plasmaron sedentes cada uno delante de un atril sobre el cual reposa un libro abierto. Uno de los monjes escribe mientras que el otro sujeta el códice como si leyera (Fig. 43). Ya la profesora Lorés había interpretado el mismo como una alusión a la lectura y la escritura como actividad cotidiana que se realizaba en el claustro de Sant Cugat $^{55}$. Anteriormente se hacía hincapié de que la presencia de los monjes que leen y estudian es una señal que marca: el lugar donde se realizaban dichas actividades y quiénes las llevaban a cabo. En este sentido recuerda a la efigié de Prudencio al inició del poema de la Psychomachia. En el ejemplo del poeta, la imagen era un signum que indicaba al monje u oblato usuario del códice quien pronunciaba las palabras al inicio y final del poema. En este caso los monjes en el capitel recuerdan a los hermanos de la comunidad que esta es la zona en la que se llevan a cabo estas tareas.

El último capitel en el que se incluyó una escena de la vida pública de Jesús es el SI 10 (Fig. 44) en el cual se plasmó la entrada de Jesús a Jerusalén. En el ángulo de las caras oeste y sur se aprecia a Jesús sobre el asno. En la cara levante la muchedumbre le recibe, ésta se representó por medio de las cuatro figuras que sujetan ramas de palma. En el lado este del capitel se aprecian dos figuras de menor dimensión, éstas se suben a coger ramos de una palmera. Entre la esquina de esta cara y la norte se labró una puerta, la entrada a la ciudad de Jerusalén, y junto a ésta una figura sujetado un ramo. A Jesús en el asno le acompañan cuatro apóstoles, los cuales se incluyeron entre las caras norte y oeste ${ }^{56}$.

\footnotetext{
${ }^{55}$ LORÉS I OTZET. "La vida en el claustra..., p. 40.

${ }^{56}$ LORES I OTZET. "La escultura del claustre i de l'eglésia..., p. 178. BALTRUSAitis. Les Chapiteaux de Sant Cugat..., pp. 85-86.
} 
Tras la entrada de Jesús a Jerusalén, una serie de eventos se desatan culminando con la Pasión y Crucifixión de éste, momento clave en términos anagógico para el cristiano. A pesar de la importancia de la Pasión y Crucifixión para con la vida del creyente, en el claustro de Sant Cugat se plasmó la escena que antecede estos eventos. "Su prefiguración bíblica es el triunfo del joven David aclamado después de su victoria sobre Goliath ${ }^{57 \%}$. La entrada de Jesús en Jerusalén, como la recoge el evangelista Mateo, es el cumplimiento de la profecía de Zacarías: “¡Exulta sin freno, hija de Sión grita de alegría, hija de Jerusalén! He aquí que viene a ti tu rey: justo él y victorioso, humilde y montado en un asna ${ }^{58}$ ".

En este capitel nuevamente se exalta la humildad. La misma se manifiesta visualmente a través de la presencia del asno el cual ha sido representado por segunda vez en la galería sur. Este animal antes de la introducción del caballo en Mesopotamia y en la cuenca del Mediterráneo, aproximadamente el siglo VI, era considerado uno noble, hábil, inteligente y paciente que luego fue degradado a animal de tiro ${ }^{59}$.

A partir del capitel SI 11 (Fig. 45) se plasman escenas relacionadas con la Resurrección de Jesús. En este capitel particularmente se recoge la visita de las tres Marías al Sepulcro. A pesar de que en el lado que da al interior de la galería, la cara sur, se representa el ángel la historia comienza con las imágenes de la cara este y norte, en la que se aprecia a las tres Marías saliendo a comprar los perfumes. En la cara oeste éstas proceden a visitar el sepulcro y se encuentran con el ángel de la cara sur, el cual se dirige a las tres como se aprecia en sus gestos. Éste se sienta sobre el sepulcro y al lado derecho se aprecian los restos de una figura cuya vestimenta es muy similar a la que llevan los soldados de Herodes en el capitel de la Huida a Egipto. Durante mucho tiempo la forma más usual de plasmar la

\footnotetext{
${ }^{57}$ RÉAU. Iconografía del arte cristiano. Iconografía de la Biblia. Nuevo Testamento. Tomo 1 , Vol. 2..., p. 413.

${ }^{58}$ Zacarías 9: 9. Mateo 21: 4-5.

${ }^{59}$ HeINZ-MOHR. Lessico di iconografía..., p. 59.
} 
Resurrección de Cristo fue a través de las Santas Mujeres en el sepulcro ${ }^{60}$. Esta imagen se toma directamente de los evangelios, en los que se relata que pasado el sábado las mujeres salieron a comprar perfumes y se dirigieron al sepulcro ${ }^{61}$. Hasta el Siglo XIII el arte cristiano de Occidente evocó la Resurrección de Cristo en la forma indirecta de Las Santas Mujeres en el Sepulcro. Por otra parte, esta es la única representación que está de acuerdo con el relato de los Evangelios.

El capitel de las tres Marías en el sepulcro (Fig. 45) da paso a una serie de escenas vinculadas con las distintas apariciones de Jesús. No obstante, la identificación de las mismas ha sido un tanto complicado. El primero de estos capiteles es el SI 14 (Fig. 46). Según Baltrusaitis y Lorés, en éste se representa el bautismo de Jesús y la Traditio Legis ${ }^{62}$. La profesora Lorés a pesar de vincularlo con el bautismo, resalta el hecho de que el tema no es muy certero para incluirlo entre medio de otros dos capiteles con temas de la resurrección. Muchas de las figuras que completan el capitel se han perdido, lo que ha incidido en la difícil identificación de los temas. En la cara de levante se aprecia una figura sedente de mayor tamaño flanqueada por otras dos de dimensiones menores. Es esta escena la que se ha vinculado con la Traditio Legis, desafortunadamente no se conservan las manos de esta figura, y las más pequeñas se encuentran en muy mal estado como para determinar si la figura principal entrega o presenta algo a las secundarias.

Con respecto al resto de las caras, la figura del lado sur ha sido identificada como Juan Bautista, pues la misma lleva una piel como, atributo propio de este personaje. Para Baltrusaitis el resto de los personajes que completan el capitel son profetas, llega a esta conclusión partiendo del hecho de que todos se encuentran descalzos y esto es un convencionalismo a la hora de representar estas figuras

60 HeINZ-MOHR. Lessico di iconografía..., p. 296. RÉAU. Iconografía del arte cristiano. Iconografía de la Biblia. Nuevo Testamento. Tomo 1, Vol. 2..., p. 563.

${ }^{61}$ Mateo 28: 1-7. Marcos 16:1-5. Lucas 24: 1-4.

${ }^{62}$ LORÉS I OTZET. "La escultura del claustre i de l'eglésia..., p. 178. BALTRUSAitis. Les Chapiteaux de Sant Cugat..., pp. 87-88. 
veterotestamentarias. No obstante, esta identificación no es del todo certera, puesto que en los capiteles que anteceden a este y se representan a Jesús y los discípulos, como el de la multiplicación de los panes y peces y la entrada a Jerusalén (Figs. 42 y 44), los protagonistas de los mismos también van descalzos.

Una posible lectura que desea proponerse es que en las caras oeste y sur de este capitel se recoge la aparición a los discípulos de Emaús, suceso que sigue a la visita de las tres Marías en el sepulcro representado en el capitel SI 11 (Fig. 45) y antecede la aparición de Jesús al incrédulo Tomas en el capitel SI 15 (Fig. 47). La figura de la cara oeste, lleva un libro, lo que ayuda a identificarlo con un apóstol, pero también lleva un cayado. Junto a éste, en el ángulo entre la cara oeste y sur, había otra figura de menor dimensión, de la que sólo se aprecian los pies descalzos y la parte baja de un objeto largo similar a un bastón. Estas dos figuras son las de dos viajeros. El personaje de la cara oeste, identificado como Juan el Bautista, realmente representa a Jesús. Los gestos de éste, la mano abierta, significa que el mismo se dirige a los dos viajeros. Él no va completamente vestido con piel de camello, sino que lleva una especia de capa de viajero y se aprecia una correa que termina en una especie de bulto que pende de su espalda. La figura de Jesús en el encuentro con los discípulos en el camino a Emaús suele representarse como la de un peregrino que lleva la piel de cabra, y bordón o zurrón o ambos ${ }^{63}$.

Si se tiene en cuenta que la escena que se plasmó aquí es el encuentro en el camino a Emaús, la siguiente escena en el lado este más que representar la Traditio Legis, podría ser la plasmación del suceso siguiente en el que Jesús se les aparece a los apóstoles, mostrándoles los agujeros de sus manos lo que explicaría el gesto de los brazos extendidos. Es en este momento que igualmente les encarga a sus discípulos la misión de evangelizar a las naciones de la tierra ${ }^{64}$. Otra posible

\footnotetext{
${ }^{63}$ RÉAU. Iconografía del arte cristiano. Iconografía de la Biblia. Nuevo Testamento. Tomo 1 , Vol. 2..., p. 585.

${ }^{64}$ RÉAU. Iconografía del arte cristiano. Iconografía de la Biblia. Nuevo Testamento. Tomo 1, Vol. 2..., p. 590.
} 
lectura es que en esta cara se plasmó el momento en que al bendecir el pan Jesús se les revela a los discípulos con los que caminaba, concluyendo así el relato de Emaús.

La identificación de la cara norte sigue siendo dudosa. En ésta se aprecia la figura de un hombre barbudo, en su mano izquierda lleva un libro, y los gestos son los de recibir a la figura erguida delante de él. Debido a su estado de deterioro es imposible identificar a la misma. Una suposición, partiendo de la idea de que en las caras oeste y sur se incluyó en encuentro en el camino de Emaús, es que en este lado del capitel se presenta alguna de las otras apariciones de Jesús, tal vez a Pedro, después de todo en los capiteles anteriores la figura de Jesús sujeta un libro igualmente, tema iconográfico que según Mâle en ocasiones acompaña a los peregrinos de Emaús ${ }^{65}$. Otra suposición es que aquí se representó el momento en el que las mujeres avisan a los apóstoles, simplificando la imagen por medio de una sola figura.

La narrativa de la resurrección continua en el capitel SI 15 (Fig. 47), en el cual se representó la incredulidad de Tomás. En la cara sur se aprecia la figura de Jesucristo, que para su fácil identificación lleva un nimbo cruciforme. Con una mano bendice a los presentes, a modo de saludo y con la otra abre su túnica para que Tomás vea la herida del costado. La figura de rodillas, de la que sólo sobreviven sus pies y un brazo, por defecto debe ser aquel al que Jesús le mostró su costado, Tomás. En el resto de las caras se representan personajes masculinos, barbudos, que portan libros. Claramente los apóstoles, los gestos de estos se encuentran todos en dirección a la escena entre Tomás y Jesús, cómo sin contemplaran la misma.

${ }^{65}$ RÉAU. Iconografía del arte cristiano. Iconografía de la Biblia. Nuevo Testamento. Tomo 1, Vol. 2..., p. 584. 


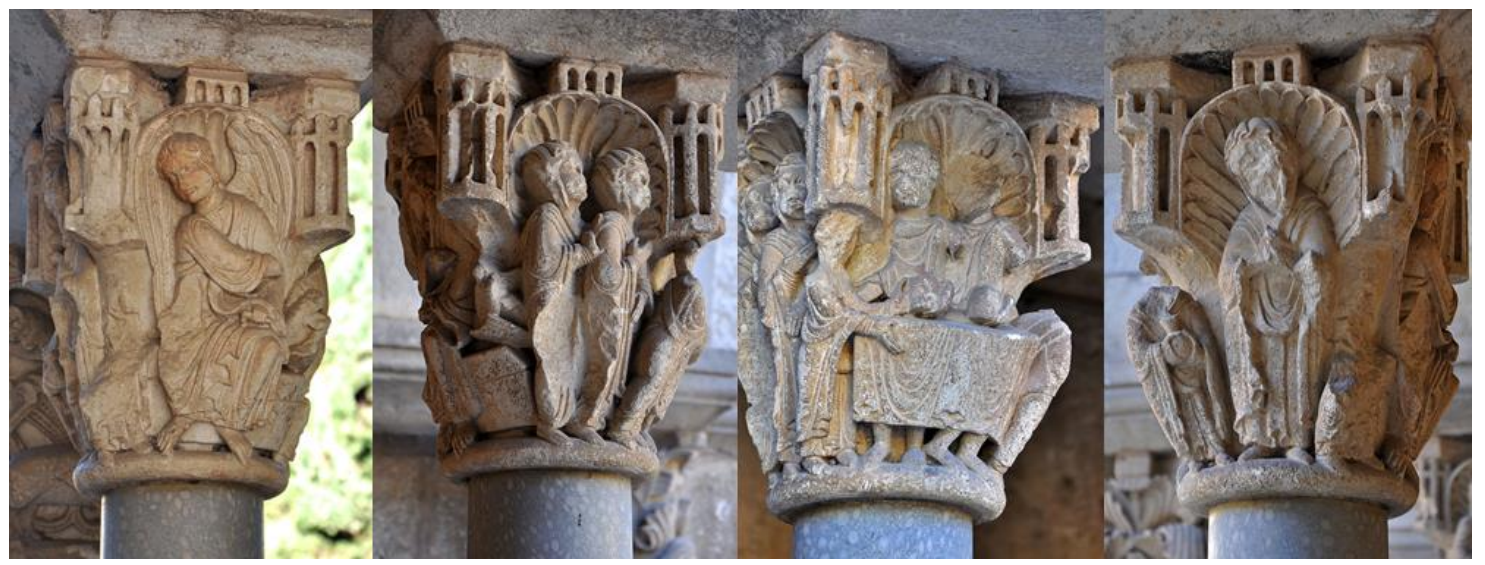

Figura 45. Las tres Marías en el sepulcro. Capitel SI 11. (Siglo XIII) Galería sur. Monasterio de Sant Cugat del Vallès.

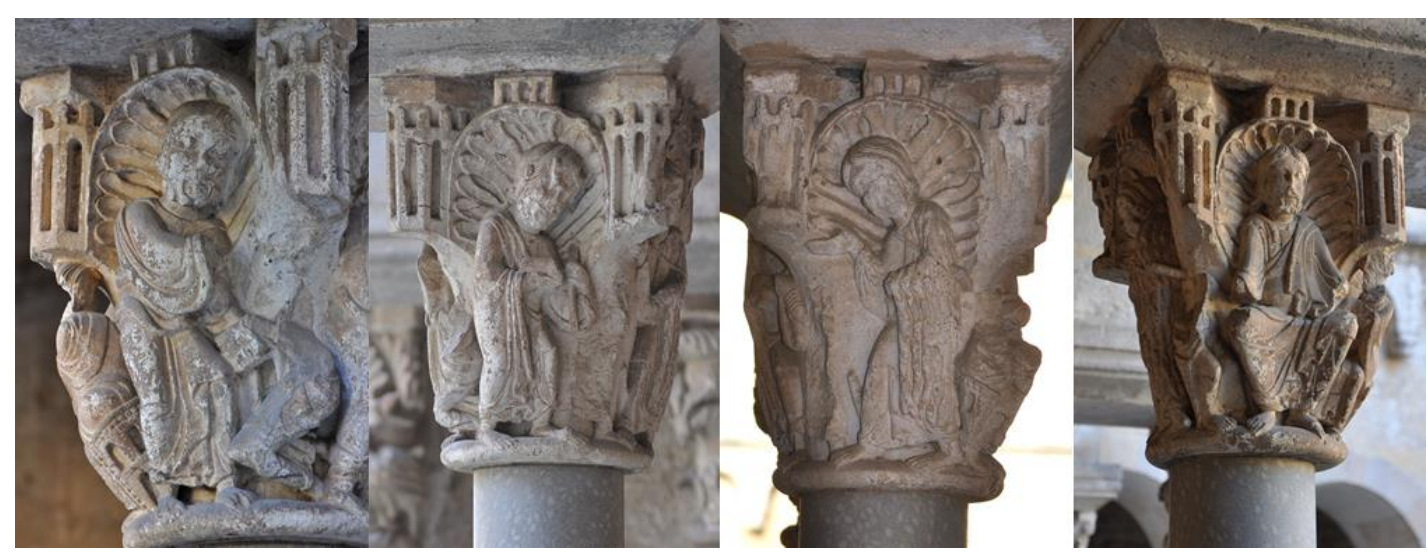

Figura 46. Aparición de camino a Emaús. Capitel SI 14. (Siglo XIII) Galería sur. Monasterio de Sant Cugat del Vallès.

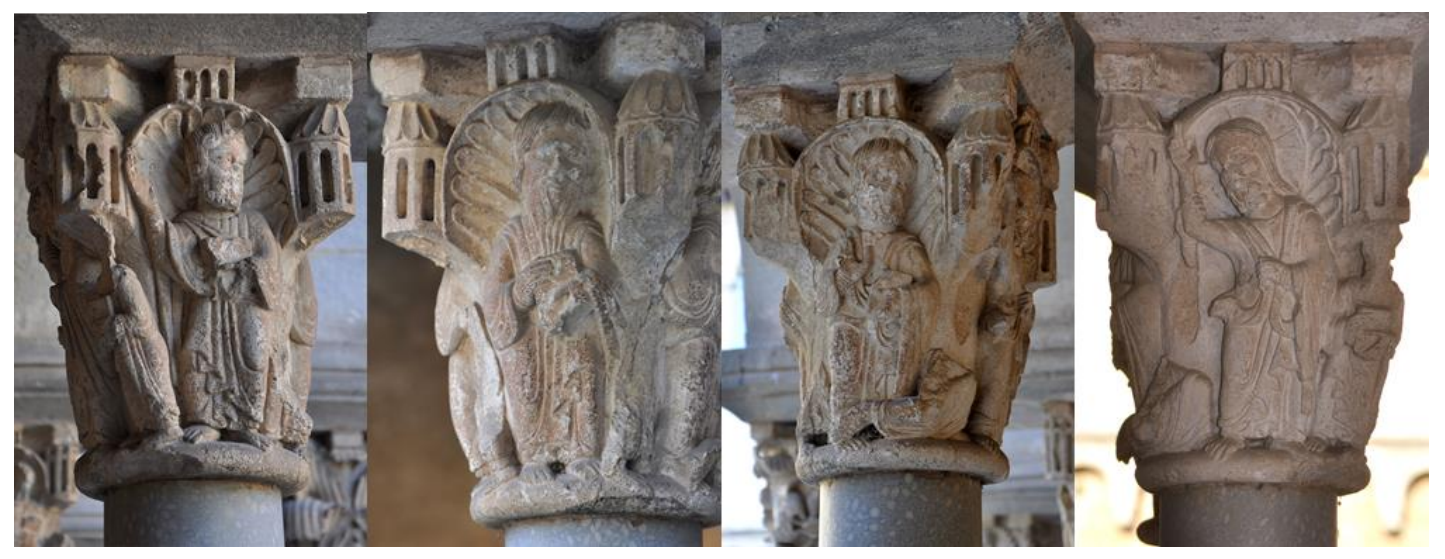

Figura 47. Incredulidad de Tomás. Capitel SI 15. (Siglo XIII) Galería sur. Monasterio de Sant Cugat del Vallès. 
Los últimos dos capiteles historiadores de la galería sur recogen dos temas no bíblicos. El primero de estos, el SI 16 (Fig. 48) se vincula con la Virgen María. En el mismo se representa el cuerpo yacente de la Virgen sobre una cama. Detrás de María se plasmó a Jesús cuya figura se encuentra en muy mal estado. A pesar del mismo, gracias al nimbo cruciforme es posible identificarla con Cristo. Éste sujeta una figura de menor dimensión desnuda, claramente la representación visual del alma de su madre la cual es recibida por dos ángeles. En el resto de los capiteles se incluyeron a los apóstoles. Algunas figuras se tocan la mejilla, gesto que plasma visualmente la aflicción. Baltrusaitis identificó este capitel con la muerte de la Virgen, no obstante, ha sido la profesora Lorés quien se ha percatado que en el mismo se recoge la Dormición de la Virgen según los modelos bizantinos ${ }^{66}$.

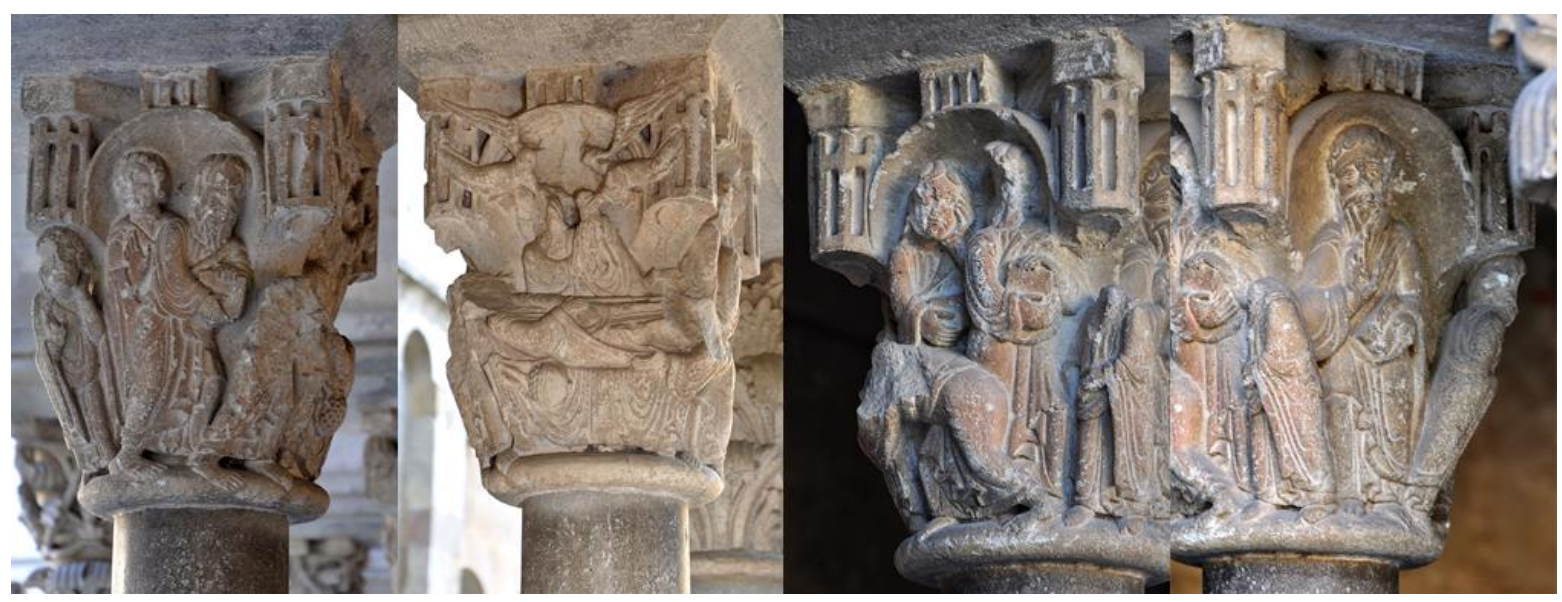

Figura 48. Dormición de la Virgen. Capitel SI 16. (Siglo XIII) Galería sur. Monasterio de Sant Cugat del Vallès.

Los modelos orientales suelen representar a María acostada sobre su lecho de muerte con las manos unidas o cruzadas, detrás de ésta y usualmente de pie la figura de su hijo Jesús que hace de psicompompos. Cristo recibe el alma de su madre. Ésta se plasma por medio de una figura de menores dimensiones y dos

${ }^{66}$ LORÉS I OtZE. "La escultura del claustre i de l'eglésia..., p. 179. BALtrusaitis. Les Chapiteaux de Sant Cugat..., p. 89. 
ángeles la conducen hasta el cielo. Alrededor del lecho de muerte se ubican los apóstoles y en algunos ejemplos se aprecia a Pedro en la cabecera balanceando un incensario y a los pies Pablo besando los pies de María ${ }^{67}$. Claramente el modelo del Vallès sigue el esquema oriental.

En Bizancio las representaciones de la dormición de la Virgen, en conjunto con la elevación del alma y la presencia del Hijo como psicompompos se designa como koimesis ${ }^{68}$. "Con este modelo se sintetiza en el mundo oriental todo el ciclo de Dormición y Glorificación mariana ${ }^{69 "}$.

\subsubsection{Psychomachia de Sant Cugat del Vallès}

En el último capitel historiado de la galería sur, el SI 17 (Figs. 49 y 50), se representa la Psychomachia. Este es uno de los pocos ejemplos del tema en capiteles y especialmente dentro del contexto monacal. Los estudiosos del tema de la Psychomachia o de los vicios y las virtudes en muchos de los casos sólo se han limitado a mencionar el mismo y no han profundizado del todo en la relación de éste con el resto del conjunto escultórico del claustro o sobre la octava figura en la cara norte del capitel (Fig. 50) ${ }^{70}$.

${ }^{67}$ RÉAU. Iconografía del arte cristiano. Iconografía de la Biblia. Nuevo Testamento. Tomo 1 , Vol. 2..., p. 628.

${ }^{68}$ LECLERCQ, Heri et Fernand CABROL. Dictionnaire d'archéologie chrétienne et de liturgie. Tomo 1, 2da parte. París: Librairie Letouzey et Ané, 924. p. 2996. RÉAU. Iconografía del arte cristiano. Iconografía de la Biblia. Nuevo Testamento. Tomo 1, Vol. 2.., p. 627.

${ }^{69}$ LAHOZ, Lucía. "La dormición de María en el arte gótico alavés", en: Boletín del Museo e Instituto 'Camón Aznar'. №. 44 (1991), p. 11.

${ }^{70}$ Adolf Katzenellenbogen y Joanne Norman se limitan a mencionar el capitel de Sant Cugat como ejemplo de la extensión del tema a las periferias de la zona de origen del tema. El Index of Christian Art en su volumen sobre los vicios y las virtudes recoge la entrada bajo el apartado de "Conflict of Virtues and Vices". Hourihane, Colum (ed.). Virtue \& Vice: The Personifications in the Index of Christian Art. Princeton: Department of Art and Archaeology of Princeton University in association with Princeton University Press, 2000. p. 441. NORMAN, Joanne S. Metamorphoses of an Allegory: The Iconography of the Psychomachia in Medieval Art. New York: P. Lang, 1988. p. 31. KATZENELlENBOGEN, Adolf. Allegories of the Virtues and Vices in 
En el capitel se utilizó el lenguaje pictórico del tema empleado en la escultura del sur-oeste de Francia, plasmando el final del combate y el triunfo de las virtudes sobre los vicios vestidas las primeras como guerras y las segundas como seres monstruosos. La victoria de las virtudes tras los siete combates recogidos en el poema de Prudencio se plasmó en las caras oeste, norte y este del capitel, distribuyéndose de la siguiente manera: tres figuras femeninas de mayor tamaño en cada una de las caras, aniquilan a sus enemigas con una lanza. En los vértices se insertan otras cuatro virtudes de menores dimensiones y dos de estas sujetan un cuchillo. Las siete virtudes en Sant Cugat, además de sus armas, portan escudos, cota de malla y visten con túnica y velo. A pesar de utilizar en lenguaje pictórico de la escultura francesa en el mismo encontramos ciertas particularidades que denotan un interés en la identificación de ciertos elementos del tema. El capitel de Sant Cugat del Vallès es uno de los pocos ejemplos en piedra de la Psychomachia cuya esencia se encuentra muy cercana a la plasmada por Prudencio en su poema ${ }^{71}$.

En las psychomachias francesas, las virtudes son mujeres guerreras vestidas con largas túnicas, llevan un casco y se encuentran armadas con una lanza o espada y un escudo largo, siendo esta la tipología por excelencia a seguir en la escultura románica sobre todo en el sur oeste de Francia $^{72}$, como son los ejemplos de Gripperie-Saint-Symphorien, Saint-Nazaire de Corme-Royal (Figs. 12 y 13). El

Mediaeval Art, from Early Christian Times to the Thirteenth Century. New York: W.N. Norton \& Company, Inc., [1939] 1964. p. 19.

${ }^{71}$ NORMAN. Metamorphoses of an Allegory: The Iconography of the Psychomachia..., p. 32.

72 "Ils figurèrent la Vertu sous les traits d'une femme à l'allure guerrière, vertu d'une longue robe, coiffée d'un heaume, armée d'une lance ou d'une épée et d'un long bouclier. [...] Il y a dans toutes ces figurations des Vertus, à l'époque romane, une ressemblance, une uniformité vraiment singulières, et c'est avec une scrupuleuse exactitude que le même type a été reproduit. Parmi les caractéristiques qui permettent d'attribuer à la région du Sud-Ouest une école romane bien déterminée et dont le Poitou semble avoir été le foyer principal on a observé l'absence des tympans et la richesse d'ornementation des voussures nombreuses qui encadrent les portails. Cette particularité n'apparait dans aucune des autres régions on la sculpture fut en honneur à l'époque romane". DESCHAMPS, Paul. Le combat des vertus et des vices sur les portails romans de la Saintonge et du Poitou. Caen: Henri Delesques, Imprimeur-Éditeur, 1914. p. 4. 
mismo no sólo se limitó a las fachadas o ventanas de los templos románicos de esta región de Francia, sino que también se utilizó en los interiores como se aprecia en los rectos de la puerta del refectorio de la antigua abadía de Saint Aubin d'Angers (Fig. 31). Para Norman, la tipología francesa del triunfo de las virtudes es una genérica que condensa el poema de Prudencio ${ }^{73}$. Usualmente la identificación de cada virtud es posible por medio de la inscripción que le acompaña o la virtud Largitas por medio del vicio derrotado Avaritia quien lleva amarrado a su garganta una bolsa, claro atributo de la avaricia. El mejor ejemplo de estos es St. Pierre de Aulnay (Fig. 14).

En Sant Cugat no sólo la túnica debajo de la cota de malla permite identificar las imágenes como figuras femeninas, sino que también el velo de éstas ayuda a dicha identificación. Las virtudes en Sant Cugat llevan velo, el cual es muy similar al de las figuras femeninas en el resto de los capiteles historiados de la galería sur, especialmente en aquellos del capitel de las tres Marías en el sepulcro (Fig. 45). Ya en manuscritos del siglo X, específicamente en el Cod. 264, se identifican las virtudes con velos y en manuscritos posteriores sobre todo del Grupo I éstas se plasmaron con el mismo.

Otra diferencia entre los ejemplos galos y el del Vallès es la plasmación del vicio. Prudencio en el poema describe a los vicios como figuras melenudas, algunas con los ojos desorbitados o espumarajos en la boca ${ }^{74}$. En la escultura francesa estas descripciones dieron como resultado la representación de los vicios como demonios desnudos con cabellos que parecen llamas y manos que son garras, no siendo hasta el siglo XIII que la plasmación de los vicios en el contexto francés

\footnotetext{
${ }^{73}$ NORMAn. Metamorphoses of an Allegory: The Iconography of the Psychomachia..., pp. 3031.

${ }^{74}$ Prudencio. Psychomachia vv. 110-115, 300-315.
} 


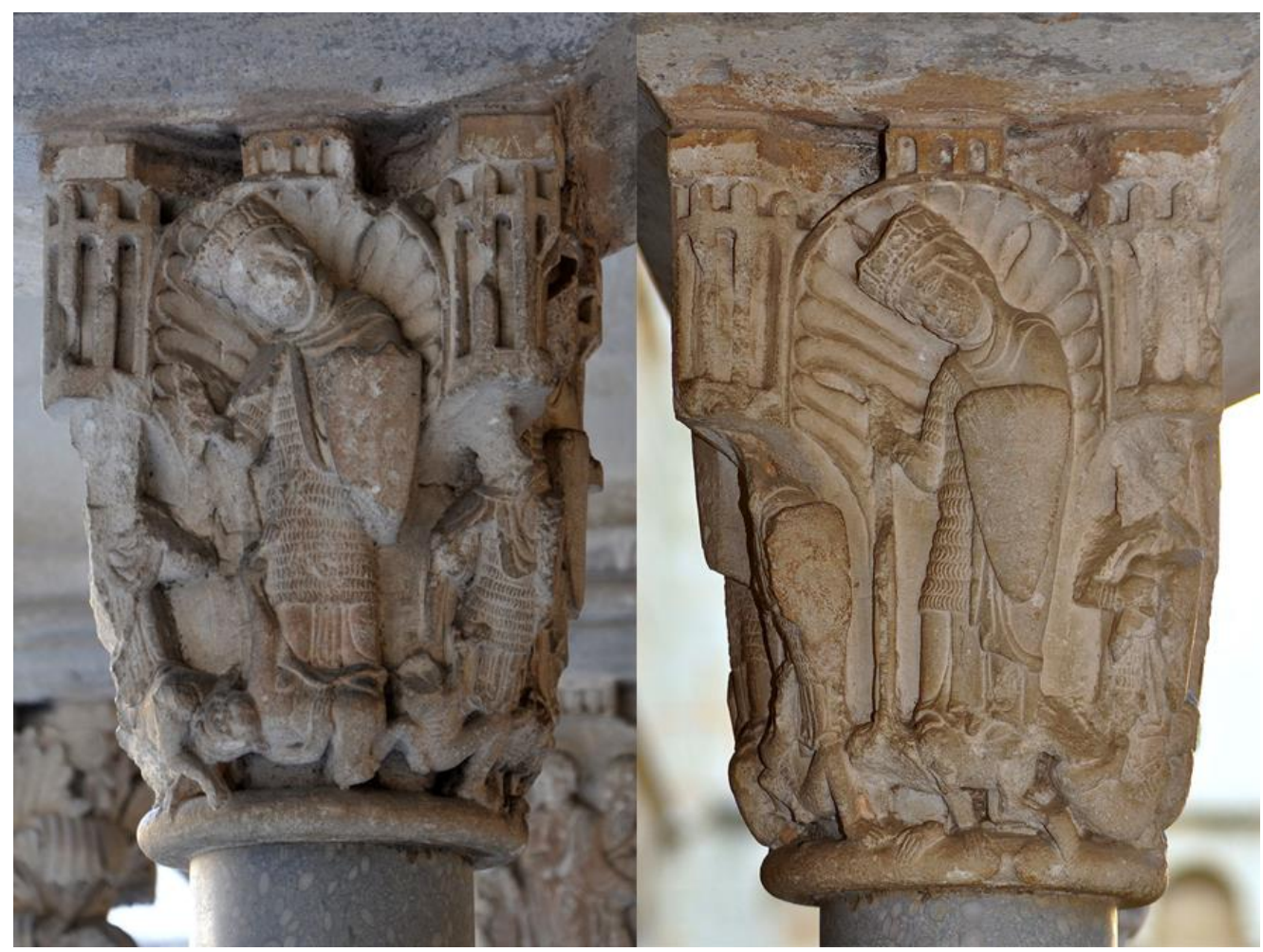

Figura 49. Psychommachia (caras oeste y sur). Capitel SI 17. (Siglo XIII) Galería sur. Monasterio de Sant Cugat del Vallès.

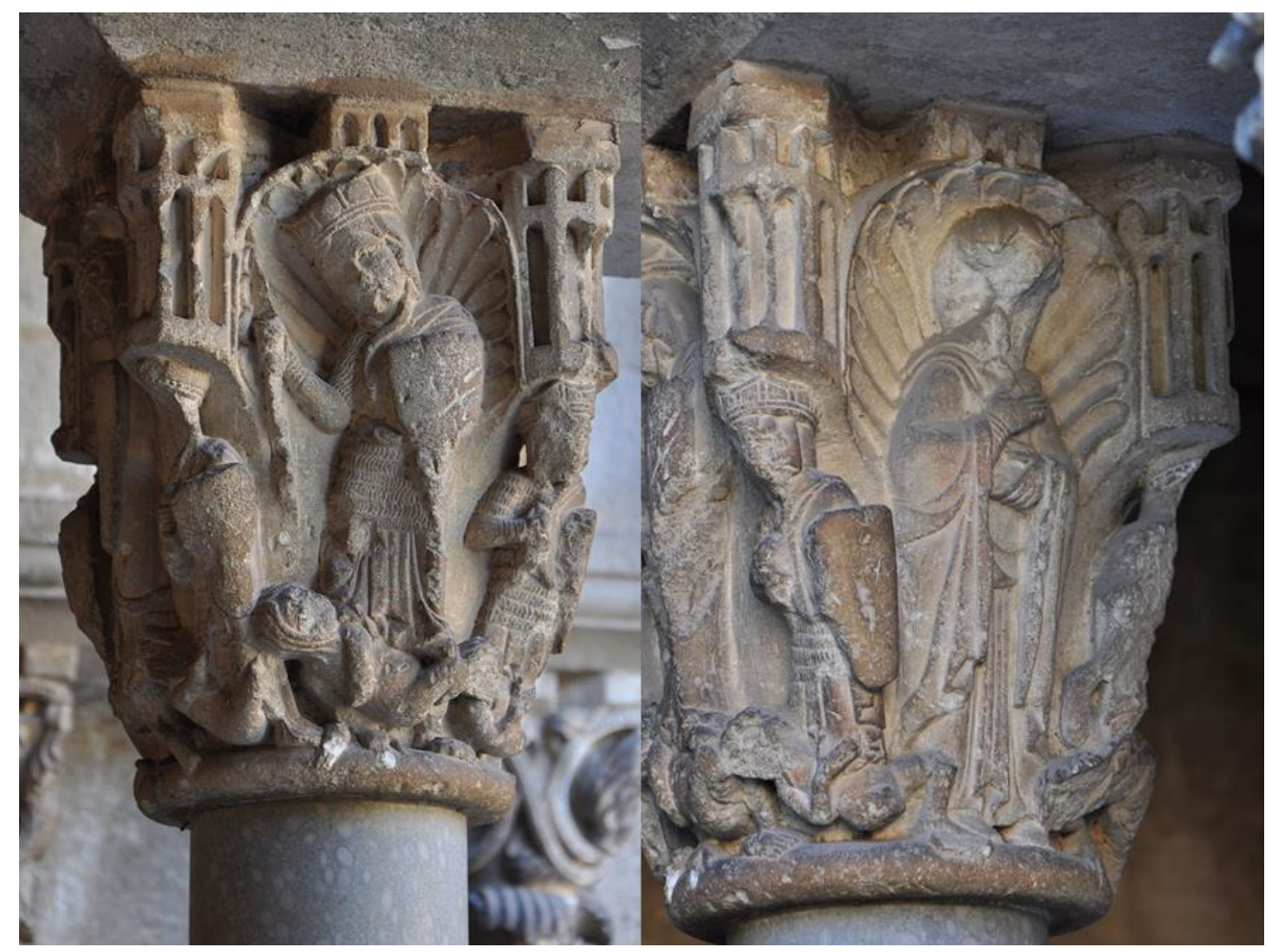

Figura 50. Psychommachia (caras este y norte). Capitel SI 17. (Siglo XIII) Galería sur. Monasterio de Sant Cugat del Vallès. 
se humanizaría ${ }^{75}$. En el caso de Sant Cugat los vicios se distanciaron de los modelos franceses, perdiendo la cualidad feroz. Según Adolf Katzenellenbogen en el siglo XII, "The theme of the triumph of the virtues as expressed in architecture gradually extended itself far beyond the limits of its original province and thus, like the later Psychomachia manuscripts, it sometimes loses its original features, which are characterized by fierce unrestraint ${ }^{76}$ ". Los vicios del claustro catalán, a pesar del muy mal estado en el que la mayoría se encuentran, en los mismos aún se pueden apreciar los cuerpos humanos de estos, sobre todo las extremidades y las manos y pies. En el capitel del pobre Lázaro y el rico Epulón (Fig. 60) los pies en forma de garras ayudan a identificar a la figura que atormenta al rico en la cara norte como un demonio. En el caso de los vicios, hay una clara intención por parte del artista o la persona a cargo del programa iconográfico de que estas imágenes a pesar de ser desaliñadas y encontrarse en posiciones extrañas conserven aún características humanas. Los vicios plasmados en las caras oeste y este son los que se encuentran en mejor estado, y los mismos se puede identificar como figuras femeninas por los cabellos largos. Si se observa con detenimiento el torso del vicio de la cara occidental se pueden observar los pechos de esta figura (Fig. 49).

En Sant Cugat todas las virtudes además de los atributos propios de un guerrero portan sobre sus cabezas coronas, a diferencia de sus homologas francesas que claramente portan yelmos. El único momento en que se menciona este atributo en el poema es en los versos 36-39 en los que se narra cómo tras su victoria, Fides corona al ejercito de mártires que le sigue, en este caso con coronas de flores. En los manuscritos estas coronas se modifican, en las representaciones del siglo IX las mismas se plasman como coronas de laureles y en uno de los ejemplos del siglo $\mathrm{X}$ ésta ya no es de flores o materiales vegetales, sino que se asemeja a una corona

\footnotetext{
${ }^{75}$ NORMAn. Metamorphoses of an Allegory: The Iconography of the Psychomachia..., p. 31. KatZENellenbogen. Allegories of the Virtues and Vices in Mediaeval Art..., pp. 17-19.

${ }^{76}$ Katzenellenbogen. Allegories of the Virtues and Vices in Mediaeval Art..., p. 19.
} 
labrada en algún metal (Miniatura 10). En los ejemplos galos las dos virtudes que coindicen en la clave del arco suelen sujetar una corona, tal como se puede apreciar en St. Pierre d'Aulnay o en Saint Aubin d'Angers (Figs. 14 y 31). En ambos casos la corona que sostienen las virtudes victoriosas es la del Agnus Dei que se encuentra debajo de la misma, siendo la corona un atributo del cordero y no de las virtudes. En este capitel, las siete virtudes victoriosas llevan corona. El uso de este atributo, al igual que en las miniaturas, se vincula directamente con la victoria y en este caso particular con la victoria de las siete virtudes sobre los siete vicios ${ }^{77}$. La presencia de la corona posee el mismo significado que el nimbo en las distintas miniaturas de los manuscritos carolingios ya estudiados: exaltar a las portadoras de dicho atributo cómo seres vinculados directamente con la divinidad.

Además de las siete virtudes victoriosas sobre los vicios en la cara norte de este capitel se representó una octava figura (Fig. 50) que ocupa todo el espacio. La misma se encuentra de pie, viste túnica, con la mano izquierda sujeta un libro mientras que la derecha la posa sobre su pecho. La profesora Lorés vinculó esta octava figura con la Virgen, considerada como la encarnación más perfecta de todas las virtudes y la presencia del libro como un vestigio de la Virgen de la Anunciación $^{78}$. Si bien la relación de las virtudes con la Virgen es irrefutable y existen ejemplos en los que las virtudes acompañan a María, el hecho de que esta figura sujeta un libro hace un tanto dudoso dicha lectura. Ya Baltrusaitis había vinculado esta octava figura con una virtud en actitud de orante y Norman la identificó con Patientia ${ }^{79}$.

El análisis de esta imagen dentro del contexto del poema de Prudencio y las miniaturas de los distintos ejemplos estudiados y muchos otros aquí no tratados en un principio llevó a vincular a esta figura con la efigie del autor por la presencia

\footnotetext{
${ }^{77}$ HeINZ-MOHR, Gerd. Lessico di iconografía ..., p. 116.

${ }^{78}$ LORÉS I OTZET. "La escultura del claustre i de l'eglésia..., p. 179.

${ }^{79}$ NoRman. Metamorphoses of an Allegory: The Iconography of the Psychomachia..., p. 32. Baltrusaitis. Les Chapiteaux de Sant Cugat..., p. 90.
} 
del libro, como ocurre en los manuscritos. En las miniaturas de la Psychomachia, a los diversos combates entre los vicios y las virtudes les antecede una miniatura en la que se plasmó al autor (Miniatura 7). A partir del siglo X Prudencio se representa con un libro que hace hincapié en su labor como escritor/poeta. A pesar de que la efigie del poeta lleva un libro en estos dos ejemplos miniados, el códice en ambos se representó sobre un atril y abierto, lo que distancia la imagen de la miniatura con la plasmación en piedra. A esto se ha de añadir que la octava figura en el capitel del claustro de Sant Cugat plasma a una mujer, pues pese a que el rostro de ésta no se conserva, en la frente y lo alto de la cabeza se aprecian los pliegues de un manto, por ende, no hay forma de vincularla con el autor.

Aun así, la clave para identificar esta figura se encuentra en el poema mismo de la Psychomachia. Los vicios y virtudes de los siete combates descritos por Prudencio son las protagonistas del poema, no obstante, en el mismo encontramos otra serie de personificaciones secundarias. A pesar de las siete virtudes que aparecen a lo largo del poema y las distintas auxiliares de éstas, la obra concluye con la entronización de una virtud en particular: Sapientia. Esta virtud no lucha contra ningún vicio, sino que es producto de la unión de las fuerzas de todas las demás. Incluso la representación de Sapientia entronizada es la miniatura con la que concluye el poema en los distintos manuscritos ya estudiados (Miniatura 89). Según el texto de Prudencio, Sapientia se sienta dentro de la cámara interior del templo que las virtudes habían construidos. Aquí ésta, sujeta un cetro y retiente en su corazón las leyes para salvaguarda de los hombres ${ }^{80}$. Los gestos de la octava figura en el capitel de Sant Cugat, sujetar un libro y tocarse el pecho, recuerda los versos de Prudencio: específicamente el 878, según el cual Sapientia en el fondo de su corazón retiene las leyes para salvaguarda de los hombres.

80 "Hoc residit solio pollens Sapientia et omne / consilium regni celsa disponit ab / aula tutandique hominis leges sub corde retractat./ In manibus dominae sceptrum non arte politum...". PRudencio. Psychomachia, vv. 875-878. Obras Completas de Aurelio Prudencio..., pp. 358359. 
Estas acciones ya se han identificado en algunos de los códices estudiados. En cuatro de los cinco manuscritos miniados de la Psychomachia se representa a Sapientia en su trono. En Burm.Q.3, Ms. Lat. 8085 y Ms. 9987-91 esta virtud, como indica el poema, y como en el capitel del Vallès se toca el pecho con la mano derecha. En los ejemplos del siglo IX, a pesar de lo difuso de los pigmentos, en Burm.Q.3 y Ms. Lat. 8085 con mucha dificultad se ha identificado en la mano izquierda de la virtud un objeto rectangular que Sapientia acerca a su pecho, tal vez un libro. En el ejemplo del siglo X, el Ms. 10066-77, la virtud no se toca el pecho, no obstante, sujeta con ambas manos unos rollos. Como indicamos en el capítulo anterior donde tratamos la miniatura 89, los gestos de la miniatura aluden al verso 878 de la Psychomachia, en el que Sapientia: "tutandique hominis leges sub corde retractat". El libro y las filacterias son soportes de textos que en las miniaturas se utilizan para como referencia visual de la ley ${ }^{81}$. Las iluminaciones de los códices nos ayudan entonces a identificar la octava figura de Sant Cugat.

El ejemplo más tardío de la miniatura 89 de la Psychomachia corrobora la relación de los gestos y el objeto en el capitel de Sant Cugat con la figura de Sapientia, pues en el mismo encontramos similitudes tipológicas. El mejor ejemplo que hemos podido identificar se encuentra en el manuscrito Lat. 15158 de 1289 (Fig. 51). Este códice del siglo XIII se iluminó o perteneció a la abadía de Saint Victor en el sur de Francia. Para Woodruff este manuscrito es uno de los últimos ejemplares iluminados que pertenece al Grupo II, vinculándolo directamente con los códices ya estudiados cómo se puede apreciar en el estema de la autora (Fig. 29) ${ }^{82}$. Si bien este códice no posee la cantidad de miniaturas que los más antiguos, es de particular interés la miniatura del folio 63r, en el que se incluyó a Sapientia en la cámara interior del templo construido por sus compañeras. En posición sedente, la virtud sujeta en su mano derecha un pequeño libro mientras que en la izquierda una vara florecida. La miniatura es una

\footnotetext{
${ }^{81}$ HeINZ-MOHR. Lessico di iconografía..., pp. 200-201.

${ }^{82}$ WoOdRUFF, Helen. “The Illustrated Manuscripts of Prudentius”. Art Studies (1929), p. 47.
} 
traducción visual de los versos 875 al 883, según los cuales la virtud Sapientia se sienta en su trono y en su corazón guarda las leyes para el bien de los hombres y sujeta un cetro de madera verde del cual florecen rosas rojas como la sangre y $\operatorname{lirios}^{83}$.

A pesar de que este manuscrito claramente responde al arte gótico, cosa que se puede apreciar a través del uso de distintos elementos arquitectónicos como el arco ojival, los pináculos o el gran rosetón para plasmar el interior del templo de Sapientia, revela una forma alterna para representar a esta virtud. La imagen de la virtud en el códice del siglo XIII se encuentra más cercana no sólo cronológicamente, sino también en la plasmación visual, al capitel de Sant Cugat. La figura a pesar de estar en posición sedente, claramente es una mujer. Lleva además de la túnica larga, manto y velo y la ley, visualmente plasmada por medio del libro, se representó con más cuidado que en los ejemplos carolingios. El hecho de que la figura en Sant Cugat se encuentre de pies podría más bien responder a una cuestión de armonía estilística, por lo demás la forma de representar a esta virtud en un período posterior a la época carolingia es sumamente similar. Al observar con detenimiento las manos y el torso de la octava figura del capitel nos hemos percatado de los restos de un objeto alargado que brota del libro y pasa por debajo de la mano derecha que posa sobre el pecho, pudiendo ser los restos del cetro del cual florecen flores. Sin ánimo de caer en la sobre especulación igualmente se desea apuntar que este detalle podría ser parte de los pliegues del manto de la figura.

\footnotetext{
83 "Hoc residet solio pollens Sapientia et omne / consilium regni celsa disponit ab aula / tutandique hominis leges sub corde retractat. / In manibus dominae sceptrum non arte politum / sed ligno vivum viridi est, quod stirpe reciso / quamuis nullus alat terreni caespitis umor / fronde tamen viret incolumi, tum sanguine tinctis / intertexta rosis candentia lilia miscet / nescia marcenti florem submittere collo." PRUDENCIO. Psychomachia, vv. 875-883. Obras Completas de Aurelio Prudencio..., pp. 358-359.
} 


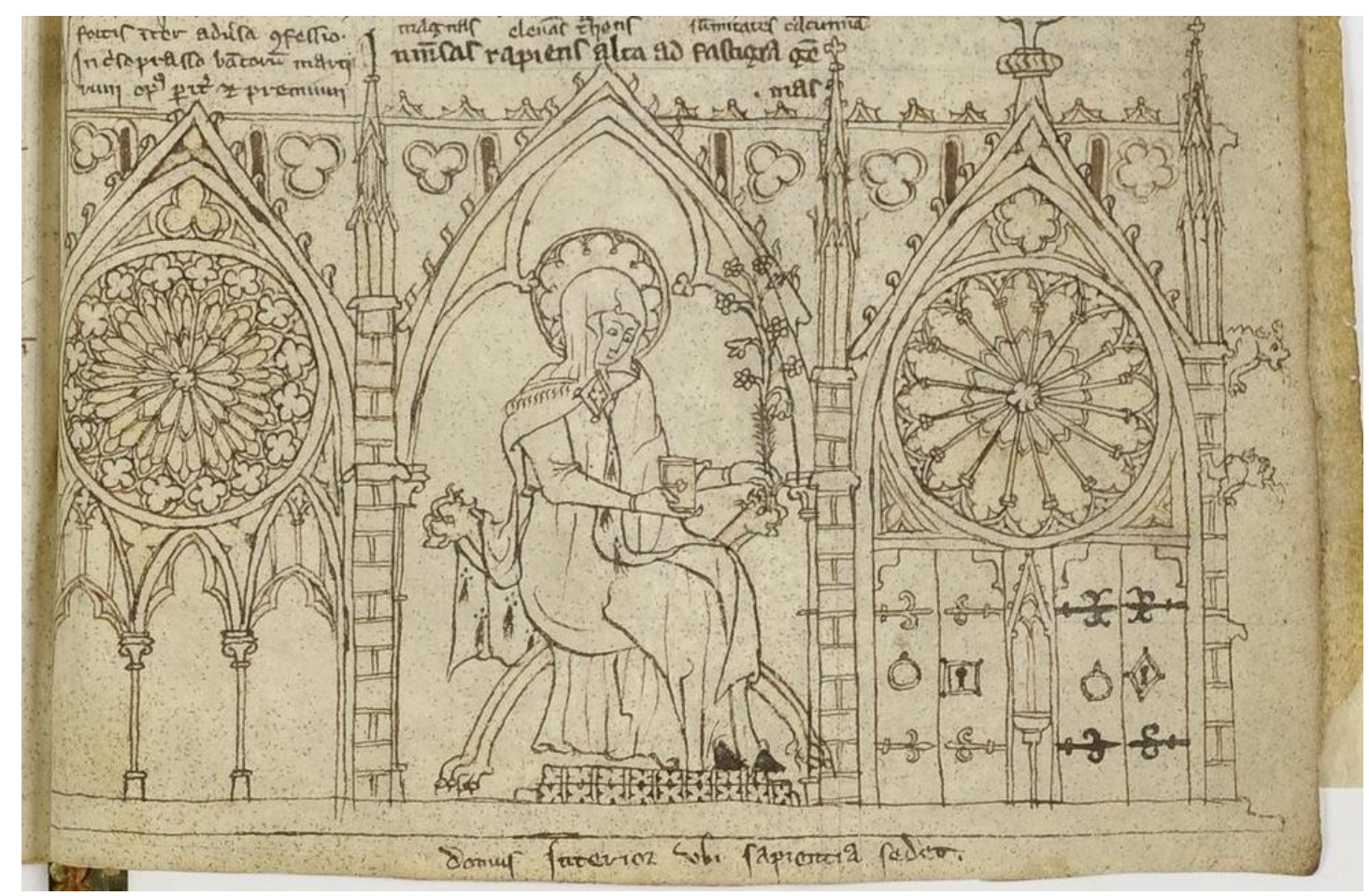

Figura 51. Sapientia en su trono. Ms. Lat. 15158 (1289), fol. 63r. Biblioteca Nacional de Francia, París.

La meditación se compara con un caminar por el que se van conquistando ciertos pasos. Estos pasos van desde los elementos más concretos y visibles, en el caso de los capiteles estudiados, la imagen misma de las escenas bíblicas y la conexión emocional que crea el espectador con éstas hasta alcanzar por último la sabiduría $^{84}$. En el recorrido del claustro el capitel de la Psychomachia es el último capitel historiado de la galería sur, el mismo manifiesta visualmente la meta del proceso de meditación, la sabiduría plasmada en la octava figura de la cara norte. En su caminar o peregrinar por el claustro, una vez obtenido los conocimientos de la escritura y dominado la Lectio divina el individuo, continua por la galería oeste. En esta ahora se exalta el trabajo manual, especialmente el de la tierra como se discutirá a continuación.

${ }^{84}$ CARruthers. The Craft of Thought..., p. 80. 


\subsubsection{Galerías este, norte y oeste}

La primera fase de construcción del claustro del monasterio de Sant Cugat del Vallès constituye las galerías este, norte y oeste y corresponden al último decenio del siglo XII. Además de los numerosos ejemplos de capiteles ornamentales, en estos tres tramos del claustro se representaron algunas escenas tomadas de la Biblia y tres de las cuatro escenas que tocan la temática de la vida en el monasterio. Todos los capiteles historiados se encuentran en el lado interior que da a la galería.

\subsubsection{Trabajo agrícola y animales}

La última galería de la primera fase de finales del siglo XII es la oeste en la cual se incluyeron dos capiteles historiados y una serie de capiteles vinculados directamente con la agricultura y el ganado. En el primer capitel exterior OE 01 (Fig. 52) aparecen dos figuras junto a un animal tumbado que ha sido identificado por Baltrusaiti como un macho cabrío ${ }^{85}$. Dado el mal estado en el que se encuentran las figuras la identificación de las acciones es difícil, sólo pudiendo deducirse que el animal está siendo preparado para ser sacrificado. A parte de este capitel, en esta galería se ha identificado otro en el que se incluye la escena de ganado y hombres. En el OE 13 (Fig. 53) aparecen tres hombres y dos de estos llevan sobre sus hombros una oveja mientras son mordidos por unos canes que para Baltrusaitis son $\operatorname{lobos}^{86}$.

En otros capiteles de esta galería aparecen distintos animales. Los capiteles OI 05 y en el OE 16 (Figs. 54 y 55) se plasmó cabezas de ganado. En el primero dos carneros luchando y en el segundo dos toros. En otras galerías se representaron animales, sin embargo, la figuración de estos en la galería oeste muestra más

\footnotetext{
${ }^{85}$ BALtRUSAitis. Les Chapiteaux de Sant Cugat..., pp. 70-71.

${ }^{86}$ Baltrusaitis. Les Chapiteaux de Sant Cugat..., p. 73.
} 
interés por plasmar a los mismos con cierto realismo ${ }^{87}$. Los carneros del capitel OI 05 (Fig. 54) nos son salvajes, por el contrario, son carneros domésticos que pueden identificarse así gracias a la campana que pende de sus cuellos.

Además del ganado encontramos capiteles en los que se plasmó a hombres trabajando la tierra o realizando actividades vinculadas con los productos de ésta. En el OI 15 (Fig. 56) distintas figuras se entrelazan con la vegetación. Según Baltrusaitis son leñadores que cortan la maleza ${ }^{88}$. No obstante, la forma gruesa y corta del cuchillo que portan estos hombres es muy similar al instrumento utilizado para la poda de la viña. Manuel Antonio Castiñeiras González hace la observación de que incluso en la documentación del monasterio de Sant Cugat se tiene constancia de la presencia de estos cuchillos propios del trabajo de la viña ${ }^{89}$. Si se considera que aquí se plasmó la poda de la viña, este capitel se vincula directamente con las escenas en OE 12 y OE 13 (Fig. 57). En estos dos capiteles se plasmaron dos figuras sujetando una tina de madera. La tina realmente es un barril o cuba que los hombres están construyendo ${ }^{90}$, tal y como revela el hacha que lleva una de las figuras en el capitel OE 13. La importancia de las labores vinculadas directamente con la producción del vino era esencial en el contexto monacal, pues en primer lugar junto al pan y la legumbre, esta bebida constituía uno de los productos básicos de la dieta benedictina y en segundo el mismo era esencial para la celebración eucarística ${ }^{91}$. Entre los elementos vegetales de estos capiteles se desarrolla una narrativa de una humanidad laboriosa ${ }^{92}$, elemento importante de la vida consagrada sobre todo de corte benedictino.

\footnotetext{
${ }^{87}$ BAltrusaitis. Les Chapiteaux de Sant Cugat..., pp. 59-61.

${ }^{88}$ BALTRUSAITIS. Les Chapiteaux de Sant Cugat..., pp. 63-64.

89 Doc. 967. RIUS SERRA. Cartulario de Sant Cugat del Vallés. Vol. III... CASTIÑEIRAS GONZÁleZ, Manuel Antonio. El calendario medieval hispano: textos e imágenes (siglos XI-XIV). Valladolid: Junta de Castilla y León, Consejería de Educación y Cultura, 1996. p. 195.

${ }^{90}$ Baltrusaitis. Les Chapiteaux de Sant Cugat..., pp. 70-71.

${ }^{91}$ CASTIÑEIRAS GONZALEZ. El calendario medieval hispano..., p. 193.

92 Baltrusaitis. Les Chapiteaux de Sant Cugat..., p. 64.
} 


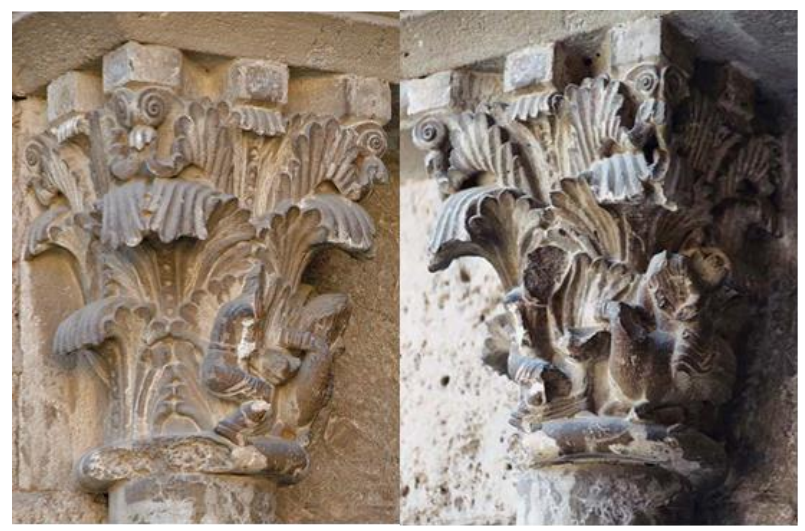

Figura 52. Hombres con toro. Capitel OE 01. (Siglo XII) Galería oeste. Monasterio de Sant Cugat del Vallès.

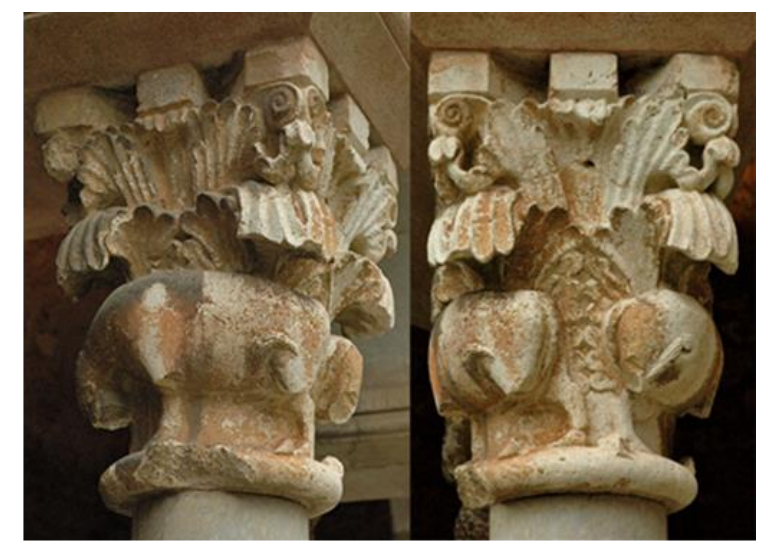

Figura 55. Toros luchando. Capitel OE 16. (Siglo XII) Galería oeste. Monasterio de Sant Cugat del Vallès.

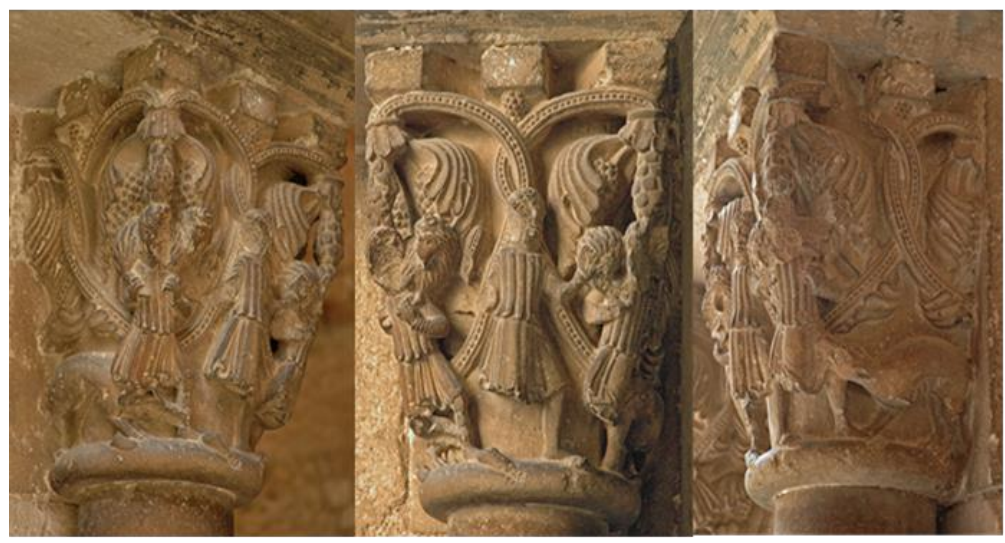

Figura 53. Hombres con ovejas. Capitel OE 13. (Siglo XII) Galería oeste. Monasterio de Sant Cugat del Vallès.

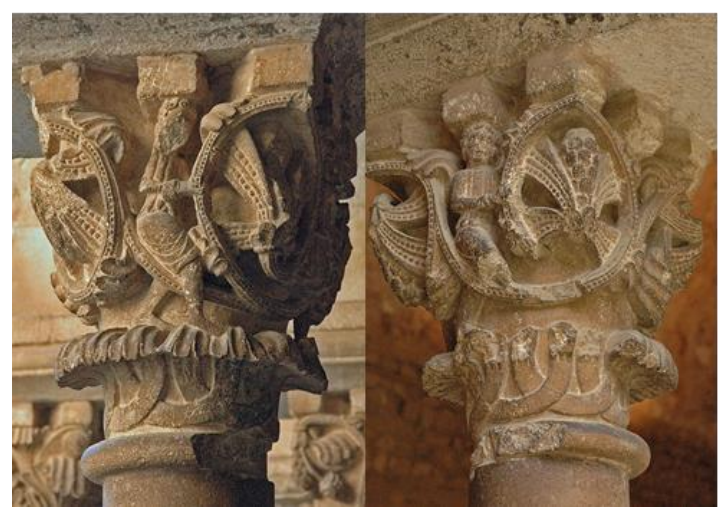

Figura 56. Hombres trabajando.

Capitel OI 15. (Siglo XII) Galería oeste. Monasterio de Sant Cugat del Vallès.

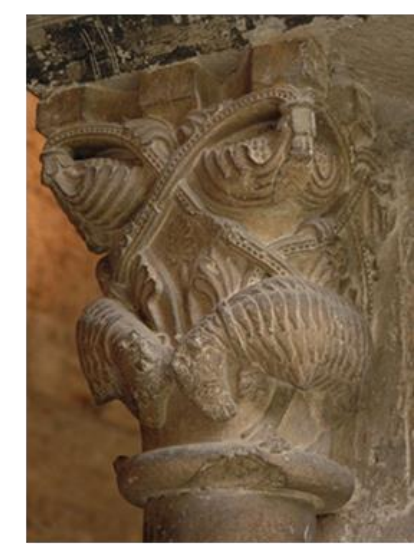

Figura 54. Carneros luchando. Capitel OI 05. (Siglo XII) Galería oeste.

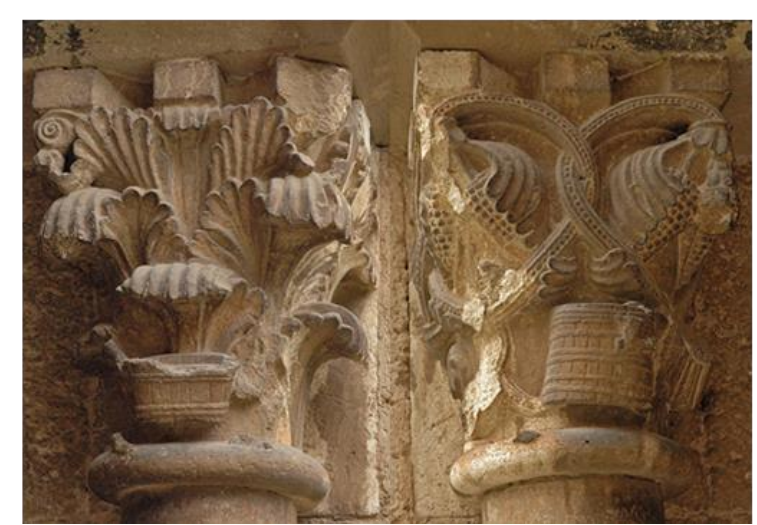

Figura 57. Hombres con tina. Capitel OE 12 y OE 13. (Siglo XII) Galería oeste. Monasterio de Sant Cugat del Vallès. 
Gracias a la documentación del cartulario sabemos que el monasterio poseía grandes cantidades de tierra con los distintos elementos necesarios para el cultivo de ésta además de la producción de alimentos. Algunos laicos para ganar favores o como parte de la dote de algunos de los niños y jóvenes entregados al monasterio, otorgaban al cenobio tierras, viñas, olivares e incluso molinos, siendo esto una práctica normal en el período en el que se construía el claustro ${ }^{93}$. Por lo tanto, estos capiteles podrían estar recogiendo actividades cotidianas realizadas ya bien por los monjes o distintos vasallos del monasterio. El particular interés por el ganado incluso se podría vincular directamente con una actividad del monasterio, la copia y escritura, pues estos animales proveían la materia prima para la elaboración de los manuscritos: el pergamino. Si bien se desconoce la ubicación y si Sant Cugat llegó a tener un scriptorium, en este monasterio sí que se practicaba el arte de copiar y escribir ${ }^{94}$.

En la galería de poniente en los capiteles interiores OI 01, OI 07, OI 10, OI 11, OI 12, OI 14 y OI 18 se plasmaron escenas de lucha, en las mismas se representan hombres combatiendo contra hombres u hombres enfrentándose a bestias. El capitel OI 11 ha sido identificado como Sansón luchando contra el león (Fig. 59), a pesar de que en el mismo la escena se representa dos veces, en las caras norte y sur. De ser Sansón, se ha de tener en cuenta que éste es una prefiguración de Cristo y su encuentro con el león simboliza la derrota del demonio y la victoria de Jesús ${ }^{95}$. Sansón junto al resto de las escenas de combate han sido interpretadas con un carácter de psychomachia, de lucha entre el bien y el mal, entre la virtud y el vicio ${ }^{96}$.

\footnotetext{
${ }^{93}$ Ver documentos: 791, 829, 1057, 1092, 1155, 1168 y 1101. RIUS SERRA. Cartulario de Sant Cugat del Vallés. Vol. II y III...,

${ }^{94}$ ZiMMERMAnN. Écrire et lire en Catalogne, Tomo I..., pp. 467-472. LORÉs I OTZET. "La vida en el claustra..., p. 40.

${ }^{95}$ RÉAU. Iconografía del arte cristiano. Iconografía de la Biblia. Nuevo Testamento. Tomo 1, Vol. 1..., p. 279.

${ }^{96}$ RODRÍGUEZ BARRAL. La imagen de la justicia divina ..., pp. 159-160.
} 
En términos históricos estos combates también podrían entenderse como eventos que tuvieron lugar en el entorno del monasterio. En los capiteles OI 07 y OI 10 los hombres luchan mano a mano parecerían recoger las pugnas o luchas entre los distintos campesinos mientras que las escenas en las que los combatientes portan armas y escudos se podrían vincular con las distintas invasiones sarracenas como ya ha apuntado Baltrusaitis ${ }^{97}$.

Las escenas de campesinos, animales y hombres luchando representadas en estos capiteles responden al microcosmos de la vida en el cenobio. Sin embargo, muchas de ellas se ajustan a la visión macrocósmica del calendario medieval, como ha señalado la profesora Lahoz. La observación es muy acertada, pues según Castiñeiras González, a finales del siglo XII -período al que pertenecen estos distintos capiteles- en Cataluña el calendario se comenzó a insertar en los capiteles de los claustros ${ }^{98}$. Encontramos ejemplos de las faenas de los meses no sólo en Ripoll, sino también en la catedral de Gerona, entorno en el que el artífice de claustro de Sant Cugat se formó y trabajó.

Con relación a la labor de los meses, en la galería oeste se identifican acciones ya utilizadas en otros calendarios hispanos contemporáneos. Al tener en cuenta la tradición pictórica de las labores, el capitel OI 15 cobra más sentido, y los hombres que trabajan entre la maleza, por los instrumentos de trabajo que llevan podrían identificarse con la acción de podar la viña, características del mes de marzo y ya representada de forma similar en León ${ }^{99}$. La construcción de las cubas en los capiteles OI 12 y OI 13 (Fig. 57) son una referencia visual directa al trabajo del tonelero, y en la zona geográfica a la que nos circunscribimos se vincula directamente con una tarea del mes de agosto. "El tonelero se convierte así en una peculiaridad iconográfica de los calendarios catalano-aragoneses ${ }^{100}$ ", siendo uno

\footnotetext{
${ }^{97}$ BALtrusAitis. Les Chapiteaux de Sant Cugat..., p. 73.

${ }^{98}$ CASTIÑEIRAS GONZÁLEZ. El calendario medieval hispano..., p. 98.

${ }^{99}$ CASTIÑEIRAS GONZÁLEZ. El calendario medieval hispano..., p. 195.

${ }^{100}$ CASTIÑEIRAS GONZÁlEZ. El calendario medieval hispano..., p. 200.
} 
de los primeros ejemplos pictóricos el del calendario de Ripoll cuyos vínculos e influencias constantes con Sant Cugat son sumamente latentes en la figuración monumental como en el intercambio intelectual.

Las escenas de ganados se asocian con las actividades del pastoreo. En Sant Cugat en dos chapiteles se insertaron escenas en las que se recogen acciones ligadas a esta labor: el OE 13 (Fig. 53) los hombres con las ovejas y el OI 05 (Fig. 54), las cuales sirven para ilustrar las faenas del mes de abril ${ }^{101}$. Con relación al capitel OI 16 con los dos toros (Fig. 55), en lugar de ser toros podrían ser dos bueyes y por lo tanto representar la labranza. En el entorno hispano ya se han identificado distintos ejemplos en los que la presencia de los dos bovinos ilustra esta actividad, y en el contexto de los calendarios medievales plasma el mes de noviembre ${ }^{102}$.

Anteriormente establecimos la posible relación entre las escenas de combate recogidas en algunos de los capiteles de la galería sur y la posible alusión a luchas y disputas históricas entorno al monasterio de Sant Cugat. Con relación al calendario, ya desde el siglo VII y VIII el mes de mayo se ilustra a través de los hombres combatiendo y de imágenes de caballería, "mayo marcaba en la Edad Media el comienzo de las hostilidades ${ }^{103}$ ". La escena plasmada en el capitel OI 01 recuerda sobre todo este carácter bélico, pues en el mismo se aprecian dos figuras de pie que portan espada y escudo y en dirección a estos se dirige un jinete (Fig. 58). La asociación de las distintas escenas de la galería oeste como ya había indicado Baltrsaitis exaltan la narrativa de una humanidad laboriosa, la cual se encuentra sujeta al tiempo medido en el calendario.

Cabe resaltar que los temas e imágenes que se insertaron en el ala de poniente del claustro del monasterio de Sant Cugat del Vallès remiten al espectador

\footnotetext{
${ }^{101}$ CASTIÑEIRAS GONZÁLEZ. El calendario medieval hispano..., p. 99.

${ }^{102}$ CASTIÑEIRAS GONZÁLEZ. El calendario medieval hispano..., pp. 168-169.

${ }^{103}$ CASTIÑEIRAS GONZÁLEZ. El calendario medieval hispano..., p. 157.
} 


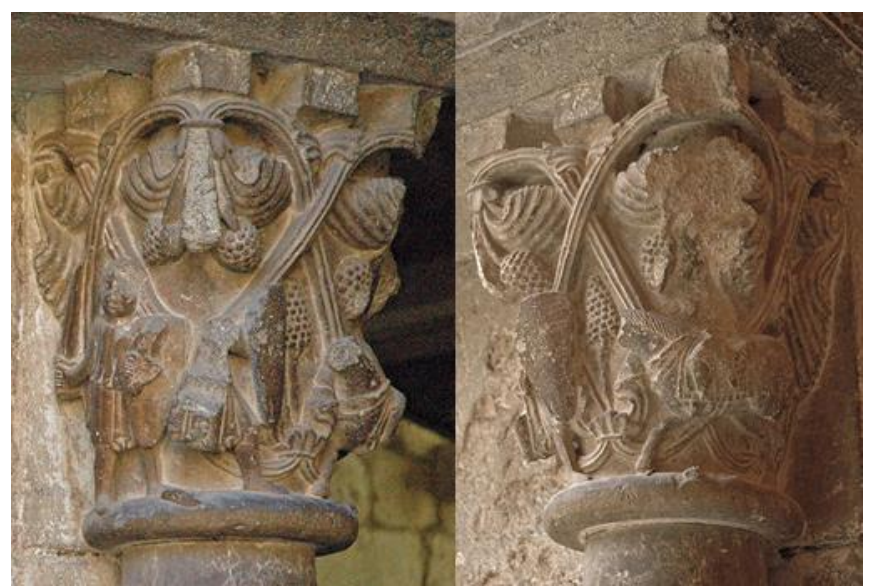

Figura 58. Hombres armas y jinete. Capitel OI 01. (Siglo XII) Galería oeste. Monasterio de Sant Cugat del Vallès.

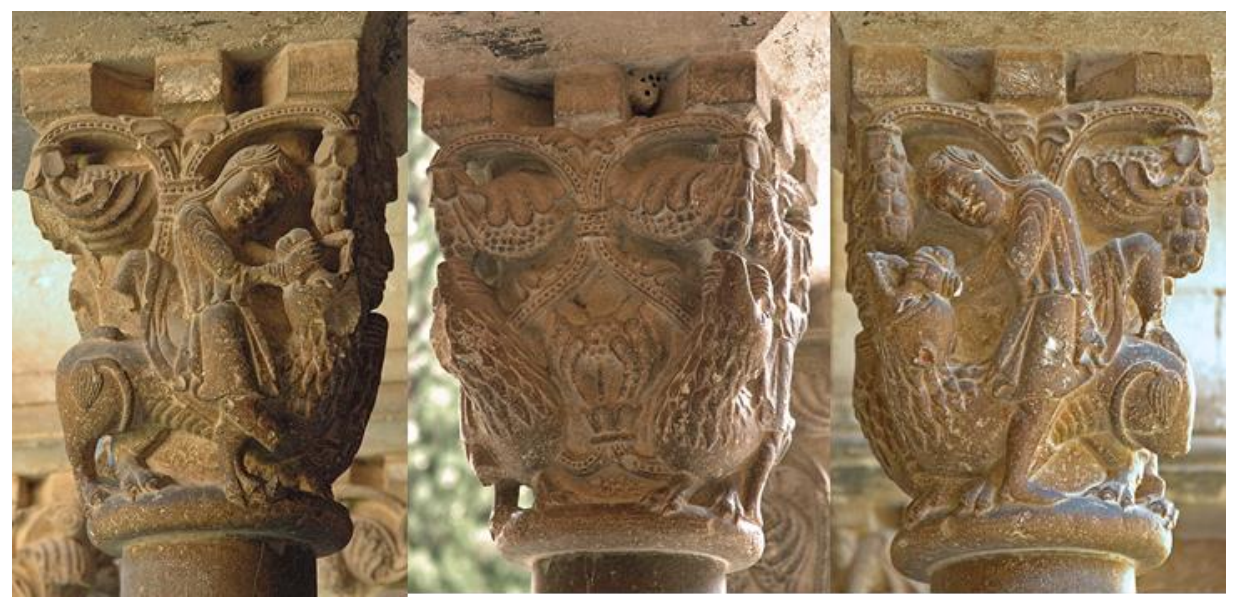

Figura 59. Sansón y el León. Capitel OI 11. (Siglo XII) Galería oeste. Monasterio de Sant Cugat del Vallès.

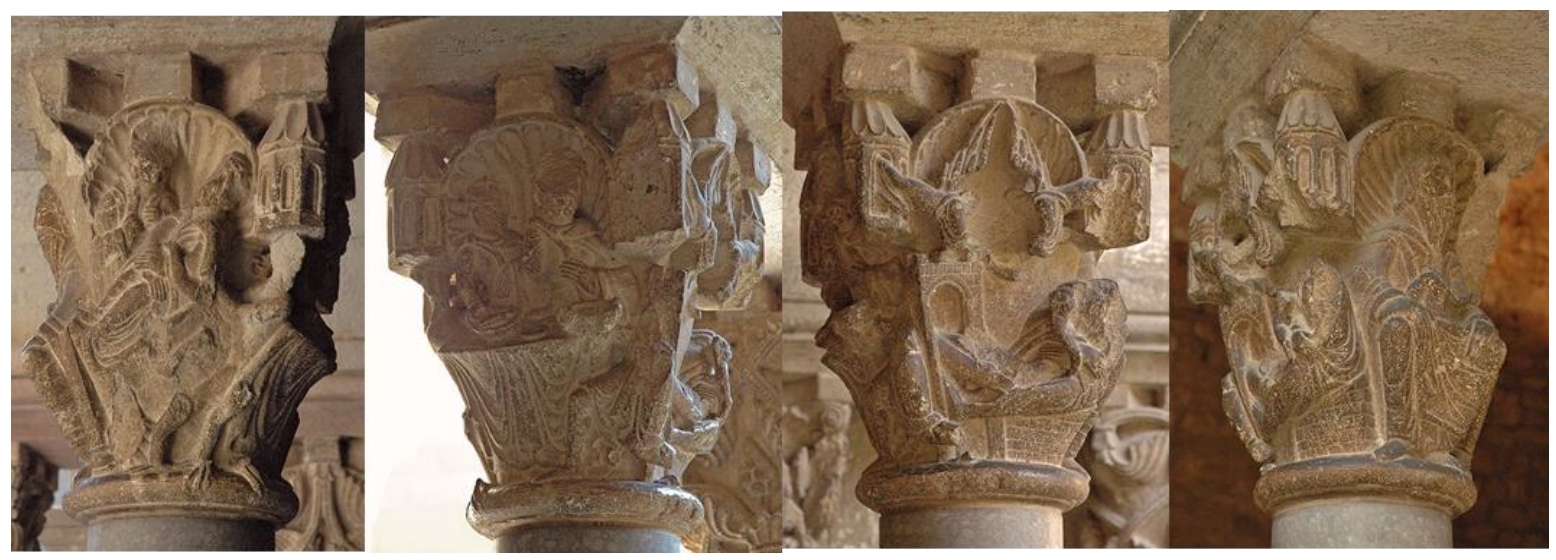

Figura 60. El pobre Lázaro y el rico Epulón. Capitel OI 17. (Siglo XII) Galería oeste. Monasterio de Sant Cugat del Vallès. 
a los plasmados en el lado sur. En este lado de la clausura se exalta el trabajo, acción que ya habíamos visto en el capitel de Adán y Eva y en el de Noé. La figura de Sansón, prefiguración de Cristo, nos recuerda la victoria de Jesús sobre el demonio manifestada en la Resurrección, la cual junto con eventos subsiguientes a esta se representaron en tres capiteles de la galería sur. Por último, la parábola del rico y el pobre Lázaro al igual que la Dormición de la Virgen presenta la muerte y el transitio animae de estos, recordando al cristiano su destino final. Además, la figura de Sansón también representa el triunfo sobre el mal y la de Lázaro la victoria de la virtud sobre los vicios ${ }^{104}$, vinculando estas acciones directamente con las virtudes victorias del capitel de la Psychomachia.

En esta galería se incluyó un capitel historiado con la parábola del pobre Lázaro y el rico Epulón (OI 17) (Fig. 60) y se representa siguiendo las palabras de Cristo recogidas en el Evangelio de Lucas ${ }^{105}$. En la cara que da al interior de la galería se aprecia el festín de Epulón. El rico disfruta del festín junto con otra figura mientras una tercera le sirve. La mesa se encuentra servida, decorada con un mantel y sobre la misma los platos y cuencos con alimento. En la cara sur junto a la puerta de la vivienda de Epulón se encuentra tumbado Lázaro, por la puerta se aproximan dos perros a lamerle sus llagas. Más que estar recostado, es el momento en el que Lázaro expira, así lo revelan los dos ángeles sobre la figura del mendigo y los restos que se aprecian de una pequeña figura antropomorfa, expresión visual del alma de Lázaro. En contraposición con esta cara, en el lado norte se recogió visualmente la muerte de Epulón, actualmente sólo se pueden apreciar restos de la figura del rico, de su esposa afligida a su izquierda y las garras de un demonio, sin embargo, Baltrusaitis en su momento logró identificar una figura pequeña que era atormentada por el demonio al que hoy en día únicamente le sobreviven los pies ${ }^{106}$. Ambas caras se complementan. Lázaro muere y junto a este sólo permanecen los

\footnotetext{
${ }^{104}$ LORÉS I OTZET. "La escultura del claustre i de l'eglésia..., p. 174

${ }^{105}$ Lucas 16: 19-31.

106 "Son âme, sous les traits d'un petit enfant, tombe dans les mains du démon qui, abrité sous la tourelle droite...”. BALTRUSAITIS. Les Chapiteaux de Sant Cugat..., pp. 94-95.
} 
perros, Epulón muere y con él se encuentra su esposa. En ambos casos se representa visualmente el alma del difunto por medio de la figura de menores dimensiones y la misma es guiada a su morada final por seres: en el caso de Lázaro por dos ángeles, la de Epulón por un demonio.

Sobre la presencia de la mujer de Epulón, Lorés señala que ésta lleva los cabellos sueltos, característica física propia de la representación del pecado de la lujuria $^{107}$. Con respecto a los vicios, no sólo se representaría la lujuria, ya había señalado la profesora Lorés y Paulino Barral la vinculación directa de la figura de Epulón y el banquete en Sant Cugat como una manifestación visual de la gula y la avaricia $^{108}$. La ubicación entonces de la figura de Abraham y Lázaro en su seno en la cara este del capitel no resulta desordenada, sino que la misma manifiesta de forma plástica el premio de aquel que acoja la vida virtuosa y el castigo del que caiga preso del vicio. La parábola del pobre Lázaro y el rico Epulón es una de carácter escatológico, que junto al transcurrir del tiempo -cuyo concepto abstracto se plasma concretamente por medio del calendario y las labores de los mesesrecuerda el destino final de todo hombre: la muerte, el Juicio Final y la resurrección ${ }^{109}$.

\subsubsection{Vida en el claustro}

El ductus del claustro continua en la galería norte. En esta como puntualizaremos a continuación se tocan temas vinculados directamente con ritos de iniciación a la vida religiosa y el orden de las tareas y horas dentro del cenobio.

\footnotetext{
${ }^{107}$ LORES I OTZET. "La escultura del claustre i de l'eglésia..., p. 175.

108 Rodríguez BARRAL, Paulino. La imagen de la justicia divina. La retribución del comportamiento humano en el más allá en el arte medieval de la Corona de Aragón. Tesis doctoral. Barcelona: Universidad Autónoma de Barcelona, 2003. p. 161. LORÉS I OTZET. "La vida en el claustra..., p. 38.

${ }^{109}$ CAMILlE, Michael. Arte gótico: visiones gloriosas. Madrid: Ediciones Akal, S.A., 2005. p. 98.
} 
En la galería septentrional en dos de los treinta y seis capiteles se plasmaron escenas de la vida en el claustro. Ambos capiteles se encuentran en el interior de la galería, facilitando al espectador la identificación y contemplación de los mismos. En dirección oeste a este, el primer capitel (NI 06) se representan a tres monjes (Fig. 61). En la cara este se encuentra un monje sentado, levemente se inclina hacia delante a la misma vez que con su mano derecha toca su cabeza tonsurada. En el lado norte aparece otro monje sentado que se inclina hacia delante mientras se apoya con los brazos sobre sus piernas y junto a él otro monje, de pies, se acerca y extiende sus brazos. Lorés i Otzet afirma que este capitel plasma una práctica cotidiana del monasterio, el acto de afeitarse, el cual se recoge incluso en el costumari del monasterio ${ }^{110}$.

En este capitel además de recoger una actividad cotidiana como la de afeitarse, también el mismo resalta un ritual de iniciación, la tonsura. Como se aprecia en el capitel el monje de pies está afeitando a los sedentes, incluso ya afeitó al religioso de la cara de levante quien sólo puede ahora tocar su cabeza recién tonsurada. La tonsura es un atributo físico propio de los monjes. En el chapitel de Sant Cugat, la importancia de la tonsura va más allá del mero acto de afeitarse. El acto de tonsurar era un rito de iniciación sagrado por el cual en el tonsurado pasaba a formar parte de la comunidad, disfrutando y comprometiéndose con los distintos privilegios y obligaciones de la misma. En el mundo latino particularmente, a finales del siglo VII la tonsura comenzó a ser utilizada particularmente por los oblatos. Si bien no hay una edad prescrita para ser tonsurado, el candidato por lo menos debía conocer los rudimentos de la fe y a leer y escribir ${ }^{111}$.

Un detalle de los monjes sedentes que a priori parece irrelevante es la especie de delantal que estos llevan sobre sus hábitos. Este delantal o paño sólo lo utilizan los dos monjes que están siendo tonsurados, en el resto de los capiteles

\footnotetext{
${ }^{110}$ LORÉS I OTZET. "La vida en el claustra..., pp. 40-41.

111 "Tonsura", en Enciclopedia de la religión católica. Tomo VII. Barcelona: Dalmau y Jover, S. A., 1956. pp. 255-256.
} 
con religiosos no se aprecia dicho detalle. Es un detalle relevante de la composición pues claramente se distingue el largo de éste del de las vestimentas religiosas. El mismo podría ser una alusión a la sobrepelliz, túnica blanca cuyo uso en la administración de los sacramentos se volvió la norma a partir del siglo XI especialmente en Francia y los religiosos utilizaban encima de su hábito ${ }^{112}$. Esta vestidura litúrgica era utilizada también en el ritual de tonsura ${ }^{113}$, confirmando así que la imagen del chapitel NI 06 representa el ritual de tonsura más que la práctica cotidiana de afeitado.

El individuo que iba a participar de este ritual ya dominaba los conocimientos expuestos en la galería sur y oeste, motivo por el cual sería integrado al a comunidad de religiosos. Con la adopción del hábito y la tonsura el aspirante renunciaba al mundo y renacía a una nueva vida. El administrador de la tonsura rogaba por sus hijos "para que, así como se mudan exteriormente, la mano del Todopoderoso les otorgue aumentos de virtud, aleje de sus ojos toda ceguera espiritual y humana y les conceda la luz eterna de la gracia ${ }^{114}$.

Dos capiteles más adelante se representa otra escena de la vida en el cenobio (NI 08) (Fig. 62), específicamente la procesión de estos a la iglesia. En la cara norte de este chapitel se aprecia la figura de un monje que toca una campana y junto al mismo una pequeña puerta. Este vano representa la entrada de la iglesia por la cual entra un monje que en sus manos lleva un libro. El resto de la escena se organiza alrededor de la figura de este religioso, ya que en fila otros miembros de la comunidad, que de igual manera sujetan libros y algunos incluso rollos, le siguen al interior del templo. En este capitel se recoge visualmente las reglas establecidas en el costumari, según las cuales los monjes se trasladaban del

112 “Sobrepelliz", en Enciclopedia de la religión católica. Tomo VI. Barcelona: Dalmau y Jover, S. A., 1954. p. 1409.

${ }^{113}$ Ver: Tonsura", en Enciclopedia de la religión católica....

${ }^{114}$ Enciclopedia de la religión católica. Tomo VII..., p. 256. 
claustro, donde habían estado leyendo, a la iglesia para la práctica del oficio divino $^{115}$.

La palabra procesión deriva del latín processio, que significa marcha adelante. En el antiguo lenguaje litúrgico se entendía como la "reunión del pueblo cristiano en la iglesia a la cual processit, esto es, a la que se iba para, allí reunidos los fieles celebras los sagrados Oficios ${ }^{116}$. El capitel de los monjes en procesión además de expresar visualmente las estipulaciones del costumari, también recuerda al espectador que el espacio en el que éste se encuentra es uno procesional por el que los cuerpos han de desplazarse en primer lugar para llegar al coro de la iglesia, lugar donde se lleva a cabo el oficio divino, pero igualmente como parte del proceso de meditación de la lectio divina.

En andar de los monjes en el capitel se proyecta en dirección a la galería este del claustro, conduciendo al espectador al encuentro del capitel EI 01 en el cual se incluyó a un monje y un cantero.

\subsubsection{Obediencia y humildad}

En el procesional hacia el interior de la iglesia, siguiendo el ductus que se comenzó en el capitel de Daniel en la galería meridional, el primer chapitel figurativo con el que se encuentra el espectador en la galería norte es el EI 01 en el que también se ha vinculado con una escena en la vida en el claustro por la presencia de un monje (Fig. 63). Este chapitel por el lado norte se encuentra adosado al muro, así que sólo se insertaron imágenes en los lados de levante y poniente. En la cara que da al interior de la galería, la este, se plasmó a un cantero

\footnotetext{
${ }^{115}$ LORÉS I OTZET. "La vida en el claustra..., p. 42.

116 "Procesiones", en Enciclopedia de la religión católica. Tomo VI..., p. 260.
} 


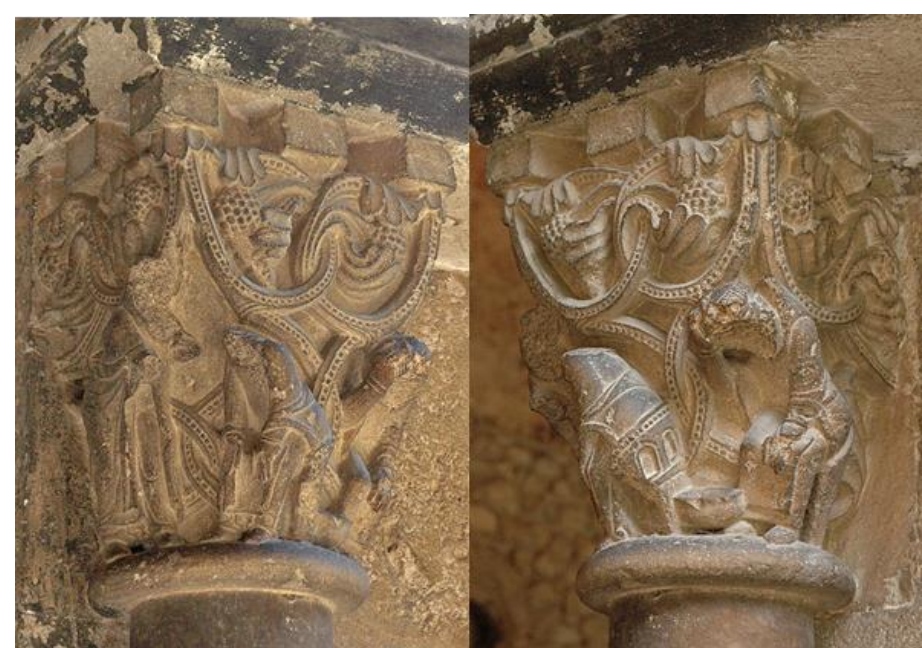

Figura 61. Tonsura. Capitel NI 06. (Siglo XII) Galería norte. Monasterio de Sant Cugat del Vallès.

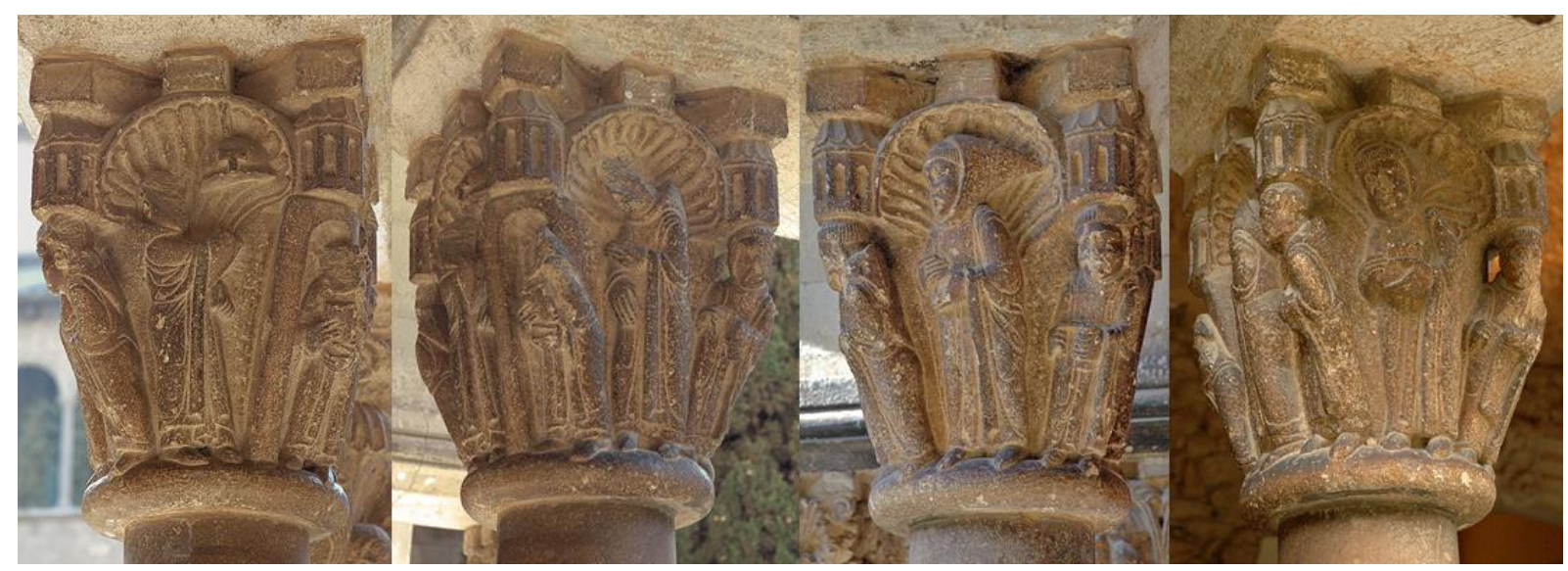

Figura 62. Procesión. Capitel NI 08. (Siglo XII) Galería norte. Monasterio de Sant Cugat del Vallès.

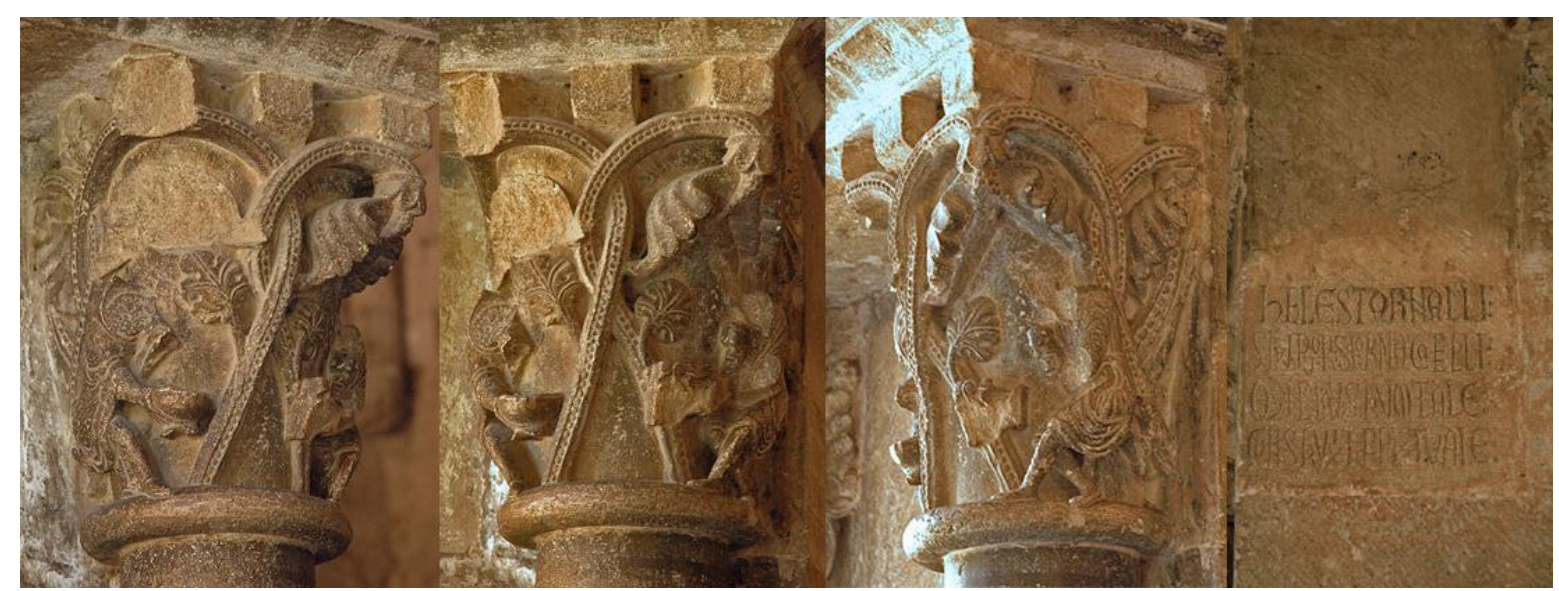

Figura 63. Monje y escultor. Capitel EI 01. (Siglo XII) Galería este. Monasterio de Sant Cugat del Vallès. 
labrando un capitel y en contraposición a éste, en la cara oeste se labró la imagen de un monje que ofrece un cuenco.

En el muro contiguo al capitel se incluyó la siguiente inscripción: “HEC EST ARNALLI / SCULPTORIS FORMA CAELLI / QUI CLAUSTRUM TALE / CONSTRUXIT PERPETUALE". Los distintos autores y estudiosos de la escultura del claustro han interpretado esta inscripción como la firma del artista, Arnau Cadell, junto a un retrato de su oficio ${ }^{117}$. Para grabar ésta, se hizo una incisión en el muro que abarca todo el largo del capitel. Los versos con la autoría del artista solamente ocupan la parte inferior de este rectángulo y toda la parte superior se encuentra vacía. Podríamos especular que se dejó así para insertar otro texto. Entre los distintos pares de capiteles con los que inician y culminan las galerías oeste, norte y este se aprecian incisiones parecidas a estas con forma rectangular, las cuales posiblemente pudieron haber estado destinadas para insertar alguna inscripción. De ser así, habría que cuestionarse si la firma corresponde al momento en el que se construyó la primera fase o es posterior a ésta. La profesora Lorés, fiel defensora de la autoría de Arnau Cadell, apunta a que en el cartulario del cenobio aparecen documentos de la primera década del siglo XIII firmados por un tal Arnau Cadell y especula que la actividad de éste pudo tener lugar entre la catedral de Gerona y Sant Cugat durante la última década del siglo XII y los primeros años del siglo XIII ${ }^{118}$.

La imagen del cantero junto al monje puede ser interpretada como un retrato de artista. No obstante, la presencia de un constructor nos remite a un elemento importante de las mnemotecnias, la noción de aedificatio y aedificare, o sea, de construcción y construir. Y es que las imágenes de artistas y arquitectos desde la

${ }^{117}$ LORÉS I OTZET. "La escultura del claustre i de l'eglésia..., p. 171. BALTRUSAITIS. Les Chapiteaux de Sant Cugat..., p. 75. PERAY, Josep de. Monografía histórica i descriptiva del poble de Sant Cugat del Vallès. Barcelona: Rourich, 1990. p. 16. VILlanueVA. Viage literario a las iglesias de España. Tomo XIX..., p. 27. PONZ, Antonio. Viage de España. Tomo XIV. Madrid: Por la viuda de Ibarra, hijos y compañía, 1788. p. 119.

${ }^{118}$ LORÉS I OTZET. "La escultura del claustre i de l'eglésia..., p. 176-177. 
antigüedad jugaron un papel importante con la memoria. Las antiguas técnicas de memorización hacían uso de construcciones arquitectónicas para ubicar los distintos loci. Durante la Edad Media, como exploramos en los capítulos anteriores se utilizó el esquema del folio para la memorización y meditación. Pero igualmente, los teólogos de este período exhortaron al ejercicio de la meditación a través de las metáforas de la construcción de edificios, basados en el texto paulino en el que éste se compara con un buen arquitecto. Según Pablo, el buen arquitecto establece el cimiento, que es Dios, y sobre el mismo otros construyen ${ }^{119}$. El texto paulino llevó a utilizar la imagen mental de los planos y alzados de edificaciones como superestructuras en las que se encuentran los distintos tropos de invención entendida ésta no sólo como la facultad de inventar, sino también la acción de encontrar o descubrir e igualmente vinculada con la noción de inventarionecesarios para el proceso de meditación ${ }^{120}$.

Si bien la imagen del cantero visualmente nos puede remitir al autor de la obra y a su trabajo, igualmente transporta al espectador a la noción de construcción y edificación. El mismo sirve como una señal o signo que recuerda al monje que de la misma forma como se construye el edificio, así ha de ser el proceso de meditación de él. Además, el objeto que labra, un capitel, también aporta a la noción de construir en alzado, colocar sobre. La función arquitectónica de los capiteles es la de transmitir y balancear las cargas ${ }^{121}$, significado que junto al

\footnotetext{
119 "Conforme a la gracia de Dios que me fue dada, yo, como buen arquitecto, puse el cimiento, y otro construye encima. ¡Mire cada cual cómo construye! Pues nadie puede poner otro cimiento que el ya puesto, Jesucristo. Y si uno construye sobre este cimiento con oro, plata, piedras preciosas, maderas, heno, paja, la obra de cada cual quedará al descubierto; la manifestará el Día, que ha de revelarse por el fuego. Y la calidad de la obra de cada cual, la probará el fuego. Aquél, cuya obra, construida sobre el cimiento, resista, recibirá la recompensa. Mas aquél, cuya obra quede abrasada, sufrirá el daño. Él, no obstante, quedará a salvo, pero como quien pasa a través del fuego. ¿No sabéis que sois santuario de Dios y que el Espíritu de Dios habita en vosotros? Si alguno destruye el santuario de Dios, Dios le destruirá a él; porque el santuario de Dios es sagrado, y vosotros sois ese santuario". 1 Corintios 3: 10-17.

${ }^{120}$ CARRUTHERS. The Craft of Thought..., p. 17.

121 "Chapiteau: élément de forme évasée qui couronne la colonne et lui transmet les charges qu'elle doit porter. Les chapiteaux sont en général fort décorés." BAYARD, Jean Pierre. La
} 
ductus del claustro se puede transponer al plano alegórico: los distintos temas antes tratados son el soporte cognitivo para las siguientes escenas.

En el tramo final de la galería de levante encontramos otros tres capiteles con historias neotestamentarias (Fig. 64). Los mismos se encuentran justo delante de la actual capilla del santísimo, espacio que antiguamente era la sala capitular. Si se prosigue el orden establecido en dirección a la iglesia, encontramos en el capitel historiado EI 15 la escena del Lavatorio de pies (Fig. 65). Este capitel recoge todo el relato de Juan 13:1-17. La narrativa del mismo comienza en la cara norte en la que se insertó un hombre barbudo que se toca sus pies, en la cara oeste aparece otro hombre barbudo que igualmente se toca los pies. A pesar de que estas dos figuras se representan de forma similar, un elemento las diferencia: la barba. El bello facial del primero es rizado, , muy similar a la figura de Pedro en la cara de levante del chapitel, mientras que la barba de la segunda figura es larga y lacia. Una posible interpretación es que la pareja representa la conversación entre Jesús y Pedro, específicamente el momento en que Pedro no se deja lavar los pies de su maestro y luego cuando Jesús le replica que aquel que está limpio sólo necesita lavarse los pies $^{122}$. La escena principal de este episodio del Nuevo Testamento, que completaría la narrativa, se recoge en las caras sur y este del capitel. En el lado meridional se aprecia a Jesús, acompañado por dos pajes, arrodillado lavándole los pies a Pedro que se encuentra en la cara contigua. Pedro toca su mejilla gesto que expresa la aceptación de éste a que su maestro le lave los pies y como afirma Lorés, gesto que indica la aceptación tras la resistencia inicial ${ }^{123}$. En las esquinas se han representado en dimensiones menores más figuras sedentes que a manera de síntesis plasman al resto de los apóstoles. La presencia del lavatorio de pies justo delante de la Sala Capitular se asocia con una práctica que tenía lugar

tradition cachée des cathédrales: du symbolisme médiéval à la réalisation architecturale. StJean-de-Braye: Éditions Dangles, 1990. p. 403.

122 Juan 13: 6-10.

123 "Aquest també es duu la mà a la galta, gest que indica la seva acceptació deprés de la resistència inicial". LORÉS I OTZET. "La escultura del claustre i de l'eglésia..., p. 175. 

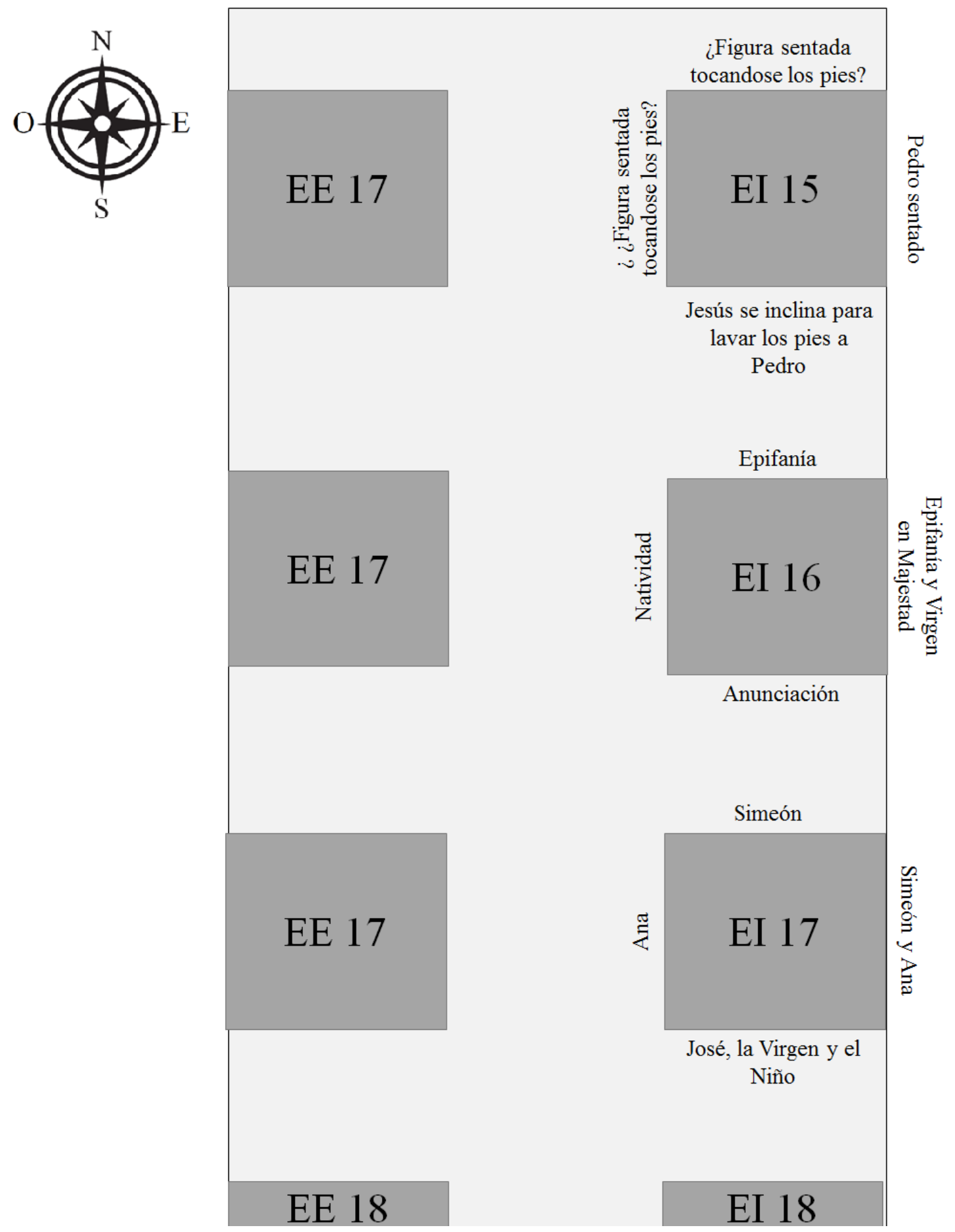

Figura 64. Distribución temas iconográficos galería este.

Capiteles EI 15, 16 y 17. 
en esta estancia, la del lavamiento de pies de los hermanos de la comunidad ${ }^{124}$ la cual se recoge en el Costumari.

El capitel contiguo al del Lavatorio de pies el EI 16, plasma la Anunciación, la Natividad y la Epifanía (Fig. 66). La Anunciación se recogió en la cara sur, según la tradición: al lado izquierdo de la composición se encuentra el ángel Gabriel y María en el derecho. Los gestos de las figuras manifiestan el diálogo en el evangelio de Lucas: el ángel señala pues se dirige a María y esta con las manos abiertas recibe su encomienda. Esta Anunciación recoge los elementos necesarios para la identificación de la misma, prescindiendo de otros propios de la tradición iconográfica como es el libro ${ }^{125}$. Luego encontramos en el lado de poniente del chapitel una escena de la Natividad que sigue muy de cerca la tradición medieval $^{126}$. En la misma se aprecia a la Virgen recostada y el Niño recién nacido fajado en el pesebre. Junto a ellos, sentado en un rincón reposando se encuentra José, quien con la mano derecha toca su rostro como si se adormilara y con la izquierda el lecho en el que reposa María. Si en la escena se omitieron elementos, aquí al contrario hasta los animales se incluyeron y a pesar del mal estado aún se aprecia la figura del buey. El discurso icónico de este capitel culmina con la plasmación de la Epifanía la cual comienza en la cara norte con los Reyes siguiendo la estrella, la cual se representó en la parte más alta del capitel, y culmina en la cara que se proyecta al interior de la galería este con la Virgen en Majestad en cuyo regazo se aprecia la Niño que recibe el regalo de uno de los magos.

Sobre la escena de la Epifanía se ha de destacar que la Virgen en Majestad aquí plasmada también era conocida como Sedes Sapientiae, sede o trono de la sabiduría pues Cristo era esta sabiduría. Es la segunda vez en el claustro que vemos como se exalta la virtud de la sabiduría a través del uso de imágenes. La

\footnotetext{
${ }^{124}$ LORÉS I OTZET. "La vida en el claustra..., pp. 36-37.

${ }^{125}$ RÉAU. Iconografía del arte cristiano. Iconografía de la Biblia. Nuevo Testamento. Tomo 1, Vol. 2.., p. 188.

${ }^{126}$ RÉAU. Iconografía del arte cristiano. Iconografía de la Biblia. Nuevo Testamento. Tomo 1 , Vol. 2..., pp. 229-230.
} 
primera en el capitel de la Psychomachia (Fig. 49) a través de la personificación de la virtud Sapientia en la cara norte y luego a través de María como trono de la sabiduría encarnada en Cristo.

El último capitel historiado de la galería sur (EI 17) trata el episodio evangélico de la presentación de Jesús en el templo, narrados en el evangelio de Lucas (Fig. 67). En la cara sur se aprecian a José, éste en sus brazos lleva cuatro palomas para el sacrificio, junto a éste la Virgen que carga al niño y lo ofrece a Simeón quien se aprecia en el lado este del capitel con los brazos extendidos para recibir al infante. Detrás de éste se encuentra la profetisa Ana, ésta con una mano sujeta un libro y con la otra señala. En la cara norte se representa un hombre barbudo con un libro y en la cara oeste una mujer de pies que muestra la palma de su mano derecha abierta, entre estas figuras se insertaron otras tres de menor tamaño. La identificación de las mismas no está del todo claro. Sobre la figura barbuda de la cara, según Lorés éste es otro sacerdote del templo como en el modelo gerundense y para Baltrusaitis éste, junto a las figuras de menor escala, forman parte del cortejo de la familia ${ }^{127}$. Por otra parte, Baltrusaitis relaciona la figura femenina de la cara oeste con la profetisa Ana mientras que para la profesora Lorés ésta forma parte con el resto de las figuras de menor tamaño del sequito o acompañamiento de la Sagrada Familia ${ }^{128}$. Entre medio de estas dos figuras, se insertaron tres figuras de dimensiones menores las cuales no conservan las cabezas. Los gestos de las manos de la que se encuentra entre las caras este-norte son muy similares a la figura femenina de la cara oeste. Las otras dos parecen sujetar algo con sus manos, posiblemente cirios que aluden a la celebración de la Candelaria $^{129}$.

127 LORÉS I OTZET, Immaculada. "La escultura del claustre i de l'eglésia..., p. 174. Baltrusaitis. Les Chapiteaux de Sant Cugat..., p. 92.

${ }^{128}$ LORES I OTZE. "La escultura del claustre i de l'eglésia..., p. 174. BALTRUSAitis. Les Chapiteaux de Sant Cugat..., pp. 91-92.

${ }^{129}$ LORES I OTZE. "La escultura del claustre i de l'eglésia..., p. 174. 
El hecho de que la figura barbuda lleva un libro la aleja de ser un mero acompañante de la familia. Si bien podría ser otro sacerdote del templo no se puede pasar por alto otras partes del relato bíblico. Se ha de resaltar las palabras pronunciadas por Simeón ante la presencia del Mesías, el Nunc dimittis. Éste fue recogido en el Evangelio de san Lucas y es uno de los cánticos bíblicos que suelen aparecer en los breviarios y se cantaba en distintas festividades durante el año litúrgico, sobre todo durante la celebración de las Candelas. En cuanto a la figura femenina, los gestos de sus manos indican que la misma está hablando, según el evangelista la profetiza Ana al ver al niño dio gracias a Dios y hablaba acerca del Niño a todos los que esperaban la redención de Jerusalén ${ }^{130}$, bien esta figura femenina podría representar este momento.

A priori la yuxtaposición de estos tres capiteles supone cierta incoherencia. Las historias del Nuevo Testamento plasmadas en los mismos no siguen el orden cronológico de los eventos en los Evangelios. Inma Lorés ha apuntado que estos tres capiteles completan la secuencia de eventos en la galería sur, sin embargo, hemos de recordar que dicha ala es posterior. Estos capiteles y las imágenes de los mismos sirven de lugares mnemónicos de recopilación sobre los cuales se construye el conocimiento que forma parte de la experiencia meditativa. La representación visual es el primer registró cognitivo, mostrando el sentido literal de la historia plasmada. Un segundo nivel recuerda al espectador las distintas prácticas litúrgicas que se llevaban a cabo en el espacio en el que se insertaron los diversos temas. En este sentido ya la profesora Lorés había identificado la relación entre la imagen del Lavatorio de pies con una práctica habitual en el cenobio.

Para Paulino Rodríguez Barral, estos tres capiteles se entienden en clave doctrinal, vinculando los mismos con la virtud de la humildad ejemplificada en la encarnación de Cristo, visualmente manifiestada en la escena de la Anunciación en el capitel EI 16 (Fig. 66), y en el acto de Jesús inclinado en la cara este lavando

${ }^{130}$ Lucas 2: 38. 
los pies de Pedro en el chapitel EI 15 (Fig.15). Estas imágenes eran una invitación a los monjes que salían de la sala capitular a la práctica de esta virtud ${ }^{131}$.

Nos hemos percatado que la práctica de la humildad no sólo se representa en el Lavatorio o en la Natividad, igualmente se exalta en el capitel de la Presentación en el templo. La figura de María en los últimos dos capiteles tiene un protagonismo prominente: en el capitel EI 16 (Fig. 66) se representa tres veces y las escenas bíblicas aquí plasmadas culminan con la plasmación de la Epifanía, específicamente con las tres figuras de la Sagrada Familia. Como en la galería oeste, vemos que las imágenes se concatenan y el siguiente chapitel inicia nuevamente con estos tres personajes: José, María y el Niño. La imagen de la presentación de Jesús en las caras sur y este como locus, también alude a la purificación de la Virgen. Según los preceptos judaicos recogidos en el Antiguo Testamento toda parturienta antes de presentar a su hijo en el templo debía esperar una cantidad de días para purificarse ${ }^{132}$. En el capitel apreciamos como ahora la Sedes Sapientiae de presenta sobre un altar a su hijo al sacerdote Simeón según las costumbres judaicas. María a pesar no tener mancha alguna se sometió a Ley de sus antepasados para dar ejemplo de humildad ${ }^{133}$.

La práctica de la virtud de la humildad no es el único elemento en común de estos tres capiteles, a ésta debemos añadir la práctica de la obediencia. La presentación de Jesús en el templo plasma la obediencia de sus padres a la Ley de Moisés ${ }^{134}$. Visualmente esto se manifiesta en el capitel EI 17 (Fig. 67) a través del gesto de María al entregar a su Hijo al sacerdote, pero igualmente en otros elementos iconográficos como son las tórtolas en los brazos de José. Como parte

\footnotetext{
${ }^{131}$ RODRÍGUEZ BARRAL. La imagen de la justicia divina..., p. 157.

${ }^{132}$ Levítico 12.

${ }^{133}$ RÉAU. Iconografía del arte cristiano. Iconografía de la Biblia. Nuevo Testamento. Tomo 1, Vol. 2..., p. 273.

${ }^{134}$ RÉAU. Iconografía del arte cristiano. Iconografía de la Biblia. Nuevo Testamento. Tomo 1, Vol. 2..., p. 273.
} 


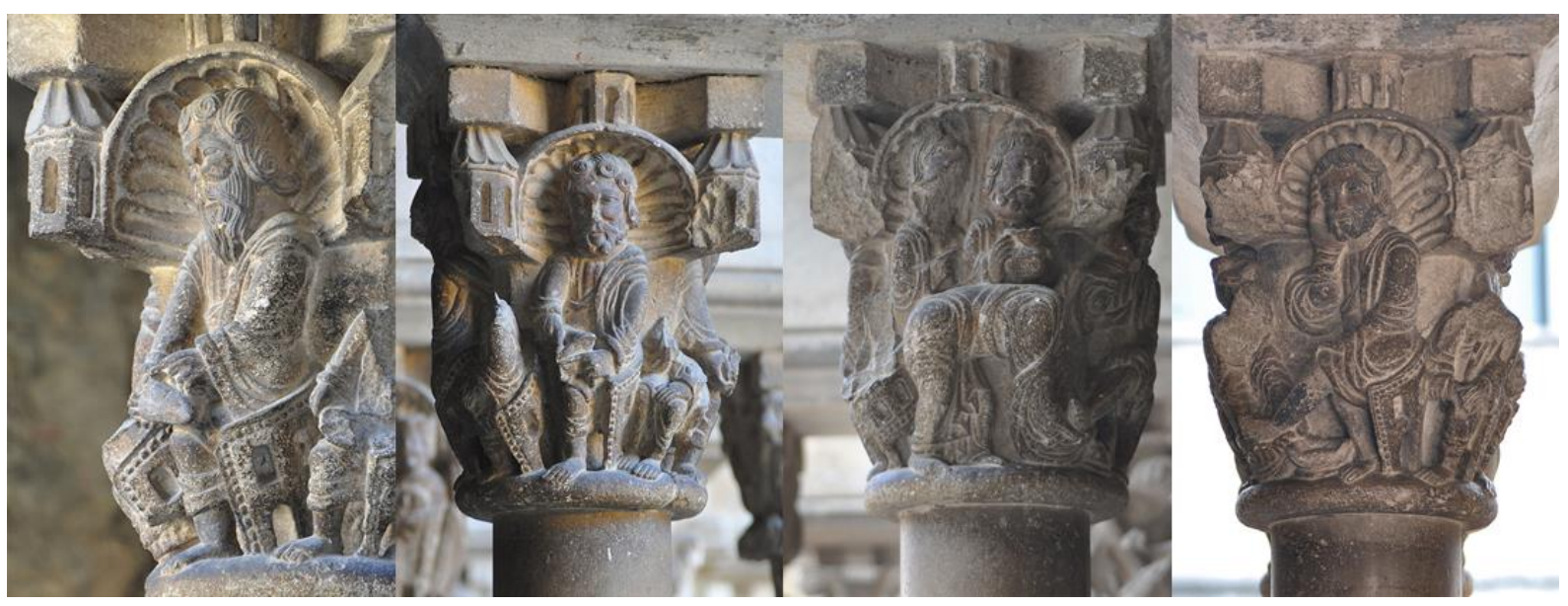

Figura 65. Lavatorio de pies. Capitel EI 15. (Siglo XII) Galería este. Monasterio de Sant Cugat del Vallès.

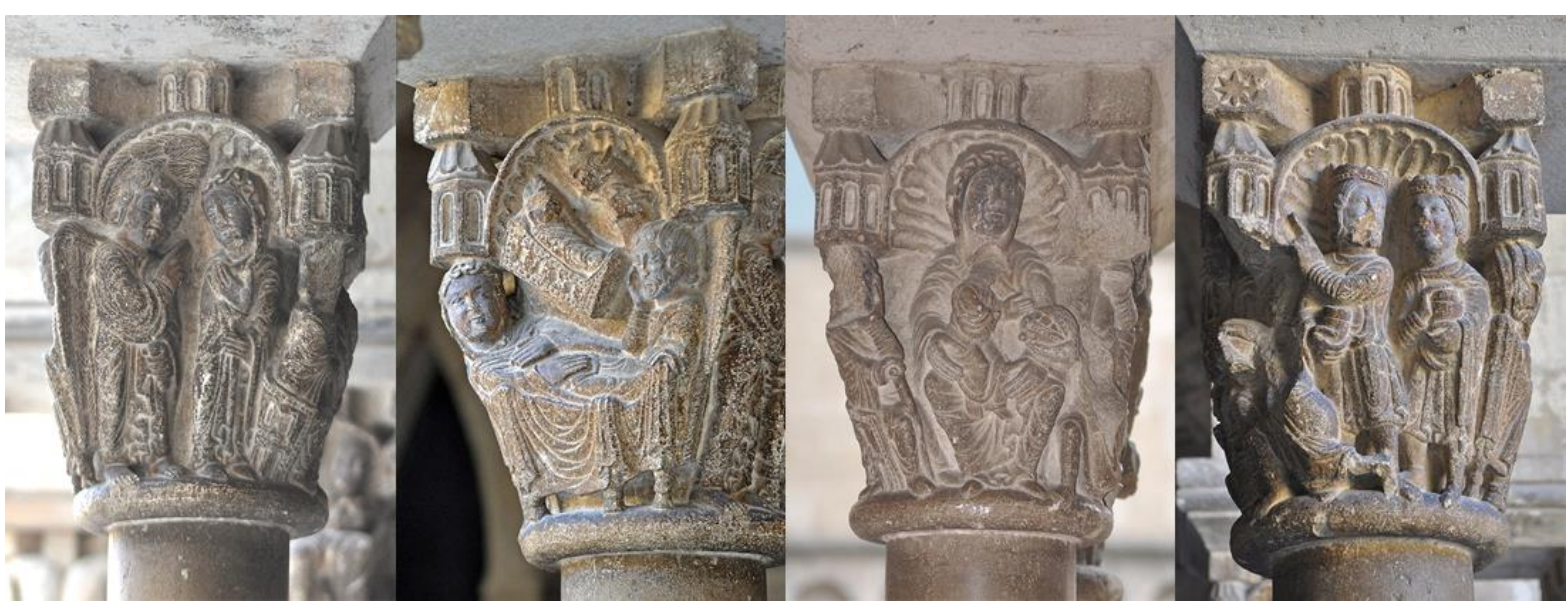

Figura 66. Natividad. Capitel EI 16. (Siglo XII) Galería este. Monasterio de Sant Cugat del Vallès.

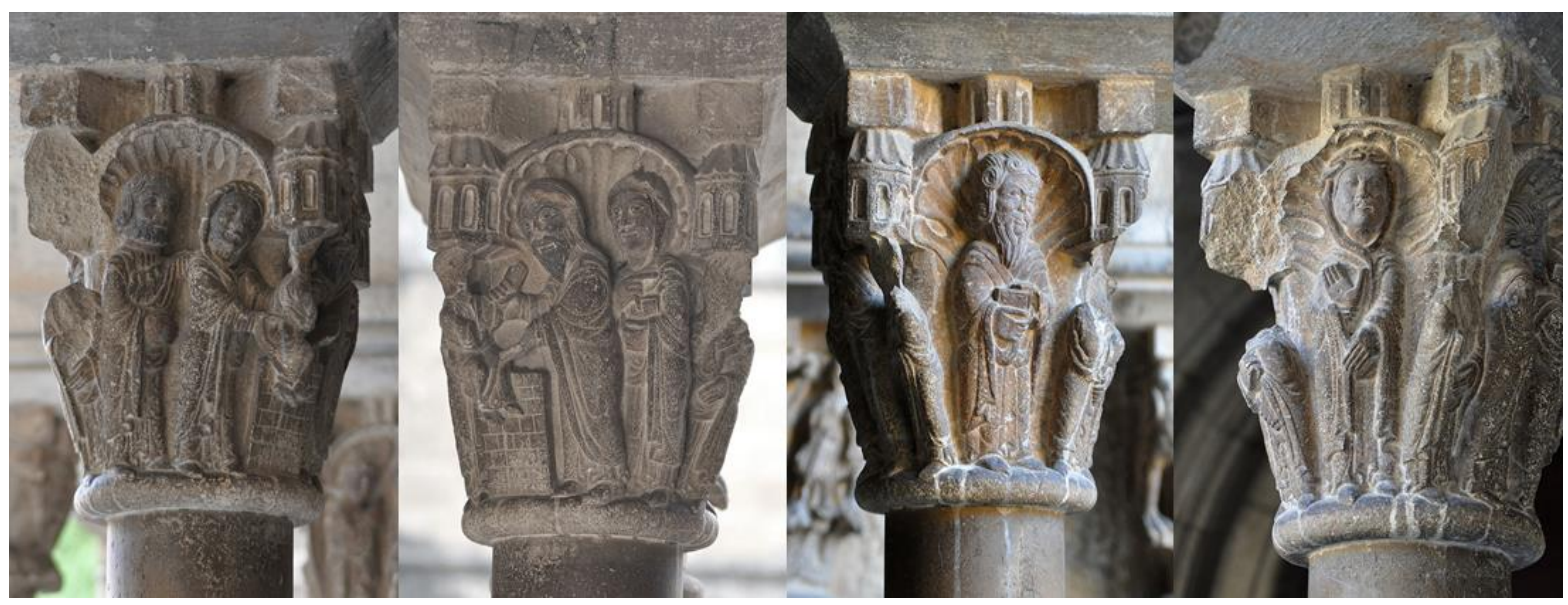

Figura 67. Presentación en el templo. Capitel EI 17. (Siglo XII) Galería este. Monasterio de Sant Cugat del Vallès. 
del ritual de presentación, se debían presentar como sacrificio un cordero o unas tórtolas ${ }^{135}$. Según Réau el cordero era el animal ofrecido por los pudientes mientras que las tórtolas por aquellos más humildes ${ }^{136}$. Con respecto al número de tórtolas encontramos ciertas disparidades, en el capitel se plasmaron cuatro, el Levítico establece una y Lucas narra que la Ley prescribía un par (Lucas 2: 24).

En el Mandatum igualmente se manifiesta un acto de obediencia, en el momento en el que Pedro acede a la orden de Jesús. Tras la cena Jesús se dispuso a lavar los pies a sus discípulos. Cuando se acercó a Pedro, éste se resistió, sin embargo, tras las palabras de su Maestro: "Si no te lavo, no tienes parte conmigo ${ }^{137}$ ", Pedro terminó obedeciéndole y aceptando. En las caras norte y oeste del capitel EI 15 se recoge visualmente la discusión de Jesús con Pedro y entre las caras sur y este el momento en el que Pedro acepta. Es el gesto de la figura del apóstol sedente, inclinar la cabeza y tocarse la mejilla fue interpretado como uno de aceptación, pero más que aceptación recuerda la resignación de éste ante el mandato de su maestro, en otras palabras, termina obedeciendo a Jesús, pues sólo así tendría parte con Él.

Dentro de la comunidad monástica uno de los votos de los religiosos es la obediencia, obediencia a la regla y a sus superiores sobre todo al abad. En el caso de Sant Cugat, se ha de resaltar que este cenobio seguía la regla de san Benito, y ésta concede particular importancia a dos virtudes: la obediencia y la humildad. La exaltación por ende a estas dos virtudes y sobre todo a que los hermanos que se reunían en capítulo en la estancia justamente delante de estos capiteles practicaran

\footnotetext{
${ }^{135}$ Levítico 12: 6.

${ }^{136}$ RÉAU. Iconografía del arte cristiano. Iconografía de la Biblia. Nuevo Testamento. Tomo 1, Vol. 2..., p. 274.

${ }^{137}$ Juan 13: 8.
} 
las mismas no es mera casualidad. Por lo menos a partir del siglo XI consta que en el cenobio se conservaba una copia de la regla ${ }^{138}$.

La exaltación de la obediencia y la humildad a través de los capiteles del claustro, específicamente de los que se encuentran justamente delante de lo que era la Sala Capitular y de la entrada a la iglesia es sumamente acertada. La obediencia y la humildad se vinculan directamente con los preceptos de la regla benedictina. San Benito dedica un capítulo completo a la práctica de cada una de estas virtudes. Estos dos capítulos, junto al dedicado a las buenas obras y al silencio conforman la constitución espiritual del monasterio, la práctica del ascetismo $^{139}$. Según la regla benedictina, la obediencia es el primer grado de humildad $^{140}$. El capítulo $\mathrm{V}$ de la regla enfatiza a través de referencias a las Sagradas Escrituras como la obediencia a Dios, y en el monasterio al abad, también conduce a la humildad. La obediencia debe llevarse a cabo sin vacilación, sin tardanza, sin tibieza, sin murmuración y sin réplica de resistencia ${ }^{141}$. La escena de la Anunciación en el capitel de la Natividad podría también interpretarse como un acto de obediencia por parte de María a la voluntad de Dios, pues el gesto de María fue el de aceptación total sin vacilación y sin replica, gesto que se plasma también en la piedra. En la regla igualmente se estipula que seguir la voluntad de Dios es parte de la práctica de la humildad ${ }^{142}$. Estos tres capiteles junto delante del espacio antiguamente utilizado como la sala capitular resaltan y exhortan la práctica de dos preceptos de la regla benedictina: la obediencia y la humildad.

\footnotetext{
${ }^{138}$ Fols. 135v-155r, Ms. No. 22. MIQUEL Rosell. Catalèg dels llibres manuscrits de la Biblioteca del Monestir de Sant Cugat..., p. 40.

${ }^{139}$ San Benito. San Benito: su vida y su regla. dirección e introducciones del Padre Dom García M. Colombas, versiones del Padre Dom León M. Sansegundo, comentarios y notas del Padre Dom Odilón M. Cunill. Madrid: Editorial Católica, S.A., 1954. p. 340.

${ }^{140}$ Regla benedictina V,1. San Benito. San Benito: su vida y su regla..., p. 359.

${ }^{141}$ Regla benedictina V,14-15. San Benito. San Benito: su vida y su regla..., p. 363.

${ }^{142}$ Regla benedictina VII,19-22. San Benito. San Benito: su vida y su regla..., p. 377.
} 


\subsection{El claustro como meditationis machina}

Distintas fuentes documentales aún conservadas resaltan -directa e indirectamente- el vínculo que existió entre los siglos IX al XIII entre el monasterio de Sant Cugat del Vallès, el mundo carolingio y la monarquía franca. A través de la historia, varios autores han llegado a afirmar que fue el mismo Carlomagno quien en el siglo VIII fundó el cenobio. Si bien hoy en día no conservamos documentos de dicho período que confirmen estos datos, no podemos descartar el hecho de que el monasterio catalán haya estado relacionado con los monarcas francos, puesto que geográficamente el mismo se ubica justamente en el límite de la marca hispana y fue por medio de estos lazos que el mismo se acogió a la regla de san Benito ${ }^{143}$. Entre los siglos VIII y IX, algún miembro de la comunidad de Saint-Denis visitó el monasterio catalán y regresó a París con una reliquia de san Cucufato, y en el siglo IX se documenta en un sacramentario de la abadía de san Dionisio, elaborado en el scriptorium de la abadía de San Amand, culto al santo del Vallès.

De la misma manera que por medio de los lazos con el mundo carolingio, los distintos monasterios a los que pertenecieron los cinco códices miniados adoptaron no sólo la regla benedictina, sino también las disposiciones educativas, algo similar pudo haber ocurrido con el cenobio catalán y se pudo continuar hasta época posterior. El manuscrito 47 de Sant Cugat, hoy custodiado en el Archivo de la Corona de Aragón posee una lista del siglo XIII con la cronología de los monarcas francos ${ }^{144}$, pudiendo confirmar el ánimo de vincularse hasta época tan tardía con estos soberanos. Tenemos constancia de que en Sant Cugat existía una escuela, en las que se estudiaban las materias del trivium y el quadrivium e igualmente se instruían niños. El currículo de enseñanza era muy similar al de las abadías de la zona del río Rin y del valle del Mosa, se conservaban textos de

\footnotetext{
${ }^{143}$ MoXo y DE FRANCOLI. Memorias históricas del real monasterio de San Cucufate..., pp. $12-$ 13.

${ }^{144}$ Fol. 159v, Ms. 47. Archivo de la Corona de Aragón, Barcelona.
} 
autores clásicos, los padres de la Iglesia y poetas cristianos ${ }^{145}$ e incluso se empleaban mnemotecnias ya utilizadas en los monasterios del mundo carolingio para agilizar el proceso de aprendizaje, como: el uso de listas y glosarios para la enseñanza de la gramática, la división de material en trozos manejables para retener el ad res, y la concatenación de ideas y conceptos para memorizar los mismos, ya identificada en las miniaturas de la Psychomachia.

El lugar por excelencia para la enseñanza y el estudio en Sant Cugat del Vallès debió ser el claustro del mismo, espacio dinámico y fundamental en la vida del cenobio. Tenemos constancia de que en el siglo XI el monasterio poseía un claustro, pero el claustro actual se edificó entre finales del XII y principios del XIII, coincidiendo así con el momento en el que se registra en la documentación un mayor número de donaciones de oblatos y sobre todo surge un mayor interés en términos de estudio por las obras literarias de corte ascético. En este sentido, la galería sur del claustro, terminada en el siglo XIII, juega un papel importante. Hemos identificado la misma como la zona principal de estudio. Son dos los elementos principales que nos llevaron a establecer dicha relación: primeramente, las condiciones geográficas y climatológicas de esta área y en segundo lugar la presencia del capitel de los monjes estudiando (Fig. 43). El trabajo de aprendizaje de los niños con los maestros tenía lugar en el claustro, y si bien la profesora Lorés cuestiona si el ala meridional era el espacio exclusivo para éstos ${ }^{146}$, no podemos descartar que el mismo, además de zona de estudio y lectura del resto de religiosos de la comunidad, igualmente pudo haber sido utilizado por este público. Y es que como hemos indicado a lo largo de la exposición del ductus de la clausura, fue en esta zona donde se plasmaron historias tomadas directamente de las Sagradas Escrituras, cuyo contenido no sólo histórico, sino también tropológico, alegórico y anagógico se vincula con el principal método de enseñanza del monasterio: el comentario fundamentado en el estudio de los textos bíblicos.

${ }^{145}$ ZIMMERMANN. Écrire et lire en Catalogne, Tomo II..., pp. 897-900.

${ }^{146}$ LORÉS I OTZET. "La vida en el claustra..., p. 40. 
Los códices con textos bíblicos de los siglos XII y XIII que hoy sobreviven corroboran la importancia del comentario en el monasterio de Sant Cugat del Vallès. La relación temática entre los distintos chapiteles de la galería puede entenderse entonces como una extensión visual del comentario de los textos. La imagen escultórica es el signo visual que señala el contenido bíblico, sobre el cual se recopilan otros conocimientos, concatenando los mismos. En el caso del capitel con la Psychomachia, este sería la marca o seña visual de nociones tropológicas y ascetas las cuales fueron muy populares en el período en el que se edificó la galería sur, y hoy en día nos han llegado algunos textos de ésta época que tocan la temática de los vicios y las virtudes, el infierno y los pecados.

En la sección que dedicamos al análisis de la representación de la Psychomachia en el claustro de Sant Cugat del Vallès resaltamos el hecho de que es uno de los pocos ejemplos en piedra que conservan la esencia del poema de Prudencio, no sólo en el uso de ciertas particularidades como las coronas o el marcado interés por plasmar a los vicios como figuras humanas y no monstruosas como ocurre en la escultura del sur-oeste de Francia, sino también en la composición, la cual sigue muy de cerca la estructura del poema. Encontramos siete virtudes victoriosas pisoteando a sus enemigas y una octava figura femenina, Sapientia. Dichas similitudes nos han llevado a plantearnos si en el monasterio pudo haber existido una copia, no necesariamente miniada, de la obra de Prudencio. De haber sido así, el capitel de la Psychomachia no solamente serviría como lugar de recopilación de los conocimientos necesarios para la práctica del ascetismo, además hubiera sido la señal visual que remitiría al espectador a la estructura del texto del poeta: siete combates o pruebas a los que se debe someter y sólo venciendo a los distintos vicios se podría alcanzar la sabiduría. En la proyección escultórica, ésta se ubicó en un lugar escondido y de difícil acceso, la cara norte, ubicación que incide en el proceso y obstáculos -los combates- por los que el individuo ha de trascurrir para acceder a ella. Al igual que en los manuscritos iluminados de la Psychomachia, la presencia de la victoria de las 
virtudes sobre los vicios y sobre todo de la figura de Sapientia alude a la sabiduría en términos cognitivos e igualmente espirituales.

La importancia del capitel de la Psychomachia en el claustro de Sant Cugat del Vallès no reside únicamente en su particularidad compositiva y sus cualidades estilísticas, las cuales lo aparta de los ejemplos de Saintonge y Poitou, sino que es por medio de la ubicación de éste y su relación con respecto a la galería sur y oeste que nos hemos percatado de que el mismo no se insertó en el lugar que se encuentra aleatoriamente. Sino que éste sirve de conector de los temas y nociones plasmados en el resto de las galerías.

El concepto de que una obra artística es también un viaje o peregrinar adquiere particular importancia en el análisis medieval. Se dice que uno se desplaza a través de una composición, ya sea de palabras u otros materiales, dirigido por sus cualidades estilísticas o sus partes y el arreglo de sus relaciones formales $^{147}$, o sea a través del ductus. A pesar de que la galería sur fue la última en construirse, entendemos que es en ésta donde comienza el camino trazado por el flujo intrínseco de los temas tratados en la clausura, siendo el capitel de la Psychomachia, e igualmente el del escultor, los que unen los tropos de los distintos chapiteles. Las galerías entonces muestran visualmente al individuo los distintos pasos o pruebas a conquistar para poder acceder a la vida religiosa. En última instancia, este recorrido, el ductus del claustro de Sant Cugat del Vallès hace del edificio, específicamente de la clausura, una meditationis machina, cuya finalidad es que el individuo, a través del recordatorio constante por medio de las esculturas, profundice en todos los aspectos que conforman la vida monacal.

Los historiadores del arte que han estudiado el claustro de Sant Cugat, suelen explicar la disposición de los capiteles siguiendo el orden cronológico en el que la clausura fue edificada, usualmente comenzando por las obras de finales del siglo XII en este orden: galerías este, norte y oeste y por último la galería sur de

${ }^{147}$ CARRUTHERS. "The concept of ductus, or, journeying..., p. 190. 
principios del siglo XIII. Por medio de este acercamiento parecería que los temas se colocaron de forma casual. A través de nuestro trabajo nos percatamos de dos aspectos que nos han llevado a pensar que el discurso icónico del claustro comienza por la galería sur, pese a ésta haber sido la última en construirse. En primer lugar, en esta ala el orden cronológico de las historias bíblicas coincide, a diferencia de la de levante. Segundo, es la zona más cercana a la iglesia. Según el costumari, los miembros de la comunidad, después de los oficios, pasaban al claustro para realizar sus tareas, entre las cuales se encontraban el estudio y la meditación. Por lo tanto, la cercanía del ala sur con el acceso a la iglesia agilizaba el desplazamiento. Los temas tratados en las distintas alas del claustro, siguiendo este orden conceptualmente, conforman entonces el ductus del claustro, en el que los conocimientos tratados en una galería conectan con los de la siguiente para en última instancia exaltar valores esenciales de la vida monacal de corte benedictino como el orat et labora y la práctica de la humildad y la obediencia.

Ya discutimos cómo los temas de la galería sur se toman directamente de las Sagradas Escrituras, y las distintas imágenes aquí plasmadas en el proceso de estudios pudieron servir de signos que recopilan o guardan los distintos conocimientos que puede poseer la historia. Igualmente, proporcionaban el material base, -el texto bíblico en imagen-, para la práctica de la meditación. A partir de los mismos, el individuo que los contemplara pasaría al acto de inventar, que en este contexto consistía en crear pensamientos sobre Dios, siendo la base de los mismos las imágenes de los capiteles. El proceso se podía auxiliar igualmente de la ubicación de los chapiteles respecto al espectador, pues los mismos se colocaron de tal manera que éstos pueden ser contemplados sin mucha dificultad.

En la galería siguiente, en la oeste, se representa el trabajo agrícola por medio de la figura de campesinos, luchas y animales. En el sentido histórico, estos capiteles recopilan visualmente diversas labores que se realizaban en el monasterio o en el entorno de éste. Como indicamos en la discusión del ala de poniente, las plasmaciones de las labores también se vinculaban con el calendario, por lo tanto, 
aportando un sentido adicional a las imágenes: una significación anagógica. El pasar del tiempo, en última instancia, evoca el Juicio Final, juicio para el que el individuo deberá encontrarse preparado y esto solamente lo habrá logrado a través de los conocimientos que se plasmaron en la galería anterior. Las galerías sur y oeste, en primer lugar, conjugan visualmente la idea benedictina de orat et labora, y en segundo aportan los distintos conocimientos que el cristiano debía aprender de memoria los cuales en última instancia le permitirían emitir los juicios morales que le ganarían al final de su vida el Cielo o el Infierno. El capitel de la Psychomachia conecta cognitiva y visualmente el principio con la meta. Los conocimientos previos en conjunto con la proyección física de la victoria de las virtudes sobre los vicios, le proveería al espectador del conocimiento y las distintas herramientas para guardarse de los distintos males que aquejaran su alma, alcanzando así la sabiduría, o sea Cristo mismo en el día del Juicio Final.

El ductus del claustro continua en la galería norte, en la que se insertaron escenas de la vida en el claustro. Sin embargo, estos capiteles únicamente no recuerdan al espectador de las actividades desempeñadas dentro de la clausura, como el acto colectivo de afeitarse o el procesional a la iglesia para la práctica de los oficios divinos, sino que las mismas también tienen un carácter de rito de iniciación. Y es que como indicamos en el apartado dedicado a esta galería, el afeitarse rememora al acto de tonsurarse, ritual por el cual un joven se volvía parte de la comunidad de religiosos. Por lo tanto, antes de ser tonsurado, el individuo debía conocer de memoria los conocimientos expresados en las anteriores alas del claustro. Una vez dominado estos pasos en su caminar, podría entonces participar junto al resto de la comunidad del oficio divino, pues los niños dentro del templo se ubicaban en un espacio distinto.

En la galería se incluyeron una escena de la vida en el claustro y tres historias tomadas directamente del Nuevo Testamento. Estos últimos tres chapiteles no se distribuyeron cronológicamente. El análisis de los mismos revela un marcado interés en exaltar dos virtudes importantes en el contexto monacal: la 
humildad y la obediencia, las cuales en última instancia llevan a la renuncia de uno mismo y el cultivo del alma. Entre estos tres chapiteles y la galería norte el capitel con el monje y el cantero literalmente puede interpretarse como el artífice del claustro, pero en términos alegóricos entendemos que es un signo visual que le recuerda, a través de la proyección del monje, que como un buen artífice debe colocar sobre los cimientos de las Sagradas Escrituras los diversos conocimientos que en última instancia le permitirán emitir los juicios morales, no sólo que le ganarán el Cielo, sino también que le ayudarán a practicar la humildad y la obediencia.

Con relación a la meditación, de la misma manera que el claustro visualmente recoge el peregrinar cognitivo y espiritual por el cual debía pasar un individuo para volverse miembro de la comunidad, la presencia de éstas imágenes eran un recordatorio constante que invitaba al espectador a contemplarlas y perderse en los tropos de éstas, pues "a menudo recordamos todo un conjunto de objetos con un solo signo y una sola imagen ${ }^{148}$ ".

El ductus del claustro se vincula sobre todo con el acto de meditar, lo cual se explica en gran medida a través del interés que surge a partir del siglo XII por las obras literarias de corte ascético, y en énfasis visual en los capiteles de temas morales, principalmente manifestado por medio de historias que exaltan virtudes en conjunto con la Psychomachia, la resurrección y la otra vida. La clausura en última instancia sirve como una máquina de meditación: meditationis machina, pues a través del recorrido de ésta es posible para los individuos reflexionar y meditar, esto principalmente por medio de la inventio, la creación de pensamientos sobre Dios, fundamentados en las historias y conocimientos almacenadas en los locis del claustro, que no son otros que los chapiteles del mismo.

${ }^{148}$ Rhetorica ad Herennium. III, 20, 33. Edición consultada: Retórica a Herenio. trad. de S. Núñez. Biblioteca Clásica Gredos, 244. Madrid: Gredos, 1997. 


\section{CONCLUSIÓN}

Hemos iniciado nuestra investigación explorando las representaciones medievales de los conceptos abstractos de los vicios y las virtudes, tarea que nos condujo al planteamiento del tema de la tesis y sobre todo a establecer el principal objetivo de nuestro trabajo: estudiar la función mnemónica de las imágenes de la Psychomachia dentro del contexto monacal, particularmente con relación a la enseñanza y el aprendizaje e igualmente con la práctica de la meditación.

Primeramente, queremos discutir la vinculación de la plasmación de la Batalla del alma y el uso de ésta como recurso mnemónico en el proceso del aprendizaje de los jóvenes alumnos que ingresaban o eran entregados a los cenobios. Como establecimos a lo largo del capítulo 3, las distintas abadías en las que se crearon los códices Burm.Q.3, Ms. 9987-91, Ms. Lat. 8085, Ms. 10066-77 y Cod. 274 o a las que dichos manuscritos pertenecieron: San Amand, San Denis, San Laurent, Stavelot, San Remi, San Galo y Reichenau poseían un estrecho vínculo con el mundo carolingio. Su relación con la monarquía franca incidió en la acogida y el establecimiento de las distintas reformas educativas y eclesiásticas fijadas a finales del siglo VIII por Carlomagno a través de la Admonitio generalis. Si bien la capitular del monarca franco es del 789, los preceptos en torno a la educación estipulados en la misma se continuaron ejecutando en los diversos cenobios vinculados con la monarquía franca o herederos de la tradición carolingia. Todavía en los siglos IX y X, período en que se crearon los cinco códices aquí estudiados, la enseñanza de las artes liberales desempeñaba un papel importante en estos centros religiosos.

El poema de Prudencio dentro del contexto carolingio se entiende principalmente con relación a las disciplinas del trivium, específicamente de la gramática. La obra de este autor hispanorromano, dentro de los diversos monasterios ya mencionados, jugó un papel importante en la educación de los jóvenes. Los cinco códices de la Psychomachia, además de contener otras obras del mismo poeta, están 
acompañados por una serie de textos contemporáneos a los períodos que estudiamos con un carácter formativo especialmente con la enseñanza de la gramática como son los: tratados de gramática, notas sobre gramática y listado de palabras.

A través del análisis de las imágenes de los cinco manuscritos miniados de las Psychomachia identificamos una serie de recursos visuales que conectan la representación pictórica con el texto facilitando al lector la comprensión de la obra y la memorización de las nociones principales. La disposición de las distintas miniaturas en los códices miniados, especialmente los del siglo IX no es arbitraria, sino que la misma antecede los distintos versos sobre los que la imagen versa, captando y recogiendo la esencia de los mismos como si de un resumen se tratara. La representación plasma el ad res de los versos que le siguen. A través del análisis de las imágenes hemos logrado identificar en las mismas distintos elementos propios de las técnicas y consejos mnemónicos del mundo antiguo y medieval. Entre estos, se encuentra el uso de imagines agentes, imágenes activas cercanas a la realidad que exaltan los sentidos del espectador por sus elementos estéticos, ya sea la belleza, la fealdad o lo grotesco. O sea, imágenes memorables, dignas de recordar. A lo largo de las noventa miniaturas entrelazadas con los versos, se identifica un particular interés por la plasmación de los vicios como seres melenudos y monstruosos, apelando así a la fealdad y lo grotesco. En Ms. 10066-77 muchas de estas personificaciones se representaron con los rostros color verde. Dentro de la idea de imágenes memorables que exalten los sentidos también se pueden encasillar las distintas miniaturas en las que se plasma sangre. En los manuscritos del siglo IX se aprecia un interés particular por la plasmación de esta sustancia, por medio del uso del color rojo. Si bien los códices Burm.Q.3, Ms. 9987-91 y Ms. Lat. 8085 son monocromos, los únicos detalles en un color diferente y sobre todo visualmente llamativo, al del dibujo principal, son estos.

El éxito de las imágenes memorables para memorizar algo residen en el detalle de elementos esenciales de la información que se desea aprender de memoria. Las miniaturas de los manuscritos de la Psychomachia siguen este consejo, pues en éstas encontramos una serie de objetos, personajes o atributos necesarios para la narración 
visual, por ejemplo: la plasmación de los reyes captores de Lot en la miniatura 2, las coronas y palmas para representar a los mártires victoriosos en la 10, en los distintos encuentros entre las virtudes y los vicios las armas con las que ambos bandos luchan; por ejemplo: las virtudes que atacan con una roca siempre portan este objeto (Miniaturas 9, 12, 48), Cultura deorum con su hacha (Miniatura 1), las teas de Libidinem (Miniaturas 11, 12, 13 y 14), etc.

El detalle se extiende a la gestualidad de las diferentes figuras representadas. En los cincos manuscritos que estudiamos, principalmente los del siglo IX, a primera vista parecería que muchas de las miniaturas se parecen y repiten. Al observar con detenimiento, especialmente los gestos de las figuras es que se pueden apreciar las diferencias de los mismos, las cuales corresponden a la acción o a las acciones que recogen la noción principal de los versos que acompañan. Esto lo hemos podido identificar partiendo del análisis de la imagen y sus gestos y examinando el poema verso por verso, cosa que sólo se logra a través del estudio de los versos en su idioma original, para el cual las imágenes fueron proyectadas. Muchos de estos detalles en traducciones consultadas en otros idiomas se pierden. Lo que corrobora que las imágenes fueron creadas teniendo muy en cuenta el texto en el que se insertaban.

Según los consejos mnemónicos, las imagines agentes de los phantasmatas (conceptos o ideas) a almacenar en la mente deben ser cercanas a la realidad. Prudencio por medio del verso construyó vívidas representaciones de los combates, y a su vez los iluminadores captaron esta cualidad en las miniaturas de los mismos. La cercanía con la realidad se aprecia en primer lugar por medio de la personificación de conceptos abstractos: los vicios y las virtudes son figuras antropomorfas que portan armas, visten armaduras y se baten en duelo. La cercanía con la realidad también se aprecia en las distintas miniaturas por medio del uso de motivos iconográficos y atributos familiares para el espectador. El mejor ejemplo de esto es la miniatura 1 con el Sacrificio de Isaac, la cual se plasmó siguiendo el motivo iconográfico ya conocido o el uso de la rama de palma para designar visualmente las figuras de los mártires a pesar de que dicho atributo no se menciona en los versos. 
El componente afectivo es sumamente importante para que un individuo sea capaz de memorizar. Las imágenes memorables deben exaltar las emociones del espectador, sólo así este podrá conectar con las mismas y grabarlas en lo más profundo de su mente. En términos literarios, a pesar de ser un poema, Prudencio logró construir imágenes vívidas de los combates, plasmaciones que evocan la sinestesia y por medio del texto escrito se evocan imágenes visuales y sonoras. Los miniaturistas de estos códices utilizaron igualmente la sinestesia, y las distintas iluminaciones de la Psychomachia por medio de la visión se evocan otros sentidos, particularmente la audición y el olfato (miniatura 12, 22 y 41).

Mediante el estudio de los tituli y su relación con las miniaturas y los versos que anteceden, nos hemos percatados de que los mismos guardan una relación estrecha con la enseñanza y la educación. Los títulos de las iluminaciones del poema, sobre todo en los códices Burm.Q.3, Ms. 9987-91 y Ms. Lat. 8085, en mayor o menor grado, pueden ser considerados como pequeños resúmenes de los versos. Son muy pocos los títulos tomados directamente del texto (miniaturas 29, 38 y 60), y el resto se limita a indicar al espectador quiénes son los protagonistas y las acciones principales que éstos ejecutan. A pesar de la brevedad de los tituli, en los mismos se aprecia un interés para que éstos sean recordados. Uno de los casos que más abunda es el del verbo increpat. Esta palabra se utilizó en los títulos de todas las miniaturas en las que se pronuncian palabras, especialmente si el discurso otorgado es una reprimenda o amonestación a pesar de que en muchos de los casos no es el verbo utilizado en el poema por el autor. Cuando la connotación de las palabras es positiva, como es el diálogo entre Patientia y Job (Miniatura 27) o una de las virtudes arenga a sus huestes entonces se utiliza el verbo alloquitur. Con esto se aprecia una sistematización entre la representación visual de una misma acción con el mismo término gramatical. Esto serviría a los alumnos en formación a aprender y recordar con mucha más facilidad.

Lo mismo pasa con el término utilizado para referirse a los pobres y desamparados en distintas imágenes. Prudencio utilizó el sustantivo inops para designar a los pobres, necesitados, impotentes, débiles, desamparados; y sin embargo, 
en los títulos de las miniaturas 65 y 69 se utiliza pauperibus, una palabra muy conocida dentro del contexto monacal de corte benedictino donde era un imperativo la limosna y caridad a los pauperis. En estos casos se utilizó un término más familiar para aquellos que se encontraban en proceso de aprendizaje.

En relación con el aprendizaje y la memorización de palabras, encontramos también que en muchas miniaturas se utilizan verbos y adjetivos distintos a los utilizados en el texto de Prudencio. Las palabras empleadas en los tituli poseen un significado más profundo. Con un término, se aluden a dos o más acciones o descripciones recogidas en el texto, o por otra parte dicho vocablo expresa con mayor viveza las acciones del ad res que aquellos utilizados en el poema. Esto se aprecia en las miniaturas $12,14,17,21,24,26,36,43$ y 78 , en los combates con un menor número de representaciones. En las batallas con un número mayor iluminaciones, las imágenes hablan por sí mismas.

Dada la cercanía de las imágenes con el texto, y el empleo de distintos recursos propios de las técnicas mnemónicas, podemos concluir que las miniaturas de los cinco códices iluminados aquí analizados se vinculan con la enseñanza de la gramática, auxiliando la mente de los jóvenes pupilos de las escuelas monacales.

Ha sido más difícil establecer la relación entre las mnemotecnias y el aprendizaje con la representación escultórica de la Psychomachia en el monasterio de Sant Cugat del Vallès. Este cenobio gozó igualmente de un vínculo cercano con el mundo carolingio. Su ubicación es justamente en el límite de lo que se conoció como la marca hispana, y su fundación, si bien no se puede atribuir al mismo Carlomagno, la documentación que se conserva del siglo IX y X confirma el vínculo del cenobio con la monarquía franca. A través de este vínculo fue que Sant Cugat adoptó la regla benedictina como norma del monasterio. Esto nos lleva a pensar que si el cenobio catalán, por medio de su vinculación franca, adoptó la regla de san Benito, igualmente debieron implementarse y seguirse normativas y prácticas del mundo carolingio, como la educación y la enseñanza.

Gracias a distintas fuentes es que sabemos que el monasterio del Vallès poseyó una escuela, cuyos maestros se encontraban a cargo de la instrucción y el cuidado de 
los jóvenes pupilos. Igualmente tenemos constancia de que en el cenobio se enseñaban las disciplinas de las artes liberales, especialmente de la gramática; y que para aprender las mismas se practicaban técnicas de memorización. El único vínculo directo con la enseñanza, la memorización y el capitel de la Psychomachia del claustro de Sant Cugat del Vallès se ha identificado en la galería sur en la que se encuentra este capitel.

El principal método de enseñanza empleado en el cenobio fue el comentario: el maestro se apoyaba sobre el texto de una obra particular y éste le servía para explicar los distintos sentidos, la naturaleza de las palabras y definir las reglas gramaticales. Con relación a la galería sur, en los capiteles de ésta se incluyeron distintas historias tomadas de las Sagradas Escrituras. Pensamos que las mismas podían ser una extensión visual del comentario. Por lo tanto, la imagen en el capitel se vincula con el estudio de los textos bíblicos, pero a la misma vez es un signo que remite y concatena con otros conocimientos sobre todo alegóricos, tropológicos e incluso anagógicos. Es el capitel de los monjes estudiando (Fig. 43) lo que apunta a que esta zona de la clausura pudo haber sido utilizada como un lugar de enseñanza.

De la misma forma que los chapiteles con representaciones de historias veterotestamentarias y neotestamentarias pudieron ser una extensión visual del comentario, y un lugar de recopilación de conocimientos concatenados con los distintos temas plasmados en la escultura, también pudo haber ocurrido algo similar con el capitel de la Psychomachia. Éste es el locus para almacenar los distintos temas vinculados con el ascetismo, los cuales a partir del siglo XII gozaron de mucha popularidad dentro del monasterio de Sant Cugat, y que actualmente de dicho período, se conservan tratados sobre vicios y virtudes y sobre el infierno y el pecado. La marcada cercanía de la plasmación de las virtudes victoriosas sobre los vicios vencidos y la figura de Sapientia con el libro en el capitel con el texto de Prudencio incluso nos ha llevado a cuestionar si en el monasterio existió algún ejemplar del poema. De haber existido, entonces la imagen esculpida podía servir como una señal que remite al espectador a la estructura del texto: siete combates, y al final alcanzar 
la sabiduría (escondida en la cara norte) quien salvaguarda las leyes (el libro que porta). Esto es un problema de estudio que queda abierto para futuras generaciones.

La segunda relación entre mnemotecnias, las plasmaciones de la Psychomachia en el contexto monacal que identificamos por medio de nuestra investigación fue con la práctica de la meditación. La memoria durante la Edad Media desempeño un papel importante con la moral y la meditación. Ésta era el arca en el que se guardaban los distintos conceptos morales, que, junto a la virtud de la prudencia, permitían a un individuo emitir los juicios que le ganarían el Cielo o el Infierno.

El conocimiento de estas nociones tropológicas en el contexto monacal igualmente servía para el ejercicio de la meditación: la creación de pensamientos creativos en torno a Dios. Estos pensamientos creativos no surgían de la nada, sino que se estructuraban sobre recuerdos previos productos de las experiencias ya vividas: fruto de la lectura y la contemplación. Las técnicas de memorización proporcionarían al individuo todo un acervo de imágenes mentales listas para ser utilizadas cuando las necesitara. La creación de éstas se vio auxiliada por las representaciones reales, siendo un proceso reciproco donde una plasmación real podía servir de imagen mental o a la inversa. La utilización de plasmaciones conocidas facilitaba y aceleraba el proceso de memorización, pues el individuo ya no se veía en la necesidad de elaborar una complicada alegoría mental, sino que ya le era dada.

Es bajo esta idea en la que se encasillan las distintas miniaturas de los códices miniados de la Psychomachia objeto de estudio de nuestra investigación. Ya hemos resaltado las diversas cualidades visuales que hacen de las noventa iluminaciones de los manuscritos imágenes memorables, imagines agentes. Por lo tanto, la memorización de las distintas representaciones en primer lugar permitiría al monje recordar con facilidad el contenido tropológico del texto. En segundo, a la hora de meditar, su mente tendría un referente visual de las artimañas de las que se sirve el vicio: Luxuria es dada a los excesos, Avaritia a la acumulación de aquello que no es de ella. Las acciones que realizan las virtudes entonces proporcionarían el remedio 
a estos males, por ejemplo: Avaritia se vence imitando el comportamiento de Largitas, la caridad a los más necesitados.

La función mnemónica de las miniaturas en los códices de la Psychomachia es latente, pero igualmente muy básica, puesto que la finalidad misma del poema tiene un contenido meditativo y moral muy bien establecido por el autor en el texto. Por medio de las representaciones visuales, el miniaturista facilitó dicha función. Con relación al claustro de Sant Cugat del Vallès, este proceso meditativo se encuentra en un nivel de mayor complejidad.

Cuando comenzamos a analizar los distintos temas iconográficos del claustro del cenobio catalán lo hicimos siguiendo el orden establecido por estudiosos anteriores, cuyo punto de partida se basaba en la cronología. El análisis de las distintas alas como grupos individuales en conjunto con la reconstrucción histórica, pero sobre todo del currículo de enseñanza y educación nos hizo percatarnos del tema principal que se presentaba en cada galería. La galería sur se vinculaba directamente con historias tomadas de las Sagradas Escrituras, la oeste con el trabajo, la norte con la vida en el claustro y en la este se conjugan el trabajo y la vida en el claustro con historias neotestamentarias. Al análisis de cada uno de los chapiteles nos reveló los distintos significados de las imágenes representadas, los cuales no sólo se limitaban al carácter histórico -entendiendo este como la escena en sí-, sino también otros significados alegóricos, anagógicos y litúrgicos.

A través del capitel de la Psychomachia pudimos conectar y reconstruir el ductus, el recorrido meditativo del claustro. En la galería se representan distintas historias del Antiguo y Nuevo Testamento, que gracias a la reconstrucción del currículo de enseñanza sabemos que pudieron servir como los textos base para la práctica de la Lectio Divina. En el proceso de desentrañar el significado de las Escrituras, en esta última galería el espectador se toparía con el capitel de las virtudes victoriosas, adentrándose a un plano tropológico. La octava figura identificada como Sapientia, sería la meta a alcanzar en este proceso. En la siguiente ala se plasman distintas escenas de trabajo. A priori, las galerías sur y oeste recuerdan la idea benedictina de orat et labora. Sin embargo, encontramos que igualmente algunas de 
estas acciones aquí recogidas podrían vincularse directamente con el calendario medieval, exaltando la creación, el pasar del tiempo y sobre todo el Juicio Final. Los conocimientos adquiridos por medio del estudio de las Sagradas Escrituras debían proveer de los conocimientos y la sabiduría necesaria para proceder por la vida como un individuo virtuoso y en el momento del Juicio Final evitar el Infierno y ganar el Cielo.

Una vez adquirido los conocimientos necesarios y dominado el ejercicio de meditación sería que el joven podría aspirar a convertirse en miembro permanente de la comunidad, siendo introducido en ella por el acto de tonsura y así podría participar del oficio divino en el mismo espacio que el resto de los monjes (los niños tenían destinado otro espacio). Esto se manifiesta visualmente en la galería norte. Por último, en la galería de levante se insertaron historias neotestamentarias, pero el orden de las misma, más que apelar a la cronología de las escenas según los evangelios, realza su sentido alegórico y tropológico. En estos tres chapiteles se exaltan las virtudes de la humildad y obediencia, esenciales para la vida monacal, remitiéndonos una vez más al capitel con las virtudes y a la práctica de éstas como un imperativo de la vida asceta. Después de todo es de nuestro conocimiento que a partir del período en el que se comenzó a construir el claustro, siglo XII, surgió en el monasterio una preferencia por los textos de corte asceta. Por lo tanto, este gusto debió manifestarse en las distintas actividades que se llevaban a cabo en el cenobio catalán.

La idea del uso de las imágenes como recursos mnemónicos durante la Edad Media no es nueva. Desde el campo de la filología, estudiosas como Frances Yates y Mary Carruthers ya habían resaltado la posible función mnemónica de representaciones concretas. Desde la Historia del Arte, Michael Camille había planteado cómo diversas imágenes góticas se elaboraron para “dejar impresas las historias sagradas en las mentes de los espectadores" y Carol Gibson-Wood había tratado de establecer la función mnemónica de las miniaturas del salterio de Utrecht. Con relación a la Psychomachia de Prudencio, Carruthers incluso llegó a abordar algunas miniaturas para resaltar la cualidad mnemónica de las mismas. Los trabajos de estos autores sirvieron como referentes para el desarrollo de nuestro trabajo. Si 
bien autoras como Carruthers y Gibson-Wood habían abordado una que otra miniatura, entendemos que el principal aporte de nuestra investigación es el análisis de la función mnemónica del corpus completo del que se constituye una obra. No nos limitamos al estudio aislado de una plasmación, sino que identificamos los recursos mnemónicos utilizados en las distintas representaciones que forman parte del corpus mayor: en el caso de los códices las noventa miniaturas y en el caso de Sant Cugat el resto de capiteles labrados. A esto hemos de incluir el análisis de la función mnemónica de las imágenes de la Psychomachia considerando, además del resto de las representaciones, el período y el contexto en que las mismas fueron utilizadas.

Entre los aportes de nuestra investigación se encuentran también la nueva lectura que hemos hecho del claustro del monasterio de Sant Cugat del Vallès, la cual no parte del orden cronológico en el que éste fue edificado, sino de los conceptos tratados en el claustro y como los mismos forman un recorrido, un ductus conceptual. Esto fue posible gracias a la reconstrucción del marco histórico y cultural en el que se fundó y desempeño el cenobio catalán, considerando sobre todo su vinculación con el mundo carolingio.

Por medio de esta investigación entendemos que son más las preguntas generadas que las soluciones encontradas. Los manuscritos iluminados vinculados al mundo carolingio del siglo IX y X, deben contrastarse con otros ejemplos miniados para tener una mayor comprensión de la cultura visual en al que fueron generados y así estudiar si la cualidad memorable de las imágenes en un elemento exclusivo de la Psychomachia, o incluso un gusto estético de la época.

Es de particular interés entre los ejemplos de manuscritos carolingio, contrastar las miniaturas de la Psychomachia con las imágenes del salterio de Utrecht, códice con el que los cinco manuscritos tratados guardan mucha relación no sólo formal y estilística, sino también cronológica e ideológica. Sería fundamental estudiar las iluminaciones de los 150 salmos y ver si tropos visuales se repiten.

El estudio de la función mnemónica de las imágenes de la Psychomachia en el contexto monacal debe extenderse al resto de manuscritos miniados. Como 
presentamos en el capítulo 3 y en los estemas de filiación (Figs. 28 y 29) otros quince manuscritos miniados de la Psychomachia se conservan. En un futuro es necesario abordar aquellos códices productos de la tradición anglosajona y analizar si las cualidades mnemónicas del mise-en-page y las imágenes se conservan en los mismos, o si sólo resulta ser que dichos elementos son una innovación directamente vinculada con el mundo carolingio y los herederos de éste.

Es de nuestro conocimiento que en distintos archivos y bibliotecas de la península ibérica se conservan copias medievales no miniadas del poema de la Psychomachia, desafortunadamente el provenance de estos ejemplares no está muy clara, lo que nos ha dificultado vincularlos a algún cenobio peninsular. Para investigaciones futuras sobre la Psychomachia de Sant Cugat del Vallès es necesario estudiar estos ejemplares con detenimiento, incluso con copias de bibliotecas extranjeras para indagar si en el cenobio catalán o cualquier otro cercano a la zona se conocía la obra y la representación de la victoria de las virtudes sobre los vicios efectivamente se toma directamente de la obra de Prudencio. 


\section{ÍNDICE DE IMÁGENES}

Figura 1. Psychomachia (c. 1170). Fol. 201r, Hortus Deliciarum 18

Figura 2. Frontispicio, Scala Paradisi (Siglo XI). Vat. Gr. 394.

Biblioteca Vaticana, Roma .18

Figura 3. Escala de virtudes, Hortus Deliciarum (c. 1170). Fol. 216r .18

Figura 4. Escala de las virtudes, Liber Scivias (Siglo XII). [Fáscimil]

Abadía de St. Hidelgarda, Eibingen. 18

Figura 5. Torre de las virtudes, Liber Scivias (Siglo XII). [Fáscimil]. Abadía de St. Hidelgarda, Eibingen 21

Figura 6. Humildad y Orgullo, Somme le roi (1294). Fol. 74r, Ms. Fr. 938.

Biblioteca Nacional de Francia, París

Figura 7. Virtudes cardinales y teologales, Ética de Aristóteles (Siglo XV).

Fol. 17v, Ms. I.2. Bibliothèque Municipale, Rouen 21

Figura 8. Templanza, Epitre d'Othéa (c. 1450). Fol. 28v, Ms. Laud. Misc. 570. Bodleian Library, Oxford .21

Figura 9. Prudencia, Livre de quatre vertu Cardinaulx (c. 1450). Fol. 9v, Ms. Laud. Misc. 570 . Bodleian Library, Oxford .24

Figura 10. Virtudes cardinales, De Quatuor virtutibus de Sénèque y La Fleur des Histoires (1470). Fol. 240v Ms. 282. Bibliothèque du château de Chantilly .24

Figura 11. Justicia, Prudencia, Fortaleza, Templanza, Fe, Caridad, Esperanza, Injusticia, Locura, Inconstancia, Ira, Idolatría, Envidia y Desesperación (1305). Giotto di Bondone. Fresco. Capilla Scrovegni, Padua .24 
Figura 12. Virtudes en la Alegoría del buen Gobierno y Vicios en la Alegoría del mal gobierno (1139). Ambrogio Lorenzetti. Fresco. Palacio Público de Siena .25

Figura 13. San Jerónimo en su celda (1450). Nicolas Francés. Pintura sobre tabla. National Gallery of Ireland, Dublín 25

Figura 14. Santo Domingo de Silos entronizado como obispo (1474-1477).

Bartolomé Bermejo. Pintura sobre table. Museo del

Prado, Madrid .25

Figura 15. Mesa de los pecados capitales (1505-1510). Jheronimus Bosch. Museo del Prado, Madrid. 25

Figura 16. Psychomachia (1130). Ventana del transepto sur. Iglesia de St. Pierre d'Aulnay, Francia.

Figura 17. Psychomachia. (Siglo XII). Iglesia de Gripperie-

Saint-Symphorien

Figura 18. Psychomachia (siglo XII). Iglesia de Saint-Nazaire de Corme-Royal

Figura 19. Psychomachia (c. 1140). Fachada occidental. Iglesia de St. Pierre d'Aulnay, Francia

Figura 20. Fe e Idolatría, Castidad y Lujuria, Esperanza y Desesperanza, Caridad y Avaricia, Humildad y Soberbia, Castidad y Lujuria, Fortaleza y Cobardía, Justicia e Injusticia, Prudencia y Locura. Arquivoltas del arco izquierdo de la fachada norte (1198). Catedral de Notre Dame de Chartres, Francia 30

Figura 21. Fe, Esperanza, Caridad, Castidad, Idolatría, Desesperanza, Avaricia, Lujuria. Columnas del pórtico sur (1225). Catedral de Notre Dame de Chartres, Francia 30 
Figura 22. Virtudes teologales y cardinales (Siglo XIV). Taller de Andrea Pisano. Lado sur, campanario. Catedra de Santa María del Fiore, Florencia 36

Figura 23. Fe, Esperanza, Caridad, Prudencia y Fortaleza (c. 1500). Simon de Colonia. Fachada. Iglesia de San Pablo, Valladolid 36

Figura 24. Virtudes cardinales (1338). Giovanni di Balduccio. Arca de San Pedro Mártir. Basílica de San Eustorgio, Milán 39

Figura 25. Caridad y Esperanza (1323). Tino de Camaino. Sepulcro de Catalina de Habsburgo. San Lorenzo Maggiore, Nápoles 39

Figura 26. Fe y Esperanza (1489). Sebastián de Toledo. Sepulcro de don Álvaro de Luna. Capilla de Santiago, Catedral de Toledo 39

Figura 27. Virtudes teologales y cardinales (1493). Juan Gil de Siloé. Sepulcro de Juan II e Isabel de Portugal. Cartuja de Miraflores, Burgos 39

Figura 28. Estema elaborado por Richard Stettiner (1895) 101

Figura 29. Estema elaborado por Helen Woodruff (1929). 101

Figura 30. Ubicación de los monasterios en los que se crearon o pertenecieron los manuscritos Burm.Q.3, Ms.Lat. 8085, Ms.9987-91, Ms. 10066-77 y Cod. 264

\section{Miniaturas de la Psychomachia}

Miniatura 1. Sacrificio de Isaac

Miniatura 2. Captura de Lot.

Miniatura 3. Rescate de Lot 146

Miniatura 4. Triunfo de Abraham. 147

Miniatura 5. Ofrenda de Abraham y Melquisedec. 151 
Miniatura 6. Abraham y los tres ángeles 152

Miniatura 7. Invocación de Prudencio (Efigie de Prudencio) 159

Miniatura 8. Cultura deorum ataca a Fides 164

Miniatura 9. Fides derriba y destroza a Cultura deorum. 165

Miniatura 10. Fides corona a los mártires 166

Miniatura 11. Combate de Pudicitia y Libidinem 172

Miniatura 12. Pudicitia golpea con una piedra a Libidinem.

Miniatura 13. Pudicitia atraviesa con su espada la garganta de Libidinem. 176

Miniatura 14. Pudicitia reprende a Libidinem

Miniatura 15. Pudicitia lava su espada en el río Jordán

Miniatura 16. Pudicitia enfunda su espada y la consagra al templo

Miniatura 17. Patientia permanece tranquila entre el ejército de los vicios 185

Miniatura 18. Ira golpea con una pica a Patientia 186

Miniatura 19. Ira increpa a Patientia

Miniatura 20. Ira arroja su lanza contra Patientia

Miniatura 21. Rotos yacen los dardos que Ira lanzó a Patientia.

Miniatura 22. Ira golpea con su espada a Patientia

Miniatura 23. La espada de Ira se quiebra y Patientia tranquila persevera 196

Miniatura 24. Ira se suicida 197

Miniatura 25. La victoriosa Patientia increpa a la Ira muerta 198

Miniatura 26. Patientia atraviesa con Job el campo de batalla 199 
Miniatura 27. Patientia habla con Job ..................................................... 202

Miniatura 28. Patientia junto a las virtudes somete a los vicios ................ 203

Miniatura 29. Superbia se pavonea entre los escuadrones en su caballo

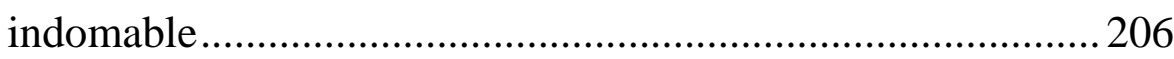

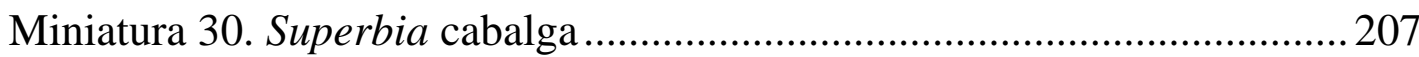

Miniatura 31. Superbia amenaza a la muchedumbre, Humilitas y Spes permanecen tranquilas ................................................ 208

Miniatura 32. Superbia se precipita sobre Humilitas y Spes ......................2213

Miniatura 33. Superbia cae en una fosa.............................................. 214

Miniatura 34. Humilitas se burla de la derribada Superbia ........................ 215

Miniatura 35. Spes ofrece su espada a Humilitas ...................................... 219

Miniatura 36. Humilitas decapita a Superbia ........................................ 220

Miniatura 37. Humilitas ofrece a Spes la cabeza de Superbia..................... 221

Miniatura 38. Spes increpa a la derrotada Superbia ............................... 223

Miniatura 39. Spes asciende al cielo................................................... 224

Miniatura 40. Luxuria sentada come ...................................................... 228

Miniatura 41. Luxuria corre al combate al escuchar las trompetas ............. 229

Miniatura 42. Luxuria en su carro asombraba a los hombres...................... 230

Miniatura 43. Luxuria con halagos engaña a las virtudes ......................... 231

Miniatura 44. Los hombres arrojan sus armas contemplando la carroza de Luxuria ......................................................... 234

Miniatura 45. Todo el ejército se rinde y pasa al lado traidor ....................235

Miniatura 46. Sobrietas advierte a su ejército de no seguir a Luxuria ......... 236 
Miniatura 47. Sobrietas con la cruz del Señor sale al encuentro del carro de Luxuria.

Miniatura 48. Sobrietas lanza una piedra y hiere la boca de Luxuria 240

Miniatura 49. Sobrietas increpa a Luxuria ya muerta .241

Miniatura 50. Iocus arroja su címbalo y huye

Miniatura 51. Amor huye dejando atrás sus flechas, aljaba y arco 243

Miniatura 52. Pompa desnuda de sus ornamentos huye. 247

Miniatura 53. Voluptas huye por las espinas lastimándose los pies 248

Miniatura 54. Sobrietas y el resto de las virtudes se abstienen de tocar los despojos

Miniatura 55. Avaritia recoge de entre la arena los fragmentos de oro 253

Miniatura 56. Avaritia oculta con su mano izquierda el botín .254

Miniatura 57. Avaritia nutre a la multitud de vicios con su negra leche ...... 255

Miniatura 58. Avaritia hiere a muchos y deja errar a otro ciego .256

Miniatura 59. Avaritia muestra algo y hiere con su lanza a uno de los hombres 260

Miniatura 60. Avaritia precipita a muchos al fuego 261

Miniatura 61. Avaritia transforma su aspecto a uno honorable. 262

Miniatura 62. La apariencia de Avaritia engaña..................................... 263

Miniatura 63. Avaritia ata a quienes engaña ....................................... 268

Miniatura 64. Avaritia llena de dudas al batallón de las virtudes................ 269

Miniatura 65. Largitas lucha contra Avaritia y reparte su botín a los pobres 270

Miniatura 66. Avaritia se encuentra aturdida y agotada 271 
Miniatura 67. Largitas estrangula a Avaritia 275

Miniatura 68. Largitas sujeta con sus pies y rodillas a Avaritia 276

Miniatura 69. Largitas distribuye entre los pobres el botín de Avaritia....... 277

Miniatura 70. Largitas con júbilo arenga a la muchedumbre .278

Miniatura 71. Pax llega y huyen Metus, Labor, Vis 280

Miniatura 72. Se silencian las trompetas y las espadas se enfundan

Miniatura 73. La legión de las virtudes se alegra de la victoria en el combate

Miniatura 74. Concordia da la señal de volver al campamento 286

Miniatura 75. Las tropas a caballo y andando entonan himnos 287

Miniatura 76. Las virtudes entran a la ciudad. 288

Miniatura 77. Discordia escondida hiere a Concordia 289

Miniatura 78. Discordia aprovecha el momento propicio para acechar y acercarse a las virtudes 293

Miniatura 79. Las virtudes rodean a Discordia con sus espadas 294

Miniatura 80. Fides hiere a Discordia 295

Miniatura 81. Las virtudes desmiembran el cuerpo muerto de Discordia ... 301

Miniatura 82. Las virtudes construyen una tribuna 302

Miniatura 83. Fides y Concordia suben a la tribuna 303

Miniatura 84. Todos acuden desde el campamento 307

Miniatura 85. Concordia dirige la palabra al ejército de las virtudes 308

Miniatura 86. Fides también dirige la palabra al ejército de las virtudes..... 309

Miniatura 87. Fides y Concordia miden en lugar donde construirán el templo del Señor 
Miniatura 88. Templo del Señor construido por las virtudes 313

Miniatura 89. Sapientia se sienta en un trono en el interior del edificio .314 Miniatura 90. Prudencio da gracias a Dios

Figura 31. Psychomachia (c. 1140-1180). Puerta refectorio. Antigua abadía de Saint Aubin d'Angers, actual Conseil Général d'Angers, Francia ...... 334

Figura 32. Distribución capiteles claustro de Sant Cugat del Vallès 357

Figura 33. Distribución temas iconográficos, galería sur. Capiteles SI 01, $02,03,04$ y 05 . 358

Figura 34. Distribución temas iconográficos, galería sur. Capiteles SI 08, 09,10 y 11 359

Figura 35. Distribución temas iconográficos, galería sur. Capiteles SI 14, 15,16 у 17 360

Figura 36. Daniel en la fosa. Capitel SI 01. (Siglo XIII) Galería sur. Monasterio de Sant Cugat del Vallès 364

Figura 37. Ciclo de Adán y Eva. Capitel SI 02. (Siglo XIII) Galería sur. Monasterio de Sant Cugat del Vallès 364

Figura 38. Ciclo de Noé. Capitel SI 03. (Siglo XIII) Galería sur. Monasterio de Sant Cugat del Vallès 364

Figura 39. Ciclo de Abraham. Capitel SI 04. (Siglo XIII) Galería sur. Monasterio de Sant Cugat del Vallès

Figura 40. Anunciación a los pastores. Capitel SI 05. (Siglo XIII) Galería sur. Monasterio de Sant Cugat del Vallès 369 
Figura 41. Huida a Egipto. Capitel SI 08. (Siglo XIII) Galería sur. Monasterio de Sant Cugat del Vallès 369

Figura 42. Multiplicación de los panes y peces. Capitel SI 09. (Siglo XIII) Galería sur. Monasterio de Sant Cugat del Vallès

Figura 43. Monjes estudiando. Capitel SE 09. (Siglo XIII) Galería sur.

Monasterio de Sant Cugat del Vallès

Figura 44. Entrada a Jerusalén. Capitel SI 10. (Siglo XIII) Galería sur.

Monasterio de Sant Cugat del Vallès

Figura 45. Las tres Marías en el sepulcro. Capitel SI 11. (Siglo XIII) Galería sur. Monasterio de Sant Cugat del Vallès 380

Figura 46. Aparición de camino a Emaús. Capitel SI 14. (Siglo XIII) Galería sur. Monasterio de Sant Cugat del Vallès 380

Figura 47. Incredulidad de Tomás. Capitel SI 15. (Siglo XIII) Galería sur. Monasterio de Sant Cugat del Vallès 380

Figura 48. Dormición de la Virgen. Capitel SI 16. (Siglo XIII) Galería sur. Monasterio de Sant Cugat del Vallès 381

Figura 49. Psychomachia (caras oeste y sur). Capitel SI 17. (Siglo XIII) Galería sur. Monasterio de Sant Cugat del Vallès. 385

Figura 50. Psychomachia (caras este y norte). Capitel SI 17. (Siglo XIII) Galería sur. Monasterio de Sant Cugat del Vallès

Figura 51. Sapientia en su trono. Ms. Lat. 15158 (1289), fol. 63r. Biblioteca Nacional de Francia, París 391

Figura 52. Hombres con toro. Capitel OE 01. (Siglo XII) Galería oeste.

Monasterio de Sant Cugat del Vallès 394 
Figura 53. Hombres con ovejas. Capitel OE 13. (Siglo XII) Galería oeste. Monasterio de Sant Cugat del Vallès 394

Figura 54. Carneros luchando. Capitel OI 05. (Siglo XII) Galería oeste.

Monasterio de Sant Cugat del Vallès 394

Figura 55. Toros luchando. Capitel OE 16. (Siglo XII) Galería oeste. Monasterio de Sant Cugat del Vallès 394

Figura 56. Hombres trabajando. Capitel OI 15. (Siglo XII) Galería oeste. Monasterio de Sant Cugat del Vallès 394

Figura 57. Hombres con tina. Capitel OE 12 y OE 13. (Siglo XII) Galería oeste. Monasterio de Sant Cugat del Vallès 394

Figura 58. Hombres armas y jinete. Capitel OI 01. (Siglo XII) Galería oeste.

Monasterio de Sant Cugat del Vallès 398

Figura 59. Sansón y el León. Capitel OI 11. (Siglo XII) Galería oeste. Monasterio de Sant Cugat del Vallès 398

Figura 60. El pobre Lázaro y el rico Epulón. Capitel OI 17. (Siglo XII) Galería oeste. Monasterio de Sant Cugat del Vallès 398

Figura 61. Tonsura. Capitel NI 06. (Siglo XII) Galería norte. Monasterio de Sant Cugat del Vallès 404

Figura 62. Procesión. Capitel NI 08. (Siglo XII) Galería norte. Monasterio de Sant Cugat del Vallès 404

Figura 63. Monje y escultor. Capitel EI 01. (Siglo XII) Galería este. Monasterio de Sant Cugat del Vallès 404

Figura 64. Distribución temas iconográficos galería este. Capiteles EI 15, 16 y 17 408 
Figura 65. Lavatorio de pies. Capitel EI 15. (Siglo XII) Galería este. Monasterio de Sant Cugat del Vallès 413

Figura 66. Natividad. Capitel EI 16. (Siglo XII) Galería este. Monasterio de Sant Cugat del Vallès 413

Figura 67. Presentación en el templo. Capitel EI 17. (Siglo XII) Galería este.

Monasterio de Sant Cugat del Vallès. 413 


\section{FUENTES}

\section{Manuscritos consultados}

Archivo de la Corona de Aragón

- ACA,COLECCIONES,Manuscritos,Sant Cugat,3. Siglo XI.

- ACA,COLECCIONES,Manuscritos,Sant Cugat,17. Siglo XII.

- ACA,COLECCIONES,Manuscritos,Sant Cugat,21. Siglo XII.

- ACA,COLECCIONES,Manuscritos,Sant Cugat,22. Siglo XI.

- ACA,COLECCIONES,Manuscritos,Sant Cugat,47. Siglo XII-XIII.

- ACA,COLECCIONES,Manuscritos,Sant Cugat,57. Siglo XIII.

- ACA,COLECCIONES,Manuscritos,Sant Cugat,63. Siglo XII.

- ACA,COLECCIONES,Manuscritos,Sant Cugat,74. Siglo XIII.

Biblioteca Civil de Berna

- Cod. 264. Siglo X.

Biblioteca Nacional de Francia, París

- Ms. Lat. 2290. Siglo IX.

- Ms. Lat. 8085. Siglo IX.

Biblioteca Real de Bélgica, Bruselas

- Brussels, KBR, ms. 9987-91. Siglo IX.

- Brussels, KBR, ms. 10066-77. Siglo X.

Biblioteca de la Universidad de Leiden

- BUR Q 3 (Burm.Q.3). Siglo IX. 


\section{Fuentes primarias}

El costumari del monestir de Sant Cugat del Vallès. Introducción y transcripción de Efrem E. Compte, prefacio de Anscari M. Mundó. Barcelona: Institut d'Estudis Catalans, 2009.

ARISTÓteles. Ética nicomáquea; Política; Retórica; Poética. traducción y notas de: J. Pallí Bonet. Madrid: Gresdos, D.L., 2011.

- Acerca de la generación y la corrupción. Tratados breves de historia natural. traducción de: E. La Croce y A. Bernabé Pajares. Madrid: Editorial Gredos, S.A., 1987.

Agustín, Santo obispo de Hipona. Obras completas de San Agustín, XL. Escritos varios, 2do. Versión de Teodoro C. Madrid. Biblioteca de Autores Cristianos. Madrid: La Biblioteca Católica, 1995.

- Obras de San Agustín, II. Las confesiones. Edición de: Ángel Custodio Vega. Biblioteca de Autores Cristianos. Madrid: La Editorial Católica, S.A., 1973.

- Obras de San Agustín, XIX. Enarraciones sobre los Salmos (1 parte). Edición de: Balbino Martín Pérez. Biblioteca de Autores Cristianos. Madrid: Editorial Católica, S.A., 1964.

- Obras de San Agustín, III. Obras filosóficas. Versión de: Evaristo Seijas. Biblioteca de Autores Cristianos. Madrid: La Editorial Católica, S.A., 1963. - Obras de San Agustín, XVI. La Ciudad de Dios. Edición de José Moran. Madrid: Editorial Católica, S.A., 1958.

- Obras de San Agustín, V. Tratado de la Santísima Trinidad. Versión y traducción de Fr. Luis Arias. Biblioteca de Autores Cristianos. Madrid: La Editorial Católica, S.A., 1956. 
Ambrosio, Santo obispo de Milán. Comentario a San Lucas, V, 62. Edición consultada: Obras de San Ambrosio, I. Tratado sobre el Evangelio de San Lucas. Edición de Manuel Garrido Bonaño. Biblioteca de Autores Cristianos. Madrid: La Editorial Católica, 1966.

. Hexameron, Paradise, Cain and Abel, trad. de John J. Savage. Nueva York: Fathers of the Church, 1961.

Benito, Santo. San Benito: su vida y su regla. dirección e introducciones del Padre Dom García M. Colombas, versiones del Padre Dom León M. Sansegundo, comentarios y notas del Padre Dom Odilón M. Cunill. Madrid: Editorial Católica, S.A., 1954.

De Broussillon, Bertrand. Cartulaire de l'abbaye de Saint-Aubin d'Angers. Tomo

I. Angers : Germain et Grassin, Imprimeurs-Libraires, 1903

CICERÓN, Marco Tulio. La invención retórica, trad. de S. Núñez. Biblioteca Clásica Gredos, 245. Madrid: Gredos, D.L.1997.

. Retórica a Herenio. Traducción de S. Núñez. Biblioteca Clásica Gredos, 244. Madrid: Gredos, 1997.

. Sobre el orador. Traducción de José Javier Iso. Biblioteca Clásica Gredos, 300. Madrid: Gredos, 2002.

ISIDORO DE SEVILLA. Etimologías. Edición bilingüe, traducción y notas de: J. Oroz Reta y M.A. Marcos Casquero, introducción de: M.C. Díaz y Díaz. Madrid: Editorial Católica, S.A., 1982-1983.

Platón. Diálogos V. Parménides, Teeteto, Sofista, Politico. Biblioteca Clásica Gredos, 117. Madrid: Editorial Gredos, S.A., 1988.

. Dialogos IV. República. trad. de Conrado Eggers Lan. Biblioteca Clásica Gredos, 94. Madrid: Gredos, 1988. 
Prudencio Clemente, Aurelio. Obras Completas de Aurelio Prudencio. Traducción de A. Ortega, introducción general de: I. Rodríguez. Ed. bilingüe. Biblioteca de Autores Cristianos 427. Madrid: Editorial Católica, 1981.

RiUs SERRA, José (ed.). Cartulario de Sant Cugat del Vallés. Barcelona: Consejo Superior de Investigaciones Científicas, Sección de Estudios Medievales de Barcelona, 1945-1947.

Tertuliano. Tertullian, Apology, De Spectaculis. Traducción de: T.R. Glover. Cambridge: Harvard University Press, 1977.

\section{BIBLIOGRAFÍA}

Enciclopedia de la religión católica. Barcelona: Dalmau y Jover, S. A., 1950-1956.

The Grove Encyclopedia of Medieval Art and Architecture, Vol. 1. Ed. Colum P. Hourihane. Oxford; Nueva York: Oxford University Press, 2012.

La idea y el sentimiento de la muerte en la historia y en el arte de la Edad Media (I). Ciclo de conferencias celebrado del 1 al 5 de diciembre de 1986, coord. por M. Núñez Rodríguez y E. Portela Silva. Santiago de Compostela: Universidad de Santiago de Compostela, 1988.

A.A.V.V. El Bosco y la tradición pictórica de lo fantástico. Barcelona: Galaxia Gutenberg, 2006.

A.A. V.V. L’image. Fonctions et usages des images dans l'Occident médiéval. Actes du 6e "International Workshop on Medieval Societies", Centre Ettore Majorana (Erice, Sicile, 17-23 Octobre 1992), ed. J. Baschet y J.C. Schmitt. París: Le Léopard d'or, 1996. 
A.A.V.V. Jeux de mémoire. Aspects de la mnémotechnie médiévale dirección de: Bruno Roy y Paul Zumthor. Montréal: Presses de l'Université de Montréal, 1985.

A.A.V.V. The New Catholic Encyclopedia. 2da edición. Washington: Thomson \& Gale, 2003.

ABOU-EL-HAJ, Barbara. "The Urban Setting for Late Medieval Church Building: Reims and its Cathedral Between 210 and 1240", Art History. Vol. 11, No. 1 (1988), pp. 17-41.

ALBERTE González, Antonio. Retórica medieval: historia de las artes predicatorias. Madrid: Centro de Lingüística Aplicada Atenea, 2003.

ARCO y GARAY, Ricardo del. Sepulcros de la Casa Real de Castilla. Madrid: Consejo Superior de Investigaciones Científicas, Instituto Jerónimo Zurita, 1954.

ARIÈS, Philippe. El hombre ante la muerte. Madrid: Taurus, 1999.

. Historia de la muerte en Occidente: desde la Edad Media hasta nuestros días. Barcelona: El Acantilado, 2000.

Assmann, Jan. "Collective Memory and Cultural Identity", New German Critique, No. 65 (1995), pp. 125-133.

BAltrusaitis, Jurgis. Les Chapiteaux de Sant Cugat del Vallès. París: Librairie Ernest Leroux, 1931.

BALDWIN, John W. The Scholastic Culture of the Middle Ages 1000-1300. Lexington: D.C. Heath and Company, 1971.

BARRERA, Pedro María. "Sepulcro de don Álvaro de Luna, en la capilla de Santiago de la Catedral de Toledo", Museo Español de Antigüedades. Tomo X (1880), pp. $255-270$. 
BÄUML, Franz H. "Varieties and Consequences of Medieval Literacy and Illiteracy", Speculum Vol. 55, №. 2 (Abril 1980), pp. 237-265.

BAYARD, Jean Pierre. La tradition cachée des cathédrales: du symbolisme médiéval à la réalisation architecturale. St-Jean-de-Braye: Éditions Dangles, 1990.

BellinAti, Claudio. Giotto. Atlante iconográfico della capella Scrovegni (13001305). Ponzano: Vianello, 2003. p. 133.

Belting, Hans. Antropología de la imagen. Madrid: Katz, 2007.

BERGMANN, Rolf. Katalog der althochdeutschen und altsächsischen Glossenhandschriften. Band I. Berlin: Walter de Gruyter, 2005.

BEST, Jan. G.P. Thracian Peltasts and their Influence on Greek Warfare. Groninga: Wolters-Noordhoff, 1969.

Beuter, Pere Antoni. Segunda parte de la Coronica general de España y especialmente de Aragon, Cathaluña y Valencia: donde se tratan las obranças destas tierras de poder de moros por los inclytos Reyes de Aragon y Condes de Barcelona... Valencia: en casa de Ioan de Mey, Flandro, 1551.

BISCHOFF, Bernhard. Katalog der festländischen Handschriften des neunten Jahrhunderts: (mit Ausnahme der wisigotischen). T. 2, Laon-Paderborn. Wiesbaden: Harrassowitz, 2004.

BOUfFARD, Pierre. "La Psychomachie sur les portails romans de la Saintonge”, Zeitschrift Für Schweizerische Archäologie Und Kunstgeschichte = Revue Suisse D'art et D'archéologie = Rivista Svizzera D'arte E D'archeologia = Journal of Swiss Archeology and Art History, Vol. 22 №. 1-3 (1962), pp. 1921.

BRISCOE, Marianne G. et Barbara H. Jaye. Artes praedicandi. Turnhout: Brepols, 1992. 
CABAllero Escamilla, Sonia. La escultura gótica funeraria de la Catedral de Ávila, Ávila, Diputación de Ávila, Institución Gran Duque de Soria, 2007.

Calzada Toledano, Juan José. "Las virtues y los vicios en Santa María del Campo", Boletín de la institución Fernán González 80 Nº. 222/1 (2001), pp. $123-145$.

CAMILLE, Michael. "Seeing and Reading: Some Visual Implications of Medieval Literacy and Illiteracy". Art History Vol. 8, № 1 (marzo 1985), pp. 26-49. . Image on the Edge: The Margins of Medieval Art. Londres: Reaktion books, 1992.

- El ídolo gótico. Ideología y creación de imágenes en el Arte Medieval. Madrid: Akal, 2000.

. Arte gótico: visiones gloriosas. Madrid: Ediciones Akal, S.A., 2005.

CARo DobÓn, Luis y María Edén FERnÁndEZ SuÁREZ. “Los enterramientos reales de la Cartuja de Miraflores”. Ambio Ciencias: revista de divulgación 2 (2008), pp. 23-37.

CARRETE Y PARRONDO, Juan. "Sebastián de Toledo y el sepulcro de Don Álvaro de Luna.” Revista de Ideas Estéticas 33 № 131 (1975), pp. 37-43.

CARruthers, Mary (ed.). Rhetoric Beyond Words. Cambridge University Press, 2010.

CARRUTHERS, Mary. The Book of Memory: A Study of Memory in Medieval Culture. Cambridge Studies in Medieval Literature. Cambridge: Cambridge University Press, 1992.

. The Craft of Thought. Meditation, Rhetoric, and the Making of Images, 4001200. Cambridge: Cambridge University Press, 1998. 
CASTIÑEIRAS GONZÁLEZ, Manuel Antonio. El calendario medieval hispano: textos e imágenes (siglos XI-XIV). Valladolid: Junta de Castilla y León, Consejería de Educación y Cultura, 1996.

Charland, T.M. Artes praedicandi: contribution à l'histoire de la rhétorique au Moyen Age. París: J. Vrin, 1936.

CHAZELlE, Celia. "Archbishops Ebo and Hincmar of Reims and the Utrecht Psalter", Speculum, Vol. 72, No. 4 (Octubre 1997), pp. 1055-1077.

Clark, J. M. The Abbey of St. Gall as a Centre of Literature and Art. Cambridge: Cambridge University Press, 1926.

Clerval, A. Les écoles de Chartres au Moyen-Age: (du Ve au XVIe siècle). Frankfurt : Unveränderter Nachdruck, 1965.

CRUZADA VillamiL, Gregorio. "Retablo y sepulcros de la capilla de D. Álvaro de Luna en la Catedral de Toledo", El Arte en España, Tomo VI (1867), pp. 7382.

D'AYZAC, Félicie-Marie-Emilie. Histoire de l'abbaye de Saint-Denis en France. Tome Premier. París: Imprimerie Impériale, 1860.

D’Ovidio, Stefano. “Cernite Robertum Regem virtute refertum. La 'fortuna' del monumento sepolcrale di Roberto D'Angiò in S. Chiara”, en: La chiesa e il convento di Santa Chiara: committenza artistica, vita religiosa e progettualità politica nella Napoli di Roberto d'Angiò e Sancia di Maiorca. Battipaglia: Laveglia \& Carlone, 2014. pp. 275-312.

DESCHAMPS, Paul. Le combat des vertus et des vices sur les portails romans de la Saintonge et du Poitou. Caen: Henri Delesques, Imprimeur-Éditeur, 1914.

DUBY, Georges. La época de las catedrales: arte y sociedad 980-1420. Madrid: Cátedra, D.L. 1993. 
DUFRENNE, Suzy. Les illustrations du Psaltier d'Utrecht : sources et apport carolingien. París: Ophrys, D.L. 1978.

ELSNER, Jas. Art and the Roman Viewer: The Transformation of Art from the Pagan World to Christianity. Cambridge: University Press, 1995.

FANG-CHEN, Wu. “'Les Arcades du cloître de l'abbaye Saint-Aubin d'Angers (11281151)," Histoire de l'Art: bulletin d'information de l'Institut national d'histoire de l'art, No. 3, 1988, pp. 37-46.

FÉLIBIEN, Michel. Histoire de l'abbaye royale de Saint-Denys en France: contenant la vie des abbez qui l'ont governée depuis onze cens ans, les hommes illustres qu'elle a donnez à l'Eglise \& à l'Etat, les privileges accordez par les souverains pontifes \& par les evêques, les dons des rois, des princes \& des autres bienfacteurs: avec la description de l'eglise \& de tout ce qu'elle contient de remarquable: le tout justifié par des titres authentiques \& enrichi de plans, de figures \& d'une carte topographique. París: Chez Frederic Leonard, 1706.

FEnTRES, James et. Chris WiCKHAM. Memoria social. Madrid: Cátedra, 2003.

FERnÁNDEZ GonZÁLEZ, Etelvina. "Don Álvaro de Luna, condestable de Castilla y maestre de Santiago: hombre de su tiempo y promotor de las artes", en: La nobleza peninsular en la Edad Media. VI Congreso de Estudios Medievales. Ávila: Fundación Sánchez Albornoz, D.L. 1999. pp. 135-170.

LÁZARO CARRETER, Fernando. Diccionario de términos filológicos. Madrid: Editorial Gredos, S.A., 1981.

FrAÏSSE, Chantal. "Un traité des vertus et des vices illustré à Moissac dans la première moitié du XI ${ }^{\mathrm{e}}$ siècle." Cahiers de Civilisation Médiévale 42 No 167 (1999), pp. 221-242.

FrANCO MATA, Ángela. “Arte y literatura. El monumento sepulcral de Margarita de Brabante. Iconografía y significación de yacentes femeninos reales en la Baja Edad Media.”, en: Lecturas de Historia del Arte, No. 2 (1990), pp. 24-44. 
. "Iconografía funeraria gótica en Castilla y León (siglos XII y XIV), De Arte, Vol. 2 (2003), pp. 47-86.

FrIEND, Albert M. "Carolingian Art in the Abbey of St. Denis", Art Studies; Medieval, Renaissance and Modern Vol. 1 (1923), pp. 67-75.

. "Portraits of the Evangelists in Greek and Latin Manuscripts", Art Studies, No. 5 (1927), pp. 115-147.

García Álvarez-Busto, Alejandro. “Al servicio del claustro. Análisis de los espacios de trabajo en los monasterios hispánicos (siglos XI-XIX)", en: Hispania Sacra Vol. 68 Nº 137 (2016), pp. 145-178.

GARNIER, François. Le langage de l'image au Moyen Âge (I). Signification et symbolique. París: Le Léopard d'Or, 1982.

. Le langage de l'image au Moyen Âge (II). Grammaire des gestes. París: Le Léopard d'Or, 2003.

GIBSON-WoOD, Carol. "The 'Utrecht Psalter' and the Art of Memory", RACAR: revue d'art canadienne / Canadian Art Review. Vol. 14, №. 1/2 (1987), pp. 9$15,33-35$.

Gómez BÁRCEnA, María Jesús. Escultura gótica funeraria en Burgos. Burgos: Diputación Provincial de Burgos, 1988.

GonZÁlez PALENCIA, C. "La capilla de don Álvaro de Luna en la Catedral de Toledo", Archivo Español de Arte y Arqueología, No. 13 (1929), pp. 109-122.

GonZÁlez HERnANDO, Irene. "El diluvio universal", en: Revista Digital de Iconografía Medieval, Vol. 3, No. 6 (2011), pp. 39-49.

GreEn, Joel B. The Gospel of Luke. Grand Rapids; Cambridge: William B. Eerdmans, cop., 1997.

GreEN, Rosalie B. "Virtues and Vices in the Chapter House Vestibule in Salisbury." Journal of the Warburg and Courtauld Institutes Vol. 31 (1968), pp. 148-158. 
Gregorovius, Ferdinand. History of the City of Rome in the Middle Ages. Vol. VI, Parte 2. Cambridge: Cambridge University Press, [1898] 2010.

HALBWACHS, Maurice. La memoria colectiva. Zaragoza: Prensas Universitarias de Zaragoza, [1950] 2004.

HASElBACH, Hans. Seneque des IIII vertus. La Formula honestae vitae de Martin de Braga (pseudo-Sénèque) traduite et glosée par Jean Courtecuisse (1403), estudio y edición crítica de H. Haselbach. Berne: Herbert Lang, 1975.

HANNA, Ralph, III. "The Sources and the Art of Prudentius' Psychomachia." Classical Philology Vol. 72, N. 2 (1977), pp. 108-115.

HARRISON, Charles. "The Arena Chapel: Patronage and Authorship", en: Siena, Florence and Padua, art, society and religion 1280-1400. Vol. II, Case studies, ed. D. Norman. New Haven: Yale University Press, 1995. pp. 83104.

HaWorth, Kenneth R. Deified Virtues, Demonic Vices, and Descriptive Allegory in Prudentius’ Psychomachia. Amsterdam: A.M. Hakkert, 1980.

HeImanN, Adelheid. "The Capital Frieze and Pilasters of the Portail Royal, Chartres", Journal of the Warburg and Courtauld Institutes. Vol. 31 (1968), pp. 73-102.

HeINZ-MoHR, Gerd. Lessico di iconografia cristiana. Milán: Istituto di Propaganda Libraria, 1995.

HERBECOURT, Pierre d'. Anjou roman. La Pierre-qui-Vire (Yonne): Zodiaque, 1959.

Hourihane, Colum (ed.). Virtue \& Vice: The Personifications in the Index of Christian Art. Princeton: Department of Art and Archaeology of Princeton University in association with Princeton University Press, 2000.

JACOBUS, Laura. "The Tomb of Enrico Scrovegni in the Arena Chapel, Padua". The Burlington Magazine, Vol. 154, № 1311 (2012), pp. 403-409. 
JEAUNEAU, Édouard. L'âge d'or des écoles de Chartres. Chartres: Editions Houvet, 1995.

KatZenellenbogen, Adolf. Allegories of the Virtues and Vices in Mediaeval Art, from Early Christian Times to the Thirteenth Century. New York: W.N. Norton \& Company, Inc., [1939] 1964.

. The Sculptural Programs of Chartres Cathedral: Christ, Mary, Ecclesia. Baltimore: The John Hopkins Press, 1968.

KELly, Samantha. The New Solomon. Robert of Naples (1390-1343) and Fourteenth-Century Kingship. Leiden; Boston: Brill, 2003.

KIDSON, Peter. Sculpture at Chartres. London: Academy Editions, 1974.

KNOWLES, David. El monacato cristiano. Madrid: Ediciones Guadarrama, S.A., 1969.

KoPITZSCH, Franklin et. Dirk BRIETZKE (eds.). Hamburgische Biografie: Personenlexikon. 2, Christians. Vol. 2. Hamburg: Christians Verlag, 2003.

Kosmer, Ellen. "Gardens of Virtue in the Middle Ages". Journal of the Warburg and Courtauld Institutes, Vol. 41 (1978), pp. 302-307.

LAHOZ, Lucía. "La dormición de María en el arte gótico alavés”, en: Boletín del Museo e Instituto 'Camón Aznar’. №. 44 (1991), pp. 109-118.

- Escultura funeraria gótica en Álava. Vitoria-Gasteiz: Diputación Foral de Álava, D.L. 1996.

• "La escultura en la corona de Castilla: una polifonía de ecos", Artigrama. Vol. 26 (2011), pp. 243-286.

LAWRENCE, Clifford Hugh. Medieval Monasticism: Forms of Religious Life in Western Europe in the Middle Ages. Londres; Nueva York; Longman, 1989. 
LE GofF, Jacque et Jean Claude SCHMITT (eds.). Diccionario razonado del Occidente medieval, trad. de A. I. Carrasco Manchado, Madrid, Ediciones Akal S.A., 2003.

LECLERCQ, Heri et Fernand CABROL. Dictionnaire d'archéologie chrétienne et de liturgie. París: Librairie Letouzey et Ané, 1924.

LORÉS I OTZET, Immaculada. "La escultura del claustre i de l'eglésia", en: Catalunya románica, Tomo XVIII. El Vallès occidental. El Vallès Oriental. Barcelona: Enciclopèdia Catalana, S.A., 1991.

. "La vida en el claustra: iconografia monàstica als capitells de Sant Cugat del Vallès i el Costumari del monestir", Butlletí del Museu Nacional d'Art de Catalunya, $\mathrm{N}^{\mathrm{o}} 6$ (2002), pp. 35-46.

MÂLE, Emile. El arte religioso del siglo XIII en Francia: el Gótico. Madrid: Encuentro, [1898] 2001.

. L'art religieux de la fin du Moyen Âge en France. Étude sur l'iconographie du Moyen Âge et sur ses sources d'inspiration. 2da edición. París: Librairie Armand Colin, [1908] 1922.

. Notre-Dame de Chartres. París: Flammarion, 1963.

MCNEILL, John. "The East Cloister Walk of Saint-Aubin at Angers: Sculpture and Archeology", Anjou: Medieval Art, Architecture and Archaeology. Ed. John McNeill y Daniel Prigent. Leeds: British Archaeological Association, 2003. pp. 111-137.

MCKITTERICK, Rosamond. The uses of literacy in early mediaeval Europe. Cambridge: Cambridge University, 1992.

(ed.). Carolingian Culture: Emulation and Innovation. Cambridge: Cambridge University Press, 1997. 
MiCHALSKY, Tanja. "The local eye: Formal and social distinctions in late quattrocento Neapolitan tombs", en: Art and Architecture in Naples, 12661713: New Approaches, ed. Cordelia Warr et. Janis Elliot. West Sussex: Wiley-Blackwell, copl, 2010. pp. 62-82.

MiQuel Rosell, Francesc X. Catalèg dels llibres manuscrits de la Biblioteca del Monestir de Sant Cugat del Vallès existents a l'Arxiuu de la Corona d'Aragó. Barcelona: Imprenta de la Casa de Caritat, 1937.

Moskowitz, Anita. “Giovanni di Balduccio's Arca di San Pietro Martire: Form and Function”. Arte Lombarda, Vol. 96/97 (1991), pp. 7-18.

. "A Tale of Two Cities: Pavia, Milan, and the Arca di Sant'Agostino". Notes in the History of Art, Vol. 11, №. 2 (1992), pp. 1-9.

. Nicola Pisano's Arca Di San Domenico and Its Legacy. Penssylvania: Pennsylvania State University, 1994.

MoXo y DE FRANCOLI, Benito. Memorias históricas del real monasterio de San Cucufate del Valles. Barcelona: Francisco Suriá y Burgada, Impresor, 1790.

NEWHAUSER, Richard. The Treatise on Vices and Virtues in Latin and the Vernacular. Turnhout, Belgique: Brepols, 1993. . et Susan J. Ridyard. Sin in Medieval and Early Modern Culture: The Tradition of the Seven Deadly Sins. Woodbridge: York Medieval Press, 2012.

NORMAN, Joanne S. Metamorphoses of an Allegory: The Iconography of the Psychomachia in Medieval Art. New York: P. Lang, 1988.

O’Sullivan, Sinéad. Early Medieval Glosses on Prudentius' Psychomachia: The Weitz Tradition. Leiden; Boston: Brill, 2004.

PÄCHT, Otto. La miniatura medieval: una introducción. Madrid: Alianza, 1987.

PANOFSKY, Erwin. El significado en las artes visuales. Madrid: Alianza, 1985. 
. La sculpture funéraire: de l'ëgypte ancienne au Bernin. París: Flammarion, 1995.

. Renacimiento y renacimientos en el arte occidental. Madrid: Alianza, 1988.

PAOLETTI, John T. y Gary M. RADKE. La Italia del Renacimiento. Madrid: Ediciones Akal, S.A., 2002.

PERAY, Josep de. Monografía histórica i descriptiva del poble de Sant Cugat del Vallès. Barcelona: Rourich, 1990.

PEREDA ESPESO, Felipe, "El cuerpo muerto del rey Juan II, Gil de Siloé y la imaginación escatológica." (Observaciones sobre el lenguaje de la escultura en la alta Edad Moderna)", Anuario del Departamento de Historia y Teoría del Arte, Vol. XIII (2001), pp. 53-85.

PÉrez MARTín, Sergio et. Luis VASALlO TORANZO. "El patronazgo de los Fonseca en la Colegiata de Toro", en: Anuario del Instituto de Estudios Zamoranos Florián de Ocampo, № 28 (2011), pp. 231-254.

Platelle, Henri. Le temporel de l'abbaye de Saint-Amand des origines a 1340. París: Librairie d'Argences, 1962.

PORCHER, Jean. Les manuscrits à peintures en France du VIIème au XIIème siècle. París: Bibliothèque nationale, 1954.

Poussin, Clovis (Abbé). Monographie de l'abbaye et de l'église de St-Remi de Reims, précédée d'une notice sur le saint apôtre des Francs d'après Flodoard. Reims: Lemoine-Canart, 1857.

PRACHE, Anne. Saint-Remi de Reims: l'oeuvre de Pierre de Celle et sa place dans l'architecture gothique. Genève: Droz, 1978.

Proske, Beatrice Gilman. Castilian sculpture, Gothic to Renaissance. New York: Hispanaics society of America, 1951. 
Pujades, Gerónimo. Crónica universal del principado de Cataluña. Tomo V. Barcelona: Imprenta de José Torner, [1609] 1829.

RIVERS, Kimberly A. Preaching the Memory of Virtue and Vice. Memory, Images, and Preaching in the Late Middle Ages. Turnhout: Brepols, 2010.

RÉAU, Louis. Iconografía del arte cristiano. Introducción general. Barcelona: Ediciones del Serbal, [1955-59] 2008.

Iconografía del arte cristiano. Iconografía de la Biblia. Antiguo Testamento. Tomo 1, Vol. 1. Barcelona: Ediciones del Serbal, [1955-59] 1999.

. Iconografía del arte cristiano. Iconografía de la Biblia. Nuevo Testamento. Tomo 1, Vol. 2. Barcelona: Ediciones del Serbal, [1955-59] 2008.

REYNOLDS, Suzanne. Medieval Reading: Grammar, Rhetoric and the Classical Text. Cambridge: Cambridge University Press, 1996.

RoDríGUEZ BARRAL, Paulino. La imagen de la justicia divina. La retribución del comportamiento humano en el más allá en el arte medieval de la Corona de Aragón. Tesis doctoral. Barcelona: Universidad Autónoma de Barcelona, 2003.

RoDríguez Porto, Rosa M. "Fartan sus iras en forma semblante: La tumba de Álvaro de Luna y el status de la imagen en la Castilla tardomedieval". Espacio, Tiempo y Forma, Serie VII, Historia del Arte No. 16 (2003), pp. 1128.

Ross, Woodburn O. "A Brief Forma Predicandi”, Modern Philology: Critical and Historical Studies in Literature, Medieval Through Contemporary. Vol. 34, No. 4 (1937), pp. 337-344

RuIZ MALDONADO, Margarita. "Los Castilla-Fonseca en la iglesia de San Lorenzo de Toro (Zamora), en Estudios de Historia del Arte en memoria de la 
profesora Micaela Portilla. Vitoria-Gasteiz: Arabako Foru Aldundia. Euskara, Kultura eta Kirol Saila. Diputación Foral de Álava, 2008. pp. 8185.

SALINAS ESPINOSA, Concepción. "De vicios y virtudes en algunos textos castellanos del siglo XV", en: Revista española de filosofía medieval, Vol. 1 (1994), pp. 149-157.

SÁNCHEZ AMEIJEIRAS, Rocío. Investigaciones iconográficas sobre la escultura funeraria del siglo XIII en Castilla y León (Tesis). Santiago de Compostela, Universidad de Santiago de Compostela, 1993.

- Los rostros de las palabas. Imágenes y teoría literaria en el Occidentel medieval. Madrid: Akal, 2014.

SchMiTT, Jean-Claude. La raison des gestes: dans l'occident Médiéval. París: Gallimard, 1992.

SEDANO MARTín, Teresa. La idea y el sentimiento de la muerte en la Edad Media en Toro (Zamora). Zamora: Instituto de Estudios Zamoranos "Florián de Ocampo", 2013.

SMITH, Alison. "The Iconography of the Sacrifice of Isaac", American Journal of Archeology. Vol. 26 (1922), pp. 159-173.

SMITH, Macklin. Prudentius' "Psychomachia": A Reexamination. Princeton: Princeton University Press, 1976. HAWORTH, Kenneth R. Deified Virtues, Demonic Vices, and Descriptive Allegory in Prudentius' Psychomachia. Amsterdam: A.M. Hakkert, 1980

STETTINER, Richard. Die Illustrierten Prudentiushandschriften. Berlin: Druck von J.S. Preuss, 1895. 
StOCLET, Alain J. Autour de Fulrad de Saint-Denis (v. 710-784). École pratique des hautes études (France). Section des sciences historiques et philologiques. Ginebra: Champion, 1993.

TCHERIKOVER, Anat. High Romanesque Sculpture in the Duchy of Aquitaine c. 10901140. Oxford: Clarendon Press, 1997.

TeIJeIRA PABlos, María Dolores. "Vicio y ¿castigo? en las sillerías del coro: una visión crítica del pecado en el tardogótico hispano." Clío \& Crímen: Revista del Centro de Historia del Crimen de Durango, No. 7 (2010), pp. 159-176.

TSELOS, Dimitri. "The Influence of the Utrecht Psalter in Carolingian Art", en: The Art Bulletin Vol. 39, №. 2 (junio 1957), pp. 87-96.

TuVE, Rosemond. "Notes on the Virtues and Vices, Part I: Two Fifteenth-Century Lines of Dependence on the 12th and 13th Centuries." Journal of the Warburg and Courtauld Institutes Vol. 26 No. 3/4 (1963), pp. 264-303.

. "Notes on the Virtues and Vices, Part II." Journal of the Warburg and Courtauld Institutes Vol. 27 (1964), pp. 42-72.

. Allegorical Imagery. Some Medieval Books and Their Posterity. Princeton; New Jersey: Princeton University Press, [1966] 1977.

Utz, Sabine. "Reprise et réivention des manuscrits antiques à l'époque carolingienne: l'exemple du Prudence de la Burgerbibliothek de Berne (Codex 264)", Actualiser le passé: figures antiques du Moyen Âge à la Renaissance. Laussane: Université de Laussane, 2012. pp.33-46.

VAuCHEZ, André (ed.). Encyclopedia of the Middle Ages. Vol. I-II. Cambrige: James \& Clarke Co., 2000.

VÉLEZ-SAINZ, Julio. “Mecenazgo y representación: imágenes de Álvaro de Luna en el Libro de las virtuosas e claras mugeres, el castillo de Escalona y la Catedral de Toledo", en: Hispanic Review, Vol. 80, No. 2 (2012), pp. 175-198. 
VILlanUeVA, Jaime. Viage literario a las iglesias de España. Tomo XIX, Viage á Barcelona y Tarragona. Madrid: Imprenta de la Real Academia de la Historia, 1851.

Warburg, Aby. Atlas Mnemosyne. Madrid: Akal, D.L. 2010.

Weitzmann, Kurt. Studies in Classical and Byzantine Manuscript Illumination. (ed.) Herbert L. Kessler. Chicago \& London: The University of Chicago Press, 1971.

. El rollo y el códice. Un estudio del origen y el método de la iluminación de textos. Madrid: Nerea, D.L. 1990.

Wethey, Harold E. Gil de Siloe and His School. A Study of Late Gothic Sculpture in Burgos. Cambridge; Massachusetts: Harvard University Press, 1936.

WIELAND, Gernot. "Review Early Medieval Glosses on Prudentius' "Psychomachia": The Weitz Tradition". Speculum Vol. 80, N. 3 (Julio 2005), pp. 944-945.

Williams, Howard. Death and Memory in Early Medieval Britain. Cambridge: Cambridge University Press, 2005.

WoODRUFF, Helen. "The Illustrated Manuscripts of Prudentius". Art Studies (1929), pp. 31-79.

YATES, Frances Amelia. El arte de la memoria. Madrid: Taurus, [1966] 1974.

YARZA LuACES, Joaquín. Los Reyes Católicos: paisaje artístico de una monarquía. Madrid: Nerea, D.L. 1993.

. Isabel la Católica: promotora artística. León: Edilesa, D.L., 2005.

- La Cartuja de Miraflores. I. Los sepulcros. Cuadernos de Restauración de Iberdrola Vol. XIII. Bilbao : Fundacion Iberdrola, 2007. 
ZimmERMANn, Michel. Écrire et lire en Catalogne (IXe-XIIe siècle). Tomo I y II. Madrid: Casa de Velázquez, 2003.

\section{Enlaces electrónicos}

\section{Manuscritos iluminados de la Psychomachia}

Cod. 264 - "Bern, Burgerbibliothek, Cod. 264: Prudentius, Carmina”, E-codices. Disponible en: http://www.e-codices.unifr.ch/en/list/one/bbb/0264. [Consulta: 7/noviembre/2013]

Burm.Q.3 - “BUR Q 3”, Universiteit Leiden Digital Sources. Disponible en : https://socrates.leidenuniv.nl/R/-?func=dbin-jump-full\&object id=3211399. [Consulta: 22/noviembre/2014]

Ms. 9987-91 - "Prudentius, Carmina. Brussels, KBR, ms. 9987-91”, Bibliothèque númerique de la Bibliothèque royale de Belgique”. Ficha técnica disponible en: http://belgica.kbr.be/fr/coll/ms/ms9987_91_fr.html. Manuscrito digitalizado disponible en: http://uurl.kbr.be/1494895. [Consulta: 7/noviembre/2013.]

Ms. 10066-77 - "Miscellany of various texts; Prudentius, Psychomachia; Physiologus de natura animantium. Brussels, KBR, ms. 10066-77”, Bibliothèque númerique de la Bibliothèque royale de Belgique". Ficha técnica disponible en : http://belgica.kbr.be/fr/coll/ms/ms10066 77 fr.html. Manuscrito digitalizado disponible en: http://uurl.kbr.be/1332800. [Consulta : 7/noviembre/2013]

Ms. Lat. 8085 - "Latin 8085”, Bibliothèque nationale de France. Ficha técnia disponible en : http://archivesetmanuscrits.bnf.fr/ark:/12148/cc13013k. Manuscrito digitalizado disponible en: http://gallica.bnf.fr/ark:/12148/btv1b6000032n/f2.image. [Consulta: 16/noviembre/2012] 


\section{Otras fuentes}

"The Reception of Ancient Virtues and Vices in Modern Popular Culture", Brill Publishers. Disponible en: http://www.brill.com/products/book/receptionancient-virtues-and-vices-modern-popular-culture [Consulta: 3/abril/2017]

"Sacramentarium Sancti Dionysii [Sacramentaire de Saint-Denis]", Bibliothèque nationale de France. Disponible en:

http://gallica.bnf.fr/ark:/12148/btv1b8423836x/f358.item.r=ms.zoom [Consulta: 31 de octubre de 2016]

"Tomb of St Peter Martyr", The Cast Court Collection of the Victoria and Albert Museum. Disponible en: http://collections.vam.ac.uk/item/O40973/tomb-ofst-peter-martyr-plaster-cast-di-balduccio-giovanni/ [Consulta: 11 de noviembre de 2015]

“The Utrecht Psalter", Universiteitsbibliotheek Utrecht, Utrecht, 2013. Disponible en : http://bc.library.uu.nl/utrecht-psalter.html [Consulta: 17 de diciembre de 2016]

ButTERFIELD, David. "Classical Manuscripts at St Gall and Reichenau”, Tours of the Libraries of Reichenau and St. Gall. California: UCLA Digital Library, 2012. Disponible en: http://www.stgallplan.org/en/tours_classical_mss.html [Consulta: 25 de abril de 2015]

FANNING, William. "Tonsure”, The Catholic Encyclopedia. Vol. 14. New York: Robert Appleton Company, 1912. Disponible en: http://www.newadvent.org/cathen/14779a.htm. [Consulta: 25 de octubre de 2016]

GANZ, David. "The Libraries, Librarians and Library Catalogues of Reichenau and St. Gall", Tours of the Libraries of Reichenau and St. Gall. California: UCLA Digital Library, 2012. Disponible en: 
http://www.stgallplan.org/en/tours_libraries.html [Consulta: 24 de abril de 2015]

POLLARD, Richard Matthew. "Carolingian Literature at Reichenau and St. Gall”, Tours of the Libraries of Reichenau and St. Gall. California: UCLA Digital Library, 2012. Disponible en:

http://www.stgallplan.org/en/tours_carol_literature.html [Consulta: $24 \mathrm{de}$ abril de 2015]

QUIVIGER, François. "Frances Yates and the Mnemonic Works of Giordano Bruno", The Warburg Institute, University of London. Disponible en: http://warburg.sas.ac.uk/library/digital-collections/giordano-bruno/yatesbrunos-mnemonics/ [Consulta: 2 de febrero de 2016]. 